\title{
Royal Courts in Dynastic States and Empires
}




\title{
Rulers \& Elites
}

\section{Comparative Studies in Governance}

\author{
Series Editor \\ Jeroen Duindam \\ Leiden University
}

Editorial Board

Maaike van Berkel, University of Amsterdam Sabine Dabringhaus, Freiburg University Yincong Dai, William Paterson University, NJ Jean-Pascal Daloz, Maison française, Oxford Jos Gommans, Leiden University Dariusz Kołodziejczyk, Warsaw University Metin Kunt, Sabanci University

VOLUME 1

The titles published in this series are listed at brill.nl/rule 


\title{
Royal Courts in Dynastic States and Empires
}

\author{
A Global Perspective
}

\author{
Edited by \\ Jeroen Duindam \\ Tülay Artan \\ Metin Kunt
}

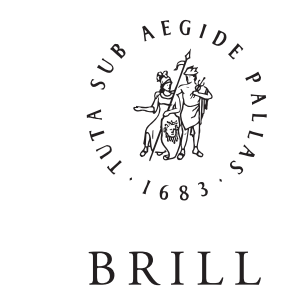

LEIDEN • BOSTON

2011 
Cover illustration: Damad Ibrahim Pasha's processions through the Hippodrome/ Atmeydanı by Jean-Baptiste Vanmour. SK-A-1998. Amsterdam, Rijksmuseum.

Despite our efforts we have not been able to trace all rights holders to some copyrighted material. The publisher welcomes communications from copyrights holders, so that the appropriate acknowledgements can be made in future editions, and to settle other permission matters.

This book is printed on acid-free paper.

Library of Congress Cataloging-in-Publication Data

Royal courts in dynastic states and empires : a global perspective / edited by Jeroen Duindam, Tulay Artan, Metin Kunt.

p. cm. - (Rulers \& elites : comparative studies in governance ; v.1) Includes index.

ISBN 978-90-04-20622-9 (hardback : alk. paper) 1. Courts and courtiers-History.

2. Royal houses-History. I. Duindam, Jeroen Frans Jozef, 1962- II. Artan, Tülay. III. Kunt,

I. Metin, 1942- IV. Title. V. Series.

GT3510.R69 2011

$395.09-\mathrm{dc} 23$

2011016712

ISSN 2211-4610

ISBN 9789004206229

Copyright 2011 by Koninklijke Brill NV, Leiden, The Netherlands.

Koninklijke Brill NV incorporates the imprints Brill, Global Oriental, Hotei Publishing, IDC Publishers, Martinus Nijhoff Publishers and VSP.

All rights reserved. No part of this publication may be reproduced, translated, stored in a retrieval system, or transmitted in any form or by any means, electronic, mechanical, photocopying, recording or otherwise, without prior written permission from the publisher.

Authorization to photocopy items for internal or personal use is granted by Koninklijke Brill NV provided that the appropriate fees are paid directly to The Copyright Clearance Center, 222 Rosewood Drive, Suite 910, Danvers, MA 01923, USA.

Fees are subject to change. 


\section{CONTENTS}

Acknowledgements ....................................................................... vii

List of Contributors ………......................................................... ix

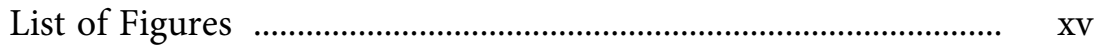

Royal Courts in Dynastic States and Empires ………………….... 1 Jeroen Duindam

\section{FROM ASSYRIA TO ROME}

Pride, Pomp and Circumstance: Palace, Court and Household in Assyria 879-612 BCE

Gojko Barjamovic

Hellenistic Court Society: The Seleukid Imperial Court under Antiochos the Great, 223-187 BCE

Rolf Strootman

The Roman Imperial Court: Seen and Unseen in the

Performance of Power

Andrew Wallace-Hadrill

Court and State in the Roman Empire-Domestication and

Tradition in Comparative Perspective

Peter Fibiger Bang

\section{SUCCESSORS AND PARALLELS IN EAST AND WEST}

Court and Capital in Byzantium

Paul Magdalino

A King on the Move: The Place of an Itinerant Court in

Charlemagne's Government

Rosamond McKitterick

Court Historiography in Early Tang China: Assigning a Place to History and Historians at the Palace Isenbike Togan

To be a Prince in the Fourth/Tenth-Century Abbasid Court .... 199 Nadia Maria El Cheikh 
Ceremonies and the City: The Court in Fourteenth-Century

Constantinople

Ruth Macrides

THE EARLY MODERN WORLD

The Pope's Household and Court in the Early Modern Age Maria Antonietta Visceglia

The Monarch and Inner-Outer Court Dualism in Late Imperial

China

Sabine Dabringhaus

Turks in the Ottoman Imperial Palace

I. Metin Kunt

The Mughal Audience Hall: A Solomonic Revival of Persepolis in the Form of a Mosque Ebba Koch

Royal Weddings and the Grand Vezirate: Institutional and Symbolic Change in the Early Eighteenth Century Tülay Artan

Versailles, Vienna, and Beyond: Changing Views of Household and Government in Early Modern Europe 401 Jeroen Duindam

Index 


\section{ACKNOWLEDGEMENTS}

Turning a successful conference into a book presents a challenge in many cases; in this case it took too many years. Hence our first thanks go to the conference participants and authors, whose patience we have seriously tested. In the end, we hope, the volume as it now stands, including many important contributions not originally part of the conference, will compensate for the delays.

Our conference was part of a programme funded by the COST organization (European Cooperation in Science and Technology). Sabanci University in Istanbul offered hospitality and contributed in many ways to the success of our initative. We have also had financial support from TUBA, the Turkish Academy of Sciences, and NWO, The Netherlands Organisation for Scientific Research.

In addition, the support of several persons has been indispensable. Zeynep Yelce assisted during the conference, and stepped in at several stages of the editing process. Kate Delaney provided invaluable editorial expertise and assistance. David Claszen carefully corrected the entire text, and compiled the index. Among our contacts at Brill, we would like to thank in particular Marti Huetink for his efficient and dynamic support.

The editors 


\section{LIST OF CONTRIBUTORS}

Tülay Artan is Profesor at Sabanci University, Istanbul. She has received her BA and MA in Architecture in Middle East Technical University, Ankara and her $\mathrm{PhD}$ in History, Theory and Criticism from Massachusetts Institute of Technology, Cambridge MA. Artan's research focuses on the Ottoman elite in Istanbul, the lives of its members and material culture that surrounded them in the 18th century. She is currently working on two eighteenth-century Ottoman princesses, married to two grand vezirs who came to office in the first half of the eighteenth century. One of her projects involves the Ottoman royal hunt. She is the author of a section on 'Art and Architecture', in: Cambridge History of Turkey, vol. 3, Suraiya Faroqhi ed. (Cambridge 2006). Her recent publications include 'Forms and Forums of Expression: İstanbul and Beyond, 1600-1800', in: The Ottoman World, Christine Woodhead ed. (London 2011); 'A Composite Universe: Arts and Society in Istanbul at the End of the 18th Century', in: Ottoman Empire and European Theater. Vol. I. Sultan Selim III and Mozart (1756-1808), Michael Hüttler and Hans Ernst Weidinger eds. (Vienna 2011); '18th Century Ottoman Princesses as Collectors: From Chinese to European Porcelain', Ars Orientalis 39 (Globalizing Cultures: Art and Mobility in the Eighteenth Century), Nebahat Avcıoğlu and Barry Flood eds. (Washington, DC 2011).

Gojko Barjamovic is Assistant Professor of Assyriology at the Department of Cross-Cultural and Regional Studies at the University of Copenhagen, Denmark. He is a Specialist in Assyrian history, society and economy.

Peter Fibiger Bang, PhD (Cantab), Associate Professor in the Saxo Institute at the University of Copenhagen, is a Roman comparative historian, interested in political economy, the sociology of power, state-formation and world history. He was chair of the COST research network Tributary Empires Compared 2005-09 (http://www.tec.saxo .ku.dk). Bang has published The Roman Bazaar. A Comparative Study of Trade and Markets in a Tributary Empire (Cambridge 2008). With Walter Scheidel (Stanford) he is editing The Oxford Handbook of the 
Ancient State (forthcoming), with C.A. Bayly, Empires in Contention (in press) and with Dariusz Kolodziejczyk, Universal Empire (in press).

Jeroen Duindam is Professor of Modern History at Leiden University. Duindam studies dynastic centres and elites in a comparative perspective, in terms of theoretical approaches as well as empirical and archival research. His publications include Myths of Power. Norbert Elias and the Early Modern European Court (Amsterdam 1995) and Vienna and Versailles. The Courts of Europe's Dynastic Rivals 1550-1780 (Cambridge 2003).

Sabine Dabringhaus is Professor of East Asian History at the University of Freiburg, Germany. She obtained her MA in Sinology, History and Political Science from Freiburg and PhD in History from the Institute of Qing History, Beijing. Her research in interests include the history of the Qing empire, nationalism in 20th century China, Mao Zedong and the communism in China, the Chinese diaspora in Southeast Asia. She is author of Das Qing-Imperium als Vision und Wirklichkeit: Tibet in Laufbahn und Schriften des Song Yun, 17521835 (Stuttgart 1994), Territorial Nationalismus in China. Historischgeographisches Denken, 1900-1949 (Cologne 2006) and Chinas Geschichte im 20. Jahrhundert (Munich 2009).

Nadia Maria El Cheikh is Professor of History at the American University of Beirut. Her book, Byzantium Viewed by the Arabs, was published by the Harvard Middle Eastern Monographs (August, 2004). The second main focus of her research investigates aspects of gender history in the Abbasid period. Her latest project seeks to explore the workings of the Abbasid court in the early fourth/tenth century. Among her recent publications are 'Servants at the Gate: Eunuchs at the Court of al-Muqtadir', The Journal of the Social and Economic History of the Orient 48 (2005), 234-252; 'Re-visiting the Abbasid Harems', Journal of Middle East Women's Studies, 1 (2005), 1-19; and 'The Court of alMuqtadir: Its Space and Its Occupants', Abbasid Studies II: Occasional Paper of the School of 'Abbasid Studies, Leuven 28 June-1 July, 2004, ed. John Nawas (Orientalia Lovaniensia Analecta, no. 177, 2010).

Евва Косн is a Professor of Asian art at the Institute of Art History, Vienna University and a senior researcher at the Institute of Iranian Studies, Austrian Academy of Sciences. Professor Koch was visiting 
professor at Harvard (2008/09), Oxford (2008), Sabanci University (2003), the American University in Cairo (1998) and, held an Aga Khan Program for Islamic Architecture Fellowship at Harvard (2002). Since 2001 she has been global advisor to the Taj Mahal Conservation Collaborative, and she was Austrian delegate to the Management Committee of COST research network Tributary Empires Compared 2005-09. Her research interests are Mughal art and architecture, the political and symbolic meaning of art, and the artistic connections between the Mughals and their neighbours and Europe. Her publications include Mughal Architecture (1991), Mughal Art and Imperial Ideology (2001), and The Complete Taj Mahal and the Riverfront Gardens of Agra (2006). She has co-authored with Milo Beach and Wheeler Thackston, King of the World: The Padshahnama: An Imperial Mughal Manuscript from the Royal Library, Windsor Castle (1997).

Metin Kunt is Professor of History at Sabanci University, Istanbul. Kunt previously taught at Bogazici University, Istanbul, and at Cambridge University; he also held visiting positions at Harvard, Yale and Leiden. His main areas of research are: Ottoman political sociology and sociology of knowledge. His Sultan's Servants (Columbia 1983) has been translated into Greek (2001); The Age of Suleiman the Magnificent which he co-edited with Christine Woodhead (London 1995) also appeared in Turkish (2002) and Polish (2000).

Paul Magdalino, FBA, studied at Oxford and taught from 1977 to 2009 at the University of St Andrews. He is currently Professor of History at Koç University, Istanbul. His numerous publications on the society, culture and institutions of the Byzantine Empire include The Empire of Manuel I Komnenos, 1143-1118 (1993); L'Orthodoxie des astrologues (2006); Studies on the History and Topography of Medieval Constantinople (2007).

Rosamond McKitterick is Professor of Medieval History in the University of Cambridge and fellow of Sidney Sussex College and has published on literacy, manuscript transmission, perceptions of the past and political culture in the early middle ages. Her current interests are the migration of ideas in the early middle ages and the implications and impact of the historical and legal texts produced during the sixth and seventh centuries in Rome. She received the degrees of MA, PhD, and LittD from the University of Cambridge and studied in Munich 
under Bernhard Bischoff in 1974-75. Since 1999 she has held the Chair in Medieval History in the University of Cambridge, after having been awarded a Personal Chair in 1997. She is a Fellow of the Royal Historical Society and of the Royal Society of Arts, Manufacturing and Commerce, a Korrespondierendes Mitglied of the Monumenta Germaniae Historica and of the Austrian Academy of Sciences, and Corresponding Fellow of the Medieval Academy of America. In 2002 she was the Hugh Balsdon Fellow, British School at Rome 2002, and in 2005-2006 Fellow-in-Residence, Netherlands Institute of Advanced Study (NIAS), in a theme group on The Formation of Carolingian Identity. From October to December 2010 she was Scaliger Fellow in the Universiteitsbibliotheek in Leiden. She was awarded the Dr. A.H. Heineken Prize for History in 2010.

Ruth Macrides teaches Byzantine history at the Centre for Byzantine, Ottoman and Modern Greek Studies, University of Birmingham, England. She has published studies on Byzantine law and society which are collected in Kinship and Justice in Byzantium, 11th-15th centuries (Aldershot 1999). Her work on Byzantine historical writing includes a translation, commentary and study of George Akropolites' History (Oxford 2007). She has edited Travel in the Byzantine World (Aldershot 2002) and History as Literature in Byzantium (Farnham 2010). She also edits the bi-annual journal Byzantine and Modern Greek Studies Her present research is on late Byzantine court ceremonial.

Rolf Strootman is Assistant Professor of Ancient History at Utrecht University, the Netherlands. In 2007 he received his doctorate for his $\mathrm{PhD}$ thesis on the Hellenistic royal courts. His research focuses on aspects of kingship and imperialism in the Near East, particularly in the Hellenistic period.

Isenbike Togan is a member of the Turkish Academy of Sciences (TUBA). Her teaching and research interests cover Inner Asian and Chinese History. She is especially interested in historiography, tribestate relations and gender studies.

Maria Antonietta Visceglia is Professor of Modern History at the University of Roma "La Sapienza". Up to the end of the 1980's her main area of research and publication was the economic and social history of Southern Italy during the Early Modern and Modern Period, specializing in the history of the feudal structures and systems 
of production and consumption. At the same time her scholarly interests have expanded to the behaviour of the aristocracy with regard to inheritance and dowries. Since the early 1990's she has concentrated on the organization of the Papal court and on the role of ceremonies and rites in this context. Her approach in this field has been a comparative one with a European perspective. She is co-editor with G. Signorotto of Court and Politics in Papal Rome 1492-1700 (Cambridge 2002) and with J. Martínez Millán of La Monarquía de Felipe III, vols 4 (Madrid 2008). She is the author of La città rituale. Roma e le sue cerimonie in età moderna (Rome 2002), Riti di corte e simboli della regalità (Rome 2009) and Roma papale e Spagna. Diplomatici, nobili e religiosi tra due corti (Rome 2010). She is a coordinator of the national research programme: The Papacy and international politics in the early modern age.

Andrew Wallace-Hadrill is Master of Sidney Sussex College, Cambridge. He previously served as Director of the British School at Rome. During his first post, as a Fellow and Director of Studies in Classics at Magdalene College (1976-1983), he published a book on Suetonius and articles on aspects of Roman imperial ideology. After a spell in Leicester (1983-1987), he moved to Reading as Professor of Classics (1987-2009). He edited the Journal of Roman Studies, the leading journal of Roman history and culture, from 1991 to 1995. Interest in Roman material culture led to the publication of a study of Houses and Society in Pompeii and Herculaneum (1994), which won the Archaeological Institute of America's James R. Wiseman Award. His work in Pompeii led to the development of a joint project with Professor Michael Fulford on a group of houses in Pompeii, and to appointment as Director of the British School at Rome (1995-2009), a post he held simultaneously with the professorship at Reading. Since 2001 he has directed the Herculaneum Conservation Project, a project of the Packard Humanities Institute which aims to protect and study this unique site. His other publications include, most recently, Rome's Cultural Revolution (2008), published by Cambridge University Press. He has held visiting fellowships at Princeton University and the Getty Museum, and is a frequent contributor to radio and television broadcasts. He was awarded an OBE in 2002 for services to Anglo-Italian cultural relations. He was elected a Fellow of the British Academy in 2010, and appointed from October 2010 by the University of Cambridge to the title of Professor of Roman Studies. 


\section{LIST OF FIGURES}

\section{Gojko Barjamovic}

1. Plan of the North-West Palace at Nimrud

2. The relief decoration of the southern wall of the outer courtyard of the North-West Palace at Nimrud

3. The relief decoration on the southern wall of Assurnasirpal II's throne-room of the North-West Palace at Nimrud

4. Reliefs showing banquet scenes. From rooms 2 and 7 in Sargon II's palace at Khorsabad (ancient Dūr Šarrukinn) .. 36

5. Relief from the North-West Palace at Nimrud, room G of the eastern reception suite

Isenbike Togan

1. Chang'an

2. Public business area of the Ta-Ming palace

\section{Sabine Dabringhaus}

1. Inner and outer court of the Forbidden City in the 17th and 18 th centuries

\section{İ. Metin Kunt}

1. A map of the main parts of the Topkapi Palace

\section{Ebba Koch}

1. Shah Jahan receives his son Awrangzeb in the Hall of Public Audience or Diwan-i 'Amm of Lahore, painted by Murar, ca. 1645

2. Diwan-i 'Amm, Agra, completed 1637

3. Diwan-i 'Amm, Delhi, completed 1648

4. Site plan of the Agra Fort, (a) courtyard of khass-u-'amm; (b) Diwan-i 'Amm hall; (c) mosque

5. Chihil Sutun, Isfahan, 1647

6. Persepolis, Apadana (c. 500-490 BCE) and Hall of Hundred Columns (c. 480-460 BCE) 
7. Ground plans of the Diwan-i 'Amms of Agra, Lahore, and Delhi

8. Elevations of the Diwan-i 'Amms of Agra, Lahore, and Delhi

9. Ground plan of the Patthar Masjid, Srinagar, 1620s

10. Main-floor plan of the Moti Masjid, Agra Fort, 1647-53

11. Facade of the prayer hall, Moti Masjid, Agra Fort

Tülay Artan

1. Map showing the routes of the 1724 processions

2. Damad Ibrahim Pasha's processions through the Hippodrome/Atmeydanı

3. The procession of Damad Ibrahim Pasha by Jean-Baptiste Vanmour

4. The procession of Ahmed III by Jean-Baptiste Vanmour

\section{Jeroen Duindam}

1. Numbers of the rulers' core staffs at the Austrian Habsburg and French courts 


\title{
ROYAL COURTS IN DYNASTIC STATES AND EMPIRES
}

\author{
Jeroen Duindam
}

\section{Introduction}

At the heart of any royal court stands a ruler, more often male than female. The ruler is accompanied by close relatives, friends, and servants in various capacities. Other groups converge around this flexible and changing core institution. A comparison of courts necessarily starts with the household itself, omnipresent but highly variable. At all levels of society, households shape reproduction, socialization and interaction. In a large share of human history, political organization, too, arose primarily in the context of family and household. The hierarchical pre-eminence of a single family or clan, continuing its hold on power over generations, led to the development of dynasties. Common attributes of family life were magnified: households expanded, quarters-mobile or fixed-acquired more elaborate forms. Servants changed character if they not only served the head of their household, but also acted as administrators of his-and sometimes her-extended domains. Throughout history a range of phenomena related to dynastic households can be found. These include the household organization itself as well as its temporary or permanent abode. Household staffs reflect basic functions such as sleeping, eating, devotion, transport and hunting. Palace complexes, moreover, tend to have relatively secluded inner areas, and zones where a wider presence is allowed and expected. Hence, rules for access into the ruler's immediate environment, or arrangements for the ruler's movement outside of the core area, can be found at most courts. Dynastic reproduction and succession could be organized in many ways, and entailed a marked presence of women at court, even if their presence did not as a rule imply a share in formal responsibilities of government. ${ }^{1}$ Politico-religious highpoints in the calendar often came with pageantry arranging participants according

${ }^{1}$ On women at court see Anne Walthall, ed., Servants of the Dynasty. Palace Women in World History (Berkeley; Los Angeles 2008). 
to rank, demonstrating hierarchy and order. Even the artefacts chosen to highlight the supremacy of the ruler-thrones and daises; canopies, parasols, pendants, standards, and fans; headgear, jewellery, rings; drums and trumpets-show some resemblance across continents and centuries. Dynastic households, moreover, inevitably attracted visitors seeking hospitality, justice, preferment-or simply charmed by the spectacle. Representatives of regions and groups were drawn towards the symbolic and administrative centre, creating common elite identities while coalescing around the ruler.

The random examples offered here are a modest starting point only of a list that can be extended and refined ad libitum. Comparison of such forms and patterns can help us to understand functions of households-and hence of the dynastic power structures prevalent in pre-modern history. We need to ask ourselves, however, whether superficial similarities do not hide more profound differences. Labelling a magnificent building as a palace, or a person attending the ruler as a courtier, establishes categories of comparison that obscure cultural and social divergences. The term 'courtier' offers a case in point. It can be used as a generic term for all people at court-including menial servants as well as the ruler's higher-ranking intimates; domestics as well as state servants. Often courtiers are viewed primarily in Castiglione's literary perspective, as suave elite characters orbiting the court, forming as well as broadcasting its manners. These multiple associations of the term complicate understanding even in a strictly European context, with varying sources and contexts suggesting widely differing interpretations. Cultural translation entails even more problems. Archetypical court functions such as the chamberlain or the cupbearer can be found at many courts, but such functions could be performed by groups of very disparate status, provenance, training, and careers. Who would count as courtiers in the Ottoman Sultan's palace or in the Qing Forbidden City? Members of the secluded inner courtseunuchs, slave-pages, boon companions, princes-or state dignitaries who in these palaces as a rule entered only the outer court? Can we compare eunuchs in West and East Asia with high-ranking noble dignitaries in Europe performing similar tasks? To what extent did pages, trained at court in Europe as well as in Asia, play similar roles? Do we find parallels in Asia for the honorary courtiers so conspicuous in Europe, incidentally attending court, but not as a rule residing there? Such questions can be multiplied; they indicate the difficulties as well 
as the intellectual appeal of comparison reaching beyond the level of easy analogy. ${ }^{2}$

\section{Project, Conference, and Volume}

This volume is an offshoot of the 14-16 October 2005 Istanbul conference on 'Royal Courts and Capitals'. The conference itself formed part of a project or 'action' (A36) funded by COST (European Cooperation in Science and Technology): 'Tributary Empires Compared: Romans, Mughals and Ottomans in the Pre-industrial World from Antiquity till the Transition to Modernity'. The project quickly went beyond the three empires listed in its title, adopting a comprehensive comparative stance. Over more than four years, a management committee consisting of representatives of fifteen countries had the opportunity to organize two conferences a year, bringing together specialists studying a wide range of empires. Initially three levels were defined to organize our conferences: historical sociology of empire, central structures of empires, and experiences of empire (i.e. in regions under imperial sway). In practice, conference themes emerged that included all levels of discussion, such as armies and warfare, or law. The 'Royal Courts and Capitals' conference stood at the beginning of our series. Several other volumes have appeared or will appear in the near future, reflecting other meetings in this joint initiative.

The project was an enriching experience in many ways, not only because participants widened their horizons of knowledge and their potential for comparative research. It also made clear that comparison can be organized in many ways, each with distinctive advantages and shortcomings. A somewhat overstated typology may help to illuminate this. A generalizing approach, focusing on a single theme or idea, based mostly on secondary literature in a limited number of languages, and performed by one scholar, can lead to concrete and coherent results. These can be discussed and tested by others, challenging, complementing, or readjusting interpretations. An approach based on knowledge of many specific cultures, languages, and sources can only be organized as a collective effort. This tactic has the advantage of

2 See Jonathan Shepard, 'Courts in East and West', in: The Medieval World, Peter Linehan and Janet L. Nelson, eds. (London 2001) chap. 2, pp. 14-36. 
highlighting diversity, exposing superficial analogy and pursuing comparison where it seems to lead to more profound conclusions. While such an approach makes ample room for individual examples and for the complexities of comparison, it usually leads to diffuse results rather than to a clear thesis. Ideally comparison combines clarity of focus, purpose, and result, with knowledge of sources and languages and an eye for the specifics of different cultures. That ideal is far from easy to reach. In fact, the two approaches are necessary as subsequent steps in an ongoing process, in which the extremes can gradually come closer.

The 'Royal Courts and Capitals' conference had the advantage of a clear focus: the dynastic household in its urban and wider social context. This clear focus allowed us to invite specialists of courtly traditions throughout global history, asking them to address specific points of the courts they study, for a general audience interested in courts in other epochs and cultures. In other words: we chose not to define a general thesis to be discussed by all participants, but accepted diversity as a necessary precondition for comparison based on specialized knowledge of various cultures. Most papers in this volume are Janus-faced: they have a point to make for their own academic communities-ancient historians, Ottomanists, and the like-but at the same time introduce their court to the general reader. Discussion during the conference helped to show where comparison promised stimulating results, and where it needed to be treated with circumspection. This introduction takes up some of the points raised in these debates.

While the conference followed a thematic grid, reaching from the nature of dynastic power, via the connections between household and government, to the household organization, the role of courts as meeting places, and finally to the court as a conspicuous cultural centre, this volume is organized chronologically. In fact most papers in their more elaborate written form deal at some length with several of our conference themes, or cover the entire field. This book includes eight selected conference contributions, expanded and adapted to fit the outcome of our discussions. In addition to these contributions seven specialists (two of whom would originally have taken part in the conference) proved willing to write chapters covering courts or themes not yet covered. Among a total of fifteen chapters, four are devoted to 'early' courts in Assyria, the Seleukid Hellenistic kingdom, and Rome; five deal with the phase between 500 and $1500 \mathrm{BCE}$, six with the early 
modern world. With two contributions on the Byzantine court and Constantinople, as well as two contributions on the Ottoman court, the venue of our conference is the geographical entity best-represented in our volume. European courts from Charlemagne via the Papal See to Louis XIV are discussed in three contributions, whereas two are devoted to the Chinese court. The Abbasid and Mughal courts are each given a chapter. Readers will immediately notice that this is by no means a representative overview of courts in world history. The Safavid court, close to the Mughal as well as the Ottoman cases in many respects, is absent. ${ }^{3}$ No contributions on African, South-East Asian, Japanese, or pre-columbian American courts are included. A rich historical and anthropological literature is available about these courts, and they have been excluded largely for practical reasons. ${ }^{4}$ Coverage even within the territories we did include is limited, as most periods and dynasties remain invisible. The aim of this volume is to make accessible to a general readership specialized knowledge of a wide range of courts in world history, in a form that invites further comparison-not to bring together a global compendium of court life.

\section{A Model for Court Studies?}

Why didn't we choose to organize our co-operative effort around a model or a debate in recent scholarship? A rich literature from a variety of disciplines, ranging from history and history of art to sociology and anthropology, provides descriptions and explanations of dynastic courts in many settings. The phase of growth and splendour of courts in Europe from the later middle ages into the eighteenth century often serves as a point of reference. In fact, interpretations of

\footnotetext{
${ }^{3}$ See Sussan Babaie and Kathryn Babayan, et al. Slaves of the Shah. New Elites of Safavid Iran (London; New York 2004).

${ }^{4}$ See e.g. Stanley J. Tambiah, 'The Galactic Polity in Southeast Asia', in: Culture, Thought and Social Action, an Anthropological Perspective (Cambridge, Mass. London 1985); Clifford Geertz, Negara. The theatre-state in nineteenth-century Bali (Princeton 1980); Geertz, 'Centers, kings, and charisma: reflections on the symbolics of power' in: Local Knowledge. Further Essays in Interpretive Anthropology (New York 1983), pp. 121-146; see also John Beattie, Understanding an African Kingdom: Bunyoro (New York 1960); Lee Butler, Emperor and Aristocracy in Japan, 1467-1680: Resilience and Renewal (Harvard 2002); Eiko Ikegami, The Taming of the Samurai: Honorific Individualism and the Making of Modern Japan (Cambridge, Mass. 1995); Takeshi Inomata, Stephen D. Houston, ed., Royal Courts of the Ancient Maya, 2 vols (Boulder Co 2001).
} 
one early modern European court in particular dominate the scene: Louis XIV's Versailles. Not only is the palace itself often compared to major palatial centres around the world; the imagery and stratagems associated with the Sun King likewise have been starting points for comparative and interpretative excursions. 'Versailles' has become a byword for many things: royal omnipotence, 'tamed' nobles, splendorous architecture-and French national pride. ${ }^{5}$ With the work of Norbert Elias, a specific interpretation of the court of Versailles turned into the single most powerful general model for studies of courts in Europe and elsewhere. In The Court Society, Elias used Versailles as a concrete case-study underpinning his general model of civilization, showing how unruly nobles through the increasing pressures of royal power adopted patterns of controlled behaviour they themselves soon started to appreciate as the essential marker of their superior social status. In his case-study, Elias showed how the king could rule in practice, by exploiting elite rivalries rather than through open confrontation. Supplementing Max Weber's discussion of the 'Veralltäglichung' or routinization of charismatic power, he asked himself how the power of dynastic rulers could be maintained over time. ${ }^{6}$ Which social contexts and mechanisms helped hereditary monarchs-not as a rule charismatic, bright, or brave-to maintain themselves? Elias provides a nuanced variant of divide et impera, in which the ruler balanced competing groups at court through the careful distribution of graces and honours. Louis XIV manipulated oppositions at court through the highly visible minutiae of ceremony, in which even the king's minor gestures could reshuffle hierarchies and alliances.

Elias' model enjoyed an immediate and protracted success, and dominated a first generation of court historians in Europe. ${ }^{7}$ Notwithstanding its acuity and verve, it has at least two fundamental shortcom-

${ }^{5}$ Hélène Himelfarb, 'Versailles: fonctions et légendes', in: Les lieux de mémoire, Pierre Nora, ed., II La Nation (Paris 1986) pp. 235-292; note the role of Versailles in 1871 and 1919-it had become a symbol both of German revenge and French resilience.

${ }^{6}$ Max Weber, Wirtschaft und Gesellschaft. Grundriss der verstehenden Soziologie (Tübingen 1972 [1921]), pp. 122-176, particularly at pp. 142-148.

${ }^{7}$ Norbert Elias, Die höfische Gesellschaft. Untersuchungen zur Soziologie des Königtums und der höfischen Aristokratie. Mit einer Einleitung: Soziologie und Geschichtswissenschaft (Darmstadt; Neuwied 1969), the publication of Elias' revised Habilitation (1933), soon published in French (1974) and English (1983); the general study: Norbert Elias, Über den Prozeß der Zivilisation. Soziogenetische und Psychogenetische Untersuchungen (Bern 1969). I-II, first published 1938. See discussion of the early 
ings. Although Elias demonstrated the relevance of details of comportment and rituals, in the end he perceived domestic offices as empty sinecures, the household as segregated from the machinery of 'actual' power. Elias' main line of reasoning, therefore, reflected the anachronistic attitude of late-nineteenth-century historiography, in which the court was seen as a gilded cage for disempowered nobles rather than as the heart of the dynastic state. Secondly, while Elias attempted to put into perspective the individual power of dynastic rulers, stressing the finely tuned power balances at court rather than the vigour of kings, his remedy seems worse than the disease. Elias' model of manipulative kingship demands a level of social intelligence as well as a strength of mind not usually found among hereditary rulers. These two points, the view of the court as a luxurious prison rather than as a place where lines of power and influence converge, and the unintended overstatement of the ruler's capabilities, are also visible in works following Elias' lead. Undoubtedly, there are examples where such views are justified, but we cannot accept them as necessary components of a general model. Other equally fundamental misunderstandings flow from the first two: Elias pictures the court as an arena of almost entirely worldly status competition, with ceremony and rank as largely secular pre-occupations. In practice, religion played a major role at most if not all pre-modern courts. It was indisputably present in ceremonies and rituals and structured mentalities as well as practices.

Elias' interpretation of the French court, dictated by the expectations of his general theory of the civilizing process, became the norm for court studies at the very moment it was losing its charm for specialists of early modern France and Europe. A fundamental revision of the Sun King's 'absolutism' gained strength from the 1980s onwards. The haughty representation of the king's omnipotence, still often illustrated in textbooks by the apocryphal phrase 'l'état c'est moi', hid a policy in which accommodation was an important ingredient. ${ }^{8}$ Louis XIV consolidated power by selectively punishing and rewarding his unruly elites. The king successfully attracted the nobles into his orbit, but in the process recreated a resilient power elite. The court, a main

reception of Elias' works in Jeroen Duindam, Myths of Power. Norbert Elias and the Early Modern European Court (Amsterdam 1995).

${ }^{8}$ See the balanced assessment by an early participant in the revision of Louis XIV's 'absolutism', William Beik, 'Review Article The Absolutism of Louis XIV as Social Collaboration', Past \& Present 188 (2005) pp. 195-224. 
theatre of this operation, quickly became a bastion of noble power, its officeholders dominating army, diplomacy and regional government. ${ }^{9}$ Hence, the very case on which Elias based his model of the court and his example of the civilizing process awkwardly fits the expectations engendered by his theory.

A recent volume on courts and court societies in antiquity edited by Anthony Spawforth exemplifies the strengths of an approach based squarely on one coherent set of questions. ${ }^{10}$ Spawforth, following the gist of Elias' model, effectively integrated a range of critical comments and elaborations in his introduction, and developed a coherent set of questions guiding the authors contributing to his volume. The strong presence of these questions in the contributions gave Spawforth's volume an exceptional coherence, a quality, however, that necessarily entailed a narrowing of perspectives. It is almost impossible to follow Elias' lead without implicitly or explicitly following the expectations generated by his model: a strengthening ruler/state as 'Fremdzwang' plus a nobility of warriors losing power and, in the process, acquiring civilized manners and self-control-or 'Selbstzwang'. It is difficult to extricate the numerous subtle and interesting perceptions from the rigid grid of civilization, state building and modernization. Elias is mentioned in many of our contributions, and discussed at some length in some. For our comparative initiative, not concentrated in one region, period, or thesis, his outdated interpretation of Versailles cannot serve as yardstick.

Alternative models and concepts are available. Anthropological studies of ritual and rulership are less inclined to choose entirely Eurocentric or wholly secular perspectives, and set a different agenda. The relationship between ritual and power, and the role of the ruler can

9 Jeroen Duindam, Vienna and Versailles. The Courts of Europe's Dynastic Rivals, 1550-1780 (Cambridge 2003); Leonhard Horowski, 'Der Preis des Erfolgs. Gunst, Kapital und Patrimonialisierung am Hof von Versailles (1661-1789)', Zeitschrift für Historische Forschung 36, 1 (2009) pp. 71-91 and his Machtstrukturen und Karrieremechanismen am Hof von Frankreich 1661-1789, (Ostfildern 2011); on the army see the fundamental studies by David Parrott, Richelieu's Army. War, Government and Society in France, 1624-1642 (Cambridge 2001) and Guy Rowlands, The Dynastic State and the Army under Louis XIV: Royal Service and Private Interest, 1661-1701 (Cambridge 2002).

${ }^{10}$ Antony J.S. Spawforth, ed., The Court and Court Society in Ancient Monarchies (Cambridge 2007) in addition to Elias, this volume reflects Aloys Winterling's pathbreaking studies, Comitatus: Beiträge zur Erforschung des spätantiken Kaiserhofes (Berlin 1998); idem, Zwischen „Haus" und „Staat“. Antike Höfe im Vergleich (Munich 1997). 
be questioned by contrasting Elias' interpretation with various anthropological approaches. Clifford Geertz famously inverted the habitual view of ritual as an instrument of power by stating that: 'power served pomp, not pomp power. ${ }^{11}$ Geertz's formula may be an overstatement, but it is clear that ritual and cultural aspects of rulership and court culture cannot be seen as separated from power. Studies of ritual kingship, moreover, underline the contrast between the all-powerful position of the ruler, and the vulnerability of the incumbent, a perspective that teaches us to discriminate sharply the representation of omnipotence from the far more difficult question of a ruler's actual possibilities. ${ }^{12}$ Anthropological studies strengthened a patron-client approach among political historians. Patronage, gift-giving, and the distribution of honours clearly fit into a pattern of political culture close to the practices of courts. Recent studies on ritual as well as on patronage tend to stress the many-sidedness of political communication and to move away from the strict top-down view of state- or ruler-controlled instrumental 'use' of such practices. It is this questioning attitude we adopt in this volume.

\section{Sources and Perspectives}

Comparison can be successful only if our knowledge of all elements to be compared is roughly equal. Can we achieve this even among specialists? For some courts, archeology, the remains of monumental buildings, and isolated bits of textual information are our only sources of information. Ottoman, late imperial Chinese and early modern European courts, on the other hand, have an immensely rich legacy of written sources in addition to buildings and artefacts. Hence, matters we can verify and elaborate for one court, we can only guess at for other courts. Nor can we expect this to be a 'neutral' process, simply providing somewhat less detail in one case than in another: the nature

\footnotetext{
${ }^{11}$ Geertz, Negara, p. 130; see discussion and various important contributions in David Cannadine, 'Introduction' in: Rituals of Royalty. Power and Ceremonial in Traditional Societies (Cambridge 1987); see also Joëlle Rollo-Koster, ed., Medieval and Early Modern Ritual: Formalized Behavior in Europe, China, and Japan (Leiden 2002); see a critical assessment of the impact of anthropology in Philippe Buc, Dangereux ritual. De l'histoire médiévale aux sciences sociales (Paris 2003).

12 Elias made this clear in his concept of 'Verkettung' yet still granted the king far more room for maneuvering than his courtiers.
} 
of the sources predetermines our interpretations. Monumental buildings and depictions of ceremony in sculpture, painting, and to some extent also in writing, tend to represent a grand and unruffled view of the court. ${ }^{13}$ Literary sources frequently present courts in a normative perspective, either by depicting the court as a model for dignified behaviour, or conversely by criticizing it as a centre of ambition, vanity and hypocrisy. In fact, the recent reorientation of court history in Europe arose partly as a consequence of the shift of research from literary and printed sources to archival materials. Literary texts usually stand within a discursive tradition and aim to create-or attack-a reputation; archival materials more often reflect routines at court. Even unpublished court ordinances, however, reiterating rules and norms for daily behaviour, have plausibly been read not as descriptions, but as indications of remaining disorders at court: rules repeated are rules unenforced. Archives dealing with requests of court personnel show a lively, competitive, and very human world rather than a temple of glory.$^{14}$ Private writings of courtiers, available for early modern Europe, likewise offer a view of 'backstage' life at court. Incidentally, reflections produced by rulers themselves, provide an acute insight into their far from easy situation. ${ }^{15}$ Even the most powerful characters experienced phases of anxiety and insecurity in their lives, as a rule in youth and old age. We should not mistake the towering pretentions of rulership for the necessarily more human and vulnerable characteristics of the persons carrying this burden.

${ }^{13}$ See e.g. on the Egyptian court, Rolf Gundlach and Andrea Klug, eds., Der ägyptische Hof des Neuen Reiches. Seine Gesellschaft und Kultur im Spannungsfeld zwischen Innen- und Außenpolitik. Akten des Internationalen Kolloquiums vom 27.-29. Mai 2002 an der Johannes Gutenberg-Universität Mainz (Wiesbaden 2006); David M. Robinson, Culture, Courtiers, and Competition. The Ming Court (1368-1644) (Harvard 2008) shows how the use of sources less dominated by Literati can give us an altogether different image of the Ming court.

${ }_{14}$ Evelyn Rawski, The Last Emperors. A Social History of Qing Imperial Institutions (Berkeley; Los Angeles 1998), refers to James Scott, Domination and the Arts of Resistance. Hidden Transcripts (New Haven 1990); Duindam, Vienna and Versailles, shows many instances of disorder and stresses the limited success of ceremonial regulations.

${ }_{15}^{15}$ Jonathan Spence, Emperor of China. Self-Portrait of Kang-Hsi (New York 1974); for Habsburg emperor Leopold I see e.g. Alfred F. Pribram, ed., Privatbriefe Kaiser Leopold I. an den Grafen F. E. Pötting, 2 vols (Vienna 1903); even the more rhetorical memoirs of the Sun King implicitly show his vulnerability, Mémoires de Louis XIV pour l'instruction du Dauphin, Charles Dreyss, ed., 2 vols (Paris 1860). 
The disproportionate availability and the unequal nature of sources, reflecting a wide spectrum ranging from rulers' propaganda and literary discourses to materials dealing with household routines, present a formidable obstacle for comparative research. ${ }^{16}$ This obstacle, however, also offers opportunities, as the richer and more varied sources available for one court, can put into perspective interpretations based on more limited materials elsewhere. We have tried to achieve such synergy in this volume by bringing together scholars who have direct research experience with the relevant sources.

\section{The Contributions}

Gojko Barjamovic analyzes the spatial structure of the Assyrian NorthWest Palace at Nimrud and the available written sources in a wideranging overview of the court and its functioning. The evidence allows him to give an image of court rituals as well as a layout of major court functions. The women in the inner court are discussed in some detail, from the queen with her own household, via concubines and palace maids, to women of intermediate status occupying formal and important offices. Barjamovic also highlights the different functions performed by either eunuchs or 'bearded men' (i.e. with reproductive potential) at court. The splendour of the North-West Palace at Nimrud, Barjamovic concludes, was the supreme articulation of an empire that in practice was still shaky, an important step towards consolidation. Rolf Strootman presents the Seleukid court on the basis mostly of literary evidence, as surviving evidence of palace architecture is very limited. The Seleukid court was far more mobile than the Assyrian court; there was no single all-important residence. Strootman studies the provenance and cultural backgrounds of courtiers, focusing on the upper layers at court, the king's friends or philoi. He stresses the role of the court as a meeting point for elites from cities throughout the empire; as the ruler's philoi they adopted a second and shared identity as 'Greek' courtiers. The peripatetic Seleukid court provided a collective point of orientation for these civic elites; it merged influences from East and West into a heritage that would influence Parthian

\footnotetext{
${ }^{16}$ In this volume, McKitterick and Macrides show the impact of sources, and the complications that can arise if we extend our reasoning from one example to another without sufficient contextual knowledge.
} 
kings as well as Roman emperors. In his succinct and incisive introduction Andrew Wallace-Hadrill asks how the Roman court, a 'centre of concentration and distribution of power' clearly present in ancient sources, could have been neglected so long by historians. Following Mommsen, who legitimately denied the court a place in the Roman constitution, historians were also discouraged from serious study of the court by converging biases of ancient republicanism and modern liberalism - a combination not unlike that of historians studying the early modern state without including the household in their view. The shifting balance between republican institutions and the increasingly monarchical make-up of the imperial court, 'outside institutions, outside the constitution' makes Rome a particularly interesting case. The Roman case also shows how ideology was inextricably mixed with our understanding of the court in the past. Peter Bang follows up this introduction, studying in greater detail the complex relationship between the Republican state and the imperial household. Bang reviews the relevance in the Roman context of Norbert Elias' notions of Verhöflichung ('courtization') and domestication: did the new monarchical order undermine the old Roman elites, binding them to the court, redefining their status by adding new groups? Bang concludes that the emperors indeed turned the governing elite into a 'cosmopolitan aristocracy', using the court as a 'vehicle of provincial integration.' On the other hand, Bang shows that emperors were subject to traditions, and stresses that they never were the sole or all-powerful actors. At court, a balance was struck among various groups as well as between the republican and monarchical traditions.

Paul Magdalino takes us from the Eternal City to the New Rome: Constantinople. The city took over many of the structures characteristic of imperial Rome, notably the juxtaposition of a palace complex and an adjoining hippodrome. Interactions between court and capital took form largely around the races in the hippodrome, with the competing 'factions' of the Blues and Greens representing the capital. They did not fit within the court hierarchy, but were present in most outward manifestations of the court, and for special occasions were allowed into the palace. Magdalino argues that this vital connection between court and capital gradually dwindled, following the diminishing imperial ambitions of Byzantium. The court increasingly withdrew from the capital, spatially and in terms of ceremonial interaction. With Isenbike Togan's study of Tang emperor Tang Taizong (626-649) we leave the zone of interaction between Europe and West Asia. Togan 
shows how the restructuring of power in early Tang went hand in hand with the institutionalization of commission-written dynastic historiography at court. This model of official history writing, in which the experiences of earlier dynasties were seen as useful examples for their successors, would set the standard for later Chinese court historiography. Togan focuses on the collective nature of this venture, and argues that this initially reflected the integration of various elite groups at court: the strategy of 'power-sharing' even influenced the modes of official historiography. On the other hand, Tang Taizong's strong personal involvement in the process of history writing becomes clear. The emperor, starting his reign by ousting his father and killing the crown prince (626) and achieving prominence through his victory over the Early Türk (630) was intent on controlling the image of his actions as represented to posterity, carefully balancing his personal interests with the longer-term interest of his dynasty. Rosamond McKitterick re-examines the familiar image of Charlemagne's itinerant rulership. Combining a careful reading of charters with modern Internet-based travel planning, she demonstrates that Charles could never have been at all the places where charters were issued with his signature: palace notaries signed in his name. A network of communication and the active intervention of senior officials were essential for Charles' rule, and 'royal movements were not integral to the system of Carolingian government.' The idea of itinerant kingship was extrapolated backwards from Ottonian and Salian examples. McKitterick argues against facile generalizing from one experience, and warns against anachronistic assumptions turning the elusive and variable early medieval court into a static institutional environment. Nadia El Cheikh looks at the court from the perspective of the Abbasid prince Abu al-'Abbas, eldest son of the caliph al-Muqtadir (AH 295-320/ CE 908-932). El Cheikh underlines the polycentric and eclectic layout of the court, partly located in a palace complex dominating Baghdad, partly scattered over other palaces. She shows the ambiguity surrounding the notion of 'courtier', and the heterogeneity of groups at court. An outline of women at court leads to a discussion of the education, retinue, and roles performed by the prince. Abu al-'Abbas formally held important offices from an early age onwards, but these were performed by substitutes. In fact his role was often mostly ceremonial, notably as the key figure in processions, and sometimes practical, when he carried his father's personal messages. Proximity to succession carried with it the threat of revolt, and hence made ruling caliphs wary of princes: they 
kept them on a short leash. Ruth Macrides opens with the contrast habitually seen between an interactive court and capital in early Constantinople and a withdrawn court in the post-1261 phase. Macrides argues that this may be an overstatement, based on the reading of the anonymous fourteenth-century Treatise on the court titles in terms of the categories of its more famous tenth-century predecessor, the Book of Ceremonies by Constantine VII. These books were very different indeed in orientation and organization. The Book of Ceremonies was a repository of ceremonies past and present, centred on movement and localities, the Treatise a very selective reflection of living ceremony, seen as a static tableau of dress and rank. Ceremonies may have continued without being mentioned in the Treatise, whereas, on the other hand, the Book of Ceremonies may have included ceremonies no longer practiced. Macrides underlines the necessity of careful contextual reading of sources.

With Maria Antonietta Visceglia we return to the court of Rome, now in its Papal guise. Visceglia presents a careful breakdown of personnel at the Papal court. She shows how staffs, groups, and hierarchies long remained fluid, conforming roughly to the tripartite division into domini, officiales and famuli-serving respectively in close proximity to the pope, in executive service, and in the establishment's household services. In the course of the sixteenth and seventeenth centuries, members of the court establishment acquired more privileges, and through their offices were entitled to noble rank. Conversely, noble rank became a requirement for entering court service. In the same period, court office in all sections came to be dominated increasingly by clerics. Sabine Dabringhaus analyzes change at the Chinese court during the transition from Ming to Qing. Both dynasties used 'inner court' groups as a counterweight against the literati-dominated central bureaucratic administration, or 'outer court'. However, the composition of the inner court changed substantially under the Qing, with a marked decrease in influence for eunuchs, partly through the introduction of Manchu bondservants at court. Changing marriage, reproduction, and succession rules, moreover, put a limit on the power of the dowager-empress. Qing rulers also introduced an element of aristocracy at court, wider than the imperial lineage itself though mostly based on the Manchu conquerors, plus Mongol and Chinese allies. Military expansion of the Qing empire went together with a policy of integrating newly conquered elites in various ways into the courtly machinery, with special rules for each group. Dabringhaus points to Elias' stress 
on balances of power at court, yet notes the fact that manipulation was possible only for a determined and astute emperor. Inner and outer court return in Metin Kunt's discussion of the Ottoman court, though in a very different context. Kunt presents a brief overview, highlighting the devshirme system of recruitment, palace training in the inner court, and promotion (chikma) to service in provincial government, in the outer (bîrûn) or inner (enderûn) court. Devshirme recruitment and palace training created a strong group identity, and secured many privileges. The intrusion of numerous Anatolian mercenaries into Selim II's service, after Süleyman's death in 1566, caused immediate disturbances and in the longer term upset the palace system by inflating numbers. A minor repetition of this process in 1574, during the succession of Murad III, shows that at least during this moment of changeover, the notion of a 'state' supervised by the imperial council or Divan, and distinct from the new household or even the will of the new ruler, was noticeably present. Ebba Koch portrays the Mughal court under Sjah Jahan (1628-1658), outlining its various audience ceremonies in their architectural settings. She then traces the multiple artistic exemplars of the Mughal audience halls throughout the Persian-Islamicate world. Sjah Jahan's audience hall followed examples from Achaemenid Persepolis via a series of intermediate dynasties to Safavid Iran. Mughals, notable for their syncretism in many realms, displayed a 'disarming lack of inhibition' in combining artistic influences from many directions. Koch illustrates through the Mughal audience hall the strength and variety of traditions of rulership in the Persian-Islamicate world. Tülay Artan studies festivals organized on the occasion of marriages of the sultan's daughters in early eighteenth-century Istanbul. Why and how did Ahmed III (1703-1730) and his grand vezir Damad Ibrahim Pasha restore the great urban festivals, flourishing in the sixteenth century, but no longer practiced in the seventeenth century apart from the isolated example of the 1675 festival in Edirne? Artan focuses on the 1724 festival, showing that this 'reinvention' entailed major redefinitions, relating to the trajectory and the form of processions, as well to the way in which these visualized the changing balances between the sultan and his grand vezir, and the connections between court and capital. Jeroen Duindam presents recent reorientations in the history of the European court, underlining its variability in terms of occasions, locations and groups present. Court life remained more dynamic and multipolar than we usually take for granted; it was never comfortably isolated from decision making. Duindam outlines three layers 
of officeholders found at the early modern European court: a small upper layer of noble officers leading household staffs and close to government, a wider echelon of honorary officers connected to the court loosely through job rotation, and finally a numerous and diverse nonnoble staff taking care of daily tasks. These three layers held very different positions, and need to be discussed separately in interpretations of the court. The notion of 'domestication' so central in Elias' model, for example, can be judged quite differently for each of these layers.

\section{Themes}

The chronological arrangement of the papers in this volume should not obscure the fact that they coalesce around several themes, equally relevant for all courts under discussion. Four themes tied closely to the history of the court-dynasty, palace and capital, staffs and groups converging around the ruler, and the contacts between the court and the outer world-serve here to highlight some of the parallels evident in the following chapters.

Dynastic power is based on transmission of power from generation to generation; spouses, mothers, heirs and siblings are the building blocks of dynasticism. The organization of reproduction ranged from monogamous marriage to slave concubinage, including combinations of these two systems. In Europe as well as in Asia, women tended to occupy the most secluded section of the palace; they were served mostly either by other women or by eunuchs-practices safeguarding the dynastic lineage. Spouses could be important, as for instance the contributions by Gojko Barjamovic and Rolf Strootman on Assyria and the Hellenistic kingdoms underline, but without exception their status would rise markedly after producing a male heir, reaching preeminence when their sons became ruling princes. ${ }^{17}$ Offspring were an absolute necessity for every dynasty and yet without a doubt also represented a persistent challenge to individual rulers. Heirs became impatient and restless, particularly during long reigns; male siblings turned into fierce competitors for the throne, even during the lifetime

${ }^{17}$ The role of mothers emerges forcefully in Walthall, Servants of the Dynasty; Leslie P. Peirce, The Imperial Harem. Women and Sovereignty in the Ottoman Empire (Oxford 1993), and Clarissa Campbell-Orr, ed., Queenship in Europe. The Role of the Consort (Cambridge 2004). 
of their fathers. Sons of brothers figure among leaders of rebellions in more than one empire. What to do with sons and siblings, guaranteeing dynastic continuity yet also dispersing sovereignty and offering a legitimate alternative to the personal power of the ruler ${ }^{18}$ In addition to rules that aimed to secure the potential successors' subservience, such as the system of secret succession that became habitual under the Qing, two options seem to have been used most consistently to neutralize successors. They were either maintained in a splendorous but relatively powerless position in the environment of the ruler (the origin of Elias' gilded cage metaphor), or alternatively sent out to govern outlying provinces and command distant armies. In his discussion of the princes' households, Metin Kunt charts the changes at the Ottoman court in the later sixteenth century, gradually turning from the second to the first alternative; Nadia El Cheikh explores the vulnerable yet ceremonially conspicuous position of princes at the Abbasid court. Tülay Artan examines the marriages of the Sultan's daughters, not relevant for Ottoman succession, but important as indicators of political alliances around court. Isenbike Togan points to Tang Taizong's takeover forcing out his father as well as his siblings; clearing the historical record ranked high among Taizong's motives for reforming court historiography.

Evelyn Rawski, in her monumental study of the Qing court, plausibly presents the talented first Manchu emperors as conscious manipulators of hierarchies and tensions, creating a finely tuned system of checks and balances that allowed them at least for a while to escape the misfortunes of earlier dynasties. While history provides endless examples of plotting courtiers and manipulative rulers it is clear that many rulers were neither willing nor able to pursue such strategies. Clifford Geertz presented Balinese kings as immobilized by an extravagant theatre of power arranged for them, as transfixed kings of chess rather than as active players. Dabringhaus stresses that the operation of the Qing court 'system', with its numerous checks and balances, remained contingent upon the active involvement of the ruler. Togan underlines not only the activist stance of Taizong, but also his power-sharing. Artan portrays the conscious 'reinvention' of the urban festival under

${ }_{18}$ This was a general elite dilemma, particularly acute for dynasties, see discussion in e.g. Gerard Delille, Les noblesses européennes au xixe siècle (Milan; Rome 1988) pp. $1-12$. 
Ahmed III, giving the dynasty a new visibility in the capital. How can we characterize the position of rulers at the heart of their courts? Where could they operate forcefully, where did they abide by rules set by their predecessors, or alternatively where did they feel forced to give in to pressures of courtiers and advisers? Kunt shows that long-term change under Selim II was engendered partly in response to demands of his own princely followers and his father's household. Strootman underlines that Hellenistic rulers were less powerful than we have imagined them to be. Bang shows the strength and active involvement of emperors as well as the necessity to situate them in a court based on interaction and negotiation with elites.

Most other contributions hint at the various positions assumed by rulers, from active involvement to total withdrawal. Clearly, the problem of agency remains a difficult one. How can we ascertain the degree to which rulers themselves were active agents, and how can we assess the balance between them and their courtiers and servants? Answers change not only from ruler to ruler, but also within the lifecycle of a single individual, particularly during long reigns. The variety in circumstances and personalities cannot adequately be expressed in generalized statements pointing in either direction. Rulers rarely were wholesale social engineers in the style of Napoleon, who struck a new balance after a protracted phase of radical change, polarization and disruption. Turbulent phases of warfare and rebellion made room for-or even demanded-such forceful intervention and change. More often, it appears, dynastic rulers embodied and defended what they perceived as tradition, even if in the process they may have introduced change and reform. The challenge taken up by Elias, to come to a more balanced understanding of the ruler's power potential, remains to be solved-although it is unlikely that it can ever be solved through a single encompassing formula.

Palaces figure in most of the contributions to this volume. ${ }^{19}$ Palace layout, architecture and decoration invite comparison and investigation of the similarity of functions as well as the impact of cultural examples-as Ebba Koch's study of Mughal audience halls illustrates. Whenever palaces are discussed at some length, we find 'inner' and 'outer' sections, usually referring both to palace layout and buildings

\footnotetext{
19 Another recent attempt at comparison of palaces: Marie-France Auzépy and Joël Cornette, eds., Palais et Pouvoir de Constantinople à Versailles (Saint-Denis 2003).
} 
as well as to the groups and functions related to these locations. The contributions by Barjamovic, Togan, Kunt and Dabringhaus show that Assyrian, Ottoman and Chinese palaces were organized spatially and institutionally on the basis of an inner-outer divide. Other palaces likewise show patterns of graduated access into the core areas, arranged through spatial, temporal, functional and social restrictions. The structure of the palaces made room for interaction with the-usually urban-environments: rituals in which outsiders entered the palace, or the ruler and his following left it for outdoor pageantry. Such spatial-ceremonial connections with the outer world were important for all courts, although patterns of contact might vary from rigid formality and seclusion to frequent mixing and even camaraderie. Rules and practices pertaining to the ceremonial connections between courts and capitals-originally our conference title-are dealt with in detail by Magdalino, Macrides and Artan, and alluded to in many other papers. Courts and capitals often developed in conjunction, with the main residence of the court stimulating the expansion and centrality of the capital. ${ }^{20}$ Rulers could also escape from cities, relocate their courts in new environments, whether new urban constructions, or country palaces-Versailles, Abbasid Samarra, and Nimrud are examples.

Most rulers did not limit their perambulations to the capital citythough others, such as the late Ming emperors, hardly emerged from their palaces. Excursions into the wider world-hunting expeditions, inspection tours, military campaigns-are typical for dynastic rule. ${ }^{21}$ Strootman underlines the essentially mobile character of the Seleukid court, often moving alongside (and overlapping with) the major army. Indeed, many rulers retained a substantial level of mobility into the modern age notwithstanding the development of capital cities as Duindam shows. Conversely McKitterick points out that Charlemagne's travels were not the necessary element of his rule that earlier historians

\footnotetext{
${ }^{20}$ See e.g. Susan Naquin, Peking: Temples and City Life, 1400-1900 (Berkeley 2000); and a rapidly expanding literature on courts and cities in Europe: Werner Paravicini, ed., Der Hof und die Stadt: Konfrontation, Koexistenz, und Integration in Spätmittelalter und Früher Neuzeit (Ostfildern 2006); Susanne Pils and Jan Paul Niederkorn, eds., Ein zweigeteilter Ort? Hof und Stadt in der frühen Neuzeit (Innsbruck; Vienna 2005); Gary B. Cohen and Franz A.J. Szabo, eds., Embodiments of Power. Building Baroque Cities in Europe (New York; Oxford 2008); Malcolm Smuts and George Gorse, eds., The Politics of Space. European Courts ca. 1500-1750 (Rome 2009).

${ }^{21}$ See a recent study underlining this for the high Qing emperors Michael G. Chang, A Court on Horseback. Imperial Touring \& the Construction of Qing Rule, 1680-1785, Harvard East Asian Monographs 287 (Cambridge, Mass.; London 2007).
} 
assumed on the basis of a misreading of evidence. In any case the kingemperor developed relatively fixed patterns later in his reign.

Palace architecture and layout form a convenient starting point for the analysis of groups at court. In addition to their location within palace topography, groups at court can be ordered according to various criteria: function, rank and status (always a key concern at court), training and provenance. On the basis of such criteria, a systematic comparison of court elites can be attempted. At all courts, we find various categories of personnel, and more often than not indeed several households. Barjamovic, Strootman, El Cheikh, Dabringhaus, Kunt, Visceglia and Duindam examine staffs and categories of personnel at court. At the level of functions, the similarities are substantial: household routines as well as administrative tasks lead to similar sets of officers. Although names vary, chamberlains, tasters, carvers, cupbearers, guards, and heralds are as ubiquitous in the history of the court as scribes and councilors. Can we translate inner and outer as pertaining respectively to the personal attendants catering for the ruler, and the groups taking care of the government of his realm? A functional differentiation fits palace topography to some extent in the Ottoman and Qing cases. At European courts, however, the borders were far less clearly drawn, with blurred and overlapping functions as well as zones. Wallace-Hadrill and Bang explain that the Roman imperial household, existing side-by-side with the formal Republican state structure, suggests yet another variant of the balance between 'state' and household. Decision-making usually included the immediate circle of intimates around the ruler-much to the chagrin of state or outer court dignitaries who felt excluded. In this sense, 'inner' indicated the political heart of the court, certainly not a 'private' sphere irrelevant for policy decisions.

Rank and status are complicated because they themselves implicitly include a variety of criteria, including Nähe zum Thron (or Königsnähe, the ruler's proximity and favour), descent, and capabilities. All courts know a tension between a hierarchy based on established social rank, and an unstable 'shadow hierarchy' based on favour and actual or perceived influence on the prince. Rulers could raise their favourites to great heights, yet steep promotions could be followed by even more abrupt downfalls. ${ }^{22}$ Ranking, training and provenance of person-

22 Two important recent volumes on European history: Jan Hirschbiegel and Werner Paravicini, eds., Der Fall des Günstlings: Hofparteien in Europa vom 13. bis zum 
nel at court show wide cultural divergences. The 'slaves of the Sultan' recruited through devshirme and trained in the palace serving in inner as well as outer court, stand out against the Chinese gentlemen-literati selected through the civil service examinations and serving in the outer court. The strong European emphasis on hereditary status, and hence the vested position of nobles at court and in government seem distant from both. ${ }^{23}$ These contrasts in elite legitimation, however, obscure a general tendency towards social reproduction, alternating with phases of greater mobility.

Courts could have many functions in addition to catering for the dynasty and organizing government. Courts were centres of education, a theme not consistently pursued in this volume. ${ }^{24}$ Also, while courts usually figure as centres of (conspicuous) consumption, they could function as centres of (luxury) production as well-a situation hinted at by Barjamovic. ${ }^{25}$ Most contributions to this volume show that courts were a heterogeneous environment. Contradictions between inner-outer, robe-épée, government-household, upstairs-downstairs; between functional and status hierarchies, and among the levels of these hierarchies; between men, women and eunuchs; between shades of religious persuasion and varieties in regional provenance, and many other elements created a multifaceted and competitive world. A recurring figure at court, on the individual as well as on the group level, seems to be the outsider, cut off from vested local power elites. Eunuchs, standing between the genders, in a sense were outsiders par excellence; go-betweens connecting the sacralized ruler and his subjects, mediating between men and women. ${ }^{26}$ The devshirme system of

17. Jahrhundert (Ostfilden 2004); J.H. Elliott and L.W.B. Brockliss, eds., The World of the Favourite (New Haven; London 1999).

${ }^{23}$ See the surprise expressed by many European travelers in West as well as East Asia on the relative lack of importance of birth as a status marker: Busbecq, The Turkish letters of Ogier Ghiselin de Busbecq, imperial ambassador at Constantinople, 15541562, E. Seymour Forster, ed. (Baton Rouge 2005), pp. 59-60; Jean-Baptiste Du Halde, Description géographique, historique, chronologique, politique et physique de l'empire de la Chine et de la Tartarie chinoise... 4 vols (The Hague 1736) vol. II, p. 69-75.

${ }^{24}$ See e.g. Werner Paravicini and Jörg Wettlaufer, ed., Erziehung und Bildung bei Hofe. 7. Symposium der Residenzen-Kommission der Akademie der Wissenschaften in Göttingen (Stuttgart 2002).

${ }^{25}$ Walthall, Servants of the Dynasty, stresses the role of women at court in production of various kinds.

${ }^{26}$ On eunuchs: Keith Hopkins, Conquerors and Slaves (Cambridge 1981) chapter IV on the political power of eunuchs; Shaun Tougher, ed., Eunuchs in Antiquity and Beyond (London 2002); Nadia M. El-Cheikh, 'Servants at the Gate: Eunuchs at the Court of al-Muqtadir', Journal of the Economic and Social History of the Orient 48, 2 
elite recruitment and reproduction through slave concubinage made 'outsiders' prominent in Topkapi palace. Strootman mentions Hannibal serving as favourite at the Seleukid court after his defeat in the second Punic war. We can add the familiar examples of Marco Polo and Ibn Battuta, who during their travels offered their services to rulers far away. The presence of outsiders at court makes clear that rulers sought and needed trusted advisers, loyal to them rather than to vested group interests represented at court. The reliance of rulers on outsiders and trusted intimates of lower rank, recurring in history, hints at the insecurity and discomfort rulers experienced in their conspicuous roles.

Among the persons at court, one last group needs to be discussed: part-time honorary servants and visitors attending special occasions rather than serving on a permanent basis. Strootman's discussion of the Hellenistic court makes clear that the king's retinue included a variable group of friends-loosely connected to the court but taking up its Greek-Macedonian high culture as a secondary identity. Duindam underlines the relevance of honorific service at the Habsburg court for creating a comprehensive court culture based on loyalty to Catholicism and the dynasty $-\mathrm{a}$ feat of the gesamthabsburgische Adel deep into the nineteenth century. The court, in other words, could serve as a powerful point of orientation in diverse and composite territories. It could achieve this through the creation of honorary distinctions, entitling persons to come to court and serve on major occasions. A great variety of ceremonial interactions between the court and the wider world could strengthen the connection between dynasty and realm. All courts organized regular points of contact, inviting in tributaries and diplomats, or following their own itineraries from court to city and further, cheered by crowds. Barjamovic, Magdalino, Macrides, McKitterick, El Cheikh, and Artan all discuss aspects of such connections. Dabringhaus, for example, points to the special relationship maintained between the Manchu and their Inner-Asian subjects, notably the Mongol tribes, typified by the rituals and buildings around the imperial summer resort at Chengde, and by the Qing cultivation of Tibetan Buddhism.

(2005) pp. 234-252; Kathryn M. Ringrose, The Perfect Servant: Eunuchs and the Social Construction of Gender in Byzantium (Chicago 2003); David Ayalon, Eunuchs, Caliphs and Sultans: A Study in Power Relationships (Jerusalem 1999); Babaie and Babayan, Slaves of the Shah; Peirce, The Imperial Harem. 
Dynastic centres could help to bring together the territories under their dominion through the creation of a common point of orientation and a common elite culture. Conversely, conspicuous consumption could have contrary results, leading the court to be perceived as centre of vanity, ambition and intrigue honest people would shun. The 'concentration and redistribution of power' given by Wallace-Hadrill as the key function of the court, connects the negative and the positive experiences. Favours drew people towards the court, stimulated competition and ambition, and hence displeased those frustrated in the fray as well as more distant moral critics. Phases of positive identification and integration alternate with phases of disintegration and disruption. Apparently, it was difficult for dynasties to command the loyalty of their supporters and subjects over a protracted period. Traditional political thinkers, from the Bible to Ibn Khaldun and Montesquieu, stress the cyclical element in power-a pattern likewise frequently applied to Chinese history. Dynasties after establishing their power succumb to luxury, decline in moral values, lose the loyalty of the initial group of supporters, and finally forfeit legitimacy by exploiting the populace.

In this introduction we have provided a thematic layout for approaching the history of the court, conforming to the basic challenges and questions that had to be addressed by all dynastic rulers-from dynastic succession, to palace layout, groups at court, and interaction with the outer world. In the following chapters, the reader will find a variety of concrete descriptions and analyses of courts. We consciously sidestep the issue of modernization and the rise of Europe, so dominant in recent comparative work. Why seek out elements of backwardness or decline in one particular phase of court history whereas similar patterns had prevailed for millennia? Only on the basis of systematic and careful comparison will it be possible to reach an analytical understanding of the variants of success and decline in a dynastic context. The diverse legacies of dynastic power organized around household and palace, the form of power predominant in world history, need to be analyzed and compared on their own terms before we can connect them to issues of modernization. The ambition of this collection of articles is to move forward this process by providing, through concrete examples and discussion, a basis for a next stage of comparative work that adds specialized knowledge and informed detail to comparative scope and vigour. 



\title{
PRIDE, POMP AND CIRCUMSTANCE: PALACE, COURT AND HOUSEHOLD IN ASSYRIA 879-612 BCE ${ }^{1}$
}

\author{
Gojko Barjamovic
}

An essential component in understanding the structure and organisation of the Assyrian imperial court is its physical manifestation. The court as a social institution was set in the spatial framework of the royal palace. This was the setting in which the king and the imperial elite would interact, and a focal point of the imperial bureaucracy. It was a venue for the advertisement and manifestation of royal power and ideology, and a conspicuous backdrop for military reviews, political negotiations and the reception of foreign dignitaries. Finally, it was the home of the royal family. The present enquiry integrates the extensive written record of the activities of the Assyrian royal court with the material evidence obtained in excavations of the imperial state capitals and link the physical environment of the royal court to elements of function and conduct.

\section{The North-West Palace at Nimrud}

Perhaps the most important and best known example of an Assyrian royal residence is the so-called North-West Palace at Nimrud (Fig. 1). The building was constructed by Assurnasirpal II as the centre of a new state capital, when power was transferred from its ancient seat in the city of Assur during the first territorial wave of Neo-Assyrian expansion in the early ninth century B.C. A new and experimental layout and program of decoration was made to reflect the confident self-perception of the budding empire, and the new design involved a reinterpretation of the traditional functions of a royal palace. In time, the North-West palace came to be the essential architectural blueprint that was copied and developed in all later royal residences. The

${ }^{1}$ While writing this article, my close friend and colleague Stine Rossel lost her life in a tragic accident. I dedicate it to the lasting memory of her extraordinary personality and her treasured friendship. 


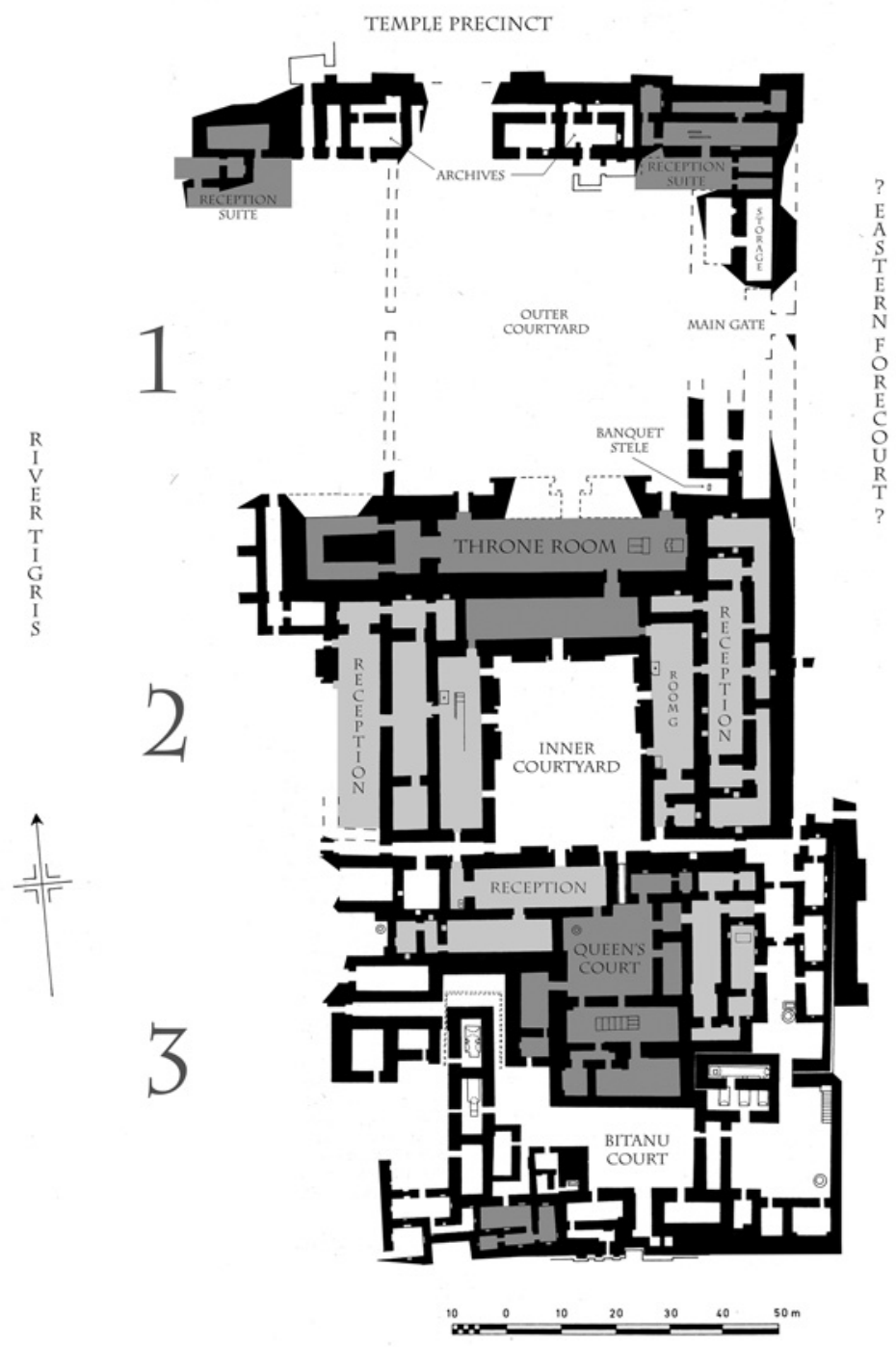

Figure 1. Plan of the North-West Palace. The three main sections of the palace have been numbered 1-3. Apparent reception areas, suites, the queen's court and a number of larger apartments in the living quarters of the palace have been highlighted in various shades of grey. 
structure itself continued to operate as a seat of the imperial family for more than two centuries, and even when the political capital moved to Dur-Sharrukin in the late 8th century and Nineveh in the early 7 th, some parts of the edifice continued to function as a seat for state activities and local provincial administration.

Although the western section of the palace has largely disappeared due to erosion, the excavated part of the building still covers an impressive area of more than $28,000 \mathrm{~m}^{2}$. This makes the structure fairly small in relation to the later Assyrian royal residences, but a comparison with the $13,000 \mathrm{~m}^{2}$ of the palace of Augustus in Rome plainly marks it as a momentous architectural, economic and artistic undertaking for its time. ${ }^{2}$ In some sections the North-West Palace would have risen to several stories, and roof space, terraces and porticos may also have played an important role in the function of the building. Unfortunately, the state of preservation and the early date of excavation of the main part of the building means that such information is now mostly lost to us. ${ }^{3}$

The North-West Palace is a particularly suitable starting point for a study of the physical setting of the Assyrian court for several reasons. A large part of its ground plan is available for study, the building represents an early prototype of a Neo-Assyrian palace, and a large and well-recorded assemblage of archaeological artefacts helps to identify the activities that took place in the structure as well as the identity of those who performed them. Also, the architectural layout shows a strong intentionality and sense of rationale, and the individual elements of the building reflect and serve a closely defined set of functions

${ }^{2}$ For the palace of Augustus see Inge Nielsen, Hellenistic Palaces. Tradition and Renewal, Studies in Hellenistic Civilization 5 (Århus 1994) pp. 173 ff. For a general overview of palaces in the ancient Near East, see Irene J. Winter, "Seat of Kingship"/“A Wonder to Behold": The Palace as Construct in the Ancient Near East', Ars Orientalis 23 (1993) pp. 27-55.

${ }^{3}$ For the early excavations, the rediscovery of Assyria in European scholarship, and its close ideological bonds with French, German and British imperialism, see Mogens T. Larsen, The Conquest of Assyria: Excavation in an Antique Land, 1840-1860 (New York; London 1996) and Suzanne Marchand, 'Orientalism as Kulturpolitik: German Archeology and Cultural Imperialism in Asia Minor', in: Volksgeist as Method and Ethic: Essays on Boasian Ethnography and the German Anthropological Tradition, George W. Stocking, Jr., ed., History of Anthropology 8 (Madison 1996) pp. 298-336. The history of excavations at Nimrud has been summarised in Joan and David Oates, Nimrud: an Assyrian Imperial City Revisited (London 2001). 
associated with the new regime. ${ }^{4}$ Even to a modern audience its decoration helps to expose a distinct set of meanings.

The spatial organisation of the building seems to follow a fairly straightforward design, each sector relating to a number of large courtyards and key rooms with a specific purpose. ${ }^{5}$ The main gate in the monumental façade on the eastern side of the palace gave access to a large outer courtyard and a number of surrounding rooms that together constituted the precinct occasionally referred to in the Assyrian texts as the 'gate' or 'outer' wing ( $b \bar{a} b \bar{a} n u)$ of the building. ${ }^{6}$ A small entrance in the northern wall of the courtyard connected a series of

${ }_{4}$ The main analysis is found in John Malcolm Russell, 'The Program of the Palace of Assurnasirpal II at Nimrud: Issues in the Research and Presentation of Assyrian Art', American Journal of Archaeology 102, 4 (1998) pp. 655-715, with particular reference to the work of Amos Rapoport, 'Systems of Activities and Systems of Settings', in: Domestic Architecture and the Use of Space. An Interdisciplinary Cross-Cultural Study, Susan Kent, ed., New Directions in Archaeology Series (New York 1990) pp. 9-20, in relation to the phenomenon of redundancy of cues in architecture.

${ }^{5}$ A number of dedicational inscriptions related to the foundation of the palace were physically incorporated in the building, showing that the Assyrian builders themselves distinguished the different wings of the palace by the use of a particular type of exotic wood in its decoration: "I cleared away the old ruin hill (and) dug down to the water level. I sank (the foundation pit) down to a depth of 120 layers of brick. I founded therein a palace of cedar, cypress, daprānu-juniper, boxwood, meskannuwood, terebinth and tamarisk as my royal residence (and) for my lordly leisure for eternity. I made beasts of mountains and seas in white limestone and parütu-alabaster (and) stationed (them) at its doors. I decorated it in a splendid fashion; I surrounded it with knobbed nails of bronze. I hung doors of cedar, cypress, daprānu-juniper (and) meskannu-wood in its doorways", Albert K. Grayson, Assyrian Rulers of the Early First Millennium BC I (1114-859 BC), The Royal Inscriptions of Mesopotamia, Assyrian Periods, vol. 2 (Toronto 1991) A.0.121.2, pp. 52-60. Hundreds of similar dedicatory inscriptions by Assurnasirpal II have been uncovered in the North-West Palace. All are edited and translated in Grayson, Assyrian Rulers. Unfortunately, the general state in which the building is preserved prevents one from tracing this ancient partition, and instead one is compelled to consider physical access, room decoration and the artefacts recovered from the building to divide the structure into meaningful functional units. One exception is the treasury just south of the western banquet suite (vide infra), where the later Assyrian ruler Sargon II left an inscription stating that he had restored the juniper-wing of the palace. Interestingly, the feature we tend to focus upon as most characteristic element of an Assyrian palace today, namely the kilometre-long rows of stone-cut panels decorated with brightly painted reliefs, receives no mention in the ancient account.

${ }^{6}$ See Oates, Nimrud, for the detailed study of the architecture and finds from the North-West Palace. The area east of the main gate has never been properly investigated, and it is entirely possible that an additional outer court would have given access to the ba $\bar{a} \bar{a} n u$ in the manner of the later Assyrian palaces at Khorsabad and Nineveh, see Julian E. Reade, 'The Ziggurat and the temples of Nimrud', Iraq. Journal of the British School of Archaeology in Iraq 64 (2002) pp. 135-216. The apparent lack of any quarters for the royal guard would seem to support this conclusion. 
storerooms and archives to the temple precinct and the ziggurat-tower beyond the palace enclosure. ${ }^{7}$ In addition, a minor gate in the western wall would presumably have led down to the Tigris quay adjacent to the citadel walls, but all remains of such a structure have been obliterated by erosion.

The $b \bar{a} b \bar{a} n u$ consisted of two parts, each tied to a similar set of apartments belonging to officials of sufficient importance to be treated with considerable ceremony. Both apartments consisted of an antechamber, a reception area, rooms for ablutions, storage facilities, and presumably also an upper structure with living quarters for the official. The remaining rooms surrounding the courtyard were laid out to store bulky commodities such as wine, grain and oil, and scribal offices were located in the immediate vicinity of the service entrance to the north. When excavated, the archives still contained filing cabinets with documents found in situ and included a large number of important state letters and official correspondence. ${ }^{8}$ Other records refer to the storage of oil, wine and large amounts of grain (a single text mentions some three million litres). One also finds physical evidence for domestic activities in the bābannu precinct, such as carbonised wheat, barley and linseed, mortars, grindstones, spindle whorls and loom weights. ${ }^{9}$ Three large gates flanked by giant statuary lead from the southern façade of the main courtyards into the central part of the palace and the throne-room suite of the king. The southern wall of the courtyard was decorated with reliefs showing a procession of foreign dignitaries carrying gifts and tribute in plain reference to the ceremonies that would have been conducted in the adjacent throne-room (Fig. 2). The physical layout of the outer courtyard precinct, the recovered artefacts, and the presence of administrative records from the palace chancery all point to the function of the bābannu as a centre of administration as well as domestic activities, and an initial reception area of visitors to the imperial court. ${ }^{10}$

\footnotetext{
${ }^{7}$ Reade, 'The Ziggurat' provides a comprehensive study of the temple precinct directly north and east of the North-West Palace.

${ }^{8}$ The state letters from Nimrud are published in Henry W.F. Saggs, The Nimrud Letters, Cuneiform Texts from Nimrud 5 (London 2001).

${ }^{9}$ Oates, Nimrud, pp. 42-47. For the skilled craftsmen (kurtaš) employed in the royal workshops at the later Persian palaces, see Pierre Briant, From Cyrus to Alexander. A History of the Persian Empire (Winona Lake 2002) p. 257.

${ }^{10}$ For the use of the terms bābānu and bitānu, see The Assyrian Dictionary of the Oriental Institute of the University of Chicago [CAD] (Chicago 1956-2010) vol B.,
} 


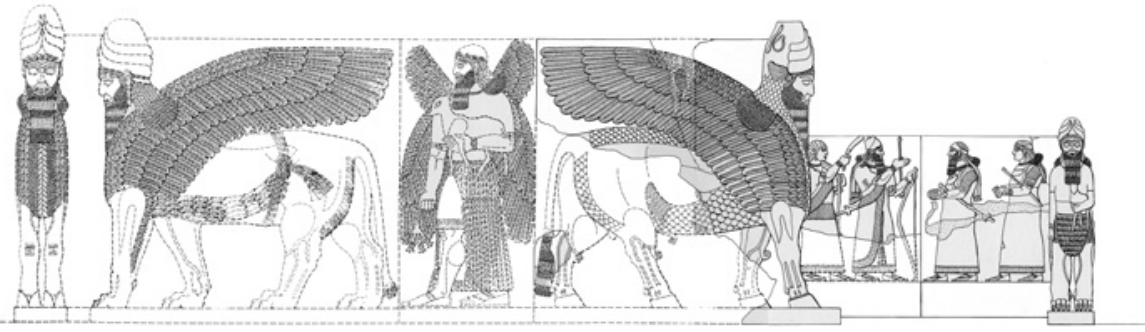

Figure 2. The relief decoration of the southern wall of the outer courtyard of the North-West Palace. The frieze continues from p. 32 onto p. 33. To the right foreign dignitaries are shown entering the doors to the throne room behind the wall carrying valuable gifts. To the left the king and the crown prince receive foreign embassies led to them by Assyrian

The grand throne-room behind the southern façade of the outer courtyard marks the nexus of the palatial complex. Its walls were covered in almost 3-m-high stone slabs carved in low relief and painted in bright contrasting colours of red, black and blue. In addition, each slab bears a long commemorative text relating the royal titles and achievements of Assurnasirpal written in the high literary dialect of the Babylonian language. The plastered walls and doorways were painted or decorated with delicate bands of glazed brick. Thick rugs similar to the later well-known Persian designs covered the floor of the room, and the tall doors were embellished with intricately sculpted bronze bands. The royal throne stood on a raised podium at the eastern end of the room.

The carved scenes on the walls show pitched battles, the siege of a walled city, open cavalry encounters, and the capture of an island fortress (Fig. 3). Both the visual impact and the authenticity of the narrative are striking and mark the first clear Assyrian attempt at producing historical narrative on a monumental scale for an audience that may have been predominantly illiterate. The geographical extent of the empire is represented by the placement of particular scenes within the composition, ${ }^{11}$ and each episode refers to specific incidents and indi-

pp. 7, 274-275. At the Achaemenid court the expression 'those of the gate' became a common term for the palace functionaries in general, see Briant, From Cyrus to Alexander, p. 260.

${ }^{11}$ An extensive literature on the subject of the Neo-Assyrian palace reliefs has appeared in the past three decades. Most important for the palace of Assurnasirpal II are: Julian E. Reade, 'Narrative Composition in Assyrian Sculpture', Baghdader 


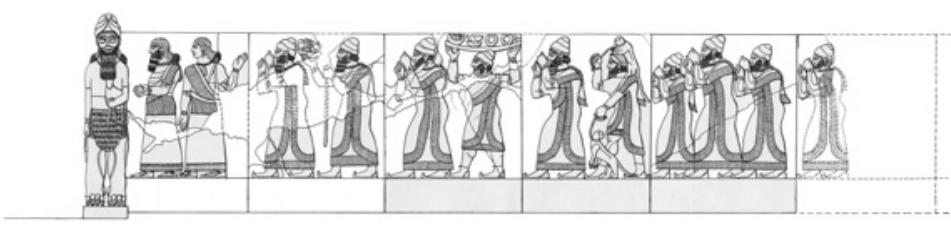

eunuchs and bearded courtiers. Some foreigners bring valuables and exotica while others present the golden torcs they presumably just received as audience gifts from the Assyrian ruler. Winged bulls and protective spirits guard the grand central gate. Reproduced from Paley and Sobolewski 1992, pl. 4.

viduals that would have been familiar to the contemporary audience: the fortress in the island was in fact taken, and the besieged city did fall to the Assyrian army led by its king and crown prince. In a sense therefore, the actions portrayed are historically correct, although they are of course far from realistic. The art could only handle victories, and natural and human-made obstacles are shown only as a preamble to the Assyrian king and his army overcoming them. The role of the Assyrian king as a universal ruler is emphasised throughout the imagery, and his military, religious and political power is underlined by juxtaposition to the generic lines of vanquished enemies-corpses and prisoners of war being led from conquered cities and battlefields. The atmosphere is one of invincible power and "calculated frightfulness", ${ }^{12}$

Mitteilungen 10 (1979) pp. 52-110; idem, 'Texts and Sculptures from the North-West Palace, Nimrud', Iraq. Journal of the British School of Archaeology in Iraq 39 (1985) pp. 203-214; Russell, 'The Program of the Palace of Assurnasirpal II'; idem, The Writing on the Wall: Studies in the Architectural Context of Late Assyrian Palace Inscriptions (Winona Lake 1999), and Irene J. Winter, 'Royal Rhetoric and the Development of Historical Narrative in Neo-Assyrian Reliefs', Studies in Visual Communication 7, 2 (1981) pp. 2-38; eadem, 'The Program of the Throneroom of Ashurnasirpal II', in: Essays on Near Eastern Art and Archaeology in Honour of Charles Kyrle Wilkinson, Prudence O. Harper and Holly Pittman, eds. (New York 1983) pp. 15-31; and eadem, 'Art in Empire: The Royal Image and the Visual Dimensions of Assyrian Ideology', in: Assyria 1995-proceedings of the 10th Anniversary Symposium of the Neo-Assyrian Text Corpus Project, Helsinki, September 7-11, 1995, S. Parpola and R. Whiting, eds. (Helsinki 1997) pp. 359-381. Recent treatments of the approach to pictorial narrative in the North-West Palace are found in S. P. Lumsden, 'Narrative Art and Empire: The Throneroom of Aššurnașirpal II', in: Assyria and Beyond. Studies Presented to Mogens Trolle Larsen, Jan Gerrit Dercksen, ed., Publications de l'Institut historiquearchéologique néerlandais de Stanboul 100 (Leiden 2004) pp. 359-385; Mehmet Ali Ataç, 'Visual Formula and Meaning in Neo-Assyrian Relief Sculpture', The Art Bulletin 88, 1 (2006) pp. 69-101, and Zainab Bahrani, Rituals of War. The Body and Violence in Mesopotamia (New York 2008).

${ }_{12}$ Albert T. Olmstead, 'The Calculated Frightfulness of Ashur Nasir Apal', Journal of the American Oriental Society 38 (1918) pp. 209-263. 

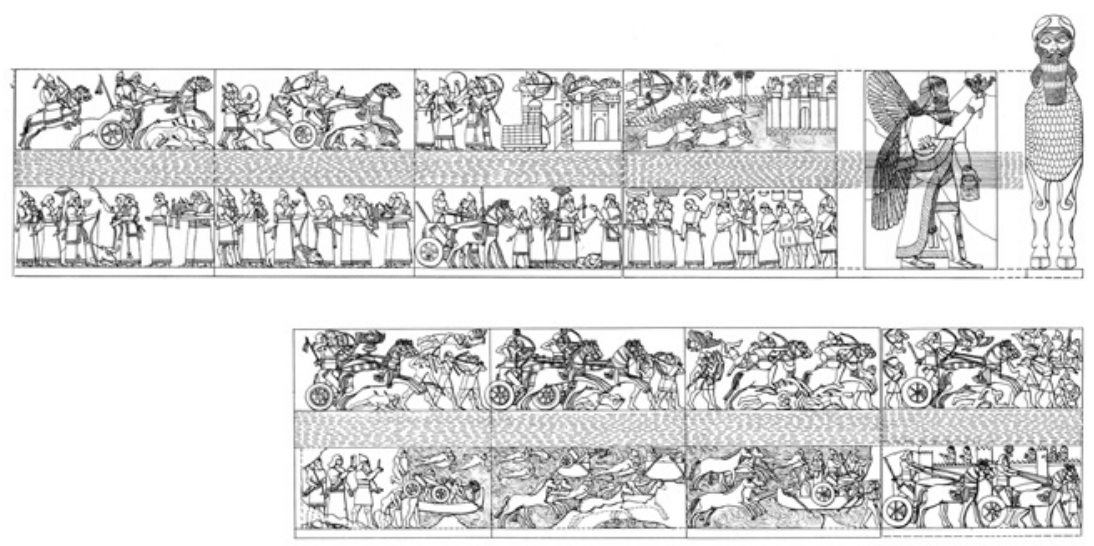

Figure 3. The relief decoration on the southern wall of Assurnasirpal II's throne-room of the North-West Palace. The illustration represents a continuous decorative band measuring $45.7 \mathrm{~m}$ that has been broken up into four parts in order to fit it onto two pages. It runs from the upper register of p. 34 onto p. 35 and it continues in the lower register on p. 34 from left to right. On the upper left, and next to where the royal throne would have stood, the reliefs show hunting scenes. The remaining scenes show open battles, siege, Assyrian forces and prisoners of war. The central

and the visual syntax underlines the intimate relation between the Assyrian king and divine Aššur as opposed to the heretical behaviour of his defeated foes.

A doorway set in the western end of the throne-room gave access to a grand staircase that presumably led to a second story or roof terrace where the ruler would stand to greet passing processions of dignitaries at grand imperial celebrations. ${ }^{13}$ Beyond an antechamber a large courtyard led to three distinct suites of reception rooms, shown in different shades of grey on the plan below. The western suite was accessible from the bābannu either directly through the throne-room or via a corridor leading to a porch overlooking the river. Judging by later architectural parallels at Khorsabad and Nineveh, the purpose of these rooms was to receive royal guests in a stately manner for banquets and

${ }_{13}$ Note e.g. the reference in the letter in Steven William Cole and Peter Machinist, Letters from Priests to the Kings Esarhaddon and Assurbanipal, SAA 13 (Helsinki 1998) no. 80: "The face of the king, my lord, has been seen by very many people. Let an order be given to the palace supervisors: when the elders pass beneath the terrace, let them allow me to see the face of the king, my lord, and may the king look at me." 

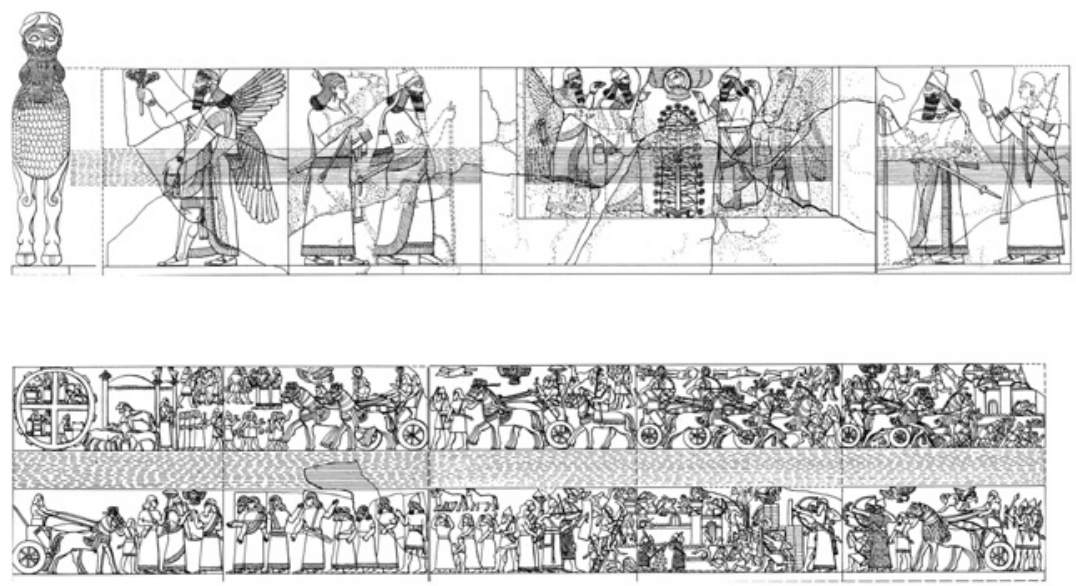

scene, which is set in a raised panel directly across from the grand entrance opening onto the outer courtyard, shows the king and winged genies flanking an image of the sacred tree. Reproduced from Meuszynski 1981, pl. 1-2.

entertainment. ${ }^{14}$ Wall reliefs illustrate such banquets and show seated guests on elaborate furniture consuming exquisite food and drink while attended by servants, singers and musicians (Fig. 4). ${ }^{15}$

The smaller rooms in the suite would have included storage facilities for fittings, dishes etc., and the so-called 'ablution-rooms' that may have functioned as toilets and baths. ${ }^{16}$ South of the banquet-suite a number of small, disconnected rooms may have formed the palace treasury. In a commemorative inscription found in situ, the Assyrian ruler Sargon II celebrates the repair of this section of the palace, stating that he had $345 \mathrm{~kg}$ of gold and $63,012 \mathrm{~kg}$ of silver stored in it. ${ }^{17}$ Likewise, in the

${ }^{14}$ See Geoffrey Turner, 'The State Apartments of Late Assyrian Palaces', Iraq. Journal of the British School of Archaeology in Iraq 39 (1970) pp. 177-213, and the comprehensive analysis in Russel, "The Program of the Palace of Assurnasirpal II at Nimrud'.

${ }^{15}$ For the records of various royal banquets, listing items on the menu and people attending, see Frederico Mario Fales and J. Nicholas Postgate, Imperial Administrative Records. Part I. Palace and Temple Administration, SAA 7 (Helsinki 1992) nos. 148-157; for lists of the aromatics, fumigants and sweets consumed at such occasions, see nos. 145-147.

${ }^{16}$ Compare e.g. to the baths found at Persepolis. Several written references show that the Persian king (Aelian, VH XII.1) and his nobles (Polyaenus VIII.16.1; Diodorus XIV.80.8) would retire here to bathe and relax on a regular basis.

17 Daniel David Luckenbill, Ancient Records of Assyria and Babylonia (Chicago 1927) vol. 2, pp. 72-73. 

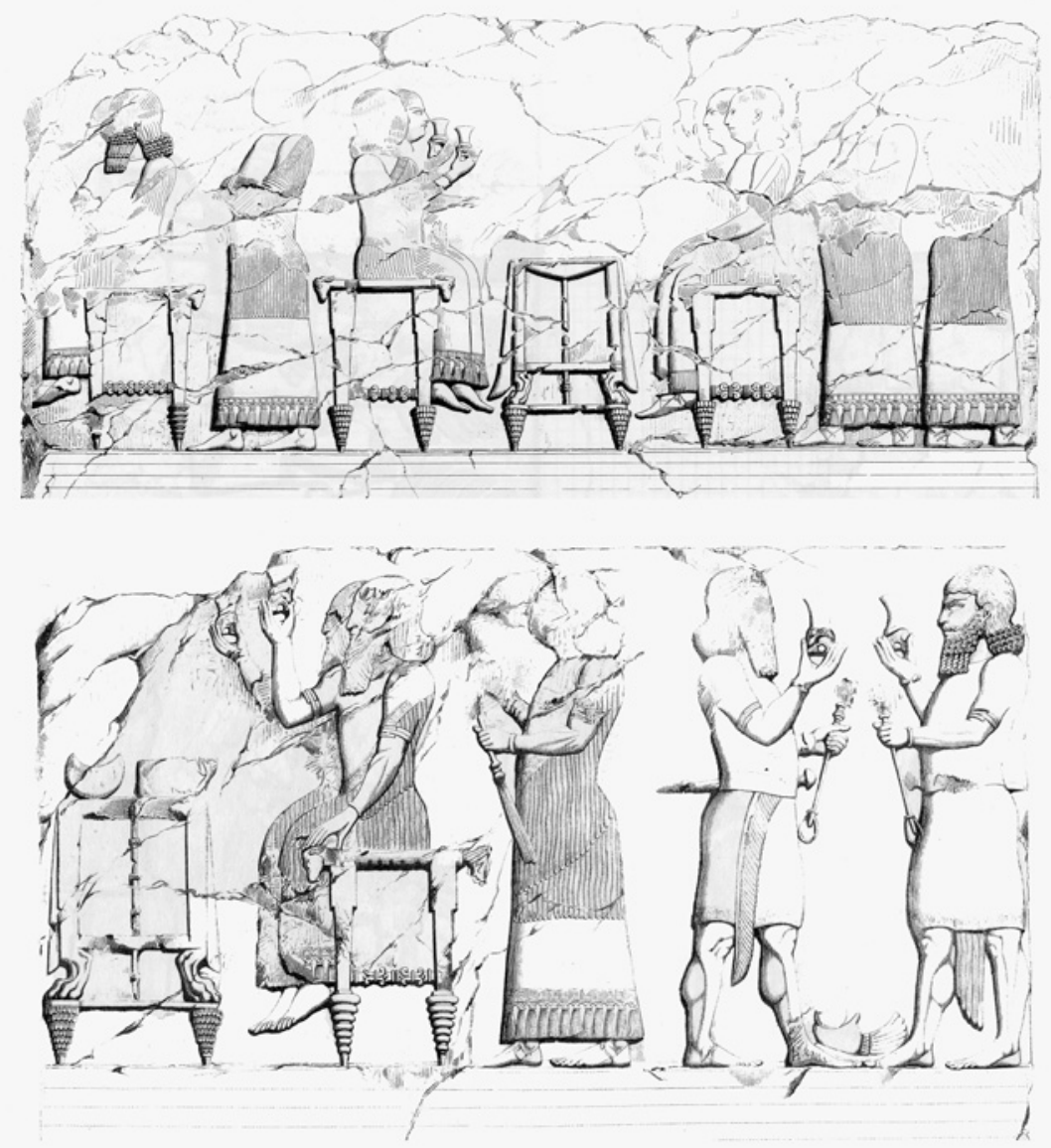

Figure 4. Reliefs showing banquet scenes. From rooms 2 and 7 in Sargon II's palace at Khorsabad (ancient Dür Šarrukinn). Eunuchs and bearded courtiers, some of them with sceptres, are shown standing or seated on elaborate chairs while eating and drinking wine served from large cauldrons in rythons. Line drawings by E. Flandin reproduced from Botta 1846-50 vol. i pl. 65 and vol. ii pl. 112. 


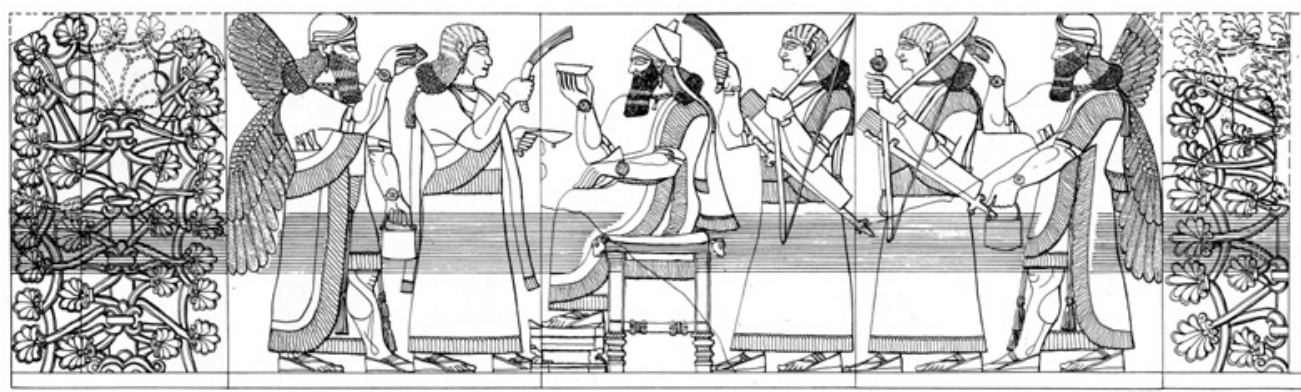

Figure 5. Relief from the North-West Palace room G of the eastern reception suite. The panels show the king drinking wine surrounded by eunuchs and protected by bearded genies and the sacred tree. Reproduced from Meuszynski 1981 plate 8.

nearby room a deep well was found to contain hundreds of fragments of fine ivory furniture and decorative pieces, presumably belonging to objects that had been kept in the nearby treasuries but were torn apart and discarded during the final sack of the palace in 612 B.C. ${ }^{18}$ On the eastern side of the courtyard was a second suite of reception rooms. ${ }^{19}$ Reliefs showing the king seated on his throne in splendid robes and drinking wine in the company of his officers, genii and images of the sacred tree may indicate its use as a setting for royal symposia (Fig. 5). ${ }^{20} \mathrm{~A}$ final third group of rooms, just south of the inner courtyard, is decorated with reliefs showing winged genii attending the sacred tree. The composition focuses on an image of the king in warlike attire flanked by armed courtiers.

${ }^{18}$ Oates, Nimrud, pp. 90ff.

19 For a different opinion on the use of these rooms, cf. e.g. Russell, 'The Program of the Palace of Assurnasirpal II', pp. 671-673.

${ }^{20}$ The importance of the royal symposia can not be gleaned directly from the textual evidence, but the large amounts of wine distributed to the officials of the palace, the rich pictorial evidence for symposia on palace reliefs, and the finds of numerous implements associated with wine drinking in the Assyrian royal palaces add to the vivid narratives from the Persian court about the delicate ceremonial surrounding such occasions. In Persepolis, the Royal Cupbearer alone had the task of tasting and delicately pouring the wine for the king, thereupon presenting: "the goblet conveying it with three fingers, to offer it in such a way as to place it most conveniently in the grasp of the one who is to drink" (Xenophon, Cyr. I.3.8), see also Briant, From Cyrus to Alexander, p. 264. Surely the Assyrian Chief Cupbearer ( $r a b$ šāqêे) portrayed on the Khorsabad reliefs had similar, if not identical, responsibilities. For the amounts of wine distributed to the officials of the palace, see J.V. Kinnier Wilson, The Nimrud Wine Lists, Cuneiform Texts from Nimrud 1 (London 1972). 
Based upon the ground plan and room decoration one may speculate about the exact functional differences between the three reception suites, but a general interpretation of the central section of the palace as a functional extension of the throne-room to receive guests in more private surroundings seems probable. Plainly, the throne-room, the treasury and the state apartments were the locus of power par excellence in the empire. It was where the king presided, where strategic decisions were made, and where the imperial magnates, advisors and foreign ambassadors were summoned for political, religious and social functions.

The southernmost extension of the palace consisted of the private living quarters of the royal family and their closest servants. In the contemporary sources occasional references to the bìtānu ('interior' or 'domestic') wing distinguish it from the bābānu ('outer' or 'official') section. Secluded from the outside world and accessible only through a fairly limited number of access points, it housed the palace women, their children, their ladies in waiting and the household staff. A number of small courtyards lead to separate sets of domestic chambers, each with fairly restricted linear access. Rooms, sometimes equipped with built-in cupboards, water-storage and adjacent bathrooms, each form a unit suitable for living quarters or administrative offices for individuals or small groups. Below the floors lay the tombs of the predominantly female occupants of the wing.

Finds from the bitānu include precious objects that can easily be associated with life in the private sector of the palace. One room was found to contain religious and lexical texts that may have belonged to a small palace library, and some chambers housed the archives of palace functionaries operating from the domestic wing. ${ }^{21}$ Occasional references in the records to the procurement of wool and livestock for the residents of the palace adds to the image of the building as a space

${ }^{21}$ Olof Pedersén, Archives and Libraries in the Ancient Near East, 1500-300 BC. (Bethesda 1998), pp. 147-151. The religious and lexical texts are published in J. Nicholas Postgate, The Governor's Palace Archive, Cuneiform Texts from Nimrud 2 (London 1973), nos. 268-272, and the administrative texts and dockets as nos. 247-265. Part of an archive was unearthed in the connecting hall west of the bitannu-court. Selected texts have appeared in Karlheinz Deller and Abdulillah Fadhil, 'Neue Nimrud-Urkunden des 8. Jahrhunderts v. Chr.', Baghdader Mitteilungen 24 (1993) pp. 243-270, and in Ali Y. Ahmad and J. Nicholas Postgate, Archives from the Domestic Wing of the NorthWest Palace at Kalhu/Nimrud, Edubba 10 (London 2007). 
for work as well as living. ${ }^{22}$ At least two wells supplied its residents with water.

A prominent court and a suite of rooms just south of the inner courtyard appear to form a larger official apartment that presumably represents the court of the Assyrian queen. She is known to have been the head of a separate household with a distinct hierarchy of administrative as well as military officials. Fragments of ivory furniture, lavish murals, glazed wall knobs for hanging tapestries, and large amounts of gold sheet were recovered from these rooms, underlining the comparative wealth and importance of its occupant. In the Greek sources, the bedchamber of the Persian king is a recurring topos in the court narratives, but next to nothing is known about the private quarters of the Assyrian ruler and his queen. Perhaps they were located on an upper floor of the building and left no discernable trace. Only a single staircase has been identified in the bitannu, but the width of the walls in the western section of the complex seems to indicate that substantial chambers could have been located on the first floor of the building, overlooking the Tigris. If the association of the nearby suite with the Assyrian queen is correct, her upper apartments would have been immediately adjacent to the king's bedchamber.

\section{Visitors and Protocol in the Assyrian Imperial Household}

The detailed archaeological record of the physical setting of the Assyrian royal court may be connected to an extensive number of written sources to help form a comprehensive image of the social hierarchy and state protocol in relation to its spatial component. Owing to the fact that the palace administration wrote its records on clay tablets, which survive very well in the archaeological record, a unique range of documents has come down to us from the everyday management of the building. In addition to state treaties, judicial records, omens, royal annals and a substantial political correspondence, a large number of administrative accounts give valuable information about the demography of the imperial household. Conversely, the type of detailed narratives set at the Persian court that one finds in the classical Greek

${ }^{22}$ Several texts list palace women and their weavers, and a docket found in the domestic wing records the substantial delivery of more than a ton of wool and almost $200 \mathrm{~kg}$ of goat's hair, cf. Postgate, The Governor's Palace Archive, no. 254. 
literature are lacking entirely from the Assyrian record. The present study therefore gains additional information through extrapolation and cross-reference to accounts of the Achaemenid royal household, whose imperial symbolism, protocol and administrative template to a large part derive from its Assyrian predecessor.

An important key to understanding Assyrian court etiquette and social hierarchy is found in a codified manual of the procedures enacted at a royal banquet. This unique text gives a detailed impression of the highly controlled ceremony and protocol associated with such occasions, and provides us important hints about the status and function of the royal servants:

On the day of the banquet, when the king enters the feast together with the magnates, the table and the divan for the king are placed opposite the doorway. When the king is seated, the palace supervisor enters, kisses the ground in front of the king, and gives his report to the king. The palace supervisor goes out and leads in the palace herald. The palace herald enters, kisses the ground before the king, and takes up position before the king with the standard. The palace herald gives his report to the king. The palace supervisor goes out, and he leads in the grand vizier. The grand vizier enters, kisses the ground before the king at the threshold, and stands opposite the king. The palace herald and the grand vizier go out. ${ }^{23}$

The palace herald and the grand vizier rank among the most important officials in the Assyrian Empire, and both belonged to the group known as the 'magnates' (rabiu) who stood immediately below the king, the queen and the crown prince in the imperial hierarchy. In the present context, however, the palace supervisor ( $\check{s} a$ pann ekalli) clearly holds the role of introducer to the king and chief of palace protocol. Although his position in the overall state hierarchy was far below the herald and the grand vizier, and each royal palace in the empire had one or more palace supervisors, his position inside this narrow social framework evidently granted him an exceptional status. At the court of the Persian king, the official known in Greek as the chiliarch carried out similar functions, and his personal intercession was allegedly required for any visitor to be granted a royal audience. In fact, several classical authors count the chiliarch among the highest ranking bureaucrats at the Achaemenid court, even if the Persian evidence sug-

${ }^{23}$ Copy and edition in Karl F. Müller, Das assyrische Ritual I: Texte zum assyrischen Königsritual. Mitteilungen der vorderasiatisch-ägyptischen Gesellschaft 41/3 (Leipzig 1937). 
gests otherwise ${ }^{24}$ His function as introducer to the king as his subjects was obviously of paramount importance to visiting outsiders, and a Greek misconception about his relative status in the imperial hierarchy is easily explained.

That the Assyrian palace supervisor would have held similar powers in deciding who could enter the palace and meet the king may be gleaned from the following passage from a letter written by Assurbanipal in a reply to a complaint filed by the city assembly at Nippur:

And in regard to what you wrote: "When fifteen of our elders came to greet the king, only half of us were (allowed) to enter before the king"... This is the fault of the sandabakku, who is your governor, and secondly, of the palace supervisor, who did not admit you into my presence. By Aršsur, my God, I swear that I did not know that only half of your number had entered before me. How should I know who is who? ${ }^{25}$

The level of formalised communication at the royal audience is also evident from the apparent failure of the elders to simply inform the king about their absent colleagues, and one may speculate whether most meetings between the king and his subjects may have been stylised to a point where they involved little direct communication. The position of an official with 'gate-keeping' duties, who decided not only who was to be granted a royal audience, but also the topic and outline of that audience, is well-known from other courts and leads to obvious conjectures about the Assyrian palace supervisor. It would appear that he was among the few high officials actually resident at the royal palace itself, and in reference to the ground plan of the North-West Palace at Nimrud one may speculate whether the reception suite immediately north of the main gate could have belonged to his office. Here the supervisor would be able to receive visitors and grant them entry to the bābānu and the king.

There was no Assyrian nobility in the strict sense of an exclusive society of interrelated landed gentry and a formalized system of hereditary titles. Certainly, several of the king's magnates could produce impressive pedigrees, but the inclusive character of Assyrian imperialism encouraged the integration of foreign and local elites

\footnotetext{
${ }^{24}$ Briant, From Cyrus to Alexander, pp. 258-261.

${ }^{25}$ Cf. Robert F. Harper, Assyrian and Babylonian Letters belonging to the Kouyunjik Collection of the British Museum vols. I-XIV (Chicago 1892-1914) p. 287, and note also the letter in Cole and Machinist, Letters from Priests to the Kings, no. 80 quoted above.
} 
directly into the highest echelons of society. In addition, a large number of magnates were eunuchs, who at least nominally had their ties to family and outside loyalties severed by castration. Although there have been recent attempts to prove otherwise, it is difficult to demonstrate the existence of a royal council with permanent membership held by particular officials. ${ }^{26}$ Rather, it seems that individual merits, devotion and loyalty were decisive for the particular privileges and responsibilities bestowed upon each officer. Nevertheless, it seems clear that the highest offices of the Empire included at least seven specific officials referred to as 'the king's magnates', namely the treasurer (masennu), the palace herald (nägir ekalli), the chief cupbearer ( $r a b \check{s} \bar{a} q \hat{q})$, the chief eunuch ( $r a b \breve{s} a-r \bar{e} s i)$, the chief judge (sartinnu), the grand vizier (sukallu) and the commander-in-chief (turtānu). ${ }^{27}$

The majority of these offices came with large territorial provinces, and evidently the main executors of the Empire would have been absent from the central court for large parts of the year to manage their households in the provinces, to lead armies in military campaigns, and to perform political or ritual obligations on behalf of king and empire. Furthermore, it is clear that the attendance of these high officials at court did not necessitate their actual residence at the royal palace. Instead, most, if not all, of the magnates maintained extensive

${ }^{26}$ See Simo Parpola, 'The Assyrian Cabinet', in: Vom Alten Orient zum Alten Testament: Festschrift für Wolfram Freiherrn von Soden zum 85. Geburtstag am 19. Juni 1993, Manfried Dietrich and Oswald Loretz, eds. (Freudenstadt 1995) pp. 379-401, and Raji Mattila, The King's Magnates. A Study of the Highest Officials of the NeoAssyrian Empire, State Archives of Assyria Studies 11 (Helsinki 2000), and the critical review of Parpola's ideas in Jerrold Cooper, 'Assyrian Prophecies, the Assyrian Tree, and the Mesopotamian Origins of Jewish Monotheism, Greek Philosophy, Christian Theology, Gnosticism, and Much More', Journal of the American Oriental Society 120, 3 (2000) pp. 430-444.

${ }^{27}$ Importantly, this image is subject to chronological variation, and there is the real danger that undated texts, such as the banquet manual and the coronation ritual, reflect very different social circumstances, more than a century apart. Most of the offices are first attested during the reign of Assurnasirpal, and may constitute a part of the same overall reform instituted during his rule that also resulted in the moving of the state capital from Assur and the construction of the North-West Palace. However, the chief judge and the grand vizier are relative latecomers, and their offices seem to gain prominence only in the late 8th century. Similarly, the office of the commanderin-chief was divided in two (the commander-in-chief of the left and the commanderin-chief of the right) in 708 B. C., when also the palace herald and the chief cupbearer may have been demoted in the relative hierarchy of the king's magnates. In contrast, the governor of Damascus during this period seems to have held very close ties to the Assyrian king, and therefore to have held a particularly strong influence at the royal court. For a comprehensive analysis of the magnates, see Mattila, King's Magnates. 
households in the state capital as an addition to their provincial territory and prebendary lands spread throughout Assyria. The chief judge, the grand vizier and the chief eunuch seem to have had no province attached to their offices, and the latter is attested as the head of the permanent royal military corps (kișir šarri) and resident of a substantial court manor in the state capital.

Returning to the document describing the royal banquet, the text continues with the Crown Prince and the remaining royal sons and their entourage entering the room where the king is seated in waiting for the dinner. A detailed account is given of the procedures related to the servants attending censers used for burning aromatics and charcoal braziers. One royal lackey has to collect dirty napkins and hand out clean ones, while another is to pour the water used for washing hands. A servant keeps constant watch with a broom and a dustpan in case anything falls to the floor, while others see to the serving of the food and drink. When the sun is about to set, select servants hold torches between the tables of the 'magnates', while others keep watch over the torches and change them as they burn down. Officials of particular importance in relation to the feast are the chief eunuch ( $r a b$ $\check{s} a-r \bar{e} s i$ ) and the chief cook (rab nuhatimmi) but once again the palace supervisor stands in charge of protocol. When the dinner is ready to begin:

Grand goblets are set on the tables. The palace supervisor steps forward, saying: "Cupbearer, pour the drink!"... Then the chief cook announces: "Dinner is served." The Crown Prince begins (the feast). (After the dinner) the 'great men' rise and remain standing. The tables of the Crown Prince and the 'magnates' are lifted up. The table of the Crown Prince and the table opposite the King are removed. Servants enter and sweep (the room) with brooms and leave.

The existence of such written codes of stylised conduct demonstrates the apparent emphasis upon court ceremonial and brings to mind Norbert Elias' study of Louis XIV's court at Versailles. ${ }^{28}$ Elias emphasized the particular nature of the relationship between the French king and his nobles that came to be entrenched in an elaborate system of etiquette and ultimately came to focus upon the granting or refusal

\footnotetext{
${ }^{28}$ Norbert Elias, Die höfische Gesellschaft: Untersuchungen zur Soziologie des Königstums und der höfischen Aristokratie, Soziologische Texte 54 (Neuwied; Berlin 1969).
} 
of prestige tokens. The system was allegedly successful in manipulating the aristocratic ambitions of the courtiers and their fixation upon honour and distinction to a point where the court became a royal venue for reducing the political power of the nobles. However, in reaction to infrastructural problems the Assyrian rulers did in fact delegate considerable political and executive power to their magnates and governors, ${ }^{29}$ and the text instead seems to point to another characteristic feature of all royal courts, namely the prominence placed on the physical re-enactment of the hierarchical structures constituting its social fabric. A more explicit example of this pattern is seen in the following excerpt from the Assyrian ritual of coronation:

After they have presented the audience gifts to the king, the grand vizier and the deputy vizier lay down their sceptres before the king, the... his money bag, the chief singer his lyre, and each of the governors the (emblem) he is holding. They leave their position, retreat, and stand (waiting). The king then announces: "Each of you keeps his office". They prostrate themselves and grovel, draw near (again) and take up their position (again). ${ }^{30}$

The constituent elements in such formalised systems of behaviour are often tied directly to a particular setting for their physical performance-a ballroom, a throne-suite, an office, a sacred place and so forth. Hierarchical divisions are made tangible through the appropriation of space, and both horizontal order (masses in lines, marching soldiers or the relative positioning of individuals) and vertical separation (balconies, thrones, terraces, 'windows of appearance') play a vital role in maintaining and emphasizing existing social order on a symbolic level. Strict protocol and court etiquette underline the boundaries of the physical space in a stylised fashion to promote or emphasize collective consciousness and relative social standing.

Hundreds of administrative records, lists and inventories add a great deal of information to the picture of life at court and the size and makeup of the imperial household. Accounts deriving from the royal wine cellars record the daily allotments of wine distributed among palace staff allowing us to offer a fairly accurate estimate that as many as

${ }^{29}$ For a critique of Elias and his followers, who construe the court of the Sun King almost as a gilded prison for powerless magnates, see the introduction to Jeroen Duindam, Vienna and Versailles: The Courts of Europe's Dynastic Rivals, 1550-1780, New Studies in European History (Cambridge 2003), as well as his contribution in the present volume.

${ }^{30}$ KAR 216+135+137 iii 7-14, edited in Müller, Das assyrische Ritual, pp. 47-49. 
6,000 people were affiliated with the royal court-or rather, the royal institutions-at Nimrud in the 8th century B.C. ${ }^{31}$ This figure, which dates to a period when the Assyrian Empire was subjected to internal crisis and decentralization, may appear improbable at first glance, but, when compared to the claims of Dinon and Ctecias that some 15,000 people were provided for each day at the Persian court, the number of staff seems less astounding. ${ }^{32}$

According to the Greek accounts only the most important visitors to the Persian court were seated near the king's table, and the remaining nobles, the army and foreign dignitaries would be served in the palace courtyard. At banquets in the North-West Palace at Nimrud the principal visitors and officials could have been entertained in the suite of reception rooms west of the inner courtyard, while less important officials may have been seated on the terrace, west of the suite overlooking the Tigris, or in the inner courtyard where postholes for the support of tents or sun sails have been uncovered by the excavators. At the truly great gatherings even the palaces would not have been sufficient to entertain all the invited guests, and on such occasions we must suppose that the great courtyards, the royal parks or some other large spaces were engaged for the purpose.

The so-called 'Banquet Stela' set up to commemorate the inauguration of the new state capital and the North-West Palace at Nimrud gives us some important clues to the demography of the royal city and the size of the extended royal household:

When Assurnasirpal, king of Assyria, consecrated the Joyful Palace, the Palace Full of Wisdom, in Calah, (and) invited inside Assur, the great lord, and the gods of the entire land; 100 fat oxen, 1000 calves (and) sheep of the stable, 14,000...-sheep which belonged to the goddess Istar my

${ }^{31}$ Wilson, Nimrud Wine Lists, with a critical review of the figures provided in Frederico Mario Fales, 'A Fresh Look at the Nimrud Wine Lists', in: Drinking in Ancient Societies, Lucio Milano, ed., History of the Ancient Near East Studies 6 (Padova 1994) pp. 361-380.

${ }^{32}$ Athenaeus XII.538c. A single set of records (Fales and Postgate, Imperial Administrative Records, nos. 21-22) appears to summarize the total number of personnel related to the households of various Assyrian officials and institutions in a rather unclear context: (beginning destroyed) [x hundred, the b]odyguards; [x hundred, the horse train]ers of the open chariotry; [ $x$ hundred, the p]refects of the royal corral; $[x$ hundred, the ch]ariot fighters; 300, the mule house men; 520, the high officials; 300, the domestics; 300, the tailor; 220, the cupbearer; 400, the cooks; 400, the confectioners; 200, the scribes; 1,200, the Lady of the House; 800, the chief eunuch, [x hundred, A]hu-duri; [x hundred, De]nu-amur (rest destroyed). 
mistress, 200 oxen which belonged to the goddess Ištar my mistress, 1,000 siserhu-sheep, 1,000 spring lambs, 500 aiialu-deer, 500 deer, 1,000 large ducks, 500 ducks, 500 geese, 1,000 mesukku-birds, 1,000 qāribu-birds, 10,000 pigeons, 10,000 turtle doves...

The list continues for about half a page more, concluding with the passage:

When I consecrated the palace of Calah, 47,074 men (and) women who were invited from every part of my land, 5,000 dignitaries and envoys of the people of the lands of...16,000 people of Calah, (and) 1,500 zariqui [officials] of my palace, all of them-altogether 69,574 (including) those summoned from all lands and the people of Calah-for ten days I gave them food, I gave them drink, I had them bathed, I had them anointed. (Thus) did I honour them (and) send them back to their lands in peace and joy. ${ }^{33}$

The presence of some 16,000 guests resident in the new city leads to the assumption that a large part of the population of the city were somehow affiliated with the palace or the religious institutions on the acropolis in various functions. The comparable figure of 1,500 officials employed at the palace may then represent the officials directly associated with the royal household, and the total seems roughly comparable to that given by Dinon and Ctecias. The volume of food and drink consumed at the feast may also be compared to the record found in Polyaenus' collection of Strategems (IV.3.32) about the ingestion of the Persian court. He states that some 2,000 ardabs of flour, 400 sheep and billy goats, 300 lambs, 100 cows, 30 horses, 500 geese, 900 assorted birds, 30 gazelles, and tons of milk, garlic, onions, spices, fruit, jellies, oil, nuts and almonds were consumed each day. ${ }^{34}$

Polyaenus draws up this list only to offer his moral conclusions about the detrimental effects of an excessive diet, yet the account, if it is to be trusted, is indicative of the huge number of palace clients associated with the Persian court before the arrival of Alexander and his army. In the case of Assyria we know that also the queen, the crown prince and the magnates maintained separate households of a substantial size in the state capital. Administrative records contain references to the

\footnotetext{
${ }^{33}$ Grayson, Assyrian Rulers, A.0.101.30, pp. 102-154.

34 The full list is given in Briant, From Cyrus to Alexander, pp. 286-287. The text by Polyaenus opens with the following statement: "Since Alexander was in the Persian royal residence, the Great King's lunch and dinner were served to him according to what was inscribed on a bronze pillar, which also bore the other rules instituted by Cyrus. Here is what they contained."
} 
eunuchs, guards, charioteers, transporters, standard-bearers, scribes, craftsmen, overseers, doctors, diviners, musicians, kitchen staff, stable attendants, interpreters etc. active in the royal cities. Lists of court personnel are also quite common, providing us with evidence for some of the different groups present at the Assyrian court at a given time. One example contains a record of some 200 individuals associated with the royal palace that includes prefects, bodyguards, confectioners, chariot drivers, priests, boatmen, couriers, wine-managers, butchers, horsetrainers, trackers, guards and shepherds, to name but a few..$^{35}$ Occasionally we find lists of professionals hired for special tasks, such as architects, doctors, scribes, ironsmiths, diviners and potters, and in a similar fashion, records assign lodgings to officials who were clearly quartered outside the building in 'the residences beneath the window' or in the 'premises of the chief eunuch', 'the magnates', 'the brewers', 'the scribes' or 'the governor'. ${ }^{36}$

The intricate makeup and complex hierarchical structure of this wider 'outer court' and the closely associated imperial army are intermittently revealed in the so-called 'insurrection queries' directed by the royal extispicists to the divinatory Mesopotamian sun deity:

Šamaš, great lord, give me a firm, a positive answer to what I am asking you!... Will any of the eunuchs or the bearded officials-the kings' entourage-or any of his brothers and uncles, his family, his father's line, or junior members of the royal line, or the 'third men', chariot drivers or chariot fighters, or the recruitment officers, or the prefects of the exempt military, or the prefects of the cavalry, or the royal bodyguard, or his personal guard, or the keepers of the betannu gates, or the keepers of the outer (qannu) gates, or the 'rakku' eunuchs, or the [...] or the palace supervisors, the staff-bearers, the watchmen, the mounted scouts or the trackers, or the lackeys, tailors, cup-bearers, cooks and confectioners, the entire body of craftsmen, or the Itu'ean (auxiliaries), or the Elamite, the mounted archers, the Hittites or the Gurreans or the Arameans, the Cimmerians or the Philistines, or the Nubians, the Egyptians or the Šabuqeans, or the armed eunuchs, or the bearded officials who bear arms and stand guard for the king... will any man make an uprising and rebellion against Assurbanipal, son of Esarhaddon, king of Assyria? ${ }^{37}$

${ }^{35}$ Fales and Postgate, Imperial Administrative Records, no. 5.

${ }^{36}$ Fales and Postgate, Imperial Administrative Records, nos. 8-12.

37 Ivan Starr, Queries to the Sungod. Divination and Politics in Sargonid Assyria, SAA 4 (Helsinki 1990) no. 142. 
No great kitchen has been found in relation to the North-West Palace, and the abundance of meat, fish, sweets, fruit, wine, beer, spices, and vegetables recorded by palace officials would have been prepared elsewhere. Similarly, records show that the Assyrian palaces resounded with song and music of various ensembles sponsored by the courts of the king, the queen and the magnates who must have resided beyond the palace walls. Clearly, the extended or 'outer' court included much more than just the royal palace and the auxiliary buildings found on the citadel mound at Nimrud, and it seems reasonable to assume that a considerable fraction of those active at the palace were in fact free agents and artisans in the occasional employment of the royal court. A letter dated to the reign of Sargon II hints at the large amounts of ready cash available in Assyrian society by reference to a number of substantial loans taken by the king from independent merchants to help finance the grand building programme associated with the moving of the state capital to the site of Khorsabad. ${ }^{38}$

\section{The 'Women's Quarters'}

The private section of the Assyrian palaces is commonly referred to in the scholarly literature as the royal 'harem'. A number of enduring stereotypes based upon prejudiced accounts of the Persian, Ottoman and Chinese courts as golden cages of deprivation or hotbeds of conspiracy have been systematically dismantled in recent years as part of the general Orientalism debate. ${ }^{39}$ The continued use of the term to denote the

${ }^{38}$ Simo Parpola, The Correspondence of Sargon II, Part I. Letters from Assyria and the West, SAA 1 (Helsinki 1987) no. 159. The loan provided by the merchant Šulmanu-[...] to the Assyrian king, which is specifically referred to in the letter, amounts to the remarkable sum of 570 minas (c. $280 \mathrm{~kg}$ ) of silver. See Mikko Luukko and Greta van Buylaere, The Political Correspondence of Esarhaddon, SAA 16 (Helsinki 2002) no. 54 for an additional example of the Assyrian king raising cash through loans from private merchants.

39 See e.g. Stephanie Dalley and Nicholas J. Postgate, The Tablets from Fort Shalmaneser, Cuneiform Texts from Nimrud 3 (London 1984); Joan G. Westenholz, 'Towards a New Conceptualization of the Female Role in Mesopotamian Society', Journal of the American Oriental Society 110, 3 (1990) pp. 510-521; Karen Radner, Die Neuassyrischen Privatrechtsurkunden als Quelle für Mensch und Umwelt, State Archives of Assyria Studies 6 (Helsinki 1997); Sarah Melville, The Role of Naqia / Zakutu in Sargonid Politics, State Archives of Assyria Studies 9 (Helsinki 1999); Marc Van de Mieroop, Cuneiform Texts and the Writing of History (London; New York 1999); Zainab Bahrani, Women of Babylon, Gender and Representation in Mesopotamia (London; New York 2001); Elna K. Solvang, A Woman's Place is in the House: 
private section of a palace where the women were typically quartered must therefore be qualified to disassociate it from the simplistic view that the women associated with the palace were invariably present for sexual purposes and forced to live under miserable conditions. As shown below, some of the royal women do indeed seem to have led prescribed lives, yet others just as clearly held powerful positions at the imperial court with wealth and agency in their own right.

A term with connotations similar to the 'harem' was used in Assyrian to refer to the social institution linked to the private sector of palace, namely the bèt issäte or the 'House of the Women'. Although the general term for the private wing of the palace appears to have been the bitānu or 'Inner Quarters', ${ }^{40}$ there existed this distinct unit within its walls, which must have included the residence for the royal women

Royal Women of Judah and Their Involvement in the House of David, Journal for the Study of Old Testament Supplement Series 349 (London; New York 2003); Saana Teppo, Women and their Agency in the Neo-Assyrian Empire, unpub. MA thesis, University of Helsinki (Helsinki 2005) Saana Teppo, 'The Role and the Duties of the Neo-Assyrian ŠAKINTU in the Light of Archival Evidence' State Archives of Assyria Bulletin 16 (2007) pp. 257-272 and the critical discussions in Julia M. Asher-Greve, 'Feminist Research and Ancient Mesopotamia: Problems and Prospects', in: A Feminist Companion to Reading the Bible, Athalya Brenner and Carol Fontaine, eds. (Sheffield 1997) pp. 218-237, and Elna K. Solvang, 'Another Look 'Inside': Harems and the Interpretation of Women', in: Orientalism, Assyriology and the Bible, Steven Holloway, ed. (Sheffield 2007) pp. 374-398. In general, the conception of the 'oriental harem' can be shown to derive from 19th-century representations of Oriental decadence, which ultimately date back to a Greco-Roman ideological discourse through the intimate intellectual bond between classical tradition and the late romanticist movement. One finds such legendary accounts as the story of Sardanapalus, "who lived in recluse in his palace, seen only by his eunuchs and wives", himself an "effeminate debauchee, sunk in luxury and sloth." - notes by E. H. Coleridge from Works / Lord Byron, 18981904, "Sardanapalus" by George Gordon, Lord Byron. The same image repeated in the poems and literary works by Choerilus, Ctesias and Dickens and in paintings e.g. by Delacroix (La Mort de Sardanapale. 1827-28. Oil on canvas. Louvre). Note e.g Charles Dickens: A Tale of Two Cities, II: XXIV: "It had never been a good eye to see with-had long had the mote in it of Lucifer's pride, Sardanapalus's luxury, and a mole's blindness".

${ }^{40}$ Note also the term 'Second House' (bètu šaniu), which may in some instances refer to the servant quarters of a royal palace, though it could also represent a separate building used to house the palace staff (for discussions, see Radner, Die Neuassyrischen Privatrechtsurkunden, p. 272, and Ahmad and Postgate, Archives, p. 6.) Note also Samuel M. Paley and Richard P. Sobolweski, The Reconstruction of the Relief Representations and their Positions in the North-West Palace at Kalhu (Nimrüd) III, Baghdader Forschungen 14 (Mainz 1992) p. 47, and Russel, 'The Program of the Palace of Assurnasirpal II at Nimrud', pp. 666-667, who on the basis on an inscribed slab discovered in secondary archaeological context suggest that the 'Second House' may have been the state apartment located west of the throne room and facing the Tigris. A 'First House' would have referred to the throne-room suite itself, and the 'Second 
and children. The recent discovery of the rich tombs of the Assyrian palace ladies ( $\check{a} a$ ekalli) in the southernmost wing of the North-West Palace corroborates the notion that the rear section of the building would have served as the private quarters of the royal family, and that its narrow rooms and halls were home to the eunuchs and ladies belonging to the king's household. Unfortunately, our understanding of the Assyrian bèt issāte and bitānu remains fairly vague.

The social institution of a 'harem' as such has a long history in Mesopotamia and goes back at least as far as the time of the Ur III Empire (2112-2004 B.C.). It is well documented in the palace archives from the state of Mari on the Euphrates (c. 1775 B.C.), and typified in the written reproach by the aging King Shamshi-Addu to his son and viceroy for preferring to lie in the arms of his concubines instead of taking care of business. It seems clear however, that the Assyrian 'harem' was rather different from the ones found in later Istanbul or Beijing both in size and character. Admittedly our main source for the Assyrian institution of the 'harem' comes from a collection of palace decrees (riksu) dated to the 11th century B.C. that pre-dates the NeoAssyrian imperial expansion, but a number of the points evidenced in the edicts may well have applied also to its later manifestation at the North-West Palace.

The documents in question are poorly preserved, and of 23 individual stipulations no more than half can be interpreted with any certainty. ${ }^{41}$ However, in spite of their fragmentary nature, the decrees give a view of what life must have been like in the Women's Quarters. The old royal palace in Assur that served as a precursor to the North-West

House' would in that case have been the 'Banquet House' of the palace (Russel, 'The Program of the Palace of Assurnasirpal II at Nimrud').

${ }_{41}$ The Middle Assyrian Palace Decrees (also referred to as the 'Harem Edicts') represents a collection of regulations dealing with the internal activities of the palace personnel. The collection as we have it was assembled in the time of Tiglath-Pileser I (1114-1076 B.C.) and includes decrees issued by nine kings. Eight of the tablets (now in Berlin) were published by Ernst Weidner, 'Hof- und Harems-Erlasse assyrischer Könige aus dem 2. Jahrtausend v. Chr.', Archiv für Orientforschung 24 (1954-56) pp. 122-127. A ninth (at Yale) without documented provenience was published in Gary Beckman, and Benjamin Foster, 'Assyrian Scholarly Texts in the Yale Babylonian Collection', A Scientific Humanist. Studies in Memory of Abraham Sachs, in Erle Leichty et al., eds. (Philadelphia 1988) pp. 1-26. An edict from 14th century Nuzi, i.e. roughly contemporary with the earliest of the Assyrian Palace Decrees, dictates the internal code of behaviour in regard to the alienation of female palace slaves and palace retainers. 
Palace in Nimrud was a crowded place, and by the time the edicts were composed the building had stood for centuries. ${ }^{42}$ The small edifice with narrow corridors and dark courtyards served a wide variety of functions that clearly made it difficult to separate people properly. Groups that were not supposed to have any contact would occasionally run into each other, and a number of edicts are concerned explicitly with correct behaviour under such circumstances. We hear about the required conduct of visiting midwives, and one paragraph deals with the impurity of menstruating women. Finally, a series of stipulations are concerned with the corporal punishments that a palace woman was sanctioned to perform upon her female servant, but also the penalties if her servant should accidentally die from the harsh treatment.

It is difficult to estimate the number of women living in the Old Palace in Assur, but it seems that only a limited number would have had permanent residence in the building. In addition to the queen and the king's mother, the palace housed a certain number of secondary wives and other 'palace women' (sekretu), ${ }^{43}$ and servant girls assigned to each of these women would have resided in the palace part-time. Some such servants were apparently married to men who lived outside in the city, since one of the edicts is concerned with the regulations for their leaving the building on their days off. In spite of all this, the Middle Assyrian decrees do in fact give the overall impression that the 'harem' of the Old Palace was a physically restricted space in which the royal women were kept in loneliness and boredom: ${ }^{44}$

If a woman of the palace has bared her shoulders and is not covered with even a loincloth, and she summons a court attendant, [saying:... "come hither"]- "I wish to give you an order", and he tarries to speak with herhe shall be struck by 100 blows. The eyewitness who denounces him shall

${ }^{42}$ For the Old Palace in Assur, see Friedhelm Pedde and Steven Lundström, Der Alte Palast in Assur. Architektur und Baugeschichte, Wissenschaftliche Veröffentlichungen der Deutschen Orient-Gesellschaft 120 (Wiesbaden 2008), and Jan Gerrit Dercksen, Old Assyrian Institutions, Publications de l'Institut historique- archéologique néerlandais de Stanboul 98 (MOS Studies 4) (Leiden 2004) pp. 7-9 with further references.

${ }^{43}$ For the sekretu, literally 'sequestered woman', cf. Sarah Melville, 'Neo-Assyrian Royal Women and Male Identity: Status as a Social Tool', Journal of the American Oriental Society 124 (2004) p. 40, and Teppo The Role and the Duties, p. 265.

${ }^{44}$ For a thorough evaluation of the conditions in the 'harem' of the Old Palace in Assur, see Solvang, 'A Woman's Place', and eadem, 'Another Look 'Inside'. 
take his clothing; and as for him, they shall tie (only) sackcloth around his waist. ${ }^{45}$

It also transpires that a palace woman was expected to remain 'veiled for her master' at all times, and that cruel punishments threatened a lady if she allowed even her female servants to see her uncovered face. Officials were forbidden to eavesdrop on them, and were whipped if they were caught overhearing them quarrelling or singing. Little freedom was provided to move within the palace for those few who were allowed entry, and palace staff was to maintain a distance of seven paces when talking to a lady. Even when a eunuch was sent to the 'harem' on an errand by the king he could only enter after informing the palace manager ( $r a b$ ekalli), who was to stand guard at the entrance while the official went in and out.

When the entire royal court journeyed to another city, the palace staff presumably had an opportunity to experience the world outside the walls. There is nothing to indicate that such travels were as common as in the later Persian Empire, but clearly the court did occasionally move from one palace to another. In Neo-Assyrian times several courts with separate households and 'harems' were present in the capital cities, and we may presume that an exchange of residents and staff took place between them. When the king chose to spend a longer period outside his residential palaces, a large part of the court would presumably have moved with him. Our only direct evidence for travelling courts once again dates back to the Middle Assyrian period and comes from the correspondence of a 13th-century governor in the regional capital of Dur-Katlimmu. A letter from his archive announces the imminent arrival of the Assyrian king to the provincial palace, and concerns itself with the minutiae associated with the coming of prominent visitors:

The court will be large. The lady Qa'i-mätu and two more ladies are in charge of the thirteen women-both our own ladies and the Kassite ones. Two female stewards, and similarly, one female šatalšuttu, in all six carriages arriving from the king... the Kassite king and his wife will arrive together with the king. ${ }^{46}$

${ }^{45}$ Most recently translated and edited in Martha T. Roth, Law Collections from Mesopotamia and Asia Minor (Second Edition), Writings from the Ancient World Society of Biblical Literature 6 (Atlanta 1997).

${ }^{46}$ E. Cancik-Kirschbaum, Die mittelassyrischen Briefe aus Tall Šêh Hamad, Berichte der Ausgrabung Tall Šēh Ḥamad/Dūr-Katlimmu 4 (Berlin 1996) no. 10. 
On the basis of this information, it would seem that the 'harem' was made up of no more than thirteen women, including the wives of the Kassite (Babylonian) king who was held captive at the Assyrian court at the time. All were under the charge of a lady named $Q a^{\prime} i-m a \bar{t} u$ assisted by five additional women. If we assume that the entire court was on the move as indicated by the additional presence of the Babylonian king, the size of the Assyrian 'harem' in the 13th century B.C. appears to have been of fairly limited proportions.

The Neo-Assyrian evidence for the 'harem' is less clear, although a few facts do emerge. Clearly, social monogamy was the norm and the king was married to one wife only. ${ }^{47}$ This first lady was regarded as the queen of the empire: she was the head of her own separate household, and as a rule she was the mother of the designated heir to the throne. As indicated also by the ground plan of the North-West Palace, she presumably occupied a palatial suite physically separate from the rest of the bitannu. However, the extended female retinue of the Assyrian king appears to have been much larger than in Middle Assyrian times, and a substantial number of 'Palace Women' (sekretu), adolescent children and servants seem to have resided in the 'House of the Women'. Relatively little is known about the life of these sekretus. Mostly they appear in lists of wine-rations and records of booty taken by the Assyrian kings, and often they are associated with the stock phrase 'beloved by the king'. The word is itself derived from the verb sekeeru, meaning 'to close, to confine, to hold in, to block or restrain', suggesting that they were generally associated with life in isolation. However, the sekretus are occasionally noted as the buyers of slaves and real estate, proving that their agency reached beyond the palace walls.

The 'Palace Women' of the Assyrian palaces are known to have originated from all over the ancient world, and local nobles, client kings and foreign rulers would send daughters to the court for political and social reasons. Similarly, incorporating the households of defeated enemies was common practice, and scattered records mention Aramean, Kassite, Hittite and Nubian women as well as ladies coming from Namri, Tyre, Arpad, Ashdod, Jerusalem, Memphis and

${ }^{47}$ But note the discussion in Julian E. Reade, 'Was Sennacherib a Feminist?', in: La Femme dans le Proche-Orient Antique: XXXIIIe Rencontre Assyriologique Internationale, Jean-Marie Durand, ed. (Paris 1987) pp. 139-145. 
Dor at the Assyrian palaces. One list appears to record all the female occupants of 'the women's quarters' in an Assyrian palace, and almost a hundred women and fifty servants (amat ekalli) appear on the list with the addition of 61 female musicians, singers and an inventory of other female personnel, including scribes, smiths, stone-borers, a hairdresser and a perfume-maker for a grand total of some 250 individuals. ${ }^{48}$ A significant part of this female staff would doubtless have resided outside the royal palace itself as indicated by the occasional reference to a "house of the palace maids". ${ }^{49}$ And surely not all the women were segregated from the male part of the population, as one record mentions the 370 sons of the slaves and the palace maids. ${ }^{50}$ Such 'sons of the palace maids' generally appear in contexts suggesting that they held a strong financial position and that they could lend out money and receive estates as royal gifts.

Administrative records found in the bitannu-wing of North-West Palace also reveal the presence of some of the male officials associ-

${ }^{48}$ Fales and Postgate, Imperial Administrative Records, no. 24; other lists of female personnel are at no. 23 and nos. 25-26. Noting the reservations found in Fales, 'A Fresh Look at the Nimrud Wine Lists', pp. 361-380 and Teppo, The Role and the Duties, p. 267, this figure fits well with the 250 members of the queen's household as calculated by Wilson, Nimrud Wine Lists, on the basis of the Nimrud wine-lists. Similar numbers are reached by Teppo for Nineveh in the early 7 th century on the basis of the amounts of flax distributed to the palace. According to her calculations, the provincial palaces in Arbail, Kilizi, Adian and Kasappa held between 70 and 164 palace women each. If the households run by the šakintus were all under the queen's administration, she would thus have been the head of hundreds of people based not only in the royal palace but spread across her holdings throughout the empire. See Melville, Role of Naqia, pp. 105-112, Teppo, Women and their Agency, and Teppo, The Role and the Duties for the relevant data on the šakintu households and the reasons for abandoning the old translation of the title as 'harem governess'. The office of the šakintu was not exclusive to the royal palace, and apparently all large households in Assyria could or would have a woman's section headed by a 'Lady of the House' (bēlat bèti) assisted by a šakintu. See e.g. the list of šakintus in Fales and Postgate, Imperial Administrative Records, no. 23, the letter in Luukko and Buylaere, Political Correspondence, no. 28 quoted below, and the lists in Fales and Postgate, Imperial Administrative Records, nos. 21-22 that appear to record almost 1,200 individuals belonging to the personnel of one particular bèlat bèti.

49 Text ND 2307, see Teppo op. cit.

${ }^{50}$ See Parpola, Correspondence of Sargon II, no. 99. A badly preserved marriage contract between a man named Atar-[...] and a woman of some apparent status, perhaps a former palace maid, was unearthed in one of the rooms (DD) in the bitannuwing of the North-West Palace. Postgate, The Governor's Palace Archive, no. 247. Among the preserved stipulations we are informed that the man is prohibited from taking a second wife, and that the lady he now marries will be excluded from any financial responsibility for her husband's eventual debts. 
ated with the private activities of the palace household and offer a glimpse of the activities going on in the 'harem'. There is evidence to show that weaving and textile production were a part of daily life, and that the study and performance of poetry and music would have been favoured pastimes. The cold building and the rich food and drink consumed in the 'women's quarters' seem to have taken their toll on the residents. ${ }^{51}$ Paleopathological examinations of the skeletons from the palace tombs show that common ailments were malnutrition (caused by excess) and rheumatism. ${ }^{52}$ Epidemic outbreaks would surely have spread fast in the confines of the private quarters, and the fact that several royal women were buried at one time and in a single grave might indicate that their deaths happened too fast and too close in time to observe the proper rites. ${ }^{53}$ One short sad poem, seemingly composed by a lady of the palace, recalls the despair associated with the loss of a stillborn child, ${ }^{54}$ and an exceptional manuscript recounts the rites performed at the burial of a palace lady by her fellow women. ${ }^{55}$ Finally, one finds occasional evidence for social tension among the residents of the royal palaces:

Word of the king's daughter to Libbali-šarrat. Why don't you write your tablet and do your homework? For if you don't, they will say: "Is this the sister of Šerua-eterat, the eldest daughter of the Succession Palace of Aššur-etel-ilani-mukinni, the great king, mighty king, king of the world,

${ }^{51}$ For various lists of food, drink and aromatics consumed at the palace banquets and the queen's court, see Fales and Postgate, Imperial Administrative Records, nos. 130-157.

${ }_{52}$ M. Schultz and M. Kutner, 'Erste Ergebnisse der anthropologischen und paläopathologischen Untersuchungen an den menschlichen Skeletfunden aus den neuassyrischen Königinnengräbern von Nimrud', Jahrbuch des Römisch-Germanischen Zentralmuseums Mainz 45 (1998) pp. 85-128, and Oates, Nimrud, pp. $87 \mathrm{ff}$. Six of seven adults examined showed signs of degenerative joint disease, and only the "child queen" of tomb III had healthy joints. Out of eight skeletons, four adults and one child bore indications of deficiency or persistent disease during infancy. It would also seem that the women of the palace ate extremely soft foods, suffered severely from colds, and were unaccustomed to exercise.

${ }_{53}$ The present explanation for the shared burial of the individuals is far from certain, and may have been caused by secondary deposit as well. Cf. Oates, Nimrud, p. 87, who suggests that the secondary interments may have been caused by power struggles among the leading families from which the women came.

${ }_{54}$ Alasdair Livingstone, Court Poetry and Literary Miscellanea, SAA 3 (Helsinki 1989) p. 15.

${ }^{55} \mathrm{~K} 164$. Wolfram von Soden, 'Aus einem Ersatzopferritual für den assyrischen Hof', Zeitschrift für Assyriologie und Vorderasiatische Archäologie 45 (1939) pp. 42-61, Taf. VII, on no. 45: "Die Palastfrauen (lit. MÍ É.GAL.MEŠ: 'queens') rufe[n:] "Kommt! Die Palastfrau, eure Tochter, [sollt ihr] begraben". 
king of Assyria?" Yet you are only a daughter-in-law-the lady of the house of Assurbanipal, the great crown prince designate of Esarhaddon, king of Assyria. ${ }^{56}$

The head administrator of the queen's household bore the title šakintu..$^{57}$ Her staff seems to have been almost exclusively female and included her deputy, stewardesses, scribes, a treasurer and several cup-bearers. The šakintus show up regularly in the texts, and actually represent the best-attested group of women within the Assyrian palaces. So far, some 54 šakintus in 22 separate households are known from the records, and clearly their position was both an influential and an economically rewarding one. A major task seems to have been the organisation of the substantial textile production that took place inside the palaces, but šakintus are also seen to buy slaves, lend money, control large amounts of provisions, and act in various types of legal transactions. Most such dealings were presumably connected to her professional duties, but some documents imply that the ladies held similar autonomy in their private lives, and that the šakintus could have or adopt children. In one case we know that a former 'Palace Woman' (sekretu) held the office of šakintu, opening the possibility that this may have been a regular career opportunity for ladies living in the palaces.$^{58}$ Obviously, they would be uniquely placed to seek this kind of promotion and to carry out the tasks involved in the job. We know of a number of sakintus distributed among the palaces of the Empire, and it seems likely that each palace had a female manager working side by side with the male staff so that the šakintu held a position comparable to the palace supervisor. ${ }^{59}$ The association between her office and the royal 'harem' is less clear, and it is difficult to determine exactly

\footnotetext{
${ }^{56}$ Luukko and Buylaere, Political Correspondence, no. 28.

${ }^{57}$ Cf. Teppo, The Role and the Duties, for a comprehensive study of the Assyrian šakintu.

${ }^{58}$ Ahi-talli, administrator of the Central City in Nineveh during the reign of Sennacherib (after 686 B.C.). She is known from several documents, buying slaves, and once a girl from her mother. Again, see Teppo, Women and their Agency, pp. 56-57.

${ }^{59}$ It is tempting to associate the small room just south of what seems to be a hall giving direct access into the bètānu at the protruding east corner of the North-West palace with the office of the šakintu. When excavated, the room contained both the traces of a rich female occupant, and a small archive of administrative dockets relating to the procurement and distribution of animals and commodities such as camels, sheep, wool and copper. For the finds in the room (HH), see Oates, Nimrud, p. 62. The dockets are published in Postgate, Governor's Palace Archive, nos. 250-263.
} 
what sort of connection existed between the 'women's quarters' and the court of the queen.

\section{The Royal Eunuchs}

A final principal component of the Assyrian royal household was made up of a substantial corps of officials referred to as 'the king's $\check{s} a$ rēši. Generally the title has been taken to refer to male eunuchs engaged by the palace, yet the matter of the existence and the number of eunuchs in the Neo-Assyrian royal household has been the subject of some controversy in recent years. The apparent omnipresence of the $\check{s} a$ réši-officials at court led the French assyriologist Paul Garelli to doubt whether the title referred to actual emasculated males. Rhetorically, he posed the question whether it would be "necessary to castrate half of the Assyrian administration and nearly everyone at court". ${ }^{60}$ As an alternative Garelli suggested that the term had simply become a general reference to denote any type of official active at the king's court. More recently Pierre Briant adopted this view in his study of the Achaemenid Empire, and concluded that:

It seems doubtful that eunuchs in the functional sense (castrated men of humble status) have obtained positions as high as the eunuchs mentioned by Ctesias... [rather, it was] a title completely unrelated to the duty it literally represented, as is often true in court hierarchy. ${ }^{61}$

This reluctance to accept the existence of high-positioned eunuchs at the Assyrian and Achaemenid court seems unwarranted. It is based mostly upon an apparent prevalence of eunuchs, even among the highest officials of the empire, and the disbelief that castrated men in

${ }^{60}$ P. Garelli, 'Remarques sur l'administration de l'empire Assyrien', Revue d'Assyriologie et d'archéologie orientale 68 (1974) pp. 129-40, and Reallexikon der Assyriologie [RlA] 4, pp. 449-450. For similar views, see also A. Leo Oppenheim, 'A Note on ša rēši', The Journal of Ancient Near Eastern Society of Columbia University 5 (1973) pp. 325-334; Wolfram von Soden, Akkadisches Handwörterbuch (Wiesbaden 1958-1981) p. 974; John A. Brinkman and Stephanie Dalley, 'A Royal Kudurru from the Reign of Aššur-nadin-šumi', Zeitschrift für Assyriologie und Vorderasiatische Archäologie 78 (1988) pp. 85-86 n. 27, and most recently, Stephanie Dalley, 'Evolution of Gender in Mesopotamian Mythology and Iconography with a Possible Explanation of ša rešen, "the man with two heads", in: Proceedings of the 47th Rencontre Assyriologique Internationale, Helsinki, July 2-6, 2001, S. Parpola and R. M. Whiting eds. (Helsinki 2002) pp. 117-122, with further references.

${ }^{61}$ Briant, From Cyrus to Alexander, p. 276. 
large numbers would obligingly function in positions of political and executive power. Substantial evidence has recently been presented in support of the notion that the Assyrian $\check{s} a$ rēš were in fact castrates adopted into a palatial household and directly tied to their master in a manner comparable to kinship. ${ }^{62}$ The male officials at the NeoAssyrian palaces were commonly divided into two functional groups, the 'bearded courtiers' (ša ziqni) and the $\check{s} a$ rēši, and a clear distinction was drawn between the former, who were understood to produce 'sons', and the latter who had only 'successors'. Upon entering royal service, the ša resši would give up his former filiation $\left(\mathrm{NN}_{1}\right.$ son of $\mathrm{NN}_{2}$ ) and receive a new name that would often include a reference to the distinct nature of his commitment to the ruler. General Assyrian belief held that a person's well-being in afterlife depended upon regular funerary offerings provided by his or her descendants, and since the $\check{s} a$ rēši lacked the capability to procreate, they could either adopt children, or the king might personally commit himself to provide for his servants in afterlife. The latter practice resulted in a number of standardized royal grants recording the creation of tax-exempt foundations to serve the $\check{s} a$ rēši.$^{63}$

The Middle Assyrian edicts include stipulations concerned with the actual procedure for checking whether court personnel (manzaz pāni) had been properly castrated before being allowed to enter the women's

${ }^{62}$ Albert K. Grayson, 'Eunuchs in Power: Their Role in the Assyrian Bureaucracy', in: Vom Alten Orient zum Alten Testament: Festschrift für Wolfram Freiherrn von Soden zum 85. Geburtstag am 19. Juni 1993, Manfried Dietrich and Oswald Loretz, eds. (Freudenstadt 1995) pp. 85-98; Radner, Die Neuassyrischen Privatrechtsurkunden, pp. 155-157, Karlheinz Deller, 'The Assyrian Eunuchs and Their Predecessors', in: Priests and Officials in the Ancient Near East: Papers of the Second Colloquium on the Ancient Near East-The City and Its Life Held at the Middle Eastern Culture Center in Japan (Mitaka, Tokyo), March 22-24, 1996, Kazuko Watanabe, ed. (Heidelberg 1999) pp. 303-311; Kazuko Watanabe, 'Seals of Neo-Assyrian Officials', in: Priests and Officials in the Ancient Near East: Papers of the Second Colloquium on the Ancient Near East-The City and Its Life Held at the Middle Eastern Culture Center in Japan (Mitaka, Tokyo), March 22-24, 1996, Kazuko Watanabe, ed. (Heidelberg 1999) pp. 313-366; J.D. Hawkins, 'Eunuchs among the Hittites', in: Proceedings of the 47th Rencontre Assyriologique Internationale, Helsinki, July 2-6, 2001, S. Parpola and R.M. Whiting eds. (Helsinki 2002) pp. 217-233, and Tadmor, 'Role of the Chief Eunuch', with further references. For the pictorial evidence, see Julian E. Reade, 'The Neo-Assyrian Court and Army: Evidence from the Sculptures', Iraq. Journal of the British School of Archaeology in Iraq 34 (1972) pp. 87-112, and Watanabe, 'Seals of Neo-Assyrian Officials'.

${ }^{63}$ Cf. Laura Kataja and Robert M. Whiting, Grants, Decrees and Gifts of the NeoAssyrian Period, SAA 12 (Helsinki 1995) pp. xxi-xxxi. 
quarters. The royal servants were subject to regular inspection by a select committee to reveal individuals who had not been properly emasculated, and in case of doubt the unfortunate officials were denied access to the inner quarters and submitted to complementary surgery. It follows that the Assyrians did not employ the practice of complete penectomy - a dangerous procedure that had serious physical and psychological repercussions. Only the testicles were destroyed in the scrotum during adolescence, and presumably the eunuchs would retain their sexual drive and be able to have intercourse.

The 'chief eunuch' ( $r a b \check{s} a$ rešsi) was the nominal head of the imperial eunuchs as well as the commander of the royal corps. ${ }^{64}$ Initially, he may have been the head of the private sector of the royal palace as well, but as the office grew into one of the key positions of power in the empire, it appears that the senior manager of the royal abode came to be the eunuch 'chamberlain' (ša muhhi bètāni-lit. 'the one in charge of the inner quarters'). The male head of the women's quarters may have been the obscure rab issate ('master of the women'). ${ }^{65}$ The archival records discovered in the private wing of the North-West Palace give us very little information about the resident male personnel and the nature of their interaction with its female occupants, but both material and written evidence indicates that palace eunuchs came into direct association with the women's quarters. Plainly, select members of the male staff had direct authority in the upbringing of the royal children, and the quote by Plato stating that it was customary for the Persian heir apparent to be "brought up-not by some nanny of no account, but by the most respected eunuchs in the royal household" has clear parallels in the Assyrian record. ${ }^{66}$

${ }^{64}$ The office of the chief eunuch was subject to significant change in political and military importance from the end of the reign of Shalmaneser III to the downfall of the empire-apparently to the point where the chief eunuch Sin-šumu-lešir took hold of the Assyrian throne during the rebellion of Nabopalassar. If a large proportion of the highest ranking eunuchs at the court were superflous male children born to the royal family, this would of course help to account for their aspirations to kinship. For the changing fortunes of the Assyrian chief eunuchs, see Mattila, King's Magnates, and Hayim Tadmor, 'The Role of the Chief Eunuch and the Place of Eunuchs in the Assyrian Empire', in: Proceedings of the 47th Rencontre Assyriologique Internationale, Helsinki, July 2-6, 2001, S. Parpola and R. M. Whiting eds. (Helsinki 2002) pp. 603-612.

${ }_{65}$ See Radner, Die Neuassyrischen Privatrechtsurkunden, p. 264 and Teppo, Women and their Agency.

${ }^{66}$ Alc. $121 \mathrm{~d}$. Note e.g. the well-known passage in Kataja and Whiting, Grants, Decrees and Gifts, no. 35 and no. 36, in which king Aššur-etel-iläni writes of his childhood that: "Sin-šumu-lešir, the chief eunuch, one who deserved well of my father and begetter, 


\section{Conclusion}

The rapid expansion of the Neo-Assyrian state in the early 9th century B.C. led to the formation of a distinctive imperial ideology and an institutionalised court protocol tied to the dramatic setting created at the North-West Palace in Nimrud. Stylised etiquette and a rigid social hierarchy, combined with strict rules of physical access and an appropriation of space on both an ideological and physical level, acted to sustain an image of a universal empire with the Assyrian king at its central axis. The new capital city celebrated the power of the imperial state and its ruler, and at its nexus stood the throne-room, the large courtyards, the elaborate reception suites and the striking decorations of the royal palace. This was the physical arena in which political and social power was negotiated and dispensed, where loyalties were affirmed, spectacles played out and foreign dignitaries received. It served as the main backdrop for court and elite integration, and functioned as a setting for grand public displays with elaborate dresscodes, musical performances and organised symposia, as well as for more intimate banquets, audiences and ceremonies. Finally, the royal palace was a centre of the imperial bureaucracy and home to the king's family. It housed the royal women, children and eunuchs, and clear physical limits were drawn between the public and the private sectors of the building.

A lot remains to be done before we may reach a detailed understanding of the social and political changes that took place at the Assyrian court throughout its two and a half century long history. Apparent developments in court life can be traced on various levels, both in the constant shifts in the hierarchy of court officials, in the administrative reforms triggered by territorial expansion and internal struggle, and even in the physical layout of the royal palaces. Nevertheless, the North-West Palace and its court remained the basic social and physical template that specifically came to identify the Assyrian imperial style. The Assyrian imperial blueprint drew many of its images and customs from a long-standing palace tradition in the Near East, but its characteristic feature seems to have been the particular combination

who led me constantly like a father, installed me safely on the throne of my father and begetter and made the people of Assyria, great and small, keep watch over my kingship during my minority, and respected my royalty". 
and use of elaborate decoration, ceremony and spectacle assembled in a setting of hitherto unseen proportions. In a sense, the NorthWest Palace became the 'Versailles of the ancient Near East', and the physical structure as well as the associated 'package' of ideas of proper courtly conduct was emulated in all later royal dwellings, as well as in the provincial palaces of imperial magnates and client states. To some degree, one may argue that the later established Persian practice of projecting its claim to world domination through the upkeep of a lavish court had its roots in Nimrud. The North-West Palace was certainly a receptacle of wealth in every manner imaginable: the daughters of allied and subdued rulers lived out their lives there; booty, taxes and tribute were stored in it; the best musicians and artists, the holiest men, the most renowned scholars, and the fiercest soldiers came there to practice their art.

An explanation for the apparent success of this 'image' of the imperial court developed in association with the North-West Palace should perhaps be sought in the fact that, for the incipient empire of Assurnasirpal II in the early 9th century, Assyrian political power remained virtually invisible. Successful military campaigns had little permanence, and the political map of the imperial territories resembled a patchwork rather than a geographic continuum. Important cities and tribal groups in dangerous proximity to the imperial heartland continued to challenge Assyrian supremacy. Instead, the Assyrian empire became fully articulated only through the creation of the new state capital, and the grand inauguration banquet acted to 'bring the empire and its ideology' to the local as well as the foreign dignitaries. In addition to the importance for the Assyrian self-image as a rising empire, the extension and relocation of the royal court from its ancient seat in Assur presumably also helped to establish and codify a new social order among the rapidly expanding political elite, and it acted to disassociate the royal court from the power of the traditional 'old' families dominant in the former capital. The new imperial elite was an inclusive group, and to some degree social status was disassociated from kinship and tied directly to the favour of the king. The North-West Palace would have provided a suitable arena for the games of social positioning, and acted as an appropriate location from which the king could 'divide and rule' his closest subjects. 


\section{HELLENISTIC COURT SOCIETY: THE SELEUKID IMPERIAL COURT UNDER ANTIOCHOS \\ THE GREAT, 223-187 BCE}

\section{Rolf Strootman}

\section{Introduction}

During the Hellenistic Age-roughly the last three centuries BCE-the political history of the eastern half of the Ancient World was dominated by three Macedonian dynasties: the Seleukids, ruling a vast land empire in the Middle East and Central Asia (312-64 BCE); the Antigonid kings of Macedonia, who tried to control Greece and the Balkans until their kingdom was destroyed by the Romans in $168 \mathrm{BCE}$; and the Ptolemies (323-30 BCE), who ruled a maritime empire in the eastern Mediterranean from their capital Alexandria, an empire which comprised Egypt but was not therefore an Egyptian empire. In the second century BCE, the Attalid kingdom, based in Pergamon, emerged as the predominant state in the Aegean region, and around 100 Pontos on the Black Sea and Armenia temporarily became major Hellenistic powers.

Of these states, the empire conquered by Seleukos I Nikator ('The Victorious', ruled 312-281 BCE) was the principal successor state of Alexander the Great (336-323 BCE), who himself had taken over the dominion of the Persian Achaemenids when he defeated the last Persian king, Darius III. In the third century BCE, the Seleukid dynasty laid claim to an empire stretching from the Hindu Kush to the Aegean coast. In 188 the emergent Roman Empire forced Antiochos III to give up Asia Minor. About the same time, Khurāsān was lost to the Parthians. As a result of Parthian expansion the provinces further east became fully independent under Greek rulers. After the death of Antiochos IV in 164 dynastic strife caused a steady decline of the empire until in $64 \mathrm{BCE}$ it disappeared from history almost unnoticed, its former territories being carved up by the Roman, Parthian and Kushan empires. ${ }^{1}$

\footnotetext{
${ }^{1}$ On the empire in general see Elias Joseph Bickerman, Institutions des Séleucides (Paris 1938); Amélie Kuhrt and Susan Sherwin-White, From Samarkhand to Sardis.
} 
In the Seleukid empire new forms of court culture and political ideology developed. A similar evolution took place in the Ptolemaic empire and, through intermarriage and diplomatic exchange, the two dynasties continually influenced each other in this respect. The Seleukid rulers adopted and reshaped the legacy of their Greek, Macedonian and Persian forebears to create a form of monarchy that was neither 'western' nor 'eastern'. Appropriated by the Parthian kings and Roman emperors, the culture and ideology of the Hellenistic courts eventually formed the basis of royal ideology and court culture in both Western Europe and the Islamic East. ${ }^{2}$

Monarchical states, of course, were no new phenomenon in the Ancient world. Until recently, however, the Hellenistic Age has been studied almost exclusively by scholars trained as Greek historians who often tended to consider Hellenistic kingship in contrast with the world of the polis, the autonomous Greek city state. They either disregarded its eastern antecedents or accentuated eastern influences on Hellenistic kingship as perversions of Classical Hellenic culture. Since the 1980's there has been a trend to place Seleukid kingship more thoroughly in an Eastern context, though at times this has led to minimising or ignoring its Greco-Macedonian aspects. ${ }^{3}$

Given the centrality of kingship in Hellenistic studies-traditional historiography sees monarchy as the principal defining element of

\footnotetext{
A New Approach to the Seleucid Empire (London 1993). There are two comprehensive accounts of Seleukid political history, both of them outdated: Edwyn Robert Bevan, The House of Seleucus, 2 vols. (London 1902), and Auguste Bouché-Leclercq, Histoire des Séleucides (232-64 avant J.-C.) 2 vols. (Paris 1913-14). More recent, concise overviews are H. Heinen, 'The Syrian-Egyptian wars and the new kingdoms of Asia Minor', Cambridge Ancient History 7, 1 (1984) pp. 412-45; Christian Habicht, 'The Seleucids and their rivals', in: The Cambridge Ancient History, vol. 8: Rome and the Mediterranean to 133 B.C., A.E. Astin, F.W. Walbank, M.W. Frederiksen and R.M. Ogilvie, eds. (Cambridge 1989) pp. 324-87 and Michel M. Austin, 'The Seleukids and Asia', in: A Companion to the Hellenistic World, Andrew Erskine, ed. (Oxford 2003) pp. 121-133.

${ }^{2}$ For the influence on Roman court culture see Jeremy Paterson, 'Friends in high places: The creation of the court of the Roman emperor', in: The Court and Court Society in Ancient Monarchies, A.J.S. Spawforth, ed. (Cambridge 2007) pp. 121-156.

${ }^{3}$ See e.g. the introduction in Kuhrt and Sherwin-White, From Samarkhand to Sardis, esp. p. 1: "[it is] our firmly held view that the Seleukid kingdom was an eastern empire"; for an example of the completely opposite view, see Burkhard Meißner, 'Hofmann und Herrscher: Was es für Griechen hieß, Freund eines Königs zu sein', Archiv für Kulturgeschichte 82 (2000) pp. 1-36, characterising the Seleukid, Ptolemaic and Antigonid courts as "Höfen im antiken Griechenland" (p. 36).
} 
the age-it is certainly surprising to see that the court has received only very limited attention. Most literature on Hellenistic courts is concerned with institutional or prosopographical aspects of court society. ${ }^{4}$ In addition, the past decades have seen a number of publications on literary patronage at the early Ptolemaic court. ${ }^{5}$ Palace architecture, too, has only recently acquired a place of its own in the bibliography of Hellenistic archaeology. ${ }^{6}$ Attempts at analysis, however, are rare and the advent of modern court studies has not yet made its mark on Hellenistic studies. ${ }^{7}$ Aside from the odd reference

${ }^{4}$ Helmut Berve, Das Alexanderreich auf prosopografischer Grundlage, 2 vols. (Munich 1926); Sylvie le Bohec, 'Les philoi des rois antigonides', Revue des Études Grecque 98 (1985) pp. 93-124; eadem, 'l'Entourage royal a la cour des Antigonides', in: Le système palatial en Orient, en Grèce et à Rome, E. Levy, ed. (Strasbourg 1987) pp. 315-326; Gabriel Herman, 'The "friends" of the early hellenistic rulers: servants or officials?', Talanta 12/13 (1980-1981) pp. 103-109; Leon Mooren, The Aulic Titulature in Ptolemaic Egypt. Introduction and Prosopography (Brussels 1975); idem, La hierarchie de cour ptolémaïque. Contribution à l'étude des institutions et des classes dirigeantes à l'époque héllenistique (Louvain 1977); idem, 'The Ptolemaic Court System', Chronique d'Égypte 60 (1985) pp. 214-22; Eckart Olshausen, Prosopographie der hellenistischen Königsgesandten, 2 vols. (Leuven 1974); W. Peremans and E. van 't Dack, Prosopographia Ptolemaica. vi: La cour (Louvain 1968); Chiara Carsana, Le dirigenze cittadine nello stato seleucidico (Como 1996); Ivana Savalli-Lestrade, Les philoi royaux dans l'Asie hellénistique (Geneva 1998).

${ }^{5}$ Alan Cameron, Callimachus and his Critics (Cambridge 1996); Gregor Weber, Dichtung und höfische Gesellschaft. Die Rezeption von Zeitgeschichte am Hof der ersten drei Ptolemäer (Stuttgart 1993); and idem, 'Poesie und Poeten an den Höfen vorhellenistischer Monarchen', Klio 74 (1992) pp. 25-77. On court historians: Burkhard Meißner, Historiker zwischen Polis und Königshof. Studien zur Stellung der Geschichtsschreiber in der griechischen Gesellschaft in spätklassischer und hellenistischer Zeit (Göttingen 1992).

${ }^{6}$ Vera Heermann, Studien zur makedonischen Palastarchitektur (Nürnberg 1986); Inge Nielsen, Hellenistic Palaces. Tradition and Renewal (Aarhus 1994); Gunnar Brands and Wolfram Hoepfner, eds., Basileia. Die Paläste der hellenistischen Könige (Mainz am Rhein 1996); Boney Lea Kutbay, Palaces and Large Residences of the Hellenistic Age (Lewiston; Queenston; Lampeter 1998); Ehud Netzer, Die Paläste der Hasmonäer und Herodes' des Grossen (Mainz am Rhein 1999); Inge Nielsen, ed., The Royal Palace Institution in the First Millennium BC (Athens 2001).

7 Gabriel Herman, 'The court society of the Hellenistic age', in: Hellenistic Constructs. Essays in Culture, History, and Historiography, Paul Cartledge, Peter Garnsey and Erich Gruen, eds. (Berkeley; Los Angeles; London 1997) pp. 199-224, uses Elias but no later literature on courts and court society, and consequently assumes too much freedom on the part of the king in manipulating his courtiers. Meißner, 'Hofmann und Herrscher' ignores even Elias. See further Leon Mooren, 'Kings and courtiers: Political decision-making in the Hellenistic states', in: Politische Theorie und Praxis im Altertum, W. Schuller, ed. (Darmstadt 1998) pp. 122-33; Gregor Weber, 'Interaktion, Repräsentation und Herrschaft. Der Königshof im Hellenismus', in: Zwischen Haus und Staat, Aloys Winterling, ed. (Munich 1997). For a synthesis of older literature see H.H. Schmitt, s.v. 'Hof', in: Kleines Wörterbuch des Hellenismus, H.H. Schmitt 
to Elias' Die höfische Gesellschaft, most Hellenistic historians still study their courts in vacuo. ${ }^{8}$

In my 2007 dissertation about the Hellenistic courts, I tried to reconsider the available sources by making use of insights from the current debate on the early modern European court and state formation. ${ }^{9}$ Thus it was possible, among other things, to re-address the old debate on the significance of Greek culture ('Hellenism') in the east by arguing-against the now prevailing view that Greek influence in the east was negligible - that it was precisely the 'limited' Hellenism of the court which functioned as a means of integrating the various regional elites of the ethnically and culturally heterogeneous empires. Like the Austrian or Ottoman court cultures of later ages, the Hellenism of the Seleukid and Ptolemaic courts was non-national. Court poets and artists consciously created an open, 'universal' Hellenic culture and language in which the regional differences that had been characteristic of Classical Greece were smoothed out. Leading families in the provinces who benefited from the empire, or who aspired to participate in the system of imperial patronage, adopted a double, e.g. HellenisticJewish, Hellenistic-Babylonian, or Hellenistic-Greek, identity as an expression of allegiance and a means of distancing themselves from those excluded from power. ${ }^{10}$ Thus the empire was united at its highest level through a shared elite culture. The royal household served as a point of contact for these otherwise unconnected elites. The upper stratum of the court itself, however, consisted predominantly of ethnic Greeks and Macedonians.

and E. Vogt, eds. (Wiesbaden 1988) pp. 251-57; for a more recent overview Aloys Winterling, s.v. 'Hof', in: Der Neue Pauly (1998) pp. 661-5. For a full bibliography see Rolf Strootman, The Hellenistic Royal Court. Court Culture, Ceremonial and Ideology in Greece, Egypt and the Near East, 336-30 BCE (Utrecht 2007).

8 This may now begin to change: see the excellent introduction by A.J.S. Spawforth in idem, ed., The Court and Court Society in Ancient Monarchies (Cambridge 2007) pp. 1-16.

${ }^{9}$ Rolf Strootman, The Hellenistic Royal Court. Court Culture, Ceremonial and Ideology in Greece, Egypt and the Near East, 336-30 BCE (dissertation Utrecht 2007).

${ }_{10}$ Rolf Strootman, 'Van wetsgetrouwen en afvalligen. Religieus geweld en culturele verandering in de tijd der Makkabeeën', in: Religies in interactie. Jodendom en Christendom in de Oudheid, B. Becking and G. Rouwhorst, eds. (Zoetermeer 2006) pp. 79-97; for the multiple identity of ethnic Babylonians see R.J. van der Spek, 'Ethnicity in Hellenistic Babylonia', in: Ethnicity in Ancient Mesopotamia. Proceedings of the 48e Rencontre Assyriologique Internationale, Leiden 2002, W.H. van Soldt, ed. (Leiden 2004). 
In what follows, we will take a closer look at Seleukid court society under one of its most important kings: Antiochos III the Great (ruled 223-187 BCE), whose reign has been documented relatively well in inscriptions and ancient historiography. ${ }^{11}$ Moreover, it was under Antiochos III that the Seleukid Empire reached its greatest territorial extent. ${ }^{12}$ Expansion was accompanied by the establishment of a new imperial order: a system of vassal rulers acknowledging the supremacy of a Great King, which replaced the practice of direct rule through centrally appointed provincial governors, who were often difficult to displace. At the end of Antiochos' reign, however, the empire suffered its first major setback when the king was forced to give up Asia Minor after his defeat in the Roman-Seleukid War of 192-188. ${ }^{13}$

Who were the courtiers surrounding Antiochos III? How were they recruited and how much freedom did the king really have in promoting or demoting the people closest to him? Was there a hereditary aristocracy or was status at court dependent on the favour of the king? ${ }^{14}$ What was the role of regional aristocracies and civic elites, and how were they integrated into the imperial system?

Modern scholarship has created an image of the Hellenistic court in the third century BCE as an 'open' society. The position of courtier was not a hereditary prerogative. The king was able to recruit at will able and loyal men who were given ad hoc responsibilities and could be removed from their positions with relative ease. Thus, the king was in full control of the social composition of his court. This changed only in the second century BCE. Because a system of apparently

${ }^{11}$ For his reign in general see Hermann Bengtson, 'Antiochos III., der Große', in: idem, Herrschergestalten des Hellenismus (Munich 1975) pp. 185-210; D. Bing, 'Antiochus III Megas', Encyclopaedia Iranica 2 (1987) pp. 127-128; Kuhrt and SherwinWhite, From Samarkhand to Sardis. The main historiographical sources are Polybios' Histories, Livy's Ab urbe condita, and Appian's Syrian Wars (Syriaca).

${ }_{12}$ Apart from re-establishing Seleukid suzerainty in Armenia, Iran and Central Asia, Antiochos forced the Indian princes of Gandhara into tributary status, wrested Phoenicia, Palestine and the Anatolian coastline from Ptolemaic control, and added Thrace to his dominions. On the eastern campaigns of Antiochos see Jeffrey D. Lerner, The Impact of Seleucid Decline on the Eastern Iranian Plateau. The Foundations of Arsacid Parthia and Graeco-Bactria, Historia Einzelschriften 123 (Stuttgart 1999) pp. 45-61, and Kuhrt and Sherwin-White, From Samarkhand to Sardis.

${ }^{13}$ For this war and its effects consult R.M. Errington, 'Rome against Philip and Antiochus', in: The Cambridge Ancient History 8 (1989) pp. 244-289; John D. Grainger, The Roman War of Antiochos the Great, Mnemosyne Supplement 239 (Leiden 2002).

${ }^{14}$ Cf. Jeroen Duindam, Vienna and Versailles. The Courts of Europe's Dynastic Rivals (Cambridge 2003) p. 319; Spawforth, Court and Court Society, p. 8. 
hierarchical court titles appears after $200 \mathrm{BCE}$, historians have postulated the development of a 'court bureaucracy', a more 'professional' form of government with specialised office-holders who were consequently no longer under the king's direct control. ${ }^{15}$

It is my contention that as early as the third century the selection of courtiers was much less in the king's hands than official documents suggest. The conflict between Antiochos III and his court at his accession in $223 \mathrm{BCE}$ demonstrates that already by then the free choice of courtiers was no longer de facto a royal prerogative. I will furthermore argue that the evolution of a court hierarchy was a reaction to a changed power balance at the top of the Seleukid Empire rather than its immediate cause.

\section{Empire and City}

Like many large empires, the Seleukid state was basically a tributetaking military organisation, offering protection and benefactions to city states and local princes. To finance its military strength, the empire depended on tribute, paid predominantly by cities. A city represented its hinterlands as well. The city was the place where the agrarian surplus was collected, and part of it turned into cash. Keeping good relations with the many cities in the realm was therefore a principal concern of the Seleukid administration. Seleukid patronage of cities included protection and the granting of various political, economic and religious rights, most notably political autonomy. Cities then repaid their benefactors with tribute or, if the king's grant had been tax-exemption, gifts. In a letter from (presumably) Antiochos II to the city of Erythrai in Asia Minor, perhaps sent shortly after his accession in 261, we read that the king grants the city autonomy and exemption from tribute in return for loyalty and a gift of gold bullion:

King Antiochos to the council and the people of the Erythraeans, greeting. Tharsynon and Pythes and Bottas, your envoys, delivered to us the decree by which you voted the (divine) honours and the crown with which you crowned us, and gave us likewise the gold intended as a gift of

${ }^{15}$ Cf. e.g. F.W. Walbank, 'Monarchies and Monarchic Ideas', in: Cambridge Ancient History 7, 1 (1984) p. 70; Gabriel Herman, Ritualised Friendship and the Greek City (Cambridge 1987) p. 164; Meißner, 'Hofmann und Herrscher', esp. pp. 26-28 and 28-30. 
friendship. Having discoursed on the good-will which you have always held toward our house and on the gratitude which the people entertain toward all their benefactors, and likewise on the esteem in which the city has been held under the former kings, they asked with all earnestness and zeal that we should be friendly to you and should aid in advancing the city's interests in all that pertains to glory and honour. We have then accepted in a friendly spirit the honours and the crown and likewise the gift.... And since Tharsynon and Pythes and Bottas have shown that under Alexander and Antigonos your city was autonomous and free from tribute...we shall help you to maintain your autonomy and we grant you exemption not only from other tribute but even from [the] contributions [to] the Gallic (war) fund. ${ }^{16}$

Because the city is not taxed but presents the king with a 'gift of friendship', it can claim that it is autonomous and deals with the monarchy on the basis of equality; the king receives his tribute nonetheless. Thus, this text, a public inscription reflecting official propaganda, presents the relationship between empire and city as harmonious. ${ }^{17}$ In reality, the simple matrix of tribute and loyalty in exchange for benefactions and protection was open for negotiation and a potential source of conflict.

\section{The Friends of the King}

International networks of aristocratic guest-friendship known in Greek as xenia or philoxenia linked up the royal household with multifarious civic elites. The cement of xenia was philia, a form of ritualised friendship between two persons with traits of fictive kinship. Philia may be defined as a personal, reciprocal bond of loyalty and solidarity between two men (or women) of approximately equal status who share roughly the same interests. They were committed to each other by mutual obligations, and could rely on each other for help. The objective of philia was normally to achieve a common goal, and united action towards that end was a means to strengthen and display the bond. Through the exchange of gifts and favours the friendship was kept alive. The parties

16 OGIS 223 = Michel M. Austin, The Hellenistic World from Alexander to the Roman Conquest. A Selection of Ancient Sources in Translation (Cambridge 1981) no. 183 .

17 See John Ma, Antiochos III and the Cities of Western Asia Minor (Oxford 1999) for an analysis of the rhetoric and ideology of royal and civic letters in the epigraphic record of Seleukid cities in the age of Antiochos III. 
involved in a philia relationship were ideally each other's peers, even when they were not equals in practice. ${ }^{18}$

Xenia and philia were not in themselves typically monarchical. Xenia had been an important aristocratic ideal in Greece since time immemorial, and undoubtedly similar types of bonding existed in various forms in other parts of the Near East as well. ${ }^{19}$ Through participation in a social sphere outside their own city, elite members distanced themselves from their inferiors. Thus xenia relations constituted supranational, 'horizontal' elite networks linking up families of approximately equal social status but of separate social units, particularly cities. ${ }^{20}$ In the Hellenistic Age, these networks became instrumental in the court's policy of influencing the internal politics of cities and supporting oligarchic regimes in order to secure goodwill and loyalty. Conversely, xenia networks offered cities the opportunity to exert influence on political matters at court and to obtain privileges.

It was through the instrumentality of philia that men attached themselves to the royal household (oikos), and thus became 'courtiers', serving the king as court officials, ambassadors or military commanders. ${ }^{21}$ Hence Hellenistic courtiers were commonly known as philoi tou basileoss, 'Friends of the King', although the title of royal philos did not in itself presuppose actual presence at court. ${ }^{22}$ As we have seen in the letter of Antiochos to Erythrai, the interdependence of city and monarchy, too, was explained in terms of philia, with its ideology of mutual aid and benefit, and equality. The relationship between city and king was therefore embedded in the moral complex of gift exchange, as we saw in the inscription from Erythrai.

${ }^{18}$ Herman, Ritualised Friendship; cf. David Konstan, Friendship in the Classical World (Cambridge 1997). For the function of gift-exchange at the Hellenistic courts see Strootman, Hellenistic Royal Court, pp. 143-148.

19 For philia as an Archaic Greek aristocratic ideal see Mary Scott, 'Philos, philotes and xenia', Acta Classica 25 (1982) pp. 1-19, and Hans van Wees, Status Warriors. War, Violence and Society in Homer and History (Amsterdam 1992) pp. 44-48.

${ }^{20}$ Herman, Ritualised Friendship, p. 200.

21 Herman, Ritualised Friendship, p. 208.

22 The word aule (literally 'court') is most often used in Greek historiography to denote a royal household. To distinguish between courtiers and philoi who were not actually at court, ancient historians sometimes speak of peri tēn aulèn, 'people of the court', or aulikoi; however, despite Bickerman 1938's assertion that these were technical terms, unlike philoi they do not figure in official contemporary documents. The word therapeia, 'retinue', sometimes is used to describe the philoi surrounding the king. For the terminology in the sources see further Strootman, Hellenistic Royal Court, pp. 13-4, and 119 n. 67. 
The royal friends played a crucial role in the negotiations between city and king both directly and indirectly. Directly, they could act as negotiators on behalf of their own cities of origin. They represented the interests of the cities at court and the interests of the court in the cities, deriving benefits from their membership of both systems. ${ }^{23}$ Indirectly, philoi could act as intermediaries between the royal power and embassies seeking audience at court. For such arbitration cities could reward philoi with public honours, citizen rights and gifts. At court, they could obtain military commands, landed estates, privileges and favours for themselves, their families, their cities and their own clients, and status.

Being continually on campaign, the courts of the Seleukid kings were peripatetic. There was no fixed capital. The Seleukids maintained palaces in cities all along the Royal Road, the main artery connecting the eastern and western edges of the empire. In the third century these included Sardis in Lydia, Antioch and Apameia in Syria, Seleukeia in Babylonia, Susa in Elam, Ekbatana in Media, Balkh in Baktria, and probably Merv in Margiana. Also the great palace excavated at Aï Khanoum in north-east Afghanistan was in all likelihood originally a Seleukid palace, perhaps built by Antiochos I. When the king was absent, these palaces served as governors' residences. Wherever they came, the Seleukids made ceremonial entries into cities and participated in local religious festivals. ${ }^{24}$ They were always accompanied by their court and the main army.

${ }^{23}$ Gabriel Herman, 'Friendship', in: Oxford Classical Dictionary, Simon Hornblower and Antony Spawforth ed. (Oxford 1996) pp. 611-3, at p. 613. On philoi as mediators between king and cities see Klaus Bringmann, 'The king as benefactor: Some remarks on ideal kingship in the age of Hellenism', in: Images and Ideologies. Self Definition in the Hellenistic World, A.W. Bulloch et al. ed. (Berkeley; Los Angeles; London 1993) 7-24. Herman, 'The "friends" of the early Hellenistic rulers' has listed civic decrees honouring philoi, mainly from third century Athens, Samos, Ephesos and Delos. Cf. Herman, 'The court society of the Hellenistic age'; Ivana Savalli-Lestrade, 'Courtisans et citoyens: le cas des philoi attalides', Chiron 26 (1996) pp. 149-81; F. Muccioli, 'La scelta delle titolature dei Seleucidi. Il ruolo dei philoi e delle classi dirigenti cittadine,' Simbolos 3 (2001) pp. 295-318. The pivotal significance of philia for Seleukid imperialism is captured by a letter to the city of Miletos in which Seleukos II assures the citizens that he is well-disposed to the city because the friends of his deceased predecessor have informed him about the loyal attitude of Miletos towards his family: I.Didyma 493; OGIS I 227; Welles, RC 22 lines 7-9. For Milesian philoi at the Seleukid court see P. Hermann, 'Milesier am Seleukidenhof. Prosopographische Beiträge zur Geschichte Milets im 2. Jhdt. v. Chr.', Chiron 17 (1987) pp. 171-92.

${ }^{24}$ Strootman, Hellenistic Royal Court, pp. 289-298, 308-314. 


\section{Antiochos' Accession}

Antiochos III succeeded to the throne unexpectedly in 223/2 BCE when his brother, Seleukos III, was assassinated by some of his courtiers while on campaign in Asia Minor. ${ }^{25}$ Antiochos, then about twenty years old, was absent from the court when the king was murdered. As in the Classical Ottoman Empire, or Qing China, it was customary that the brothers of the reigning Seleukid king be kept away from the centre of power. Antiochos' accession immediately caused a vicious power struggle in which two rival factions at court vied for the favour, or rather, the control of the young king. The conflict is described in detail by the historian Polybios, who wrote only several decades after the events had taken place. ${ }^{26}$ At the same time, the satraps of Media and Persis, the brothers Molon and Alexandros, who had been appointed by the former king, rebelled against his successor. Such conflicts were normal. Virtually every new reign sooner or later saw attempts of the new king to replace the men who had risen to positions of power under his predecessor by his own philoi, and hence also attempts by the predecessor's philoi to retain their positions. ${ }^{27}$ Molon and Alexandros, too, may have rebelled partly from fear of, or in reaction to, attempts at their being replaced. Although Antiochos, as we shall see, was ultimately successful in these enterprises, it was no matter-ofcourse that a Hellenistic king was able to manipulate the composition of his sunedrion, the royal (war) council. ${ }^{28}$

According to Polybios, power at first came into the hands of a certain Hermeias the Karian, a trusted philos of the former king who had been left as viceroy at Seleukeia on the Tigris when Seleukos III moved into Asia Minor. Although he was not at court at that time, he probably owed his initial supremacy to the fact that the successor, Antiochos, was with him at Seleukeia, the most important of the Seleukid

${ }_{25}$ Appian, Syriaca 66; cf. Polybios 4.48.7-10.

${ }^{26}$ Polybios 5.40.-56; Polybios' informants were insiders at the Seleukid court, including a grandson of Antiochos III, Demetrios, to whose philia network Polybios belonged when they both lived as exiles in Rome.

${ }_{27}$ Note that in the inscription from Erythrai, cited above, the king at the beginning of his reign speaks explicitly of the advice given by his father's friends, patrikoi philoi, whom apparently he regarded as his own.

${ }^{28}$ Polybios is aware that decisions at court are not always made by the king, but the historian, he says, 'is obliged to ascribe to the ruler the opinion which prevailed at his councils' (4.24.2); cf. Mooren, 'Kings and courtiers', esp. p. 131. 
capitals, and was inaugurated there. His superior position was soon contested when the philoi who had accompanied Seleukos on his campaign returned from Anatolia with the main army. Their leader was a general called Epigenes, who was popular with the troops. A third prominent philos of Seleukos III, Achaios, remained in Asia Minor to continue the war. Like Molon and Alexandros, he too refused to accept Antiochos as king. Because Hermeias was so powerful and was taking all the decisions and preventing Antiochos from appointing his own associates to key positions, the king allied himself with Epigenes' faction. Or so it seems: perhaps Antiochos, who later proved to be one of the most competent monarchs ever to rule the Seleukid empire was in reality playing off Hermeias against the other courtiers of his brother. ${ }^{29}$

Epigenes fell when the army mutinied over arrears of pay. Hermeias offered to pay the troops from his own funds, but demanded in return that Epigenes and his followers be banished from the court:

The king was much displeased with this proposal... but troubled as he was by Hermeias' machinations and enthralled by the obligations of the court, and permanently surrounded by a host of guards and courtiers, he was not even master of himself, so that he gave way and acceded to the request. ${ }^{30}$

As soon as Epigenes was driven from court, Hermeias produced a letter evidencing his having sided with the rebels, and had him summarily executed: 'The king was forced to admit that Epigenes had merited

${ }^{29}$ Polybios' impression of things, however, is problematic. By supporting the established philoi who had been favoured by his brother, the king weakened his own position. If we pursue this point somewhat further, it becomes even doubtful whether the king in reality supported Epigenes' faction at all. Hermeias is described by Polybios as a typical 'wicked advisor' in constant conflict with the court in such a way that we may reasonably ask whether he was not in reality the king's favourite. Cf. e.g. Polybios 5.41.3: Hermeias 'was jealous of all the holders of prominent court offices, and as he was naturally of a savage disposition, he inflicted punishment on some for errors which he magnified into crimes, and trumping up false charges against others, showed himself a cruel and relentless judge.' Also the haste with which Antiochos rid himself of Hermeias after the latter had succeeded in destroying Epigenes points in that direction.

${ }^{30}$ Polybios 5.50.4-5. Hellenistic kings often relied for funds on wealthy philoi, cf. Strootman, Hellenistic Royal Court, p. 147. An anecdote about Ptolemaios V (Diodoros 29.29) suggests that it was not unusual for the Ptolemaic king to borrow money from his courtiers to finance campaigns, later to pay them back with interest from the war booty; thus we hear that Apollonios, the wealthy Ptolemaic courtier and land-owner known from the Zenon Papyri, had become rich from trading slaves from Syria. 
his own fate,' Polybios writes, 'and the courtiers, though they had their suspicions, were afraid to utter them'. ${ }^{31}$ Only after Antiochos had achieved two resounding military victories-against the rebel satraps in Babylonia and against the Armenian king Artabazanes-were his prestige and wealth sufficient to stand up against Hermeias and his entourage. He was then able to remove them from court as well ${ }^{12}$ and replace them with his own intimates. Below, we will see who these new courtiers were and how they were recruited.

\section{The Courtiers of Antiochos III}

As we saw above, the accession of Antiochos III was accompanied by violent struggles among the philoi of his predecessor, Seleukos III, who were afraid they would lose their status and offices under the new king. ${ }^{33}$ Simultaneously, a number of Seleukos' philoi who were not at court rebelled under the leadership of Molon, the satrap of Media. In the end, this rebellion was put down with surprising ease: although the satraps' forces had already destroyed two royal armies that had been sent against them, the troops refused to fight when confronted with the legitimate king in person and surrendered; the rebel satraps committed suicide and were replaced by lesser governors who had remained loyal. ${ }^{34}$

Of the three most influential philoi in the reign of Seleukos III two were dead by the winter of 222/221 BCE. The third, Achaios, the viceroy of Asia Minor, had allied himself with Molon upon Antiochos'

31 Polybios 5.50.14.

32 Hermeias could not be disposed of easily. See details in Polybios 5.56.7, Polybios 5.56.12, and the posthumous accusation against Hermeias in Polybios 5.55.5.

${ }^{33}$ We are informed that also Attalos III of Pergamon and the Seleukid king Alexandros I Balas eliminated the philoi of their predecessors upon their accession (Diodoros 34-34.3; Livy, Periochae 50). The court of Alexander the Great, too, was troubled by the king's constant and increasingly violent attempts to rid himself of the established court grandees who dominated his council, and to replace them with his own confidants, cf. Strootman, Hellenistic Royal Court, pp. 96-101; Sabine Müller, Maßnahmen der Herrschaftssicherung gegenüber der makedonischen Opposition bei Alexander dem Grossen (Frankfurt am Main 2003). The difficulties encountered by both Alexander and Antiochos, two of the strongest kings in Hellenistic history, and the devious and violent methods they resorted to, suggest that their ultimate success in manipulating the personal composition of their courts was exceptional.

${ }^{34}$ Polybios 5.54.4. Achaios body, like Molon's, was mutilated and crucified, the common punishment for 'betrayal'. 
accession and openly rebelled in 220. His planned invasion of Syria and Babylonia was hampered by the fact that his troops, too, refused to fight the king directly. ${ }^{35}$

With the most powerful philoi of his predecessor and their followers out the of way, Antiochos proceeded to make new appointments in the army and provincial government-together with membership of the sunedrion the main indicators of rank at court. We are relatively wellinformed about the composition of Antiochos' court in various phases of his reign, the principal sources being Livy, Appian and, again, Polybios. In addition, there is epigraphic evidence, mainly from western Asia Minor ${ }^{36}$ Who were these men? How were they recruited and how was their loyalty secured?

The inner circle of the king at first consisted of young men of his own age class. The Seleukid court had a system of royal pages, basilikoi paides, sons of the king and of important, particularly Macedonian philoi as well as, presumably, non-Greek aristocrats, who were brought up at court. Under the guidance of a regent known as a tropheus, one of the most important court offices in the Hellenistic world, they were educated and trained as military commanders. They guarded and waited in attendance on the king. The system had been institutionalised at the Macedonian court of Philip and Alexander. ${ }^{37}$ Men who had in their youth been pages together with the reigning king, could later be awarded the honorific title of suntrophos, 'foster-brother' of the king, and were addressed by him as 'brother'. Such philoi were really friends of the king. Notably Alexander the Great had used his circle of suntrophoi as the main source for recruiting favourites. Antiochos III initially promoted his former fellow-pages to important positions, too, but royal suntrophoi did not dominate his court as they had dominated Alexander's. One powerful suntrophos at his court was a certain Philippos, who held the prestigious post of elephantarchos, commander of the war elephants, throughout Antiochos' reign. ${ }^{38}$ Another

${ }_{35}$ Allying himself with a number of Anatolian peoples, and supported by Ptolemy IV, Achaios held out until 216 until Antiochos arrived personally in Asia Minor, and Achaios lost most of his support. He finally fell into Antiochos' hands through treason and was executed for disloyalty (Polybios 4.48; 5.41, 57, 66; 8.19-21).

${ }^{36}$ The epigraphical evidence has been collected by Savalli-Lestrade 1998.

${ }^{37}$ N.G.L. Hammond, 'Royal Pages, personal pages, and boys trained in the Macedonian manner during the period of the Temenid monarchy', Historia 39, 3 (1990) pp. 261-290; Strootman, Hellenistic Royal Court, pp. 181-188.

${ }_{38}$ Polybios 5.82.8; Livy 37.41.1; Appian, Syriaca 33. 
was Antipatros, whom Polybios calls a 'brother of the king. ${ }^{39}$ Like Philippos, Antipatros in all likelihood was an (ethnic) Macedonian. Together with Zeuxis (about whom more shortly) Antipatros was the most trusted of Antiochos' courtiers. He commanded the cavalry on the left flank in the battles of Raphia (217 BCE) and Magnesia (190), and was Antiochos' principal ambassador during the peace negotiations following these battles with a mandate to accept terms in the name of the king. ${ }^{40}$ Command of the left flank in battle was a position of honour indicative of very high status. It was reserved for the crown prince or the most important philos, the right flank being commanded by the king himself. ${ }^{41}$ In the battle against Molon in 221 it had been Hermeias who commanded the left flank, together with Zeuxis.

With Zeuxis we have arrived at a second category of courtiers who rose to prominence early in Antiochos' reign. These were the philoi who had been office-holders of secondary rank when Antiochos succeeded to the throne, and had proven their loyalty during the war with Molon. After the defeat of Molon, and the deaths of Epigenes, Hermeias and Achaios, they took over their positions. Thus, Diogenes the military governor (stratēgos) of Susiana (Elam), who had defended the citadel of Susa against the rebels, was given Molon's satrapy of Media. ${ }^{42}$ The first prize went to Zeuxis, who possibly was satrap of Babylonia under Seleukos III and thus perhaps an older and more experienced man than Antiochos. ${ }^{43} \mathrm{He}$, too, had remained loyal to the king during the revolt, resisting Molon's offensive in Babylonia with only a small

${ }^{39}$ Polybios 5.79.12 and 87.1; cf. Livy 37.41.1 and 55.3; Philippos' title of adelphos was honorific.

${ }^{40}$ Polybios 21.7.9. Antipatros as commander: Polybios 5.79.12, cf. 16.18.7; Livy 37.41.1. As ambassador: Polybios 5.87.1; 21.16.4; Livy 37.45.5-6; 37.55.3, and 56.8.

${ }^{41}$ Thus, in the great battles of Alexander the Great, this position was reserved for Parmenion, whether Alexander liked that or not. Crown princes commanding the left flank include: Alexander at the Battle of Chaironeia; Antiochos (I), the son of Seleukos Nikator, at Ipsos (Plutarch, Demetrios 29.3); Antiochos, the son of Antiochos III at Panion; and Seleukos (IV) son of Antiochos III together with Antipatros at Magnesia (Livy 37.41.1).

${ }_{42}$ Polybios 5.46.7, 48.14; 5.54.12. Diogenes later accompanied Antiochos on his eastern campaign, fighting the Parthian king in Hyrkania in 209 BCE (Polybios 10.29.5, 30.6-9), but thereafter disappears from the sources. Diogenes' place as stratēgos of Susiana was taken by a certain Apollodoros, while Tychon, the chief secretary (archigrammateus) of the army, was given the Persian Gulf region as province (Polybios 5.54.12). The lesser commanders in Molon's satrapy were pardoned and maintained their positions (5.54.8).

${ }^{43}$ According to Josephus, Jewish Antiquities 12.148, Antiochos honoured Zeuxis with the title of 'father', which may imply that he had been the tropheus of Antiochos 
army.$^{44}$ After Antiochos had arrived on the scene with the main army, Zeuxis began to take part in the meetings of the sunedrion. ${ }^{45}$ Together with Hermeias he commanded the left flank of the royal army in the final battle against Molon. ${ }^{46}$ After having distinguished himself as a general in the Fourth Syrian War against the Ptolemies (219-217), Zeuxis was installed as satrap of Lydia and viceroy of Asia Minor, a function he held at least from the beginning of Antiochos' campaigns in Iran and Central Asia in 211 until the king's return to Asia Minor in 199. His service as viceroy is well-attested in the epigraphical record. In the historiographical sources he turns up again during Antiochos' wars in Asia Minor and Greece (199-190) as a military commander and ambassador. ${ }^{47}$ At the end of his reign, Antiochos promoted his by then adult sons to high offices in the army and the administration: first the crown prince Antiochos, who died in c. 193, and subsequently Seleukos, the later king Seleukos IV Philopator (ruled 187-175). It is relevant to note here that Seleukid heirs were not really 'crown princes', for no such thing existed in Macedonian tradition; to forestall succession strife, the king's chosen heir was raised to the status of basileus, 'king', during the father's lifetime. ${ }^{48}$

and his suntrophoi Antipatros and Philippos, and explain his exceptional loyalty and commitment to Antiochos' cause.

${ }^{44}$ Polybios 5.45.4, 46.11, 48.12.

${ }^{45}$ Polybios 5.51.5. Interestingly, also Apollophanes of Seleukeia, the physician who had played a key role in the elimination of Hermeias, became a member of the royal council (Polybios 5.58.3).

${ }_{46}$ Polybios 5.53.6-7.

${ }^{47}$ Zeuxis commanded part of the infantry in the Battle of Magnesia (Livy 37.41.1, cf. Appian, Syriaca 33). In 190, Zeuxis and Antipatros were commissioned to negotiate a peace with the Roman consul Scipio and Eumenes of Pergamon (Polybios 21.16.5; Livy 37.45.5); the two men later travelled to Rome to ratify the peace (Polybios 21.24.1). This treaty entailed first of all the loss of Zeuxis' own province of Asia Minor. For philoi serving their king as ambassadors see Leon Mooren, 'Die diplomatische Funktion der hellenistischen Königsfreunde', in: Antike Diplomatie, Eckart Olshausen and Hildegard Biller, eds., Wege der Forschung 162 (Darmstadt 1979) pp. 256-290.

${ }^{48}$ See Strootman, Hellenistic Royal Court, pp. 111-14. The moral superiority of the father over the son hierarchised this system of dual kingship, while the presence of other sons secured the junior king's loyalty. Similarly, one of the king's wives could be raised to the status of basilissa, meaning 'queen' in her own right (or: 'female king'), not 'wife of the king', which was called basilinna in Greek, cf. Grace Harriet Macurdy, Hellenistic Queens. A Study of Woman-Power in Macedonia, Seleucid Syria, and Ptolemaic Egypt (Baltimore 1932) p. 8; Elizabeth D. Carney, "What's in a Name?" The Emergence of a Title for Royal Women in the Hellenistic Period', in: Women's History and Ancient History, Sarah B. Pomeroy, ed. (Chapel Hill; London 1991) pp. 154-172. Antiochos the son as commander in the Fifth Syrian War: Polybios 16.18.5-8. As viceroy of the Middle East during the Seleukid-Roman War: 35.13.4-5. Seleukos installed 
Still it seems that Antiochos had to reckon with opposition from his courtiers, as the men most favoured, apart from those mentioned above, were in some way or other outsiders among the philoi. We see a distinct preference on the part of the king for patronising defectors from rival courts, and exiles-men who had, forcibly or voluntarily, abandoned their earlier social milieu and had become dependent on the favour of a new patron. ${ }^{49}$ When an influential philos changed sides, members of his own personal network of friends followed him. ${ }^{50}$

Theodotos the Aitolian was governor of southern Syria and Palestine for Ptolemy IV, and in that capacity had successfully defended his province against the advance of Antiochos' army in $221-220 .{ }^{51}$ As he did not receive a proper reward during his next visit to Alexandria, 'holding the king in contempt... and mistrusting the court circles', Theodotos felt so insulted that he decided to offer his services to Antiochos; ordering his generals to occupy strategic positions, he offered Antiochos the cities that were under his control and urged him to enter his province with his army. ${ }^{52}$ In the ensuing Fourth Syrian War, Antiochos confirmed Theodotos as governor of his province (which he lost again after the Seleukid defeat in the Battle of Raphia in 217). ${ }^{53}$ Theodotos was given prestigious positions in the Seleukid army, including command of the Silver Shields, the royal infantry guard. ${ }^{54}$

as viceroy in Thrace: Polybios 18.50.8; Livy 35.15.4-5, cf. 36.7.15. As general in Asia Minor: Livy 37.11.15, 18.1-5, 21.6; Appian, Syriaca 26. As co-ruler of the empire: Livy 35.13.4-5; V. Messina, "Presto sarò re": Seleuco IV come Helios sulle cretule da Seleucia al Tigri', Parthica 3 (2001) pp. 9-23.

${ }^{49}$ The prominence of exiles at court is also emphasised by James L. O'Neil, 'The Ethnic Origins of the Friends of the Antigonid Kings of Macedon', Classical Quarterly 53 (2003) pp. 510-522, esp. 516: "Such men did not have an independent power base and were reliant on royal favour for their influence".

${ }^{50}$ Polybios 5.70.10.

${ }^{51}$ Polybios 5.61.3.

${ }^{52}$ Polybios 5.40.1-3, 61.4-9.

${ }^{53}$ Polybios 5.66.5. Theodotos made himself a name for daring when on the eve of the battle he sneaked into the Ptolemaic camp with two companions in an (abortive) attempt to kill king Ptolemy, and thus take his revenge (Polybios 5.81.1-7). The history of Antiochos III shows that it was not unusual for philoi to change their allegiance and associate themselves with rival courts (pace Meißner, 'Hofmann und Herrscher', pp. 15-16), the main reason for their 'treason' being the impugnation of their honour when their patron did not live up to the obligations of philia.

${ }^{54}$ Polybios 5.79.3; 7.16.1-18.10. 
Alexandros the Akarnanian had been a key office-holder at the court of the Antigonid king Philip V. ${ }^{55}$ When Philip became an ally of Rome, Alexandros attached himself to the Seleukid court and immediately made an exceptional career. As a member of Antiochos' sunedrion he advised the king concerning the conquest of mainland Greece, and served him as a general until he was mortally wounded in the Battle of Thermopylai (191). ${ }^{56}$

The admiral Polyxenidas was exiled from his native town of Rhodes. He held several commands during Antiochos' eastern campaigns, was a member of the sunedrion, and during the war against Rome and her allies (including Rhodes) commanded Antiochos' Aegean fleet. After suffering two major defeats, Polyxenidas of Rhodes eventually succeeded in destroying a large part of the Rhodian fleet in the combined land and naval battle at Panormos, taking his revenge on the Rhodian admiral Pausistratos, a personal enemy who had offended him, and who was killed in the battle. ${ }^{57}$

Our last example is the best known philos of Antiochos the Great, and his principal favourite in the final part of his reign: Hannibal of Carthage. Hannibal sought refuge at the Seleukid court in 196 after his defeat by Scipio in the Second Punic War. He became a senior advisor of Antiochos during the Seleukid-Roman War. ${ }^{58}$ Although the Carthaginian commander was obviously an anomaly in the Seleukid sunedrion, distrusted and hated by the other philoi, Hannibal nevertheless enjoyed the full confidence of the king, who sought and followed his advice in personal interviews and gave him important commands. ${ }^{59}$ Hannibal appears in the sources as a typical favourite, an outsider who stands up against the other courtiers and supposedly brings the king under his influence.

Antiochos' most trusted favourite, however, was neither a defector nor an exile but his principal wife, Laodike, the daughter of his vassal Mithradates II of Pontos. For various reasons, queens were considered

\footnotetext{
${ }^{55}$ His title epi tēs therapeias (Polybios 4.87.5 and 8) means either 'captain of the bodyguard' or 'major-domo'.

${ }^{56}$ Livy 35.18.1-8; 36.11.6, 20.5-6.

${ }^{57}$ Polybios 10.29.6; Livy 36.41.7, 43.4-7; 37.8.1-4, 10.3-5, 11.7-14, 23.7, 24.5-11, 26.5-8, 28.4, 30.1-10, 45.2; Appian, Syriaca 14; 17; 21; 22; 24; 27.

${ }^{58}$ Livy 34.42.6-14, cf. 37.45.16; Polybios 21.17.

${ }_{59}$ Distrusted by the philoi: Livy 34.14.4-5, 19.1; 41.2-3, 42.5-14; cf. Appian, Syriaca 10. Trusted by the king: Diodoros 29.3; Livy 34.19.7, 42.6-14; 36.6.7, 15.2, 41.2, cf. 34.7.1-21; 37.8.3, 24.4.
} 
trustworthy persons to whom power could be delegated, especially when a king was on campaign far from the geographical core of his empire. Thus, when Antiochos III was campaigning in the Aegean, Laodike represented him as monarch, having authority over the royal treasury, as is apparent from a letter to the city of Iasos, which had suffered from an unspecified natural disaster:

Queen Laodike to the council and people of Iasos, greetings. Having often heard my brother recall the help he constantly provides to his friends and allies,... and since it is my policy to act in accordance with his zeal and eagerness, (I will) confer a benefaction on those citizens who are destitute, which would be of general advantage to the entire people, I have written to Strouthion, the financial official (dioikètess), to have brought to the city every year for ten years 1,000 Attic medimnoi of corn to be delivered to the people's representatives.... If you continue to be (well) disposed towards my brother and in general towards our house as is fitting, (and) gratefully remember all our benefactions, I will try to help in securing in every way the other benefits I intend to confer, acting in accordance with the wishes of my brother. For I know that (he) is very eager to bring about the restoration (of the) city. Farewell. ${ }^{60}$

Because of the Macedonian practice of polygamous marriage and the absence of primogeniture, the Seleukid dynasty did not in principle have an official crown prince. There were, however, means by which a king could favour one of his sons ${ }^{61}{ }^{1}$ The mother of the king's favourite son could be expected to be a most loyal ally and to regard the interests of her husband's family as her own, lest her son be removed from the centre of power and replaced by the son of another wife as the designated successor. ${ }^{62}$

Above we have seen three categories of people who rose to positions of power in the early reign of Antiochos: first, members of the young king's own age class, former royal pages who had grown up

${ }^{60}$ Austin, Hellenistic World from Alexander to the Roman Conquest, no. 156; SEG 26, 1226 (c. 195).

${ }^{61}$ Cf. n. 48 , above.

${ }^{62}$ In Laodike's letter to Iasos, the dyad of king and queen is emphasised by the queen's designation of her husband as 'brother', and her dominant position among the king's wives by her use of the title of 'queen' (basilissa); in his correspondence from the field, Antiochos III likewise emphasised that Laodike was his other self by calling her 'our sister and basilissa', cf. Austin, Hellenistic World from Alexander to the Roman Conquest, nos. 151 and 158. Often competition among court factions organised around the respective queens and their sons, destabilised the Seleukid court or even led to succession war; for a comprehensive overview of all occasions see Daniel Ogden, Polygamy, Prostitutes and Death. The Hellenistic Dynasties (London 1999). 
together with him; second, magistrates and officers who had held positions of secondary rank in the preceding reign and were rewarded for their loyalty to the new king by promotion to the upper stratum of the court, taking over the positions of the powerful figures whose downfall they had helped to accomplish; and third, defectors, exiles and other outsiders who served as favourites. The promotion of favourites later in Antiochos' reign as a counterweight to balance the power of the philoi, suggests that the latter had become an established group with relatively secure positions at court and in the government. What we have also seen is how in the Seleukid Empire positions at court were linked directly with positions in the government and the army.

\section{The Ethnicity of the Seleukid Ruling Class}

In an influential article, Christian Habicht calculated that in the third century a mere $2.5 \%$ of the Seleukid imperial elite consisted of nonGreeks. He based his conclusion on a sample of about 250 leading men in the empire, using their personal names as indication of their ethnicity. ${ }^{63}$ Frank Walbank commented that 'The exclusion of nonGreeks from this circle probably reflected the prejudices of the Greeks and Macedonians rather than any incapacity or reluctance to serve on the part of the indigenous population. ${ }^{64}$

In the past decades, Habicht's view of the Seleukid court as an ethnically homogeneous group has become an object of controversy. The supposed ethnocentrism of the court seemed difficult to reconcile with the Seleukid Empire's nature as a Vielvölkerstaat and the existence of powerful autochthonous elites in rural areas and non-Greek cities. The principal arguments against Habicht's calculation have been collected by Kuhrt and Sherwin-White; apart from several methodological objections, they argued that Greek personal names do not necessarily indicate Greek ethnicity since non-Greeks in high positions would probably assume Greek names. ${ }^{65}$

${ }^{63}$ C. Habicht, 'Die herrschende Gesellschaft in den hellenistischen Monarchien', Vierteljahrschrift für Sozial- und Wirtschaftsgeschichte 45 (1958) pp. 1-16. Cf. Herman, 'Court Society of the Hellenistic Age', p. 201.

${ }^{64}$ F.W. Walbank, 'Monarchies and Monarchic Ideas', p. 68.

${ }^{65}$ Kuhrt and Sherwin-White, From Samarkhand to Sardis, pp. 124-5, cf. pp. 150-1. Leah McKenzie, 'Patterns in Seleucid Administration: Macedonian or Near Eastern?', Mediterranean Archaeology 7 (1994) pp. 61-68, goes even further by arguing that 
Although it is certainly true that personal names are flimsy indicators of ethnicity, the philoi at Seleukid court often figure in the sources with an ethnikon attached to their name, and from this evidence it seems that Habicht may have been right after all. ${ }^{66}$ Furthermore, ethnicity is not a matter of genealogy alone; it is also to some degree a cultural construct. ${ }^{67}$ If non-Greeks indeed gained access to court, yet assumed a dual identity, this did not make them ethnic 'Greeks', but it does testify to the dominance of Greeks and Macedonians at court. Finally, the rare non-Greek courtiers who do turn up in the sources unconcealed were favourites who had risen to prominence precisely because they were outsiders.

Under Alexander the Great, members of the Persian ruling class had initially retained their positions. As Macedonian hegemony was not yet firmly established, Alexander and his immediate successors, including Seleukos I, had to come to terms with the settled elites of the former Achaemenid Empire in order to pacify and govern the conquered territories. Some were allowed a place of honour at the Macedonian court, but most were merely confirmed in positions in the provincial administration. ${ }^{68}$

Already at the end of Alexander's reign efforts had been made to replace Iranian satraps with Macedonians, a policy which was continued by his successors. The Achaemenid aristocrats reacted to their exclusion from the empire's upper level by retreating to their rural power bases in relatively peripheral and little urbanised regions like northern Anatolia, Armenia and southern Iran. While French aristocrats in the seventeenth and eighteenth centuries would compensate for their loss of power in the provinces by attaching themselves to the royal court, ${ }^{69}$ the former Achaemenid elites drew away from the Seleukid court because they could gain in the periphery what they had lost in the centre. During the third century the Seleukids maintained

since the Seleukid administration combined Persian and Macedonian elements, an infrastructure was created that welcomed non-Macedonians, which in turn encouraged the creation of a shared culture.

66 Strootman, Hellenistic Royal Court, pp. 124-9. Cf. Weber, 'Interaktion, Repräsentation und Herrschaft', pp. 40-1; Herman, 'The Court Society of the Hellenistic Age', p. 208.

${ }^{67}$ Greek identity as a cultural construct: Jonathan Hall, Ethnic Identity in Greek Antiquity (Cambridge 1997); Irad Malkin, ed., Ancient Perceptions of Greek Ethnicity (Cambridge, Mass.; London 2001).

${ }^{68}$ Strootman, Hellenistic Royal Court, pp. 131-132.

${ }^{69}$ Duindam, Vienna and Versailles, p. 10. 
bonds of friendship and alliance with these local dynasts. Seleukos I was married to an Iranian noblewoman from Sogdia, the mother of his successor Antiochos.

\section{Governors into Kings}

In the reign of Antiochos III, indigenous, non-Greek aristocrats re-emerged as independent regional rulers. In his Armenian campaign of 212 and the so-called anabasis, Antiochos' great eastern campaign between 211 and 205, the king violently forced independent dynasts and unruly satraps into submission, then made them kings by his own grace. In return for their acceptance of his suzerainty, the Seleukid king offered his vassals protection. Thus, the 'governor' Zariadris became ruler of western Armenia, Xerxes of Armenia proper, Arsakes of Parthia, Demetrios of Baktria and Sogdia, and Sophagasenos of Gandhara. In Persis (Fars), the Persian heartland, a dynasty was founded by a local priest-king known as frataraka. Antiochos also accepted the existence of autonomous dynasties in Pontos, Kappadokia and Kommagene. The alliances between Antiochos and his vassals were cemented by dynastic marriages. With the exception of the Macedonian Demetrios, these dynasts were all non-Greeks. Regional rulers struck their own coins. Some of them, in particular the Parthian king and the frataraka of Persis, were depicted on coins wearing a kyrbasia, the satrapal cap, over the royal diadem. Apparently, these regional kings were still fitted into a court-based system of rank.

Although the new arrangement of the empire may have been a reaction to growing regional independence, that did not necessarily mean that the empire was weakened. The revolts of Molon and Achaios had demonstrated how difficult it could be to replace governors once appointed and in control of a provinces' resources and armed forces. To put it simply, the Seleukid court developed from an institution where high military offices were distributed into one where the title of king could be obtained. ${ }^{70}$ This process had in fact started before

${ }^{70}$ The Roman and Parthian Empires continued in the Middle East the Seleukid system of imperial rule through dependent autonomous kingdoms, cf. RolfStrootman, 'Queen of Kings: Kleopatra vii and the "Donations of Alexandria"', in: Kingdoms and Principalities in the Roman Near East, Margerita Facella and Ted Kaizer eds. (Stuttgart 2010) pp. 139158; a similar claim has recently been made by Maria Brosius, The Persians (London; New York 2006) pp. 114-116. After the disappearance of the Seleukid dynasty, the 
Antiochos' reign, when Seleukos III (246-225) formally accepted the autonomy of the Parthians, and was not able to suppress the growing independence of his Baktrian satrap, Diodotos. However, it seems that the change from a system of more or less direct rule by appointed provincial governors to a system of indirect rule through vassal dynasties was institutionalised under Antiochos, who assumed the title of Great King on his return from the east. ${ }^{11}$

Notwithstanding the rise of non-Greek, particularly Iranian elites, Antiochos' court continued to be dominated by ethnic Greeks tied to Greek poleis, with a small upper stratum of ethnic Macedonians. ${ }^{72}$ Iranians and others probably were increasingly present at court but they were not among the circle of persons closest to the king. From the available sources it is impossible to determine the exact status of 'Orientals' at court; perhaps their informal influence was greater than the 'western' historians Polybios and Livy suggest. Also the non-Greek troops that formed the majority of Antiochos' army in the great battles were almost without exception commanded by Greek and Macedonian senior officers. This dominance was not necessarily the consequence of an active policy on the part of the king; it may as well have been the result of the existence of an established, hereditary court aristocracy of Greek land-owners whose families had served the Seleukids for generations and who were not willing to give up their positions to newcomers. $^{73}$ This question, however, must at present remain inconclusive.

What we do see at this time, is the beginning of the development of a more refined system of aulic hierarchy and titulature, and this may

imperial court in Rome became the place where the princes of the Middle East turned to for confirmation of their royal status.

${ }^{71}$ So also Brosius, The Persians, p. 115.

72 Strootman, Hellenistic Royal Court, p. 126. Of the 41 office-holders and commanders who are known by name and ethnic, only three were non-Greeks. Apart from Hannibal, these were Aspasanias 'the Mede', commander of 5,000 Iranian light infantry in the Battle of Raphia, and Zabdibelas, an Arabian ally or vassal who commanded 10,000 'Arabs and neighbouring tribes' in the same battle (Polybios 5.79.7 and 8); nine of them, counting the king's sons Antiochos and Seleukos, were Macedonians.

${ }^{73}$ It is only in the course of the second century BCE that we hear more often of Iranian favourites being promoted to positions of power at the Seleukid court; at the same time, Egyptian favourites became a common presence at the Ptolemaic court. In both cases, they are described as eunuchs. See Strootman, Hellenistic Royal Court, pp. 177-178, for references; cf. R. Strootman, 'Eunuchs, concubines and renegades: The "paradox of power" and the promotion of favorites in the Hellenistic Empires', in: A. Erskine and L. Llewellyn-Jones eds., The Hellenistic Royal Court (forthcoming). 
well have been related to the rise of new elites in the course of the third century.

\section{Court Titulature: Offices and Honorific Titles}

Hellenistic court titulature grew from the basal system of titles of the fourth century Macedonian court, and developed through the adoption of Achaemenid practices into a more complex and refined system in the third century. Distribution of titles was part of the complex of gift exchange at court. Titles were presented by the king as rewards, comparable to, and presumably coming together with, material gifts of honour. In the third century, philoi mainly carried the type of titles that Léon Mooren in the context of Ptolemaic titulature has classified as 'real aulic titulature'-titles indicating concrete court functions, to be distinguished from 'honorific titulature', titles awarded honoris causa-and military offices. ${ }^{74}$ The latter category, omitted by Mooren, includes the generic titles of stratēgos, archistratēgos and satrap, as well as specific ones like elephantarchos. ${ }^{75}$ To the former category belong such offices as major-domo, Master of the Pages (tropheus), Chief Physician (archiatros), Chief Secretary (archigrammateus), Captain of the Bodyguard, Master of the Hounds, and Queen's Chamberlain. More honorific titles were Kinsman of the King (sungenès tou basileōs, perhaps an originally Achaemenid title) and Foster-Brother of the King (suntrophos tou basileoss). Similar or comparable titles existed at the Ptolemaic court and it is clear that the two dynasties influenced each other. ${ }^{76}$ The evidence however is unclear, as we rarely are informed what these functions implied in actual practice.

${ }^{74}$ Mooren, Aulic Titulature, p. 2.

${ }^{75}$ Military titles were indicative of status at court, court and army being interwoven; high officers in the army were always at the same time philoi, and the philoi mentioned by Polybios as members of Antiochos' royal council were also his supreme military commanders in the field. For a different view see however Herman, 'Court Society of the Hellenistic Age', p. 214 and K. Ehling, 'Der "Reichskanzler" im Seleukidenreich', Epigraphica Anatolica 30 (1998) pp. 97-106, assuming a formal distinction between 'civil' and 'military' office-holders at the court of Antiochos III.

${ }^{76}$ Bickerman, Institutions des Séleucides, p. 31; Mooren, Aulic Titulature, pp. 2 and 5. In the third century, the Antigonids stuck to the old Macedonian titles predating Alexander, retaining for instance the honorific office of somatophulax 'royal bodyguard' at the heart of the court hierarchy (cf. e.g. Diodoros 30.10.2, 30.11.1; on this title in Alexander's reign: Strootman, Hellenistic Royal Court, pp. 97-98. 
From c. 200 BCE onwards, purely honorific titles appear that suggest a hierarchisation of the philoi. Thus we hear of such titles as First Friends (prōtoi philoi), Honoured Friends (timōmenoi philoi), and First and Highly Honoured Friends (prōtoi kai prōtimōmenoi philoi) at both the Seleukid and Ptolemaic courts. ${ }^{77}$ What exactly these designations implied is impossible to reconstruct but it is safe to assume that they indicated status differences. A hierarchisation of court titulature may have been advantageous for the king. ${ }^{78}$ However, it could as well have functioned as an instrument for the established Greek philoi at the top of court society to close their ranks and to secure positions and privileges, both vis-à-vis outsiders and courtiers of lesser rank as well as vis-à-vis the king.

It is likely, but difficult to prove, that the later Seleukid kings had to reckon with an established social group of Greek court aristocrats who had become a landowning class due to the land distributions with which the monarchy in the past had rewarded their ancestors for their services. The existence of an established aulic aristocracy with fixed privileges and prerogatives at court may be confirmed by my earlier point that Antiochos III favoured Iranian and other indigenous dynasties-landed aristocracy without prerogatives at court-as provincial and municipal rulers, replacing temporary governors recruited among (Greek) philoi. Whether the king did so voluntarily or simply accepted new power relations that were ultimately beyond his control, is irrelevant for the present argument. What counts, is the result. Cemented by dynastic marriages, the principal bond between the king and his

${ }^{77}$ Kay Ehling, 'Gelehrte Freunde der Seleukidenkönige', in: Gelehrte in der Antike. Alexander Demandt zum 65. Geburtstag, A. Goltz, A. Luther and H. SchlangeSchöningen, eds. (Cologne; Weimar; Vienna 2002) pp. 41-58, esp. p. 45, and F. Muccioli, 'Crisi e trasformazione del Regno Seleucide tra il II e il I Secolo A.C.: titolatura, ruolo e competenze dei suggeneis', in: Politics, Administration and Society in the Hellenistic and Roman World, Leon Mooren ed. (Louvain 2000) pp. 251-274, esp. p. 260, perhaps assume too much 'frozen formalism' (Herman, 'Court Society of the Hellenistic Age', p. 223) for the title system. Although this honorific titulature is best attested for the Ptolemaic empire (see e.g. Mooren, Aulic Titulature, and idem, La hierarchie de cour ptolémaïque; Herman, 'The "friends" of the early Hellenistic rulers') it is impossible to determine where the system originated; Bickerman, Institutions des Séleucides, p. 31 suggested that it was imported into the Ptolemaic court when Antiochos III's daughter Kleopatra married Ptolemy V in 194/3.

${ }^{78}$ Weber, 'Interaktion, Repräsentation und Herrschaft', explained it as a mechanism by which the king could retain the loyalty of his philoi, since he was unable to recruit new friends among the Aegean Greeks, who were no longer willing to attach themselves to a declining empire. 
non-Greek allies was kinship. Through kinship ties, non-Greek elites must have gained access to the royal household, perhaps even to the inner court directly surrounding the king. Moreover, local aristocrats visited the court for great occasions such as inaugurations and weddings, as well as for major religious festivals. ${ }^{79}$ The historian Diodoros says that Antiochos IV in organising a festival of Apollo and Artemis at Daphne in 166/5 BCE 'brought together the most distinguished men from virtually the whole inhabited world... and, as it were, put upon a stage his entire empire (basileia)'. ${ }^{80}$

Since, however, in the second and first centuries non-Greeks still do not appear in the sources as among the persons closest to the king in any substantial numbers, we may assume that they were consciously excluded. The evolution of a more or less hierarchical and formalised complex of aulic titulature cannot but have served as a means to regulate proximity to the throne. Those non-Greeks who did participate in the distribution of offices and titles, had to adopt the forms and values of court culture, becoming 'Greeks' in more or less the same way that Turks, Arabs or Serbs became Ottomans when serving the padishah in Constantinople. A case in point is the Judean aristocrat Yannai, who had forcibly captured the high-priesthood of Jerusalem around 150 BCE. The Seleukid king, Alexandros I Balas, confirmed him in this office, giving him the titles of philos and adelphos of the king along with a purple court dress and a golden wreath. ${ }^{81}$ Yannai, who adopted the Greek name Jonathan, was able to accumulate massive power as a Seleukid ally, taking advantage of the dynastic wars that weakened the central power. His brother Simeon, who succeeded him in 142, founded the Hasmonean dynasty, a Seleukid vassal state renowned for the Hellenism of its court.

\section{Conclusion}

In the recent past, scholars studying the Ancien Régime have 'attacked the notion of "absolutism", stressing the financial limits of monarchical

\footnotetext{
${ }^{79}$ See e.g. 1 Maccabees 10.51-66.

${ }^{80}$ Diodoros 31.16.1; cf. 2 Maccabees 18-20, where Jewish delegates from Jerusalem travel to Tyros where the king celebrates the annual festival of Melkart-Herakles.

${ }^{81} 1$ Maccabees 10.20; cf. 10.62. The wreath was a gift of honour, often given as a reward for valour in battle.
} 
rule and the resilience of regional powers. ${ }^{82}$ As far as the Hellenistic kingdoms are concerned, however, the myth of absolutism is still alive. As Spawforth wrote: 'In the nineteenth and twentieth centuries the students of monarchical institutions in the ancient world have often been preoccupied with modernist attempts to define their legal basis. ${ }^{83}$ As a result, historians often fail to distinguish between the official rhetoric of imperialism and the more complicated reality of power relations, postulating a real and virulent absolutism for Alexander and his successors, who ruled their empires and courts unhindered by any constitutional regulations. This is true first of all for the relationship between kings and cities. Although the old notion that the Greek city state declined 'after Chaironeia' is now challenged more often, the opinion that Hellenistic cities lacked political freedom and had no voice in the affairs of the monarchies of which they formed part, still prevails. But the declaration of the autonomy and freedom of the cities, the most popular slogan in Hellenistic royal propaganda, was not a hollow phrase. ${ }^{84}$ Through the agency of the philoi, cities were able to negotiate with the empire, often to their own great advantage. The philoi not only acted on behalf of the king vis-à-vis the cities, but also promoted the interests of the cities at court.

As the problems accompanying the accession of Antiochos III have shown, Hellenistic kings were also not the absolute masters of their own courts. Even though Antiochos initially succeeded in rearranging the social composition of his court, he later ruled primarily through favourites who were relative outsiders within the society of philoi: Macedonians, defectors from rival courts, refugees from the Greek mainland, a Carthaginian outlaw, and a queen. We also saw how the king was forced to acknowledge the rising power of autochthonous aristocracies. Antiochos reacted by expanding an already ongoing process of indirect rule through local dynasts. The new vassals were fitted into the imperial superstructure through dynastic marriages and the facilities of the court, which they or their ambassadors visited on specific festive and ceremonial occasions. Adopting the Hellenism of the court, local rulers and civic elites became in part Hellenised as an

\footnotetext{
${ }^{82}$ Duindam, Vienna and Versailles, p. 10.

${ }^{83}$ Spawforth, Court and Court Society in Ancient Monarchies, pp. 1-16.

${ }^{84}$ Rolf Strootman, 'Kings and cities in the Hellenistic Age', in: The Postclassical Greek City. Volume II: Political Culture. Richard Alston, Onno van Nijf, and Christina Williamson eds. (in press).
} 
expression of their allegiance to the imperial court. Conversely, the Seleukid kings themselves shaped their monarchical representation to match the expectations of their heterogeneous subject peoples, particularly in religious contexts. They always took care, however, to fit these respective cultural 'faces' into an umbrella culture and ideology of empire which in essence remained Hellenic. 


\title{
THE ROMAN IMPERIAL COURT: SEEN AND UNSEEN IN THE PERFORMANCE OF POWER ${ }^{1}$
}

\author{
Andrew Wallace-Hadrill
}

\begin{abstract}
Reflect continuously how everything of the same sort as what happens now, also happened in the past, and think of how it will happen again; put before your eyes whole dramas and scenes of the same types you have encountered in your own experience or in ancient history, such as the whole court of Hadrian and the whole court of Antoninus and the whole court of Philip, Alexander and Croesus. All of them were of the same sort, only the people were different. ${ }^{2}$
\end{abstract}

An emperor, if anyone, should know. All the world's a stage, and the court he knew was only a specific re-enactment of a drama or scene that had played in the past and would play again in the future. We could hardly ask for a stronger or more authoritative invitation to consider courts as a cross-cultural phenomenon. Gibbon indeed seems to have taken the message, in a chapter that gives a devastating account of the ceremonials of the court of Constantine and his successors, marking the degeneration of the 'manly pride' of the Romans into the condition of 'abject dependents':

By a philosophic observer, the system of Roman government might have been mistaken for a splendid theatre, filled with players of every character and degree, who repeated the language, and imitated the passions, of their original model.

Gibbon's footnote points to 'Pancirolus ad Notitiam utriusque Imperii'; but in this last sentence, it is not the sources for ceremonial he is thinking of, but the philosophic emperor Marcus. Tacitly, the authority of

\footnotetext{
${ }^{1}$ I have preserved the text of my paper as delivered in Istanbul with only minor modifications to take into account more recent publications. I am grateful both to the organizers of the conference, and to Jeroen Duindam for discussion.

${ }_{2}$ Marcus Aurelius Meditations 10.27. On which see P.A. Brunt, 'Marcus Aurelius in his Meditations', Journal of Roman Studies 64 (1974) pp. 1-20; A.S.L. Farquharson, The Meditations of Marcus Aurelius (Oxford 1944) vol. 2, pp. 845-846 ad loc.; Aloys Winterling, Aula Caesaris. Studien zur Institutionalisierung des römischen Kaiserhofes in der Zeit von Augustus bis Commodus (31 v.Chr.-192 n.Chr.) (Munich 1999) pp. 1-3.
} 
the emperor of the Romans at their manly best is used to condemn the degeneration of the later Empire. ${ }^{3}$

Marcus' assertion of continuity was right in more senses than one: it is not just that imperial courts had a generic similarity to other royal courts, but that there were strong ties of historical continuity that linked the Roman court to those of the Hellenistic east after Alexander, and to the Persian court which Alexander's conquests absorbed and incorporated; and his prediction of future re-enactments was true in the stronger sense that the imperial court would provide models for the Byzantine, papal and early medieval courts, which in turn would influence the courts of absolutist Europe, and through Byzantium, the Ottoman and Russian courts. ${ }^{4}$ Constantinople is a good place to reflect on Marcus' prescience.

Nevertheless, Roman historians have, at least until very recently, either ignored the imperial court as a phenomenon, or dismissed its importance, or even denied it. This much has now been shown in detail by the recent studies of Aloys Winterling, Aula Caesaris and Mario Pani, La Corte dei Cesari. ${ }^{5}$ Winterling in particular shows how despite the attention drawn by Ludwig Friedlaender to the imperial court as the central phenomenon of Roman imperial society, Roman historians continued to follow the lead of Mommsen, who excluded the court from his Staatsrecht on the grounds that it was not a legally-based institution. ${ }^{6}$ Mommsen was quite right: the court had no place whatsoever in the Roman constitution. On the other hand, Roman imperial history is incomprehensible without it, and the correct inference to draw was that a legal/constitutional approach was not appropriate for Roman imperial history. A century and more of post-Mommsenian

${ }^{3}$ Edward Gibbon, The Decline and Fall of the Roman Empire, John Bagnell Bury, ed. (London 1896) vol. 2, p. 160 with n. 77.

${ }_{4}$ There is a notable lack of a comparative study of such courts. A welcome first step (published after this conference) is Antony S. Spawforth, ed., The Court and Court Society in Ancient Monarchies (Cambridge 2007). See my review in The Court Historian [Andrew Wallace-Hadrill, 'Courts and Classicists', The Court Historian 14, 1 (2009)]. For a comparative perspective on early modern courts, see Jeroen Duindam, Vienna and Versailles: the Courts of Europe's Dynastic Rivals, 1559-1780 (Cambridge 2003); Reinhardt Butz, Jan Hirschbiegel and Dietmar Willoweit, eds., Hof und Theorie: Annäherungen an ein historisches Phänomen (Cologne; Weimar; Vienna 2004) and further literature cited below n. 23.

${ }^{5}$ Mario Pani, La corte dei Cesari fra Augusto e Nerone (Rome; Bari 2003).

${ }^{6}$ Winterling, Aula Caesaris, pp. 12-18. 
historiography was based on the false premise that one could only access Roman imperial rule through its legal, constitutional and bureaucratic structures. The drama which Marcus continuously had before his eyes was thus veiled from sight.

It is worth asking why modern historiography has chosen to ignore a power-structure about which the ancient sources speak plainly and repeatedly. ${ }^{7}$ Beyond Mommsen's influence is an interesting convergence of ideologies, between modern liberalism and ancient republicanism. For the modern world, antiquity has been a critical source of models of anti-monarchical systems: Roman republicanism and Athenian democracy are such cornerstones of modern ideology that we do not want to hear that the imperial court has had a longer, deeper and wider influence. Here modern ideology finds convenient confirmation in the republicanism of Tacitus. By his ironical tactic of narrating from the perspective of the constitutional organs of the Roman state, the senate and people, he denies the legitimacy of the court, around which nevertheless, as his narrative reveals, the entire action revolves. From Mommsen on, Roman imperial history has been told from an insistently Tacitean perspective. When Fergus Millar deliberately broke from that perspective in the Emperor in the Roman World, and adopted instead the perspective of Greek writers like Dio, his claim that the imperial system (normally referred to, for equally ideological reasons, as 'the Principate') was in fact a form of monarchy was regarded as controversial. ${ }^{8}$ I believe we can now take it for granted.

The imperial court, then, was something Roman historians knew about but preferred not to discuss, the skeleton in the cupboard of Roman history. Even Paul Veyne, who saw imperial rule as a form of monarchy, made the explicit comparison with the court of Louis XIV, on which his friend Le Roy-Ladurie was working, and concluded that the Palatium was no Versailles, and that the true court of Rome was

\footnotetext{
7 On the explicit ancient discussion of the court, see Winterling, Aula Caesaris, pp. 194-203; Andrew Wallace-Hadrill, 'The Imperial Court', in: Cambridge Ancient History new ed. vol. X (Cambridge 1996) pp. 283-308, esp. pp. 283-285; Jeremy Paterson, 'Friends in high places: the creation of the court of the Roman emperor', in: The Court and Court Society in Ancient Monarchies, Antony S. Spawforth, ed. (Cambridge 2007) pp. 121-156, esp. pp. 123-126.

${ }^{8}$ See also Fergus Millar, 'Emperors at Work', Journal of Roman Studies 57 (1967) pp. 9-19.
} 
the Colosseum, the emperor with his people at the games. ${ }^{9}$ One might as well say that the true court of Ferdinand IV of Naples was the popular spectacle of the Cuccagna, when the starving Neapolitans tore apart heaps of living animals in the piazza, and not the Reggia at Naples or Caserta. Public spectacles are fine for a display of power, but do not touch on the crucial function of the court, which is the concentration and redistribution of power. The Palatium remains the single largest structure in Rome, and until we can get our heads around it, alongside its familiar neighbours the Colosseum and the Forum, we cannot understand how or why the Roman empire worked. ${ }^{10}$

That the court was not examined analytically as a system of concentration and redistribution of power is the stranger in view of the turn taken by Roman republican historiography. Particularly in the acute formulation of Matthias Gelzer, the Roman republican nobility was seen as a system of reproducing social power. ${ }^{11}$ Power was conceived as dependent on the control of the magistracies, especially the consulships. Gelzer demonstrated the strong tendency for descendants of consuls, the self-styled nobiles, to dominate high office (and in consequence opportunities for military command, enrichment and religious and social prestige). He attributed their success to the system of patronage whereby networks of friendship and ties of vertical dependence were activated to procure votes in the elections. This thesis has more recently come under sustained attack by Peter Brunt and Fergus Millar, and at the least we must admit that the mechanism of clientela was simplified mechanically by Gelzer; even so, it remains a characteristic of the last century of the Republic that office, influence and power were kept within a limited circle of dominant families. ${ }^{12}$

The paradox is that if access to high office was seen as the key to the Republican power system, access to office should also be the key

9 Paul Veyne, Le Pain et le Cirque (Paris 1976) pp. 682-685; cf. Emmanuel Le Roy Ladurie, 'Versailles observed: the court of Louis XIV in 1709', in: The Mind and Method of the Historian, S. and B. Reynolds, trans. (Brighton 1981).

${ }_{10}$ See Claudia Cecamore, Palatium: topografia storica del Palatino tra III sec. a.C. e I sec. d.C. (Rome 2002); Ricardo Mar, El Palatí: la formació dels palaus imperials a Roma (Tarragona 2005). It is the focus of an important new project by the German Archaeological Institute in Rome.

${ }^{11}$ Matthias Gelzer, Die Nobilität der römischen Republik (1912), translated R. Seager, The Roman Nobility (Oxford 1969).

${ }_{12}$ P.A. Brunt, The Fall of the Roman Republic and Related Essays (Oxford 1988) pp. 382-442; Fergus Millar, The Roman Republic and the Augustan Revolution (Chapel Hill; London 2002) pp. 109-61. 
to the imperial system. How and where did individuals access office, influence, and wealth? The answer, evidently, is that such things now depended not on the popular vote but imperial favour. Since epigraphy provides abundant evidence on the personnel involved, the prosopographic instinct, which in the case of republican power-holders focused on the networks and intrigues by which groups held power, was focused in the case of the empire on bureaucratic systems: endless volumes on Kaiserliche Verwaltungsbeamten catalogued a supposed imperial bureaucracy at every level, from senatorial office holders to equestrian officials and procurators, to the vast army of imperial freedmen and secretariat. ${ }^{13}$ Arnaldo Momigliano's short biography of Claudius, first published in 1932, is eloquent on the Tendenz of this approach. He presented Claudius as a great bureaucratic reformer, and refused explicitly to consider the abundant evidence of court intrigue, specifically that involving female members of the imperial family and freedmen. ${ }^{14}$

Yet at exactly the same moment, Robert Graves was using this material for his memorably vivid evocation of the imperial court in I Claudius. ${ }^{15}$ The intrigues of the imperial court were evidently material for historical novels, not for serious history. But there was another, ideological, factor at play. Momigliano, writing in Mussolini's Italy, wished to defend empire and the imperial system, even in the hands of one whom the outside world might regard as something of a buffoon; Graves, writing from an anti-fascist perspective, wished to expose imperial power as a web of intrigue. What most demands explanation is why Roman historians writing after the war still refused to confront the realities of imperial power. The defensive tone became stronger, and with it the representation of that power as a logical bureaucratic system. Even Syme, so fearless in the 1930s in exposing the foundations of imperial power in party factionalism, and who read for amusement the memoirs of the Versailles court of Saint-Simon (so he told me), fails in his Tacitus volumes to tackle head-on the phenomenon of a court system.

\footnotetext{
13 See Winterling, Aula Caesaris, pp. 23-6.

14 Arnaldo Momigliano, L'opera del imperatore Claudio (Firenze 1932), translated W.G. Hogarth, Claudius: the Emperor and his Achievement (Cambridge 1961).

${ }^{15}$ Robert Graves, I Claudius, first published 1934.
} 
Millar's Emperor in the Roman World was the first book to confront imperial power as a system of distribution of office, wealth, favour and judgement, and even then, he left it to Richard Saller to spell out the mechanisms of patronage and clientelism on which such a system must rest. ${ }^{16}$ For all Millar's emphasis on the personal actions of the emperor, it is evident that he could not distribute hundreds of offices and benefices without a web of recommendations. Saller spelled out the system of brokerage whereby recommendations were filtered to the emperor, in a chapter tellingly entitled, 'The emperor and his court'. But again, though he vigorously contests the thesis of any bureaucratic system of promotion, and argues for benefices and access to justice mediated by brokers ranging from members of the female family and potent freedmen to favoured members of the elite, he stops short of offering a conceptualization of the court as system. ${ }^{17}$

It was in studying Suetonius' imperial biographies that I was struck by how casual and persistent was the idea that the emperor was surrounded by a court, and that the court was the arena in which power was traded..$^{18}$ As an imperial secretary under Hadrian, the author might be assumed to have a reasonable understanding of the workings of the court; nor did he share the apparent disdain of the senatorial Tacitus for dealings that took place outside the senate. What he offers, after his fashion, is not analysis, but a series of vivid snapshots. The word aula, court, and its derivatives are recurrent. It is from the intimi aulici, intimate courtiers, of Caligula that Suetonius' own grandfather had heard the emperor's reason for building the bridges of boats across the bay of Naples: the astrologer Thrasyllus had said Caligula would no sooner be emperor than ride on horseback across the bay (Cal. 19.3). Claudius was a figure of fun at Caligula's court (Tacitus uses the expression inter ludibria aulae): he used to fall to sleep and snore at dinner, so the jesters put boots on his hands so he would rub himself with them when he awoke (Claud. 8). Otho owed his promotion to feigning love for an influential court freedwoman, libertinam aulicam gratiosam, despite the fact she was over the hill; hence he insinuated himself into

\footnotetext{
${ }^{16}$ Fergus Millar, The Emperor in the Roman World (London 1977); Richard P. Saller, Personal Patronage under the Early Empire (Cambridge 1982).

${ }_{17}$ Saller, Personal Patronage, pp. 41-78; see also Andrew Wallace-Hadrill, 'Patronage in Roman society: from republic to empire' in: Patronage in Ancient Society, Andrew Wallace-Hadrill, ed. (London 1989) pp. 63-87.

${ }^{18}$ See Andrew Wallace-Hadrill, Suetonius: the Scholar and his Caesars (London 1983) pp. 177-80.
} 
Nero's circle (Otho 2.1). Vespasian similarly owed his rise to his affair with Caenis, freedwoman of Antonia, mother of Claudius; he got his command in Britain through the influence of the freedman Narcissus; his membership of Nero's entourage was cut off when he fell asleep during Nero's singing. The doorman told him next morning he wasn't welcome, and when he asked where to go, the man replied, 'To Hell!' (Vesp. 3-4, with Dio). Vitellius' father was the perfect courtier: he carried one of Messalina's slippers in his toga, and would take it out and kiss it; he included images of the freedmen Narcissus and Pallas among his household gods (Vit. 2.5); the son obtained a leading place at court (praecipuum in aula locum) by his flexible propensity for the vice of the day, chariot-racing under Caligula, dicing under Claudius, and encouraging cithara playing under Nero (Vit. 4). Titus was brought up in court (educatus in aula) with Britannicus, step-brother of Nero; he was reclining at table next to Britannicus when the young prince was given his fatal draft of poison (Tit. 2).

Tittle-tattle this may all be, and Suetonius is regarded as less than serious for passing these stories on. But is there any reason to suppose that he and his sources were fantasising the whole set-up of a court society within which the ambitious networked, and made what connections they could, via women and freed slaves if appropriate, in order to achieve power and influence? The picture is abundantly confirmed by the other sources whom had good reason to be intimate with court life: Epictetus, former slave of Epaphroditus, potent freedman of Nero, who had to humiliate himself with his ex-slave Felicio, whom he had sold as good for nothing, became the emperor's cobbler; ${ }^{19}$ and Seneca, courtier to Claudius and Nero, whose philosophical writings are full of court anecdotes, including the reply of the aged courtier who when asked the secret of survival at court, replied 'By taking insults and returning thanks'. But it is not the anecdotes of Suetonius, Epictetus, and Seneca, nor even the resigned wisdom of Marcus Aurelius, that guarantees the importance of the imperial court, but its structural function.

The court, I propose, should be defined as the space around the ruler within which access to imperial favour is negotiated. The aula is not a building, though it has its monumental expression in the Palatium.

19 The relevance of Epictetus to understanding the court was shown by Fergus Millar, 'Epictetus and the Imperial Court', Journal of Roman Studies 55 (1965) pp. 141-148. 
Nor is it a legal or constitutional institution, such as Mommsen could recognize: the senate retained an institutional identity the court never had. Nor is it a bureaucracy, nor even the imperial household, whether the freeborn family members, domus Caesaris or the slave-born support system familia Caesaris. It is the space within which all these groups and institutions intersect in the pursuit of power.

As a space, it is fundamentally theatrical: it is where people come to see and be seen, and as in the theatre, to watch each other as well as the spectacle. They come to see the emperor and catch his eye; or catch the eye of those who know how to catch his eye; to observe their rivals catching eyes. It is consequently a dangerous space: everyone is visible, but everyone has something to hide from someone else. The fundamental feature of a democracy, and even of the Roman republic, whether we call that a democracy or not, is that power is pursued in the open, before the eyes of fellow citizens. However much you may depend on clientelism, you still have to bid for power openly in public, and win the votes of the people. At the imperial court, everything is veiled, only partially visible. However 'open' the court may have been in terms of access, this rendered the decision-making process no less covert: the openness of the social life stands in constant tension with the necessary veiling of the political process. ${ }^{20}$ The imperial decision is made public by a charade, public elections for the consuls from a closed list of preselected candidates. The court is where the decision is made: not in the sense of a specific place, but of the whole network of contacts and communications that spin a web around the emperor.

The most vivid statement of the theatrical nature of a court is the Duc de Saint Simon's account of the death of the son of Louis XIV, Monseigneur.

It must be admitted that, for him who is well acquainted with the privacies of a Court, the first sight of a rare event of this nature, so interesting in so many different respects, is extremely satisfactory. Every countenance recalls the cares, the intrigues, the labours employed in the advancement of fortunes-in the overthrow of rivals: the relations, the coldness, the hatreds, the evil offices done, the baseness of all; hope, despair, rage, satisfaction, express themselves in the features. See how all eyes wander to and fro examining what passes around-how some are

${ }^{20}$ A point made explicitly by Cassius Dio 53.19. Paterson, 'Friends in high places', p. 123 objects that the court was open and visible: he might not have convinced Tacitus. 
astonished to find others more mean, or less mean than was expected! Thus this spectacle produced a pleasure, which, hollow as it may be, is one of the greatest a Court can bestow. ${ }^{21}$

Specific observations of the varied reactions to the death bear out this general observation:

...Monseigneur was no more: it was known: it was spoken of: constraint with respect to him no longer existed. Amidst the surprise, the confusion, and the movements that prevailed, the sentiments of all were painted to the life in looks and gestures.

In the outside rooms were heard the constrained groans and sighs of the valets...Farther on began the crowd of courtiers of all kinds: The greatest number-that is to say the fools-pumped up sighs as well as they could, and with wandering but dry eyes, sung the praises of Monseigneur... Others, really afflicted-the discomfited cabal-wept bitterly, and kept themselves under with an effort as easy to notice as the sobs. The most strong-willed or the wisest, with eyes fixed on the ground, in corners, meditated on the consequences of such an event... Those who already looked upon the event as favourable in vain exaggerated their gravity so as to make it resemble chagrin and severity; the veil over their faces was transparent and hid not a single feature. ${ }^{22}$

Saint Simon's analysis, as Norbert Elias fully appreciated, underlines a fundamental feature of court life. ${ }^{23}$ Not only is it the place where the ruler and the elite keep each other under mutual observation, but where the elite watch each other, all competitors in the power game. And once that is understood, it is easier to appreciate that Tacitus too, for all his disdain, is a skilled and attentive observer of court life. One moment of drama and revelation that matches that of the death of the Monseigneur is the death of Britannicus. ${ }^{24}$ The young prince

${ }^{21}$ Memoirs of the Duke of Saint-Simon on the reign of Louis XIV. and the Regency, Bayle St. John, trans. (New York 1901) vol. 2, p. 378; see French original in fulltext online version: Saint-Simon, Louis de Rouvroy duc de, Mémoires complets et authentiques du Duc de Saint-Simon sur le siècle de Louis XIV et la régence, PierreAdolphe Chéruel, ed. (Paris 1856-58) 20 vols., vol. 9 chapter VI via http://rouvroy .medusis.com/.

${ }^{22}$ Saint-Simon, Memoirs, vol. 2, pp. 373-374, or vol. 9 chapter VI via http://rouvroy .medusis.com/

${ }^{23}$ Norbert Elias, Die höfische Gesellschaft. Untersuchungen zur Soziologie des Königtums und der höfischen Aristokratie (Darmstadt 1969), translated E. Jephcott, The Court Society (Oxford 1983).

${ }^{24}$ See Andrew Wallace-Hadrill, 'Rhetoric and Myth-Making at the Court of Nero', in: Neroniana VI: Rome à l'époque néronienne, Institutions et vie politique, économie et société, vie intellectuelle, artistique et spirituelle. Actes du VIe Colloque international de 
is dining at table with Nero, the other members of the imperial family, and various elite courtiers. Nero's poisoners choose ingeniously to administer the dose not in the wine, which is passed first to a taster, but in the cold water with which it is mixed. Britannicus at once suffers a seizure.

Trepidation spread among those sitting nearby, the foolish fled; both those with deeper understanding stayed immobile, with eyes fixed on Nero. He lay back as he was and as if he was unaware, remarked that it was usual for Britannicus to suffer epileptic fits from his infancy, and that his sight and senses would soon return. But with Agrippina such terror, such mental consternation, even though suppressed in her expression, flashed out as to make it clear that she was as innocent of the plot as his sister Octavia; indeed, she understood that her last help had been seized from her, and a precedent set for parricide. Octavia too, tender though her years, had already learned to conceal grief, affection, indeed every sentiment. (Ann. 13.16).

The imperial court seems several steps ahead of Versailles in the sophistication of its watching game. Everyone has learned to veil their feelings so effectively that the knowing eye only reads the truth through the very efforts of concealment.

Norbert Elias' analysis of the court of Versailles has come under heavy criticism in recent literature, not least for his excessive reliance on Saint Simon. In particular, his thesis that the court was the instrument whereby the king kept the nobility under watch and thereby under control, playing them off against their social rivals, is seen to be a model at best partly satisfactory for France, and not at all convincing for other courts. ${ }^{25}$ As study of the archives grows, so we can expect our understanding of the operation of such courts to become more nuanced, and above all to see that the ruler is as vulnerable as any other players, and that all the competing social elements gained as

la SIEN (Rome, 19-23 mai 1999), Jean-Michel Croisille et Yves Perrin, eds. (Collection Latomus vol. 268, Brussels 2002) pp. 472-478.

${ }^{25}$ See Aloys Winterling, Der Hof der Kurfürsten von Köln 1688-1794. Eine Fallstudie zur Bedeutung "absolutischer" Hofhaltung (Bonn 1986); Jeroen Duindam, Myths of Power: Norbert Elias and the Early Modern European Court (Amsterdam 1995); Jeroen Duindam, Vienna and Versailles: the Courts of Europe's Dynastic Rivals, 1559-1780 (Cambridge 2003); idem, 'Norbert Elias and the history of the court: old Questions, new perspectives', in: Hof und Theorie: Annäherungen an ein historisches Phänomen, R. Butz, J. Hirschbiegel and D. Willoweit, eds. (Cologne; Weimar; Vienna 2004) pp. 91-104. 
much as they lost. ${ }^{26}$ But this is perhaps where Tacitus, or Suetonius or Epictetus, can help us. They never suggest an emperor fully in control of his court. A Tiberius or a Nero emerges as fully vulnerable in these accounts, as much a victim as an instigator of the process of mutual watching. It is a dangerous game for all involved.

If we take the imperial court as the theatre where the elite of the empire assemble to watch each other, watch the power game, and take their chance, what consequences flow for its structural significance for the empire? Here it seems to me that in the very distaste for court life which Tacitus shared with Marcus Aurelius, historians have missed the fundamental contribution of the court. One of the most remarkable features of the Roman empire, and one that is basic to its long duration, is the ability to assimilate and draw into the centre of power the elites of geographically widespread and culturally diverse areas around the entire Mediterranean. Once we have got beyond the myths that the Empire owed its strength to legions (which were few) or to an efficient bureaucracy (which was virtually non-existent), we are thrown back on the willingness of local elites to collaborate with the Roman system. The successive waves by which provincials from different areas, first Spain and the western provinces, then Greece and Asia Minor, then the margins including Syria and the Balkans, penetrated to office and eventually imperial power, have been much documented, not least by Syme. The question is what mechanism allowed this penetration to happen? Popular elections in the city of Rome were the mechanism by which the Republican elite maintained its exclusivity and kept out newcomers.

The imperial court is the space within which newcomers gained access to power. Corrupt it may have been, and painful to those who found paying court to influential ex-slaves distasteful. But it drew together diverse elites from across the empire and enabled them to network, ally, and bargain. Its inherent instability was structurally incompatible with the long-term formation of stable elites. It promoted mobility, since the new arrivals have less baggage than the well-established, and are more alert to changing sides when the winds of fortune shift direction. ${ }^{27}$ Because loyalty to the emperor was everything, rises to fortune and power could be rapid and dramatic, whether the

${ }^{26}$ I am grateful to Jeroen Duindam for discussion of this point.

27 Cf. Keith Hopkins, Death and Renewal (Cambridge 1983) pp. 171-193. 
ex-slaves like Narcissus and Pallas who flourished under Claudius, or even the suave courtier Vitellius, who kissed Messalina's slippers, and was rewarded with a statue inscribed 'for unshakable loyalty to the emperor'. Undoubtedly, as Winterling has argued, the tendency was for the court to become more institutionalised over time; the rules of the game were better known in Marcus' court than in that of Tiberius. Yet its strength was its ability to exist outside institutions, outside the constitution. It provided an element of constant flexibility and change at the heart of the empire which contributed to its survival. 


\title{
COURT AND STATE IN THE ROMAN EMPIRE- DOMESTICATION AND TRADITION IN COMPARATIVE PERSPECTIVE
}

\author{
Peter Fibiger Bang
}

\begin{abstract}
Such a degree of obedience is also shewn by servants to their masters, and looked upon by them as a source of blessings. Hence for the disciples of His Majesty [the Emperor], it was necessary to add something, the prostration of the sijdah; and they look upon a prostration before His Majesty as a prostration performed before God; for royalty is an emblem of the power of God, and a light-shedding ray from this Sun of the Absolute. Viewed in this light, the prostration has become acceptable to many, and proved to them a source of blessings upon blessings. But as some perverse and dark-minded men look upon prostration as blasphemous man-worship, His Majesty, from his practical wisdom, has ordered it to be discontinued by the ignorant, and remitted it to all ranks, forbidding even his private attendants from using it in the Darbár $i^{\prime} A$ 'm (general court days). ${ }^{1}$
\end{abstract}

This discussion of prostration as a ritual of greeting used by a select and specially favoured group of courtiers to pay obeisance to Akbar, the Mughal emperor (1556-1605) appears in the copious manual of his realm written by the nobleman and ideologue Abul Fazl. The Mughals self-consciously presented themselves as rulers in the grand traditions of central Asia and of Persia. They boasted descent from Timur, the Turko-Mongol conqueror formerly known as Tamerlane, and championed a Persianate style of culture. Persian was the preferred or privileged language at court. Shahjahan, the grandson of Akbar, even had his audience halls designed metaphorically to emulate Persepolis. ${ }^{2}$ This was the fabled palace of the Achaemenids which the victorious Macedonian king Alexander had later senselessly burned down at the end of

1 Abul Fazl, Ain-i-Akbari I, 74 [H. Blochman, trans. (Calcutta 1927-1949) vol. 1, pp. 158-19]. Apart from the sijdah, the more regular forms of greeting were called the kornish (right hand on forehead which is then bent down) and the tasli'm (back of right hand placed on ground, raised up gently and when standing erect palm of hand on crown of head). John F. Richards, The Mughal Empire. The New Cambridge History of India, vol. 1.5 (Cambridge 1993) pp. 47-49 for a brief discussion.

${ }^{2}$ See the contribution of Ebba Koch in this volume; eadem, 'Diwan-i 'Amm and Chihil Sutun: The Audience Halls of Shah Jahan', Muqarnas 11 (1994) pp. 143-165. 
a drunken party. Rightly or wrongly, the act of prostration, whatever its varying historical forms, holds a prominent place in the Western historiographical conception of Persian imperial lordship. The ancient Greeks and Romans frowned on the performance of the ritual they described with the term proskunésis. Prostration in front of the ruler was reproached as a humiliating act of submission not becoming of free men; it was a degrading act of slavery.

One of the main charges brought against Alexander by posterity was that he had allowed himself to be lured by the splendour and rituals of the Persian court and had forgotten about his Greek and Macedonian roots. Later historians celebrated in their works an episode where the nobleman Callisthenes had spoken out against the plans of Alexander, prompted by the advice of a certain Anaxarchos, to demand prostration of his nobles now that he had won the Achaemenid throne:

It was improper of you to take the lead in this topic; you should rather have remembered that you are not attending, nor advising a Cambyses or Xerxes, but a son of Philip, a descendant of Heracles and of Aecus, whose forefathers came from Argos to Macedonia, and have continued to rule the Macedonians, not by force, but in accordance with custom and law. ${ }^{3}$

In Graeco-Roman political discourse, prostration/proskunesis was identified with tyranny and despotism, violent oppression rather than the rule of law. Roman emperors were repeatedly reminded not to demand such excessive demonstrations of loyalty from their nobility. Tiberius, emperor CE 14-37, is even reported once to have tripped in his attempt to avoid a senator who threw himself at his feet. ${ }^{4}$ Emperors who less carefully upheld the etiquette of modesty regulating the interaction of ruler and aristocracy were frequently subjected to hostile criticism. The reputations of emperors such as Caligula, Domitian and later Galerius and Diocletian have all been blackened by accusations of megalomania and tyranny. By accepting or demanding the so-called proskunesis, it was alleged, they allowed barbarian and Persian ways to debase the proud traditions of Roman liberty. ${ }^{5}$ This kind of critique, however, should not be mistaken, as it often is, for evidence of direct

\footnotetext{
${ }^{3}$ Arrian Anabasis IV, 11, 6 (oude biai, alla nomoi). Cf. Diana Spencer, The Roman Alexander (Exeter 2002).

${ }^{4}$ Suet. Tiberius 27.

${ }^{5}$ E.g. Philo Leg. ad Gaium 116 (Caligula); Ammianus Marcellinus 15, 5, 18 (Diocletian); Lactantius de mort. persc. 21, 2 (Galerius).
} 
emulation or introduction of Persian court ceremonial by Roman emperors. ${ }^{6}$ The idea of Persian imperial tyranny was a Graeco-Roman, and later Western, caricature, a cultural construct-monarchs in the Persian tradition were as we have just seen equally subject to critique and constraints. The bugbear notion of the Persian Great King served as a cultural stereotype which gave expression to a basic conflict within Graeco-Roman culture: ${ }^{7}$ city-state and imperial majesty co-existed uneasily. This paper will examine that tension through the prism of the sociology of Norbert Elias and portray it as a specific expression of a conflict and social dialogue characteristic not of the Roman court in particular, but of monarchical societies in general.

\section{A Roman Court or the Aristocratic Republic Domesticated?}

It has been one of the major concerns of modern Roman historiography to explain the nature of the relationship between the personal rule of the emperor and the old, legal institutions of the Roman republic which continued after the institution of monarchy under Augustus (31 BCE-CE 14). As the centre of government moved from the senate to the corridors of the imperial household, the state changed character.

${ }^{6}$ Pace Rowland Smith, 'The imperial court of the late Roman empire, c. AD 300c. AD 450', in: The Court and Court Society in Ancient Monarchies, Anthony S. Spawforth, ed. (Cambridge 2007) pp. 157-232 [partly following Aloys Winterling, ed., Zwishen "Haus" und "Staat": Antike Höfe im Vergleich (Munich 1997) p. 161n29]. The point was established by András Alföldy, Die monarchische Repräsentation im römischen Kaiserreiche (Darmstadt 1970) pp. 6-25. H. Stern's discussion ['Remarks on the 'Adoratio' under Diocletian', Journal of the Warburg and Courtauld Institutes 17 (1954) pp. 184-89] of late antique ceremonial changes to the imperial audience does not show any direct Persian influence behind these developments. The key point of Alföldy was not to deny the more rigidly hierarchical image projected by late antique imperial ceremony, but to make less of the contrast with the preceding period than previous scholars had done; the Princeps was already an august, quasi-divine lord. Similarly, as Sabine G. MacCormack showed in her study of late antique monarchical symbolism [Art and Ceremony in Late Antiquity (Berkeley; Los Angeles 1981)], not all aspects of the earlier ideal of a civic, accessible ruler disappeared.

7 The claim, e.g. of Mario Pani [La Corte dei Cesari (Rome; Bari 2003) pp. 73-104] that the Roman monarchy was torn between an Eastern and a Western model, therefore, seems of doubtful value. A clear distinction between two such models would in any case be difficult to identify by the time of the Roman monarchy. Cultural exchange, back and forth, had been much too intense and had a thousand-year-old record in the Mediterranean. Alexander might, for instance, have been accused of adopting Eastern ways, but following in his footsteps, Greek was elevated to a position of prominence in the Levant and the Middle East. 
Historians, equipped with the instruments of constitutional and administrative study, however, have found it difficult to account for this change. They have addressed the problem primarily as a question of the growth of formal bureaucracies and debated arcane details of public law to determine whether the imperial household was a public or a private institution. ${ }^{8}$ Others, more interested in the naked realities of power have preferred to follow in the footsteps of the senator Tacitus. A historian with a more than sentimental attachment to the Republican constitution, he famously dismissed what survived of it under the rule of the emperors as an empty shell. The Principate, the label which is normally tagged to the monarchy between $31 \mathrm{BCE}$ and CE 235 to emphasise the idea that the emperor was merely the leading citizen, the first among equals, was from a Tacitean perspective a sham devoid of political content. ${ }^{9}$ But whether one focuses on private intrigue and patrimonial rule or the public realm of law, formal bureaucracy and politics, the surviving institutions of the republic and the imperial monarchy continue to seem fundamentally foreign to each other.

Court history would seem to offer an avenue to cut across these divisions, as pointed out in recent years. ${ }^{10}$ In the work of Norbert Elias, the court is theorised, not merely as a private patrimonial establishment,

8 Theodor Mommsen, Römisches Staatsrecht, bd. 2, 2 (Leipzig 1887); Heinrich Otto Hirschfeld, Die kaiserlichen Verwaltungsbeamten bis auf Diocletian (Berlin 1905); Fergus Millar, The Emperor in the Roman World (London 1977) pp. 175-202; Elio Lo Cascio, Il Princeps e il suo impero. Studi di storia amministrativa e finanziaria romana (Bari 2000) pp. 97-150, 163-176.

9 The most famous modern Tacitean analysis of the Augustan monarchy is Ronald Syme's classic, but still fresh The Roman Revolution (Oxford 1939).

${ }_{10}$ Andrew Wallace-Hadrill, 'The Imperial Court', in: The Cambridge Ancient History, A.K. Bowman et al., eds., 2nd Ed., vol. X (1996) pp. 283-308; Aloys Winterling, ed., Zwishen "Haus" und "Staat". Antike Höfe im Vergleich (Munich 1997); idem, Aula Caesaris. Studien zur Institutionalisierung des römischen Kaiserhofes in der Zeit von Augustus bis Commodus (31. v. Chr.-192 n. Chr.) (Munich 1999); Pani, La Corte dei Cesari; Jeremy Paterson, 'Friends in high places: the creation of the court of the Roman emperor', in: The Court and Court Society in Ancient Monarchies, Anthony J.S. Spawforth, ed. (Cambridge 2007) pp. 121-56, and Smith, 'The imperial court of the late Roman empire'. Much of the textual evidence was assembled in Ludwig Friedländer's, mostly antiquarian, portrait of the Roman court [Darstellungen aus der Sittengeschichte Roms, 10. Aufl., Bd. 1 (Leipzig 1922) vol. 1, pp. 33-103]. The attempt of Alexander Demandt, Das Privatleben der römischen Kaiser (Munich 1997) to draw attention to the "private lives" of Roman emperors has some merit, but remains analytically a dead end because it insists on the category "private life" when it is clear that, in a court, this area of activity was inseparable from high politics. 
but as a public theatre of government and politics characterised by its own particular way of functioning; it provided an interface between monarch and political elite, the aristocracy. By transforming his household into a court the emperor could hope to attract and integrate the nobility into the government of his extensive realm. High offices and rewards distributed through the court, were supposed to make life in the service of the monarch more attractive to the landed aristocracy than retention of its old political independence. ${ }^{11}$ The rise of an imperial court entailed, in Elias' terms, a domestication and disciplining of the old senatorial, republican élite. The concepts of domestication and disciplining, however, must be used cautiously. Even more than a sociologist of court societies, Elias was a theorist of modernity. His model was based on the late seventeenth- and eighteenth-century absolutist French court to which he ascribed a pivotal position in the development of modern statehood and pacified civil societies. Government in the Roman Empire evolved under very different conditions. The style of rule and administration was much less intense than the forms of social control which gradually developed between the 17th and 19th centuries in European states. Elias may also in general have inflated the capacity of monarchs to control their courts. Yet, history abounds with examples of weak rulers. Rome is no exception. Nevertheless, with these caveats in mind, domestication and disciplining do seem apposite in the Roman case. ${ }^{12}$ The imperial monarchy was erected on

${ }^{11}$ Elias' ideal-type of the court was developed first in his study of Versailles. Here the emphasis was more narrowly placed on the mechanics of court society and the ability of the monarch to control and manipulate the nobility. In the later Über den Process der Zivilisation (1939/1997), particularly Bd. 2: 132-465 ('Zur Soziogenese des Staates' and 'Zusammenfassung'), the scope of the analysis was broadened to embed the model of the court more firmly within wider social developments and processes of state formation. For a general critique, see Jeroen Duindam, Myths of Power: Norbert Elias and the Early Modern European Court (Amsterdam 1995).

${ }^{12}$ Jeroen Duindam, Vienna and Versailles. The Courts of Europe's Dynastic Rivals, 1550-1780 (Cambridge 2003) emphasises the frequently weak position of the early modern French and Austrian Habsburg monarchies; collaboration more than domestication was the key component of court politics. See Sebastian Olden-Jørgensen, 'At vi maa frycte dig af idel kjærlighed-magtudøvelse og magtiscenesættelse under den ældre danske enevælde', Fortid og Nutid (1997) pp. 239-253, and his 'Hofkultur, ritual og politik i Danmark 1536-1746', in: Ritualernes Magt. Ritualer i europoisk historie 500-2000, Ulrik Langen, ed. (Roskilde 2002) both studies describing the domesticating capacity of the early-modern absolutist Danish court. At any rate, domestication, used flexibly and not as the only important aspect of court politics, does hold some analytical advantages for the Roman historian: it situates the process of the subjection 
the ruin of many aristocratic houses whose members and properties fell victim to the struggle for sole power among the leading magnates and generals. It was a weary senatorial élite, exhausted and depleted by several rounds of vicious civil wars, which eventually resigned itself to the metamorphosis of Octavian, the adopted heir of Julius Caesar, into the solemn world ruler Augustus. Over the following century, occasional spurts of proscriptions and summary executions reminded the senate of the price of disloyalty to the monarch.

Conflict, however, may also be a sign of relative failure. The continued need to pay heed to the old established republican governmental machinery, it has recently been suggested by Aloys Winterling in a thought-provoking study, is a sign of the lack of integration between court and society. The Roman world had been shaped decisively by the city-state and remained impermeable during the first centuries of monarchy to the attempts by the emperors to transform it. The Caesars, for instance, had not been able to supplant the old republican system of offices and orders with a hierarchy of rank of their own design. The imperial household remained the centre of a Hof ohne 'Staat'. ${ }^{13}$ This is an elegant hypothesis; it also fits well with professional prejudice among us historians always displaying a preference for the individual and specific characteristics of a culture. The notion of Hof ohne 'Staat' accords that crowning achievement of Graeco-Roman civilisation, the city-state, a primary role in the evolution of a wholly distinct Roman form of imperial court. Admittedly, any satisfactory explanation of the Roman court will have to take its republican heritage into account. Republican notions undoubtedly represent a significant aspect of what gives the study of the Roman court its particular flavour. The vestiges of republican political culture offer an important part of the explanation for the relatively frequent turn-over of monarchs and dynasties, which Scheidel has shown seems to be a distinct feature of Roman imperial history, particularly compared to the monarchies of earlymodern Europe. The emperor-to use the key insight of Egon Flaig's admirable study - was challengeable; his person and family could be

of the Roman republican aristocracy to the rule of one man firmly within the context of a court society rather than drawing on a-historical analogies to modern dictatorships and totalitarian states, as is done e.g. by Vasily Rudich, Dissidence and Literature under Nero: the Price of Rhetoricization (London 1997), and Maria H. Dettenhofer, Herrschaft und Widerstand im augusteischen Principat. Die Konkurrenz zwischen res publica und domus Augusta (Stuttgart 2000).

${ }_{13}$ Winterling, Zwishen "Haus" und "Staat". 
substituted. ${ }^{14}$ But the idea of a 'court without state' is too general and misleading; it exaggerates the specificity of the Roman court and in so doing seems to me to misrepresent the role of republican political culture and institutions within the monarchical system. Emperors and dynasties may have been more easily changed than in some other cultures. But the monarchy as such was solid and stable; the remaining republican institutions were, as Winterling openly admits, not the seat of the state. They did not represent an alternative to monarchy; they were unable to take over the functions of government on their own.

The basic premise of Winterling's thesis that the resilience of republican political titles, offices and institutions is a sign of the very limited domestication of the imperial aristocracy achieved by the court, is highly questionable. Before anything else, as Elias pointed out, the monarch is the leader of aristocratic society to which he himself belongs. ${ }^{15}$ The king had to appeal to and reflect the culture and sentiments of the aristocracy. Few courts have articulated this issue more acutely than the monarchy created under Augustus. ${ }^{16}$ In Rome the elite was defined by a centuries-old tradition of service to the state and a firmly entrenched ideology celebrating the freedom, libertas, procured for the Roman people by the legendary founder of the Republic, the elder Brutus. According to tradition he had ousted the last of the kings, Tarquinius, who just to avoid any trace of ambiguity had been stigmatised with the epithet 'Superbus', the 'haughty'. The title of rex, king, was anathema in Roman political discourse and had become synonymous with illegitimate tyranny. Octavian's own entry onto the stage of high politics only followed in the chaotic aftermath of the successful attempt of the younger Brutus and Cassius to mobilise these sentiments to form the conspiracy which ended with the murder of the dictator Caesar, on the Ides of March 44 BCE, for fear

${ }^{14}$ As pointed out by Egon Flaig, Den Kaiser herausfordern: Die Usurpation im Römischen Reich (Frankfurt 1992). Cf. W. Scheidel, 'Towards a comparative study of monarchical succession and dynastic continuity', forthcoming.

${ }^{15}$ Norbert Elias, Die höfische Gesellschaft. Untersuchungen zur Soziologie des Königtums und der höfischen Aristokratie mit einer Einleitung: Soziologie und Geschichtswissenschaft (Berlin 1969) p. 278.

${ }^{16}$ The classic, and in many ways unsurpassed, study of the transition to monarchy remains Ronald Syme, The Roman Revolution (Oxford 1939). Josiah Osgood, Caesar's Legacy. Civil War and the Emergence of the Roman Empire (Cambridge 2006) brings the tradition up to date. Kurt Raaflaub and Mark Toher, eds., Between Republic and Empire. Interpretations of Augustus and His Principate (Oxford 1990) is a strong collection of articles. 
he was transforming himself into a king. Octavian was quick to learn. In the final struggle for supremacy, the heir of Caesar deftly exploited Roman republican traditions of liberty. Antony, his rival, was vilified as harbouring dreams of an Oriental despotism and accused of plotting together with his mistress, the queen of Egypt Cleopatra, to move the capital of the empire to Alexandria. ${ }^{17}$ When victory was secure and sole rule his, Octavian went out of his way to avoid following in the ill-fated footsteps of Caesar. The time-honoured republican constitution was ostensibly re-instated, or as the emperor liked to phrase it, 'transferred' as a gift from him to the senate and people. ${ }^{18}$ Studiously avoiding the title of king, Octavian would henceforth reign as Augustus, the solemn one; the revolutionary leader had reinvented himself as patron of the state and guardian of the republic-the first citizen among his senatorial peers.

But cultural and symbolic continuity masked a process of profound change. The old republican institutions were not simply left intact; they were mobilised and refashioned to suit the demands of the new absolutism. Not for the last time in history, renovation turned out to be ostensibly more traditional in its outlook than the tradition it was meant to revive. Claudius, the emperor of the Julio-Claudian dynasty known for his stammer and with an eccentric delight in antiquarian study, only had the accent wrong, not the spirit, as he professed his official commitment to the preservation of 'the good old' ways by reintroducing all sorts of quaint and obscure customs and practices against the backdrop of a bemused Roman public. ${ }^{19}$ The Augustan monarchical settlement involved a thorough reorganisation and reorientation of the old republican political order..$^{20}$ The army was now controlled by the emperor; he was commander-in-chief and the title of Impera-

${ }^{17}$ Cf. Richard Beacham, 'The Emperor as Impressario: Producing the Pageantry of Power', in: The Cambridge Companion to the Age of Augustus, Karl Galinsky, ed. (New York 2005) pp. 152-59, though too "loyal" to the Augustan version. For a wider study of the image of Cleopatra in Roman culture, see Diana Kleiner, Cleopatra and Rome (Cambridge, Mass. 2005).

${ }_{18}$ Augustus, Res Gestae, chap. 34: rem publicam ex mea potestate in senat[us populique Rom]ani [a]rbitrium transtuli. Quo pro merito meo senatu[s consulto Au]gust[us appe]llatus sum.

${ }_{19}$ Suet. Claudius 16 (censorship imbued with a spirit of archaic eccentricity); 21, 2; 22 (reviving obsolete rituals, as well as introduction of novelties); 41-42 (antiquarian study).

20 The discussion of Mommsen, Römisches Staatsrecht, remains valuable on many points. 
tor became a preserve of the imperial majesty. Celebration of military triumphs through the streets of Rome-the crowning achievement of a noble career during the time of republican politics and a prize coveted by all the old aristocratic families-was quickly reserved for the reigning monarch and his family. Behind the proud claim 'Res Publica Restituta' a new, if not exactly invented, then certainly reinvented order was being harnessed to serve the needs of imperial monarchy. ${ }^{21}$ This meant reinforcing the dignity of hierarchy and the preservation of privilege. ${ }^{22}$ The two highest aristocratic orders of Roman society, the senatorial and the equestrian, received more strict regulation and greater formal demarcation than before. The property qualification of senators was significantly raised; 'unworthy' members of the venerable council were purged and overall numbers reduced. Laws regulating marriage and social 'mores' for the highest echelons of society were passed; ${ }^{23}$ restrictions on the 'overseas' travels of senators, without imperial consent, introduced. ${ }^{24}$ Later came rules for the geographical composition of the portfolios of landed estates which constituted the backbone of senatorial wealth. ${ }^{25}$

As so often in court societies, loss of political autonomy was twinned with enhanced symbolism and a more elevated definition of aristocratic rank. Nothing perhaps illustrates this better than the fate of the consulship under the emperors. ${ }^{26}$ During the republic, the two annually elected consuls had been the leaders of the state. In the beginning of his reign Augustus had, therefore, almost as a matter of course reserved

${ }^{21}$ The reconstituted republic under the emperors is an exemplary instance of an "invented tradition", in the sense of Eric Hobsbawm and Terence Ranger, eds., The Invention of Tradition (Cambridge 1983). Paul Zanker, Augustus und die Macht der Bilder (Munich 1987), for the novel ideology and symbolism projected by the imperial court under the guise of traditionalism.

${ }_{22}$ Greg Rowe, Princes and Political Cultures. The New Tiberian Senatorial Decrees (Ann Arbor 2002), for a recent study of the enhanced symbolic presence in imperial society of dignity and hierarchy under the monarchy.

${ }^{23}$ Andrew Wallace-Hadrill, 'Family and inheritance in the Augustan marriage laws', Proceedings of the Cambridge Philological Society, 207 (1981) pp. 58-80; Catherine Edwards, The Politics of Immorality in Ancient Rome (Cambridge 1993), on moral legislation.

${ }^{24}$ Tac. Ann. 2, 59; Dio Cass. 52, 42, 6. Cf. Suet. Claudius 16.2. and Plin. Ep. X, 8-9 (the emperor Trajan granting Pliny leave of absence to tend to his estates during his tenure of the prefecture of the public treasury, aerarium Saturni).

${ }_{25}$ Plin. Ep. VI 19, 4 ; Hist. Aug. Marcus Aurelius 11, 8.

${ }^{26}$ Syme, Roman Revolution, pp. 372-74; Keith Hopkins and Graham Burton, 'Ambition and Withdrawal: the senatorial aristocracy under the emperors', chapter 3, in: Keith Hopkins, Death and Renewal (Cambridge 1983) pp. 120-200. 
one of these positions for himself. But that bred frustration and resentment among the senators who saw their prospects of achieving the highest republican magistracy significantly reduced. After a few years, and prompted by the detection of a conspiracy, Augustus decided that he could do without the office. The consulship now reduced mainly to a symbolic and ceremonial position, the practice developed of annually appointing more than the two customary incumbents. The pair appointed at the beginning of the year would resign after a few months and thus make room for a variable number of substitutes, so-called suffect consuls, to take up the magistracy in turn. Opportunities for aristocratic advancement significantly expanded through the agency of the emperor.

Successful participation in aristocratic political life now depended on the favour and patronage of the monarch. The Roman aristocracy had not primarily been defined by hereditary titles and rights, but through office-holding, renewable in each generation, in the service of the republic. With the monarchy, senatorial rank was made hereditary, though through three generations only, but all the traditionally important markers of high aristocratic status, full membership of the senate and access to high political office, were to a very large extent left at the emperor's discretion to grant or deny. ${ }^{27}$ Not only the consulship, but all of the old hierarchy of republican offices was transformed into a more firmly settled career in the service of the ruler. ${ }^{28}$ The appointment of provincial governors was wholly controlled by the emperor. Those who went to provinces with military garrisons were simply designated as legati Augusti, 'deputies' of the emperor. Where once political competition had focused on the popular assemblies, it now revolved around the emperor's household. Aristocrats vying for the trappings of power, wealth and prestige were, again to speak in Elias' terms, pitted against each other in a monopolistic game with the

27 On the emperor as a patron of the aristocracy, see Millar, Emperor in the Roman World, chap. 6; Richard P. Saller, Personal Patronage under the early Empire (Cambridge 1982), chap. 2 and Jon E. Lendon, Empire of Honour (Oxford 1997). Anton von Premerstein, Vom Werden und Wesen des Prinzipats (Munich 1937) was pathbreaking. An element of elections remained in the selection of the senate, but monarchical influence operated on many levels from direct appointments, to permission to seek election as well as denying unwanted candidates access.

${ }_{28}$ Werner Eck, 'Part II: Government and Civil Administration', Chaps. 4-7, in: The Cambridge Ancient History, Alan Bowman, Peter Garnsey and Dominic Rathbone, 2nd ed., vol. XI (2000) pp. 195-292 surveys the details. 
emperor as the final arbiter of rank and privilege..$^{29}$ In short, the old republican order had been absorbed within the social configuration of a court society.

The term society is important here. Roman nobles continued to have their own establishments in the capital. Augustus chose to live in conspicuous modesty and could not aspire to accommodate most of the elite within his dwellings on a scale comparable to that attempted by Louis XIV with Versailles. This would gradually change, however, as the imperial palace swelled effectively to take over all of the Palatine Hill. But long before that, aristocratic life had been reorganised in courtly fashion with Rome as its scene, defined increasingly by the proliferating monumental architecture of the Caesars. ${ }^{30}$ Here was enough of state religious ceremony, pageantry and public shows to keep the entire senatorial cohort both busy and bored. In the morning, it became established practice that senators would show up regularly at the imperial audience. A senator would be considered a 'friend' of the emperor, 'unless specifically renounced'-the latter amounting to a political death sentence and frequently a real one as well. ${ }^{31}$ Already under Augustus the senate began on many occasions to meet in what was to all intents and purposes a 'wing' of the imperial palace, namely in the library of the temple of Apollo which the emperor had built in connection to his domus. ${ }^{32}$ Soon scions of noble families would be brought up in the palace together with the imperial off-spring; and through a complex web of matrimonial alliances, the ruling house of the Julio-Claudians ended up absorbing almost the entire old nobility. ${ }^{33}$

As befits a court, sycophancy and conceit, flattery and pretence belonged to the order of the day. Self-restraint and polishing of social

${ }^{29}$ Cf. Hopkins and Burton, 'Ambition and Withdrawal', pp. 149-176; Flaig, Den Kaiser herausfordern, chap. 2.

${ }^{30}$ Paul Veyne, Le pain e le cirque. Sociologie historique d'un pluralisme politique (Paris 1976) pp. 638-641. The long period for court and aristocracy to become integrated suggested by Winterling, Aula Caesaris, seems unnecessarily protracted and puts too much emphasis on formal senatorial residence in the palace. Zanker, Augustus und die Macht der Bilder, pp. 59-61 on the relative modesty of Augustus' private domus, compensated in part by the construction of the adjoining temple of Apollo.

${ }^{31}$ Paterson, 'Friends in high places', p. 143.

32 E.g. David L. Thompson, 'The Meetings of the Roman Senate on the Palatine', American Journal of Archaeology, 85 (1981) pp. 335-339.

${ }_{33}$ Pani, La Corte dei Cesari, p. 11. 
mores to master the rigid decorum required to play the game of politics in the ambience of the ruler became de rigueur, as described in Wallace-Hadrill's contribution to this volume. With the formation of a court, the traditional aristocracy also found itself facing the increasing influence of the emperor's domestics, slaves and freedmen, as well as family. These groups benefited from their proximity to the ruler to carve out for themselves positions of power and influence. Aristocratic opinion would harp on tirelessly about the disgrace and humiliation involved in having to deal with such lowly people, perhaps even having to beg for favours. ${ }^{34}$ But in the absence of an elaborate bureaucracy, much of the administration had to be staffed from within the emperor's own and increasingly vast household. In Rome and across the Empire, significant numbers of imperial freedmen and slaves were employed in governmental jobs. ${ }^{35}$ Apart from these, a parallel hierarchy of offices gradually developed to be manned from among the members of the second aristocratic order, the equestrian. ${ }^{36}$ Previously the knights used to be thought of in terms of a rival commercial class, but this alternative branch of the élite was in fact drawn from the same layer of wealthy landowning families as the senate. ${ }^{37}$ Among the positions reserved for equestrian service were particularly important posts which emperors could not as safely trust to senators, their peers, for fear they might use them to make a rival bid for power. These jobs included positions such as governor of the vitally important province of Egypt, prefect of the Roman grain supply and of the praetorian guard, the legionary cohorts stationed in Rome as the emperor's élite corps.

To sum up, the Roman emperors presided over a political order which had undergone significant reform and modification to suit the

\footnotetext{
${ }^{34}$ Examples are legion, a good illustration is Seneca's spiteful Apocolocyntosis, a satire on the apotheosis of Claudius which imagines the defunct emperor being rejected by the Olympian gods and relegated to the underworld. Here justice is finally done when Claudius is reduced to slavery and made to serve as a secretary to a freedman of Aeacus, judge of the underworld. This was a suitably humiliating and disgraceful punishment for an emperor that had allowed himself to be dominated by his own slaves and freedmen who in consequence had been able to tyrannise and humiliate the senators.

${ }_{35}$ P.R.C. Weaver, Familia Caesaris: A social study of the emperor's freedmen and slaves (Cambridge 1972); G. Boulvert, Esclaves et affranchis impériaux sous le HautEmpire romain: Rôle politique et administrative (Naples 1970). 1950).

${ }^{6}$ H.G. Pflaum, Les procurateurs équestres sous le Haut-Empire romain (Paris

${ }^{37}$ Cf. Saller, Personal Patronage, pp. 77-78, p. 139 on the close social integration of senators and equestrians.
} 
needs of monarchy. During the first and second centuries CE, the emperors would slowly, but inexorably effect a profound change in the composition of the aristocratic elite. The senate of the late second century CE was a very different body from the senate which had existed in the times of Augustus. ${ }^{38}$ Most significantly many members of dominant provincial families had been recruited into its ranks, not always without resentment it is true. Claudius' proposal to admit leading nobles from Gaul to the ranks of the senate was not received with unequivocal approval by the body. Titus on ascending the throne felt compelled to put an end to his relationship with Queen Berenike, a member of one of Rome's royal client dynasties in the East, as a token of his dedication to the interests of the Roman aristocracy. But this kind of resistance never hardened into an unbridgeable fault line. Ethnic identity was not strong enough to preserve the integrity of the senate in the long run. ${ }^{39}$ Rank and hierarchy were too important in fashioning senatorial status to seal off the political body. In each generation some aristocratic families would fail to reproduce themselves; others would simply withdraw from political life. Court politics was a dangerous business. The hazards were aggravated by the ruinous costs of participating in the conspicuous consumption of upper-class life in the imperial capital. Most families would not be able to maintain more than a few heirs at the level of existence required of aristocratic life in the proximity of the emperor. Restricting the number of children, however, increased the risk that none would survive to adulthood. The senatorial aristocracy was in constant need of replenishment. ${ }^{40}$ The desire of senators to form advantageous marriage alliances and build up strong networks of powerful allies made resourceful provincial aristocrats attractive partners. Over the long-term, senators therefore ended up collaborating with the emperors in gradually admitting some provincial families into their midst. ${ }^{41}$

\footnotetext{
${ }^{38}$ Sergio Roda, 'Il Senato nell'alto impero Romano', in: Il Senato nella Storia (Rome 1998) for a recent survey of the development of the Roman senate under the emperors.

${ }^{39}$ CIL XIII 1668 (speech of Claudius); Tacitus, Ann. 11, 23-24 (for an account of the debate, partly hostile, which arose in response to Claudius' proposition); Suet. Titus 7, 2. Benjamin H. Isaac, The Invention of Racism in Classical Antiquity (Princeton 2003) on ethnic prejudice.

${ }^{40}$ Hopkins and Burton, 'Ambition and Withdrawal'.

${ }^{41}$ Saller, Personal Patronage, pp. 73-77 and chaps. 4-5 on the role of senators as brokers; Ramsay MacMullen, Corruption and the Decline of Rome (New Haven 1988)
} 
The failure of the Roman senate to turn itself into a closed hereditary aristocracy and its dependence on imperial patronage is, incidentally, a characteristic which has often been connected with the prebendal, 'slaves on horses', service élites of Muslim monarchies and empires. To return briefly to our Persianate comparison, membership of the Mughal nobility never became restricted to the group of 'original' conquerors. Mughal rulers continued to admit substantial numbers of defeated provincial nobles as well as Persian and other immigrants into the ranks of the corps of imperial mansabdars. ${ }^{42}$ The court enabled the rulers of both the Roman and Mughal empires to reach out from their core 'constituency' to attract men of power and ambition from wider contexts. Attainment of the highest rank and position thus remained to a significant degree dependent on imperial service and the governing élite was turned into a cosmopolitan aristocracy. The emperor's court became a vehicle of provincial integration. Thus, through the workings of imperial patronage, the composition of the Roman senatorial aristocracy was drastically changed from a group exclusively of Italian families to one with a majority of members originating in the provinces by the late $2 \mathrm{nd}$ century $\mathrm{CE} \cdot{ }^{43}$ The institutions of the republic had been grafted onto the imperial court.

The close intermingling of republican institutions with the imperial household can be seen very clearly from the manual describing the administration of the Roman water-supply written by the senator and prominent noble Frontinus, public water commissioner in the reign of Nerva. ${ }^{44}$ The aqueducts of Rome were maintained by two gangs of slaves. One had been donated by Agrippa, the designated number 2 of Augustus, to the republican state treasury, the aerarium. The other, the larger one, belonged to the imperial privy purse, the fiscus. Both, however, served under the same magistrate, a public commissioner appointed by the emperor. As is clear, the boundaries between household and republic were permeable and porous. This impression is only

pp. 75-76 with fig. 15 analyses a network based in the Lycian aristocracy and the complex web of alliances which saw it penetrate the senatorial élite.

${ }^{42}$ M. Athar Ali, The Mughal Nobility under Aurangzeb (Oxford 1997), chap. 1 for the composition of the Mughal nobility. Patricia Crone, Slaves on Horses: The Evolution of the Islamic Polity (Cambridge 1980) for the "slaves on horses" tradition of Islamic state-craft.

${ }^{43}$ Mason Hammond, 'Composition of the Senate, AD 68-235', Journal of Roman Studies 47 (1957) pp. 74-81.

${ }^{44}$ Frontinus De Aquis II, 116-118, citations from 118. 
reinforced when we read that in the reign of Domitian (81-96), the income from the sale of water-rights used to pay for the 'state' gang had been transferred from the aerarium to the fiscus. Nerva (96-98), in turn, had reversed this decision by 'his sense of justice' and returned the right to these incomes to 'the people'.

\section{A Contested Arena}

At first sight, the last act may not seem to fit into the image of a court domesticating its aristocracy. It is difficult to see why an emperor in such circumstances would bother to make such a gesture to 'the people. ${ }^{35}$ Observation of ceremony and symbolic acts, however, were an important part of the semantics of the political discourse. ${ }^{46}$ The intricate manipulation of formality and symbolism may be illustrated from the official decision of the senate in the cause celebre involving the prominent noble Cn. Piso. ${ }^{47}$ During his governorship of Syria he had fallen foul of Germanicus, the adopted son of the emperor Tiberius, who had been granted superior powers and sent on a special mission to sort out the Roman Middle East. Piso, a proud nobleman and old 'friend' of Augustus, was accused of insubordination and suffered the intolerable affront of being thrown out of his province by

\footnotetext{
${ }^{45}$ Additional confirmation that this should not be interpreted as lack of domestication may be sought from the fact, that Frontinus proudly declares that he could do without his public lictors when he ventured into the countryside around Rome. He was secure by the authority of imperial appointment (auctoritas a principe data pro lictoribus erit), De Aquis II, 101.

${ }^{46}$ It is in this perspective that the maintenance of republican forms takes on significance. The need to take seriously the republican formalities of the Principate was addressed by Eder, 'Augustus and the Power of Tradition. The Augustan Principate as binding link between Republic and Empire', in: Between Republic and Empire. Interpretations of Augustus and His Principate, Kurt Raaflaub and Mark Toher, eds. (Berkeley; Oxford 1990) pp. 71-122. But his view that the republic continued unabated fails to take proper account of the dramatically changed relations of power.

${ }^{47}$ The senatorial decree containing the judgement in the case of Piso is preserved on an official inscription, recently recovered in Spain. The text of the S(enatus) C(onsultum) de Cn. Pisone Patre was published by Eck, Caballos and Fernandez [Werner Eck; Antonio Caballos and Fernando Fernandez, Das senatus consultum de Cn. Pisone patre, Vestigia 48 (Munich 1996)]. The official version is complemented by the copious narrative of Tacitus in the 2nd and 3rd book of the Annals which provides an impression of the competing claims and rival factions involved in the whole affair, cf. Miriam Griffin, 'The Senate's Story', Journal of Roman Studies 87 (1997) pp. 249-263.
} 
Germanicus. ${ }^{48}$ Following this, Germanicus had died (CE 19). He and his powerful adherents believed that he had been poisoned by Piso who did nothing to improve his delicate situation by returning to his former province and attempting to win back his command by military force. This was in any case an act of open rebellion and could not easily be condoned. When Tiberius, whose tense relationship to the deceased was well known, came under suspicion for being the mastermind behind the whole affair, the fate of Piso was sealed. Tiberius courteously handed over the conduct of the criminal trial to the senate. Here the influential faction of Germanicus, thirsting for revenge, could find retribution while Tiberius displayed his liberal disposition and respect for the senatorial aristocracy. Piso would enjoy the privilege of being judged by his peers rather than behind the 'closed' doors of the palace. At the same time, an example would be made of Piso's 'feritas/wildness' to remind other leading nobles not to forget themselves and overstep the bounds of loyalty in the service of the emperor and his house. ${ }^{49}$

Piso committed suicide before the trial was concluded. Posthumously the senate reached a verdict of treason: the majesty of the imperial house had been slighted. ${ }^{50}$ The properties of Piso were confiscated and awarded to the old republican treasury, the aerarium, bar some pastures in the province of Illyricum. A gift from Augustus, these were now to be returned to Tiberius and the fiscus. The emperor, in other words, took care not to appear capricious and grasping after aristocratic property. This message was further underlined by the provisions made for the noble offspring of the condemned traitor. From

${ }^{48}$ The official version glosses over Germanicus' role in the departure of Piso which is presented as his own reckless act (SC de Cn. Pisone Patre, 1l. 48). Any person, however, who would contemplate returning to his abandoned province to try and win back the command with recourse to military action, is not likely to have left his province voluntarily. Whatever the formalities, Tacitus's judgement must in essence be correct.

${ }^{49}$ SC de Cn. Pisone Patre, 1l. 27. The official application of the word feritas, denoting an untamed and wild state, to describe the transgression of Piso is not insignificant in a discussion of Elias. The notion of domestication did enter into relations between emperor and nobles. But as is clear from the senator Seneca's treatise On Anger, book 3 , the idea had implications for both parties. The emperor, no less than the successful courtier, should know how to discipline and control his anger. William V. Harris, Restraining Rage: The Ideology of Anger Control in Classical Antiquity (Cambridge, Mass. 2003) chaps. 9-10, surveys debates about anger in Roman politics.

${ }^{50}$ SC de Cn. Pisone Patre, 1l. 32-33: "neglecta Maiestate domus Augustae". 
the aerarium, it was immediately decreed to return to his two sons their half portions of the confiscated family estate; and the daughter was awarded a separate fund. The head had fallen, but the noble house was allowed to continue..$^{51}$

While there can be little doubt that the official judgement of the senate bore the stamp of the emperor's version of the conflict, it is also clear that this incident cannot easily be reduced to a simple case of the monarch disciplining a defiant and querulous nobleman. Behind the obstinate resistance of Piso to Germanicus, a significant part of the aristocracy suspected the manipulating hands of Tiberius stirring up trouble for his adopted heir. The condemnation, in their version, was forced on the emperor as a face-saving act and a victory for the opposition to his reign. It was and is impossible to decide about the 'truth' of the opposing versions; it is also beside the point. Once the events up to and after Germanicus' death became part of the struggle for power, the competing versions, aided by a thick mist of rumours and allegations, took on political existence. Whether they were literally true was immaterial; what mattered was whether they could be made to appear true. In such questions, the emperor was not the sole arbiter. He was confronted by competing claims and would often have to make concessions to opposing camps. Indeed, in this case Tiberius was far from in control of the situation. The extraordinary extent to which attempts were made to publish the official version on inscriptions around the empire is a strong indicator. ${ }^{52}$ The position of Tiberius was a precarious one. At the death of Augustus some legions had in fact attempted to proclaim Germanicus as new emperor. The mother and the wife of Germanicus were the sister and grandchild, respectively, of Augustus. This arguably made him more truly 'royal' than Tiberius who was himself adopted by Augustus and only chosen as his successor as other preferred options had died prematurely. Even though Germanicus had stayed loyal, the adopted son of the reigning emperor remained a potential rival and a focus for the aspirations of the enemies of Tiberius. High hopes were pinned on the junior Caesar.

SC de Cn. Pisone Patre, 11. 84-105.

52 A point well made by Griffin, 'The Senate's Story', p. 260. Cf. the observation of Paterson, 'Friends in high places', p. 132 on the competing interpretations of Marc Antony's attempt to offer Julius Caesar the royal diadem. 
To make things even more complicated and increasingly tense, Tiberius also had a 'real', slightly younger son of his own, Drusus. The unexpected death of Germanicus had paved the way for Tiberius' blood-line to the imperial purple. Many looked in the direction of those who stood to benefit to identify the person responsible for the tragedy. 'The whole state was up on its toes...', as Tacitus saw with unfailing judgement, 'would Tiberius be able to contain and repress his sentiments. At no other time was the people more intent on allowing itself the freedom of whispered critique and suspicious silence against the princeps. ${ }^{53}$ In those circumstances, had Tiberius decided to let Piso go, it would have been seen as a sign of his complicity in Germanicus' death, or at least in the conflict between the latter and Piso, and thus further alienate a powerful segment of the imperial family and aristocracy. On the other hand, by allowing the condemnation of Piso he laid himself open to the complaint that he would sacrifice high-ranking nobles to serve his own purposes and security. Either way, the court did not function as a battleground where the rules were defined by the emperor alone. ${ }^{54}$

\section{A Vehicle of Negotiation and Compromise}

To be a successful instrument of rule, the imperial court could not merely be applied to discipline or destroy the aristocracy. Such a course was decried as murderous tyranny and lacked legitimacy. ${ }^{55} \mathrm{~A}$ patrimonial emperor did not dispose of a vast, fully-fledged independent bureaucracy to govern his far-flung territories. As Dio Cassius

${ }_{53}$ Tac. Annales III, 11 (my translation).

${ }^{54}$ The analysis of Rowe, Princes and Political Cultures, focuses too much on the official image projected of social and ideological consensus. Even within the elite we have to recognise that such notions were contested and variously interpreted by different groups to serve their own purposes.

${ }_{55} \mathrm{Cf}$. The tragedy Octavia, which makes a poignant portrayal of the terrors of Nero's court, provides a good impression of the ideology of critique directed against the "unrestrained monarch". He is presented as a bloodthirsty tyrant who relies on fear and the sword (vv. 492-532) and is contrasted with the good king who preserves the peace and enables men to prosper (vv. 472-91). Matthew B. Roller, Constructing Autocracy. Aristocrats and Emperors in Julio-Claudian Rome (Princeton 2001), chap. 4 for a recent discussion of the opposition between tyranny and good lordship in Roman political discourse. However, he is mistaken to see these as representing two competing models of monarchy; rather they regulate a structural conflict characteristic of the court in general. 
observed, the emperor needed 'the best men', that is the aristocracy, to lend lustre to his reign and assist him in running the empire. ${ }^{56}$ Emperors who failed to maintain a tolerable dialogue with the senatorial aristocracy were steering a dangerous course. Direct, intense and sustained confrontation locked emperor and political élite in a lethal embrace. Alienated by the detection of a conspiracy against his life, the young Caligula withdrew in disgust from the senate and embarked on a campaign of public humiliations and vindictive purges. This has earned him the reputation of a madman. But that was hostile aristocratic slander; it is hard to credit that someone truly mad should have been able to hold the reigns of the empire and mount a serious challenge to powerful circles in the aristocracy. Nevertheless, by intensifying conflict and refusing dialogue, Caligula literally chose a dead end. He left the political élite no way out; compromise was impossible. Several conspiracies followed in close succession till finally one succeeded in the fourth year of his reign. ${ }^{57}$

The Roman court, therefore, was not simply a 'revolutionary' institution; it also needed to make overt concessions and appeals to established tradition in order to attract and appease an aristocracy which jealously guarded its privileges and standing. This is not uniquely a characteristic of the Roman court. In the quotation I used at the beginning, we saw the Mughal emperor stand down from his demand to receive prostration in the form of the sijdah in order to placate his critics who denounced the act as ungodly and against religious tradition. Islam could, as in the writings of Badauni, serve as a basis for articulating critique of Mughal rulers and hold them to the ways of proper scripture. ${ }^{58}$ By pledging to be the champion of the mos maiorum, that

${ }^{56}$ Dio Cassius 52, 9 \& 19; cf. Norbert Elias, Über den Prozess der Zivilisation, bd. 1-2, Edition Suhrkamp (Baden-Baden 1997) vol. 2, pp. 156, 280-284 and 378-79. As Duindam, Vienna and Versailles, pp. 18 and 279-87 points out, aristocrats were not simply domesticated; many were able to claim rich and extensive rewards in return for their loyalty and service.

57 Aloys Winterling, Caligula. Eine Biographie (Munich 2003), chaps. 3-5 describe well the gradual intensification of conflict between Caius and the aristocracy.

${ }^{58}$ Badauni's critique of Akbar, Mughal emperor 1556-1605, is contained in the Muntakhab al-Tawarikh (an English translation in 3 volumes is available as Muntakhab al-tawarikh [a general history of India from the Mohammedan conquest to A.H. 1004 (CE 1595/6)] / ed. by W.N. Lees et al., Calcutta 1884-1925); For analysis, see e.g. Ali Anooshahr, 'Mughal historians and the memory of the conquest of India', Indian Social and Economic History Review 43 (2006) pp. 275-300 emphasising the anti-absolutist nature of Badauni's critique of Akbar, Mughal emperor (15561605), and Rosalind O'Hanlon, 'Kingdom, Household and Body History, Gender and 
is the old republican traditions, Roman emperors attempted to accommodate aristocratic interests. When Nero, for instance, in a speech made early in his reign promised to 'keep his household and the republic separate', he was not thinking of establishing a civil service in our sense of the term, with equal and impersonal treatment of all. Nor did he intend to withdraw the vast resources at the disposal of the imperial patrimony from the running of the state. Any such scheme would have jeopardised the operation of government. Quite the reverse, it was a pledge to give preferential treatment to the republican aristocracy, rely on his peers and admit them to a share in the business of government rather than allow his slaves, freedmen and female relations to influence decisions, such as his predecessor Claudius had been accused of doing. Senate and Princeps were to be partners in power: that was the message. ${ }^{59}$

Aristocratic opinion presented the emperor with an ideal of personal rule. Emperors were praised for taking a personal hand in the execution of government. Edifying tales of hard-working monarchs who would give attention to every detail and deprive themselves of sleep in order to master the many tasks of rule were part of the moral discourse of kingship in extensive empires as well as in smaller monarchies. Ammianus Marcellinus noted with admiration how the emperor Julian surpassed even Alexander in managing to keep to a rigorous regime with nights divided between rest, public business and intellectual pursuits. The latter needed the assistance of a silver ball to help him stay alert, the reader is told. Held over a bronze basin by an outstretched arm, the ball would drop as the body of the Macedonian king was overtaken by sleep. The noise caused by the fall would then wake

Imperial Service under Akbar', Modern Asian Studies 41, 5 (2007) pp. 1-35 relating Badauni's critique to resistance against Akbar's attempts to "domesticate" his nobles by regulating their masculinity and sexual mores.

${ }_{59}$ Tac. Ann. 13, 4, 2. Winterling's comment (Zwischen "Haus" und "Staat", p. 107) that the discourse opposing imperial domus to res publica presented the court "als unzulässige Vermischung der Sphären von domus und res publica" is inadequate. Rather the dichotomy structured a debate over the character of the imperial monarchy. Was government to be based on a closed household or on a domus turned into a real court open to aristocratic influence. Tacitus, therefore, goes on to relate a tense moment at Nero's court. The emperor is in the process of receiving a deputation from Armenia as his mother decides to join him on his tribunal and preside next to him. The court looks on in consternation. But Seneca, senator and leading advisor of Nero, averts the scandal by ordering Nero to descend from the platform and as a dutiful son meet his mother before she ascends $(A n n .13,5)$. 
him up again. Julian, however, needed no such devices and would wake up at will. ${ }^{60}$ The notion of the ever-attentive monarch similarly reverberates in Mughal ideas of kingship. Court ritual carefully aimed to make the Timurid rulers appear visibly performing the duties of government. In his memoires, the emperor Jahangir even congratulates himself on having built up an ability to go with very little sleep. For 'this has two benefits. One is awareness of what is going on in the realm, and the other is wakefulness of the heart to remembrance of God. ${ }^{61}$ But in practice no ruler, however diligent, could hope to stay on top of the flood of requests and petitions for favours reaching his court: the more extensive the territories and powerful the lord, the greater the challenge. A court had to work through exclusion.

The imperial aristocracies were under no illusions in that respect. The all-important issue, therefore, was to whom the ruler was willing to lend his ear. From their perspective, the monarch had to make himself accessible, especially to them: the emperor should seek his courtiers among 'the best men' it was constantly repeated. ${ }^{62}$ That would enable the aristocracy to defend and promote its interests at court. Roman emperors can be seen responding to such demands, for instance, by declaring their palace a public house rather than a private residence. ${ }^{63}$ Another such gesture was the increasing use of equestrians, the second aristocratic order in Roman imperial society, to man some of the most important secretarial positions in the imperial household (in charge of Latin and Greek correspondence, of accounts and of legal hearings) instead of the controversial imperial freedmen. The court evolved not merely as a disciplining mechanism to pacify the nobility; this was only one dimension of a more complex situation. Monarch and aristocracy were interdependent: this was the basis of the court as a social institution. Absolute in name, the emperors were by no means free to do as they pleased, but also had to make service to them appear attractive. This gave the aristocracy a measure of bargaining power and made the court not simply a tool in the hands of the ruler. It functioned even more as an institution of government, allowing forces

\footnotetext{
${ }^{60}$ Amm. Marc. XVI, 5, 4-5.

${ }^{61}$ The Jahangirnama, Wheeler M. Thackston, trans. (New York; Oxford 1999) p. 265; Ain-i-Akbari, Book I, chaps. 72-73 (trans. Blochmann, pp. 153-157). Koch, 'Diwan-i 'Amm and Chihil Sutun', pp. 143-165 on Mughal audiences and accessibility.

${ }^{62}$ A stock theme of imperial political discourse, cf. also Aristeides, Oration To Rome, chaps. 59 and 64.

${ }^{63}$ Plin. Pan. 47, 4.
} 
to be balanced against one another and the relative strength of participants to be determined, in other words, a theatre of contact and integration where ruler and aristocracy met to negotiate the distribution of privilege, favour and power. ${ }^{64}$

Imperial government, therefore, was a fairly exclusive affair. The core of the Roman aristocracy under the principate comprised the body of 600 senators and a comparable, but probably smaller, number of equestrians in the emperor's service. Many more sought out the seat of the emperor, but access to his favour had more or less to be obtained through the mediation of either this select aristocratic group or the personal servants of the monarch. Between emperor and his realm was a screen of influential nobles and courtiers on whom he depended as much as they did on him. For the vast majority of the landed elites in the provinces which effectively ran government on the ground, the imperial court was a very distant centre. The dialogue here was much less intense and communication intermittent. As long as these groups remained within broad bounds of loyalty, they would frequently be able to fashion an image of the emperor which would serve their own purposes and prop up their position within local society. ${ }^{65}$ Much of

${ }^{64}$ Cf. Duindam, Vienna and Versailles, p. 319 who prefers to use the concept of integration rather than domestication to describe the interaction of monarch and aristocracy at early modern courts. Particularly in the analysis of Die höfische Gesellschaft, Elias placed the emphasis on the court as an instrument in the hands of the ruler (chap. 6). Nevertheless, he also made clear that the court could not be reduced to just this. The king was in a sense no less a prisoner of court ceremony and ritual than the nobles (pp. 206-221). Attempts to cancel privileges were fiercely resisted (pp. 133-135); and the ruler was under constant pressure from vast numbers to grant new favours (p. 209). This aspect of court life was brought further to the foreground in Über den Prozess, e.g. vol. 2, p. 285, where the French absolutist court is seen as a product of the historical process which led to greater concentration of taxation capacity and military power in the hands of the monarch through the growing interdependence of social and political elites; the king's power was shaped by the social figuration it was part of. In other words, domestication and integration perhaps need not be treated as mutually exclusive options, but rather as complementary aspects of a complex reality. The Roman court combined both functions; peaceful cooperation appears next to covert resistance and coercive subjection-the latter already described by Syme (Roman Revolution, p. 404) in the language of domestication, "the principes viri were tamed, trained and harnessed", independently of Elias.

${ }^{65}$ Cf. Duindam in his contribution to this volume about the court as a way of achieving a fairly loose integration of provincial aristocracies. Peter Garnsey and Richard Saller, The Roman Empire. Economy, Society and Culture (London 1987), chap. 2 (on Roman government without bureaucracy). M.N. Pearson, 'Shivaji and the Decline of the Mughal Empire', The Journal of Asian Studies 35 (1976) pp. 221-235 provides a comparable perspective on Mughal government. As pointed out by Keith Hopkins, 'Rules of Evidence', Journal of Roman Studies 68 (1978) pp. 178-186 in his review of 
the time, in other words, the challenge facing central authority was less one of domesticating the various levels of aristocratic society than one of avoiding being fully appropriated by such élite groups striving to promote their own agendas.

\section{Between Domestication and Tradition}

Occupied, almost to the point of obsession, with forms of greeting and paying obeisance to the monarch, Western commentators have been inclined to focus on the domesticating and disciplining aspects of Oriental imperial courts. Graeco-Roman political discourse defined itself in express opposition to the Persian style of monarchy. Greek and, later, Roman freedom was pitted against a vilified Oriental tyranny. Courts have, therefore, traditionally been presented as foreign elements in this world dominated by the city-state. The claim made by the Roman princeps to be the protector of the res publica has been understood as setting the Roman monarchy apart from the personal style of rule characteristic of patrimonial emperors. While it is undeniable that Roman republican traditions did lend the government of the Caesars some of its particular colouring, it has been the contention of this paper that it is precisely and paradoxically the survival of republican forms and traditions under the rule of the emperors which makes the Roman court comparable to other patrimonial regimes. Established traditions of political authority and privilege have generally been able to stamp their mark on the specific appearance of royal courts. No monarch, not even of the August and elevated kind with universal and imperial aspirations, could simply replace pre-existing political structures with an entirely new set-up of their own design. In order to rule successfully, a Mughal emperor, no less than a Roman, had, like other monarchs, to bow to traditional forms of authority such as Islam and Hindu kingship. Much of the time, domestication had to give way to compromise and negotiation.

Millar, Emperor in the Roman World, government through the court significantly limited the capacity of Roman emperors to penetrate provincial society. Clifford Ando, Imperial Ideology and Provincial Loyalty in the Roman Empire (Berkeley 2000) and Fergus Millar, A Greek Roman Empire. Power and Belief under Theodosius II, 408-450 (Berkeley 2006) tend to underestimate how few persons the dialogue between central authority and provincial elite involved, even at its most intense. 
The obvious inspiration for Elias' concept of domestication and its effects on aristocratic personalities is, of course, modern psychology. But behind the Freudian facade lurk ancient notions of the monstrous tyrant, often in Oriental dress, against which rulers were habitually warned in the sundry versions of Mirrors for Princes literature; rulers should know better than to reduce their nobilities to a condition of dependent slavery. Elias' main concern was to explain the process of modernization; in the realm of politics that meant the rise of the modern state characterised, in Weberian fashion, by the possession of a monopoly on the legitimate use of violence. Thomas Hobbes was among the first to consolidate this idea when he insisted that the state should be likened to the biblical monster of the Leviathan, striking fear into the hearts of the subjects to keep them in passive submission. ${ }^{66}$ In Elias' interpretation, the court became a key vehicle in the emergence of the modern coercive, or tyrannical, state. But the connection between the process of modernisation and the formation of court societies is complex, if not tenuous. Royal courts, after all, much predate the processes of modernization. Domestication and dependence have to be thought of in several different shapes and sizes and degrees of intensity, not all of them inter-linked with the development of modern state power. ${ }^{67}$ Adam Ferguson, a predecessor of Elias in charting the emergence of a modern, pacified civil society, noted with some wonder that:

The manners of the imperial court, and the conduct of succeeding Emperors, will scarcely gain credit with those who estimate probabilities from the standard of modern times. But the Romans were capable of much greater extremes than we are acquainted with. ${ }^{68}$

Freed from the processes of modernization, the notion of a domestication of the aristocracy may be reduced to just one facet of court politics. The position of an emperor like the Roman was strong, but he

\footnotetext{
${ }^{66}$ In chapter 20 of Leviathan Hobbes thus extended the ancient notion of despotism, as based on fear, to characterise sovereignty in general.

${ }^{67}$ Cf. Elias, Über den Prozess der Zivilisation, vol. 2, pp. 366-371; pp. 151-168 on the monopoly on violence and the court.

${ }_{68}$ Adam Ferguson, The History of the Progress and Termination of the Roman Republic (Edinburgh; London 1799) vol. 5, p. 404, and he continued: "Although it would be absurd to imagine such a satire levelled at the corruptions of a modern court, whose principal weakness is vanity, and whose luxury consists in ostentation; we must not therefore reject every supposed application of it to the pollutions of a Roman barrack" (p. 406).
} 
was not the monopolist of the modern state. The very size of his realm prevented that. Even if the Roman court exercised a strong pull and constituted a powerful influence on provincial aristocracies, it was still a long way off for most of the members of the local landed elites that administered and in many respects represented the imperial 'peace' on the ground. Court society while permeable to such groups comprised a much narrower segment of the aristocracy. From that perspective, the imperial court seems rather like an institution for maintaining a minimal level of central government and control. Contact with the subject population was to a very large extent mediated through a very select and privileged aristocracy. If the emperor exercised a profound influence on the lives of individual nobles, he was nevertheless heavily dependent on the collective; in the court, he was far from the sole actor and the nobility, even if it depended to a large extent on imperial patronage, not a powerless body, as Duindam rightly comments in his contribution on Vienna and Versailles in this volume.

The lasting attraction of Elias' conceptualisation, therefore, is more in his understanding of the court as a social configuration where the movements of individual agents are shaped by a set of common rules as in a game. But that game would frequently have resembled chess. The king may be the most important piece, but left to his own devices a fairly weak one. ${ }^{69}$ To function as an instrument of government, the imperial court both had to work towards domesticating its aristocracy and at the same time appeal to tradition and open itself to aristocratic demands. The Roman court was a complex and dynamic institution where the balance was constantly being (re)struck between these two opposing principles. The result was far from given and is reflected in the varying vicissitudes of Roman dynastic history. As the aristocracy risked being decimated and humbled by the emperor, the emperor had to avoid being caught in stifling tradition and ritual which reigned in his field of action and risked rendering him superfluous.

This paper began with a vignette from the Persianate world of Mughal India. We end with an image from imperial Rome describing the funeral rites of Septimius Severus (193-211). These culminated in a sumptuous cremation ceremony on the Campus Martius during which the dead emperor's spirit was supposed to ascend to the heavens

${ }^{69}$ Cf. the observation of Duindam, Vienna and Versailles, pp. 213-214 on the king being caught in the competitive struggles of his courtiers. 
and join the gods. But preceding the staged apotheosis of the ruler, another public display had been performed over several days. Outside the palace, a wax effigy of his body was placed in a bed. Around it assembled the senators and high-ranking women as if they were concerned family-members attending the sickbed of a dying father. 'For seven days these ceremonies continue', Herodian reported to his Hellenic readership, 'Each day the doctors come and go up to the couch, and each day they pretend to examine the patient and make an announcement that his condition is deteriorating. Then, when it appears he is dead, the noblest members of the equestrian order and picked young men from the senatorial order lift the couch up and take it along the Sacred Way... ${ }^{70}$ From one perspective, these rites are, of course, testimony to the power of the court to domesticate the senatorial aristocracy and recast it in the role of loyal and dutiful subjects. Seen from another angle, it is a demonstration of the independent potential of court ritual and ceremony; it could literally go on without the emperor, a puppet might just do. ${ }^{71}$

${ }^{70}$ Herodian IV, 2 (trans. Whittaker).

${ }^{71}$ I am much obliged to Peter Garnsey and John Hall for the helpful suggestions and perceptive comments they made to an earlier draft of this paper; and to the audience at the conference in Istanbul for constructive and inspiring discussion. Ancient Latin and Greek texts are cited using the customary system of abbreviations in Oxford Latin Dictionary and Liddell \& Scott, Greek-English Lexicon. 
SUCCESSORS AND PARALLELS IN EAST AND WEST 


\section{COURT AND CAPITAL IN BYZANTIUM}

\section{Paul Magdalino}

The relationship between court and capital is perhaps what best defines the structural singularity of any court society, since it is infinitely variable. A court can exist without a single fixed capital, though such independent self-sufficiency is the exception in the long term, and a pure court that stays put long enough will put down roots and become the nucleus of a capital. A royal capital presupposes a royal court, but not necessarily at its heart or in permanent residence. Most court societies fall somewhere within the spectrum between total integration and total detachment, and the longer they last the greater the range of permutations they are likely to exhibit. The Byzantine imperial court, which lasted over one thousand years, did not have a static relationship with the empire's capital, Constantinople. It left the city when the emperor went on campaign, or retired for the summer to a suburban palace on the Bosphoros. Within the city, it bilocated during the twelfth century between the downtown Great Palace and the semisuburban Blachernae, before withdrawing completely to the latter. The Latin conquest of 1204 not only forced the court out of Constantinople on a temporary basis, but also caused it to splinter into three centres, in northern Greece, western Asia Minor, and the Pontos. The courts in northern Greece and Trebizond survived the recovery of Constantinople by their western Anatolian rival in 1261. The restored empire of the Palaiologoi itself became progressively split by civil wars and divisions within the ruling dynasty, and provincial courts emerged at Thessaloniki and Mistra, not to mention the more ephemeral centres at Didymoteichon, Adrianople and Selymbria.

However, all these developments stemmed from a very strong bond between court and capital. On the scale of possible permutations, the only monarchy that came as close or closer to a model of total integration was the regime from which Byzantium derived, namely imperial Rome. The Roman imperial monarchy was the creation of a city that was already the capital of an empire, and for the first three hundred years of its existence it remained firmly rooted in the civic institutions and topography of that Eternal City. With Diocletian and the 
Tetrarchy, government devolved from Rome to a number of subsidiary capitals, each of which housed its own court. Yet it is significant that each of these Tetrarchic 'Romes from Rome', at Trier, Milan, Nicomedia, Thessalonica, and elsewhere, replicated not only the emperor's palatine residence, but also the unique juxtaposition of the Palatine complex and the Circus Maximus. ${ }^{1}$ Thus every Tetrarchic palace came complete with an adjoining hippodrome where the emperor and his entourage joined the local populus Romanus to watch the games from the imperial box. When Constantine ended the Tetrarchy, he adopted the same model in the foundation of Constantinople, to which he and his successors added other distinctive Roman features: a Senate, a Capitolium, imperial fora with triumphal columns and triumphal arches, an array of classical statues pilfered from other cities, huge public baths, a massive infrastructure of grain and water supply, and, eventually but inevitably, the title of New Rome. ${ }^{2}$

With time, Byzantium became more and more of an oriental despotism, but the Byzantine imperial court remained encased in the husks of Roman civic tradition. At its core it was a secretive, private household screened and staffed by eunuchs, but on the outside it was a hierarchy of public officials which ramified beyond the Palace, and whose upper ranks, at least, were always known as the Senate. ${ }^{3}$ The essential activity of the court was the performance of ritual: an elaborate round of ceremonies designed to elevate and celebrate the emperor as the image of God on earth, alternately occluded and highlighted, moving and motionless, in a variety of settings with a many-layered apparatus of attendants, partitions, vestments, lights, and pregnant silences punctuated by rousing sounds. ${ }^{4}$ But court ceremonial reached out as well as looked inward. It honoured all who took part by display-

${ }^{1}$ See John H. Humphrey, Roman Circuses. Arenas for Chariot Racing (London 1986) passim and pp. 636-637.

${ }^{2}$ See in general Gilbert Dagron, Naissance d'une capitale, Constantinople et ses institutions de 330 à 451 (Paris 1974); Cyril Mango, Le développement urbain de Constantinople (IV $-V I I^{F}$ siècles ) 3rd ed. (Paris 2004); Sarah Bassett, The Urban Image of Late Antique Constantinople (Cambridge 2004); Franz A. Bauer, Stadt, Platz und Denkmal in der Spätantike. Untersuchungen zur Ausstattung des öffentlichen Raums in den spätantiken Städten Rom, Konstantinopel und Ephesos (Mainz 1996).

${ }^{3}$ See Michael McCormick, 'Emperor and Court', in: The Cambridge Ancient History, XIV. Late Antiquity: Empire and Successors, A.D. 425-600, Averil Cameron; Bryan Ward-Perkins, Michael Whitby, eds. (Cambridge 2000) pp. 135-163.

${ }_{4}^{4}$ Paul Magdalino, The Empire of Manuel I Komnenos, 1143-1180 (Cambridge 1993) pp. 237-248, with bibliography. 
ing their status within the hierarchy of proximity to the sovereign. It maintained the bond between court and capital that had been emphasised in the foundation of Constantinople, by linking the closed spaces of the inner Palace to the open spaces of the City. Above all, it animated the enduring architectural association between the Palace and the Hippodrome that Constantine had reproduced from Rome via the Tetrarchic capitals.

The main source for this picture of the Byzantine court is the Book of Ceremonies, a voluminous compilation commissioned by the emperor Constantine VII between 945 and 959, and added to after his death. ${ }^{5}$ Six chapters describe the procedure for the emperor's attendance at the Hippodrome games, ${ }^{6}$ which consisted essentially of chariot races between the teams of the four colours, Blue, Green, White and Red, the Whites and Reds being paired with and subordinated to the other two. ${ }^{7}$ The emperor presided over the races, and rewarded the victors, from the upper story of a palace building known as the Kathisma, which contained a dining hall and a bedchamber as well as the grandstand where he and his court overlooked the arena, in full view of the people arrayed according to faction on the opposite side. Apart from the actual races, the proceedings included lengthy sets of acclamations addressed to the emperor by the two main factions, in which the chants of the cheerleaders alternated with the shouts of the crowd.

The court's day at the races as described by the Book of Ceremonies was a very tame, ritualised and infrequent affair compared with what had happened in imperial Rome, or in Constantinople four centuries earlier. The number of race days and the number of races per day had been drastically reduced; the factions no longer used their acclamations to confront the emperor with embarrassing protests or requests, and their rivalry no longer erupted into violence now that their officers were appointed and controlled by the authorities. However, the existence of these officers shows that the factions were serious organisations, with considerable responsibility for training and equipping the

${ }^{5}$ The most complete edition is still that of J.J. Reiske, Constantini Porphyrogeniti imperatoris De cerimoniis aulae byzantinae libri duo (Bonn 1829-30); Book I is edited with a French translation by A. Vogt, Constantin Porphyrogenète, Le livre des cérémonies, Livre I, 2 vols. (Paris, 1935-9; repr. 1967).

${ }^{6}$ De cerimoniis I.77-82: new edition of these chapters with French translation and extensive commentary by G. Dagron, 'L'organisation et le déroulement des courses d'après le Livre des cérémonies', Travaux et mémoires 13 (2000) pp. 1-200.

See in general Alan Cameron, Circus Factions (Oxford 1976). 
chariot teams, for composing, staging and orchestrating the chants and dances, and, presumably, for filling up the tiers of seats in the sections assigned to their supporters on the north side. The Blues and the Greens had their own churches, their own stables, and their leaders, the demarchoi, appear to have had an administrative role in two of the city's fourteen regions. At times they functioned as urban militias. Though not political, social or religious parties, it is becoming increasingly clear from other cities that the factions represented deeply rooted patterns of civic allegiance and organisation. ${ }^{8}$ Their faceto-face encounter with the emperor in the games brought court and capital together in the performance of a common ritual that marked moments of significance to both. Games were held to celebrate not only the major dates in the religious calendar and important events in the life of the imperial family, such as weddings and births, but also victories over the Empire's enemies and the most symbolically significant date in the existence of Constantinople, namely the anniversary of its foundation on 11 May 330.

The games were not the only occasions and the Hippodrome was not the only place in which the Book of Ceremonies shows court ceremonial reaching out to the public spaces of the city. Once a year, at the beginning of Lent, the emperor delivered a public speech, the silention, from the steps of a great hall called the Magnaura. ${ }^{9}$ He was surrounded by his household guards and attendants, and his audience consisted of the senior court dignitaries 'and all of the urban populace'. The Magnaura, like the Kathisma, was a Palace building, but it lay at the outer entrance to the Palace complex, opening onto a freely accessible public space, and it was not used for very exclusive functions. It had probably originated as a senate house, and apart from the yearly silention, it served mainly for the routine reception of foreign ambassadors and the convening of occasional 'parliamentary' assemblies to approve imperial policy; it also housed a law court in the ninth century, and even, for a short time, a university. ${ }^{10}$

${ }^{8}$ Charlotte M. Roueché, Performers and Partisans at Aphrodisias (London 1993); eadem, 'Looking for Late Antique Ceremonial: Ephesos and Aphrodisias', in: 100 Jahre Österreichischer Forschungen in Ephesos, Denkschriften der Österreichischen Akademie der Wissenschaften 260, H. Friesinger and F. Krinzinger, eds. (Vienna 1999) pp. 161-168.

${ }^{9}$ De cerimoniis, II.10, ed. Reiske, I, pp. 545-548.

${ }_{10}$ De cerimoniis, II.15, pp. 566-594; Cyril Mango, The Brazen House (Copenhagen 1959) pp. 57-58; Albrecht Berger, Untersuchungen zu den Patria Konstantinupoleos 
Ceremonial outreach also happened when the emperor went, on a religious feast day, to worship at a church outside the Palace. ${ }^{11}$ The most important of these venues was the Great Church of Hagia Sophia, the patriarch's cathedral, which like the Hippodrome and the Magnaura lay in close proximity to the Palace and allowed the emperor direct, exclusive access. ${ }^{12}$ This is where he attended the liturgy on the great dominical feasts of the Christmas and Easter season..$^{13}$ But the sacred calendar took the emperor to other churches in the vicinity, as well as to churches much further afield, and occasionally to other institutions, notably to the city's old-age homes, which he visited to distribute alms on Holy Thursday, ${ }^{14}$ and to the 'holy bath' at the Blachernae, where he went to bathe on certain Fridays. ${ }^{15}$ The services and receptions at these places involved a variety of personnel, both secular and clerical, who were not regularly in attendance on the emperor. Among them the representatives of the Blue and Green factions often played a prominent role. The emperor's processional route from his bedchamber to Hagia Sophia took him past alternating sets of Blue and Green militias, who acclaimed him in turn as he approached the northern exit from the Palace complex; at the first reception, they were accompanied by visiting foreigners and the city's guilds. He was then received and acclaimed by different, civilian Blues and Greens stationed between the Palace gate and the atrium of the church; on his return, the same process was repeated in reverse. ${ }^{16}$ On other occasions, between Easter and Pentecost, it was enacted over a much longer distance when the imperial cortège returned from a visit to one of three churches in

(Bonn 1988) pp. 242ff., 267 n. 207; Paul Magdalino, 'Justice and Finance in the Byzantine State, Ninth to Twelfth Centuries', in: Law and Society in Byzantium, NinthTwelfth Centuries, Angeliki Laiou and Dieter Simon, eds. (Washington, D.C. 1994) pp. 97-99.

${ }^{11}$ See in general Albrecht Berger, 'Imperial and Ecclesiastical Processions in Constantinople', in: Byzantine Constantinople: Monuments, Topography and Everyday Life, Nevra Necipoğlu, ed. (Leiden 2001) pp. 73-87.

12 Mango, Brazen House, pp. 87-91.

13 Procedure outlined mainly in the first two chapters of the Book of Ceremonies: De cerimoniis, I.1-2, ed. and trans. Vogt, I, pp. 3-34; cf. George P. Majeska, 'The Emperor in his Church: Imperial Ritual in the Church of St. Sophia', in: Byzantine Court Culture from 829 to 1204, Henry Maguire, ed. (Washington, D.C. 1997) pp. 1-11; Gilbert Dagron, Emperor and Priest. The Imperial Office in Byzantium (Cambridge 2003) pp. 84-95.

${ }^{14}$ De cer., I.42: Vogt, I, 165-6.

${ }^{15}$ De cer., II.12: Reiske, I, 551-6

${ }^{16}$ De cer., I.1: Vogt, I, 8-10, 14-15; I.2: Vogt I, 29-34 (Christmas acclamations). 
the west of the city: the Holy Apostles, ${ }^{17}$ St Mokios, ${ }^{18}$ or the Virgin of the Spring (Pege) outside the walls. ${ }^{19}$ The Blues and Greens took turns in greeting the procession at regular intervals all the way to the palace, along a route which led through the commercial heart of the city, taking in all of its important nodal points and most of its important Roman monuments, including the Forum of Constantine and the Capitolium. This route coincided more or less exactly with the triumphal avenue along which ninth- and tenth-century emperors paraded on their return from victorious campaigns. ${ }^{20}$ On these occasions, too, they were acclaimed by the factions: thus did the capital share symbolically in the emperor's victory and identify with his homecoming. The use of the same route for imperial processions on religious feasts made victory ceremonial a regular annual occurrence, as of course did the Hippodrome games associated with the birthday of Constantinople and the Christmas and Easter cycles. ${ }^{21}$

Court ceremonial involved the capital, moreover, by including the city's residents in exclusive Palace events. Only the eunuchs of the bedchamber and a few service personnel normally lived on site; all other court dignitaries normally commuted from their own urban homes. ${ }^{22}$ Apart from the privileged title-holders who regularly attended, lowlier functionaries came as occasional guests, notably to one of the great banquets held on the twelve days of Christmas in the Triclinium of the Nineteen Couches, where the diners dined reclining in the Roman style. ${ }^{23}$ On several occasions, the Blue and Green factions took part. They performed acclamations at imperial coronations and weddings,

17 I.5, 10: Vogt, I, 41-5, 65-77

${ }^{18}$ I.7, 26: Vogt, I, 48-9, 92-100.

19 I.8, 27: Vogt, I, 50-53, 101-5.

20 Constantine Porphyrogenitus, Three Treatises on Imperial Military Expeditions, J.F. Haldon, ed. and trans. (Vienna 1990) pp. 136-51; cf. Michael McCormick, Eternal Victory. Triumphal Ruldership in Late Antiquity, Byzantium and the Early Medieval West (Cambridge 1986) pp. 144-176.

${ }^{21}$ Dagron, 'L'organisation', pp. 127-132. The order of ceremony for victory games is described in De cer., II.20: Reiske, 612-5.

${ }^{22}$ Alexander P. Kazhdan and Michael McCormick, 'The Social World of the Byzantine Court', in: Byzantine Court Culture from 829 to 1204, Henry Maguire, ed. (Washington, D.C. 1997) pp. 167-197, at pp. 185-187.

${ }^{23}$ Kazhdan and McCormick, 'The Social World', pp. 175-176, 180-181, based on the Kletorologion of Phliotheos (899), a treatise concerning the order of seating at imperial banquets: Nicolas Oikonomides, ed., Les listes de préséance byzantines des IX et $X^{e}$ siècles (Paris 1972) pp. 164-189. 
and at the promotions of major dignitaries. ${ }^{24}$ This mainly happened in the older, upper parts of the palace complex which were used for state occasions. But there was one ceremony held in the new, lower palace area where the factions were the stars of the show: the deximon or parakyptikon. ${ }^{25} \mathrm{~A}$ day before the staging of games at the Hippodrome, the Greens and the Blues treated the emperor and the court to a day of song and-usually-dance. From the reign of Justinian II at the end of the seventh century, each faction was assigned its own courtyard with a central fountain on a terrace below the main halls of the lower palace. ${ }^{26}$ There, they would assemble to perform acclamations and chants accompanied by organ music as the emperor looked down on the proceedings, flanked by the court dignitaries, and framed by an awning, the parakyptikon, which was mounted on a parapet in front of his throne. ${ }^{27}$ After the ceremony had been performed in both courtyards, the emperor and a selection of dignitaries retired for lunch to the Hall of Justinian II. Depending on the occasion, the factions would either lunch separately in their courtyards, or each in turn would be ushered in turn into the dining hall after the main course, for the faction leaders to dance around the tables three times while the chanters sang acclamations. ${ }^{28}$

Inside as outside the Palace, the Blues and the Greens were not integrated with the court hierarchy; they were strictly separated by role and space from the dignitaries and household attendants who stood, walked, rode or-sometimes-sat beside the emperor. The presence of the factions at Palace festivities nevertheless served to emphasise the point made by the court's appearance at external ceremonial venues

24 De cer., I. 47-63: Vogt, II, 1-78.

25 Seven chapters of De cer. are concerned with various aspects of the deximon: I. 70-76: Vogt, II, 86-111. The description of the main event in ch. 73, pp. 94-101, associates it with the 'Golden Hippodrome', the games held in May between Easter and Pentecost, but it is clear from other chapters that this was not the only occasion (72, p. 93), and that the deximon was also held in winter, when in bad weather it would be transferred to the more sheltered courtyard of the Triconch $(75, \mathrm{p} .105)$.

${ }^{26}$ Justinian II laid out the courtyard and fountain of the Blues in 694, at about the same that he built the palace hall named after him: Theophanes, Chronographia, C. de Boor, ed. (Leipzig 1883) vol. 1, pp. 367-8; Cyril Mango and Roger Scott, trans., The Chronicle of Theophanes Confessor (Oxford 1999) p. 513. The courtyard of the Greens, which was also close to the Hall of Justinian II, cannot have been far removed in date. On both courtyards, see Rodolphe Guilland, 'Les Phiales des factions', Études de topographie de Constantinople byzantine I (Amsterdam 1969) pp. 211-6.

${ }_{27}$ For the parakyptikon, see Vogt, II, pp. 96, 99, 111.

28 Vogt, II, 101-4. 
that were either liminal, like the Hippodrome, the Magnaura, and Hagia Sophia, or fully located in public space, like the Holy Apostles, involving processional movement through the city's avenues and squares. The point was that the court was symbolically attached to the capital, and could not be detached without violating the proper, constitutional order of things, the katastasis, taxis or eutaxia that ceremonial represented, as the prefaces to the Book of Ceremonies make clear. ${ }^{29}$ Other sources for the period covered by the Book of Ceremonies, the sixth to tenth centuries, record many other occasions on which emperors appeared in public, making pragmatic as well as symbolic use of civic spaces like the Hippodrome, the Magnaura, Hagia Sophia and the processional route through the city centre. To take just one example: in 713, on the day before Pentecost, the emperor Philippikos organised a festive reception at the ancient public bath of the Zeuxippos, adjacent to the Palace. He rode in accompanied by music, dancing and acclamation, and when he had bathed-presumably in public-he feasted with "citizens of ancient lineage". Unfortunately for him, the occasion-well publicised in advance-provided perfect cover for a coup d'état. The conspirators seized him as he was enjoying his siesta, and took him to the dressing room of the Green faction, who were clearly part of the plot. Here he was blinded and held until his successor was publicly acclaimed the next day in Hagia Sophia. ${ }^{30}$

Yet the relationship between court and capital reflected in the Book of Ceremonies was changing even as that compilation was being put together in the 960s. It included material that was up to four centuries old, and in many cases where it appears to be prescribing current practice, it is in fact describing ceremonies known only from written records. This is most clearly demonstrated in the case of the receptions in the courtyards of the Blues and the Greens. The exact procedure outlined in the Book of Ceremonies could not have taken place in the tenth century, because the emperor Basil I, as we learn from his biography, had taken the fountains to adorn the atrium of the new church he had founded to the east of the Palace, and had built a bath-house in the courtyard of the Blues. ${ }^{31}$ Basil may have confined the reception ceremonies to what had previously been their winter venue, the

\footnotetext{
${ }^{29}$ Vogt, I, 1-2; Reiske, I, 516-7.

30 Theophanes, Chronographia, ed. de Boor, vol. 1, 383; trans. C. Mango and R. Scott, p. 533.

31 Theophanes Continuatus, I. Bekker, ed. (Bonn 1838) pp. 327, 336.
} 
sheltered courtyard of the Triconch in the upper Palace, ${ }^{32}$ but equally he may have done away with them altogether. Either way, many other ceremonies are likely to have suffered a similar fate, particularly those which the Book of Ceremonies sets in the upper, older parts of the Palace. These areas-corresponding effectively to the palace of Constantine and Justinian-are seldom heard of again, although the Hall of the Nineteen Couches was apparently still functioning c. $1040 .{ }^{33}$ As Cyril Mango has plausibly argued, they probably lay outside the fortification wall which the emperor Nikephoros II Phokas put up around the inhabited section of the palace between 963 and 969-thus at exactly the time when the Book of Ceremonies was being compiled. The fortification turned the Palace into "a kind of castle, called by disgruntled contemporaries a 'tyrant's acropolis" ". ${ }^{34}$ The fortified sector, which became known as the Palace of the Boukoleon, remained the principal location of the court until the late eleventh century, when the Comnenian dynasty developed the Blachernae as the favourite imperial residence.

By first retrenching within the fortified "Kremlin" of the Boukoleon Palace, and then by moving to the semi-suburban Blachernae, far from the Hippodrome, Hagia Sophia and the Forum of Constantine, the court was progressively distancing itself from the city in ways that had not existed in the period covered by the Book of Ceremonies. Yet this observation needs to be qualified. ${ }^{35}$ Games continued to be staged at the Hippodrome until the end of the twelfth century. ${ }^{36}$ The Great Palace remained the seat of government, and the financial administration, at least, was lodged in the old part of the complex, outside

\footnotetext{
${ }^{32}$ See above, n. 25.

${ }^{33}$ Michael Psellos, describing the unhappy lot of the lowly Palace bureaucrats, the asekretai, mentions that their one treat was an invitation (kletorion) to a meal where they had to eat in a reclining position: Antony Robert Littlewood, ed., Michaelis Pselli oratoria minora (Leipzig 1985) p. 46. This seems to correspond to the practice in the Hall of the Nineteen Couches as described in the Kletorologion of Philotheos, which mentions the asekretai among the 'Sandal Senate' who received invitations to two of the ten Christmas dinners: Oikonomides, Listes de préséance, pp. 169, 181.

${ }^{34}$ Cyril Mango, 'The Palace of the Boukoleon', Cahiers archéologiques 45 (1997) pp. 41-50.

${ }^{35}$ See Paul Magdalino, 'Manuel Komnenos and the Great Palace', Byzantine and Modern Greek Studies 4 (1978) pp. 101-114 [repr. in Tradition and Transformation in Medieval Byzantium (Aldershot 1991), no. V].

${ }^{36}$ Rodolphe Guilland, 'La disparition des courses', Études de topographie I, pp. 542-55.
} 
the walled Palace of the Boukoleon. ${ }^{37}$ The palace guards units were quartered where they always had been, just inside the main entrance on the northern side. New buildings were added to the Palace of the Boukoleon in the twelfth century, and emperors took up residence here on important state occasions when games were celebrated, such as coronations, triumphal homecomings, and the births and weddings of imperial children. It was important for these children to be born "in the Purple", that is in the ancient imperial birth chamber of porphyry stone. The birth of an imperial baby was announced by hanging a red, pearl-embroidered child's slipper in front of the main ceremonial entrance to the Palace, the Chalke Gate, ${ }^{38}$ just as the emperor's departure on campaign had formerly been advertised by hanging a coat of chain mail, sword and shield in the same place. ${ }^{39}$ It was in the Boukoleon Palace, too, that the emperor Manuel Komnenos convened a church council in 1166, and entertained two royal visitors, the sultan of Konya in $1161^{40}$ and the King of Jerusalem in $1171 .^{41}$

An important reason for bringing distinguished visitors to the Palace of the Boukoleon was to show them the precious and ancient imperial heirlooms kept in the palace treasuries-objects like the crowns, thrones and sceptres that had been used by Constantine and other early Byzantine emperors. ${ }^{42}$ Christian visitors like the King of Jerusalem were also given a private viewing of the sacred relics in the palace chapel, whose centrepiece was the collection of objects associated with Christ and his crucifixion. Although access to the chapel was restricted, there are good indications that it was on the tourist trail of pilgrimage sites followed by Christian travellers. ${ }^{43}$

Thus despite or indeed because of being partially abandoned by the court, the Great Palace became part of the historic, monumental fabric of the capital, a showcase of ancient and holy memorabilia and mirabilia, to be admired along with the great triumphal columns, the

37 The domed building known as the Oaton was still a fiscal archive in 1094, as it had been in the tenth century: see Paul Magdalino, Studies on the History and Topography of Byzantine Constantinople (Aldershot 2007) no. I, p. 45.

${ }_{38}$ Magdalino, Empire of Manuel, p. 243.

39 Constantine Porphyrogenitus, Three Treatises, pp. 96-97.

${ }^{40}$ John Kinnamos, Epitome, Augustus Meineke, ed. (Bonn 1836) pp. 204-206.

${ }^{41}$ William of Tyre, Chronique, R.B.C. Huygens, ed. (Turnhout 1986) pp. 943-946.

${ }^{42}$ Kazhdan and McCormick, 'The Social World of the Byzantine Court', p. 195.

${ }^{43}$ Paul Magdalino, 'L'église du Phare et les reliques de la Passion à Constantinople ( $\left.\mathrm{VII}^{e} / \mathrm{VIII}^{\mathrm{e}}-\mathrm{XIII}{ }^{\mathrm{e}} \mathrm{s}.\right)^{\prime}$ ', in: Byzance et les reliques du Christ, Jannic Durand and Bernard Flusin, eds. (Paris 2004) pp. 15-30. 
statues in the Hippodrome, Hagia Sophia and the numerous other churches and monasteries. Since at least the tenth century, visits to Hagia Sophia had been part of the treatment used to awe foreign envoys to the imperial court; ${ }^{44}$ indeed, it is hard to believe that all the great public monuments had not served this purpose from the beginning. So the capital was an indispensable instrument of 'palace diplomacy', and never more so than in the twelfth century, when the court's move to the Blachernae effectively added the Great Palace to the list of 'state heritage' sites that displayed the glories of the 'national' past.

After 1261, however, when the restored Byzantine Empire simply lacked the resources to restore Constantinople to its full pre-1204 glory, the court's return to the Blachernae did mark the beginning of an unambiguous disengagement from the life and institutions of the capital. The Hippodrome games were never revived, the Great Palace fell into ruin after 1300, and the court itself was progressively downsized by the Empire's territorial contraction and dynastic disintegration. The end result is documented by a treatise on court hierarchy and protocol written in the late fourteenth century-the only one of its kind later than the Book of Ceremonies. ${ }^{45}$ Nearly all the action described by the anonymous author, known to scholars as Pseudo-Kodinos, is limited to a single reception-cum-dining hall, with a few closely adjoining structures making occasional appearances: the imperial bedchambers, a palace church, another chapel, an elevated walkway, and a raised tribunal both overlooking a courtyard. Not only was this ceremonial space, which occupied just a part of the fortified Blachernae complex, very modest compared with the multiple halls and corridors of the Great Palace evoked by the Book of Ceremonies; it also did not provide for regular ceremonial interface between court and capital. There were no liminal spaces equivalent to Hagia Sophia, the Hippodrome and the Magnaura. On certain feast days Pseudo-Kodinos' emperor does venture out of his castle to worship at a church or monastery, sometimes at the other end of the city, and his cavalcade is an occasion for

${ }^{44}$ Theophanes Continuatus, ed. Bekker, p. 402; Samuel H. Cross and Olgerd P. Sherbowitz-Wetzor, trans., The Russian Primary Chronicle (Cambridge, Mass. 1953) p. 111.

${ }^{45}$ Jean Verpeaux, Pseudo-Kodinos, Traité des offices (Paris 1966); cf. Paul Magdalino, 'Pseudo-Kodinos' Constantinople', in: Paul Magdalino, Studies on the History and Topography of Byzantine Constantinople (Aldershot 2007) no. XII. 
people to approach him with petitions. ${ }^{46}$ But there are no Blues and Greens acclaiming him along the route, and the only rituals where the emperor is acclaimed by the people are those associated with his coronation. ${ }^{47}$

This is not to deny that acclamation was still an important feature of the festive ceremonial for the Christmas and Easter seasons, notably in the ceremony called the prokypsis. ${ }^{48}$ After their devotions in the palace chapel, the emperor and his sons proceeded to an outdoor tribunal, also called prokypsis, hung with curtains and tapestries; a curtain was drawn to reveal the emperor alone in full regalia, cut off at the knees by a balustrade that also hid the two kneeling men holding the candle and the sword both visible beside him. At his appearance, the chanters and musicians in the assembled crowd burst into songs and acclamations. Now the prokypsis ceremony has distinct echoes, in name and in form, of the old parakyptikon of the Book of Ceremonies, the emperor's 'leaning over' the acclaiming factions in their respective courtyards, which itself reproduced the ritual performed in the Hippodrome. ${ }^{49}$ But in this case, the assembly over which he 'leaned' consisted entirely of court personnel: the Varangian guard of English axebearers, the palace clergy, and the hierarchy of dignitaries, a number of whom acted as standard bearers. The only hint of a popular presence in PseudoKodinos' description lies in the mention of banners belonging to the demarchs-the traditional term for the faction leaders. Thus although the fourteenth-century prokypsis ceremony may have been the direct lineal descendant of the ninth-century parakyptikon, it differed significantly in not being a symbolic face-to-face encounter between the court and the people of the capital, and in not being the prelude to events at the Hippodrome. Now the people's place was reduced to a minimum and absorbed by the court, which took over their role as spectators and applauders of the emperor's solitary, still epiphany. It was a similar story in the banquet that followed the prokypsis. ${ }^{50}$ There were no guests; the emperor sat alone at table, with the court standing in attendance. He was served not by lowly domestic servants, but by

\footnotetext{
${ }^{46}$ Magdalino, 'Pseudo-Kodinos', pp. 172-173; cf. Ruth Macrides, 'The ritual of petition', in: Ritual in Greece: interdisciplinary perspectives, P. Roilos and D. Yatromanolakis, eds. (Cambridge, Mass. 2004) pp. 356-370.

${ }^{47}$ Verpeaux, Pseudo-Kodinos, pp. 252-253.

48 Verpeaux, Pseudo-Kodinos, pp. 195-204.

49 The connection is made by Dagron, 'L'organisation', p. 123.

${ }^{50}$ Verpeaux, Pseudo-Kodinos, pp. 207-218.
} 
noble dignitaries, bearing the high-ranking titles of Grand Domestic (megas domestikos), Domestic of the Table (domestikos tes trapezes), and Seneschal (pinkernes). Their status is clear not only from their hierarchical rank, but also from their functions and their prosopography, as documented by other sources: they belonged to the emperor's social peer group, from which leading military commanders were appointed. The Grand Domestic was indeed the ex officio commander-in-chief of the armed forces-the Marshal of the realm.

A palace consisting of a Great Hall and minor adjuncts in a castle courtyard, where household offices were ritually performed by peers of the realm: this does not look like imperial Rome or Byzantium. It looks much more like a Western medieval royal court of the eleventh and twelfth centuries. It is a striking manifestation of the evolution that Gilbert Dagron has recently highlighted in an evocative comparison of the French and Byzantine monarchies: as kingship in France took on imperial claims and attributes, the Byzantine Empire became more of a national kingdom. ${ }^{51}$ We may add that in the process, it looked east as well as west. Pseudo-Kodinos was conscious of the Persian and Assyrian heritage that the empire shared with the neighbouring Turkish powers. ${ }^{52}$ Courtiers sported Oriental as well as Western fashions ${ }^{53}$ and when the Castilian ambassador Clavijo visited the Byzantine court in 1402, he had an audience with the emperor "in his private chamber... seated on a raised dais, carpeted with small rugs, on one of which was spread a brown lion skin and at the back was a cushion of black stuff embroidered in gold". ${ }^{54}$

Another Spanish visitor around the same time, Pero Tafur, observed, “The Emperor's state is as splendid as ever, for nothing is omitted from the ancient ceremonies, but, properly regarded, he is like a Bishop without a See". ${ }^{55}$ To put it another way, Byzantium was now an imperial court and capital without an empire. Until the bitter end

\footnotetext{
${ }^{51}$ Gilbert Dagron, 'Empires royaux, royautés impériales. Lectures croisées sur Byzance et la France médiévale', Summa. Dieter Simon zum 70. Geburtstag, R.M. Kiesow, R. Ogorek, Sp. Simitis, eds. (Frankfurt 2005) pp. 81-97.

${ }^{52}$ Verpeaux, Pseudo-Kodinos, pp. 205-206, 218-219.

${ }^{53}$ Nikephoros Gregoras, Byzantina Historia I, Ludwig Schopen, ed. (Bonn 1829) pp. 567-568.

54 [Ruy Gonzalez de] Clavijo, Embassy to Tamerlane 1403-1406, G. Le Strange, trans. (London 1928) p. 61.

${ }^{55}$ Pero Tafur, Travels and Adventures 1435-1439, M. Letts, trans. (London 1926) p. 145 .
} 
came in 1453, court and capital remained indispensable to each other's imperial identity, but curiously neither depended on the other for its existence. In losing their imperial substance, they had lost the main thing they had in common, and they had lost touch. Constantinople had become the symbolic, spiritual capital of an Orthodox oikoumene, a polycentric Byzantine commonwealth of which the patriarch, not the emperor, was the effective head. The court, meanwhile, had become virtually indistinguishable from its many princely and royal neighbours, where the capital was of secondary importance. 


\section{A KING ON THE MOVE: \\ THE PLACE OF AN ITINERANT COURT IN \\ CHARLEMAGNE'S GOVERNMENT}

\section{Rosamond McKitterick}

In 1965, Adolf Gauert published a now famous map of Charlemagne's itinerary. It was produced in association with the Council of Europe's Charlemagne exhibition at Aachen and was a remarkable piece of reconstruction and investigation of battlefields and military camps, episcopal sees, monasteries and royal residences, and even the site of the canal Charlemagne tried to build to connect the Rhine and Danube rivers. The map claimed to illustrate how the king at one time or another throughout his reign moved right across western Europe, from the Pyrenees to the Elbe, from the English Channel almost to the Danube Bend, and across the Alps as far south as Capua. ${ }^{1}$ This picture of a king on the move accorded with the received understanding of itinerant kingship, developed in relation to the Ottonian and Salian rulers of Germany in the late tenth and eleventh century and often extrapolated to many other medieval realms. ${ }^{2} \mathrm{I}$ shall argue in this paper that such an understanding of Charlemagne as an itinerant king in the technical sense is simply inappropriate in relation to early Carolingian government. I want to challenge in particular the validity of one category of information on which Gauert relied to map the king's movements. This is the charter evidence, though in this respect Gauert was simply following standard practice in all studies of medieval rulers. In every existing study of a king's movements in the Middle Ages, it is assumed that the charter or royal diploma in the king's name is also confirmation of the king's presence. I shall suggest here that we should abandon this assumed correlation, and that once we have done

1 Adolf Gauert, 'Zum Itinerar Karls des Grossen', in: Karl der Große I Persönlichkeit und Geschichte I, W. Braunfels, ed. (Darmstadt 1965) pp. 307-321, between pp. 320 and 321.

${ }^{2}$ Conrad Peyer, 'Das Reisekönigtum des Mittelalters', Vierteljahrschrift für Sozialund Wirtschaftsgeschichte 51 (1964) pp. 1-21. See Eckhard Müller-Mertens, Die Reichsstruktur im Spiegel der Herrschaftspraxis Ottos des Großen, Forschungen zur mittelalterlichen Geschichte 25 (Berlin 1980). 
so, a very different picture of Charlemagne's itinerary between 768 and 814 , and consequently of his government, emerges.

Let me first explain how itinerant kingship is usually defined. It is a 'form of government in which a king carries out all the administrative functions and symbolic representations of governing by periodically or constantly travelling throughout the areas of his dominion. ${ }^{3}$ Thus it is not merely the ceremonial circumambulation of the royal progress to take symbolic possession of the kingdom, but actually a means of ruling. The king's subjects came to him in the places he visited. The iter was also a vehicle for the king's sacrality in the Ottonian period. ${ }^{4}$ The itinerary is thought to reflect not only the relationship between the importance of personality and personal power, regarded as an essential characteristic of medieval kings, but also the limited extent of the use of writing in government. Indeed, both the size of the kingdom and poor written communications have been posited as strong determining factors for the practice of itinerant kingship. Two other interlocking elements have been identified. The first is the notion of the palace as part of an economic system. It has been assumed, for the Carolingian period as well as for the Ottonian, that the king would not use his own resources from the royal estates and that anyone coming to a royal palace would expect to be fed by the king. ${ }^{5}$ Such a focus on the economic logistics of provision has sometimes become confused with necessity, so that a persistent image has been created of the king and his court as nomadic pastoralists or even a plague of locusts eating up the local produce and constantly on the move in search of new pasture. The Carolingians are even claimed to have had to renounce the idea of a fixed centre of government for economic reasons, and to content themselves with different royal residences. ${ }^{6}$ This does not make sense for the richly endowed early Carolingian rulers and what has been pieced together about the royal estates in the Frankish heartlands as well as on newly confiscated land from Westphalian, Saxon, and Bavarian landholders. Most crucially, discussions of the king's

${ }^{3}$ John Bernhardt, Itinerant and Royal Monasteries in Early Medieval Germany, c. 936-1075 (Cambridge 1993) p. 45.

${ }^{4}$ Bernhardt, Itinerant and Royal Monasteries, p. 293.

${ }^{5}$ Einhard, Epistolae, K. Hampe, ed., MGH Epp V (Berlin 1899) Ep. 5, pp. 111-112.

${ }^{6}$ Carlrichard Bruhl, "Remarques sur les notions du 'capitale' et du 'residence' pendant le haut moyen âge", Journal des savants (1967) pp. 195-215; reprinted in idem, Aus Mittelalter und Diplomatik. Gesammelte Aufsätze 2 vols. (Hildesheim 1989) vol. 1, pp. 115-137, at p. 207. 
economic needs have rarely taken the remarkable wealth of the Carolingian royal estates and the extensive forest support for hunting and fishing, in proximity to agricultural and pastoral land, into account: ${ }^{7}$ it was not the need for food which governed the king's movements. ${ }^{8}$

If we consider the territory inherited, conquered, annexed, or attached as tributary regions by treaty in the course of Charlemagne's reign, a rough categorization of the king's movements can be made. The places from the Rhine eastwards into Thuringia, Westphalia and Saxony are mostly linked with the Saxon campaigns recorded in many different sets of Frankish annals. Those in Italy reflect the conquest of the Lombard kingdom and subsequent interventions by Charlemagne thereafter in the affairs of the Lombard kingdom, Benevento and the Papacy. The little group in the Pyrenees includes the site of the famous defeat, traditionally located at Roncesvalles, which inspired the later Chanson de Roland, and the palaces in Bavaria and the camps placed in the middle Danube region witness to Charlemagne annexation of his cousin Tassilo's Duchy of Bavaria and his triumph over the Avars. Apart from these military campaigns, intermittent visits to other places are recorded in some of the narrative and documentary sources of the reign.

There are a number of difficulties with this representation of the king's movements within his own domains. Gauert's map could not explain without further commentary either the duration or the reason for the visits and travels of Charlemagne, and how much the pattern of movement may have changed in the course of his reign. Although some of these visits, as in Regensburg in 791-793 are prolonged, the pattern does not make a powerful case for a king ruling by means of his physical presence in the areas under Frankish rule beyond the Rhineland and Moselle region. Only in 787, 800-801 (mostly in Italy) and 791-3, when he spent such an extended period in Bavaria, did Charlemagne apparently not reside in or cross either the MeuseMoselle region (Aachen-Liège down to Metz) or the Rhineland-Main areas (Mainz, Ingelheim, Worms, Frankfurt). In many years his travelling is between and within these regions, even if only for the winter,

\footnotetext{
7 Wolfgang Metz, Zur Erforschung des karolingischen Reichsgutes, Erträge der Forschung 4 (Darmstadt 1971).

${ }^{8}$ R. Hennebicque (R. Le Jan), 'Espaces sauvages et chasses royale dans le Nord de la France', Revue du Nord 62 (1980) pp. 35-57, and E. Ewig, 'Les Ardennes au haut moyen âge', Ancien pays et assemblées d'états 28 (1963) pp. 3-38.
} 
Christmas, and/or Easter. This of course includes the years in which he crosses the Rhineland region in order to reach Saxony.

If the military campaigns are left out of consideration, it would appear that the king travelled mostly within the Frankish heartlands, and that many regions of his kingdom were never honoured by his presence. The implications of this are discussed further below but let us first address the practical matter of the distances and logistics of travelling involved. For this I offer estimates based on the information for motorists supplied by the Netherlands website Routenet.nl (with downloadable maps of all recommended routes). This may give some indication of distances, even if it can tell us nothing about the time absorbed by the journey, the speed of travel, the terrain, the conditions of the roads (ranging from local tracks to the extensive network of old Roman roads, many of which were maintained, at least those close to towns), the journeys Charlemagne took by boat on such major rivers as the Rhine, Moselle and Main rivers (as in 793 to Würzburg ${ }^{9}$ ) instead of overland, or the weather. Still less do we know about any of the detours necessary to find fords and bridges to cross rivers, and the scheduled and, no doubt, unscheduled stops on the way to talk to people, listen to petitions, eat, rest, pray and the like. It should be noted in passing that many of the arterial roads of western Europe still follow the routes of the old Roman roads, so the Routenet.nl suggestions about the distances involved may not be so very wide of the mark. ${ }^{10}$ We can probably assume that Charlemagne himself would have travelled on horseback overland, that there would have been faster riders with the party to carry messages and warn a place of the imminence of the king's arrival, and possibly a slower part of the cavalcade travelling by road with baggage on horses or mules, or in carts, or by water on barges. A conservative estimate might therefore be a speed of thirty kilometres a day. ${ }^{11}$

\footnotetext{
9 Annales Regni Francorum (ARF), Friedrich Kurze, ed. (Hannover 1895, 1909, 1950), p. 92.

10 See the Barrington Atlas of the Greek and Roman World (Princeton 2000), Maps 7, 10-19, 39-45.

${ }^{11}$ Le Jan, 'Espaces sauvages', also uses the computation of thirty kilometres per day. Michael McCormick, 'Pippin III, the embassy of Caliph al Mansur, and the Mediterranean world', in: Die Dynastiewechsel von 751. Vorgeschichte, Legitimationsstrategien und Erinnerung, Matthias Becher and Jörg Jarnut, eds. (Münster 2004) pp. 221-242, based his calculations of travel in the eighth century on information relating to the American civil war and army manoeuvres in the nineteenth century, and calculated similarly, namely, twenty-five miles per day.
} 
In 769, for example, Charlemagne, having reached Fronsac near Bordeaux, then travelled to somewhere beyond the Garonne river to the palace at Worms. From Fronsac to Worms is $1081 \mathrm{~km}$ or 34 days. In 774 one journey was from Pavia to Ingelheim, a distance of $701 \mathrm{~km}$ or about 24 days, but possibly using Worms as a stopping place, which is $46 \mathrm{~km}$ from Ingelheim (one very long day or two shorter ones). In 782, one journey was from Thionville to Paderborn, that is, $423 \mathrm{~km}$ or a fortnight, and in 788 Charlemagne's travels included the $574 \mathrm{~km}$ trip from Regensburg to Aachen (19 days) and in 795 from Aachen to Mainz, that is, $240 \mathrm{~km}$ ( 8 days).

If we follow the route of the round trip recorded in the Royal Frankish annals for 800 and 801 , the estimate is the following:

\begin{tabular}{|c|c|c|}
\hline From Aachen to Boulogne & $372 \mathrm{~km}$ & (13 days) \\
\hline From Boulogne to Rouen & $183 \mathrm{~km}$ & (6 days) \\
\hline From Rouen to Tours & $354 \mathrm{~km}$ & (12 days) \\
\hline From Tours to Orleans & $116 \mathrm{~km}$ & (4 days) \\
\hline From Orleans to Paris & $130 \mathrm{~km}$ & (5 days) \\
\hline From Paris to Aachen & $420 \mathrm{~km}$ & (14 days) \\
\hline From Aachen to Mainz & $40 \mathrm{~km}$ & (8 days) \\
\hline From Mainz to Ivrea & 696 km (via Strasbourg and Basel) & (23 days) \\
\hline From Ivrea to Rome & 678 km (via Florence) & (22 days) \\
\hline From Rome to Spoleto & $134 \mathrm{~km}$ & (5 days) \\
\hline From Spoleto to Ravenna & $237 \mathrm{~km}$ & (8 days) \\
\hline From Ravenna to Pavia & $282 \mathrm{~km}$ & (10 days) \\
\hline From Pavia to Ivrea & $148 \mathrm{~km}$ & (5 days) \\
\hline From Ivrea to Aachen & $894 \mathrm{~km}$ & (30 days) \\
\hline
\end{tabular}

The grand total is $4885 \mathrm{~km}$ which would involve approximately 165 days on the road. I have calculated the average distance between 794 and 804 as over a thousand kilometres per annum. Between 805 and 814, the average is 460 kilometres per annum (only 15 days), including the expedition to Saxony in $810(800 \mathrm{~km})$ and the years 809 and $812-814$ when only hunting trips to the Ardennes, a short distance of about one hundred kilometres from Aachen, are recorded. ${ }^{12}$

It is self-evident that none of these places can be reached from the one before it in a day. It is necessary, therefore, to envisage an entire

\footnotetext{
${ }^{12}$ Le Jan, 'Espaces sauvages', p. 47.
} 
network of stopping places on the way. ${ }^{13}$ For the most part we can only guess at the planning involved in terms of packing and unpacking weapons, clothes and possibly bedding and utensils as well, the supply of fresh mounts en route, giving notice of intended arrival or ensuring sufficient food, drink and firewood for the entourage (whatever its size) and their animals. The Capitulare de villis, a detailed account of the royal estates from the end of the eighth century gives some indication of a system of villae on royal estates kept ready and fully equipped to receive the king, and of the notice of arrival that would be expected, a bit like a system of second homes. ${ }^{14}$ Some places may only have received the king once or twice in the course of his reign, whereas he was very often at others. We have no information about the logistics, though Carlrichard Brühl has discovered a great deal about the means of supplying provisions and hospitality. ${ }^{15}$

Considerable indications of the reasons for Charlemagne's visits to places are provided by the various narrative and documentary sources, though there remain many months of many years unaccounted for. There is often uncertainty about the status of a particular place, whether as a customary resting place, temporary, occasional or unusual stopping place en route to somewhere else, or an established royal residence. ${ }^{16}$ In Italy, for instance, Charlemagne may have stayed in episcopal residences as well as making use of Lombard palaces. In Rome he probably stayed near St Peter's, though one wonders for whom the nice little Carolingian villa was built in the Forum of Nerva at the end of the eighth century. ${ }^{17}$ Occasionally another palace presents itself as very likely, such as Worms for a stay en route between Pavia and Ingelheim. ${ }^{18}$

${ }^{13}$ Gauert, 'Zum Itinerar'.

${ }_{14}$ Capitulare de villis, cc. 38, 42, 65, A. Boretius, ed., Monumenta Germaniae Historica, Capitularia I (Hannover 1883), No. 32, pp. 82-91 at pp. 86-87 and 89.

${ }^{15}$ Carlrichard Brühl, Fodrum, gistum, servitium regis. Studien zu den wirtschaftlichen Grundlagen des Königtums im Frankenreich und in den fränkischen Nachfolgestaaten Deutschland, Frankreich und Italien vom 6. bis zur Mitte des 14. Jarhhunderts, Kölner Historische Abhandlungen 14, 1-2 (Cologne; Graz 1968).

${ }_{16}$ Brühl, Fodrum, gistum, servitium regis, p. 312.

${ }_{17}$ Riccardo Santangeli Valenziani, 'Profanes Bauwesen in Rom um das Jahr 800', in: 799 Kunst und Kultur der Karolingerzeit III. Beiträge zum Katalog der Austellung, Christoph Stiegemann and Matthias Wemhoff, eds. (Mainz 1999) pp. 550-557.

${ }^{18}$ On palaces see Rosamond McKitterick, Charlemagne: The Formation of a European Identity (Cambridge 2008), and eadem, Karl der Große (Darmstadt 2008) and the references there cited. 
A royal residence appears to have been a building or estate that the king owned, and was purpose-built or designated as royal so that only the king lived or stayed there (as distinct from being a guest there). These may have included secular places that he visited as a guest of the local count, or town houses in the civitates or trading centres, such as Bardowick. ${ }^{19}$ It is certainly possible that Charlemagne would have preferred in particular instances to stay with the local bishop. At Rouen, for instance, the bishop appears to have presided over the construction of a new residence early in the ninth century. ${ }^{20}$ It is also a possibility that he could have stayed, if not in his own residence, or that of the local missus or count, then even in some kind of public hospice, with rooms commandeered for the occasion if a monastery's guest house were not within reach. The endowment of monasteries and the number of new buildings to serve the king on the move could presumably have been intended for the royal agents as well. The Capitulare de villis also related the organization of the royal estates and houses for receiving the king to the movements of the army. The produce of the estates was one of the things that would be loaded onto carts for the campaigns. ${ }^{21}$

The capitulary and narrative references to assemblies also indicate that meetings of secular and clerical magnates were frequent. In no source is there any reference to billeting on the local populace and it is likely that temporary 'tent-cities' sprang up. The advantage of camps would have been that everyone was there with horses and carts to hand and ready to move very quickly if necessary. Open spaces for camps also offered a major extension of the space within which the king moved.

${ }^{19}$ Gauert, 'Zum Itinerar', following up Carlrichard Brühl, 'Königspfalz und Bischofstadt in fränkischer Zeit', Rheinische Vierteljahresblätter 23 (1958), also said the inner organization, the function of these palaces in the itinerary, and their relationship to royal estates, royal forests and to trade and commerce should be investigated. Some discussion since 1965 has undoubtedly pursued these questions. See, for example, Inge Lyse Hansen and Chris Wickham, eds., The Long Eighth Century: Production, Distribution and Demand, The Transformation of the Roman World 11 (Leiden 2000).

${ }^{20}$ Jacques Le Maho, 'Die erzbischöfliche Pfalz von Rouen (Frankreich) zu Beginn des 9. Jahrhunderts, in: Splendor palatii. Neue Forschungen zu Paderborn und anderen Pfalzen der Karolingerzeit, Lutz Fenske, Jörg Jarnut and Matthias Wemhoff, eds., Deutsche Königspfalzen. Beiträge $z u$ ihrer historischen und archäologischen Erforschung 5 (Veröffentlichungen des Max-Planck-Instituts für Geschichte 11/5) (Göttingen 2001) pp. 193-210.

${ }^{21}$ Capitulare de villis c. 30, MGH Cap. I, No. 32, p. 85 and see also c. 64 and 68, ibid., p. 89. 
The places apparently visited, moreover, reflect a network of social and political connections that it is sometimes possible to document in greater detail from other sources. This suggests that the distribution of royal residences across the empire needs to be seen as functioning within this network and was far from being higgledy-piggledy. ${ }^{22}$ Yet the palaces that have been identified were for the most part too far apart for us to envisage them as the only stopping place for the ruler or any of his officials. What has to be surmised, therefore, is a combination of halts by the side of the road, using tents or rough shelters, the possibly frequent use of the guest houses of abbeys or bishoprics, and use of royal estates and royal residences or palaces en route as indicated by the provisions of the Capitulare de villis. Although in some instances the route taken-by ship down the Rhine, crossing the Alps by the Great St Bernard pass, by land from Boulogne to Tours via St Riquier, Rouen and Orleans (probably on old Roman roads) is known, for many of these journeys we know only the destinations (though the exact location cannot always be identified), rather than details about the means of travel or routes followed.

If much of the itinerary of Charlemagne is to be attributed to war and the consolidation of conquest as a military leader on the one hand, and to religious devotion and the observance of Christian festivals on the other, ${ }^{23}$ it would suggest that we need to look more closely at the remainder of the evidence to establish how much, in addition to the information about assemblies, can be assigned to governmental and administrative action.

There are many aspects of Carolingian royal government and 'the court' which I cannot explore in detail here. These include the structure of the royal household, the practical evidence for its designation as a court, the stylized glimpses of a court setting offered in poems by Alcuin, Modoin, Theodulf and Angilbert in the late eighth and early ninth centuries, the religious role of the palace chapel, and the role of Aachen alongside many other administrative and ceremonial centres in Charlemagne's topography of power. Pippin III and his son

\footnotetext{
${ }^{22}$ I here differ from Stuart Airlie, 'The Palace of Memory. The Carolingian Court as Political Centre', in: Courts and Regions in Medieval Europe, Sarah Rees Jones, Richard Marks and Alaister J. Minnis, eds. (York; Woodbridge 2000) pp. 1-20.

${ }^{23}$ For fuller details on the sacred topography of Charlemagne's kingdom and the organisation of his court, as well as other aspects alluded to in the next two paragraphs, but not considered here, see the detailed discussion in McKitterick, Charlemagne.
} 
Charlemagne had undoubtedly shifted the focus of political power within Austrasia, centred on Aachen, Liège, Nijmegen and Cologne, but new residences were established in the Rhineland and Saxony at Frankfurt, Paderborn and Ingelheim. Many former Merovingian and Lombard royal residences were also taken over by Charlemagne. ${ }^{24} \mathrm{I}$ propose instead to tackle one particular hitherto rock-solid category of evidence supporting the royal itinerary, namely, the redaction of royal charters and their implications. These prove to be vital evidence in particular for the extent to which the Frankish court of Charlemagne at any stage during his reign was actually itinerant in the technical sense or functioned as a centre of communication. So, let us now turn to the question of charters and the royal itinerary.

Royal diplomas record royal business. Charlemagne's charters grant lands, royal protection, immunity, the revenue from tolls, and free abbatial election to different places. They record the settling of property disputes and the return of confiscated land. This charter evidence has appeared to scholars in the past to provide an exact and uncontestable source of information about the king's whereabouts with a simple equation: where the charter was drawn up, there was the king and his court. Unfortunately, it is not as simple as that.

Let us look at the year 775 to highlight the problems, though it needs to be registered that 775 was the year from which the greatest number of charters, twenty-two, survives in the whole of Charlemagne's reign. Between 5th January and 26th June there is a series of charters drawn up ad carisiaco palatii publici (sic), that is, at Quierzy. The dates given are 5th and 22nd January; 14 March, 4th April, 24th and 29th May, 9th and 26th June. During these six months one charter was also drawn up at St Denis (actum in monasterio) on 25th February and two at Thionville on 3rd and 10th May (apud theodonem). For the rest of the year charters are recorded at Düren 28th July, 3rd August, 25th October, and November. Thionville is recorded again in November, and the last document for the year is at Sélestat in December. The Quierzy charters record grants to Hersfeld in Thuringia, Metz, St Denis, Farfa and Honau. The St Denis documents are grants for St Denis. The Thionville documents in the early part of the year make grants to

\footnotetext{
${ }^{24}$ Günther Binding, Deutsche Königspfalzen von Karl dem Grossen bis Friedrich II (765-1240) (Darmstadt 1996).
} 
Flavigny and St Martin at Tours and in the latter part to Salonne and Prüm. The Sélestat charter records the settling of a dispute between Honau and Corbie. In the case of St Denis in February, Düren in July and Sélestat in December, the transactions are actually recorded as being drawn up or enacted at a meeting where the king was to administer justice in the place concerned. The Quierzy documents record business concerning very distant places in Germany and Italy as well as closer to Quierzy at St Denis. The two Thionville charters concern places in Burgundy and the Loire region.

Let us look at this sequence again with the distances between the various places in mind. Charlemagne spent Christmas 774 at Quierzy according to the Annales regni francorum and grants were drawn up at Quierzy in favour of Hersfeld and Metz, dated 5th and 22nd January $775 .{ }^{25}$ Next, at St Denis, $109.8 \mathrm{~km}$ or 3 days distant via Noyon and Compiègne, a charter dated 25th February (original, written by Wigbald ad vicem Hitherii) recorded land granted to St Denis. ${ }^{26}$ Then back again at Quierzy, grants were made to St Denis on 14th March of freedom from tolls and immunity. ${ }^{27}$ In 775, Easter fell on March 26th which, according to the Annales regni francorum, Charlemagne spent at Quierzy. A grant of immunity redacted at Quierzy by Wigbald was made to Murbach on 4th April. The king then supposedly moved on to Thionville, a distance of $303.5 \mathrm{~km}$ or ten-days' journey, possibly via Reims, Chalons and Metz. At Thionville, freedom from tolls was granted to Flavigny on 3rd May, and confirmation of the possession of estates to St Martin of Tours on 10th May. These charters were written by Rado but survive only in later copies. $^{28}$ Thereafter, the king apparently returned, another ten-day journey of $303 \mathrm{~km}$ to Quierzy, according to the charters of Quierzy of 24th May, 29th May, 9th June, and 26th June granting freedom of election to Farfa, confirming possessions of Honau, and of

${ }^{25}$ E. Mühlbacher, ed., Diplomatum karolinorum Tomus 1. Pippini, Carlomanni, Caroli Magni Diplomata, Monumenta Germaniae Historica Diplomata I (Hannover 1906; reprint Munich 1979) (hereafter DKar. I), Nos. 89 and 90 (both survive in the original and were written by Hitherius, and 91 (Gorze cartulary copy of s.XII; no scribe recorded).

${ }^{26}$ DKar. I, No. 92.

${ }^{27}$ DKar. I, No. 93. (This survives in a s.XII/XII cartulary), and 94 (an original, written by Wigbald ad vicem Hitherii).

${ }^{28}$ DKar. I, Nos. 96 and 97. 
earlier alienated land to St Denis. All four of these charters were written by Wigbald advicem Hitherii but only the grant for St Denis survives in the original. ${ }^{29}$ The Annales regni francorum record an assembly of the army at Düren before setting out for a summer campaign in Saxony. From Quierzy to Düren (between Aachen and Cologne) is $361 \mathrm{~km}$ or twelve days. Thereafter the Annales regni francorum records the campaigns in the Weser river region, at least ten days journey away, the capture of Syburg and the rebuilding of the Eresburg. Charters are also recorded at Düren on 28th July, 3rd August, 25th October, and November. ${ }^{30}$ The grants in July, August and October were to Hersfeld and that in November was to Fulda. Those include one original and one copy each of charters written by Rado and Wigbald, both ad vicem Hitherii. The charter of 28th July, however, was written by Theudegarius and records a settlement of a dispute between Fulrad of St Denis and Erchanrad bishop of Paris, presided over by Charlemagne, and in the presence of many fideles, including Anselm, count of the palace. ${ }^{31}$ From Düren the charter record takes us $267 \mathrm{~km}$ or nine days journey to Thionville and there Rado ad vicem Hitherii wrote a grant of land to Salonne which survives in the original in the St Denis archive. ${ }^{32}$ The Prüm cartulary records two further grants drawn up at Thionville in November, granting immunity and confirming Pippin III's gifts to Prüm. ${ }^{33}$ Lastly, at Sélestat, where Charlemagne spent Christmas 785 (according to the Annales regni francorum) a dispute was again recorded by Theudegarius in the presence of Anselm, count of the palace, and survives only in early modern copies. ${ }^{34}$ With the record of the dispute between Fulrad of St Denis and Bishop Ercanrad of Paris, this is one of the very few to record the king's presence in the charter itself. It explains that the king was in his palace in Sélestat in order to listen to cases and administer justice. ${ }^{35}$

${ }^{29}$ DKar. I, Nos. 98-101.

30 DKar. I, Nos. 102-105.

${ }^{31}$ DKar. I, No. 102.

${ }^{32}$ DKar. I, No. 107.

${ }^{33}$ DKar. I, Nos. 108-109.

${ }^{34}$ DKar. I, No. 110.

${ }^{35}$ The formula is standard: For example, in D.Kar. I, No. 102, the formula is as follows: cum nos in dei nomen Duria villa in palacio nostro ad universorum causas audiendum vel recta iudicia termenandum resederimus. In DKar. I, No. 110, it is: Cum nos in dei nomine sclatistati villa in palacio nostro ad universorum causas audiens dum vel recta iudicia terminandum resideremus. 
What does even this small example tell us about charter redaction in relation to the king's movements? The grants are a combination of royal decisions to exert patronage, and the consequence of petitions, requests for royal favour or the judicial intervention of the ruler in meetings possibly organized by the count of the palace to settle disputes. In the case of Quierzy, the Royal Frankish annals tell us that the king spent Christmas and Easter at Quierzy, so we surmise that he was there for winter and early spring before he is then recorded setting out for the assembly of the host at Düren, also a royal palace, and the campaign in Saxony. If we were to accept the charter record literally then we would have to add in the $606-\mathrm{km}$ round trip between Quierzy and Thionville in April and May. If we accept all the charters of Quierzy of 775 as an indication of the king's presence then the campaign in Saxony did not start until July. The charters issued from Düren are dated June, July, August and October which would require Charlemagne to be returning from the Weser river campaign, at least a ten-day journey, at regular intervals before finally reaching the palace of Thionville, in order to grant land to Salonne and Prüm, and Sélestat in December to judge the dispute between Honau and Corbie.

Rather than accepting the charters as an indication of the physical presence of the king, therefore, it is much more likely that we are seeing in many, if not most, instances the activities of the king's officials, with notaries and the scribes working for them sent out or based on site to record transactions in the name of the king, possibly accompanied by the count of the palace. The itinerary for the year is much more likely to have been simply from Quierzy to Düren to Saxony, back to Thionville and then on to Sélestat for Christmas (confirmed by the Annales regni francorum) before Charlemagne set out for Italy the following year, with none of the zig-zagging back and forth that the charters have hitherto been thought to record.

It would also suggest that we should take the ad vicem note in the charters more seriously as an indication of a notary acting as a deputy for the cancellarius when the latter was elsewhere. The indications are that Wigbald did indeed go to St Denis and remain at Quierzy to oversee transactions in the spring, and that both Rado and Wigbald acted for Hitherius at Düren during the Saxon campaigns of the summer and autumn.

Thus there would appear to have been a system of itinerant scribes and notaries responsible for the correct redaction and the authentica- 
tion of charters, accompanying officials for the king. The wide range of places where transactions were recorded suggests written petitions being dealt with from one of the palaces where the king has been resident at some stage, and also transactions drawn up as a result of a hearing elsewhere which had indeed been in the presence of the king. One of these is the charter of 6th December 777. It survives in the original written by Rado at Aachen, granting a privilege for the church of Salonne near St Denis, as agreed at the synod of Paderborn in the preceding summer. The meeting in Paderborn, moreover, is confirmed by the Annales regni francorum; these recorded the king holding a synodum publicum at Paderborn in spring. ${ }^{36}$

That the sequence of charters for 775 and the charter of 777 are not isolated instances is clear from other charters issued in Charlemagne's name. Use of notaries acting on behalf of the king is also indicated, for example, by the movements for 770-773. According to the various annal accounts, the king was present at an assembly in Worms in 770 with Christmas at Mainz and Herstal in the spring of 771, possibly on the way to the assembly in Valenciennes, with Christmas at Attigny in 771 and then at Herstal again for Easter in $772 .{ }^{37}$ The settlement of the dispute at Longlier in 771 is in keeping with the king's movements recorded in the narrative sources, not least the meeting at Corbeny with Carloman's followers after Carloman's death. ${ }^{38}$ It is not impossible that Charlemagne was present at Reims for the burial of his brother, for Reims, Samoussy, Attigny and Corbeny are all within one- or two-days journey from each other along the Roman road from Reims to Saint-Quentin nearby. ${ }^{39}$ The text of the Herstal charter in 772 fits the narrative record of the itinerary, for it describes the settling of a dispute about Lorsch possessions. ${ }^{40}$

Acceptance of other charters in the period $770-773$ as indications of the king's presence, however, would again involve Charlemagne in a great deal of to-ing and fro-ing, with journeys to Worms in 771

${ }^{36}$ DKar. I, No. 118. and $A R F$ 777, ed. Kurze, p. 48.

${ }_{37}$ ARF 770, 771, ed. Kurze, pp. 80 and 82.

38 DKar. I, No. 63.

39 On Carloman's burial see Annales mettenses priores 771, B. De Simson, ed. (Hannover 1905) p. 57. Samoussy to Reims is $67 \mathrm{~km}$ (2 days) and to Corbeny less than a day $(24 \mathrm{~km})$. Corbeny to Attigny is $68 \mathrm{~km}$ or two days. From the assembly at Valenciennes down to Reims would take five or six days $(172 \mathrm{~km})$.

${ }^{40}$ DKar. I, No. 65. 
and then over to Quierzy and to Longlier en route to Geneva in 773; these would have been major detours. In October 778, moreover, at Goddingas villa (Godinne) south-west of Liège, a charter to confirm St Denis's immunity was drawn up by Giltbertus ad vicem Radonis at a point when Charlemagne would still have been in Saxony, unless he took a circuitous route back from Saxony in the early autumn in order to arrive at Herstal, west of Aachen, for Christmas. ${ }^{41}$ In the following year many annals record that Charlemagne retired to Worms for the winter after the Saxon campaigns, yet there is also a charter in favour of Hersfeld drawn up at Herstal in September, by Wigbald ad vicem Radonis, many miles from either the Saxon strongholds or the palace at Worms. ${ }^{42}$ When returning from Italy in 781 to spend Christmas at Quierzy, the king travelled via Worms. He may also have gone to Herstal again on the way, to be there when an exchange of land between Abbess Eufemia of St Peter's in Metz and Fulrad, abbot of St Denis was written by one scribe and recognized by Widolaicus ad vicem Radonis. But the difference in the journeys would have been approximately $112 \mathrm{~km}$, that is, four days on the road..$^{43}$ Given the extraordinary distances traversed to Saxony or to Rome, such a detour may be entirely reasonable, but it seems less likely than the charter drawn up by the anonymous notary being sent to Herstal for recognition, or the notary visiting Herstal to get the job done in the king's absence. This is especially the case if the beneficiaries and the lands granted, themselves far removed geographically from the place of redaction, are taken into account.

Some places where charters were drawn up may well have been on the route taken and could have acted as feasible stopping places. Thus in returning to Worms from dealing with the revolt in Friuli in 776, the king may have chosen to go via Vicenza and Ivrea from which we have two charters dated 9th and 16th June on his way to cross the Alps by either Mont Cenis or, more likely, the Great St Bernard pass. Vicenza and Ivrea are approximately ten days $(314 \mathrm{~km})$ apart, though the distance might have been covered faster. Similarly, in 782,

${ }^{41}$ DKar. I, No. 120. This survives in the original.

42 DKar. I, No. 126; the editor, Mühlbacher, acknowledged this but thought there might be a mistake in the dating, p. 176.

${ }_{43}$ DKar. I, No. 136: see Alain Stoclet, Autour de Fulrad de Saint-Denis (v. 710-784) (Geneva; Paris 1993) and ChLA XVI, No. 628, Paris, Archives nationales K7, No. 8. Folradus abbas is also written in tironian notes. 
the grant recognized by Wigbald at Gondreville, if the king has to be presumed to be present, would have involved doubling back to Thionville and an extra six-days' journey at the end of the Saxon campaign that year. ${ }^{44} 786$ was a year that Charlemagne, according to all our other evidence, did not get as far north as Aachen, but Ercanbald ad vicem radonis drew up a charter there. ${ }^{45}$

Occasionally there are direct correlations between the places enjoying the king's presence in the narrative sources and the charter or capitulary record, as in the visit to Rome in 787, the Christmas and Easter 787-788 spent at Ingelheim and the assembly there on 28th March 788. There is a cluster of charters from Mainz, Worms and Kostheim during the year Charlemagne spent there in $790,{ }^{46}$ and his sojourn in Regensburg in 792 is also reflected in grants for Aniane and Aquileia drawn up there. ${ }^{47}$ Conversely, if we look at the last twenty years of Charlemagne's reign in relation both to the places of charter redaction and to the summary above of the winters spent in Aachen or elsewhere, a similar pattern emerges. From the period from 794 to 803, with no charters surviving at all for the years 796 and 798, of twentyseven charters, one third were redacted at Aachen. In the years 803, with no charters at all from 804 and 805 , and a total of sixteen surviving charters, only four were produced somewhere other than Aachen. Seven of the remainder, dated at Aachen, were written between 811 and 813 . On the charter evidence at least, therefore, it is only during the last three years of the reign that charter scribes and the now elderly king completely coincide in a prolonged residence at Aachen.

Such details are suggestive, for they undermine the solidity of assumptions about the charter evidence hitherto. Yet three further factors need to be taken into account, namely the uneven pattern of Charlemagne's charter survival, the changing pattern of charter redaction over time, and our lacunose knowledge of the royal writing office itself. These in their turn, moreover, throw further light on the functioning of the royal household.

${ }^{44}$ DKar. I, No. 147: immunity granted to Modena.

${ }^{45}$ DKar. I, No. 152, a grant of immunity and freedom of election to the abbacy for the monastery of Ansbach. This led Mühlbacher to doubt that the charter had been drawn up in Aachen.

${ }^{46}$ DKar. I, Nos. 163-167, but No. 167 for Salzburg may have been written somewhere else.

${ }^{47}$ DKar. I, Nos. 173-175. 
We have an imperfect and probably distorted impression in terms both of the geographical and chronological distribution of the charters, and of the relative intensity of charter redaction or final approval. It is dependent on the efficiency of certain archives with the chance of their documents surviving to the present day, and on the orchestration of royal favour for a particular institution. Neither can be assumed to be evenly distributed across the entire reign. ${ }^{48}$

Discussion of Charlemagne's charters hitherto has also not taken sufficiently into account either the sphere of operations of the notaries or the implications of what are known as the ad vicem and recognovi notes, supplied by the notaries, at the end of the charters. As well as the script, the formulae used, the details of what the charter was granting or confirming, and the information about where the charter was drawn up and signed, Carolingian royal diplomas provide the portion of the charter text known as the eschatocol, with the signum and name of the ruler, his monogramme and the name of the notary responsible who provides the recognovi note, that is, the official confirmation of the charter. He adds another chrismon and subscription symbol or beehive, beside which in notarial shorthand or tironian notes, the details of the recognovi note are often repeated, sometimes with additional indications of who may have requested that the document be drawn up. In a typical charter, such as that in which Charlemagne granted villas in the regions of Paris and Meaux to St Denis, there is the Signum Caroli gloriosissimi regis. Then the notary's formal recognition of the charter follows: Uuigbaldus ad vicem Hitherii recognovi and in Tironian notes is added uuigbaldus advicem Hitherii recognovi et subscripsi (that is, [I] Wigbald witnessed/validated and signed [this charter] on behalf of Hitherius). ${ }^{49}$

For the purposes of mapping both the itinerary and the activities of the scribes and notaries, it is the eschatocol and date clause which

${ }^{48}$ Daniel Sonzogni, 'Le chartrier de l'abbaye de Saint-Denis en France au haut moyen âge. Essai de reconstituion', Pecia. Resources en médiévistique 3 (2003) pp. 9-210. See also Heinrich Fichtenau, 'Archive der Karolingerzeit', in: idem, Beiträge zur Mediävistik, Ausgewählte Aufsätze 2 Urkundenforschung (Stuttgart 1977) pp. 115125, and Benoît-Michel Tock, 'La diplomatique francaise du haut moyen âge, vue à travers les originaux', in: La Diplomatique française du Haut Moyen Âge: inventaire des chartes originales antérieures à 1121 conservées en France, M. Courtois and M.J. Gasse-Grandjean, eds., ARTEM 4 (Turnhout 2001) pp. 54-60.

${ }^{49}$ DKar. I, No. 92, and Paris, Archives Nationales K6, No. 4; facsimile in: Hartmut Atsma and Jean Vezin, eds., Chartae Latinae Antiquiores XVIII, No. 615 (Dietikon 1990). 
are crucial. It needs to be stressed, however, that any chancery-trained notary, or even a scribe supplied by the recipient, could actually write the charter, but it is one of the royal notaries on his own or on the chief notary's behalf who supplies the recognovi note and subscriptio and who arranges for the seal to be attached.

The charter evidence thus provides information about the 'chancery' personnel, but the latter's relation to the royal household and to royal government, and whether the charters actually witness to the king's presence and the royal itinerary, still needs to be explored.

It may be most helpful, therefore, to consider the activities of the men who took responsibility for the production of the king's charters, and on occasion even wrote them themselves rather than relying on anonymous underlings. These can be reconstructed in chronological order of the chief notary and his named assistants. By convention the chief notary is known as the cancellarius though this term is never used by those supplying the recognovi notes and the subscriptiones in the royal diplomas of Charlemagne.

Hitherius was the head of the notaries under Pippin III and continued in this role in the early years of Charlemagne's reign. His place was taken in due course by Rado, who had himself served as a notary under Hitherius, and then Ercambald who in his turn had served under Rado. Hitherius was responsible for charters between 768 and 775 enacted at Aachen, Orville, Herstal, Valenciennes, Blanzy, ${ }^{50}$ Brumath, ${ }^{51}$ Longlier, Quierzy (773 and 775) ${ }^{52}$ and Pavia. Notaries who acted on his behalf were Wigbald and Rado. ${ }^{53}$ Wigbald was active between 774 and 782. He was responsible for charters at Düren, Samoussy,

${ }^{50}$ ChLA XIX, No. 672, Colmar, Archives départmentales du haut-Rhin, fonds de Murbach 10G generalia 3, no. 2, and DKar. I, No. 64, in favour of Murbach.

${ }^{51}$ St Gallen, Stiftsarchiv E.E.5.B.44, DKar. I, No 69, in favour of Arnald priest, and kept at St Gallen. For a facsimile see Albert Bruckner, ed., Diplomata karolinorum 1 (Basel 1974) Tafel 3.

${ }^{52}$ ChLA XII, nos. 533 and 534, Marburg Hessisches Staatsarchiv Kaiserurkunden Hersfeld 775 I 5 and 775 I 5 (redacted at Quierzy) DKar. I, Nos. 89 and 90 in favour of Hersfeld.

${ }_{53}$ Cited ad vicem Hitherii by Rado (772) at Herstal, $774 \times 6$ at Worms, Düren, Verberie, $775 \times 2$ at Thionville and Düren, and one at Vicenza by Wigbald (776). 
St Denis, Quierzy, ${ }^{54}$ Vicenza, Herstal ${ }^{55}$ Pavia, Cispliaco(?), Hersfeld ${ }^{56}$ and Gondreville. Wigbald served under Hitherius (to 776) and Rado (777-782), but the latter had done a stint as an under-notary between 772 and 783 before heading the writing office. Rado subscribed charters at Thionville, ${ }^{57}$ Herstal,${ }^{58}$ Worms,${ }^{59}$ Düren, ${ }^{60}$ Verberie,${ }^{61}$ Patris Giagio (possibly Patri Gagio in Lombardy), Aachen, ${ }^{62}$ Quierzy, and an unidentified place..$^{63}$ At the first five of these Rado provided the recognovi notes ad vicem Hitherii.

As head of the writing office, Rado had a number of notaries working for him between 777 and 799 in addition to Wigbald. Those whose names we know include Gislebertus/Giltbertus, ${ }^{64}$ Optatus, ${ }^{65}$

${ }^{54}$ Of the eight charters Wigbald subscribed at Quierzy, three survive in the original: DKar. I, Nos. 94, 95 and 101. See ChLA XV, Nos. 616 and 617 (Paris, Archives nationales K6 5/1 and 5/2), ChLA XIX (Colmar, Archives départmentales du haut-Rhin, fonds de Murbach 10G generalia 3 no. 3) and ChLA XCV, No. 618 (Paris, Archives Nationales K6, No. 6) DKar. I, No. 101. Of these, two are from the St Denis archive in Paris and one from Murbach, now in Colmar.

55 Of the four enacted at Herstal two survive in the original: DKar. I, Nos. 116 and 123 for Fulda and St Marcel, Chalon respectively. See ChLA XII, 539 (Munich Bayerische Hauptstaatsarchiv Kaiserselekt I) and ChLA VII, No. 651 (Paris, BnF Coll. Bourgogne 75, no. 4, CL 8837).

56 DKar. I 144, for Hersfeld. See ChLA XII, No. 538 (Marburg, Hessisches Staatsarchiv Kaiserurkunden Hersfeld 782 VII 28).

${ }^{57}$ Of the four at Thionville one original, DKar. I, No. 107 for Salonne preserved in the St Denis archive, is extant. See ChLA XVI, no. 620 (Paris, Archives Nationales K6 No. 8) and 799 Kunst und Kultur, I, No. III.3. pp. 127-8. The scribe's name is recorded in tironian notes as Adarulfus, one of Fulrad of St Denis's notaries.

58 Three, including one original, DKar. I, No. 121 for Hersfeld. See ChLA XII, no. 537 (Marburg, Hessisches Staatsarchivv, Kaiserurkunden Hersfeld 779. III.13).

59 One of the two survives in the original, DKar. I, No. 130 in St Gallen. (St Gallen, Stiftsarchiv A.4.A.1, facsimile in Bruckner, Diplomata karolinorum, Tafel 4.

${ }^{60}$ Two of the four survive in the original. The St Denis archive had two copies, one subscribed by Rado and the other by Wigbald: DKar. I, Nos. 84 and 103. The former is for St Denis and the latter for Hersfeld. See ChLA XVI 613 and 614 (Paris, Archives Nationales K6 no. 5/1 and K6 no. 5/2) and ChLA XII, 535 (Marburg, Hessisches Staatsarchiv Kaiserurkunden Hersfeld 775.VIII.3).

${ }^{61}$ This survives in the original, DKar. I, No. 88, for St Denis. This is a tractoria and lacks a royal subscriptio or date clause ChLA XVI, No. 621 dated 774-776 by Atsma and Vezin (Paris, Archives Nationales K6 No. 9).

62 DKar. I, No. 118 for Salonne. See ChLA XIX, No. 679 (Nancy, Archives Départmentales Meurthe-et-Moselle G. 468).

${ }^{63}$ DKar. I, No. 83, for St Denis, preserved in the St Denis archive.

${ }^{64} \mathrm{Gi}[\mathrm{s}] \mathrm{l}[\mathrm{e}]$ bertus Writes charters from 778-781, 795. in St Denis: DKar. I, No. 120. See ChLA XVI, 620 (Paris, Archives Nationales K7, No. 3), and in Worms (x2), Lippspringe, Aachen, and Pavia: DKar. I, Nos. 128, 129, 131, 133, 151, 179.

${ }_{65}$ Optatus wrote charters in 779, 788 in Herstal and Regensburg: DKar. I, Nos. 122 and 162. See the Herstal original in Regensburg ChLA XVI, No. 625 (Paris, Archives Nationales K7, No. 2) the other survives in a s. XIII Salzburg cartulary. 
Widolaicus, ${ }^{66}$ Iacob $^{67}$ and Gudulfus. ${ }^{68}$ They subscribed charters at the palaces of Herstal, Worms, Hersfeld, Pavia, Cispliaco, Capua, Rome, and Regensburg. In addition there was Ercambald who succeeded Rado as head notary. For Rado, Ercambald provided the recognovi note and subscriptio in charters between 777 and 797 at Regensburg, Thionville, and Aachen, as well as in the cluster of palaces on the Rhine at Worms, ${ }^{69}$ Ingelheim, Mainz, Frankfurt, and Kostheim. His own charters at Aachen in 797 include one for which Maginardus acted as the ambasciator and one written by Genesius for which Ercambald supplied the recognitio. ${ }^{70}$

From 799 to 812, Ercambald had notaries under him, including not only Genesius, ${ }^{71}$ but also Amalbertus ${ }^{72}$ Hagdingus, ${ }^{73}$ Aldricus, ${ }^{74}$ Altfredus, ${ }^{75}$ Blado, ${ }^{76}$ Ibbo, ${ }^{77}$ Suavis, ${ }^{78}$ and Gilbertus. ${ }^{79}$ Apart from the

66 Widolaicus wrote charters in 781, 794 in Herstal: DKar. I, no. 136, see ChLA XVI, No. 628 (Paris, Archives Nationales K7, no. 8/1), as well as Quierzy x 2 and Frankfurt.

67 Iacob wrote from 787-792 in Capua, Rome, Worms, Regensburg.

68 Gidulfus wrote one charter in 790 at an unnamed place (no. 168).

${ }^{69}$ Of the two charters written at Worms one is original: DKar. I, No. 150 in favour of Arezzo ChLA XXV, No. 797 (Arezzo, Archivio Capitolare canonica, 783 ottobre).

${ }^{70}$ DKar. I nos 181 and 183. See also ChLA XVI, no. 637 (Paris, Archives Nationales K7, No. 15). Maginardus is probably the chaplain Maginarius, abbot of St Denis.

${ }^{71}$ Genesius wrote from 799-802 at Aachen, St Martin at Tours, Rome, the Reno river, Schweigen. The last named, in Hersfeld's favour, DKar. I, No. 198 survives in the original in the Marburg archive.

72 Amalabert wrote charters from 799 and 806 in Thionville, and Aachen in 799. Amalbertus also wrote ad vicem Ercambaldi at an unnamed place, in a charter for Lagrasse near Narbonne: D.Kar. I, No. 189. See ChLA XVIII, no. 667 (Carcassone, Archives Départmentales de l'Aude, Serie H.11, No. 1).

73 Hadingus's charter was dated at Salz and granted Grado immunity: DKar. I, No. 200.

74 Aldricus wrote one charter in 807 in Ingelheim, DKar. I, no. 206, which survives in the original. It records an exchange between Bishop Agilward of Würzburg and Count Audulf, and was also confirmed by the chaplain Hildebold.

${ }^{75}$ Altfredus wrote a charter at Aachen in 808, DKar. I, No. 207, in favour of Piacenza.

${ }^{76}$ Blado's charter written at Aachen survives in the original, DKar I, No. 208, in Modena. It confirmed Lantreicus (later altered to read Manfred) of Reggio, who had been a hostage in Francia, in possession of lands returned to him.

77 Ibbo's two charters were copied at Aachen and Verden respectively 809 and 810, and the latter, DKar. I, No. 210, in favour of the monastery of Ebersheim, survives in the original in the Municipal archive in Sélestat.

78 Suavis's two charters are from Aachen, DKar I, No. 213, an original confirming Count Bennit's ownership of land that had once belonged to his father Amalung a Saxon), see 799 Kunst und Kultur, 1, VI.5, pp. 328-9 (Münster, Nordrhein-Westfälisches Staatsarchiv, Kaiserurkunde 1,813), and an undated charter in an unidentified place in favour of Fulda.

${ }^{79}$ Gilbert's sole charter was written at Aachen: DKar. I, No. 217. 
five subscribed by Genesius's hand, and three by Amalbertis, the others were responsible for only one or two charters each and the places of redaction, apart from Aachen itself were Thionville, Ingelheim, St Martin's Tours, Rome, and a place on the Reno river near Bologna.

If these notaries are plotted on a map it becomes clear that there are different spheres and concentrations of activity as well as areasAlemannia, Aquitaine, Brittany, Saxony, Septimania and most of Bavaria and Italy - for which we have only one or two, or even no palaces recorded as places where charters were enacted, although the gifts and grants of privileges to religious institutions and to lay individuals by Charlemagne extended throughout the empire. ${ }^{80}$ The period when Hitherius and Rado presided over the notaries before 782-3 was one in which there were many charters drawn up in the palaces of west Francia, especially Quierzy, as well as outlying places such as Regensburg, Lippspringe, and Rome. Ercambald's period of office on the other hand, from 783 onwards, sees a greater concentration of charters enacted in the Rhine-Main-Moselle region and Aachen, again with outlying charters dated at Verden, Salz, Regensburg, Tours, Rome and near Bologna. It is Genesius who is responsible for the range of places from Tours to Rome. It seems likely that it was he, perhaps with some other scribes as assistants, who went to Rome as Charlemagne's secretary in 800-801, and Hadingus who accompanied the king to Salz where Charlemagne received envoys from Byzantium on his way to Bavaria. ${ }^{81}$ The notary Ibbo appears to have gone with the king on his expedition to Saxony and Verden in $810 .{ }^{82}$

There are instances in the earlier years of local scribes of charters, or scribes writing ad vicem a royal notary, that is, on behalf of a royal notary, who do not themselves seem to have been palace notaries. Two charters granting immunity and fishing and other rights respectively to Lorsch in response to requests, and drawn up at Thionville and Herstal in 772 and 777, were given the recognovi note ad vicem Liutbert (Liudberd) by Rado, which may indicate a copy had been sent to the palace to be authenticated. ${ }^{83}$ The charters also indicate

\footnotetext{
${ }^{80}$ See the maps of endowed institutions in Prinz, $K d G$ I, p. 488.

${ }^{81}$ Compare ARF 803, ed. Kurze, p. 118 and Annales mettenses priores 803, ed. Simson, pp. 89-90.

82 D.Kar. I, No. 210 and see Annales sancti Amandi and Chronicle of Moissac, G.H. Pertz, ed., MGH SS I, pp. 14 and 309.

${ }^{83}$ D.Kar. I, Nos. 67 and 114.
} 
variable documentary practice. The reports of the settlement of disputes were presented in a different style, and the notary responsible was not among the usual group of officials. Instead, he was associated with the count of the palace responsible for the record of the decisions reached ${ }^{84} \mathrm{~A}$ few of these distinctive charters survive from the reign of Charlemagne. They incorporate explicit statements about the proceedings having been conducted in the king's hearing when he was in his palace in order to listen to cases and administer justice. The groups gathered at these hearings are mentioned, such as counts and fideles listed by name, ${ }^{85}$ or the 'bishops, abbots, dukes, counts, gastalds and the rest of our faithful subjects' ${ }^{86}$ These charters are invaluable documents in affording rare glimpses of the king's judicial hearings in the course of his travels and in the presence of the disputants, witnesses, counts, scabini, fideles, and the notary, all of whom attended these hearings in the king's presence.

The charters, therefore, reflect a network of palace notaries, possibly distributed among the various royal palaces, or who at least journeyed out from a base to serve a particular region. Notaries may have had a great deal of responsibility and freedom of action, though the fact that the documents are drawn up in the king's name would imply royal approval, if not initiative. Further, the charter evidence only occasionally corroborates the presence of the king; royal diplomas reflect the conduct of royal business but are of limited value in reconstructing the royal itinerary. A great deal of day-to-day administration in the name of the king was carried out across the kingdom in the various palaces in the king's absence, even if some of these notaries actually appear to have accompanied the king himself. ${ }^{87}$

\footnotetext{
${ }^{84}$ These scribes are generally known as Gerichtsschreiber. See Bautier, 'La chancellerie royale', and R. Hübner, 'Gerichtsurkunden der fränkischen Zeit. I Die Gerichtsurkunden aus Deutschland und Frankreich bis zum Jahre 1000', Zeitschrift der Savigny Stiftung für Rechtsgeschichte, Germanistische Abteilung 12 (1891) pp. 1-118 and idem, 'Die Gerichtsurkunden aus Italien bis zum Jahre 1150', Zeitschrift der Savigny Stiftung für Rechtsgeschichte, Germanistische Abteilung 14 (1893) pp. 1-258.

${ }_{85}$ See DKar. I, No. 110.

${ }^{86}$ See, for example, DKar. I, No. 196. This is the dispute subscribed by Genesius rather than a count of palace's scribe, though the reference to dukes and gastalds is pertinent to the Italian context.

${ }^{87}$ On particular palaces and services see the Capitulare missorum 808, c. 9. de operibus palatii ad Vermeriae; c. 10. de illo broilo ad Attiniacum palatium nostrum, MGH Cap. I, No. 53, p. 140, in BnF lat. 9654 fol. 21v and BAV pal.lat. 582 fol. 24v. See also the Capitula omnibus cognita facienda 801-814 (?801-806), c. 1 ut infra regna Christo propitio nostra omnibus iterantibus nullus hospitium deneget, mansionem et focum
} 


\section{Conclusion}

By the end of the eighth century, Charlemagne's kingdom extended from Brittany to the Danube Bend, and from north of the Elbe to the duchy of Spoleto in Italy. I have argued that there are a number of fundamental problems with the customary interpretations of the surviving evidence and the consequent assessments of Charlemagne's rule of this vast realm in relation both to the functioning of an itinerant court and to the Frankish palaces, usually judged to have had a symbolic role as locations of royal power from time to time as a result of the king's residence or the conduct of royal business. The ambiguities and uncertainties of the evidence have to be acknowledged, however distressing the consequences for what historians like to think as appropriate for a ruler of most of western Europe. Any questions about the physical topography of power in the Frankish realm, furthermore, have to consider its mental counterpart in the early Middle Ages. ${ }^{88}$

Certainly, the Frankish empire ruled by Charlemagne between 768 and 814 was distinctive for the plurality of its political and administrative centres and the maintenance of communications between these centres and their surrounding regions. Yet the notion of a court itself in the early Middle Ages has proved difficult to determine once any attempt is made to find evidence to support anachronistic assumptions about a court as an institutional structure. It is even difficult to establish the scale of the royal household as a domestic unit, quite apart from the limited degree to which a Frankish royal 'court', virtual or actual, as distinct from larger assemblies, was able to act as a 'meeting place and centre of elite integration'. ${ }^{89}$ Charlemagne's 'court', even if defined merely as a group comprising family and essential officials who sometimes shared the king's current residence, is too often seen in the modern scholarly literature as a static and unchanging institution and described solely in terms of the conditions apparently prevailing during the very last few years of his half-century reign or even in those of the early years of the reign of Charlemagne's son Louis the Pious.

tantum; similiter pastum nullus contendere faciat, excepto pratum et messem, MGH Cap. I, No. 57, pp. 144; and Capitulare missorum Aquisgranense primum, c. 1: de clamatoribus qui magnum impedimentum faciunt in palatio ad aures domni imperatoris, MGH Cap. I , No. 64, p. 153.

${ }^{88}$ See Mayke de Jong, Frans Theuws and Carine van Rhijn, eds., Topographies of Power, The Transformation of the Roman World 6 (Leiden 2001).

${ }^{89}$ Again, I argue this in detail in McKitterick, Charlemagne. 
The understanding of the royal itinerary itself has also been based on ill-founded assumptions. The links between the many Frankish political and administrative centres were not in fact dependant on itinerancy. In its turn, the royal movements were not integral to the system of Carolingian government as it was developed under Charlemagne. On the contrary, an elaborate system of written and oral communications provided the essential underpinning of Charlemagne's government. At first assumed to be itinerant, the court is alleged to have 'settled at Aachen around 794', even though according to the contemporary evidence available to us, only in the last four years of Charlemagne's life, did Charlemagne remain at Aachen most of the year rather than only during the winter-a state of affairs that probably had as much to do with advancing age as with any political ideology. Aachen's place in the structures of Frankish royal power was far from being as dominant as was once supposed. That the king travelled with a small entourage is undoubted, but his journeys do not accord with the technical definition of itinerant kingship, for it was not a fundamental aspect of his method of rule. Certainly the assemblies and the meetings to administer justice were gatherings of groups of people within a locality or a region who came, or were summoned, to meet the king. The king travelled for specific purposes, to go to war, to honour a saint, to convene assemblies, and to go hunting, but the pattern of his journeys is not that of a systematic or comprehensive system of rule. Courts have been regarded as a reflection of centralized power and the centre for competition for royal favour and individual prestige. ${ }^{90}$ An itinerant court might in any case seem to be a contradiction in terms, for it implies either no centre or a variable centre, and thus a shifting kaleidoscope of power. If, on the other hand, the king and his notaries were the ones who moved, often independently of each other, it would make the personal aspects of Carolingian government potentially more prominent. The energy put into administration and justice by the king himself was emulated by the officials installed in the localities, and the elaborate system of counties and missatica (administrative districts) regularly inspected by the king's agents known as the missi dominici. ${ }^{11}$

\footnotetext{
${ }^{90}$ See Jeroen Duindam, Myths of Power: Norbert Elias and the Early Modern Court (Amsterdam 1995).

${ }^{91}$ Karl-Ferdinand Werner, 'Missus-Marchio-Comes. Entre l'administration centrale et l'adminsitration locale de l'Empire carolingien', in: Histoire comparée de
} 
Charlemagne's solution to the problem of royal control and government of his realm was thus a combination of itinerancy and stability with a complex network of officials empowered to conduct business on his behalf, so that the king himself, to adapt Stuart Airlie's evocative phrase, was 'like a great railway junction shunting personnel all over the kingdom'. ${ }^{92}$ This undoubtedly was a method of rule that developed gradually. Towards the very end of his reign and his life it is clear that the king moved about less and less and was indeed much more constantly at Aachen. This, as already noted earlier, could have been as much biological as it was ideological, for it is a pattern reflected in the careers of any number of warrior kings. In due course, however, Charlemagne augmented the powers and numbers of the missi dominici, especially in 802 , so that there would be less need for the king, let alone any of his officials other than the missi, to travel. There appears to be a greater dependence on agents and use of communications to secure rule without the king's physical presence. In other words, royal government from the royal household was increasingly dependent less on the king's own movements, for his accessibility was not the key issue, but on the effectiveness of his officials and, above all, on the means of communication.

This story has, furthermore, three obvious general morals for historians of royal courts: do not accept a proposition about the king and his court until you have checked that it was practically and physically possible; make sure that the detail supports the generalization; and do not extrapolate backwards from one apparent system on the assumption that it could apply perfectly well to others. But there is a larger point about government and statehood that emerges from this study of Charlemagne's movements. The decentralisation of political power in the post-Roman world has become a commonplace and the Carolingian 'topography' of power, partly manifested in what has aptly been described as a 'great chain of palaces', has been regarded as a model instance of such decentralization within the vastly expanded Frankish realm. ${ }^{93}$ Such perceived decentralisation has even led to

l'administration (IV ${ }^{e}-X V I I I^{e}$ siècles), Karl-Ferdinand Werner and Werner Paravicini, eds., Beihefte der Francia 9 (Munich 1980) pp. 191-239.

${ }_{92}$ The evocative phrase is from Airlie, 'The Palace of Memory'.

${ }^{93}$ See Janet L. Nelson, 'Aachen as a Place of Power' in: Topographies of Power, Mayke de Jong, Frans Theuws and Carine van Rhijn, eds., The Transformation of the Roman World 6 (Leiden 2001) pp. 217-242 at p. 222. See also again, Airlie, 'The Palace of Memory'. 
the demotion of early medieval polities as states or even as moving towards statehood. There is no particularly compelling reason why the different power structures and methods by which rulers were able to exert power over their subjects should disqualify them as states if one accepts Chris Wickham's definition of a state, viz.: 'the centralization of legitimate enforceable authority (justice and the army); the specialization of governmental roles, with an official hierarchy which outlasted the people who held official position at any one time; the concept of a public power, that is, of a ruling system ideologically separable from the ruled population and from the individual rulers themselves; independent and stable resources for rulers; and a class-based system of surplus extraction and stratification' ${ }^{94}$ Elites within such a state in the early Middle Ages were legitimized by their connection with public spheres of power. ${ }^{95}$ This attempt to chart Charlemagne's movements has also exposed an essential part of his network of communications, and the role of particular officials with distinct responsibilities in particular places who maintained it. They were a fundamental part of the structure of his government and of the Carolingian state.

${ }^{94}$ Chris Wickham, Framing the Early Middle Ages. Europe and the Mediterranean, 400-800 (Oxford 2005) p. 57.

${ }^{95}$ See also the discussions in Stuart Airlie, Walter Pohl and Helmut Reimitz, eds., Staat im frühen Mittelalter, Forschungen zur Geschichte des Mittelalters 11, Denkschriften der Österreichischen Akademie der Wissenschaften, phil.hist. Klass 334 (Vienna 2006). This paper was delivered in the preliminary stages of writing my book, Charlemagne (2008) and it was a direct and happy consequence of Metin Kunt's request to think about the royal itinerary that encouraged me to think again about the charter evidence. I should like to record my thanks to him and to Jeroen Duindam for this opportune question. I subsequently wrote the results of this research up in detail in Charlemagne, of which the paper in this volume forms a summary. Another discussion using this same charter evidence, with the emphasis on communications in the context of Staatlichkeit, has been published as 'Court and communication in the early middle ages: the Frankish kingdom under Charlemagne', in: Walter Pohl and Veronika Wieser eds., Der Frühmittelalterliche Staat-Europäische Perspektiven, Forschungen zur Geschichte des Mittelalters 16, Denkschriften der Österreichischen Akademie der Wissenschaften, phil. -hist. Klasse 386 (Vienna 2009) pp. 357-68. 


\title{
COURT HISTORIOGRAPHY IN EARLY TANG CHINA: ASSIGNING A PLACE TO HISTORY AND HISTORIANS AT THE PALACE
}

\author{
Isenbike Togan
}

\section{Introduction}

In Tang China (618-907 CE) policies and political interaction took shape at court, in the context of palace life. During the early Tang, court life came to include activities such as the writing of history: historians were assigned a place in the palace. The placement of the historians within the precincts of the palace was an illustration of the 'politicization of history', the institutional and political appropriation of history writing by the Tang court. This new trend did not only shape the interpretation of past events, but also the approach and methods of future historiography. It was during this time that the major histories of the preceding four centuries were written and the groundwork laid for future history writing by professional historians.

These changes were initiated by the second Tang emperor Li Shimin, known as Tang Taizong (626-649). He was regarded as an exemplary figure by later dynasties; his reign of Zhen Guan (True Vision) is known in Chinese history as the 'good rule of the Zhen Guan reign.' This 'Golden Age' lasted for 23 years from 627 to 649. Taizong, who reached power by killing the crown prince and forcing his father to abdicate, was able to achieve high standing in history, irrespective of these events. He gained this standing initially through a policy of sharing power with political contestants and consolidated his position with a victory (630) over the Early Türk, the foreign power in the north and the west. Immediately following this victory, he started his Tang history project with which he was actively involved. Power-sharing was reflected in the way history was written. It was no longer written by individuals, but by a commission whose members were employed at court. This paper discusses the timing of the history project, and shows that it was an ingenious move by Tang Taizong. The project was launched when the emperor had a strong hand following his victory 
over the Early Türk. The victory provided the starting point for the glorification of the emperor in historiography.

\section{Early Tang Court: Encampment and Palace}

The Tang Dynasty was established in 618. Tang court life, however, started in Taiyuan when Li Yuan, the then garrison commander, 'raised his flag' in revolt in 617. His associates who later became part of his entourage and bureaucracy can be considered as constituting the preliminary Tang court. After entering the capital of the defunct Sui dynasty, and proclaiming his dynasty as the Tang, Li Yuan mounted the throne on 18 June 618. He renamed his capital 'Chang'an' as it had been known during the Han dynasty. In history Li Yuan is known to us as Tang Gaozu (618-626).

From then on the new dynasty had its capital and court in Chang'an around the site of present Xi'an. With the conquest of the capital and the establishment of the dynasty, Li Yuan and his close associates started holding formal court. These associates, who were now occupying important positions at court, were familiar with the ways of court life from their earlier service to the former dynasties of Sui (581-618), the Northern Zhou (557-581) and the Northern Qi (550-577).

Initially, the court established itself in the former Sui palace, renamed Taiji dian or Great Joy Palace. It was situated in the southern part of the palace city. As the layout of the capital city shows (Fig. 1) the palace city was situated in the north of the city, a location which would also be adopted by later dynasties. As was also the custom in later dynasties, the private quarters of the imperial family were found in the north of the palace city (Fig. 2). The court of the earlier Tang consisted of Li Yuan's former associates as well as fresh talents who had joined the ranks of the new dynasty. Wechsler describes how the emperor would meet with his officials:

On the first and the fifteenth days of each lunar month, all officials of the ninth rank and above, that is, all officials 'within the current' (liunei), met with the emperor in special audience at the Taiji Hall, situated in the southern portion of the palace city. To the east and west of the Taiji Hall were two smaller council chambers (shangguo). After the audienceessentially ceremonial in nature-was concluded, the emperor retired to one of these council chambers, where soon afterwards he would be joined by his chief ministers, other designated high-ranking officials, remonstrating officials (jianguan) charged with pointing out errors in 


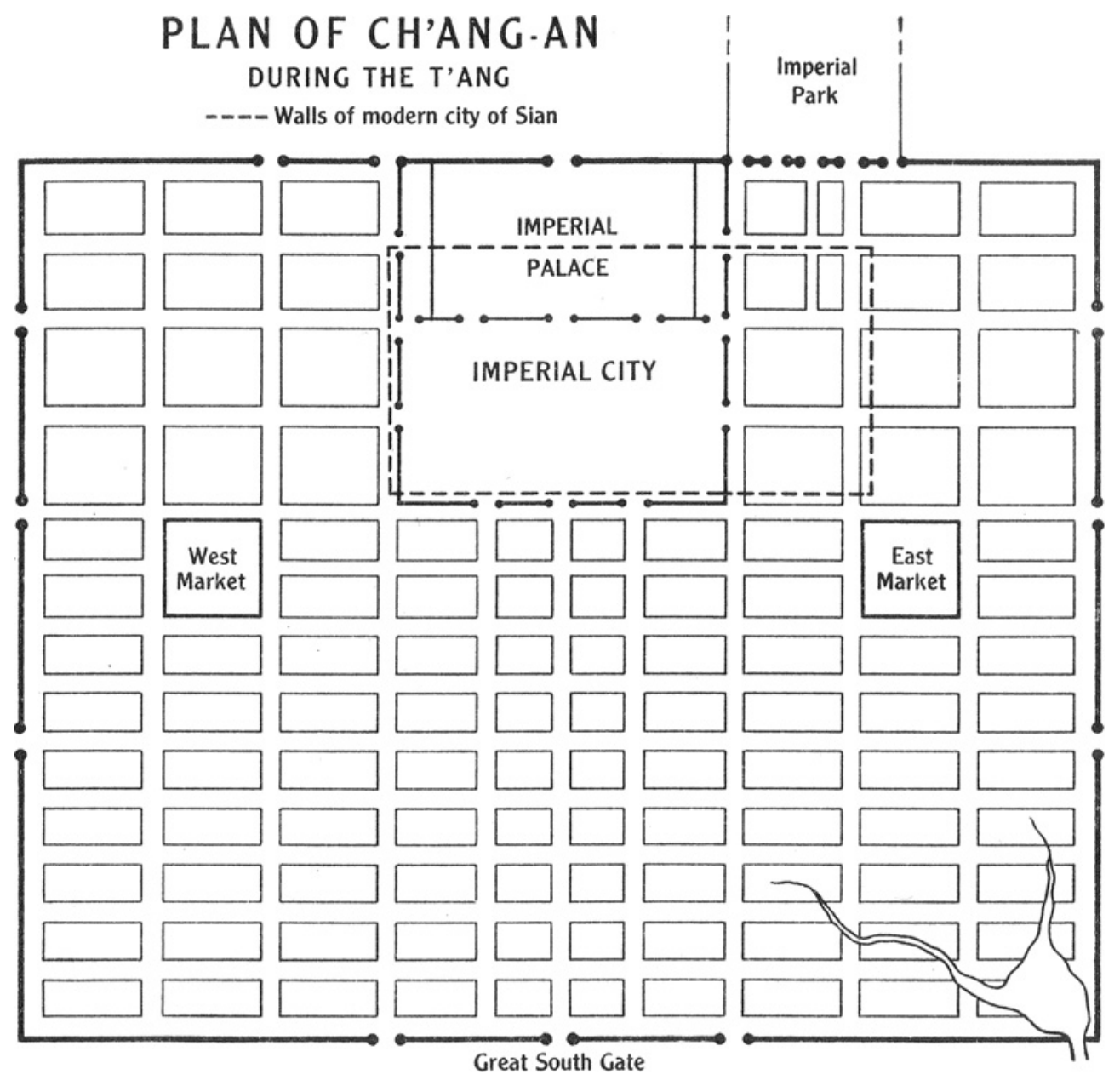

Figure 1. Chang'an, from Reischauer and Fairbank, East Asia. The Great Tradition (Boston 1960) p. 165. 


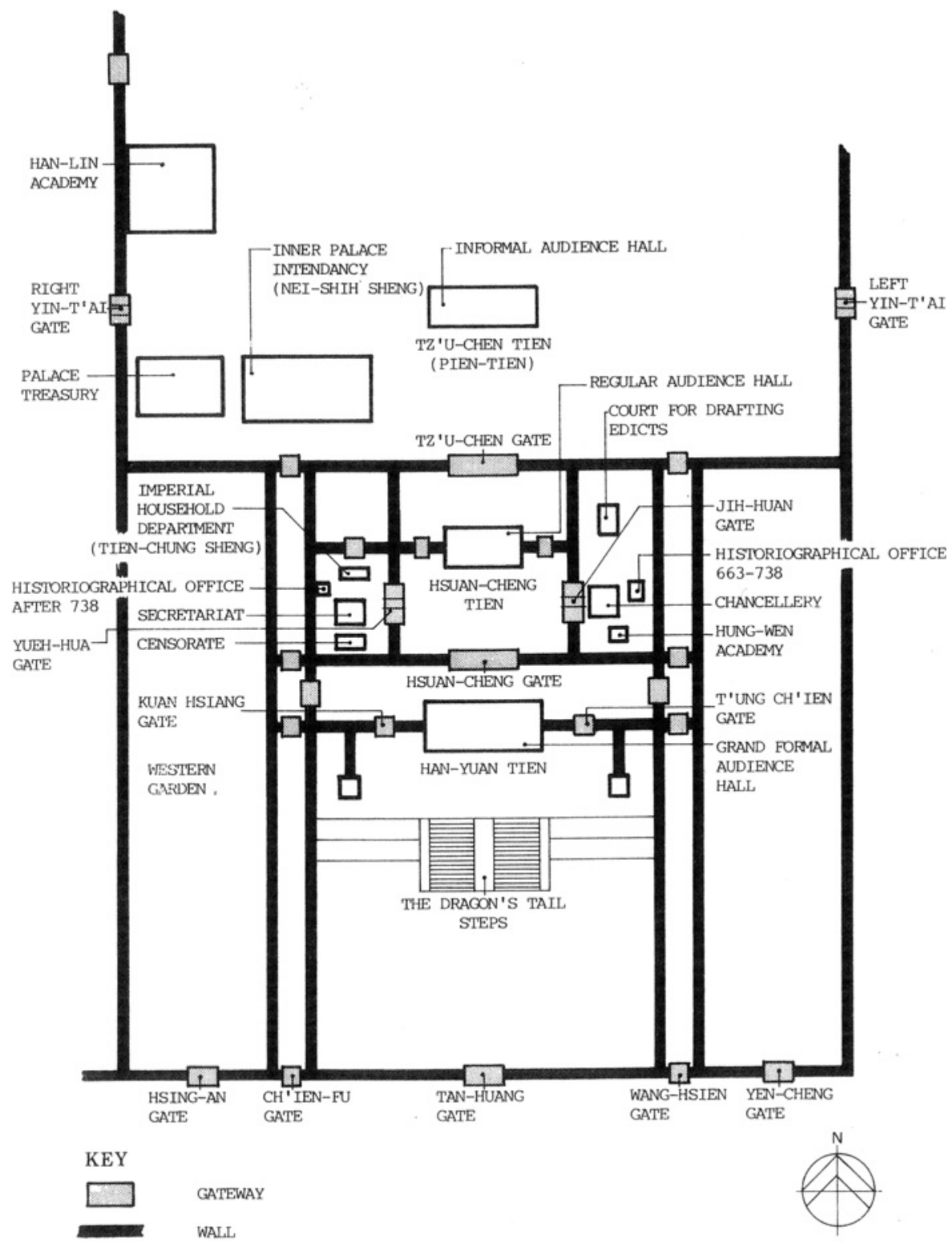

Figure 2. Public business area of the Ta-Ming palace, from: Denis Twitchett, The Writing of Official History under the T'ang (Cambridge 1992) p. 18. 
their deliberations, and one scribe to make a record of proceedings. Since the meetings in the council chambers were shorn of elaborate ceremony, the atmosphere was far more intimate than at the preceding large audiences, and the attending officials could speak their minds with relative ease. ${ }^{1}$

We know that in 618 envoys from the Early Türk in the north were received in the palace city and given a banquet with nine musical numbers. ${ }^{2}$ After 630 Taiji Hall was known for lavish and alcoholfueled entertainments hosted by the Tang emperor. ${ }^{3}$ Normally, court (called chao) was held early in the morning-and indeed the Chinese term for court was the same as that for early morning. Only on exceptional occasions-during periods of mourning, for example, were the meetings of the court suspended.

There were also palaces in other parts of the country. One of these was the former Renshou Palace of the Sui, renovated and renamed Jiucheng (Nine Perfections). This summer palace was located in the Tiantai Mountains about one hundred miles north of Chang'an. Additions to palaces were numerous especially during the reign of Tang Taizong. We are told that at the beginning of his reign Taizong was modest in his taste, but after his 630 victory over the Türk, he undertook a program of palace renovation and reconstruction. ${ }^{4}$ We see him holding court not only in various palace buildings but also on the move in encampments enclosed by cloth screens. On one such occasion after he left the palace in Chang'an and was heading towards Jiucheng Palace, there was an attempt on his life by one of the guards coming from the Türk royal family.

In 634 construction was begun on Daming Palace in the northeast of the imperial city. It began as a residence for the abdicated ruler Gaozu who refused to live in the Jiucheng Palace because it had originally been a Sui palace. However, he died before moving to this new

\footnotetext{
${ }^{1}$ Howard Wechsler, Mirror to the Son of Heaven. Wei Cheng at the Court of T'ang T'ai-tsung (New Haven; London 1974) p. 95. For the sake of consistency for the nonChina specialist, the original transcription in Wade-Giles has been changed to pinyin.

${ }^{2}$ Among the nine numbers were Chinese as well as foreign pieces including music from Cambodia, Korea, Central Asian Kingdom of Kucha, Bukhara, Kashgar, Semerkand. Liu Mau-Tsai, Die Chinesischen Nachrichten zur Geschichte der Ost-Türken (T’u-Kue), 2 vols. (Wiesbaden 1958) vol. II, p. 572, n. 684).

${ }^{3}$ Wechsler, Mirror to the Son of Heaven, p. 126.

${ }^{4}$ Wechsler, Mirror to the Son of Heaven, pp. 130-131.
} 
palace building, ${ }^{5}$ which went through further renovations. In 663 the court was moved to the Daming Palace. ${ }^{6}$ The illustration of the layout of Daming Palace shows (Fig. 2) that the court consisted of inner and outer quarters. The government sections were in the outer court. There, the major divisions were the Imperial Secretariat-drafting memorials-on the right of the throne facing south (on the left of the map) and the Imperial Chancellery-reviewing and emending memorials - on the left side of the throne. ${ }^{7}$

The Historiographical Office (663-738) to be discussed below was established within the palace and its location changed according to changes in the court hierarchy. When the Chancellery was of great importance, the Historiographical Office was located in close proximity to it. Later, when the Imperial Secretariat gained importance, it was moved to the other side of the main courtyard to be close to the Imperial Secretariat. The changes in the location of the Historiographical Office, always staying in close proximity to the most important government office, reflect the new position that history writing had attained at the Tang Court.

The writing of history was not new in China, but its location at court was. In fact, the writing of history in China goes back to the centuries before our era. While modern scholars have concentrated more on the techniques of collecting, organizing and presenting the documents in historical works, the integration of history writing at court and its politicization have not been a focal point of studies of Chinese historiography.

The Tang dynasty gave historians a place at the court within the palace grounds in 629-630. History writing was first entrusted to political associates of the dynasty, and later to professional historians. The trend towards the politicization of history writing can be observed during the reigns of the first three rulers (618-683). However, it was Taizong who started this trend by appointing close associates to oversee the task of history writing. The new approach to history writing was closely related to the transition from a fragmented political order to power-sharing among former rivals. Power-sharing was a way to overcome the conflicts that were the rule during the fragmented politi-

\footnotetext{
5 Wechsler, Mirror to the Son of Heaven, p. 136.

${ }^{6}$ Denis Twitchett, The Writing of Official History under the T'ang (Cambridge 1992) p. 18.

7 Wechsler, Mirror to the Son of Heaven, p. 54.
} 
cal order of the previous 400 years. After the collapse of the Later Han dynasty at the beginning of the third century CE, China was ruled by many small dynasties. Some of these were local, others were of foreign origin. Remnants of the Xiongnu, various tribal groups of proto-Mongolian and proto-Turkic background roamed around in north China, where they sometimes established their rule. Most of the close associates of Gaozu the founder, and his son Taizong came from diverse political backgrounds as they had earlier been in the service of the Sui, Northern Zhou, and Northern Qi dynasties. This multifaceted group was also joined by some members of the old literati class coming mostly from the central areas and from the northeast. Together, they would constitute the bureaucracy and the elite of the first two reigns of the new dynasty. By giving a place to these men from diverse ethnic and political backgrounds, the Tang dynasty achieved a consensus among them. It made them share-holders of power whose status was later going to be preserved for eternity by their inclusion into the imperial funerary complex. The consensus eliminated the contestation among different groups and made possible consolidation under the Tang dynasty. ${ }^{8}$

The Li family, founders of the Tang dynasty, originated in the northwest and came from a mixed background; mixed marriages continued well into the first two reigns. The mother of the founding emperor Gaozu was of Xianbei origin, as was the beloved wife of the second ruler Taizong, whose brother-in-law played a significant role in court politics as well as in writing of history during the reign of the second and third emperors. This 'northwestern aristocracy', a label commonly used by modern historians, had been formed during the previous 400 years through interaction with foreigners such as the Sogdians, Xianbei, and Turkic groups. As a result of this mixed heritage, they were successful in combining civil and military powers in their administration as the Sui dynasty (581-618) had done before them. The Li family emerged dominant from these circumstances. The consensus that was reached on the internal scene, though still fragile, was strengthened by a defensive strategy against the outside world. The major external power, the Early Türk empire founded in 552, was pacified in 630, twelve years after the establishment of the dynasty.

${ }^{8}$ For an elaboration of this view see Wechsler, Mirror to the Son of Heaven, pp. 89, 92, 95 . 
The then Early Türk ruler was defeated and taken prisoner, and thus the eastern part of the Türk empire came under Tang control. About three decades later, the Western Türk were also brought under Tang control; Central Asian possessions now brought the borders of Tang China to Transoxiana.

Gradually, the strategies of power-sharing and consensus-building, themselves never wholly unchallenged, were supplanted by a policy of concentration of power in the hands of the dynasty. The institutionalization of the concentration of power was a long process. The politicization of history, initially tied closely to power-sharing strategies, was also one of the earliest steps taken in this process. Opposition became visible when the Empress $\mathrm{Wu}$ (684-705) - the consort of the third ruler-came to power. ${ }^{9}$ She moved the capital to the east, to Luoyang, unsettling the balance of power. It was also during her reign that the dynasty began to patronize Buddhism. The upheavals of her reign were mostly due to the contestations between the 'classical' northeastern literati, which formed a quasi-aristocracy, and the flourishing Buddhist church. After these upheavals, under the long rule of Xuanzong (713-756) the first signs of the dominating Confucian order were to be seen; however, this period ended with the rebellion of An Lushan (756-759). The regeneration of the empire after this rebellion is referred to as 'the Glory of the Tang.' The chapter on Tang institutions in the Cambridge History of China, a typical example, deals only with the period after 759 .

\section{The Tang History Writing Project: Court Historiography}

Before the Tang, under the Qin and Han dynasties, there had been histories produced during the lifetime of the dynasty. The first of these, the Records of the Historian ${ }^{10}$ by Sima Qian (ca. 145-90 BCE) and the History of the Former Han ${ }^{11}$ by Ban Gu (32-92 CE) had been

${ }^{9}$ Denis Twitchett and Howard J. Wechsler, 'Kao-tsung (649-83) and the empress Wu: the inheritor and the usurper', in: The Cambridge History of China III. Sui and T'ang China, 589-906, Denis Twitchett, ed. (Cambridge 1979) pp. 242-289.

${ }_{10}$ Burton Watson, Records of the Grand Historian of China, translated from the Shih chi of Ssu-ma Ch'ien (New York 1961).

${ }^{11}$ Homer H. Dubs, The History of the Former Han Dynasty, 3 vols. (Baltimore 1938-55). 
written by private individuals. ${ }^{12}$ The much cherished Record of the Three Kingdoms ${ }^{13}$ was also written by a private individual, Chen Shou (233-297 CE). The history of the Northern Wei (386-550 CE) by Wei Shou was also commissioned by one or two individuals. ${ }^{14}$ After Wei Shou's compilation in 554, there was a vacuum.

In 621-622, three or four years after the founding of the Tang dynasty, Linghu Defen proposed that the histories of the past six dynasties be written. ${ }^{15}$ This project was authorized by an edict on 1 February $623 .{ }^{16}$ However, after several years the project was suspended. Later between 19 January and 17 February $630,{ }^{17}$ the young emperor Taizong ordered the compilation of five (and not six) of these histories and made assignments. He took this decision in the midst of the campaign against the Early Türk. The importance of the timing cannot be emphasized enough. Let us look more carefully at these developments. Around March and April 629 Li Jing had been appointed Minister of War. Carrying out an assault from five sides, the imperial forces defeated the Early Türks by November. The assault was so successful that at the beginning of January 630, Tuli Qaghan, Elig (Xieli) Qaghan's nephew as well as the second in command, took refuge in China. The great victory was achieved on 26 February 630; Li Jing crushed the forces of Elig Qaghan. By the end of April and in the beginning of May Elig Qaghan was brought as a captive to Chang'an where he would die a few years later from sorrow. On May 24, 630 Tang Taizong was beseeched by the northern tribes to assume the title of tian kohan, that is Heavenly Qaghan. Thus by the end of May 630, he was both Son of Heaven (tianzi) and Heavenly Qaghan. We can see that the commissioning of the historians to write the history of the preceding dynasties took place exactly at this juncture.

12 Michael Nylan, 'Sima Qian: A True Historian?', Early China 23-24 (1998-99) pp. 203-246.

${ }_{13}$ Acilles Fang, The Chronicle of the Three Kingdoms, 2 vols. (Cambridge, Mass. 1965).

${ }^{14}$ Endymion Wilkinson, Chinese History: A Manual (Cambridge, Mass.; London 2000) p. 504.

${ }_{15}$ William Hung, 'The T'ang Bureau of Historiography before 708', HJAS 23 (196061) p. 94, from Tang huiyao 35.15 a.

${ }_{16}$ Hung, 'The T'ang Bureau of Historiography', p. 94.

17 The exact date is the intercalary 12th month of the 3rd year of the Zhenguan reign period. The 3rd year of the Zhenguan reign period, on the other hand, lasted from 30 January 629 to 17 February 630 . This is why the date is given sometimes as 629 . But the chronological order of the events shows that the exact dating is important. 
The compilation of the histories was entrusted to the head of the Secretariat (zhongshuling) Fang Xuanling. Among those assigned to this task were Taizong's favorite minister and associate Wei Zheng, historian Linghu Defen, librarian Cen Wenben, Assistant Secretary Li Boyue, and writer Yao Silian. They were entrusted with the task of collaborating on the histories of the Sui, Zhou, and Qi dynasties of the north and the Liang-Chen dynasties in the south. Tang Taizong's brother in-law and close associate Zhangsun Wuji was also involved with the history writing process. It is to be noted that Taizong's associate and minister Wei Zheng was entrusted with the history of the defunct Sui dynasty. Wei Zheng, who worked with Taizong for 17 years as his close associate, was well acquainted with the circumstances of the Sui dynasty. He 'successfully fought against the compilation de novo of a history of the Northern Wei dynasty, a version of which had been compiled earlier by Wei Shou, ${ }^{18}$ who was also a member of the founder clan of the Wei.

History writing by a commission rather than by individuals, as had been the earlier custom, reflected the consensus reached at the establishment of the dynasty. Despite severe criticism by a historian a century later, this practice of assigning commissions to history writing would remain one of the fundamental traits of official Chinese historiography well into the nineteenth century. ${ }^{19}$ Moreover, while one might expect that history writing would develop after full institutionalization and consolidation of authority, a condition realized only in the eighth century, it was initiated by Tang rulers at the onset of their rule. ${ }^{20}$ Early Tang rulers decided that history writing was not to be delayed. This decision could be seen as a manifesto of the consensus reached after all the centuries of 'disunion.'

The new dynasty's resolution to take history writing under its control and shape the past in such a way as to make it a guideline for the

\footnotetext{
${ }_{18}$ Wechsler, Mirror to the Son of Heaven, p. 35.

${ }^{19}$ Edwin George Pulleyblank, 'Chinese Historical Criticism: Liu Chih-Chi and Ssu-ma Kuang', in: Historians of China and Japan, W.G. Beasley and E.G. Pulleyblank, eds. (London 1961) pp. 135-151.

${ }^{20}$ For the 8th century, institutionalization can be documented in the form of The Tang Manual of Government and (Da Tang Liu Dian) from 739. The Collection of Tang Regulations and Procedures (Tang huiyao) were compiled much later in 961. These works are all illustrations of the institutionalization that established the Confucian world view as the dominant order not only of the Tang dynasty but also of the following centuries in Chinese history.
} 
future deserves closer examination. Wechsler states that Chinese historiography was designed above all to teach moral lessons, lessons that could be conveyed most clearly by the judicious selection of materials and the coloring of narrative for effect. ${ }^{21}$ Chinese historiography and policymaking, in fact, relied heavily on the writings of the past. The statesmen and bureaucrats at court constantly referred to past incidents, contemplating them as examples to be followed or rejected. In the Old History of the Tang we encounter many examples of this kind. However, these examples come either from the classics like The Book of History, The Spring and Autumn Annals, The Zou Tradition, or from Sima Qian's Records of the Historian and Ban Gu's History of the Former Han (Hanshu). These latter works continue to this day to have a readership that enjoys their literary quality. The five dynastic histories produced during the reign of Taizong did not and still do not enjoy such a readership. They also do not seem to be quoted extensively in the official Old History of the Tang.

Historical works written by a commission did shape the past, but these works do not seem to have served as a mirror for the future with a wide readership across centuries. However, by making the writing about the preceding dynasties a first priority, the Tang also set a model for the future. However, this was not predestined; it evolved as a historical and historiographical process. There was a difference between intent and impact. The intent had been the legitimization of the power-sharers who established the Tang dynasty, and the glorification of the second ruler Tang Taizong rather than the founder. This is all the more striking, as according to the traditional Chinese belief, 'because of the great store of morality and virtue possessed by a founding ruler, Heaven transfers to him a Mandate to govern in place of the corrupt last ruler of a defunct dynasty. ${ }^{22}$ On the contrary, the accomplishments of the second ruler as well as the success of the history writing project gave rise to the 'traditional interpretation of the founding of the Tang, which held that Taizong rather than his father Gaozu was the genius behind the revolt that eventuated in the establishment of the dynasty'. ${ }^{23}$ This view achieved its final form in the 10th and 11th centuries when The Old and the New History of the

\footnotetext{
21 Wechsler, Mirror to the Son of Heaven, p. 5.

22 Wechsler, Mirror to the Son of Heaven, p. 6.

${ }^{23}$ Wechsler, Mirror to the Son of Heaven, p. 8.
} 
Tang, two official histories (zhengshi) were compiled on the basis of the materials collected and compiled during the time of Taizong and his close associates. While the intent of this history writing project was realized in the long run, its impact has been to set a pattern for dynastic history writing per se. This is why Yang Lien-sheng starts his study of traditional Chinese historiography with the Tang. ${ }^{24}$ From 630 on official historiography and its methods gained the upper hand. But this impact is not only visible in later history; it also covered earlier periods, so that the writing of official history was seen as a general trend of Chinese history. Let us look more closely at this project of history writing which eventually became the norm.

\section{The Actual Writing of Tang History}

Before the Tang, history writing was considered as a literary activity. Since ancient times there had always been court diarists but there was no Historiographical Office. A deliberate separation of the routine keeping of a Court Diary from the process of state-sponsored historical composition was formalized under the Northern Zhou and later under the Sui. ${ }^{25}$ History was written in the Bureau of Literary Compositions zhuzo cao, and historians would be employed in this office. ${ }^{26}$ At first the Tang continued this practice, but later they established a separate historiographical office. According to the Tang Manual of Government: 'At the beginning of the Zhenguan period [627-649], the Bureau of Historiography was separately established within the Palace, especially charged with Dynastic historiography. ${ }^{27}$ William Hung is of the opinion that even if the establishment of a Historiographical Office which he calls the Bureau of Historiography might have taken place during the time of Taizong, the process of recording history under a separate organization had started already at the time of Gaozu. ${ }^{28}$ By

${ }^{24}$ Lien-sheng Yang, 'The Organization of Chinese Official Historiography: Principles and Methods of the Standard Histories from the T'ang through the Ming Dynasty', in: Historians of China and Japan, W.G. Beasley and E.G. Pulleyblank, eds. (London 1961) pp. 44-59.

${ }_{25}$ Twitchett, Writing of Official History, p. 6.

${ }^{26}$ Hung, 'The T'ang Bureau of Historiography', p. 94.

${ }^{27}$ Hung, 'The T'ang Bureau of Historiography', p. 95.

${ }^{28}$ Hung, 'The T'ang Bureau of Historiography', pp. 95-96. 
the establishment of the Historiographical Office history was separated from the Bureau of Literary Compositions. Hung also states:

Emperor Taizong set up the Historiographical Office especially within the Palace, thus to emphasize the importance of the office and to protect its work from public knowledge. The work on the Histories of the Five Dynasties needed to be protected from premature disclosure lest some of the descendants of the historical figures might try to influence the historiographers in matters of praise and censure. ${ }^{29}$

To protect them from outside pressures, the historians were located in the Palace. ${ }^{30}$

About 10-12 years after these developments, the practice of keeping Veritable Records (shilu) started. Thus the Veritable Records which later became a prerequisite for writing official history ${ }^{31}$ were a Tang innovation. The Veritable Records of Tang Taizong were first written under the guidance of Tang Taizong himself. Twitchett gives a vivid illustration of the circumstances behind Taizong's complaints that he did not have access to them..$^{32}$

The story of the process of the writing of these early records is very complicated. There were different stages of the preparation of the Veritable Records. The Veritable Records of the Reigning Sovereign (the jinshang shilu) in twenty chapters were presented to the throne in 643 by Fang Xuanling and his colleagues. ${ }^{33}$ Emperor Taizong had these chapters read aloud to him. He was so deeply moved that he lost his composure and ordered that the scrolls be accepted and sent to the imperial library. He also ordered that a copy be given to the heir apparent and other princes. Metropolitan officials of the third rank and above were permitted to have copies made for themselves. I think that this copying helped the work to survive through the centuries. This early version of the historical records of the Tang dynasty has also survived in the Zhen Guan Zheng Yao. ${ }^{34}$ These were the records on the reign of Gaozu and Taizong.

${ }^{29}$ Hung, 'The T'ang Bureau of Historiography', p. 98.

${ }^{30}$ See figure 2 above from Twitchett, Writing of Official History, p. 18.

${ }^{31}$ On the process of preparation of official histories the general assumption is that there are 24 or 25 histories and that each was prepared by the succeeding dynasty and that official histories were prepared on the basis of the "Veritable Records", i.e. the Shilu that were compiled by the succeeding ruler for the previous reign.

32 Twitchett, Writing of Official History, p. 124.

${ }^{33}$ Twitchett, Writing of Official History, p. 124.

${ }^{34}$ Twitchett, Writing of Official History, p. 124. 
A next version called 'The Veritable Records of the Zhen Guan Period', (Zhen Guan Shilu), with additional chapters covering 641649 , was presented to the throne in 654 by Zhangsun Wuji. ${ }^{35} \mathrm{He}$ was a close associate from the early days of Taizong's career and also his brother-in-law. At that time he was the director of the Historiographical Office. There were two more sequences before the last version. Even this final version prepared by $\mathrm{Wu}$ Jing, exists in two incomplete forms. Wu Jing never finished it because of his perfectionist attitude. After his death his work was given to Wei Shu who started elaborating it. Apparently $\mathrm{Wu}$ Jing had taken his draft to his country residence and thus it survived destruction after the burning of the archives during the An Lushan rebellion. Twitchett says that it was:

... suggested that the censors and local officials should trace former officials of the office and offer a reward to anyone who could send the authorities any surviving portions of the National History or Veritable Records. If the historians themselves had taken the books from the office, they would be given amnesty for their offense. ${ }^{36}$

Eventually this copy made it possible to incorporate records surviving from the earlier part of the Tang into the official history. Hence we are now able to use the earlier part of the Old History of the Tang (Jiu Tangshu) as a reliable source. The complicated process of versions and variants in the genesis of the official history underlines the significant role played by writers outside of or in the margins of official history writing. The survival of their work allows us to study differences between the private and official versions from the same period.

\section{Private Histories Written at the Court}

Official histories were based on the court diaries (qiju $z h u)$ that were kept on a daily basis. We know that this was an old practice. Dur-

${ }^{35}$ See Twitchett, Writing of Official History, p. 126. However, this work is different from the Taizong Shilu that survived into the 11th century. The compiler of this latter work was a certain Xu Jingzong. Twitchett says, "his biographers, however, tell us that he twisted the facts and cut and changed the text of the Veritable Records of Gaozu and Taizong that had been compiled by Jing Bo, and that these changes were considered very serious." Twitchett, Writing of Official History, p. 127. Gaozong expressed dissatisfaction with Xu's work. Twitchett, Writing of Official History, p. 129. A revision was requested.

${ }_{36}$ Twitchett, Writing of Official History, p. 79. 
ing the Tang the court diaries were the only official record compiled continually throughout the dynasty. They were written by the court diarists (qiju lang and qiju shiren) who were part of the retinue of the emperor. While the former were responsible for recording the emperor's acts, the latter were responsible for recording his utterances. Court diaries were not meant for the emperor's eyes. However, the newly introduced Veritable Records-based on court diaries-were presented to the throne and attained official sanction.

Two works from the early Tang did not attain official sanction as they were written by individuals. Although these persons were closely associated with the court, they wrote in their capacity as private individuals. The first of these works is called Diary of the Founding of the Great Tang Dynasty and was written by Wen Daya. It seems that it was started at a time when Li Yuan, the founder of the Tang 'was still a Sui official and not an emperor and the work ceases with his assumption of the imperial throne. ${ }^{37}$ Besides this work there was another private history: Important Principles of Government from the Zhenguan Period (Zhenguan Zhengyao) by $\mathrm{Wu}$ Jing. Both of these works were written by personalities active under the early Tang; they deal with the founding process of the Tang.

Wen Daya, the compiler of Diary of the Founding of the Great Tang Dynasty was the son of a well-known scholar/official of the Northern Qi and the Sui. His father retired to Taiyuan when the Sui were on the verge of collapse. He had three sons and two of these three sons worked closely with Li Yuan, when he 'raised his flag' in Taiyuan. A third son Wen Yenbo (584-637) later became chief minister under Taizong; one of his sons became the consort of Gaozu's daughter. Wen Daya also became the president of the Board of Rites after Taizong ascended the throne in 626. As we can see Wen Daya came from a family which was in very close contact with the Tang royal family. He was an eyewitness to many events from the beginning of the Tang. He was one of the officials who conducted the ceremonies of abdication for the Sui child-emperor and for the ascension of Gaozu. The importance of Wen Daya's work was recognized by Sima Guang (1019-1086 CE) and was used by him quite extensively. Wen Daya's Diary must have been written during the reign of Gaozu but never

\footnotetext{
37 Twitchett, Writing of Official History, p. 41.
} 
became part of official historiography and indeed in many instances was in conflict with it.

The author of the second private history, $\mathrm{Wu}$ Jing, was a person with many official duties; he was involved in the writing of the national history (guoshi), but also in the writing of other works like the shilu of Empress Wu, Zhongzong and Ruizong. All this work was written in an official capacity. One would think that these official duties would have taken all his time but this was not the case. His private history, the Zhenguan Zhengyao is the work for which he is remembered and known. ${ }^{38}$

These private histories contain information that is not to be found in the Veritable Records, i.e., in official history writing. The Veritable Records show a bias in favor of Taizong. We know that these records in any case originated from a political purpose. Taizong 'ordered the Veritable Record for the first years of his reign after the death of his dethroned father Gaozu. ${ }^{39}$ Thus Taizong was able to control what was written about his father's achievements as well as his own seizure of power. In this connection Wechsler says:

the traditional accounts portray Shimin, who at the time of the revolt was about 17 years of age, as a brilliant military commander [....] they depict Li Yuan, then about 51 as a doddering and spineless old man, buffeted about by events over which he had no control, an unwilling pawn in the hand of his wily son, Shimin. ${ }^{40}$

The bias present in traditional Chinese works is repeated in English writings ${ }^{41}$ Eberhard, for example states that: 'The nominal leadership in the rising that now began lay in the hands of Li Shimin's father, $\mathrm{Li}$ Yuan; in practice Li Shimin saw to everything.' Wen Daya's work, on the other hand, helps us 'to counterbalance the bias written into the official record of the early Tang. ${ }^{42}$

${ }^{38}$ There is also an MA thesis (unpublished) on this work: Winston George Lewis, The Chen-kuan Cheng-yao: A Source for the Study of Early Tang Government, University of Hong Kong (Hong Kong 1962). Twitchett says that it includes a complete English translation, Twitchett, Writing of Official History, p. 172.

${ }_{39}$ Twitchett, Writing of Official History, p. 120.

${ }^{40}$ Wechsler, Mirror to the Son of Heaven, pp. 15-16.

${ }^{41}$ C.P. Fitzgerald, Son of Heaven: A Biography of Li Shih-min, Founder of Tang Dynasty (Cambridge 1933); Wolfram Eberhard, A History of China, New Enlarged Edition (Berkeley; Los Angeles 1955/1971) p. 172; Reischauer and Fairbank, East Asia. The Great Tradition, p. 155.

42 Twitchett, Writing of Official History, p. 41. 
Knowing that Taizong was very eager to control his future image, historians have puzzled over how these private histories were able to survive at all. For instance Wechsler says:

It seems strange that Taizong failed to suppress the Diary even after he began to take a supervisory role in the compilation of the dynastic history and veritable records. Did he underestimate the Diary's threat to his historical image because only the dynastic history and veritable records were intended to be transmitt[ed] to posterity? Did he never himself read the Diary since it was a short, private account of the founding of his house, and so remain[ed] completely ignorant of its content and the necessity for its destruction? All these questions, unhappily, remain unresolved. ${ }^{43}$

\section{Taizong's Personality and his Interest in Historiography}

The answer to these questions seems to lie in Taizong's personality. He was curious and anxious to see the records; he was even in favor of influencing the records. Yet as a brave man he respected the bravery and uprightness of other persons. Wen Daya had been a trusted associate of Taizong as well as of his father. Maintaining the relationship between the two may have been more important than destroying a historical record at odds with official history. Taizong had not incorporated this record into the approved Veritable Records of Gaozu (Gaozu shilu). Wen Daya's work dealt with his father only during the period before his enthronement in 618. Consequently, it did not deal with Taizong's rule. Yet by portraying Gaozu (Li Yuan) favorably, it potentially undermined the heroic image of Taizong, and shed a different light on his violent ascent to power-killing two brothers and forcing his father to abdicate during the Xuanwu gate incident of July 626 .

Taizong's long-term associate and minister Wei Zheng had worked until the last minute with the emperor of the defunct dynasty and had gone over to the Tang side only after the conquest of the capital. His first patron, moreover, was not Taizong but his brother, the assassinated crown prince. Taizong did not hold these acts against Wei Zheng. Instead as he 'needed all the men of high caliber he could recruit to

\footnotetext{
${ }^{43}$ Wechsler, Mirror to the Son of Heaven, pp. 26-27.
} 
aid him in governing the empire, ${ }^{44}$ he did not hesitate to employ him in his service. Wei Zheng benefited from the atmosphere of powersharing in the early years of the dynasty. In Wechsler's words: 'There was an impressive degree of official participation in decision making and official freedom to criticize the throne, more perhaps, than during most other periods of history. ${ }^{35}$ It was within this atmosphere that Wei Zheng worked with Taizong. ${ }^{46}$ Wei Zheng was the emperor's close associate for 17 years and has been seen 'as a prime motive force behind the success' of the Zhen Guan period. ${ }^{47}$ Wei Zheng's past was brought up only once in this relationship. ${ }^{48}$

In general Wei Zheng's frankness was appreciated by the emperor. But this exceptional emperor who was concerned about his historical image could not resist asking the official in charge of recording the deeds and actions of the emperor:

Generally, is the ruler allowed to examine [the records] or not? We wish to read these records so that We may take as a warning what they consider to be Our successes and failures. ${ }^{49}$

The response of this official named Zhu Shuliang to the emperor has acquired proverbial qualities. He said:

'I have never heard that rulers could themselves examine the histories [of their reigns].' Taizong said: 'If We have bad points, must you record them?' Suilang replied: 'I have heard that 'it is better to fulfill the duty of one's office than an obligation towards one's ruler. [italics added. I.T.] My duty in office is to uphold the brush, so how could I not record them? ${ }^{50}$

${ }^{44}$ Wechsler, Mirror to the Son of Heaven, p. 75.

${ }_{45}$ Wechsler, Mirror to the Son of Heaven, p. 4.

${ }^{46}$ These years of collaboration between the emperor and his adviser were seen as exemplary throughout Chinese history. In the 18th century we see the young prince who later became the Qianlong emperor reading this work as an account of "the model king whose record was required for all who aspired to rule." Harold L. Kahn, 'The Education of a Prince: The Emperor Learns His Roles', in: Approaches to Modern Chinese History, Albert Feuerwerker, Rhoads Murphey and Mary C. Wright, eds. (Berkeley; Los Angeles 1967) p. 26.

${ }^{47}$ Wechsler, Mirror to the Son of Heaven, p. 2.

${ }^{48}$ Being angry at Wei Zheng Taizong is quoted saying: "Wei Zheng was not an official who righteously followed Our Office [as Prince of Qin], yet We selected him from the midst of criminals and gave him wealth and honor." Wechsler, Mirror to the Son of Heaven, p. 153.

${ }^{49}$ Wechsler, Mirror to the Son of Heaven, pp. 22-23.

${ }^{50}$ This passage is from Zhengguan Zhengyao $7.7 \mathrm{~b}-8$ translated by Wechsler, Mirror to the Son of Heaven, p. 23, n. 45. 
The 11th-century historian Sima Guang tells us that although there were vehement protests from the remonstrating councilor (jianyi dafu) 'the emperor did not pay heed.' That is, he did not listen to the protests. Wechsler states: 'He [Taizong] ordered Fang Xuanling and his fellow historians Xu Jingzong and others, to edit the dynastic history into chronicle (bian-nian) form, the results of which were the Gaozu and Taizong Veritable Records.' He goes on to say that 'It is apparent, then, that during the period of their compilation both the dynastic history and the Veritable Records received Taizong's strong editorial influence. ${ }^{51}$

Finally when the Veritable Records were completed they were brought to his attention in the seventh month of 643. Examining these records he was not satisfied with the way the records dealt with the Xuanwu Gate incident. At the Xuanwu Gate, north of the palace, Taizong, then prince Li Shimin, had assassinated his elder brother the crown prince and forced his father Gaozu (Li Yuan) to abdicate. Looking back in 643 Taizong commented:

My action was as righteous as theirs because it has brought security to the state and benefit to all the people. Why then do the historians obscure [this fact] with their brushes? They should delete their embellishments and write a true account of the affair. ${ }^{52}$

This passage from the private history of Wu Jing (Zhengguan Zhengyao) tells us that the emperor did not object to the recording of the events themselves, but to the fact they had been described in obscure language. Taizong was insistent that they should be recorded directly, and without any attempt to hide them. This was the reason, Taizong stated, he asked for a correction. ${ }^{53}$ Thus from the account in the second private history written about this early period, we have a glimpse of the real man who was not interested in destroying a private account because it was not in line with his own outlook, yet made sure that this view was not represented in the official historiography prepared during his reign.

\footnotetext{
${ }^{51}$ Wechsler, Mirror to the Son of Heaven, p. 24.

${ }^{52}$ Translated by Wechsler, Mirror to the Son of Heaven, p. 24, n. 49 from Zhenguan Zhengyao $7.8 \mathrm{~b}$.

${ }^{53}$ Twitchett, Writing of Official History, p. 125, n. 18 where Twitchett denies that Taizong falsified history, as stated by Wechsler, Mirror to the Son of Heaven, pp. 22-27.
} 
It seems that Tang Taizong was a courageous person. This impression of his personality first emerged from the passages in the chapter on the Early Türk in the Jiu Tangshu where he boldly faced the enemy (the Early Türk), had a man-to-man relationship with the Early Türk rulers, delivered long speeches, but also listened carefully to his advisers. Visiting Chaoling, the monumental mausoleum that he built for himself, and studying the names of his horses and his poems reflecting his joy over the victories in Central Asia, one gets the impression that he was a man of great enterprises. However, the fact that Taizong built a smaller mausoleum for this father again suggests his concern about his personal reputation in relation to that of his father.

\section{The Emperor Changing the Unfavorable to his Favor}

The tone of majestic boldness found in the account of Important Principles of Government from the Zhenguan Period also permeates the chapter on the Early Türk (194a) in the Old History of the Tang (Jiu Tangshu, hereafter JTS), the Tang official history. It is interesting to note that although chapter 194-consisting of two parts-is called 'The Tujue (the Early Türk): 1st Part' it does not give much information about the Early Türk.

The chapters on foreign peoples in the official histories of the former dynasties written at the Historiographical Office do not usually have such a majestic tone. On the contrary they contain mostly basic information about foreign peoples. For instance when we look at the Zhoushu, Beishi and Suishu-all works completed by 636 as the first task of the Historiographical Office-we see that they talk about social life, customs, and legends of the Early Türk. These earlier histories as well as the earlier versions of the Veritable Records on which the Old History of the Tang was based, were written at about the same time. Therefore this kind of 'anthropological' information was sometimes repeated, yet omitted at other times. The chapter on the Early Türk in the JTS does not contain any such 'anthropological' information, which can be found in other chapters. The JTS moreover, was written from the political perspective and framework of the early Tang: it glorifies Tang Taizong as the emperor who won a victory over the Early Türk, making them dependents of China. The chapter only briefly deals with previous matters, such as the rule of warlords in North China, the famous Mayi or 'Horse [Bazaar] City', and the Early Türk's constant raids which posed difficulties for the early Tang. 
Interestingly, the section which deals mainly with the five years leading up to the submission of the Early Türk occupies more than half of the chapter, while the rest of the chapter deals with the period after 630 to 740 - that is with a period of more than a hundred years. The disproportionate weight given these five years in Taizong's early reign show the relevance of this phase for the glorification of the emperor. ${ }^{54}$ In this part we come across Taizong's policies dealing with the Early Türk rather than with information about the Early Türk themselves. Neither their life style nor their social organization or their customs and beliefs are mentioned. Likewise, there is no information about economic organization or trading activities. The Early Türk are presented as a people that the reader is already familiar with. Furthermore they are depicted as a culturally static society. The name Early Türk (Tujue) is used in alternation with names of their cultural 'forefathers' the Xiongnu. There are some lengthy passages about the psychological characteristics of the Early Türk. They are portrayed as people with a distinct culture and history. These passages give the impression of having been composed by a process of cut and paste.

The major emphasis is on the question how the Early Türk fell under Tang rule. The process leading to this achievement is described in great detail, not as a mere chronology of events, but as part of a larger discourse on how rulers have to deal with such complicated situations. As a result there are long passages of memorials presented to the throne and replies by Taizong, all discussing policies. These documents, on the one hand, display Tang Taizong's achievements; on the other hand, they convey in general terms how an unfavorable situation can be changed to one's advantage. For Taizong, the feat of changing an unfavorable situation into a favorable one was so important that it functioned like the major melody in a symphony, a theme recurring in his poems as well as in the Tang official history. ${ }^{55}$

In order to understand the complexity of the issues involved it would be helpful to first look at how Taizong became emperor and examine his situation before and after becoming emperor. How did these situations affect historiographical writing? The following four phases represent the major landmarks in Tang Taizong's political life:

\footnotetext{
${ }^{54}$ Jiu Tangshu, pp. 5153-5166.

55 See Helmuth Wilhelm and David R. Knechtges, 'T'ang T'ai-tsung's Poetry', T'ang Studies 5 (1987) pp. 1-23.
} 
1. Li Shimin as a prince

2. The Xuanwu Gate incident

3. Li Shimin's ascendance to the throne in August of 626

4. Tang Taizong's victory over Early Türk in April 630

However, instead of following this chronology, the chapter was composed in a narrative style in which perspectives of different persons were given. This style blurs the chronology: Li Shimin appears as if he had always been known as Taizong. Although Taizong's success in bringing the Early Türk under Tang control was greatly emphasized, his newly acquired title of Tian Kohan (Tengri Qaghan) received only little attention. In view of the fact that the chapter on the Early Türk in the JTS does not mention enthronement and speaks of him as Taizong even during the time when he was a prince, we can see that mentioning his ascendancy would also be an allusion to the Xuanwu Gate incident. Avoiding a chronological account meant that the Xuanwu Gate incident need not be mentioned.

We have first a narrative telling us how things happened under Taizong; then we are presented with a view involving Elig Qaghan (Xieli Kohan) and then another view from the side of Tuli Qaghan (Tuli Kohan). All these different perspectives are then followed by lengthy discussions at the court evaluating the submission of the Early Türk. While this evaluation is being carried out, there are many retrospective glances to the recent past as well as to the remote past involving the Xiongnu. These discussions, on the other hand, were being carried out to shape policies for the future, especially in terms of what to do with the submitted households and where to settle them. Let us examine more closely how at the beginning the situation was not so favorable for Taizong and how he was able to change these circumstances to his favor and to advance the prosperity of his state and empire.

Li Shimin was Gaozu's second son; his father had named his eldest son, and not Li Shimin heir to the throne. We are told that Li Shimin grew up in the border areas and spent a great deal of his childhood and youth in close contact with the Early Türk. We also know this from his own words when he makes a remonstrance against Tuli Kohan reminding him of their bonding and vow by incense (xiang huo). ${ }^{56}$ It is probably this statement that led to the rumors that he

${ }^{56}$ Jiu Tangshu, p. 5156 and İsenbike Togan, Eski T’ang Tarihi 194a, p. 126. 
was a childhood friend of Elig Qaghan (Xieli Kohan)'s nephew Tuli Qaghan (Tuli Kohan). While Li Shimin was spending time in the border areas practicing military arts, his elder brother was gaining stature among bureaucrats from East China at the capital. This situation made Li Shimin eager to take charge of the situation, and led to his assassination of his elder and younger brothers in 626 at the Xuanwu Gate in Chang'an. This gate was at a strategic location at the center of the north wall of Chang'an and opened the way to the Palace City. Li Shimin spread a false rumor about his brother who thereupon proceeded to the court to defend himself. With twelve of his most trusted followers-his brother-in-law Zhangsun Wuji being among themLi Shimin waited in ambush and killed his elder brother. In the aftermath Li Shimin was proclaimed heir apparent and on 4 September 626, Gaozu had to abdicate in Li Shimin's favor. ${ }^{57}$

These actions violated the Confucian principles, which required respecting one's father and elder brothers. But the times were such that military skill and the ability to pull together different factions were much needed. In the years preceding the collapse of the Sui, north China had been torn apart among warlords; these warlords in many cases were supported by the Early Türk. ${ }^{58}$ As a skillful politician and valiant leader who also knew the Early Türk and their ways, Li Shimin was able to overcome the remaining obstacles and ascend to the throne. From then on he would be called huangdi 'emperor' or jinshang 'the reigning sovereign' as stated in his first Veritable Records. Taizong was his temple name which was used posthumously.

Tang control over the Early Türk changed the balance of power in Asia in China's favor, and paved the way for subsequent prosperity. For Taizong, this achievement was first and foremost a result of his ability to change an unfavorable situation into a favorable one. This skill is emphasized in the historiography of his time, created under the supervision of the emperor. Taizong had a say in the compilation of the Veritable Records both for his father-with whom we know he had problems-and for himself. Examples of his involvement in history writing show how he viewed and influenced his father's and his own reputation, while trying to find a balance between personal and

${ }^{57}$ Howard Wechsler, 'The Founding of the T'ang Dynasty: Kao-tsu (reign 618-26)', in: The Cambridge History of China III. Sui and T'ang China, 589-906, Denis Twitchett, ed. (Cambridge 1979) pp. 182-187.

${ }_{58}$ Wechsler, 'The Founding of the T'ang Dynasty', p. 164. 
dynastic interests. ${ }^{59}$ He seems to have privileged dynastic reputation and issues of long-lasting impact.

\section{Taizong as a Man in Pursuit of a Long-Lasting Image}

We will now examine Taizong's interest in historical record keeping on the basis of the chapter on the Early Türk in the JTS. The chapter begins with Gaozu's igniting the uprising against the Sui in Taiyuan. Soon we are informed that Gaozu had to ask the help of the Early Türk which was duly rendered: the Early Türk Qaghan sent troops and horses.$^{60}$ Later, however, we are told that on 24 September 626 Taizong told the Early Türk envoy 'when the righteous army entered the capital for the first time, your [ancestors], father and son sincerely submitted to us and followed us. ${ }^{61}$ It is apparent that this statement is in conflict with what was said at the beginning of the chapter, which stated that Gaozu requested help from the Early Türk.

Moreover, there is additional information which is not to be found in JTS but only in Wen Daya's work. ${ }^{62}$ There it is said that Gaozu sent a letter to the Early Türk Qaghan, Shibi, 'professing a desire to save the Sui and, to that end, offering to restore harmonious relations with the Early Türk.' H. Wechsler comments: 'The proposal was sweetened with the promise that if Shibi allied with Li Yuan, all the booty to be gained from the campaigns against the rebels would be turned over to the Qaghan. The letter was very respectful in tone, and when it was completed Li Yuan affixed to it the character $q i$ "communication from inferior to superior." ${ }_{63}$ There is a scholarly controversy about the exact meaning of this issue, ${ }^{64}$ but the exact meaning of the term is not an issue here. Our concern is that although Gaozu's asking for help is a fact established by the JTS as well as by Wen Daya's work, according to the record cited above on 24 September $626 \mathrm{Li}$ Shimin, the later Taizong, stated just the opposite.

\footnotetext{
${ }^{59}$ Jiu Tangshu, p. 5157 and Togan, Eski T'ang Tarihi, p. 134.

${ }^{60}$ Jiu Tangshu, p. 5153 and Togan, Eski T'ang Tarihi, pp. 87-89.

${ }^{61}$ Jiu Tangshu, p. 5157 and Togan, Eski T'ang Tarihi, p. 134.

${ }_{62}$ Wen Daya, Datang chuangye qijuzhu (Shanghai 1983) vol. 1, pp. 11-12.

${ }^{63}$ Wechsler, Mirror to the Son of Heaven, p. 28; Wen Daya, Datang Chuangye qijuzhi, vol. 1, p. 9.

${ }^{64}$ Wechsler, Mirror to the Son of Heaven, p. 28, n. 60 and Wechsler, 'The Founding of the T'ang Dynasty', p. 158.
} 
Obviously Gaozu's asking for help could diminish his personal standing in history. Conversely, it potentially enhanced Taizong's personal status, as he had proved able to drastically change the balance in his favor. Assuming that Taizong's conflict with his father outweighed other concerns and that he was willing to change the records to improve his standing, Taizong should have destroyed Wen Daya's work. In that case, moreover, he would have insisted firstly on mentioning Gaozu's use of a term indicating respect for the superior in his address to the Early Türk. Secondly, he would not have made any statement about the Early Türk being the followers of the Tang when they entered Chang'an for the first time, as this statement put his father in a better light. From these discussions we can see that it was not his personal standing but issues of lasting importance for the dynasty that seem to have been central for him.

Another matter demands our attention. The 24 September statement of majestic boldness cited above was made just two days before the agreement on the Bian Bridge to the west of Chang'an. ${ }^{65}$ Wechsler says:

According to the traditional account, at this point Taizong employed a strategem to separate Xieli from his main force, surround him with a small band of his men, and convince him to sue for peace $[\ldots .$. However, there is evidence that in fact Taizong not only failed to capture the Tujue Kaghan but also he was forced to part with a great deal of treasure to secure the Tujue withdrawal. ${ }^{66}$

Taizong himself alluded to the fact that the agreement of the Bian Bridge on the Wei River had been won by giving out riches. ${ }^{67}$ Issuing the strongly worded statement just two days prior to the negotiated agreement gives the impression that Taizong had a strong hand, which was not the case. Here we can see Taizong's impact on historical record keeping; he influenced the tone, the light under which an event was shown rather than changing the wording or the record. In the account we also hear that suddenly the Early Türk Qaghan Elig (Xieli)

${ }^{65}$ Jiu Tangshu, p. 5157 and Togan, Eski T'ang Tarihi, p. 141.

${ }^{66}$ Howard Wechsler, 'T'ai-tsung (Reign 626-49). The Consolidator', in: The Cambridge History of China III. Sui and T'ang China, 589-906, Denis Twitchett, ed. (Cambridge 1979) p. 221.

${ }^{67}$ JTS 194s:5158 and Togan 2006, 5158: 6-8; see also Tang Chi, 'Wei Nehri Barış Anlaşmasına Dair Araştırmalar', Tarih Dergisi (İ̈EF) Fatih Sultan Mehmed'e Hatıra Saylsı 33 (March 1980/81) [1982] pp. 215-226. 
became apprehensive, considered withdrawing and asked for peace. Tang Chi's study shows in detail that this was not case. Elig Qaghan (Xieli) had nothing to be apprehensive about.

It is also to be noted that the agreement was made by sacrificing (cutting) a white horse. ${ }^{68}$ In the JTS text this incident is described with the words xing baima. This is a custom found among different Inner Asian peoples. Tang Chi has given examples from the Xiongnu. ${ }^{69} \mathrm{We}$ also know of similar incidents from the Secret History of the Mongols where a vow is made by cutting a white horse in two. I am not familiar with such a custom prevalent among the Chinese, although Wechsler calls it the traditional sacrifice; Tang Chi also sees this as an Inner Asian custom. ${ }^{70}$ As Taizong was familiar with the ways and customs of the Early Türk, he did not shy away from pleasing them both materially and psychologically. Alluding to this incident, he later remarked: if you want to get hold of something, you have to give. ${ }^{31}$ Taizong flexibly adapted to a difficult situation, with the Early Türk present in the interior of the country, while he himself had only recently, and not without difficulty, ascended the throne. As he could not hope to completely control this situation, he chose not to fight, even if this could be achieved only by giving out jade and silk:

Today if I roll up my armor and put away my bow case and lance and can lure them with silk and jade, the haughty manners of the obstinate enemy will starting from now come to an end. ${ }^{72}$

The lesson is clear: a ruler needed to have patience, give in if necessary and wait for the right moment.

When the right moment came in 630, Taizong was quick in defeating and subjecting the Early Türk. At this time the Türk were in distress because of weather conditions and internal strife. Revolt by subjugated tribes in the north added another dimension to their difficulties. After emerging successfully Taizong did not shy away from accepting the title of the defeated enemy 'Heavenly Qaghan (tian kohan)'. The way in which he accepted this title, symbolizing hegemony over the 'steppe and the sown' is also of significance. After April 630 when Elig Qaghan

\footnotetext{
${ }^{68}$ Jiu Tangshu, pp. 5157 and 5158 and also Togan, Eski T'ang Tarihi, pp. 141 and 143.

${ }^{69}$ Tang Chi, 'Wei Nehri Barış Anlaşması'.

${ }^{70}$ Wechsler, 'T'ai-tsung', p. 221.

${ }_{71}^{71}$ Jiu Tangshu, p. 5158 and Togan, Eski T'ang Tarihi, p. 145.

72 Jiu Tangshu, p. 5158 and Togan, Eski T'ang Tarihi, pp. 144-145.
} 
(Xieli) submitted to China, messengers came from the North who asked Taizong to accept the title of Heavenly Qaghan (tian kohan), because he was now the rightful ruler. Although there is some confusion in the sources regarding the bearers of this request, his assumption of this title had a historical significance. ${ }^{73}$ Thus Taizong acquired this not by warfare $w u$; it was presented to him voluntarily. He was now the universal ruler, both Son of Heaven (tianzu) of the 'sown' and Heavenly Qaghan (tian kohan) of the steppe, thus symbolizing the harmony all under Heaven.

With these achievements Taizong towered above the local powers in China as well as in the steppe and was able to change the balance of power in Asia in China's favor. He expanded his lands as far west as Ferghane in present Uzbekistan, a process bringing western Asian cultural influences to China as well as acknowledgement of Chinese culture in western Central Asia. ${ }^{74}$ Taizong's universalist position made him promote all-embracing policies toward different religions, too. In this connection Kenneth Chen says in his Buddhism in China:

In his policy toward Buddhism during the early years one might discern the emperor's desire to use the religion for the benefit and advantage of the state. ${ }^{75}$

Chen also states that:

Though the imperial clan claimed descent from Laozu-actually this idea was emanating from Taizong - and thus favored Taoism, the central authorities pursued a policy of religious toleration, giving each religion an opportunity to develop. Nestorian Christianity, Islam, and Manichaeism all were introduced during Tang times, and each faith found adherents among the Chinese. ${ }^{76}$

These policies that were put forward by Taizong can be called allembracing and universalist. It was within this atmosphere that the Tang history project was initiated and brought to completion.

\footnotetext{
${ }^{73}$ Our sources say that the request was made by northern tribes but the names that are mentioned are western tribes.

${ }_{74}$ Berthold Laufer, Sino-Iranica: Chinese Contributions to the History of Civilization in Ancient Iran, with Special Reference to the History of Cultivated Plants and Products (Chicago 1919).

${ }^{75}$ Kenneth Ch'en, Buddhism in China (Princeton 1964) pp. 217-218.

${ }^{76}$ Ch'en, Buddhism in China, p. 213.
} 


\section{Conclusion}

There is a general tendency to regard Chinese historiography as being designed to teach moral lessons. 'The judicious selection of materials and the coloring of narrative for effect' were geared towards illustration of these lessons. However, under the early Tang there was an additional dimension to history writing. The Tang dynasty showed a resoluteness to take history writing under control and shape the past in such a way as to make it a guideline for the future. This was not done on the basis of authoritarian principles but reflected power-sharing.

While earlier histories had been composed by individuals, the Tang history was written by a commission. The writing of history by a group of officials reflects the consensus reached by those who shared power. The timing of this project is noteworthy as it immediately followed the 630 military victory over the Early Türk who had been ruling since 552 . This significant victory occurred outside the territory of early Tang China. However, the glorification of this victory was accompanied by the construction and renovation of palaces, the building of funerary complexes, the establishment of new rituals in connection with these complexes, and the introduction of a history writing project. ${ }^{77}$ The victory in the exterior strengthened the imperial hand in instituting and implementing new policies in the interior, leading to centralization and the concentration of power. It was precisely these developments which later led to the glory of the Tang.

The success of the Tang was possible only because Emperor Taizong was a man who had the ability to change the unfavorable to his favor. This skill gave him a strong hand in initiating his history writing project. By the ingenious method that he initiated he was able to sanction the completion of the Veritable Records providing the basis for official history. Setting the tone for the future, he paved the way for official history written by commissions-a method employed by later dynasties. As he was a person interested in long-lasting implications rather than short-term policies, he emerged from this project as the model emperor of the 'good rule of the Zhenguan reign' who was known for his tolerance for criticism and for permitting the participation of court officials in decision making.

77 Howard Wechsler, Offerings of Jade and Silk: Ritual and Symbol in the Legitimation of the T'ang Dynasty (New Haven, Connecticut 1985). 


\title{
TO BE A PRINCE IN THE FOURTH/TENTH-CENTURY ABBASID COURT
}

\author{
Nadia Maria El Cheikh
}

Court studies are almost nonexistent for early Islamic history, including the Abbasid era. Many questions need to be investigated in connection with the Abbasid court. What terminology was used in the sources to define the court and the courtiers? Who was a 'courtier'? What was the distinction between the household and the bureaucracy? How was the environment around the ruler organized spatially? Who filled it? How did it represent itself, and with what degree of ceremonial or spectacle? What were the rights and duties, obligations and privileges of the officers within the court and household? What do the sources tell us about the members of the caliphal households, whether women or princes?

In recent years, historians of the court have become interested in the ritual and symbolic aspects of rulership as part of the political system. They have, additionally, refocused attention on the whole personal and domestic world within which the ruler lived. ${ }^{1}$ This paper explores one aspect of the personal world that constituted the fourth/ tenth century caliphal court by focusing on the life and career of the Abbasid prince Abu al-'Abbas, eldest son of the caliph al-Muqtadir (AH 295-320/CE 908-932). Questions that I discuss revolve around the various spaces in which the prince lived, the education and tutorship that he received, the duties to which he was assigned from an early age, and the ceremonial role that he assumed. Information about his life prior to his assumption of the caliphate help us formulate a conception of the expected roles of princes at the fourth/tenth century Abbasid court, the possibilities and limitations open to them, and the networks that formed around them.

I have elsewhere investigated the varieties of functions that the eunuchs and harem stewardesses performed in the early fourth/tenth century Abbasid court. These investigations, like the one reported

\footnotetext{
1 Trevor Dean, 'The Courts', Journal of Modern History 67 (1995) pp. 136-151.
} 
here, are based on the premise that it is essential to limit the inquiry to a particular historical moment in order to free ourselves from the 'deadly sameness' of abstraction which allows no differences among times and places. ${ }^{2}$ The narratives pertaining to the reign of the Abbasid caliph al-Muqtadir offer particularly rich grounds for such an investigation. Accounts of this period underscore the weakening of the institutional integrity of the Abbasid caliphate which in turn contributed to problems plaguing the caliphate in the first part of the fourth/ tenth century. In this view, the youth and personal incapacity of alMuqtadir, in contrast to the vigour and ability of his immediate predecessors, opened the door to the 'meddling' of harem women and influential 'courtiers'. The sources for the reign of al-Muqtadir are, in some ways, unique in providing insights on the workings of the 'court' and the domestic world. For this particular period we are able to get behind the scenes and have a glimpse at the personal and informal networks operating at court.

\section{The Abbasid Courtier: Some Definitions}

The Abbasid court of the fourth/tenth century was polycentric and eclectic and seems to have constituted a space open to a vast range of outside influences. Sourdel defines the Abbasid elite as 'all those who surrounded the caliph, who had access to him, who were part of the court or the administration, and who served as his delegates in the army and the judiciary.' There was, thus, no real 'nobility' but rather those 'whose functions rather than their birth' provided them with the privilege of attending the caliph's audiences, of participating in the mazalim court and of figuring among those who gave the oath of allegiance to the new ruler. ${ }^{3}$

The term that most closely describes the courtiers is al-hashiya/alhawashi. In Tajarib al-umam, the most notable source for this period, Miskawayh (d. 421/1030) mentions that 'Ali b. 'Isa abolished increases which had been extended to all ranks of the army, to the eunuchs (al-khadam), to al-hashiya, and to all clerks (al-kuttab) and employees

\footnotetext{
2 Adrienne Rich, 'Notes Towards a Politics of Location', in: Feminist Postcolonial Theory: A Reader, Reina Lewis and Sara Mills, eds. (Edinburgh 2003) pp. 29-42.

3 Dominique Sourdel, l'État imperial des caliphes abbasides: VIII $-X^{e}$ siècle (Paris 1999) pp. 212-213.
} 
(al-mutasarrifin). In one passage Miskawayh states that the vizier Ibn al-Furat proceeded to examine 'Ali b. 'Isa with reference to the allowances of the hashiya: 'You, he said, in the five years of your administration, reduced the allowances of the harim (the court of women), the princes, al-hasham and the horsemen. In his defence, 'Ali b. 'Isa answered: 'Your plan for meeting expenditure was to transfer sums from the private to the public treasury, thereby pleasing the hashiya...' From this passage it would seem that the term al-hashiya is inclusive of the harim, the princes, the hasham and the horsemen. ${ }^{4}$

Miskawayh also provides another list where he states that during his second vizierate, 'Ali b. 'Isa adopted strict measures. He reduced the allowance of the eunuchs (al-khadam), the courts attendants (alhasham), the courtiers (al-julasa'), the table-companions (al-nudama'), the minstrels (al-mughannin), the purveyors (al-tujjar), the intercessors (ashab al-shafa'at) and those of the retainers (ghilman) and the dependents of the heads of bureaux (asbab ashab al-dawawin). ${ }^{5}$ Evidently large categories of people were implicated, making it quite difficult to determine the boundaries between the different categories of courtiers, retinue and bureaucrats. ${ }^{6}$

Another term which defines at least one circle of courtiers is the khassa/khawass. The khawass of al-Muqtadir are singled out among those who refused to partake in the conspiracy of Ibn al-Mu'tazz. Miskawayh states: 'There were present the commanders of the army, the heads of bureaux...the judges and notables (wujuh al-nas), with the exception of Abu al-Hasan b. al-Furat and the khawass of alMuqtadir." One way of defining the term is by exclusion: The term would thus exclude the groups that appear on this list. That the two terms khawass and hawashi define different categories of people seems clear in al-Sabi's text where it is stated that al-khawass and al-hawashi paid official visits to the vizier. ${ }^{8}$ But are these really two categories of people, clearly distinct, particularly in the minds of our authors? In his

${ }^{4}$ Ahmad b. Muhammad Miskawayh, Tajarib al-umam, Henry F. Amedroz, ed. (Oxford 1920) vol. 1, p. 108; Henry F. Amedroz and David S. Margoliouth, trans., The Eclipse of the Abbasid Caliphate (Oxford 1921) vol. 1, pp. 120-121.

${ }^{5}$ Miskawayh, Tajarib, vol. 1, p. 152; Amedroz and Margoliouth, Eclipse, vol. 1, pp. $170-171$.

${ }^{6}$ David Bruce Jay Marmer, The Political Culture of the Abbasid Court, 279-324

(A. H.), unpub. PhD. Diss., Princeton University (Princeton 1994) p. 183.

${ }^{7}$ Miskawayh, Tajarib, vol. 1, p. 5.

${ }^{8}$ Hilal al-Sabi', Kitab tuhfat al-umara' fi tarikh al-wuzara' (Beirut 1904) p. 268. 
discussion of the literary genre of the mirror of princes, al-'Allam lists the following seemingly synonymous terms referring to the courtiers: hashiya, khassa, bitana, a'wan, atba', khassat-al-khassa. ${ }^{9}$ There is a lack of clarity as to what these terms exactly mean in the various contexts in which they appear. The ways in which these terms were used in the texts and the ways in which they have been translated mask a confusion and an imprecise conceptual understanding of the terms and of the categories implied. It is, thus, necessary to undertake an exhaustive study of Abbasid terminology that would rely on concordances.

The other way, which is the one I have been pursuing, is to follow the life of particular individuals associated with the court. I have previously investigated the lives and careers of the caliph's mother, of the harem stewardesses Umm Musa and Zaydan, of the eunuch Muflih, and of the chamberlain Nasr. Tracing the roles of one of the princes helps fill the gap in our understanding of the roles of court and household during the caliphate of al-Muqtadir.

\section{The Birth of a Prince}

Archaeologically, the palaces related to the Abbasid dynasty in Baghdad are not well known since almost nothing of the monuments and of the urban fabric of the Abbasid city remains. However, some information about the Baghdad palaces can be derived from literary descriptions. ${ }^{10}$ We know that starting with the reign of al-Mu'tamid (256-279/870-892), the Hasani palace, built during the reign of Harun al-Rashid (170-193/786-809), became the center of a huge mass of buildings which were to form the core of Dar al-Khilafa. Al-Mu'tadid (279-289/892-902) built two palaces called al-Thurayya and al-Firdaws and laid foundations of a third, Qasr al-Taj. All three buildings stood on the Tigris bank, with great gardens stretching to the back, enclosing many minor palaces within their precincts.

By the time of al-Muqtadir, the caliphal residence had expanded into a vast complex of palaces, public reception and banqueting halls, residential quarters, prayer halls and mosques, baths, pavilions, sports grounds, pleasure and vegetable gardens, orchards and the like. It

9 'Izz al-Din al-'Allam, al-Sulta wa al-siyasa fi al-adab al-sultani (n. p. 1991) pp. 95-99.

io Oleg Grabar, The Formation of Islamic Art (New Haven 1987) p. 134. 
occupied an area nearly a square mile in extent, surrounded by a wall with many gates. ${ }^{11}$ The caliphal residence came to resemble a small city, deep within which the caliph and his throne room were located, reached by a long route. Al-Muqtadir enlarged al-Taj which became the principal caliphal residence and which was linked by a subterranean passage to the palace of al-Thurayya for the benefit of the harem women. ${ }^{12}$ The expansion of the palace complex allowed for the spatial articulation of political hierarchy.

Al-Muqtadir and his family lived in this great complex surrounded by his court and his guards, removed from the population and any agitation. Entry was reserved for a select group of individuals; that the rest could only imagine the opulence within the palace walls added to the mystery enshrouding the palace and increased the perception of distance separating the caliph from his people. ${ }^{13}$

The Dar al-Khilafa functioned simultaneously as a stage set for the representation of caliphal power, as the administrative centre of a vast empire and as a residence for the caliphal family. Prominent women had their own apartments within this complex and it is probably from this time that a separate women's quarter within the palace first emerged. ${ }^{14}$ The family members in the Abbasid harem of the early fourth/tenth century included the caliph's mother, the wives of the caliph, his concubines, the children and the unmarried, widowed or divorced sisters and aunts. The harem also included the administrative officers of the harem, and the female servants who performed the housekeeping tasks of the harem, and female slaves. Concerning the harem of al-Muqtadir, al-Sabi' states that: 'It is believed that in the days of al-Muqtadir...the residence contained 11,000 servants ...4,000 free and slave girls and thousands of chamber servants. ${ }^{15}$

The polygamous nature of the fourth/tenth-century caliphal harem was real. The notion of polygamy is not limited to the four legal wives but to the multiplicity of concubines who populated the caliphal harem. The concubine, once she had borne a child, became an umm walad and enjoyed a legally and socially enhanced position. The hope

${ }^{11}$ Guy Le Strange, Baghdad during the Abbasid Caliphate (Oxford 1900) p. 263.

${ }_{12}$ Le Strange, Baghdad, pp. 252-255; Yaqut, Mújam al-buldan (Beirut 1956) vol. 2, p. 4.

${ }^{13}$ D. Fairchild Ruggles, Gardens, Landscape, and Vision in the Palaces of Islamic Spain (University Park, Pa. 2000) p. 92.

${ }^{14}$ Hugh Kennedy, The Court of the Caliphs (London 2004) p. 164.

${ }^{15}$ Hilal al-Sabi', Rusum dar al-Khilafa, Mikha'il 'Awwad, ed. (Baghdad 1964) p. 8. 
of attaining the status of queen mother must have been entertained by every concubine taken into the harem. The prospect was not impossible since al-Muqtadir's mother herself had climbed through these ranks: A Byzantine by birth, she was bought by the caliph al-Mu'tadid; after giving birth to her son, Ja'far, she achieved the status of umm walad and was freed on al-Mu'tadid's death.

One concubine in the harem of al-Muqtadir was Zalum. On Tuesday night, the fifth of Rabic II, the year 296/908, Zalum brought forth to the world Abu al-'Abbas Muhammad, the eldest son of al-Muqtadir. ${ }^{16}$ Zalum is not mentioned on this occasion. It is only later on, once her son became caliph, that Zalum is mentioned in the sources. ${ }^{17} \mathrm{Her}$ bringing forth a male child meant that she would be freed as $u m m$ walad on al-Muqtadir's death. Upon the accession of her son to the caliphate, she would become an influential person at the court.

'Arib mentions that Abu al-'Abbas was born in Dar Hanina', just before dawn. ${ }^{18}$ The royal children lived with their mothers in the harem of the caliphal palace. In 302/914, at five years of age, Abu al-'Abbas and four of his brothers were circumcised and honoured with a lavish celebration. ${ }^{19}$ Al-Suli also provides a vignette which shows all the royal children gathered around their father, al-Muqtadir. The youngest son at the time was al-Fadl. The caliph made him sit with him on his throne and cuddled him. The caliph thought that his action may have displeased his eldest son Abu al-'Abbas, and so he addressed him reminding him that al-Fadl was the youngest: 'It still holds true that tenderness and playfulness are the share of the youngest, while respect and due position are the share of the eldest. ${ }^{20}$

One source provides a description of Abu al-'Abbas at a later age, once he had become Caliph al-Radi: He was short and slender, browneyed, high-colored and smooth-cheeked. ${ }^{21}$ One description pertaining

16 Abu Bakr al-Suli, Ma lam yunshar min awraq al-Suli: akhbar al-sanawat 295-315, Hilal Naji, ed. (Beirut 2000) p. 68. See also al-Mas'udi, Muruj al-dhahab wa ma'adin al-jawhar, Charles Pellat, ed. (Beirut 1974) vol. 5, p. 217. Ibn al-Sa'i in Nisa' al-khulafa' (Cairo, n.d.) pp. 106-108, includes some information on one of the concubines of al-Muqtadir: Khumra who was an umm walad.

${ }^{17}$ Abu Bakr al-Suli, Akhbar al-Radi billah wa al-Muttaqi lillah, J. Heyworth Dunne, ed. (Cairo 1935) p. 1.

18 'Arib, Silat al-Tabari, Michael Jan De Goeje, ed. (Leiden 1897) p. 33.

19 Al-Hamadhani, Takmilat tarikh al-Tabari, Albert Kan'an, ed. (Beirut 1959) p. 22.

20 Al-Suli, Ma lam yunshar, p. 32.

${ }^{21}$ Al-Mas'udi, Kitab al-tanbih wa al-ishraf, Michael Jan De Goeje, ed. (Leiden 1993) p. 388. 
to his character as an adult mentions his noble manners, his judicious usage of the literary arts, as well as his active participation in the discussions of the learned and the 'philosophers. ${ }^{22}$

\section{The Education of a Prince}

Abu al-'Abbas was put into the palace school at an early age, in 302/914. ${ }^{23}$ His first tutor was al-'Arudi who was appointed by al-Muqtadir to educate the young prince. ${ }^{24}$ When Abu al-'Abbas was in the prime of his youth al-'Arudi recalls mentioning to the prince a report on the subject of greatness and the attributes of those in leadership, what is to be commanded and what is to be reprimanded. As he spoke, the prince took down notes in his own handwriting. Later on al-'Arudi saw him intently studying what he had written and trying to apply it in his actions. Abu al-'Abbas told his teacher: 'God willing I should achieve these qualities so as to become a paragon of these virtues. ${ }^{25}$

Abu al-'Abbas's most famous tutor was al-Suli (d. 336/946), who wrote a history of the contemporary caliphs based on first-hand knowledge. He was a prominent man of letters in Baghdad, a tutor and companion of several Abbasid caliphs. Evidence of al-Suli's tutorship of Abu al-'Abbas is related in a number of anecdotes. Al-Suli recounts that the chamberlain Nasr prescribed that 'I place myself at the disposition of the two princes, Abu al-'Abbas and Harun.' Al-Suli was assigned to meet with them twice a week. He found the two princes to be intelligent and sensible, albeit lacking in knowledge. ${ }^{26}$

Al-Suli underlines that Abu al-'Abbas was the more refined and more avid learner of the two. He bought for them books of jurisprudence, poetry, language and history. The princes organized their respective libraries and they studied, under the direction of al-Suli, history and poetry. However, al-Suli told them that prophetic tradition, hadith, was more profitable for them than anything else. For that purpose he

\footnotetext{
Al-Mas'udi, Muruj, vol. 5, p. 218.

Al-Hamadhani, Takmila, p. 22.

Al-Suli, Akhbar, pp. 8-9.

Al-Mas'udi, Muruj, vol. 5, p. 222.

Al-Suli, Akhbar, p. 25.
} 
brought into the court the most important traditionist of that time, Abu al-Qasim b. bint Manic. ${ }^{27}$

Al-Suli was appointed to be the tutor of Abu al-'Abbas in 307/91920 and continued in this function until 315/927. During this period he had to struggle with the interferences of the caliph's mother who had her agenda regarding the education of her grandson. Al-Suli recalls a day when Abu al-'Abbas was reading the poetry of Bashar b. Burd and had in front of him books of philology and history when the eunuchs of his grandmother arrived. They took away the books and Abu al-'Abbas was upset with their action. Al-Suli tried to calm him down by saying that his grandmother had been informed that he was reading 'proscribed' books. A few hours later the eunuchs brought the books back. The prince Abu al-'Abbas told them:

Tell whoever ordered you to do what you have done that these are purely learned and useful books on theology, jurisprudence, philology, poetry, history... and are not the kinds of books that you read, such as stories of the marvels of the sea, Sindbad, and the fable of the cat and the mouse..$^{28}$

Al-Suli also taught the princes a number of philological treatises, including the work entitled khalq al-insan, by al-Asma $i$ (d. 213/828). Eunuchs reported to al-Muqtadir and his mother that al-Suli was teaching the princes the names of the genital organs. Chamberlain Nasr once more intervened, interviewed al-Suli, asked him to bring in the volume and then took it to the caliph to explain to him that such knowledge is necessary for jurists and judges. ${ }^{29}$

That the caliph's mother and her entourage had a different view regarding the education of the princes is clearly stated in an anecdote in which the prince Abu al-Abbas is praised by the scholar Husayn al-Mahamili for his knowledge acquired through al-Suli's teaching. Al-Mahamili asked that his praise be reported to the harem stewardess Zaydan: 'What have you done for the man [al-Suli] who has transformed the prince in such a way?' The answer that was given by Zaydan reflected that their ideas were diametrically opposed to those of al-Suli:

${ }^{27}$ Al-Suli, Akhbar, p. 25. The mother of the princes declined to pay the traditionist. It was the chamberlain Nasr who immediately agreed to pay his fees.

${ }_{28}$ Al-Suli, Akhbar, pp. 5-6.

29 Al-Suli, Akhbar, pp. 25-26. 
The qualities of this man [al-Suli] are in the eyes of al-Sayyida [alMuqtadir's mother] and those who serve her, shortcomings. So please tell him: we do not want our children to be men of letters or learned scholars... Look at their father [caliph al-Muqtadir]: we find in him all the qualities that we like and yet he is not a learned man. ${ }^{30}$

It was soon after that al-Suli left the service of Abu al-'Abbas, although he maintained a correspondence with his pupil. ${ }^{31}$ The bonds between the prince and his tutor remained so strong that later on, when Abu al-'Abbas became caliph, he asked al-Suli to help him choose a throne name. ${ }^{32} \mathrm{Al}$-Suli became one of his favoured boon-companions.

At some point in their education, the princes seem to have been assigned to different individuals at court for further training. The tutorship of the princes seems to have constituted one of the spaces of competition of the factions at court. Al-Suli states that Abu al-'Abbas was put under the tutorship of Mu'nis, the commander of the troops (kana fi hijr Mu'nis). ${ }^{33}$ His brother Harun was entrusted to Nasr the chamberlain for training; the third brother 'Abbas grew up under the tutorship of Gharib, the maternal uncle of al-Muqtadir. ${ }^{34}$ The three princes were thus attached to the most important figures at court.

We do not know what kind of tutorship Abu al-'Abbas received from Mu'nis but the loyalty that they felt towards each other was obvious during their difficult years. Upon the death of al-Muqtadir, Mu'nis came out clearly in favour of the succession of Abu al-'Abbas. Miskawayh states that upon the death of al-Muqtadir Mu'nis burst into tears saying:

You have killed him! By God we shall all be killed. The least that you can do is to announce that this happened without your intention or order and to place on the throne his son Abu al-'Abbas, for he is my nursling (tarbiyati); once he becomes caliph, his grandmother... his brothers and his father's retainers will be willing to spend money. ${ }^{35}$

${ }^{30}$ Al-Suli, Akhbar, p. 26.

31 Al-Suli, Akhbar, pp. 27-28.

32 Al-Suli, Akhbar, pp. 2-4.

${ }^{33}$ Al-Suli, Akhbar, p. 5; According to 'Arib, the prince Harun had first as a tutor Nasr the chamberlain and following the death of the latter, Yaqut the chamberlain was appointed as Harun's tutor. In 'Arib, Silat, pp. 154-155.

${ }^{34}$ Al-Suli, Akhbar, p. 5.

${ }_{35}$ Miskawayh, Tajarib, vol. 1, pp. 241-242; Trans. in Amedroz and Margoliouth, Eclipse, vol. 1, p. 272. 
However, when it was observed that to promote this prince would in fact perpetuate the existing regime, Mu'nis yielded to the argument and al-Qahir succeeded.

\section{The Court of the Prince}

Unlike other court models, such as Versailles, for instance, which was self-contained, outside the city, subsuming both the prince's household and the administration, the court of al-Muqtadir was an integral part of the city, a factor manifested by the sheer amount of coming and going between the Dar al-Khilafa and the city of Baghdad. We know that the viziers lived outside the caliphal residence and that they went to court on the days of audience. The palace of Mu'nis was located in the Shammasiyya quarter while the office of the police chief was across the river from the palace complex. ${ }^{36}$ The residence of the Chamberlain Nasr was, by contrast, inside Dar al-Khilafa and this allowed him precious access to the caliph.

Abu al-'Abbas received a home of his own at an early age. In 306/918 the vizier Hamid b. al-'Abbas took up residence in Bab al-Basra, and the caliph gave the vacant waziral palace to prince Abu al- Abbas. ${ }^{37}$ When Ibn al-Furat was appointed vizier five years later, al-Muqtadir returned the waziral palace to him, at his request. There is no indication as to where Abu al-Abbas moved. ${ }^{38}$ Having a residence inside the palace complex would have afforded a useful physical proximity for the prince as he would have been able to influence caliphal decisions in a more immediate way. However, by establishing a residence outside the royal complex, the prince was able to assert his independent political identity. This increased the possibility of his participation in a coup against his father. ${ }^{39}$ Indeed, in 319/931, al-Muqtadir heard that Mu'nis was plotting to carry off the prince Abu al-'Abbas from his palace in al-Mukharrim to Egypt or Syria and there proclaim him caliph. Al-Muqtadir therefore returned the prince from al-Mukharrim

36 Al-Sabi', Rusum, p. 31.

37 Al-Hamadhani, Takmila, p. 30.

38 Al-Hamadhani, Takmila, p. 43.

39 Marmer, Political Culture of the Abbasid Court, p. 137. 
palace to his apartment in the caliphal palace to keep a closer watch over him. ${ }^{40}$

Abu al-'Abbas gradually developed his own sub-court. He acquired very early on a personal retinue. When in 301/913 the commander Mu'nis al-Khazin died, his men were joined to the detachment of Abu al-'Abbas. ${ }^{41}$ We also know that Abu al-'Abbas had a secretary, katib, Abu Sa id b. 'Amru, who was in fact his closest servant (akhass al-nas bihi). ${ }^{42} \mathrm{~A}$ eunuch in the service of Abu al-'Abbas is also mentioned: he was sent by the prince to announce to al-Suli that al-Khasibi had been appointed vizier in 313/925. ${ }^{43}$

The prince also had his own majlis. The majlis/majalis as a versatile social and cultural institution could house activities 'ranging from serious religious, exegetical, philosophical and intellectual debate to frivolous or amusing poetic recitation and composition, singing, winedrinking and an ostentatious enjoyment of leisure in the company of witty and elegant people. ${ }^{34}$ The boon-companions (nadim/nudama') formed a narrow circle of companions who were expected to converse about all sorts of subjects and to participate in many types of activities. ${ }^{45}$ Von Grunebaum has specified that "what secured success in social gatherings of this kind would be first and foremost esprit. An epigrammatic turn of mind would... go far in making a visitor to the majlis an effective contributor. ${ }^{36}$ The nadim was also expected to function as a source of council and moral guidance. ${ }^{47}$ The very principle of the majlis allowed the meeting of two axes of organization and sociability: a horizontal egalitarian axis, that of fraternity; and a vertical hierarchical axis, that of 'distinction'. This intimate court was not an extension of the circle of servants. The criteria for recruitment emanated directly from the personal choice of the host. ${ }^{48}$

${ }^{40}$ Miskawayh, Tajarib, vol. 1, p. 221; al-Hamadhani, Takmila, p. 83.

${ }^{41}$ Al-Suli, Ma lam yunshar, p. 94; 'Arib, Silat, p. 45.

42 Al-Suli, Akhbar, p. 5.

43 Al-Suli, Ma lam yunshar, p. 149.

44 Cynthia Robinson, In Praise of Song: The Making of Courtly Culture in al-Andalus and Provence, 1005-1134 A.D. (Leiden 2002) p. 75.

45 Anwar Chejne, 'The Boon-Companion in Early 'Abbasid Times', Journal of the American Oriental Society 85 (1965) pp. 327-335.

${ }^{46}$ G.E. Von Grunebaum, 'Aspects of Arabic Urban Literature mostly in the Ninth and Tenth Centuries', Islamic Studies 8 (1969) pp. 281-300.

${ }^{47}$ Julie Scott Meisami, Medieval Persian Court Poetry (Princeton 1987) p. 7.

48 See Bernard Hours, Louis XV et sa cour: le roi, l'étiquette et le courtesan. Essai historique (Paris 2002) pp. 117-123. 
We have several reports on Abu al-'Abbas's hosting of such gatherings. On one occasion Abu al-'Abbas invited his brother Harun to drink with him in the palace of al-Thurayya. The occasion resulted in an exchange of verses during which Abu al-'Abbas recited poems by Abu Nuwas. ${ }^{49}$ Al-Suli mentions another instance when Abu al-'Abbas invited him to participate in an evening of drinking in his palace in alMukharrim. ${ }^{50}$ We also read of a majlis hosted by the caliph al-Muqtadir to which were invited Abu al-'Abbas and his brothers: 'We went in our boon-companionship attire, except for my brother Harun,' who was then ordered by the caliph to put on the proper attire. ${ }^{51}$ Al-Suli has described Abu al-'Abbas on such occasions: he was intelligent, prompt at understanding whatever was said, and quick to find his words without needing to think. ${ }^{52}$

The composition of such gatherings is provided by al-Suli, who gives an eyewitness description of the first gathering of the Tablecompanions of Abu al-'Abbas, after he became caliph. The caliph sent to al-Suli a message in which he inquired about the companions of earlier caliphs who were still around and who were still fit to be invited to his receptions. Al-Suli answered that of such companions, the only remaining one was Ishaq $\mathrm{b}$. al-Mu'tamid but he suggested others who have the qualities necessary to be present at the caliph's receptions. When the group arrived at the caliphal palace for the caliph's reception, they sat in strict order: to the right sat first the prince Ishaq $b$. al-Mu'tamid; then al-Suli, then a philologist, private tutor of a Prince, and Ibn Hamdun. To the left sat three literary courtiers of the family of Munajjim and Baridis of high official descent. ${ }^{53} \mathrm{Al}$-Suli reports on the two activities that dominated such receptions: reciting poetry and drinking wine. ${ }^{54}$

In order to maintain a separate household and pay social companions and military units, the prince needed income. The stipends allotted to the princes were a most sensitive financial issue at court. Aspirants to the wazirate offered increases of stipends. In 304/916,

${ }^{49}$ Al-Suli, Akhbar, p. 8.

50 Al-Suli, Akhbar, p. 50.

${ }^{51}$ Al-Suli, Ma lam yunshar, p. 31.

52 Al-Suli, Akhbar, p. 7.

53 Al-Suli, Akhbar, pp. 8-9. See this passage also in Adam Mez, The Renaissance of Islam, Salahuddin Khuda Bukhsh and David S. Margoliouth, trans. (London 1937) pp. 143.

54 Al-Suli, Akhbar al-Radi, pp. 9, 19, 55. 
for instance, 'Ibn al-Furat undertook to pay al-Muqtadir, his mother and the two princes 1500 dinars a day of which one thousand dinars went to the caliph, 333 and one third to his mother, and 166 and two thirds to the two princes Abu al-'Abbas and Harun. ${ }^{55}$ We also have the budget statement prepared by 'Ali b. 'Isa for the year 306/918 and it includes the monthly allowance prescribed to Umm al-Muqtadir, to the princes, to the female relatives and to the servants. ${ }^{56}$

\section{The Roles of the Prince}

From an early age, Abu al-'Abbas received important governmental posts. In 301/913, while he was four years old, a robe of honour was bestowed on him. He was given command of the war in Egypt and the Maghrib. Mu'nis al-Khadim was appointed his deputy in Egypt. ${ }^{57}$ Abu al-'Abbas could not take on the governorship of the western provinces at this young age; he never took on such duties in practice. Indeed, much later on, in 318/930, al-Muqtadir robed and appointed Abu al-'Abbas to the West, and again Mu'nis was asked to perform the prince's duties, even though the prince was now over twenty years old. ${ }^{58}$ In fact with all of the military crises of the period we never hear of Abu al-'Abbas or any of the other princes involved in military actions. Although he received official appointments and although he developed a large retinue, the prince does not seem to have been involved in the real politics of his time. This was in line with what had effectively become the practice starting with the mid-third/ninth century when the caliph's children were confined to the palaces of Baghdad and Samarra' rather than being sent to govern the provinces. ${ }^{59}$

One main function that Abu al-'Abbas did fulfill was to act as an emissary of his father in sensitive missions. Al-Muqtadir used Abu al-'Abbas as an intermediary with important state officials, especially when he wanted to convey a personal message to someone's home. Abu al-'Abbas undertook such a delicate mission in 317/929. When Mu'nis had heard rumors that he would be replaced as chief

\footnotetext{
5 Miskawayh, Tajarib, vol. 1, p. 42.

6 Al-Sabi, Rusum, pp. 21-25.

7 Miskawayh, Tajarib, vol. 1, p. 32.

58 Miskawayh, Tajarib, vol. 1, p. 202.

59 Kennedy, Court of the Caliphs, p. 168.
} 
commander, al-Muqtadir sent Abu al-'Abbas and the vizier Ibn Muqla in order to alleviate Mu'nis's fears and suspicions and to convince him of the caliph's good intentions and continued favour. Perhaps al-Muqtadir employed Abu al-'Abbas in this instance because of the prince's special relationship with Mu'nis, but, in any case, since the caliph was restricted by protocol from leaving the palace and delivering the message in person, sending his son was the most effective way of getting around such barriers while maintaining a symbolic authority that enhanced that of the caliph.

Indeed, the main role that Prince Abu al-'Abbas seems to have been assigned was a ceremonial one. By the fourth/tenth century caliphs had almost completed the process of distancing themselves from the general populace, removing themselves architecturally and ceremonially. Gulru Necipoglu singles out one palatine paradigm which emerged during the third/ninth and fourth/tenth century and which was characterized by sprawling extra-urban palatine complexes no longer attached to congregational mosques. This change in the spatial relationship between the palace and the mosque marked the increasing seclusion of the Abbasid caliphs from their subjects. ${ }^{60}$ The ceremonies codified the internal structure of the court and also presented to the public an idealized image of the caliphate. Changing ideas about rulership were articulated in the idiom of protocol and ceremonial.

According to Paula Sanders, 'the protocol of the courts expressed symbolically a developing set of assumptions about authority, rule and rulers. ${ }^{61}$ During the reign of al-Muqtadir the weakness of the caliph and of the state were compensated for by ritualized and ceremonial forms. Cynthia Robinson has argued that the ceremonial space served as a place where dynastic solvency, legitimacy and power could be physically demonstrated. ${ }^{62}$ Malcom Vale has indicated that the semblance of power 'could be just as potent a force in the creation and sustenance of princely ideology. ${ }^{163}$ By the fourth/tenth century,

\footnotetext{
${ }^{60}$ Gülru Necipoğlu, 'An Outline of Shifting Paradigms in the Palatial Architecture of the Pre-Modern Islamic World', Ars Orientalis 23 (1993) pp. 3-24.

${ }^{61}$ Paula Sanders, Ritual, Politics and the City in Fatimid Cairo (Albany 1994) p. 15.

${ }^{62}$ Robinson, In Praise of Song, p. 49.

${ }^{63}$ Malcolm Vale, The Princely Court: Medieval Courts and Culture in North-West Europe, 1270-1380 (Oxford 2001) pp. 200-207.
} 
ceremonies became more sumptuous, the caliphs seeking to compensate for the loss of their powers by a greater magnificence. ${ }^{64}$

Our knowledge of daily ceremonial is slight. The invisible caliph was occasionally made officially visible to members of his court, although we do not have information on his routine daily visibility to his officials and courtiers. We have even less information about the ceremonial surrounding members of the caliphal household, notably the princes. Abu al-'Abbas appears in the sources most frequently in processions in which his primary function was to add royal dignity to the proceedings. There the prince was the center of an elaborate event. Surrounded by the most important men of state, the prince was the real focus of the procession. On those occasions, the procession is often described in detail, and even seems like the most important aspect of the entire event.

The young prince's first appointment over the Maghrib and Egypt was celebrated by an impressive parade:

Abu al-Abbas... rode from the Hasani palace while in front of him was the banner which al-Muqtadir had given him over the Maghbrib. Accompanying the prince were all of the commanders, the al-hujariyya retainers and many eunuchs, all surrounding his mount. On his right was 'Ali b. 'Isa; Mu'nis was on his left; and the chamberlain Nasr was in front of him. He traveled along the main road and returned via the river, with the people accompanying him... ${ }^{65}$

The procession included the most powerful men of state: the vizier, the chamberlain, and the chief commander. In 304/916 as part of the prisoner parade for the rebel al-Husayn b.Hamdan,

al-Husayn was conducted from the Shammasiya gate to the caliphal palace attached to a cross... His son was exposed on another camel. In front of them went the prince Abu al-'Abbas, the vizier 'Ali b. 'Isa, the commander Mu'nis... ${ }^{66}$

The prince's presence added weight to this important occasion which was celebrating the Abbasid state's victory over the rebel al-Husayn b. Hamdan. Abu al-'Abbas is also seen repeatedly escorting and receiving

${ }^{64}$ Dominique Sourdel, 'Robes of Honor in Abbasid Baghdad during the Eighth to the Eleventh Century', in: Robes and Honor: The Medieval World of Investiture, Stewart Gordon, ed. (New York 2001) pp. 137-145.

65 Al-Suli, Ma lam yunshar, p. 93; 'Arib, Silat, p. 43.

${ }^{66}$ Miskawayh, Tajarib, vol. 1, pp. 37-8; Al-Hamadhani, Takmila, p. 24; al-Suli, Ma lam yunshar, p. 104; 'Arib, Silat, p. 57. 
Mu'nis to and from military campaigns. For instance, when Mu'nis was heading with the troops towards Egypt in 308/920, Abu al-'Abbas accompanied him to his camp site. ${ }^{67}$ Upon Mu'nis' return to Baghdad the following year, he was received by Abu al-'Abbas. ${ }^{68}$ We also read that in 315/927, as Mu'nis was leading the troops to fight the Byzantines, he was escorted by Abu al-'Abbas, 'Ali b. 'Isa, Chamberlain Nasr, and Harun b. Gharib. ${ }^{6}$

Such public processions made Abu al-'Abbas the focus of important state rituals. As a symbolic representative of the caliph, Abu al-'Abbas disseminated the caliph's majesty to the public while the ruler remained distanced in the palace. The prince's presence during processions added dignity to any event and brought to the public of Baghdad a sense of caliphal splendour and decorum. Public perceptions of the caliph via the prince influenced the shaping of contemporary maps of political reality, informing, correctly or incorrectly, assessments of where power lay and the general well-being of the state. The effectiveness of the caliphate and court have at least as much to do with representations, beliefs, expectations and rumours, as with 'objective' arrangements. ${ }^{70}$ The glorification of the prince, moreover, served to reinforce two political principles that supported al-Muqtadir's claim to the caliphate: the notion of inheritance and primogeniture and that this particular branch of the Abbasid family should rule. Al-Muqtadir, thus, used Abu al-'Abbas to assert the political principle of succession. ${ }^{71}$

\section{The Plight of the Prince}

Upon his accession in 320/932, al-Qahir, brother of al-Muqtadir, ordered raids on the houses where the sons of al-Muqtadir were possibly hiding. This order was carried out until Abu al-'Abbas, Harun, 'Ali, al-'Abbas, Ibrahim, and al-Fadl were found. ${ }^{72}$ Abu al-'Abbas was placed

${ }^{67}$ Al-Suli, Ma lam yunshar, p. 125; 'Arib, Silat, p. 79.

${ }_{68}$ Al-Hamadhani, Takmila, p. 31.

${ }^{69}$ Al-Hamadhani, Takmila, pp. 65-6.

${ }^{70}$ Jacques Revel, 'The Court', in: Realms of Memory, Vol. II: Traditions, Pierre Nora, ed., Arthur Goldhammer, trans. (New York 1997) pp. 72-122.

${ }_{71}$ Marmer, Political Culture, pp. 148-9.

72 Ibn al-Athir, al-Kamil fi al-Tarikh, Carl Johan Tornberg, ed. (Beirut 1979) vol. 8, p. 246; al-Suli, Akhbar, p. 1 . 
under house arrest for years. After he became caliph, Abu al-'Abbas, recounted during a majlis, what he had had to endure at the hands of al-Qahir: Abu al-'Abbas and his mother languished in confinement; the prince was afraid night and day of being put to death, and he had to disguise his feelings towards al-Qahir who could not be trusted. ${ }^{73}$ On another occasion al-Radi told al-Suli that after the execution of Mu'nis, al-Qahir sent him Mu'nis' head as a threat:

At the time I was imprisoned because I had been under the tutorship of Mu'nis. I understood his intention and decided to misguide him as to my true feelings. And so I prostrated myself thanking God and manifested in front of the eunuchs a great happiness...I started thanking al-Qahir... and wrote him verses. ${ }^{74}$

For a number of years Abu al-'Abbas experienced a difficult and sometimes dangerous isolation. His accession to the caliphate came as a surprise to him. Indeed, he states that he did not seek power and did not strive to attain it:

I got into power without having attempted anything to obtain it and without having desired it...not out of ignorance on my part as to what it entails in honour and majesty but because of the changed circumstances, the paucity of money, the army's insatiability, and the country's ruin. It seemed to me that I would have as companions, distress, sadness, anger, preoccupations, more than the expected happiness and joy... But I hope that God will help me because of my good intentions...75

His good intentions paid off, at least verbally, in the sources. The judgment on his character is mostly positive. Miskawayh talks about him as

a scholar and poet, with a command of elegant language; a man who loved the society of the learned, and was never without companions; a man of liberal mind and generous disposition. ${ }^{76}$

Abu al-'Abbas died of illness in 329/940. According to later historians, the death of al-Radi brought changes to the caliphate: he was the last caliph to leave a compiled collection of poetry; the last caliph to pronounce regularly in public the Friday sermon; the last to entertain boon-companions; and the last whose establishment was on the scale

Al-Suli, Akhbar, p. 17.

Al-Suli, Akhbar, pp. 49-50.

5 Al-Suli, Akhbar, pp. 16-17.

${ }^{76}$ Miskawayh, Tajarib, vol. 1, p. 417. Trans. in Amedroz and Margoliouth, Eclipse, vol. 1, p. 462 . 
adopted by his forefathers. ${ }^{77}$ Following Abu al-'Abbas' death, Bajkam stated that the caliph 'was intelligent, crafty and, a flatterer...but I blame him for having been too weak and for having let his passions influence his judgment. ${ }^{78}$ His tutor and companion al-Suli praised him in the following terms:

Among the Abbasids caliphs, he was the most talented poet, the most fecund in poetry, the most generous and kind to his companions. I have never seen or heard of a caliph better than him in nobility of character, more liberal in money or in food, to the point of exaggeration, or in his gifts of cloths and perfumes. He had not the slightest avarice... had he not followed his passions in the ways he did...I would think that he has no superior. ${ }^{79}$

${ }^{77}$ Ibn al-Athir, al-Kamil fi al-tarikh, vol. 8, p. 368.

${ }_{78}$ Al-Suli, Akhbar, p. 43.

79 Al-Suli, Akhbar, p. 19. See also al-Mas'udi, Muruj, vol. 5, p. 228. 


\title{
CEREMONIES AND THE CITY: THE COURT IN FOURTEENTH-CENTURY CONSTANTINOPLE
}

\author{
Ruth Macrides
}

Modern reconstructions of Constantinople and its court life after 1204 delineate a city that never recovered from the events of the Fourth Crusade. While a restoration of buildings and traditions associated with Constantinople before 1204 was undertaken by Michael VIII as the 'New Constantine' ${ }^{1}$ upon his recovery of the capital, the imperial treasury was depleted by subsequent territorial losses to the Turks and the civil wars of the 1320 s and ' 40 s. Disasters such as the plague of $1347^{2}$ contributed to the reduction in the empire's resources. Decline, it is reasonably assumed, took its toll also on the ceremonial life of the court. 'Ceremonial space'3 diminished and the content of the ceremonies became impoverished. There was a reduction in the scale of the ceremonies performed and an isolation of the court's routines. ${ }^{4}$

This picture of court life in the reconquered Constantinople, which is generally regarded as representative of the whole of the late Byzantine period from the late thirteenth century to $1453,{ }^{5}$ is based on the one surviving text from the period after 1204 that contains descriptions of

\footnotetext{
1 Alice-Mary Talbot, 'The Restoration of Constantinople under Michael VIII', Dumbarton Oaks Papers 47 (1993) pp. 243-261; Ruth Macrides, 'The New Constantine and the New Constantinople-1261?', Byzantine and Modern Greek Studies 6 (1980) pp. 13-41; eadem, 'From the Komnenoi to the Palaiologoi: Imperial Models in Decline and Exile', in: New Constantines, ed. P. Magdalino (Aldershot 1994) pp. 269-282, here at pp. 270-275. The study by V. Kidonopoulos, Bauten in Konstantinopel, 1204-1328 (Wiesbaden 1994) was not available to me.

${ }^{2}$ For a narrative of the events of the late thirteenth and early fourteenth centuries see Donald M. Nicol, The Last Centuries of Byzantium, 1261-1453 (Cambridge 1972, 1993).

${ }^{3}$ André Grabar, 'Pseudo-Codinos et les cérémonies de la cour byzantine au $\mathrm{XIV}^{\mathrm{e}}$ siècle', Art et société à Byzance sous les Paléologues (Venice 1971) pp. 195-221, here at p. 200.

4 Argued by Paul Magdalino, 'Pseudo-Kodinos' Constantinople', Studies on the History and Topography of Byzantine Constantinople (Aldershot 2007) study XII, pp. 1-14 (first publication); idem, 'Court and capital in Byzantium', in this volume.

${ }^{5}$ Nuance has not been introduced so far to modern representations of ceremonial in the 'Palaiologan period'. An exception is the careful approach of T. Kiousopoulou,

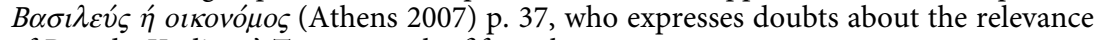
of Pseudo-Kodinos' Treatise to the fifteenth century.
} 
ceremonies, the so-called Treatise on the court titles by the anonymous author known to us as Pseudo-Kodinos. The text dates to some time in the mid-fourteenth century, to the reign of John VI Kantakouzenos, ${ }^{6}$ the emperor whose crown was made of glass paste gems and whose coronation banquet tableware was earthenware and pewter. ${ }^{7}$

The modern portrayal of a reduced and impoverished ceremonial and court life, I will argue, relies not so much on the text of PseudoKodinos itself, as on expectations and preconceptions created by the tenth-century Book of Ceremonies. The latter is the standard against which the Treatise is measured, explicitly or implicitly. The contrast in the two works is indeed great. The De cerimoniis is a large text with a reputation that goes beyond the boundaries of the academic community; the Treatise is a slim work, barely known even to Byzantinists. The Book of Ceremonies has an ascribed author, Constantine VII, an emperor, and a learned one at that, and an approximate date, 957959. ${ }^{8}$ It has a preface or, rather, two, one for each book of the work. In these prooimia, Constantine VII lays great emphasis on taxis, 'order', the principle behind the work. The word appears six times in the first preface and four times in the second, together with ataxia, 'disorder', and eutaxia, 'good order'. The much-quoted prefaces make clear the central importance of maintaining good order in the palace, both for the subjects of the emperor and for foreigners. ${ }^{9}$

${ }^{6}$ The text, with facing-page French translation, notes and introduction was published by Jean Verpeaux, Traité des offices (Paris 1966). For the date, see Verpeaux, Traité, pp. 25-40. John VI is the last emperor mentioned by name in the text: ed. Verpeaux, 135.6-136.1; 147.17-148.3. A new study of the Treatise, with Greek text and facing English translation is forthcoming: Pseudo-Kodinos, The Constantinopolitan court offices and ceremonies, ed. and trans., with commentary, R. Macrides, J. Munitiz, D. Angelov (Farnham 2013).

${ }^{7}$ Nikephoros Gregoras, Byzantina Historia II, Ludwig Schopen, ed. (Bonn 1830) 788.15-789.8; Nicol, Last Centuries, p. 215. The glass paste crown is not mentioned again after Kantakouzenos' coronation.

${ }_{8}$ Michael McCormick, 'De ceremoniis', The Oxford Dictionary of Byzantium, A.P. Kazhdan, ed., 3 vols. (New York; Oxford 1991) vol. 1, pp. 595-597, here at p. 595. For Constantine as the author of the prefaces and instigator of the compilation which we call the Book of Ceremonies and which was continued after his death, see Ihor Ševčenko, 'Re-reading Constantine Porphyrogenitus', in: Byzantine Diplomacy, Jonathan Shepard and Simon Franklin, eds. (Aldershot 1992) pp. 167-196; Michael Featherstone, 'Further remarks on the De cerimoniis', Byzantinische Zeitschrift 97, 1 (2004) pp. 113-121.

${ }_{9}$ The complete work was edited by Reiske in one volume: Johann Jacob Reiske, ed., Constantini Porphyrogeneti De Cerimoniis aulae byzantinae I (Bonn 1829) pp. $3-5 ; 516-517$. Book I has been published with French translation and commentary 
The Treatise, in contrast, has no known author, no known date, no preface, nor any reference to the circumstances of its writing or to the significance of ceremonial. These aspects of the text contribute to its marginalisation. Because of the above mentioned factors, it lacks in the eyes of its readers a status as authoritative as the Book of Ceremonies; its date also contributes to this assessment: in the fourteenth century the empire was a shadow of its former self, while in the tenth, the empire was powerful and large.

Yet, before conclusions can be drawn about Byzantine ceremonial in the fourteenth century, it is important to understand the nature of the books that describe Byzantine ceremonies. The Book of Ceremonies appears to be a record of court ceremonial procedures 'whose accuracy is guaranteed by its authorship'. ${ }^{10}$ But how many of the ceremonies recorded in it were regularly performed? To what extent can it be a guide to the ceremonial life of the contemporary court? If the purpose of the tenth-century author-compiler was to put together a collection for the use of future masters of ceremony, to make accessible a wide range of protocols, then what we have in the Book of Ceremonies is a guide to the tenth century's relationship to the past. ${ }^{11}$

The Treatise on the court titles, as its editor, Jean Verpeaux, named it, differs from the Book of Ceremonies in a number of ways. First, in its content. It provides a list of titles and the functions attached to them, but also includes a description of the clothing of each title-holder, the hats worn and staffs carried by each. In addition, the anonymous author gives an account of the ceremonial for the major feast days, the Christmas and Easter cycles, and other feasts, coronations and promotions of high dignitaries and the installation of the patriarch. Other chapters deal with the clothes worn by an emperor in mourning, the reception of a foreign imperial bride-to-be in Constantinople, and the duties of the megas domestikos in the army.

From this list of contents one can see immediately that PseudoKodinos' work is like no other surviving book on Byzantine ceremony. In its combination of hierarchy and ceremony it is closer to the late

by Albert Vogt, Le livre des cérémonies, 2 vols. (Paris 1967). References here will be to the Reiske edition.

${ }^{10}$ Averil Cameron, 'The construction of court ritual: The Book of Ceremonies', in: Rituals of Royalty, David Cannadine and Simon Price, eds. (Cambridge 1987) pp. 106-136, here at p. 106.

${ }^{11}$ Cameron, 'The construction of court ritual', p. 119. 
ninth-century book on banquets, the Kletorologion by Philotheos, ${ }^{12}$ than to the Book of Ceremonies. But in its detailed delineation of clothing and insignia, it goes far beyond Philotheos and Constantine VII.

Furthermore, although the Treatise has no known author, its anonymous author has left his mark on the text throughout, in the most direct manner, through his interventions-sometimes in the first person, ${ }^{13}$ sometimes in the third. Like Philotheos and Constantine VII or a later redactor ${ }^{14}$ of the Book of Ceremonies, the author makes didactic comments: 'One should know that'; 'This too should be known'. ${ }^{15}$ But Pseudo-Kodinos goes beyond them by uniting the various parts of the Treatise with cross-references: 'As mentioned above'; 'The reason will be given afterwards'; 'One must return again to the point from which we started'. ${ }^{16} \mathrm{He}$ introduces excurses in a direct manner by pointing out that they are notes on a specific point. ${ }^{17} \mathrm{He}$ rounds off a section by summarising and pointing forward to the next. ${ }^{18}$ Among 'authors' of ceremonial books, Pseudo-Kodinos is the most interventionist, showing his editorial work in a direct manner and establishing an internal cohesion, as well as a direct connection with his readers. If his text is a compilation, made up of texts not originally composed by him, ${ }^{19}$ he manages to create the impression of a composition that is a coherent whole.

By contrast, the Book of Ceremonies shows clearly the disparateness and separateness of the sources which make up its composition, for Constantine VII, or a later editor of the work, does not attempt to

${ }^{12}$ Nicolas Oikonomides, Les listes de préséance Byzantine des IXe et $X^{e}$ siècles (Paris 1972).

${ }^{13}$ Ed. Verpeaux, 148.16-17; 173.6-19.

${ }^{14}$ Jeffrey M. Featherstone, ' $\Delta \mathrm{I}$ ' EN $\Delta$ EIEIN. Display in court ceremonial (De cerimoniis II, 15)', in: The Material and the Ideal: essays in medieval art and archaeology in honour of Jean-Michel Spieser, Anthony Cutler and Arietta Papaconstantinou, eds. (Leiden 2007) pp. 75-112, here at pp. 77-79; cf. A. Moffatt, 'The Master of Ceremonies' bottom drawer. The unfinished state of the De ceremoniis of Constantine Porphyrogennetos', Byzantinoslavica 56 (1995) pp. 377-388, here at p. 381.

${ }_{15}$ Ed. Verpeaux, 168.28, 191.22, 199.3, 223.22, 226.22, 230.23, 240.5, 272.21, 273.1, 274.28, 281.6, 281.24, 286.2, 287.22.

${ }_{16}$ Ed. Verpeaux, 167.7-11, 200.11-13, 257.26, 272.4, 272.5, 287.7.

17 Ed. Verpeaux, 199.3-200.13, 204.24-206.8, 218.29-219.21, 222.14-223.21, 235.12237.5, 259.1-8, 270.1-12, 273.1-18, 287.22-29.

${ }^{18}$ Ed. Verpeaux, 207.9-10.

19 Verpeaux had not identified fully the compilatory nature of the work, evident in several sections. The list of titles is based on a ready-made list of the early fourteenth century; the coronation section is certainly taken from another source. For the latter, see Verpeaux, Traité, pp. 31-34. 
create a unified whole from the different documents of differing dates. Thus, the work has been characterised as 'more a dossier than a finished work' ${ }^{20}$ Sources from the fifth to tenth centuries are found next to passages that date to a time after Constantine VII's death. Prescriptive passages can be found next to old material that has been included simply to make it accessible. ${ }^{21}$

Another characteristic of the Treatise is its overwhelming attention to detail. The author-compiler lavishes most attention on details that have to do with the hierarchical order of the court officials, their insignia of office, especially their clothing and their batons, but above all their headgear. ${ }^{22}$ From both visual and textual records it appears that hats had become an item of court attire from the eleventh century on. ${ }^{23}$ However, this author-compiler's account is the only systematic description of headgear for the entire Byzantine period and only his description makes it possible to reconstruct to some extent the appearance of the court when it met twice daily also on feast days. No surviving image provides this picture. ${ }^{24}$

Two hats are described by the author, the skiadion, the everyday hat which has not been identified securely with any hat from the visual record, and the skaranikon, the feast day hat which is better documented. It is on the latter that the author concentrates and there are many surviving portraits of officials wearing these hats. ${ }^{25}$

The author divides the court officials into two groups, the goldskaranikon wearers and the red-skaranikon wearers. ${ }^{26}$ However, the

${ }^{20}$ McCormick, 'De ceremoniis', p. 595.

${ }^{21}$ For an analysis of the dates of the documents in the work, see the groundbreaking study by J.B. Bury, 'The Ceremonial Book of Constantine Porphyrogennetos', English Historical Review 86 (April 1907) pp. 209-227, and idem, English Historical Review 87 (July 1907) pp. 417-439; Mc Cormick, 'De ceremoniis', pp. 596-597. For the unfinished state of the work and the 'scissors and paste' nature of the compilation' see Moffatt, 'The Master of Ceremonies' bottom drawer', pp. 377-388.

${ }^{22}$ Ed. Verpeaux, 141-166.

${ }^{23}$ Nancy Sevčenko, 'Headgear', Oxford Dictionary of Byzantium, ed. A.P. Kazhdan, 3 vols. (Oxford; New York 1991), vol. 2, p. 904; Maria G. Parani, Reconstructing the Reality of Images (Leiden 2003) p. 67.

${ }^{24}$ The only image of the court from the later Byzantine period is the manuscript illumination of John VI Kantakouzenos presiding over the council of 1351: Par. gr. 1242, f. 5 v. See Parani, Reconstructing the Reality of Images, pl. 24.

${ }^{25}$ See, for example, the images from the Lincoln College Typikon (ms. gr. 35) and Par. gr. 2144, both fourteenth century, reproduced in Parani, Reconstructing the Reality of Images, pl. 67, 68.

${ }^{26}$ Ed. Verpeaux, 211.8-10; 216.5-8; 219.27-30. 
differences in the appearance of the skaranika are far greater than this division implies. The distinctions have to do with fabric, colour, type of decoration and material of decoration. The author gives the names of the title holders who belong to each group. The hats described as 'gold' skaranika begin with the brilliant imperial colour of red and become paler, from apricot to white and yellow, the latter two being colours that the emperor wears when he is in mourning. These court title holders, it seems, wear silk hats of red, apricot, white or yellow, with threads of gold woven into them. The hats in this group are also described as syrmateina, perhaps an indication that the skaranika were embroidered with gold-wire thread. ${ }^{27}$

The quality of the fabric-silk-and the decoration-gold threaddistinguishes the first group, the highest members of the court, from the second. The second group, the wearers of 'red' skaranika, officials lower down in the hierarchy, ${ }^{28}$ are sharply distinguished from group one by the fabric of their hats, the design and colour. Their skaranika are solid red, made of a fabric with a nap, ${ }^{29}$ such as velvet or felt. These skaranika have no gold but rather a tassel. All the officials in this group are coiffed in identical red-tasselled hats. There are no variations. There is no gradation within this group and it is immediately recognizable and distinct from the first.

Within the first group, however, a further internal hierarchical distinction is made. These are the hats that are gold with red, apricot, white and yellow. They all bear the image of the emperor, on the front and the back. It is the portrait of the emperor on the hat that makes the skaranikon so easily identifiable in manuscript illuminations and elsewhere. The emperor's image was an additional element that contributed to the ranking based on colour. The material and technique used to create the emperor's image distinguished smaller groups within the larger one. The gold-red hats at the top of the hierarchy had the emperor's image engraved or beaten onto a metal plaque attached to the front and the back. The gold-apricot and gold-white hats had the

27 Ed. Verpeaux, 142 n. 3.

28 Ed. Verpeaux, 211.8-20; 163.7-9.

${ }^{29}$ For the material of this hat, chasdeon, see Maria Mavroudi, A Byzantine Book on Dream Interpretation (Leiden 2002) pp. 65-66 n. 14; p. 471. 
image painted on glass to imitate enamel. ${ }^{30}$ Finally, the gold-yellow hats had the image of the emperor embroidered in gold-wire thread.

The iconography of the imperial image varied also, depending on the medium. The metal plaques-silver or silver gilt-depicted the emperor standing on one side and enthroned on the other. The painted glass and the embroidered images showed the emperor enthroned on one side and on horseback on the other.

The distinctions between the two main groups, the 'gold' and 'red' skaranika, therefore, were multiple, based on differing fabric (silk or velvet), colour (gold and another colour or red alone), decoration (portrait of the emperor or tassel), and medium of decoration (metal, imitation enamel, embroidery or cloth tassel). Just as colour marked the higher court officials from the lower, so too did material used and medium employed. The observer would know at once to which rank the official belonged.

Likewise the staffs, or dikanikia, held by most of the title-holders show enormous variety. The highest title-holders carried gold and silver batons; those below in rank had batons of wood, painted gold in combination with red, black or blue. The knobs could be incised or not, while the segments between the knobs were decorated in different ways. $^{31}$

The same attention to detail is evident in other sections of the Treatise, notably in matters of horse etiquette. Pseudo-Kodinos refers, in various parts of his work, to places in the courtyard of the palace that are specifically for mounting and dismounting. ${ }^{32}$ Only the highest dignitaries, the despot, the sebastokrator and the caesar can enter and leave the courtyard on horseback. But these three dignitaries must dismount at specifically designated areas of the courtyard.

As with dress and insignia, Pseudo-Kodinos' detailed specifications of the space in the palace courtyard have a hierarchical significance.

\footnotetext{
${ }^{30} \mathrm{~W}$. Woodfin, 'The materials make the man: hierarchies of media and hierarchies of offices in the Palaiologan court', unpublished paper read at the workshop on PseudoKodinos, Centre for Byzantine, Ottoman and Modern Greek Studies, University of Birmingham, 20-21 May 2005. Woodfin identifies the technique used to create the image, described by Pseudo-Kodinos as being 'under glass' as 'verre eglomisé', painting on the reverse side of glass. On the latter see Dillian Gordon, 'A Sienese verre eglomisé and its setting', Burlington Magazine 123 (1981) pp. 148-153.

${ }^{31}$ Ed. Verpeaux, 141-166.

32 Ed. Verpeaux, 145.13-15 (the despot), 148.14-21 (the sebastokrator), 149.11-14 (the caesar), 281.6-9 (the patriarch).
} 
Similarly, hierarchical principles are at the core of the protocol of the 'kiss' given to the emperor on Easter Sunday. 'All the title-holders enter', reports Pseudo-Kodinos,

each one down to the humblest, and kiss, first the right foot of the emperor, then his right hand and, after this, his right cheek. If, at that moment, the podestà of the Genoese in Galata also happens to be at the place where the emperor is, he too enters and with his companions kisses the emperor in the manner of the title-holders.... However, the Venetians come neither to the 'many years' acclamations nor to the kiss. ${ }^{33}$

In this passage the author gives a short guide to the diplomatic gestures of the representatives of the Latins in Constantinople. The Genoese are treated differently from the Venetians. The author explains the origins of the differentiation made, ${ }^{34}$ as he does the origins of peoples, objects, articles of clothing, customs and practices. ${ }^{35}$

By providing explanations of origins Pseudo-Kodinos relates to the past and shows awareness of continuity and discontinuity. ${ }^{36}$ But there are also many cases where he declares his ignorance. He expresses the latter with the characteristic phrase, 'It is unknown', expressed in Greek in a variety of ways. ${ }^{37} \mathrm{~A}$ considerable range of subjects falls into the category of the unknown. It is Pseudo-Kodinos' curiosity about all kinds of practices that leads him to pose the question out loud, even if he has no answer. Why are trumpets not sounded when the emperor rides out after lunch to receive his subjects' petitions? Why do the kraktai, the singers, precede the emperor to the palace after the coronation, holding spears decorated with red and white silk streamers? ${ }^{38}$

33 Ed. Verpeaux, 234.22-235.13.

34 Ed. Verpeaux, 235.14-237.5. For a discussion of the passage see Ruth Macrides, " "The reason is not known." Remembering and recording the past. Pseudo-Kodinos as a historian', L'écriture de la mémoire. La littérarité de l'historiographie, Paolo Odorico, Panagiotis Agapitos, Martin Hinterberger, ed. (Paris 2006) pp. 317-330, here at pp. 323-325.

35 Peoples: the Vardariots (182.6-10); objects: pilatikia (205.21-206.1), dragon banner (206.5-22); clothing: turban, skaranikon, epilourikon, caftan (206.5-22), granatza (218.29-219.12); customs: emperor's horse decoration (270.1-10); emperor's gifts to clerics (237.29-238.4); practices: pinkernes' cup (211.27-212.3); archdeacon of church (222.14-223.21). On the clothing, see Maria G. Parani, 'Cultural identity and dress: the case of late Byzantine ceremonial costume', Jahrbuch der Österreichischen Byzantinistik 57 (2007) pp. 95-134.

36 Macrides, "“The reason is not known.”', pp. 321-330.

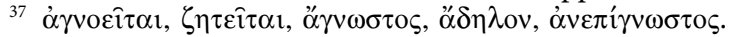

38 Ed. Verpeaux, 173.1-15; 263.4-20. 
From these examples it can be seen that Pseudo-Kodinos' Treatise is marked by its detailed description of dress and insignia and the author's curiosity about origins of practices and of objects which he expresses in a direct and open manner. ${ }^{39}$ These two aspects of his work set him apart from Philotheos and Constantine VII. In his study of the Treatise, André Grabar remarked that the Book of Ceremonies does not have one-tenth the detail of the Treatise. ${ }^{40}$ One could add that the Book of Ceremonies does not reveal its author or redactor, as does the Treatise.

The Treatise has another characteristic that sets it apart from the Book of Ceremonies: it is organised and orderly. Although the Treatise is also a compilation, the compiler has made efforts to unite not only the various sections of the work into one coherent whole but also to bring together the information within each section that derives from different sources. The impression is created of a single work written by one author. The exact opposite is the case with the Book of Ceremonies which was ostensibly compiled to reintroduce 'order' into the court ceremonies but actually achieves disorder.

As is apparent from what has been said so far, each of the ceremonial books that have survived is distinctive and unique. It follows, therefore, that there is no such thing as a model book of ceremonies. We have no handbook outlining the constituent parts of a ceremonial book, no equivalent of a Menander Rhetor for those who want to compile a ceremony book. Yet, I would argue, we have come to think of the Book of Ceremonies as the prototype and to interpret the Treatise accordingly. Thus, the Treatise appears to be the site of loss and decline, both with regard to the topography of the ceremonies and their content. Gone are the face-to-face encounters of the emperor with the people at the Hippodrome meetings, gone are the processions to churches all over the city, gone are the labyrinthine processions within the palace, winding through numerous named rooms. According to this view, the fourteenth-century ceremonial book shows a limited number of ceremonies taking place in a small number of palace rooms. Court and emperor are rarely seen by the people of the city. Ceremonies have retreated to the confined space of a few rooms in a

${ }^{39}$ Macrides, "“The reason is not known.”', pp. 320-328.

${ }^{40}$ Grabar, 'Pseudo-Codinos et les cérémonies de la cour byzantine au XIV ${ }^{\mathrm{e}}$ siècle', p. 203. 
fortified palace building, ${ }^{41}$ a single structure rather than the sprawling complex of late antiquity and of the Book of Ceremonies.

That palace was the Blachernai in the northwest corner of the city. ${ }^{42}$ The former heart of the capital in the southeast, with the Great Palace and the neighbouring Hagia Sophia, hardly appears in the Treatise. On only one occasion is the Great Palace mentioned explicitly: the emperor sleeps there the night before his coronation and has a meal there the evening of his coronation. ${ }^{43}$ Hagia Sophia is the venue for only a small number of feast days. ${ }^{44}$ Thus, from the Treatise we have a view of Constantinople from a side of the city diametrically opposite that which the Book of Ceremonies presents..$^{45}$

The view of the city from the northwest corner is one that the emperor and the court had, with increasing frequency, in the course of the twelfth century. The Blachernai became the preferred imperial residence from the end of that century ${ }^{46}$ and continued to be during the Latin occupation ${ }^{47}$ and beyond. When Michael VIII recovered Constantinople in 1261, he occupied the Great Palace while the Blachernai was being cleaned of the Latins' soot and grease..$^{48}$ In the reigns

${ }^{41}$ Grabar, 'Pseudo-Codinos et les cérémonies de la cour byzantine au XIV e siècle', pp. 200-201; Magdalino, 'Pseudo-Kodinos' Constantinople', pp. 1-3; idem, 'Court and Capital in Byzantium' in this volume pp. 141-143.

${ }_{42}$ Although Pseudo-Kodinos never mentions the Blachernai by name as the site of the ceremonies, it can be identified through internal references.

${ }^{43}$ Ed. Verpeaux, 252.2-7, 271.1-3.

${ }^{44}$ Ed. Verpeaux, 252.12-15 (coronation); 237.21-23 (Easter Sunday vespers); 242.22-243.1 (13 November: feast of John Chrysostom); 245.11-13 (15 August: Dormition); 246.7-9 (Sunday of Orthodoxy).

${ }_{45}$ Magdalino, 'Pseudo-Kodinos' Constantinople', p. 1.

46 Paul Magdalino, 'Manuel Komnenos and the Great Palace', Byzantine and Modern Greek Studies 4 (1978) pp. 101-114, here at pp. 110-113; repr. in Paul Magdalino, Tradition and Transformation in Medieval Byzantium (Aldershot 1991) study V. Magdalino shows that, contrary to received opinion, Manuel I Komnenos (11431180) made considerable use of the Great Palace until the end of his reign, having added to its buildings.

47 The Byzantine sources refer to Baldwin II, in particular, in association with the Blachernai: George Pachymeres, Relations historiques, A. Failler, ed., 5 vols. (Paris 1984-2000) vol. 1, pp. 199.12-17; Nikephoros Gregoras, L. Schopen, ed., 3 vols. (Bonn 1829-1855) vol. 1, pp. 304-305, esp. pp. 304.24-305.6.

${ }^{48}$ Pachymeres, Relations historiques, vol. 1, pp. 219.2-10. It seems, however, that Michael VIII was able to occupy the Blachernai early in his reign, while Arsenios was still patriarch (1260-1264): Pachymeres, Relations historiques, vol. 2, pp. 341.23-28. 
of his successors the Great Palace is occasionally mentioned as the venue for an event but it is the Blachernai that is occupied. ${ }^{49}$

However, although it was occupied continuously in the Palaiologan period, evidence for the Blachernai palace is meagre. Robert of Clari, writing shortly after the Fourth Crusade, is the only author to give a general impression of the palace which he describes as consisting of 'two hundred rooms or three hundred' 'all connected with each other', and twenty chapels. ${ }^{50}$ Occasional references to the palace and its rooms in Byzantine narrative sources are insufficient to attempt any kind of reconstruction. In contrast, the Great Palace's layout can be pieced together to some degree using the Book of Ceremonies and narrative sources. ${ }^{51}$ The Book of Ceremonies gives the names of the rooms and spaces in which ceremonies were performed and through which the title-holders moved in their processions. Indeed, in many descriptions of actual ceremonies that took place, as well as in the prescriptive material, the author appears to put more emphasis on the locations than on any other aspect of the ceremonial. ${ }^{52}$

Nothing could be more different than the approach of PseudoKodinos who makes reference to only a small number of rooms, none by name. In the Treatise three rooms or areas are mentioned: the triklinos $^{53}$ which acts as a reception room and dining room, the kellion or kellia ${ }^{54}$ the emperor's private apartments, and the ekklesia, the chapel or palace church. ${ }^{55}$ The latter two are connected to the triklinos or adjacent to it. In addition, there is an external elevated gallery, the peripatos, ${ }^{56}$ which connects the triklinos to the palace church. In the courtyard, in addition to the peripatos, there is a chapel dedicated

49 For occasional use of the Great Palace, see Pachymeres, Relations historiques, vol. 3, pp. 163.9-14 (1289: the Justinianeion); vol. 3, pp. 221.18-21 (1294: the Manuelites), vol. 4, pp. 401.7-12 (1303: the peripatos outside the Chrysotriklinos).

50 Robert of Clari, La conquête de Constantinople, Philippe Lauer, ed. (Paris 1924) $\$ 83$; Peter Noble, ed. (Edinburgh 2005) \$83, pp. 102-3.

51 Jeffrey M. Featherstone, 'The Great Palace as reflected in the De Cerimoniis', in F.A. Bauer, ed., Visualisierungen von Herrschaft. Frühmittelalterliche ResidenzenGestalt und Funktion, Byzas 5 (Istanbul 2006) pp. 47-61; Magdalino, 'Pseudo-Kodinos' Constantinople', p. 3.

${ }^{52}$ Ed. Reiske, 75-112. This certainly applies to the protocols from the embassy of Olga of the Rus in the reign of Constantine VII. On these see Featherstone, ' $\Delta \mathrm{I}$ ' EN $\Delta$ EIछIN', pp. 75-112.

53 Ed. Verpeaux, 174.18, 176.21,180.3, etc.

54 Ed. Verpeaux, 180.2, 189.9, 194.9, 212.5, etc.

55 Ed. Verpeaux, 195.9-10, 197.5, etc.

56 Ed. Verpeaux, 224.6, 17; 225.7, 28; 226.6. 
to the Mother of God 'the Victory Bringer' with a mural icon of St George facing the courtyard ${ }^{57}$ and also a tall structure, the prokypsis. ${ }^{58}$ The gate by which one enters the courtyard, Ta Hypsela ${ }^{59}$ is also mentioned. Within the courtyard also, a couple of places are specified as the areas for dismounting, the pezeuma and the tetrastylon. ${ }^{60}$

As the above summary of Pseudo-Kodinos' references to spaces shows, the greatest number of specifications is for the courtyard of the palace. It is only with respect to this area that we find references to named structures or objects: the chapel of the Mother of God 'the Victory Bringer', the icon of St George, Ta Hypsela, the pezeuma, the tetrastylon and the prokypsis. Within the palace, by contrast, rooms are known only by their generic names: the hall (triklinos), the private apartment (kellion), the chapel (ekklesia).

Apart from the prokypsis platform in the courtyard, mentioned by Nikephoros Gregoras also and attributed by Nikephoros Kallistos Xanthopoulos to Andronikos $\mathrm{II},{ }^{61}$ and the chapel of the Mother of God 'the Victory Bringer' with its mural icon of St George, known also from Gregoras, ${ }^{62}$ it is not possible to locate the structures mentioned by Pseudo-Kodinos, nor to identify them securely with buildings known from other sources. ${ }^{63}$ The triklinos of Pseudo-Kodinos' ceremonies may have been the Alexiakos triklinos, built by Alexios I Komnenos in the late eleventh century ${ }^{64}$ It is cited three times as the venue for assemblies of churchmen presided over by the emperors Michael VIII, Andronikos II, and John VI Kantakouzenos ${ }^{65}$ The chapel of the palace can perhaps be identified with that of St Demetrios, mentioned by Kantakouzenos.$^{66}$ Otherwise, the late Byzantine narrative accounts refer to various residences, part of the Blachernai palace or distinct

57 Ed. Verpeaux, 227.10-15, 228.1.

58 Ed. Verpeaux, 197.8, 25-26.

59 Verpeaux, 243.23, 244.6.

${ }^{60}$ Verpeaux, 168.21; 244.8; 148.16, 20-21.

${ }^{61}$ Gregoras II, 616-617; Xanthopoulos, Migne, Patrologia Graeca 145, 585-588, here at 585 B; translation of Xanthopoulos passage in Magdalino, 'Pseudo-Kodinos' Constantinople', pp. 13-14, here at p. 13.

${ }^{62}$ Gregoras, I, 304.8-12.

${ }^{63}$ Magdalino, 'Pseudo-Kodinos' Constantinople', p. 3.

${ }^{64}$ For another view see Magdalino, 'Pseudo-Kodinos' Constantinople', p. 4.

65 Pachymeres, Relations historiques, vol. 2, pp. 339.23-341.20; vol. 3, pp. 209.25211.7; Gregoras II, 898-899. The Par. gr. 1242, fol. 5v shows John VI presiding over the synod of 1351 .

${ }^{66}$ John Kantakouzenos, ed. L. Schopen, 3 vols. (Bonn 1828-1832) II, 47.15-17; 66.10-12. 
from it: the residence (oikia) in the courtyard of the palace where John Kantakouzenos' mother was kept imprisoned and which was built by Andronikos II ${ }^{67}$ and the 'house of the Porphyrogennetos' ${ }^{68}$

These identifications are tentative and the references to palace buildings do not amount to much. The conclusion has therefore been drawn that in the late period ceremonies took place in a restricted space, in a ruin of a palace hardly worthy of the name. This impression is reinforced by the later, fifteenth-century accounts of foreign visitors to Constantinople, Clavijo and Tafur, Spanish travellers to the city in the reigns of Manuel II (1391-1425) and John VIII Palaiologos (1425-1448) who have left reports of their receptions in the palace. ${ }^{69}$ Clavijo and his party crossed over from Pera and found horses and officers to take them up to the palace. There the emperor received them graciously in his 'private chamber', seated on a raised dais, carpeted with small rugs. On one was spread a skin. 'With the emperor at our audience had been present the Empress, his wife, with three young princes his sons... ${ }^{70}$ Is this private chamber the kellion of PseudoKodinos' account? The audience is familial and intimate.

Tafur was in Constantinople at the time of John VIII's departure for the church council of Ferrara-Florence in 1437. He describes the impression that the palace made on him:

The Emperor's Palace must have been very magnificent, but now it is in such state that both it and the city show well the evils which the people have suffered and still endure... Inside, the house is badly kept, except certain parts where the Emperor, the Empress, and attendants can live, although cramped for space. ${ }^{71}$

${ }^{67}$ Kantakouzenos II, 164.20-165.2; Gregoras II, 616-617; Xanthopoulos, Patrologia Graeca 145, 585B; Magdalino, 'Pseudo-Kodinos' Constantinople', pp. 5, 13-14.

${ }^{68}$ Kantakouzenos I, 305.21; III, 290.15. The 'house of the Porphyrogennetos' is usually identified with the three-storey palace whose remains can be seen at the north termination of the Theodosian land walls. See Cyril Mango, 'Tekfur Sarayi', The Oxford Dictionary of Byzantium, A.P. Kazhdan, ed., 3 vols. (New York; Oxford 1991) vol. 3, pp. 2021-2022. Neslihan Asutay-Effenberger, Die Landmauer von Konstantinopel-Istanbul (Berlin; New York 2007) pp. 134-42 argues that the Tekfur Sarayi was the palace occupied in the last years of the empire.

${ }^{69}$ M. Angold, 'The decline of Byzantium seen through the eyes of western travellers', in: Travel in the Byzantine World, Ruth Macrides, ed. (Aldershot 2002) pp. 213-232, here at pp. 220-221, 223-225.

${ }_{70}$ Embajada a Tamorlan, F. López Estrada, ed. (Madrid 1943) p. 34; Clavijo, Embassy to Tamerlane 1403-1406, G. Le Strange, trans. (London 1928) p. 61.

${ }^{71}$ Pero Tafur, Travels and Adventures 1435-1439, M. Letts, trans. and ed. (London 1926) p. 145. 
Tafur also was given audience before the emperor: 'I then entered the Palace, and came to a hall where I found him [the emperor] seated on a tribune, with a lion's skin spread under his feet'. ${ }^{72}$

In the two accounts of Clavijo and Tafur one is struck by the intimate nature of the reception-the emperor and his family-known also from some tenth-century receptions. ${ }^{73}$

Does Tafur's description of the palace-'Inside the house is badly kept, except certain parts where the emperor, the empress and attendants can live, although cramped for space'-conform to the palace in Pseudo-Kodinos' time? The Spanish traveller was in Constantinople approximately 100 years later than Pseudo-Kodinos, close to the Ottoman conquest. By then the palace might indeed have been reduced to a ruinous state. But, it is not even certain that the palace Tafur describes is the Blachernai, for his description comes in the part of his account that is a general description of the city; it follows his mention of the Hippodrome which adjoined the Great Palace. ${ }^{74}$

A further obstacle to uncovering the nature of Pseudo-Kodinos' palace is his lack of a protocol for the reception of foreign visitors to the capital. As it is impossible to conclude from the absence of such a protocol that foreigners were not given audience, we must assume that Pseudo-Kodinos omitted the protocol for another reason. Again we return to the differences in the nature of the two ceremonial books.

Receptions of ambassadors are not the only ceremonies that do not appear in Pseudo-Kodinos' work. Descriptions of processions inside the palace are likewise missing. In fact, for Pseudo-Kodinos, the word $\dot{\alpha} \pi \dot{\varepsilon} \rho \chi \varepsilon \tau \alpha 1-$ 'he goes', ${ }^{75}$ suffices for any description of movement. On the occasion when the emperor is said to leave the palace to accompany the icon of the Hodegetria to the boundaries of the palace, to the gate called Ta Hypsela, we are not told what route he took or what spaces or rooms he passed through to arrive at his destination. ${ }^{76}$ No processions are recounted in detail and, therefore, no (other) rooms

${ }^{72}$ Tafur, Travels and Adventures, p. 117.

${ }^{73}$ E.g. the receptions of Olga of Kiev: see Featherstone, ' $\Delta \mathrm{I}$ ' EN $\Delta$ EIEIN', 107-108, $109,111,112$.

${ }_{74}$ Tafur, Travels and Adventures, pp. 141-146. Tafur's palace description (p. 145) comes much later than his mention of his reception by the emperor (p. 117). G.P. Majeska, Russian Travelers to Constantinople in the Fourteenth and Fifteenth Centuries (Washington, D.C. 1984) p. 244, assumes that Tafur refers to the Great Palace.

${ }^{75}$ E.g., ed. Verpeaux, 242.10, 14, 23; 243.8, 10, 14; 244.13.

${ }^{76}$ Ed. Verpeaux, 231.6-12. 
are mentioned. Yet we know that processions did take place for, the 'daily procession' of the title-holders that occurred twice a day, as in the time of the Book of Ceremonies, is mentioned more than once. ${ }^{77}$ Yet, unlike the earlier ceremonial text, the fourteenth-century one does not relate how the title-holders reached the reception room.

The lack of description of internal processions is paralleled by an equally uninformative account of movement outside the palace. The emperor celebrates certain feast days in churches and monasteries scattered throughout the city. ${ }^{78}$ The closest venues are the Blachernai church and the Petra monastery, while the Peribleptos and St Demetrios, on the Sea of Marmara, and the Mangana and St Lazaros, on the Bosphoros, are the furthest from the palace. ${ }^{79}$ When the emperor leaves the palace to attend services in these places Pseudo-Kodinos does not relate how the emperor travelled, except in two cases, for the celebrations in the Blachernai church on his doorstep, and in the Petra monastery, not far away. In these instances, he states: 'The Varangians accompany the emperor. They always accompany him when he rides on horseback' ${ }^{80}$ Are we therefore to conclude that the emperor went by sea on the other occasions? ${ }^{81}$ Rather, it seems that Pseudo-Kodinos specifies the Varangian escort in these cases simply because it is only then that the Varangians accompany the emperor all the way to the church or monastery. In the other cases, they go as far as the outer gate of the palace and wait there for the emperor to return. ${ }^{82}$ Thus, although it can be inferred that the emperor went on horseback to the other venues, we are not told what kind of an escort he had.

It would appear from these examples that, although Pseudo-Kodinos provides detail in relation to dress and other aspects of court life, ${ }^{83}$ description of movement does not feature much in his work, in great contrast to the Book of Ceremonies which could be said to be mainly about processions ${ }^{84}$ Instead, it is the static tableau on which

77 Reiske, 518-522; ed. Verpeaux, 191.22-23; 212.15-17.

${ }^{78}$ Ed. Verpeaux, 242-247.

${ }^{79}$ Magdalino, 'Pseudo-Kodinos' Constantinople', pp. 6-11.

${ }^{80}$ Ed. Verpeaux, 243.17-21.

${ }^{81}$ Albrecht Berger, 'Imperial and ecclesiastical processions in Constantinople', in: Byzantine Constantinople, Nevra Necipoğlu, ed. (Leiden 2001) pp. 73-85, here at pp. 83-85.

${ }_{82}$ Ed. Verpeaux, 243.20-244.8; 244.16-245.2.

${ }^{83}$ See above, pp. 221-224.

${ }^{84}$ Cameron, 'The construction of court ritual', pp. 112, 114; Berger, 'Imperial and ecclesiastical processions', pp. 73-85, here at p. 77; McCormick, ODB I, p. 596. 
Pseudo-Kodinos lavishes most time and space. His account of the prokypsis ceremony that took place on Christmas Eve and Epiphany constitutes the longest single description of a ceremony in his work. ${ }^{85}$ The emperor, elevated on a tall structure in the courtyard of the palace, stands motionless, illuminated by artificial light and acclaimed by court officials and the people. Pseudo-Kodinos builds up suspense in his description. He describes the setting, the performers, their clothing, the props and, finally, the performance. Like a radio or television commentator he fills in time, while the emperor and his sons are changing their clothes on the platform, behind closed curtains, and taking up their positions. We can almost hear him whispering his commentary on the items of imperial clothing and their symbolic significance, ${ }^{86}$ as we wait for the curtains to part, revealing the emperor from the knees up and the emperor's sons from the chest up. ${ }^{87}$

I would suggest that if the Blachernai palace, as it emerges from the Treatise, seems pitifully small, if ceremonial space in the midfourteenth century seems terribly limited, this has more to do with the nature of the Treatise than the physical reality.

Indeed, that there is more to fourteenth-century ceremonial and the space in which it was conducted than the Treatise shows is indicated by Pseudo-Kodinos' mention only in passing of the twice daily receptions of title-holders before the emperor, ${ }^{88}$ and his omission of many ceremonies which, there can be no doubt, did take place in his time: imperial births, baptisms, weddings, funerals, and receptions of ambassadors. He does not give an account of any of the above directly, yet he describes aspects of some of these ceremonies, giving us reason to believe that the ceremonies did take place. For example, he provides the protocol for the reception of a foreign imperial bride-to-be in Constantinople, relating in passing the provisions for the suppliers of the drinks and for the entertainers. ${ }^{89}$ However, the protocol for a wedding is not given. Likewise, the anonymous author of the Treatise devotes a section to the attire of an emperor who is in mourning ${ }^{90}$ and elsewhere in the work he discusses the different arrangements for an emperor in

${ }^{85}$ Ed. Verpeaux, 195.24-204.23.

${ }^{86}$ Ed. Verpeaux, 200.14-202.14.

87 Ed. Verpeaux, 203.7-11.

88 Ed. Verpeaux, 191.22-23; 212.15-17.

${ }^{89}$ Ed. Verpeaux, 286-287, here 287.22-29.

90 Ed. Verpeaux, 284-285. 
mourning during the Christmas and Easter celebrations. ${ }^{91}$ Yet, there is no protocol for an imperial funeral. Again, he relates the different ways in which the representatives of the Genoese and the Venetians are received before the emperor at Christmas and Easter and when they first arrive in the capital, ${ }^{92}$ but he gives no specific protocol for the receptions of foreign ambassadors. Finally, Pseudo-Kodinos discusses at length the reason for the suite of horses that accompanies the emperor when he rides out to receive petitions from his subjects. ${ }^{93}$ To explain the origin of the custom, he relates an incident in the reign of the emperor Theophilos (829-842).$^{94}$ Furthermore, he recounts the kinds of instruments that accompany the emperor's riding out, when they are played and why ${ }^{95}$ However, he relates all this information as an aside to his description of the functions of the protostrator, ${ }^{96}$ and not as one of the ceremonies. ${ }^{97}$

Thus, comparison with the Book of Ceremonies shows the Treatise to provide a more limited description of ceremony. But the differences in content are misleading. It has been argued here that there is much more to the ceremonial life of the court in the mid-fourteenth century than Pseudo-Kodinos includes in his Treatise. And, if the Treatise is thin because it does not include all ceremonies, the Book of Ceremonies is fat because it includes a great deal of material not in use at the time of its compilation. Here we come to another important difference in the two works: the Book of Ceremonies is antiquarian, while the Treatise presents living ceremony, protocols that reflect ceremonies that were being performed in the mid-fourteenth century. Examples are the Christmas and Epiphany prokypseis, described also by Gregoras, the coronation protocol, given also by Kantakouzenos in his account

\footnotetext{
${ }^{91}$ Ed. Verpeaux, 226.22-228.3.

${ }_{92}$ Ed. Verpeaux, 234.28-235.13; 235.14-237.5.

${ }_{93}$ Ed. Verpeaux, 168.28-169.2; 170.6-171.7; Macrides, “"The reason is not known.”, pp. 325-328.

${ }_{94}$ Ruth Macrides, 'The ritual of petition', in: D. Yatromanolakis and P. Roilos, Greek Ritual Poetics (Washington, D.C. 2004) pp. 356-370, here pp. 359-364. The Madrid Skylitzes illustrates the emperor Theophilos' ride to the Blachernai in the course of which he was stopped by petitioners: Vasiliki Tsamakda, The Illustrated Chronicle of Ioannes Skylitzes in Madrid (Leiden 2002) fig. 95 (fol. 43 r).

${ }_{95}$ Ed. Verpeaux, 173.1-15.

${ }^{96}$ Ed. Verpeaux, 168.1, $28 \mathrm{ff}$.

${ }^{97}$ It could be the case that the author-compiler and his contemporaries did not consider the emperor's 'riding out' to hear petitions a ceremony as such. It did, however, have ritual elements such as its repetitive nature, the suite of horses in train, the fanfare that accompanied the emperor. See notes 93-95 above.
} 
of Andronikos III's coronation, the acclamation of the emperor by the Genoese ships, described by Gregoras, and the wearing of white for mourning, known also from Kantakouzenos and Gregoras. ${ }^{98}$ Therefore, the differences in size and content of the two texts have more to do with the different purposes and approaches of the compiler-authors than with a reduction in ceremonies.

Finally, the ceremonial of the late Byzantine court is also said to be isolated from the city, taking place in seclusion in the fortresslike remains of a palace. ${ }^{99}$ The Treatise, however, gives evidence for the emperor's attendance at the holy day celebrations in a number of churches throughout the city, the same number as in the time of the Book of Ceremonies. ${ }^{100}$ The emperor would have travelled to those churches on horseback and thus could have been seen by people lining the processional route, even if that route is not described by PseudoKodinos. Furthermore, the emperor's kaballikeuma or 'riding out' to receive petitions, brought emperor and inhabitants of the city into contact. ${ }^{101}$ Another point of contact was at the prokypsis ceremony in the courtyard of the palace. If the kathisma, that held the emperor and projected onto the Hippodrome, formed the interface between palace and Hippodrome in former times, the prokypsis in the courtyard of the Blachernai ${ }^{102}$ performed the same function in the later Byzantine period. Twice a year, at Christmas and Epiphany, the people of the city saw the emperor on an elevated platform, illuminated by artificial light and acclaimed with accompanying trumpets and other instruments. ${ }^{103}$

In the four hundred years separating the Book of Ceremonies from the Treatise of Pseudo-Kodinos, Byzantine ceremonial practice underwent many changes. Some change was brought about by external factors-

98 Prokypseis: Gregoras II, 617.23-618.5; coronation: Kantakouzenos I, 196.17204.3; acclamation of ships: Gregoras I, 134.15-18; white: Kantakouzenos II, 167.6-8; Gregoras II, 612.5-9.

99 Magdalino, 'Court and Capital in Byzantium', in this volume, pp. 141-143.

100 Magdalino, 'Pseudo-Kodinos' Constantinople', p. 1.

101 See above, p. 233.

102 Ed. Verpeaux, 197.1-204.7.

${ }^{103}$ Gregoras, II, 616.16-617.9 makes several references to the crowds of people, in addition to the army, gathered at the Christmas prokypsis of John V in 1341. He compares the mass of people to rivers that converged. See, in particular, II, 616.21, 24; 617, $6,8,9$. For the origins of the prokypsis ceremony which has parallels with the appearance of the emperor in the kathisma box at the Hippodrome, see G. Dagron, 'Trônes

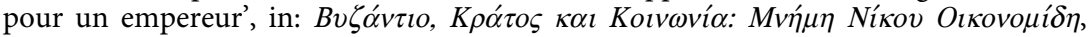
A. Avramea, A. Laiou and E. Chrysos, eds. (Athens 2003) pp. 179-203, here at pp. 184-185. 
the impoverishment of the state and the difficult political conditions. ${ }^{104}$ But everything we see in the Treatise cannot be explained by the latter. Imperial ceremonies are 'subject to the relentless process of historical change'. ${ }^{105}$ Even as the Book of Ceremonies was being compiled 'the great public imperial occasions in the Hippodrome were beginning to give way to private ceremony in the imperial palace'. ${ }^{106}$ Furthermore, exactly at the time when the Book of Ceremonies was being compiled (963-969), Nikephoros II Phokas erected a fortified wall dividing the upper terraces of the palace from the lower inhabited section. ${ }^{107} \mathrm{He}$ thereby turned the palace into 'a kind of castle'. ${ }^{108}$ Thus, already in the tenth century, the Great Palace was being compared to a fortress, as has been the Blachernai palace of the fourteenth century, ${ }^{109}$ and already in the tenth century ceremonial was taking on a less public role which has been described as a 'retreat of government from the public scene'. ${ }^{110}$ The same has been said of Pseudo-Kodinos' ceremonial. One should not therefore assume that what one sees in the Treatise are the signs of decay and loss. What we see, rather, is a development that had its origins in the great days of empire.

${ }^{104}$ Pseudo-Kodinos (ed. Verpeaux, 237.29-238.4) seems to acknowledge change effected by a lack of resources when he states 'It was an old custom at this vesper service for the emperor to enter the holy sanctuary and to cense the holy altar table and to give the clerics a gift of 100 pounds of gold from the vestiarion. Now this does not take place.'

${ }^{105}$ Michael McCormick, 'Analyzing imperial ceremonies', Jahrbuch der Österreichischen Byzantinistik 35 (1985) pp. 1-20, here p. 2; Cameron, 'The construction of court ritual', 136.

106 Cameron, 'The construction of court ritual', p. 131, citing Michael McCormick, Eternal victory (Cambridge 1986).

${ }_{107}$ Cyril Mango, 'The palace of the Boukoleon', Cahiers archéologiques 45 (1997) pp. 41-50, here at pp. 42-45.

${ }^{108}$ Ioannes Skylitzes, Synopsis Historiarum, I. Thurn, ed. (Berlin; New York 1973) 275.77-87.

${ }^{109}$ See Magdalino 'Court and capital in Byzantium', above p. 139; Henry Maguire, 'Images of the court', in: The Glory of Byzantium, Helen C. Evans and William D. Wixom, eds. (New York 1996) pp. 183-191, here p. 183; S. Ćurčić, 'Late medieval fortified palaces in the Balkans: security and survival', Monument and Environment 6 (2000) pp. 11-41, here pp. 11-17.

${ }_{110}$ Cameron, 'The construction of court ritual', p. 131. 
THE EARLY MODERN WORLD 


\title{
THE POPE'S HOUSEHOLD AND COURT IN THE EARLY MODERN AGE
}

\author{
Maria Antonietta Visceglia
}

Traditionally, the international historiography of the papal court in the Modern Age has concentrated on the origins and development of the curial bureaucracy, ${ }^{1}$ and on the relationship between this bureaucracy and the Italian aristocracy. This practice was in line with the general debate about the rise of the modern state-of which the Ecclesiastical State could be considered an early, original model. ${ }^{2}$ Studies on the figure of the cardinal-nephew-the secretary of state ${ }^{3}$ - and on pontifical diplomacy added a lively field of research still fitting into the above-mentioned debate. ${ }^{4}$

${ }^{1}$ Peter Partner, The Pope's Men: the Papal Civil Service in the Renaissance (Oxford 1990).

2 Paolo Prodi, Il sovrano pontefice. Un corpo e due anime: la monarchia papale nella prima età moderna (Bologna 1982) translated Susan Haskins, The Papal Prince, One Body and Two Souls: The Papal Monarchy in Early Modern Europe (Cambridge 1987). The bibliography on the themes of bureaucracy and Italian aristocracy of the papal state in the modern era is extensive. These research themes were established at the end of the 1990s with the reviews of Marco Pellegrini, 'Corte di Roma e aristocrazie italiane in età moderna. Per una lettura storico-sociale della curia romana', in: Rivista di storia e letteratura religiosa XXX (1994) pp. 543-602; Maria Antonietta Visceglia, 'Burocrazia, mobilità sociale e patronage alla corte di Roma tra Cinque e Seicento. Alcuni aspetti del recente dibattito storiografico e prospettive di ricerca', in: Roma moderna e contemporanea. Rivista interdisciplinare di storia III, 1 (1995). I will point out among the most recent contributions: Armand Jamme and Olivier Poncet, Offices et Papauté. Charges, Hommes, Destins (XIV e-XVII siècle) (Rome 2005); Antonio Menniti Ippolito, Il governo dei papi nell'età moderna. Carriere, gerarchie, organizzazione curiale (Rome 2007).

${ }^{3}$ Madeleine Laurain-Portemer, 'Absolutisme et Népotisme. La Surintendance de L'État Ecclésiastique', Bibliothèque de l'École des Chartes CXXXI (1973), and most recently Antonio Menniti Ippolito, Il tramonto della Curia nepotista. Papi, nipoti e burocrazia curiale tra XV e XVII secolo (Rome 1999).

${ }^{4}$ Georg Lutz, 'Le ricerche internazionali sulle nunziature e l'edizioni delle istruzioni generali di Clemente VIII', in: L'Archivio Segreto Vaticano e le ricerche storiche, Paolo Vian, ed. (Rome 1983); Georg Lutz, ed., Das Papsttum, die Christenheit und die Staaten Europas, 1592-1605: Forschungen zu den Hauptinstruktionen Clemens' VIII (Tübingen 1994); Alexander Koller, ed., Kurie und Politik; Stand und Perspektiven der Nuntiaturberichtsforschung (Tübingen 1998). 
This institutional approach has since become more elaborate and been enriched by German ${ }^{5}$ and Italian ${ }^{6}$ research on the social history of the Roman Curia. These later studies have stressed the courtly dynamic that contributed to the selection of papal personnel, highlighting the role of kinship within the familia of the reigning pontiff and among the cardinal families, the meaning of friendship as a system of reciprocity, and the practice of patronage leading to groups of clients. While the theme of the pontiff's household can be seen as part of this subject, unlike the cardinal families, it has not to date been the object of specific research. ${ }^{7}$

In contrast, at the European level there have been many studies on the relationship between Household and Court in the Medieval and Modern ages, which have opened up new questions and reflections about the relationship between the sovereign's private entourage and the bureaucratic structures of the State. ${ }^{8}$ At all European courts the

${ }^{5}$ I restrict myself to citing Wolfgang Reinhard, Freunde und Kreaturen. "Verflechtung" als Konzept zur Erforschung Historischer Führungsgruppen. Römische Oligarchie um 1600 (Munich 1979); Wolfgang Reinhard, 'Amici e creature. Micropolitica della curia romana nel XVII secolo', Dimensioni e problemi della ricerca storica 2 (2001) p. 61; Irene Fosi Polverini, 'Amici, creature, parenti: la corte romana osservata da storici tedeschi', Dimensioni e problemi della ricerca storica 2 (2001); Julia Zunckel and Wolfgang Reinhard, eds., Römische Mikropolitik unter Papst Paul V. Borghese (1605-1621), zwischen Spanien, Neapel, Mailand und Genua (Tübingen 2004).

${ }^{6}$ Renata Ago, Carriere e clientele nella Roma barocca (Rome 1990); Irene Polverini Fosi, All'ombra dei Barberini: fedeltà e servizio nella Roma barocca (Rome 1997); Gianvittorio Signorotto and Maria Antonietta Visceglia, eds., La corte di Roma fra Cinque e Seicento "Teatro" della politica europea (Rome 1998).

7 Pierre Hurtubise, 'Familiarité et fidelité à Rome au XVI' siècle: les 'familles' des cardinaux Giovanni, Bernardo et Antonio Maria Salvati', in: Hommage à Roland Mousnier. Clientèles et fidelité en Europe à l'époque moderne, Y. Durand, ed. (Paris 1981) p. 342. On the cardinal "family", refer to, Pierre Hurtubise, "La "familia" del cardinale Giovanni Salviati (1517-1553)', in: "Familia" del Principe e famiglia aristocratica, Cesare Mozzarelli, ed. (Rome 1988) pp. 589-609; Lucinda Byatt, 'Aspetti giuridici e finanziari di una "familia" cardinalizia del XVI secolo: un progetto di ricerca', in: "Familia" del Principe, Cesare Mozzarelli, ed. (Rome 1988) pp. 611-627; Gigliola Fragnito, "Parenti" e "familiari" nelle corti cardinalizie del Rinascimento', in: "Familia" del Principe, Cesare Mozzarelli, ed. (Rome 1988) pp. 565-587; Gigliola Fragnito, 'Le corti cardinalizie nella Roma del Cinquecento', Rivista storica italiana, CVI (1994) pp. 5-41.

${ }^{8}$ From the rich bibliography on this theme, I restrict myself to citing the contributions that I have directly utilized in these pages: John Adamson, The Princely Courts of Europe: Ritual, Politics and Culture under the Ancien Régime 1500-1750 (London 1999); Jacqueline Boucher, 'L'évolution de la Maison du Roi des derniers Valois aux premiers Bourbons', XVII ${ }^{e}$ siècle, XXXIV (1982) pp. 359-379; Miguel Angel Ladero Quesada, 'Casa y Corte. L'Hôtel du roi et la Cour comme institutions économiques au temps de Rois Catholiques', in: La cour comme institution économique, Maurice 
terms Casa, Household, Maison-corresponding to the Latin term Familia $^{9}$-cover diverse sectors with distinct functions. Schematically, we can amalgamate these into domestic service, and financial and administrative offices. The sovereign depended on these offices for the needs of daily life and the expression and exercise of his sovereignty, firstly in the palace but also during particular ceremonial or political occasions outside of it. Rank, dignity, duty, and favor defined various hierarchies. Courtiers of the highest rank held offices endowed with particular competences, but the household also included subordinate ranks and offices. As we shall see in our case study, belonging to the lower level of the family entailed particular advantages, but it did not as a rule grant rights of access to the sovereign. Therefore if, as Ronald G. Asch writes, 'the real criterion for membership of the court was access to the ruler, ${ }^{10}$ we cannot simply equate the household and the court. A more careful delineation is necessary, including institutional divisions as well as ranks.

The familia of the pontiff and the Roman Court covered two groups of individuals partly overlapping and partly different. Service to the pope united court and family. Yet while courtiers, who lived in the Palace or carried out missions for their sovereign far away, had access to the person of the pope on certain occasions, even if it might have been limited and regulated, Famuli that carried out humble duties did not enjoy the privilege of being near the pontiff, even though they lived under the same roof. Moreover, in the space in which court and palace coincided, service to the pope could be service to the 'private' person but also to the public person of the sovereign, thus including financial, political, diplomatic and governmental functions.

Aymard and Marzio A. Romani, eds. (Paris 1998) pp. 43-54; José Jurado Sánchez, 'La financiación de la Casa Real española y sus repercusiones sobre la Hacienda y la economía', in: La cour comme institution économique, Aymard and Romani, eds. (Paris 1998) pp. 57-64; José Martínez Millán, ed., La Corte de Carlos V, vol. III. Los servidores de las Casas Reales, vol. IV and V (Madrid 2000); José Martínez Millán and Santiago Fernández Conti, eds., La monarquía de Felipe II: La Casa del Rey II (Madrid 2005).

${ }_{9}^{9}$ In this paper I will use the Latin term familia and the English word family interchangeably in this extended sense. I also will use the term famuli for minor members of the familia. Where I intend family in the more limited and usual sense of kinship by blood or through marriage alliances I shall make this reference explicit.

${ }_{10}$ Ronald G. Asch, 'Introduction: Court and Household from the Fifteenth to the Seventeenth Centuries', in: Princes, Patronage and Nobility: The Court at the Beginning of the Modern Age, Ronald G. Asch and Adolf M. Birke, eds. (London; Oxford 1991) p. 8. 
In his comprehensive study of the papal court of Avignon, Bernard Guillemain considered the papal stay in Avignon to have stabilized the functions and shape of the officiales Sedis apostolicae. This not only comprised administrative posts, but also the service workers linked to the domestic sphere and members of the military orders. ${ }^{11}$ The French historian calculated that 500 to 650 persons followed the pontifical court, of which a more limited number (around 50\%) composed the domestic entourage. ${ }^{12}$ These figures would indicate that the definition of spheres was almost complete at that time. However, as Guillemain often underlines, administrative work and domestic functions remained highly interwoven. They were not always separable and their staffs were interchangeable. ${ }^{13}$

We certainly need to recognize the centrality of the Avignon period as a phase that accelerated the structuring process of the papal court, influenced by the French kingship model and the French nationality of the popes elected in that period, as well as by the court's location on French soil. Nevertheless, even in the 1500s and 1600s it appears to have been uncertain how to define a domestic servant of the pope. However, it is clear that these centuries saw significant changes in the structure of the household of the pope.

In this paper, we will consider two aspects of this transformation process:

I. the organisation of offices into sectors in the late Medieval period;

II. the clarification of privileges and prerogatives in the course of the Modern era.

Our intent is to draw a-necessarily schematic-picture of the household of the pope that shows the many features that this segment of the pontifical court shared with the palace offices of other European sovereigns' courts. It also shows how the specific features became clear and then rigid until the papal court acquired its own distinctive configuration in the course of the Modern age

${ }^{11}$ Bernard Guillemain, La cour pontificale d'Avignon: (1309-1376); Étude d'une société (Paris 1962).

${ }_{12}$ Guillemain, La cour pontificale, p. 722.

${ }_{13}$ Guillemain, La cour pontificale, p. 423. 
Table 1. List of popes $1417-1774$

\begin{tabular}{llll}
\hline Martin V & $(1417-31)$ & Urban VII & $(1590)$ \\
Eugene IV & $(1431-47)$ & Gregory XIV & $(1590-91)$ \\
Nicholas V & $(1447-55)$ & Innocent IX & $(1591)$ \\
Callistus III & $(1455-58)$ & Clement VIII & $(1592-1605)$ \\
Pius II & $(1458-64)$ & Leo XI & $(1605)$ \\
Paul II & $(1464-71)$ & Paul V & $(1605-21)$ \\
Sixtus IV & $(1471-84)$ & Gregory XV & $(1621-23)$ \\
Innocent VIII & $(1484-92)$ & Urban VIII & $(1623-44)$ \\
Alexander VI & $(1492-1503)$ & Innocent X & $(1644-55)$ \\
Pius III & $(1503)$ & Alexander VII & $(1655-67)$ \\
Julius II & $(1503-13)$ & Clement IX & $(1667-69)$ \\
Leo X & $(1513-21)$ & Clement X & $(1670-76)$ \\
Adrian VI & $(1522-23)$ & Innocent XI & $(1676-89)$ \\
Clement VII & $(1523-34)$ & Alexander VIII & $(1689-91)$ \\
Paul III & $(1534-49)$ & Innocent XII & $(1691-1700)$ \\
Julius III & $(1550-55)$ & Clement XI & $(1700-21)$ \\
Marcellus II & $(1555)$ & Innocent XIII & $(1721-24)$ \\
Paul IV & $(1555-59)$ & Benedict XIII & $(1724-30)$ \\
Pius IV & $(1559-65)$ & Clement XII & $(1730-40)$ \\
Pius V & $(1566-72)$ & Benedict XIV & $(1740-58)$ \\
Gregory XIII & $(1572-85)$ & Clement XIII & $(1758-69)$ \\
Sixtus V & $(1585-90)$ & Clement XIV & $(1769-74)$ \\
\hline
\end{tabular}

\section{Organization of the Household}

A document from the beginning of the fifteenth century entitled $D e$ officialibus palatii pontificii enumerates a good 25 categories for officials that served the pope. The Lateran canon Giovan Battista Gattico edited and published this text in the mid-eighteenth century, considering it a significant statement about the customs of the Roman court in earlier eras. ${ }^{14}$

The cubiculari (private chamberlains), intimate domestic servants assigned to the pope's personal service and part of the familia, were divided into cubiculari d'onore (only some of whom were prelates), and cubiculari domestici, (these could be either prelates or laymen). Even as laymen, these servants enjoyed rights of sustenance for themselves

${ }^{14}$ Johannes Baptista Gattico, Acta selecta caeremonialia Sanctae Romane Ecclesiae ex variis Mss. Codicibus et diariis saeculi XV, XVI, XVII. apud haeredes Jo. Laurentii Barbiellini (Rome 1735) p. 263. 
and for two retainers in the Apostolic Palace. In late medieval sources, the office of the cubiculario covered a vast and still not very clearly defined sphere: control of the papal chamber, compilation of a register documenting the order of persons received by the pontiff, care of clothing and valuables. But the office also dealt with letters, petitions and other writings-even secret ones-directed to the pope, and the real possibility of reporting on these to alleviate the work of the pope. The ambiguous nature of these duties contrasts with the more precise definition of other offices that concerned only 'administrative' duties or 'custody' of the person and palace of the sovereign. If in fact the cubicularii could act as referendaries, this did not mean that the pope did not need and have a larger group of official referendaries in the Apostolic Palace for the registration of petitions and letters.

The various specific tasks of court life were each entrusted to a special group of servants. Even the guarding of the doors required specific figures. The hostarii (ushers) were usually honest, trustworthy, and virtuous laymen that slept in the room in front of the papal chamber. The custody of the iron doors was entrusted to two hostiarii chosen from the minor attendants. Six cursori (couriers) served weekly in the Palace as messengers, linking the internal and external space of the court. The scutiferi (shield-bearers, écuyers), an office of honor performed by laymen not living in the Palace, marched in processions carrying the insignia and garments of the pontiff and the court dignitaries behind the Magister palafrenariae who was usually one of the scutiferi, an expert knight in command of an indeterminate number of heralds. Palace organization as a whole pivoted around the Magister Hospitii. He was a layman, a man of authority whose duty-in addition to receiving guests-consisted of keeping watch over everything pertaining to the economic and moral governance of the palace. For example, he oversaw games, prevented brawls, and verified and signed all the coupons of payment concerning the familiares.

The de officialibus palatii pontificii describes in detail the functions of various other positions: the panateria, directed by two presbyters, the buticularia and officium acquae (with three magistri of whom at least two were clerics) saw to the supply and distribution of bread, wines and water, and the floreria (whose holder could be a cleric or a layman) took care of those objects and vestments not falling under the responsibility of the cubicularii. Furthermore, there was the office that supervised the purchase and use of wax as well as the care of the papal 
candelabras (officium cerae). This position was considered very honorable and assigned to an honest and faithful cleric. The office dealing with the custody of the furnishings (de custode vaxellae) was also entrusted to a cleric.

Each of these sectors involved in management of the household also had its own internal hierarchy. The magistri needed to deliver the receipts documenting expenses to the Magister hospitii daily. Even if this administrative-accounting was exclusively their duty, in day-today work they were supported by minor officials. These latter were sometimes clerics and sometimes laymen, like the magister coquinae (secular), the expensor (ecclesiastic), the custos cibariorum (ecclesiastic), the magister operum, the magister aulae and numerous famuli. As at other contemporary courts, the distinction between high and low familia could be blurred within single offices. Except for the easily identifiable major offices, there was still no delineated hierarchy among them.

The offices that strictly concerned the spiritual sphere merit mention. Firstly, the pope's confessore-chosen according to the pontiff's wishes-enjoyed continuous residence in the palace and assisted the pope in the liturgical offices. He had the privilege of riding in the celebration of Corpus Domini immediately following the mule that carried the Holy Sacrament. Secondly, there was the Sacrista. ${ }^{15}$ Thirdly we find the Magister Palatii (the office of doctrinal control distinct from the Magister Hospitii), appointed by the pope from among the Dominican friars. ${ }^{16}$ Then there was the Elemosinarius, who only occasionally resided in the Palace and was a cleric entrusted with assistance of the poor and intercession with the pope on behalf of the prelates, the religious, and ecclesiastical institutions. Finally there was the Magister capellae who governed the service of the papal chapel. Alongside him were 12 choristers

15 The Confessore and Sacrista of the pope were a single figure until Sixtus IV; the functions were then separated into two offices and so the family had a confessore that was "part of the apostolic palace." The end of the 1620s settled the right of the order of Servi di Maria to the confessorato of the pontifical conclave. The confessore of the pontifical family could become the confessor of the conclave. See P.A.M. Vicentini, Dei Servi di Maria Memorie storiche (1925). In contrast to the rich bibliography on royal confessori, an up-to-date work on this significant theme is missing.

${ }_{16}$ Giuseppe Catalani, De Magistro Sacri Palatii Apostolici libri duo (Rome 1751). Also refer to P. Innocentius Taurisano, 'Series chronologica Magistrorum Sacri Palatii Apostolici ab anno 1217 ad annum 1916', in: Hierachia Ordinis Praedicatorum (Rome 1916) pp. 111-121. 
and three clerics 'clerici capellae seu caerimoniarum' who only dined in the Apostolic Palace during feasts but received a stipend, the amount of which was noted in the books of the Apostolic Chamber. ${ }^{17}$

Even before the de officialibus palatii pontificii the care and management of the Palace, the physical and spiritual attendance of the person of the pope, and the governance of the curia had been described as specific offices, even if in practice these domains were not sharply differentiated. Moreover the uncertainty about the number of office titleholders is significant: the number of cubicularii, scutiferi, and also hostiarii was not rigidly defined but left to the decision of the pontiff who named them.

Finally, as the formula 'cleric or layman' that in some cases appears alongside the definition of an office demonstrates, the original character of the papal family was not completely clerical. If we take one of the oldest sources, the list of familiares of Nicholas III (1277) published by Galletti, we find numerous dominicelli among the domestic officials distinguished by function and by rank: young noble laymen serving the pope. ${ }^{18}$ In the Medieval period and still at the beginning of the fifteenth century, the household was a fluid social configuration. It was neither static nor completely clerical, even if it tended toward a split between offices of government of the Palace (entrusted to clerics) and offices of honor (entrusted to noble laymen).

Beyond their value for ascertaining the manner of naming offices, ${ }^{19}$ the first nominative lists of papal officials in domestic service inform us of the officials' national identity, reflecting the important change that came about in the papal court after its return to Rome. The Liber officialium of Martin V gives us a diachronic image of the staff of the

17 Etienne Anheim has identified the birth of the office of magister capelle in the first half of the fourteenth century (1336) with management of the chapel, liturgy, and music. At the beginning of the fifteenth century the master of the chapel also received the duty of reading the Bible. In the course of the century the clerics of the chapel alongside him became clerici capelle/clerici caerimoniarum and then became masters of ceremonies. Etienne Anheim, 'Naissance d'un office. Pierre Sintier, premier maître de la chapelle du pape (1336-1350)', in: Jamme and Poncet, Offices et Papauté, pp. 267-301.

${ }^{18}$ Paolo Piccolomini, 'La famiglia di Pio III', Archivio della R. Società Romana di Storia Patria XXVI (1903) pp. 143-164.

19 I have permitted myself to refer to Maria Antonietta Visceglia, 'Denominare e classificare: Familia e familiari del papa nella lunga durata dell'età moderna', in: Armand Jamme and Olivier Poncet, Offices et Papauté, 159-195. 
court. Whether chamber officials or members of the household, those who entered service during the pontificate of the Colonna pope took oaths to the Camerario (the Camerario signed the 'litterae de fructis percipiendis' that allowed the familiares to cash office emoluments) or to the Vice-Camerario. ${ }^{20}$ The cubicularii of the Roman pope Ottone Colonna, whose election put an end to the Western Schism, were highranking prelates, predominantly French, but also German and English. The scutiferi d'honore were also dominicelli of various nationalities.

The courts of Martin V and his successor Eugene IV present an international makeup, ${ }^{21}$ with a strong French presence also in the court of the latter. ${ }^{22}$ But within a few years (in 1460), the domus pontificalis of Pius II (Enea Silvio Piccolomini) had a clearly Italian (in fact Sienese) predominance ${ }^{23}$ and the pontiff's blood relatives were in the key positions of Palace government. Upon the death of the pontiff in August 1464, however, they would be rapidly excluded from management of power. ${ }^{24}$ The nephew of Pius II (Francesco Todeschini-Piccolomini) became pope in September 1503. Although the brevity of his pontificate, which lasted only a month, did not give him the opportunity to make any substantial changes in the family of his predecessor Alexander VI, he brought to the Palace those who had served him as cardinal and those who had belonged to his uncle Pius II's entourage, as well as his blood relatives whose servants were included in the household's ranks. ${ }^{25}$ Pius III's camerarius et depositarius was the Sienese banker

\footnotetext{
${ }^{20}$ Archivio di Stato di Roma, Le Liber officialium de Martin $V$ published by François-Charles Uginet (Rome 1975).

${ }^{21}$ On pope Condulmer see Denys Hay, 'Eugenio IV', Enciclopedia dei Papi, vol. II (Rome 2000) pp. 634-640.

${ }^{22}$ Georges Bourgin, 'La "familia” pontificia sotto Eugenio IV', Archivio della $R$. Società Romana di Storia Patria XXVII (Rome 1904) pp. 203-224.

${ }^{23}$ Gaetano Marini, Degli archiatri pontificii, vol. II (Rome 1784) pp. 152-66; but also in Gaetano Moroni's own voice, see Gaetano Moroni, 'Famiglia Pontificia', in: Dizionario di erudizione storico-ecclesiastica, XXIII, Gaetano Moroni, ed. (Venice 1843), cited pp. 54-57. On Pius II see M. Pellegrini, Enciclopedia dei Papi, vol. II (Rome 2000) cited pp. 663-685, ad vocem. On ceremonial role of Siena during the long stay of the papal court (1460) see: Fabrizio Nevola, 'Ritual geography: Housing the Papal Court of Pius II Piccolomini in Siena (1459-1460)', Renaissance Studies 20, 2 (2006) pp. 202-225, and idem, "'La più gloriosa solemnità che a di de padri nostri giammai fusse veduta": Feste e apparati urbani durante il pontificato di Pio II Piccolomini', in: I luoghi del Sacro, Fabrizio Ricciardelli, ed., Yearbook of Georgetown University at Ville le Balze, Firenze (Firenze 2008) pp. 171-186.

${ }^{24}$ Matteo Sanfilippo, Pio III, Enciclopedia dei papi, vol. III, p. 23.

${ }^{25}$ Piccolomini, "La famiglia di Pio III", cited pp. 143-164.
} 
Giulio Spannocchi, son of Ambrogio Spannocchi who had earned considerable standing in the curia. Ambrogio had already received charge of the Depositaria della Crociata under Callistus III and then became general secretary and treasurer of the city of Rome under Pius II. ${ }^{26}$ The Italianization of the household and the curia, accomplished in the passage from the fifteenth to the sixteenth century, is a complex phenomenon. ${ }^{27}$ It was certainly the result of the change in the characteristics of medieval papal nepotism which lost its original feature as an instrument of military control of the territory. ${ }^{28}$ But it was as well a consequence of the 'pact' that was established between the Italian nobility and urban patricians, on the one hand, and the papacy, on the other. It also reflected the predominance of Italian merchants and bankers in the financial apparatus of the curia. This development was one of the distinctive characteristics of the papacy of the Renaissance and would be consolidated by the Medici popes, the embodiment of a merchant-banker dynasty ascending the papal throne.

But let us return to the familia of Pius III. In total, the Sienese pope had at his service as familiares primae sortis 8 cubicularii (all qualified as domini), 48 camerarii and scutiferi (of which 41 were domini), 8 doctors (one of whom had the title of dominus, the others magistri), and 26 officiales capellae (including 19 cantors). As second-rank members of the familia there were 7 quartermasters and custodians, 34 messengers and heralds, and 56 officiales assigned to the management of the palace. Finally, the third rank of the familia numbered 48 famuli. To this aggregate of 235 people, the 168 famuli of the prelates, cubicularii and scutiferi need to be added. ${ }^{29}$

${ }^{26}$ Recently, the relationship between the Spannocchi and the Roman curia has been reconstructed very analytically. See Ivana Ait, 'Mercanti-banchieri nella città del papa: gli eredi di Ambrogio Spannocchi fra XV e XVI secolo', Archivi e cultura XXVII, nuova serie (Rome 2004) pp. 9-44 (a monograph of Mercanti stranieri a Roma tra '400 e '500).

${ }^{27}$ This turning-point stands out if we consider the nationality of the cardinals created by the popes of the fifteenth century: 7 Italians of the 17 established by Eugene IV, 4 of the 11 by Nicholas V, 4 of 9 by Callistus III, but 8 Italians out of the 12 named cardinals by Pius II, 9 of 12 by Paul II, and 21 of 34 by Sixtus IV (Menniti Ippolito, Il governo dei papi, p. 77).

${ }_{28}$ Sandro Carocci, Il nepotismo nel Medioevo: papi, cardinali e famiglie nobili (Rome 1999) pp. 143-167.

${ }^{29}$ I took these figures from a document of the Apostolic Vatican Library, ms. Vat. Lat. 9027 published by Piccolomini, La famiglia di Pio III, cited pp. 151-164. 
The tripartite division between domini, officiales, and famuli was old. As the list of the familiares of Nicholas III shows and as the representation of the familia later affirmed, the division implies a more articulate distinction than the simple binary opposition between high and low family. It also delineates a triple classification into the intimate sphere, the functional sphere, and the low offices of kitchen, stewardship, and stable. Analogous indications can be obtained from the Rotulus familiae of Leo X, compiled in May 1514. ${ }^{30}$ It lists 28 domestic prelates whose names are preceded by the title reverendus dominus or simply dominus, 64 chamber clerks, 69 cubiculari, 93 scutiferi, 3 people assigned to the chapel ( 1 chaplain and 2 clerics), 4 heralds, 19 custodians (which also included the custodians of the library), almost all had the title of domini. They followed the officiales divided into secreti, a small group that had access to the most exclusive rooms of the Palace, and communes (137).

In its concluding page, the Rotulus reports the comprehensive figures of the familiares: 244 domini, 174 officiales, for a total of 418 individuals to which 265 famuli need to be added. In comparison to the family of Pius III, these figures highlight the growth in the number of the active members of the papal family in all components. This increase certainly relates to the centrality of the papal court in the Renaissance and to the pomp and opulent lifestyle of the period. It was under Leo X, as shrewd observers like the Venetian ambassadors quickly pointed out, that the expenses of the papal House significantly increased compared to past pontificates. ${ }^{31}$

As the biographical profiles of 28 domestic prelates show, the more restricted entourage of Leo X's papal familia comprised prevalently Tuscans. This again demonstrates the very strong connection between the sovereign pontiff's provenance and the composition of his family in the palace, established with the pope's return to the Vatican. But there were also prelates who had initiated their career in different paths, proving themselves in various sectors like the Apostolic Chamber, diplomatic missions, and the army.

The greatest number of private offices were entrusted to those tied by close bonds to the blood family of the reigning pontiff. Each pope

\footnotetext{
${ }^{30}$ Alessandro Ferrajoli, Il ruolo della corte di Leone X (1514-1516) ed. Vincenzo de Caprio (Rome 1984).

${ }_{31}$ Ludwig von Pastor, Storia dei Papi dalla fine del Medio Evo, vol. IV, p. I (Rome 1960) p. 349.
} 
tended to select his own entourage, signaling a discontinuity with his predecessor. However, those who held the offices of the privy chamberlain, the chamber master or others already settled in their curial career would as a rule continue in their positions. The typical structure of the Roman court was always a result of this ongoing precarious dialectic between continuity and discontinuity.

Holding a domestic office implied a relationship of absolute fidelity, but it was neither limited exclusively to the pontiff 's private service nor to specialization in one single duty. The familiaris could be a privy chamberlain from time to time, a financial official, a diplomat, and sometimes even a soldier. At the beginning of the modern era, the career of a courtier was not spelled out in an orderly and consistent way according to a cursus. Often it entailed exhausting and apparently disorderly movement between different offices in the familia and the court, in the Palace and far away from it. Moreover, the practice of some venal offices (generally financial) and membership of certain collegia militum gave access to familiarity through monetary transactions. At the start of the sixteenth century the popes did not begrudge knightly titles and offices of cubicularii and scutiferi. In the bull of 3 September 1515, while war was breaking out in Lombardy (the reference to the war is explicit in the text), Leo $\mathrm{X}$ constituted a college of 60 cubicularii and another of 140 scutiferi. In 1521, he created 41 titles of milites Sancti Petri (the Knights of Saint Peter) placing 26 of them at the disposition of the vice-chancellor. Paul III sold 200 titles of cavaliere dei Santi Pietro e Paolo (the Knights of Saint Peter and Paul 1541), Julius III instituted the college of milites lauretani, Paul IV that of the Cavalieri della Fede (the Knights of Faith) and in 1562 Pius IV created a college of 275 Cavalieri Pii (Pious Knights). The duties of these knights were purely theoretical-following the pontiff to the crusades and general councils-but the prerogatives were concrete. Paul III made it clear that even if they had no precise duties in the Apostolic Palace and even if they did not eat in the 'dining room' (tinello) of the Palace, they needed to be retained as true familiares and continuous dinner companions of the pontiff. In addition, these titles could be accumulated without causing problems of incompatibility with other offices.

But how profitable were these titles of familiarity to the Apostolic Chamber? And what hierarchy was established between them? Two registers compiled in the 1580 s tell us that in 1588 the price of the 
office of a participating cubiculario was 2,082 scudi. ${ }^{32}$ In the same year Francisco Peña, the famous Spanish auditor of the Rota, bought the office of scutifero, vacant because of the death of Aurelio Savignani, for 1,130 scudi. Meanwhile the Bolognese layman Francesco Maria Boschetti bought an analogous office for 1,140 scudi. The knighthood of the Saints Peter and Paul was valued at around 1,300 scudi, that of Saint Peter at 1,035 scudi, the 'lauretano' at 520 scudi, and the 'pious' at 450 scudi. If we think that in the same year Giovan Battista Savelli bought the office of cleric of the Chamber for 40,000 scudi, these are modest figures. But the geographical links of the applicants, the inclusion of laymen and ecclesiastics among them, and the possibility of developing business through the office render the buying of titles a very interesting phenomenon from a social and economic perspective. ${ }^{33}$

The popes of the Renaissance, assigning the title of familiaris to holders of offices and venal titles, created a link between the Palace offices and venality inside the complex machine of papal finance. Among the monarchies of Western Europe, however, this overlap was not unique. An analogous process occurred in France with the offices of the Maison $d u$ Roi. Louis XIV still sold Palace offices, although at the same time the Sun King sought to limit the right of resigning the office in favor of someone else by removing the faculty of resignation except with royal permission. ${ }^{34}$

\section{Prerogatives and Privileges of the Familiares}

In the early modern period, the process of enlarging the ranks of the pontifical familia took place in a fast and disorganized way. It was not always clear to contemporaries themselves which segments of the

32 Archivio Segreto Vaticano (ASV), Instrumenta Miscellanea 4802 (Liber Officiorum 1588), 4803 (Liber Officiorum 1581).

${ }_{33}$ At the Roman court the power to assign the office to a different person (pro admissione resignationis) could be obtained with a modest pecuniary sum: 81 scudi for the office of the participating cubiculario, 54 scudi for that of the knight of Saint Peter, 49 scudi for that of knight of Saints Peter and Paul, and 27 scudi for that of the pious knight (cavaliere pio).

${ }^{34}$ Olivier Chaline, 'The Valois and the Bourbon courts c. 1515-1750', in: John Adamson, The Princely Courts of Europe: Ritual, Politics and Culture under the Ancien Régime 1500-1750 (London 1999) pp. 72-73; Boucher, 'L'évolution de la Maison du Roi', pp. 364-365. 
courtly and curial world fell within the area of familiarity, what profile was required for access, or which honors and privileges derived from being considered a familiaris of the pope.

In the Bulla officii Cubicularium et Scutiferorum Apostolicorum (1515), Leo X established that those holding such offices needed to be generically men of honest living and people of quality, not unaware of or inexperienced in the rites and ceremonies of the Roman church. A doctorate could facilitate the practice of some prerogatives of the office of the cubiculario, but it was by no means necessary. The first Medici pope did limit the number of laymen that could hold this office but nevertheless did not exclude non-ecclesiastical personnel. ${ }^{35}$

More important was the legislative intervention of Paul III (15341549). On 22 December 1534 with the decree de Familiaribus, he put an end to the uncertainties and conflicts by specifying the categories of those that should be considered 'veri familiares pontificis et continui commensales eiusdem. ${ }^{36}$ In other words, these were the cubicularii, referendaries, protonotaries, subdeacons, Rota judges (whose privileges had already been outlined by Clement VII with the decree Convenit aequitati of 2 August 1525), acolytes, secretaries, writers of apostolic letters, heralds and the knights of Saint Peter (provided they served in the palace and carried custodial duties). The privileges of familiaris were quite varied and changed from office to office. They included fiscal exemptions, advantages in property inheritance, the possibility of legitimating bastard children, enjoying special terms of access to benefices and above all, being exempt from ordinary jurisdiction.

If living and serving in the Vatican Palace was indispensable for certain familiares, it was not an unavoidable condition for membership of the pontiff's family, as Paul III again reaffirmed with a new decree dated 18 May 1543. The growing distance between the group of servants actually present in the Palace and those formally considered 'panem habentes' without residing there was a predictable consequence of the increase in Roman offices in the first half of the sixteenth century. It may also be seen in relation to the chaotic and somewhat random growth of the Vatican Palace before the popes moved their

${ }^{35}$ I consulted the bull in the miscellaneous collections of the Biblioteca Apostolica Vaticana (BAV), marked RIV 1333/1.

${ }^{36}$ Aloys Guerra, Pontificiarum Constitutionum in Bullariis magno et romano contentarum epitome, tom. I (Venice 1772) p. 384. 
court to the Quirinal Palace at the turn of the sixteenth and seventeenth centuries. ${ }^{37}$

With the Farnese pope Paul III who from his cardinalship was surrounded by a family of 325 members, the papal household acquired its modern physiognomy. As the household grew larger, the prerogatives of the Master of the pontiff's household were outlined, and the crucial role of the Datary, the link between the household of the pontiff and the financial offices' was confirmed.$^{38}$ In the mid-sixteenth century when the papal family was made up of 421 familiares and 313 famuli of the palace (the figures refer to the pontificate of Paul IV), ${ }^{39}$ a uniform and continuous documentation was initiated that allows us to trace the development of the papal household. The three old categories of domini, officiales and famuli that, as we have seen, were applied until the reign of Leo $\mathrm{X}$, were now abandoned and other criteria were introduced to register the familiares in a Ruolo. ${ }^{40}$

The Ruolo is a document similar to those drawn up for analogous aims by the English monarchy (rolls) and the French monarchy (états). The little book lists all those who received the so-called parte di Palazzo that could be a tutto vitto (in other words bread, wine, oil, biscuit, wax, wood, etc., plus a monetary compensation), a pane e vino (bread and wine compensation) or alternatively a pane solo (bread only compensation). This group notably included the blood relatives of the pontiff-the eccellentissimi signori della Casa with whom the document normally began, including the ladies (mother, sisters, sisters-inlaw, nieces of the pope...). It also comprised members of the papal Secretariat, officials of the Datary, the Chancery, the Chamber, Palace chaplains, judges in the Rota, valets of honor and also ambassadors.

\footnotetext{
${ }^{37}$ On the implications for city life and the curia that was transferred to the Quirinale, see Antonio Menniti Ippolito, I papi al Quirinale. Il sovrano pontefice e la ricerca di una residenza (Rome 2004).

${ }^{38}$ Léon Dorez, La cour du pape Paul III d' après les registres de la Trésorerie secrète, preface by Pierre de Nolhac (Paris 1932) p. 26.

39 The role of the family of Paul IV is discussed in Gaetano Moroni, 'Famiglia Pontificia', in: Dizionario di erudizione storico-ecclesiastica, XXIII, Gaetano Moroni, ed. (Venice 1843) pp. 66-73.

${ }^{40}$ Christoph Weber was the first to call attention to the importance of this document. See 'La corte di Roma nell'Ottocento', in: La corte nella cultura e nella storiografia, Cesare Mozzarelli and Giuseppe Olmi, eds. (Rome 1983) pp. 167-204. There are 432 registers contained in the Ruoli, conserved in the Apostolic Vatican Library. They cover a chronological span from Julius III to Pius IX. On the familia of Pius IV, see Theodor von Sickel, Ein Ruolo di famiglia des Papstes Pius IV Mitteilungen des Instituts für Österreichische Geschichtsforschung, 14 (1893) pp. 537-588.
} 
Those who fell into the category 'Of bread only' included assistant bishops, protonotaries, abbreviators de parco maggiore, consistorial lawyers, referendaries, etc.

This reference to sharing sustenance is only one of the criteria described in the Ruoli. It is significant that the generic term 'domestic prelates,' which in sources from the fifteenth and sixteenth century includes the Master of the Household, the Datarius, the Sacrist, the General Treasurer, etc., would be replaced in the Ruoli by a series of rubrics, each one referring to a bureaucratic department. Thus the Secretariat, originally represented without divisions, was now subdivided into the Segreteria dei Brevi and dei Memoriali. ${ }^{41}$ It became a more composite organ in which the Secretary of State was flanked by a dozen prelates heading the work of the Congregations of the cardinals. ${ }^{42}$ The Datary, a key office for papal finances further augmented under Sixtus V, comprised a total of 30 officials in the 1600s. It arbitrated the delicate matter of pensions, concessions of benefices, curial offices, as well as dispensations regarding consanguineous marriages. The section 'Offitiali di Camera' consisted of 9-10 officials and included a general Treasurer, Commissioner of the Chamber and various 'accountants.'

As has been seen in its rolls, the pontifical family appears to have developed from its original tripartite matrix, which was still heterogeneous, into one divided between a bureaucratic camp that increased in complexity and a sphere of the palace that remained linked to personal service to the pontiff. The two spheres were not integrated into one hierarchy, however, and the Palace offices in the sixteenth and seventeenth centuries still represented around $50 \%$ of the total personnel enjoying the privilege of familiarity. This approximate percentage needs to be clarified and possibly corrected by analytic studies, but it is essentially analogous to Guillemain's proposition for the Avignon period.

A growth in the number of minor offices connected to the demanding services of this increasingly complex machinery is evident in the

${ }^{41}$ This is presented in the Rotulo of the family of Paul IV, published by Moroni after 12 "intimate" prelates put down the names of the six secretaries of the pontiff, among which were Angelo Massarelli and Giovan Francesco Commendone (Moroni, Famiglia Pontificia, cit. p. 67).

${ }_{42}$ Besides the Segreteria dei Brevi, of the Brevi to the Princes, of the Latin Letters, the last role of Clement X (1 June 1676) comprised, in order "Mons. Gio. Battista Spinola de Vescovi e Regolari, Urbano Cerri di Propaganda Fide, Fani di Consulta, Brancacci del Concilio, Gio. Bussi de Bono Regimine" (BAV, Ruoli, vol. 169, 1676, f. 1). 
realm of the household offices. But the dynamics of certain honorific offices regulating access to the person of the pope are no less interesting. The formalization of ceremonial practices and the further elaboration of the criteria of distinction required more personnel to manage an ever more refined etiquette..$^{43}$ For example, the bussolanti (ushers) passed from an average of 6 individuals on the rolls at the end of the 1500 s, to 12 in the second half of the 1600s. They were assigned to service in the more numerous antechambers of the pontifical apartments in the new Quirinal Palace. Dressed in red cloaks with hoods, they were considered equivalent to grooms and extra muros valets (camerieri extra muros). ${ }^{44}$

In addition, we note the increase in Chapel personnel and their distribution into various sections (privy and common chaplains, cantors). The Pontifical Chapel expanded from 14-15 registered units at the end of the $1500 \mathrm{~s},{ }^{45}$ to 60 units (of which half were cantors) at the end of the 1600 s. ${ }^{46} \mathrm{~A}$ survey of the rolls from the mid-1700s describes an even more crowded Pontifical Chapel: 72 units (46 choristers) in 1741 and 98 units (68 choristers) in $1758 .^{47}$ During the pontificate of Clement XI (1700-1721), the master of the chapel Andrea Adami da Bolsena (who had already been employed as a cantor during the time of Alexander VIII), wrote his Observations for the good regulation of the chorus of the Pontifical Chapel. It shows how recent the tradition of ecclesiastical music-considered the 'invention' of the Spaniard Ambrogio Morales and naturally of P. Luigi Palestrina-was in modern Rome. Moreover, it listed all of the ceremonial occasions, and ordinary and special liturgies in which the pontifical cantors took part, highlighting that the chapel and its cantors gained a more important role in papal ceremonial. ${ }^{48}$

\footnotetext{
${ }^{43}$ Maria Antonietta Visceglia, 'Etichetta cardinalizia in età barocca', in: Estetica barocca, Sebastian Schütze, ed. (Rome 2004) pp. 263-284.

${ }_{44}$ Brevi notizie sul collegio dei bussolanti pontifici (Venice 1886).

${ }_{45}$ This agrees with the number that we obtained from Gattico's above-cited document which refers to the fourteenth and fifteenth centuries.

${ }^{46}$ Visceglia, Denominare, classificare, pp. 190-191.

47 BAV, Ruoli vol. 290 (1741) and vol. 323 (1758).

${ }_{48}$ Andrea da Bolsena Adami, Osservazioni per ben regolare il coro della Cappella Pontificia tanto nelle funzioni ordinarie che straordinarie (Rome 1711). Beyond the celebrations of the liturgical calendar, the cantors of chapel took part in the canonization of the saints, the solemn baptism of Jews, the funeral rites of the cardinals, the coronation ceremonies and funeral rites of the pope. Adami also points out the rivalry over precedence and benefices inside the court between the college of apostolic writers
} 
The enlargement of the 'offitiali di Libreria' section, with its Latin, Greek, Hebrew, Chaldea and Arabic scriptors and printers (personnel that traditionally formed part of the household), was more restrained. The increase in the 1600s, however, shows how the ambition of the Counter-Reformatory Church to play a universal role could translate into specific and specialized responsibilities. To cite just one example, from among the 14 officials of the library (including two attendants) recorded in the roll of Alexander VII (1659), we find the Prefect Domenico Salvetti, Luca Holstenio as first custodian, Leone Allacci among the Greek scriptors, three Hebrew scriptors and the printer Zenobio Massotti. ${ }^{49}$

In the middle of the eighteenth century there were 15 officials in the library of Benedict XIV, ${ }^{50}$ the number of attendants having evidently stabilized. Among these illustrious names of eighteenth-century scholarship we find the Lebanese and Maronite scholar Giuseppe Simonio Assemani, the principal writer of Arab and Syriac, who was the librarian of the Vatican, and author of the famous Bibliotheca Orientalis (1719-28). ${ }^{51}$ There is also his nephew Stefano Evodio (called in the roll 'reader of Syrian'), the Florentine Giovanni Bottari (librarian of the Vatican, member of the Academy of ecclesiastical history and of the synods), ${ }^{52}$ Father Roberto di Santa Maria, the Pisan Pietro Foggini, ${ }^{53}$ and Giuseppe Garampi, author of a noted unification and inventory project for the archives. ${ }^{54}$

and the college of pontifical cantors (Adami, Osservazioni, p. 11). On the role of sacred music in the ceremonial and on the circulation of ecclesiastical music in Europe of the seventeenth and eighteenth centuries, see Bernard Dompnier, Maîtrises et Chapelles aux XVII et XVIII ${ }^{e}$ siècles. Des institutions musicales au service de Dieu (ClermontFerrand 2003); Stefano Lorenzetti, 'Intersezioni del sacro nell'esperienza musicale tra tardo Medioeo e prima età moderna', in: I luoghi del Sacro, pp. 235-255.

49 BAV, manuscripts chigiani, B I 13, f. 19.

${ }^{50}$ BAV, Ruoli vol. 290 (1741) and vol. 323 (1758).

${ }^{51}$ Giorgio Levi Della Vida, Dizionario biografico degli Italiani (DBI) 4 (Rome 1962) pp. 436-440 (ad vocem).

${ }_{52}$ Giuseppe Pignatelli and Armando Petrucci, DBI 13 (Rome 1971) pp. 407-418 (ad vocem).

${ }_{53}$ Marina Caffiero, DBI 48 (Rome 1997) pp. 449-453 (ad vocem).

${ }^{54}$ On Garampi, see Dries Vanysacker, Cardinal Giuseppe Garampi: (1725-1792): an enlightened ultramontane (Brussels 1995); Marina Caffiero, DBI 52 (Rome 1999), pp. 224-229. On the cultural milieu to which these characters were exposed, see Maria Pia Donato, Accademie romane: una storia sociale, (1671-1824) (Naples 2000); Maria Pia Donato, 'Mecenatismo papale e mecenatismo cardinalizio a Roma tra Sei e 
An important source like the rolls allows us to verify the exchange of offices connected to the most intimate sphere of the court for every pontificate, and can be systematically utilized in working out the names of officials. Even a brief consultation of this documentation clarifies some tendencies of the politics of familiaritas of the Roman pontiffs, which in the Modern age were complex and not always coherent. Between 1500 and 1600, there was a fairly consistent development in the rules and directional lines of the government of the familia, which we can summarize in three points:

\section{Reinforcement of the Area of Privilege}

Gregory XV's bull from 31 March 1621, De cubiculariis pontificiis, ${ }^{55}$ reaffirmed traditional terms of pensions and benefices while it also specified that the cubicularii must be considered comites Sacri Palatii and nobiles romanae Urbis. In other words, being a close familiaris of the pontiff automatically involved access to the Roman nobility. At the beginning of the seventeenth century, privilege was still consistent with the way it had operated in the Renaissance. Members of nobility and patricians sought ecclesiastical careers and service in the Palace in the entourage of the pontiff, but these doubled as a vehicle for social ascendance and ennoblement.

In contrast, in the second half of the seventeenth century, a different dynamic was established when the quality of nobility became indispensable for some offices of the papal family. The turning point can be dated to the papacy of Alexander VII, who required proof of nobility as a precondition for access to even the first step of curial careers and ordered that ministers of the papal chapel had to be noble. ${ }^{56}$ Innocent XII also decreed that only members of families holding the title of the Knights of Malta could be the pontiff's private chamberlains. Urban VIII had enhanced the pontifical Major-domo's office (the ancient Magister hospitii) by ascribing it to his domestic prelates (at times obscure

Settecento e il ruolo della famiglia Corsini', in: Il trionfo sul tempo. Manoscritti illustri dell'Accademia dei Lincei, catalogo della mostra (Modena 2002) pp. 57-64.

${ }^{55}$ Guerra, Pontificiarum Constitutionum, cited p. 383.

${ }^{56}$ Vittore Falaschi, La gerarchia ecclesiastica e la Famiglia pontificia con rami rappresentanti le diverse persone che la compongono, ognuna rivestita dell'abito sagro o civile che gli conviene e l'indicazione del posto che esse occupano nelle cappelle papali (Macerata 1828) p. 86. 
but always faithful) who were then appointed cardinals. At the turn of the eighteenth century, it was regularly held by ecclesiastics of the most exclusive Roman and Italian noble families, ${ }^{57}$ by the pope's blood relatives, or even by his nephew. Typically, in 1713, Pope Albani nominated Fabio Olivieri, his cousin and schoolmate. Pope Rezzonico (Clement XIII) appointed his nephew Giovan Battista who then became cardinal in 1770, and in 1780 Pius VI conferred the position on his nephew Romualdo Braschi Onesti, the son of his sister Giulia. ${ }^{58}$

At the beginning of the eighteenth century, Monsignor Camillo Cybo, holding the office of Major-Domo, staunchly defended its primacy within the pontifical family, always arguing in favor of its privileges. 'The office of Major-domo'-he wrote in one of his many memorials-'is among the most conspicuous of the Court. He is first among the familiares of the Supreme Pontiff and from this post each one usually is promoted to the cardinalate without an example to the contrary. He has total jurisdiction over all familiars described in the pontifical Ruolo. The administration of the Apostolic Palace and the regulation of access depend entirely on him. ${ }^{59}$

The renewed importance of the Major-domo's office after the abolition of nepotism but in a period of unrestrained favoritism (it suffices to think of the famous Coscia case) is connected to a problem of jurisdiction. The reform of the judicial apparatus introduced by Innocent XII suppressed, in fact, the Major-domo's exclusive jurisdiction over the Palace. However according to Cybo, who had ample sectors of the curia behind him, it was an 'error' or misunderstanding that needed to be corrected. ${ }^{60}$ In the practice of the office during the pontificate of Benedict XIII, Cybo took actions to restore the 'economic' and jurisdictional authority of the Major-domo in the Apos-

${ }^{57}$ Filippo Maria Renazzi, Notizie storiche degli antichi vicedomini del Patriarchio lateranense de' Moderni Prefetti del Sagro Palazzo Apostolico, ovvero Maggiordomi Pontifizi (Rome 1784) pp. 139-148. They cover the office between the sixteenth and seventeenth centuries: Ercole Visconti (1688), the three exponents of the Colonna family (Carlo Colonna in 1696, Girolamo in 1732, Marco Antonio in 1758), Ludovico Pico, son of the duke of Mirandola (1712) Nicolò Giudice of the Cellammare prince who would become "protector of the Austrian States" for the Holy See (1716), Camillo Cybo (1725) Francesco Borghese (1729, but only for a few months) Trojano Acquaviva d'Aragona, supporter of the Bourbon party and "plenipotentiary minister and protector of the Kingdoms of Naples and Spain” (1729), and Giovanni Archinto (1770).

${ }_{58}$ Renazzi, Notizie storiche, pp. 165-172.

${ }^{59}$ ASV, Fondo Cybo, b.2, f. 7v.

60 ASV, Fondo Cybo, b.2, f. 432v. 
tolic Palaces and in places he considered their dependencies. ${ }^{61} \mathrm{He}$ also attempted to recover control of all the licensed workers: craftsmen and suppliers of the Palace who for minor offences (insults, thefts, brawls) had to be turned over to the Major-domo. ${ }^{62}$ Cybo emerged victorious from the controversy. In September 1728, the pope consented to restore the authority of the Major-domo and to end the dispute provoked by the instructions of Innocent XII.

\section{Limitation of the Expenses of the Papal Family}

Even if the considerable records of the State Archive of Rome's Fondo Camerale still await systematic exploration, we know from the account books of the Major-domo and Secretary Treasurer that it was Sixtus V (1585-1590) who stigmatized his predecessors, above all Gregory XIII, as excessively prodigal in Palace expenditures. The guidelines of prudence and parsimony imparted by Pope Peretti were applied, and the Apostolic Chamber president, banker Olgiati noted in 1589 that 'the expense for the Table of Our Lord is very limited. ${ }^{63}$

An undated document conserved in the Bodleian Library entitled $O f$ the Palace of the Pope and his servants and all the offices and tribunals of Rome, probably goes back to the pontificate of Paul V. ${ }^{64}$ It repeatedly describes the papacy of Gregory XIII as a golden age of the court ('the court bloomed') because of the nobility of courtiers forming the pope's entourage and the level of Palace expenses. Contemporaries came to consider the 1570 s and 1580 s as a peak, almost as a transitory phase between two models of the court. We can understand this transformation as the passage from a court in which 'traditional' nobility was still decisive, to a court which, while maintaining close contacts

${ }^{61}$ For example, this included the Ethiopian church of Saint Stephen of the Moors (f. 248), the Apostolic hospice (f. 394) and the church of Santa Marta where there was a hospital for the family of the pontiff, that "served very few only of low level." Thus, Cybo decided to assign 60 dukes to the hospital on the Tiber Island, sending sick familiares there instead (f. 138v).

62 Interesting lists of the cases : ASV, Fondo Cybo, b.2 ff. 427-447.

${ }^{63}$ G. Ramacciotti, 'Le spese private di Sisto V', Archivi d'Italia e Rassegna Internazionale a.VII (1940) edition excerpt. This article is based on the revised figures of the cameral documentation that the average monthly expenditures for the refectory were about 2,832 scudi monthly (calculation of the second semester) in 1587, 1,438 scudi in 1589. But "in the happy times" of Pope Gregory XIII, they were 4,000 scudi monthly.

${ }^{64}$ Oxford, Bodleian Library, manuscript Selden supra $71 \mathrm{ff} .1 \mathrm{r}-71 \mathrm{v}$. 
with aristocratic lines, was dominated by the figure of the cardinalnephew-Secretary of State.

At the end of the pontificate of Paul V, the total expenses 'for the Palace of Our Lord' were valued at 91,300 scudi. This was almost double the figure (however uncertain) of 48,000 scudi attributed to the time of Julius II, but was analogous to the amount estimated (which retains a degree of uncertainty) for the Renaissance court of Leo X. ${ }^{65}$ Naturally, these figures represent only estimates that need to be substantiated by analytical studies on Palace expenditures and their evolution between the sixteenth and seventeenth centuries. Projects to restructure the spending of the Palace certainly circulated in the second half of the seventeenth century, particularly during the Odescalchi papacy. Innocent XI's broad reform plan included an anti-nepotistic framework, a proposal to diminish the number of cardinals, and the imposition of a strict and severe style in court life. Moroni would write that from the year of his election, Innocent XI 'reformed the table of the Palace and did not admit anyone other than those recommended for their modesty.'66

At the time of Benedict XIII, however, the banquets of the Apostolic Palace were not 'frequent' but 'held with magnificence and dignity. ${ }^{\text {'67 }}$ Among those in which the pontiff participated, Cybo cites the banquets for consecrating bishops and those following the investiture of the Kingdom of Naples which the pope traditionally repeated for each sovereign succession. More frequent were banquets of the Palatine cardinals (in which the pope might decide to participate), Christmas Eve, the evening and the morning of Maundy Thursday and Good Friday, and on the occasion of visits from great princes and the Viceroy of Naples. After listening to the singing of 'virtuosos' and music in the Papal Chapel, the banquets took place in the Hall of Constantine. But from Cybo's report on his activities written in the 1720s, we get the impression that it was not conviviality that cemented the membership of the household in those years. There were other ritual occasions that mobilized the pontifical familia: the distribution of medals, ${ }^{68}$ the gift

65 Pastor, Storia dei papi, IV, p. 349.

${ }_{66}$ Moroni, Famiglia Pontificia, p. 85.

${ }^{67}$ ASV, Fondo Cybo, b.2, f. 25r.

${ }^{68}$ Cybo gives an analytical report on the ceremony for the distribution of the pontifical medals in 1726, some to servants of the Palace. A total of 190 individuals received them (ASV, Fondo Cybo, b.2, ff. 152r-154v). 
of candles on the day of the Candlemas to the cardinals, royal ambassadors, 'ministers' and to all the nobility including noblewomen nuns, ${ }^{69}$ and finally the rite of the Agnus Dei.

This last banquet, held on Holy Saturday, was a ceremony loaded with double symbolic significance, serving as celebration of the mystery of the resurrection and as declaration of obedience to the pope at the same time. It was possibly a transformation of the more ancient rite, already affirmed in the medieval ordines, in which the pope distributed a roasted lamb to his 'messmates'. This was then superimposed upon another Easter rite, the distribution of waxes. ${ }^{70}$

The Agni Dei were in fact wax medals prepared from the remainders of the Easter waxes and pure wax. In the presence of his familia, the pope blessed them with a symbolic baptism, immersing the lambs in holy water to which was added a balsam. The cardinals and the high prelates gathered them up, and the papal chaplains spread them out on white tablecloths. After singing mass on Holy Saturday in the Palace Chapel, the pope would distribute them to the high familia. The rest of the court went to take them from the hands of the pope, 'kissing him on the hand, the knee, the sacred foot,' and receiving a number of agni, varying 'according the diversity of the quality' (that is of the people concerned). ${ }^{71}$ There are many possible readings of this ceremony, but here I would only like to underline the idea of a symbolic banquet, after a baptismal rite, that had as actors the pope and members of his household, a sacralization of communal dining in a court that was gradually becoming more of a church.

\section{Strengthening the Clerical Dimension of the Papal Entourage}

This deals with a long-term phenomenon culminating in the second half of the seventeenth century, the same phase in which the social profile of certain courtly figures became more markedly aristocratic. ${ }^{72}$ Offices of honor also tended to marginalize the lay component of the

\footnotetext{
${ }^{69}$ ASV, Fondo Cybo, b.2, ff. 127r-128v and ff. 142r-144r.

${ }^{70}$ Sergio Bertelli, Il corpo del re: sacralità del potere nell'Europa medievale e moderna (Florence 1990) pp. 120-130.

${ }^{71}$ F. Vincenzo Bonardo, Discorso intorno all'origine, antichità, virtù, benedizioni e cerimonie che usa il Sommo Pontefice in benedire gli Agnus Dei (Rome 1621) pp. 40-55.

${ }_{72}$ On this process, refer to Maria Antonietta Visceglia, 'Figure e luoghi della corte romana', in: Storia di Roma dall'antichità ad oggi. Roma moderna, Giorgio Ciucci, ed. (Rome 2002) pp. 39-78.
} 
Roman Court. For example, among the camerieri d'onore, the number of those of 'cloak and sword' decreased in favor of those 'of the purple dress.' Among the important papal household offices, the secular component retained only the posts of main Quartermaster, (responsible for the buildings, the gardens, and the furnishings of the Palace), the Rider and the Postmaster. The compactly ecclesiastical character of the household of the pope and the Court of Rome, helps to explain why in the eighteenth century there are a growing number of studies on the Palace offices, and especially on their origins.

To reaffirm the privileges of the cubicularii, the Renaissance popes did not hesitate to recall to and even emphasize the imperial derivation of this term, as Leo X had done in the frequently cited bull on cubicularii in 1515. Scholars of the eighteenth century were embarrassed by this profane tie to the classical Roman world. They used their philological skills and qualifications to reconstruct a Christian origin for the offices of the papal household, even if in some cases they had to admit their ancient imperial roots. So when, in 1758, the Benedictine scholar Pietro Luigi Galletti wrote about the 'noblest' office of preserving the pontiff's robes, he did not exclude that it might have been introduced in Rome as an imitation of that of Costantinople. ${ }^{73}$ However in 1776, in a work of a more general nature, dedicated to Pius VI, he appealed to ecclesiastical history and the archives to show how the origin of this office, as well as all offices of the papal Palace in general, was indissolubly connected to the functions of the early church. ${ }^{74}$

According to Galletti the primicero headed the ancient Palace offices of the pope. He was the first of the apostolic notaries in charge of gathering proof of the 'gesta martyrum.' Next was the arcario, who may have also been 'heir of the arcario of the prefect of the praetorium, ${ }^{75}$ but then became the custodian of the early Church's money just as the saccellario, originally the military paymaster, would become the distributor of alms; ${ }^{76}$ the protoscriniario would become the keeper of the writings of the Church, ${ }^{77}$ and the nomenclatore would have the

\footnotetext{
${ }^{73}$ Pietro Luigi Galletti, Del Vestatario della Santa Romana Chiesa discorso (Rome 1758) p. 5.

${ }^{74}$ Pietro Luigi Galletti, Del Primicero della Santa Sede Apostolica e di altri officiali maggiori del Sacro Palagio Lateranense (Rome 1776).

${ }_{75}^{75}$ Galletti, Del Primicero della Santa Sede Apostolica, p. 107.

${ }^{76}$ Galletti, Del Primicero della Santa Sede Apostolica, p. 125.

77 Galletti, Del Primicero della Santa Sede Apostolica, p. 133.
} 
task of calling and inviting guests to the refectory of the pope at the pontifical court.

To sum up this argument, though the offices of the Apostolic Palace coincided with the names of the ancient imperial offices in some cases, as ecclesiastical or papal offices they held totally different responsibilities and functions. This theory was accepted by contemporary authors occupied with the origins of the offices of the papal household. According to the abbot Francesco Antonio Vitale, author of a history of the pontifical treasurers, ${ }^{78}$ the office of arcario may have been the ancestor to that of the chamberlain (camerlengo). Its more modern name was adopted by the papal court from the example of Valois-Anjou sovereigns.

The characterization of the origins of the Major-domo's office appeared even thornier because the name of the office had changed over time: prefect of the Sacred Apostolic Palace, Master of the papal Household, and finally Major-domo by the pontificate of Urban VIII. A heated debate on the question of the pontifical Major-domo's jurisdiction arising between the end of the seventeenth century and the first decades of the eighteenth century entangled the historical and practical levels. Arguing that the office derived from the judex officiorum aulicorum, transformed into the Christian Vicedomino (that is the archdeacon of Rome, head and master of the lower clergy), ${ }^{79}$ legitimized its extensive jurisdictional powers-powers that Benedict XIII wanted to keep in his own hands. In the second half of the eighteenth century, the jurist Filippo Maria Renazzi dedicated a scholarly history on this office to a nephew of the pope, Monsignor Don Romualdo Braschi, Major-domo of Pius VI. In it, he endorsed a theory that the Majordomo originated from the Vicedomino who was destined 'to preside over the pontifical family in the place of the Apostolic Lord, ${ }^{80}$ and to exert jurisdiction over the Palace and the Roman clergy that served in it. According to the Bolognese jurist, it was in the Medieval period, beginning in the twelfth century and continuing during the Avignon interlude that 'they began to create new offices under other names. ${ }^{81}$ With the return of the Holy See to Rome, a process of rearranging the pontifical family 'in the ancient model of domestic discipline'

\footnotetext{
${ }^{78}$ Franciscus Vitale, Memorie istoriche de' Tesorieri generali pontifici dal pontificato di Giovanni XXII a' nostri tempi (Naples 1782).

${ }^{79}$ Renazzi, Notizie storiche, p. 5.

${ }^{80}$ Renazzi, Notizie storiche.

${ }^{81}$ Renazzi, Notizie storiche, p. 4.
} 
was carried out 'little by little,' as far as 'the diversity of times and the changes of customs' would permit. Like many of his contemporaries, he thought this development was still in progress. ${ }^{82}$

The apologetic character of these works and their intent to anchor the history of the Court of Rome exclusively in ecclesiastical history are certainly evident, and yet their reading is neither tiresome nor superficial. Fundamentally, there is a problem and a real question: what was the relationship between an imperial and a papal model of the court? And when we speak of an imperial model, do we mean the Carolingian or the Byzantine?

Without entering into this complex question reaching beyond the scope of my competence, I would like to briefly recall how the first residence of the pope in the Lateran complex in Rome was transformed into the sacrum palatium between the 8th and 9th centuries at the very moment of significant transformation of the papacy's political role in relation to the new-born Carolingian empire. This cultural climate of renovatio imperii, symbolized by the construction of the Palatium Caroli, destined to be the residence of the imperial dignitaries of Charlemagne to the south of the Vatican Basilica, occurred three centuries before Eugene III undertook the construction of the Vatican Palace to its north. ${ }^{83}$

Yet the idea of the sacrum palatium takes us back even further, to the imperial classical roots from which the two pivotal concepts of the Court of Rome grew: familiaritas, and amicitia principis. The eighteenth-century dispute over the relationship between ancient terms and new realities was hardly a mere pedantry of the erudite, but a scholarly and exciting attempt to purge a too courtly and profane genealogy from the papal offices.

${ }^{82}$ Renazzi, Notizie storiche, p. 26.

${ }^{83}$ Maria Teresa Gigliozzi, I palazzi del papa. Architettura e ideologia: Il Duecento. (Rome 2003) pp. 45-61. 


\title{
THE MONARCH AND INNER-OUTER COURT DUALISM IN LATE IMPERIAL CHINA
}

\author{
Sabine Dabringhaus
}

For more than two millennia, the emperor was the most important symbol of China's unity. In traditional Chinese thought, he mediated as the "son of heaven" (tianzi) between "all under heaven" (tianxia) and the cosmic world. From the first dynasty, founded by Qin Shihuangdi in $221 \mathrm{BCE}$, emperors represented the head of the government, but real power often rested in the hands of prime ministers. Only under the Ming dynasty was this influential position finally abolished and the emperor able to assume personal control of the government. Historians in China and abroad have often characterized Ming rule, as well as its successor, the Qing political system, as the height of autocracy—or even despotism. This image requires reconsideration.

The founding of the Ming dynasty in 1368 marked the beginning of the late imperial era in Chinese history. After a century of Mongol rule under the Yuan dynasty (1271-1368), Chinese government was restored by a native monarchy. Outwardly, the Ming dynasty (13681644) appeared as a period of powerful autocratic rule. The founder Taizu (r. 1368-1398) created a strong, assertive and highly centralized government. The emperor's purview was comprehensive: he was the final author of the state's political decisions, its supreme legislator, the commander of its military forces, the highest patron of religious institutions and the foremost sponsor of arts and letters.

The rulers of the Qing dynasty (1644-1911), originating from the northern frontier, successfully amalgamated the image of late imperial emperorship with the tradition of Inner Asian khanship. As far as ruling over China proper was concerned, they largely perpetuated the institutions of the Ming state. The pre-conquest Qing adoption of Chinese techniques of governance helps to explain the dynasty's effectiveness and staying power. ${ }^{1}$ In fact, the Manchu emperors created a bifurcated system of governance, separating the bureaucratic model

${ }^{1}$ H. Lyman Miller, 'The Late Imperial State', in: The Modern Chinese State, David Shambaugh, ed. (Cambridge 2000) pp. 15-41, here p. 16. 
of the Ming dynasty, applied to the administration of China proper, from the banner system used for controlling the north-eastern Manchu homeland and the Inner Asian frontier. The "national" Ming state evolved into a multiethnic empire that prefigured the framework of the modern Chinese nation-state of the twentieth century. Important sources of this enormous political success were new methods in court politics introduced by the Qing monarchs.

As in Europe, the monarchical court represented the centre of the dynastic state. From the Han dynasty (206 BCE to $220 \mathrm{CE}$ ), Chinese court society was divided into an inner and an outer part, separating the personal household of the emperor from the central bureaucratic administration of the state. Thus, China had overcome feudal structures much earlier than Europe. From the late seventh century, officials were selected by open civil service examinations and served as a countervailing force in relation to the power of the aristocrats. ${ }^{2}$ They played an important role in securing central authority within the empire. Apart from the imperial family and their servants (concubines and eunuchs), officials were the most important actors at court. But their sphere of activity was restricted to the outer spaces of the palace. They were frequently moved from posts in the central government at the capital to offices in the provincial administration. Membership in the outer court underwent frequent change and fluctuation. The emperor strengthened his authority by controlling the circulation of offices, merits, grants and information. In the sphere of the inner court, however, the personal composition was much more stable. Only members of the imperial family, concubines and eunuchs were admitted.

Emperors of both dynasties, Ming and Qing, safeguarded their positions as autocratic rulers by playing off the different groups. The Ming monarchs used eunuchs against the traditional bureaucratic literati elite, and the Qing emperors relied on Manchu and Mongol nobles as counterweights in the struggle for balance of power at court. On the Ming social scene, nobility, like most of the titles and ranks, had only been an ornament and had not counted as a factor in government. The Qing, in contrast, reintroduced the aristocratic element into court politics. If we want to understand the working of imperial authority at the peak of Chinese court society, we have to examine these different

\footnotetext{
${ }^{2}$ Benjamin A. Elman, 'Imperial Politics and Confucian Societies in Late Imperial China: The Hanlin and Donglin Academies', Modern China 15, 4 (1989) pp. 379-418, here p. 379.
} 
modes and methods of transgression between inner and outer spheres used by both dynasties of late imperial China. What role did the innerouter-court-dualism play in the late imperial era? What were the continuities in the Ming-Qing-transition, bracketing the two dynasties in a single period? In what ways did the Manchu monarchs alter the function of the palace system as the power base of imperial rule?

In agreement with $\mathrm{Wu}$ Han, the famous Chinese biographer of Taizu, ${ }^{3}$ Charles O. Hucker describes Taizu as the "bad first emperor of the worst sort", who cast his shadow over all of Ming history. ${ }^{4}$ This judgement is mainly based on Taizu's changes within the government system. Moreover, the context of the emergence of the dynasty is important. In a time of popular uprisings against the foreign rule of the Mongolian Yuan dynasty, Taizu had managed to rise from rebel leader to emperor. After his takeover, he regarded the reconstruction of the weakened state structure as his main task. In his combination of reconstruction and innovation, Taizu granted the emperor unprecedented preeminence.

In line with orthodox Confucian doctrine, Taizu created an image of the ruler fulfilling two complementary functions: As the autocratic head of state the emperor was personally responsible for devising effective means of controlling the world. In his role as teacher and reformer, he claimed, at the same time, supreme authority as the source of change and moral improvement. Thus, the first Ming monarch carried out two related reforms: He reemphasized the leading power role of the emperor and he reconfirmed society in the ancient moral and hierarchical norms. Taizu believed it was his mission to eliminate "barbarian" influences and to reconstruct the ideal Chinese world order. ${ }^{5}$ The introduction of a network of legal regulations and institutions reflected the emperor's desire to save the world through

\footnotetext{
${ }^{3}$ Wu Han, Zhu Yuanzhang zhuan [Biography of Zhu Yuanzhang] (Peking 1991) p. 301 .

${ }^{4}$ Charles O. Hucker, 'Ming Government', in: The Cambridge History of China, Volume 8: The Ming Dynasty, 1368-1644, Part 2, Denis Twitchett and Frederick W. Mote, eds. (Cambridge 1998) pp. 9-105, here p. 104.

${ }^{5}$ Edward L. Farmer, Zhu Yuanzhang and Early Ming Legislation: The Reordering of Chinese Society following the Era of Mongol Rule (Leiden; New York; Cologne 1995) pp. 18-32.
} 
comprehensive moral reform, to discipline his followers and to govern the realm.

In the scholarly literature, the Ming founder's reorganization of the central government is often labelled as the introduction of "Ming despotism". ${ }^{6}$ In fact, the Ming founder increased imperial authority to an unprecedented degree by restructuring government agencies. In 1380 , when the grand councillor $\mathrm{Hu}$ Weiyong was charged with plotting rebellion and was executed along with thousands of others, Taizu abolished the whole upper echelon of the central government ${ }^{7}$ and concentrated power securely in his own hands. ${ }^{8}$ This "decapitation" of the central bureaucracy represented a watershed in the Ming founder's assertion of his patrimonial prerogatives. ${ }^{9}$ No single appointee could gain overall control of the military, the general administration or the surveillance agencies, especially the censorate. The emperor was his own prime minister, took direct control of the six ministries and splintered the chief military commission into five coequal offices, each directly responsible to the throne. ${ }^{10} \mathrm{He}$ even fragmented censorial authority by placing it into the hands of low-ranking investigating censors, who answered directly to the ruler. ${ }^{11}$ Disciplinary problems within the bureaucracy were solved with ruthless brutality. Taizu justified his extremely contemptuous, distrustful and cruel behaviour towards his subordinates by citing his opposition to the mistreating of the common people by civil officials. ${ }^{12}$ The reorganization of government greatly increased the amount of work that fell to the emperor.

\footnotetext{
${ }^{6}$ Jiang Yonglin, The Great Ming Code/Da Ming lü (Seattle; London 2005) p. xxxvii.

7 The secretariat disappeared along with the tribunal of censors and the chief military commission. See John D. Langlois, Jr. 'The Hung-wu reign, 1368-1398', in: The Cambridge History of China, Volume 7: The Ming Dynasty, 1368-1644, Part I, Frederick W. Mote and Denis Twitchett, eds. (Cambridge 1988) pp. 107-181, here pp. 139-140.

${ }^{8}$ Charles O. Hucker, The Ming Dynasty: Its Origins and Evolving Institutions (Ann Arbor 1978) pp. 41-43.

9 Michael G. Chang, A Court on Horseback: Imperial Touring and the Construction of Qing Rule, 1680-1785 (Cambridge; London 2007) p. 15.

${ }_{10}$ These were the ministries of personnel, revenue, rites, war, justice and public work.

${ }^{11}$ Yonglin, Great Ming Code, pp. xxxvi-xxxvii.

12 John Dardess, Confucianism and Autocracy: Professional Elites in the Founding of the Ming Dynasty (Berkeley; Los Angeles; London 1983) p. 244. See also Wang Zhao, Zhongguo lidai zhongyang guanzhi shi [The bureaucratic system of the central government in Chinese History] (Shanghai 2005) p. 173; Hucker, 'Ming Government', p. 104).
} 
In 1385, Taizu stated that no ruler could fulfil his imperial Mandate of Heaven by simply radiating "mercy and virtue". In his institutional reorganisation, Taizu put into practice a model of rule already announced in 1377:

When the ruler, who settles a myriad of exigencies every day, becomes negligent, then everything comes to a standstill and endless disaster results. Ever since taking the throne I have forced myself to be diligent. I come to court before dawn and go back to the palace after dark. When I can't help sleep at night I get up and dress. Sometimes I scan the skies and take alarm if a star is out of place, and sometimes I ponder public matters, and if I find that something needs immediate action I make a written note of it so I can issue the appropriate orders at dawn. I would like to relax, of course, but I fear the Mandate of Heaven and have to do as I do. ${ }^{13}$

The official "Veritable Records of the Ming Dynasty" (Mingchao shilu) reported Taizu's work-load for an eight-day period in the fall of 1384 as covering 1,660 documents to which he gave his personal attention. ${ }^{14}$ For day-to-day administrative advice, the emperor continued to rely on scholar-advisors. In 1382, he established the position of grand secretary (da xueshi) to review state documents and to offer advice. The grand secretaries were chosen from the prestigious Hanlin Academy (Hanlin yuan) in the capital that had become a fully developed government institution and an important stepping-stone to political influence in the imperial court and state bureaucracy of the Ming state. ${ }^{15}$ Hanlin members served the emperor as private secretaries and consequently could rise easily to the pinnacles of power in the central bureaucracy as well as in the inner court. ${ }^{16}$ During the Ming dynasty, three out of four grand secretaries had earlier been members of the Hanlin Academy. ${ }^{17}$

As officials on call, the grand secretaries were stationed at various palaces in the Forbidden City and not clustered in one office. ${ }^{18}$ They

\footnotetext{
${ }_{13}$ Ming Taizu shilu [Veritable Records of Ming Taizu], Volume 5, p. 1882 (October 9, 1384), quoted in Dardess, Confucianism and Autocracy, p. 202.

${ }_{14}$ Ming Taizu shilu, [Veritable Records of Ming Taizu], Volume 6, pp. 2544-2545 (October 9, 1384).

${ }_{15}$ See Adam Yung-ch'eng Liu, The Hanlin Academy: Training Ground for the Ambitious, 1644-1850 (Hamden, CT 1981).

${ }^{16}$ Elman, 'Imperial Politics', p. 384.

${ }^{17}$ See Hung-Ting Ku, 'Upward career mobility patterns of high-ranking officials in Ch'ing China, 1730-1896', Papers on Far Eastern History 29 (1984) pp. 45-66.

${ }^{18}$ Langlois, 'The Hung-wu reign', pp. 148-149.
} 
were responsible for the coordination and supervision of the six ministries. Straddling the middle ground between outer and inner court, the Ministry of Rites (libu) became increasingly important. It was responsible for two major functions of government: education and foreign affairs. At the same time, it took care of imperial sacrifices and imperial family matters. It was the only ministry that was not only a full-fledged part of the outer court bureaucracy, but also an integral part of the inner court administration. Moreover, the Ministry of Rites served as a springboard for promotion to the Grand Secretariat. ${ }^{19}$

Not until the third Ming emperor, Chengzu (r. 1402-1424), was an "Inner Cabinet" (neike) formed to fill the gap between the throne and the imperial bureaucracy which had been created by the founding emperor when he had done away with the Central Secretariat (zhongshusheng) during the plot of 1380. In 1402, seven young officials were appointed to the Inner Cabinet, serving for many years, even after the end of the Chengzu reign. ${ }^{20}$ Under the guidance of an informally designated Senior Grand Secretary they developed collegial procedures. But their influence rested only on individual personality and therefore Grand Secretaries possessed weaker institutional foundations than the Grand Councillors of previous dynasties. Ming rulers formed very close relations with them, meeting them frequently in formal and informal settings. Chengzu even took some of his Grand Secretaries along on his field campaigns. Scholarly services like editing and compiling rather than administrative career paths led into the Inner Cabinet. Because Grand Secretaries were representatives of the inner court and without roots in the outer court, other officials of the central government in the outer court commonly associated them with the inner parts of the palace, consisting of palace women, eunuchs, imperial kinsmen and in-laws. From the point of view of the outer court officials, the Grand Secretaries were instruments of imperial authority and therefore represented a highly unwelcome, irregular intrusion between themselves and the emperor. The emperor for his part regarded his Grand Secretaries as important go-betweens. Their authority in either

\footnotetext{
${ }^{19} 66 \%$ of all Ming grand secretaries had also been members of this ministry. See Elman, 'Imperial Politics', p. 386.

${ }^{20}$ Hok-lam Chan, 'The Chien-wen, Yung-lo, Hung-hsi, and Hsüan-te Reigns, 18991435', in: The Cambridge History of China, Volume 7: The Ming Dynasty, 1368-1644, Part 1, Frederick W. Mote and Denis Twitchett, eds. (Cambridge 1988) pp. 182-304, here pp. 208-212.
} 
direction derived exclusively from their individual abilities and from the force of their personalities, not from their institutional role within imperial government. ${ }^{21}$ Actually, some of them even dared to contradict imperial decisions and to persuade the emperor to adopt different policy alternatives. ${ }^{22}$ The famous seventeenth century philosopher and Confucian scholar Huang Zongxi came to the conclusion:

It was not so clear whether [it] was a Liaison Office between the civil service and the throne, a command post over the ministries, merely an advisory agency, or even an arbitrating agency. ${ }^{23}$

The other significant institutional change under the third Ming emperor was the transfer of the imperial capital from Nanking to Peking, where his personal power base had been located as an imperial prince. The new palace city was completed in 1420. Also called the "Forbidden City" (zijin cheng), it symbolized two main characteristics of Ming rule: the distance of the monarchs from their subjects as well as the dominance of orders, prohibitions and other kinds of top-down-communication. The emergence of provincial governors, multi-province supreme commanders (zongdu) and the Inner Cabinet at court during the Chengzu reign indicated a kind of "relaxation" of the extreme centralization of power achieved under Taizu. ${ }^{24}$ This easing tendency continued under Chengzu's successors. Only strong rulers, however, could make any kind of centralized government work efficiently. Abilities of later Ming emperors inevitably fluctuated. They increasingly withdrew from their Grand Secretaries, and allowed other members of the court society to wield imperial authority. After the Tumu incident in 1449, when the emperor was taken prisoner during his campaign against Mongol tribes, Ming emperors became more and more passive and retreated into the inner court of the palace. Almost no audiences with ministers were held during seventy out of 137 years between 1465 and 1602. Messages were simply sent by eunuchs to the Secretariat's building. Moreover, after the death of Zhengde (r. 1505-1521) Ming rulers never left the Forbidden City. From the mid-fifteenth century,

\footnotetext{
${ }^{21}$ Hucker, The Ming Dynasty, p. 91.

${ }^{22}$ Zhang Jinfan, Zhongguo guanzhi tongshi [A Complete History of the Chinese bureaucratic system] (Beijing 1992) pp. 503-504.

${ }^{23}$ Cited in W.T. de Bary, 'Chinese Despotism and the Confucian Ideal: A Seventeenth-Century View', in: Chinese Thought and Institutions, John K. Fairbank, ed. (Chicago 1957) p. 175.

${ }^{24}$ Hucker, The Ming Dynasty, p. 73.
} 
the last indigenous government in China seemed to be without imperial direction at all.

Imperial affairs were conducted mainly through eunuchs, whose actions often provoked factional disputes at court that seriously disrupted governance. Eunuchs had been part of all imperial courts in Chinese history. ${ }^{25}$ They were a sumptuary privilege reserved to royalty. No one else in Chinese society was allowed to employ them. In 1367, Taizu established a bureau for eunuchs. Later he reorganized it in twelve functionally distinct supervisory offices handling services needed within the inner court and gradually displacing palace women in many of those roles. After his coup d'état, the third emperor Chengzu founded the first regular training school for eunuchs. He had to rely on them, because the court ministers opposed his usurpation of the throne and remained loyal to his nephew, the Jianwen Emperor (r. 1398-1402). ${ }^{26}$

Literacy changed eunuchs into a dominant group in court society to be reckoned with. A eunuch bureaucracy, consisting of all twentyfour offices, emerged with its own ministry of personnel, called the Directorate of Palace Eunuchs (neiguanjian). Despite Taizu's intention to reduce eunuch staff to no more than one hundred persons, their numbers increased constantly to about seventy thousand by the end of the dynasty. ${ }^{27}$ Eunuch bureaucrats were ranked and paid on the model of officialdom though their salaries were minuscule. As extensions of the ruler's person, eunuchs could wield great power that civil officials could not aspire to. As members of the imperial bodyguard, they formed the core of the emperor's private machinery of surveillance. ${ }^{28}$ They ran the entire imperial household and took control of all official communication. In the imperial household, only one agency was left in female responsibility. ${ }^{29}$ Matters such as foodstuffs, ritual regalia, ceremonies, utensils, document handling, seals, and staff surveillance were all arranged by eunuchs. They maintained the palace treasury and

${ }^{25}$ Yuan Lükun and Wei Jianqin, Taijian shihua [A History of Eunuchs] (Zhengzhou 1984) pp. 1-15. See also Henry Shih-shan Tsai, The Eunuchs of the Ming Dynasty (Albany, NY 1996).

${ }_{26}$ Tsai, Eunuchs of the Ming Dynasty, p. 13.

${ }_{27}$ Hucker, The Ming Dynasty, p. 93. Shih-shan Henry Tsai estimated their number even to 100.000 persons. See Tsai, Eunuchs of the Ming Dynasty, p. 11.

${ }^{28}$ Frederick W. Mote, Imperial China, 900-1800 (Cambridge, Mass. 1999) pp. 602-605.

${ }_{29}$ Hucker, The Ming Dynasty, p. 71. 
served in the imperial secret service. Granted the right to memorialize the emperor directly, they could act in total separation from the institutions of the outer court, where their influence also grew. ${ }^{30}$

Eunuch power penetrated into the outer court domain by the way of the Civil Documentation Bureau (wenshufang), staffed by ten eunuchs, who officially registered all incoming documents and all outgoing imperial comments or instructions. They functioned as mediators between the emperor and the Grand Secretaries, who rarely had personal contact with the emperor on a daily basis. ${ }^{31}$ From the midfifteenth century, when Ming rulers increasingly paid more attention to personal affairs than to state matters, eunuchs of the Civil Documentation Bureau also inserted their own ideas into the documents before passing them from the Inner Cabinet to the throne. If Grand Secretaries learned how to cooperate closely with their eunuch counterparts, some sort of balance was possible in the Ming court polity. As imperial special agents, eunuchs were also sent on diplomatic missions. They exercised military functions by commanding armies and navies, and they supervised tax collections. ${ }^{32}$ Under weak emperors some senior eunuchs became extremely influential, controlling the government as "eunuch dictators" ${ }^{33}$ In such cases, the ongoing tension between the "irregular" eunuch bureaucracy and the proper court administration of the officials reached destructive heights.

During the late Ming period the bureaucracy was increasingly driven by cliques, factions, and personal antagonisms and unable to generate a coherent policy. After the death of the Wanli-Emperor (r. 1602-1620), a faction of ultra-puritanical Confucian scholars and ex-officials, who were loosely connected through the private Donglin Academy in the Yangzi delta, infiltrated the central bureaucracy in order to attack the young emperor's favourite, the illiterate, but influential eunuch Wei Zhongxian (1568-1628). ${ }^{34}$ The power vacuum at the imperial centre was filled by contending eunuchs and gentry-official groups, who each

${ }^{30}$ Robert B. Crawford, 'Eunuch Power in the Ming Dynasty', T'oung Pao 49 (1961) pp. 115-148, here p. 135.

${ }^{31}$ Tsai, Eunuchs of the Ming Dynasty, p. 226.

32 Tsai, Eunuchs of the Ming Dynasty, pp. 14-17, 135-164.

${ }^{33}$ Charles O. Hucker, 'Government and Organisation of the Ming Dynasty', Harvard Journal of Asiatic Studies 21 (1958) pp. 1-66, here p. 11.

${ }^{34}$ See in detail John E. Dardess, Blood History in China: The Donglin Faction and Its Repression, 1620-1627 (Honolulu 2002). 
sought control of the inner court. ${ }^{35}$ During Wei Zhongxian's counterattack the Donglin faction was almost destroyed. ${ }^{36}$ The political atmosphere of the late Ming period discouraged many scholar-officials from seeking central government employment at all. They preferred congenial environments in the provinces and devoted their energies to a more scholarly spiritual life. ${ }^{37}$ After Wei Zhongxian's death, the emperor ordered a purge within the government: 260 leading collaborators were named by the emperor's inner court assistants and subsequently punished. But these actions failed to restore dynastic vigour. Imperial failure, peasant rebellion and Manchu intervention finally destroyed the last Han-Chinese dynasty in history. ${ }^{38}$

The Qing dynasty created one of the largest and longest-lived multiethnic empires of the early modern world. To win the allegiance of the different ethnic groups they ruled, the Manchu deployed the various rhetorical resources they had acquired during their rise to the Chinese throne. They simultaneously embodied crucial elements of the political traditions of the several peoples. Qing emperorship can be described as "simultaneous expressions in multiple cultural frames." 39 The "sinicization" of Manchu rule in China reflected the need of early Qing monarchs to appeal ideologically to the traditional Chinese elite. NeoConfucianism served as a source of rhetoric for the Manchu court as it struggled to find a language to win over the Confucian literati. ${ }^{40}$ To meet the needs of the Inner Asian peoples of their empire, the Manchu added a Court of Colonial Affairs (Lifanyuan) to the Chinese central government. The Lifanyuan was the institutional tool to transform Inner Asian peoples into subjects of the Qing empire without making them Chinese. Together with the six ministries and the Censorate (duchayuan) it belonged to the eight most important governmental offices situated in the outer court of the palace. The difference between

35 Elman, 'Imperial Politics,' p. 389.

36 Elman, 'Imperial Politics,' p. 395.

37 Mote, Imperial China, p. 770.

38 See Mote, Imperial China, pp. 781-783.

39 Pamela Crossley, A Translucent Mirror: History and Identity in Qing Imperial Ideology (Berkeley; Los Angeles 1999) p. 1.

40 Crossley, A Translucent Mirror, pp. 226-232. 
the various ethnic groups of the empire was formalized and reified. Their myths of descent and lineage histories were systematically documented. In this way, Manchu rulers were able to be all things to all people. As Qing emperors performed their different ritual obligations, they imagined themselves as embodying the roles they were playing. ${ }^{41}$ To clarify cultural differences and to prove subsequently the universal competence of the ruler was the "mission" of Qing emperors. ${ }^{42}$

At the same time, the Manchu monarchs as north-easterners were very conscious of their historical, cultural and linguistic separation from the Chinese speakers to the south. Like earlier non-Han conquest regimes from the tenth to the fourteenth century, the Manchu maintained their separate identity. ${ }^{43}$ The ruling formation of the Qing court marked itself off from those it ruled by certain religious, linguistic, ritual and social characteristics, all manifested by the imperial household. ${ }^{44}$ Manchu customs and practices survived through their imbrication in specifically Manchu institutions, especially the banner system. ${ }^{45}$ The Qing was a conquest dynasty and it remained organized like a "nation at arms" during the entire period of its rule in China.

The military system of banners had already been established in 1601 to break down traditional tribal divisions. Manchu soldiers and their families were organized into eight fighting groups, distinguished in formation by flags of different colour. ${ }^{46}$ Gradually by accretion eight Chinese and eight Mongol banners were organized. The banner elite was graded into ranks of varying nobility. After 1644, the banners represented the main military force of Qing China. They were stationed in the capital and throughout the empire, receiving for their support tracts of land surrounding the capital. ${ }^{47}$ The traditional Chinese troops

${ }^{41}$ Angela Zito, Of Body and Brush: Grand Sacrifice as Text/Performance in Eighteenth-Century China (Chicago 1997) p. 210.

${ }_{42}$ Crossely, A Translucent Mirror, p. 270.

${ }^{43}$ Eveleyn S. Rawski, 'The 'Prosperous Age': China in the Kangxi, Yongzheng and Qianlong Reigns', in: China: The Three Emperors, 1662-1795, Evelyn S. Rawski and Jessica Rawson, eds. (London 2005) pp. 22-40, here pp. 22-23.

${ }^{44}$ Evelyn Rawski, The Last Emperors: A Social History of Qing Imperial Institutions (Berkeley, CA 1998) p. 9, pp. 29-55.

${ }_{45}$ Mark C. Elliott, The Manchu Way: The Eight Banners and Ethnic Identity in Late Imperial China (Stanford, CA 2001) p. 12.

${ }_{46}$ Wang Jingze, Qingchao kaiguo shiqi baqi yanjiu [The Eight Banners at the beginning of the Qing Dynasty] (Changchun 2002) pp. 8-51.

${ }_{47}$ Ding Yizhuang, Qingdai baqi zhufang yanjiu [The Garnisons of the Qing Eight Banners] (Shenyang 2002) pp. 117-189. 
of the Green Standards (lüying) were reduced to gendarmerie forces. In the capital, bannermen were organized in outer and inner banner divisions, the latter responsible for protecting the imperial palace. Only members from the three superior banners of the inner banner divisions were chosen as imperial bodyguards, who had access to the inner court. Bannermen enjoyed a highly privileged status. The inner city of Peking was reserved for them, where there were special quarters for bannermen and their families to live in accordance with the colours assigned to the different banner divisions. ${ }^{48}$ Bannermen took for themselves never less than one half of the key posts in the imperial bureaucracy. A separate system of military examinations was maintained for them. They filled both military and civil positions provided for them in the Qing institutional hierarchy. Intermarriage with Han-Chinese was prohibited for the elite of Manchu, Mongol and Chinese banner forces. A form of political endogamy excluded ties between the ruling house and the Chinese bureaucrats. ${ }^{49}$ Bannermen formed a hereditary warrior caste, alimented by the state. Their residence, livelihood, training, and status in China were all arranged by the dynasty. The mutual support of imperial house and the banner community reinforced their sense of common destiny. ${ }^{50}$

In the early eighteenth century, the banner order underwent a process of bureaucratization. A routine procedure for the evaluation and promotion of banner personnel developed, and bannermen made their way into the civilian administration. ${ }^{51}$ Half of the presidencies of the six boards were reserved for them and most of the governors-general came from the banner nobility. What made them unique in the early modern world was their extraordinary loyalty to the ruling house. Banner armies never turned on the court that had created them. Instead, bannermen evolved into one of the longest-lived and most loyal service elites in history. ${ }^{52}$ Though officials of the banner institutions were

${ }^{48}$ Rawski, The Last Emperors, pp. 26-27.

49 Evelyn S. Rawski, 'Ch'ing Imperial Marriage and Problems of Rulership', in: Marriage and Inequality in Chinese Society, Rubie S. Watson and Patricia Buckley Ebrey, eds. (Berkeley, CA 1991) p. 170.

${ }^{50}$ For examining the special status of the Eight Banners in Qing dynasty see Elliott, The Manchu Way, especially pp. 133-174.

51 Elliott, The Manchu Way, pp. 203-205. See also Pamela K. Crossley, 'Manchu Education', in: Education and Society in Late Imperial China, 1600-1900, Benjamin A. Elman and Alexander Woodside, eds. (Berkeley, CA 1994) pp. 340-378.

${ }^{52}$ R. Kent Guy, 'Who were the Manchus? A Review Essay', Journal of Asian Studies 61 (2002) pp. 151-164, here p. 152. 
responsible for less than two percent of the population, banner officialdom became the biggest subsection of the Qing bureaucracy. While the Han-Chinese population was administered according to traditional Chinese methods, the banner people were subjected to a kind of micromanagement by the Qing court: Births, deaths, marriage, employment, retirement, and residence were all monitored by triennial censuses. Of all imperial institutions, only banners had their own, exclusive administrative handbook, the "Comprehensive History of the Eight Banners" (Baqi tongzhi), first published in 1739. The selection of banner officials and officers was a prerogative of the emperor. ${ }^{53}$ Banners never entirely escaped their fragmented origins as a tribal organization. There was no central banner board, which would have made them independent from the traditional Chinese outer court government.

In the emperor's eyes, his imperial guards (shiwei) constituted an alternative tool of imperial will to the civil service bureaucracy of the Han-Chinese elite, and thus enhanced the ruler's flexibility. They were visible, prestigious elite units responsible for the security of the monarch. Their special status was signalled by their garments, peacock feathers and bright yellow riding jackets, setting them apart and nurturing a corporate solidarity. They fulfilled a wide variety of tasks. Their chamberlains even enjoyed the same top status in the ranking hierarchy as the sons of princes. Moreover, for the banner nobility, the imperial guards represented a channel of upward mobility at the Qing court. ${ }^{54}$

The court nobility was another new element introduced by the Qing to intertwine inner and outer court responsibilities. Under the Ming, the imperial family had been the only group of nobles with influence in the government and only the Heir Apparent (taizi), usually the eldest son, was allowed to reside in the imperial palace at the capital. All other sons received territorial titles and lived in princely establishments (wangfu) throughout the empire. They were salaried dignitaries and no more. Though noble titles were also granted to relatives by marriage of the emperors, they mostly were prevented from taking any part in routine administration..$^{55}$ Instead, the Qing styled all brothers and sons of emperors as imperial princes (qinwang), moulding them

${ }^{53}$ Elliott, The Manchu Way, pp. 135-134.

${ }_{54}$ Rawski, The Last Emperors, pp. 82-87.

${ }^{55}$ Hucker, 'Government and Organisation of the Ming Dynasty', pp. 9-10. 
into a kind of ruling kin-coalition. The Ming system of primogeniture was replaced by choosing the best-suited prince as heir and keeping his name secret until his accession. ${ }^{56}$ Sons of all consorts were made eligible to become emperor. The delayed designation of the heir triggered intensive succession struggles, which could expand even into the outer court realm. Qing imperial sons were not barred from political participation. Rather, they were expected to carry out ritual, military, and diplomatic tasks. The co-residence of all imperial princes in the palace strengthened familial sentiments and allowed the emperor to control his sons' activities and to evaluate their personalities and talents. In this way, the throne could assess their fitness by their performance. ${ }^{57}$

Though favoured dignitaries and new members of the imperial family were all ennobled, they never were granted territorial fiefs and they were not required to live away from the capital as during the Ming period. The first actual Qing ruler, Prince Dorgon (1612-1650), a younger brother of Huang Taiji, is an early example of this strategy. As regent for the Shunzhi Emperor (r. 1644-1661), he governed China until his death. ${ }^{58}$ Imperial princes headed the five lesser banners that complemented the three upper banners under direct command of the emperor. In 1723, the Yongzheng Emperor even decided to appoint imperial princes to the ministries of revenue, works and rites. ${ }^{59}$ His son Qianlong ordered the construction of 360 additional rooms for royal princes in the Forbidden City. ${ }^{60}$ Manchu tribal leaders, Mongol rulers, early Chinese collaborators and generals were rewarded for their support with career opportunities for their sons and with wives from the imperial lineage. ${ }^{61}$ Such marriage arrangements functioned as

\footnotetext{
${ }^{56}$ Huang Pei, Autocracy at Work: A Study of the Yung-cheng Period, 1723-1735 (Bloomington 1974) pp. 95-96.

${ }^{57}$ Rawski, 'Ch'ing Imperial Marriage', p. 172.

${ }^{58}$ Jin Xingyao, Qingdai Gongting zhengbian jiyao [Political Changes at the Qing Court] (Xi'an 2005) pp. 62-68; Wan Yi, Wang Shuxiang and Liu Yao, Qingdai gongting $s h i$ [History of the Palace in Qing times] (Shenyang 1990) pp. 25-34.

${ }_{59}$ Zhang, Zhongguo guanzhi tongshi, 650.

${ }^{60}$ Qin Guojing, 'Lun Qianlong huangdi zhili gongting de gongze' [Merits of the Qianlong emperor in governing the palace], in: Qingdai gongshi luncong, ed Qingdai gongshi yanjiuhui, (Beijing 2001) pp. 1-11, here 5.

${ }_{61}$ The privilege of receiving official posts without entering the difficult state examinations for sons of government officials already existed under former dynasties. The Qing government used it to elevate their bannerrmen and Mongolian allies. For the Qing bureaucratic system in detail see Ai Yongming, Qingchao wenguan zhidu [The civil service system of the Qing dynasty] (Beijing 2003).
} 
important means of winning new allies and of stabilizing coalitions at court and throughout the expanding Qing empire. ${ }^{62}$

Etiquette, ranks and ceremonies served as important instruments of communication and control for the Qing rulers. During the conquest era, the "courtization" of Manchu warriors was realized through the transformation of military titles into titles of nobility. A system of hereditary titles with 27 separate ranks was devised giving rise to a highly stratified court aristocracy. According to their self-image as rulers of a multiethnic empire, the Qing integrated peoples of the Inner Asian regions as major actors into their imperial enterprise. As subjects of the Qing state they were on equal footing with the Han Chinese of China proper. Manchu emperors aimed at the coexistence of diverse cultures within the loose framework of their personalistic rule. They adopted a policy of residential, administrative and institutional segregation to perpetuate the separate identities of the various peoples. To redefine the political, economic and cultural relationships between China proper and Inner Asia, the Qing court set up the imperial rituals of pilgrimage to the emperor (chaojin), imperial hunt (weilie) and tribute (chaogong), which were all organized and controlled by the Lifanyuan. ${ }^{63}$ Inner Asian nobles were divided into rotas for annual journeys to the Qing emperor. At the summer palace in Chengde they had to perform rituals of submission, the chaojin. The imperial hunt at Mulan was another court ritual designed for the Inner Asian subjects of the Qing throne. Celebrations of the emperor's birthdays with magnificent banquets and entertainments were used to demonstrate the glory and generosity of the monarchy. In this way, previously independent and often rebellious Inner Asian nobles were tamed and "domesticated" at the Manchu court. Court rituals, in general, were used by Qing monarchs as instruments of power. At the same time, they limited their own freedom as the emperors became enmeshed in a self-created web of symbols, rules and obligations.

Unlike their European counterparts, the Qing peers constituted a service nobility, whose power derived entirely from the monarch. During the succession of infant emperors in the late nineteenth century, imperial agnates even played a leading role in national politics. Prince

${ }^{62}$ Cui Mingde, Zhongguo gudai heqin shi [The History of Marriage Alliance in Traditional China] (Beijing 2005) pp. 475-513.

${ }^{63}$ Ning Xia, 'The Lifanyuan and the Inner Asian Rituals in the Early Qing (16441795)', Late Imperial China 14 (1993) pp. 60-92, here p. 61. 
Gong (1833-1899), son of the Daoguang emperor (r. 1821-1850), negotiated with the foreign powers in 1860 after the second Opium War, when his half brother, the Xianfeng emperor (r. 1851-1861), had fled Peking. Of the four adjutants-general protecting the capital in the late Xianfeng reign, three were imperial agnates and the fourth an imperial affine. ${ }^{64}$ At the Qing court a "lean aristocracy" was available to exercise a wide variety of political and military functions. ${ }^{65}$ Like the bannermen the imperial nobility turned into a useful instrument for influencing outer court policy from within inner court domains. Both groups, seen within the overall configuration of the imperial court, were a genuine Manchu contribution to the history of governance in China.

A third group at the Qing court with a special role and status were the bondservants (baoyi). They represented a different class of imperial household servants and replaced the Ming eunuchs in the management of the emperor's domestic affairs. In comparison with previous Chinese dynasties, the Manchu government was relatively free from eunuch abuses. The Imperial Household (neiwufu) staffed mainly by bondservants, played an important role in government and society, controlling all activities within the palace establishment and the aggregated 56 service agencies. ${ }^{66}$ Many of its departments resembled organs of the official bureaucracy, acting as functional equivalents of the six ministries and the censorial office. Starting with a staff of 400 members, the Imperial Household grew to over 1,600 members by the end of the eighteenth century, most of them imperial bondservants. ${ }^{67}$

Qing bondservants were often former prisoners-of-war and their descendants. They were drawn from the three upper banners under the direct command of the emperor. Similar to eunuchs or householdslaves, they were entirely dependent on the monarch's personal will. The position of an imperial baoyi at court could lead to a remunera-

64 Rawski, The Last Emperors, p. 196.

65 Rawski, The Last Emperors, pp. 77-80, 91-93.

66 The Imperial Household Department had to feed, clothe, and house the monarch, provide him with entertainment such as libraries, theatrical performances and the harem of palace women. The administration of the three upper banners, the imperial estates and of the commercial enterprises throughout the empire was also assigned to this institution. The Department derived revenue directly from the imperial estates in Manchuria and around Peking, from ginseng trade and other commercial operations, from collection of customs revenue and foreign tribute, from loans to merchants and from expropriation of private property.

${ }^{67}$ Qi Meijin, Qingdai neiwufu [The Department for Internal Matters of the Qing Period] (Beijing 1998) pp. 276-280. 
tive career. After attending special schools under the Manchu banner system, the hereditary bondservants entered the Imperial Household as junior clerks. They were promoted by seniority within its extensive and elaborate bureaucracy. Top posts were only given to personal favourites of the emperor. ${ }^{68}$ Moreover, the monarchs placed trusted bondservants (baoyi) in key positions in various government commissions and departments that were in charge of the extensive public economic organisations, thus transcending the boundaries of the inner domain. The network of bondservants throughout the empire provided the emperor with money, information and critical reports on the work of the regular bureaucrats, functioning as a parallel bureaucracy to the official one. ${ }^{69}$

In general, the Qing dynasty did not simply take over the Ming apparatus of government in its entirety, but restructured the governmental system, infused new energy into it and made it work more efficiently than ever before. While the traditional division in six ministries survived, these institutions lost the authority they had in Ming times. Ministers could no longer issue direct orders to provincial governors, and the lines of communication between them were often hopelessly entangled. Vice ministers were now allowed to send their own memorials, dispersing authority within a single institution. Everyone was now directly responsible to the monarch. ${ }^{70}$ But just as in the Ming period, only strong rulers succeeded in using these opportunities to enhance autocratic power. In Qing China, only the three emperors of the High Qing period-Kangxi (r. 1662-1722), Yongzheng (r. 1723-1735) and Qianlong (r. 1736-1796)-demonstrated such personal qualities. All three were workaholics, who rose before five o'clock every morning to read memorials and who handled several hundred items a day. They also invented new instruments to strengthen imperial leverage. ${ }^{71}$

One of them was the system of secret palace memorials (zhupi zouzhe). An autonomous circuit of information-inflow and decision-making was created to bypass the Grand Secretariat, the official guardian of

\footnotetext{
${ }^{68}$ Preston M. Torbert, The Ch'ing Imperial Household Department: A Study of its Organisation and Principal Functions (Cambridge, Mass. 1977) pp. 60-78, 175-182.

${ }_{69}$ Jonathan D. Spence, Ts'ao Yin and the K'ang-his Emperor. Bondservant and Master (New Haven 1966) pp. 7-17.

${ }^{70}$ Zhao, Zhongguo lidai zhongyang guanzhi shi, pp. 267-269.

${ }^{71}$ About the Kangxi-Emperor it is said, that he managed as many as 700-800 items of business in one day. See Jonathan D. Spence, Emperor of China: Self-Portrait of K'ang-hsi (London 1974) pp. 54-56.
} 
transmission. This system was created by Kangxi when he used Manchu officials to keep him apprised of developments in the palace and in the capital. ${ }^{72}$ The emperor was beset by intrigues from competing princes in the heir-apparent crisis and he asked selected officials, often members of the Imperial Household on secondment to provincial posts, to report to him secretly. ${ }^{73}$ These letters were sent by private couriers in a box to which only the sender and the emperor held keys. ${ }^{74}$ During the 1690s, he extended this system to include regular field-officials. After deposing the heir-apparent in 1712, Kangxi ordered all court officials of the third grade upwards to provide him with such secret memorials..$^{75}$ The flow of secret information to the emperor weakened the influence of the outer court bureaucracy. Imperial bondservants in the provinces, nobles and officials in the capital regularly submitted secret reports to the emperor, bypassing the transmission of routine memorials through the Grand Secretariat, which was thereby demoted to an impotent secretarial office. ${ }^{76}$

The influence of the Grand Secretariat was further weakened by the Southern Study (nanshufang), which had originally been created in 1659 by the Kangxi emperor to supply him with intellectual resources when he retired to the private quarters of the palace. Later it was also used for imperial pronouncements. ${ }^{77}$ Members of the Hanlin Academy were appointed into this inner court agency as writers, calligraphers and copyists. Because most of them were Han-Chinese, the nanshufang was used as a liaison office to the traditional Confucian elite. ${ }^{78}$ The court supported Confucianism as cultural code for the administration of its Chinese-speaking subjects. From the Yongzheng reign on, the

${ }_{72}$ Elliott, The Manchu Way, p. 60.

${ }^{73}$ Yang Qiqiao, Yongzheng di jiqi mizhe zhidu yanjiu [The Yongzheng emperor and his system of secret palace memorials] (Shanghai 2003) pp. 157-158.

${ }^{74}$ Mark C. Elliott, 'The Manchu-Language Archives of the Qing Dynasty and the Origin of the Palace Memorial System', Late Imperial China 22 (June 2001) pp. 1-70, here pp. $49-56$.

${ }^{75}$ See Silas Wu, Communication and Imperial Control in China-The Evolution of the Palace Memorial System, 1693-1735 (Cambridge, Mass. 1970).

${ }^{76}$ Elliott, The Manchu Way, pp. 46-47.

77 Jinfan, Zhongguo guanzhi tongshi, p. 619.

${ }^{78}$ Zhu Jinpu, 'Lun Kangxi shiqi de nanshu fang' [The Southern Study during the Kangxi period], in: Qingdai gongshi yanjiuhui [Research association for Qing palace history], ed. Qingdai gongshi tanwei [Researches on Qing palace history] (Beijing 1991) pp. 1-24, here p. 1. 
numbers of Hanlin members were reduced while their status increased. They often received simultaneously appointments as ministers. ${ }^{79}$

The most important institutional invention at the Qing court was the Grand Council (junjichu, lit. "Office of Military Plans"). By its very existence, it weakened the outer court bureaucracy in favour of emperor's inner circle superseding the Grand Secretariat as the centre of decision-making. The Grand Council was originally set up by Yongzheng as a cabinet of trusted advisers to handle military campaigns. ${ }^{80}$ This highly confidential group met in a small building on the borderline between the inner and outer court parts of the palace. Like other inner court agencies it was exempted from censorate control. ${ }^{81}$ Always headed by an imperial prince, its usually six members changed frequently until the nineteenth century. They were chosen from among the heads and deputy heads of the Six Ministries, the Grand Secretariats, and sometimes from its own thirty-two senior secretaries. The Grand Ministers of the State met daily with the emperor and countersigned all documents in his name. They held their positions concurrently with their civil service ones. The result was an overlap between the Grand Secretariat, the Six Ministries and the Grand Council. This combination of concurrent posts and a large loyal body of former clerks gave the Grand Council valuable contacts throughout the capital and the provincial bureaucracy.

On a long-term basis, the mixing of Manchu and Chinese in the empire's top ruling body contributed to the reduction of old Manchu princely and grandee preponderance at court and allowed new scope for the influence of Chinese officials on policymaking. Moreover, the creation of the Grand Council made it possible to run the government effectively even if no strong monarch prevailed at court. In the late nineteenth century, in a period of infant and debilitated emperors, the dependence on the Grand Councillors in the running of state affairs to

\footnotetext{
${ }^{79}$ Zhang Deze, Qingdai guojia jiguan kaolue [State institutions during the Qing period] (Beijing 2001) p. 154.

${ }^{80}$ Zhao, Zhongguo lidai zhongyang guanzhi shi, p. 176; Bao Jingsheng, 'Junjichu yu Qingdai huangquan' [The Council of State and imperial authority in the Qing period], in: Ming Qing luncong [A Collection of Essays on the Ming and Qing Dynasties], Zhu Chengru and Wang Tianyou, eds. (Beijing 2005) pp. 257-267, here p. 257.

${ }^{81}$ Bo Zheng, Zhongguo gudai guanzhi [The Bureaucratic System in Ancient China] (Beijing 1989) p. 133. According to Wang Zhao it was no regular state institution or independent office, but a private organ of the emperor. See Zhao, Zhongguo lidai zhongyang guanzhi shi, p. 177.
} 
some extent compensated for the weakness at the imperial centre and thus prolonged the life of the Qing dynasty. ${ }^{82}$

From the tenth century, the power of Chinese emperors increased by a continuous process of institutional evolution reaching its zenith in late imperial times. Though the form of the two dynastic systems was different, emperors of both dynasties tried to strengthen their autocratic position not only through reforms of the central government in the outer court part of their palace, but also through an intertwining of inner and outer court realms. Social groups from the inner court were mobilized and their new functions institutionalized. At the Ming court, Grand Secretaries furthered the integration of the imperial administration; eunuchs acted as the monarch's eyes, ears, and arms. Under the third Ming emperor Chengzu both groups received their own agencies within the palace administration becoming a kind of "buffer" between the emperor and his outer court central government. ${ }^{83}$ Eunuchs like their rivals in the Grand Secretariat acted mainly through factions within the court system. Therefore, only strong emperors could use them effectively in the power struggles between the inner court, the emperor's faction, and the outer court, which was identical with the official literati faction.

Qing emperors demonstrated an even more casual attitude towards the traditional division between inner and outer court by moving the high-level decision-making of the central government to their private quarters in the inner court. ${ }^{84}$ Admission into the inner court was strictly limited to a select "inner circle", mostly members of the Manchu elite, at the expense of the Han-Chinese bureaucracy. Routine government business was increasingly located within the inner court. ${ }^{85}$ The confidential system of palace memorials increased the monarch's ability to

\footnotetext{
${ }^{82}$ See Beatrice S. Bartlett, Monarchs and Ministers: The Grand Council in MidCh'ing China, 1723-1820 (Berkeley 1991) pp. 257-278.

${ }^{83}$ Hucker, The Ming Dynasty, p. 95.

${ }^{84} \mathrm{Liu} \mathrm{Lu}$, 'The Forbidden City during the Qianlong reign', in: The Qianlong Emperor: Treasures from the Forbidden City, Zhang Hongxing, ed. (Edinburgh 2002) pp. 151-155, here p. 154.

${ }_{85}$ See Bartlett, Monarchs and Ministers, pp. 13-64.
} 


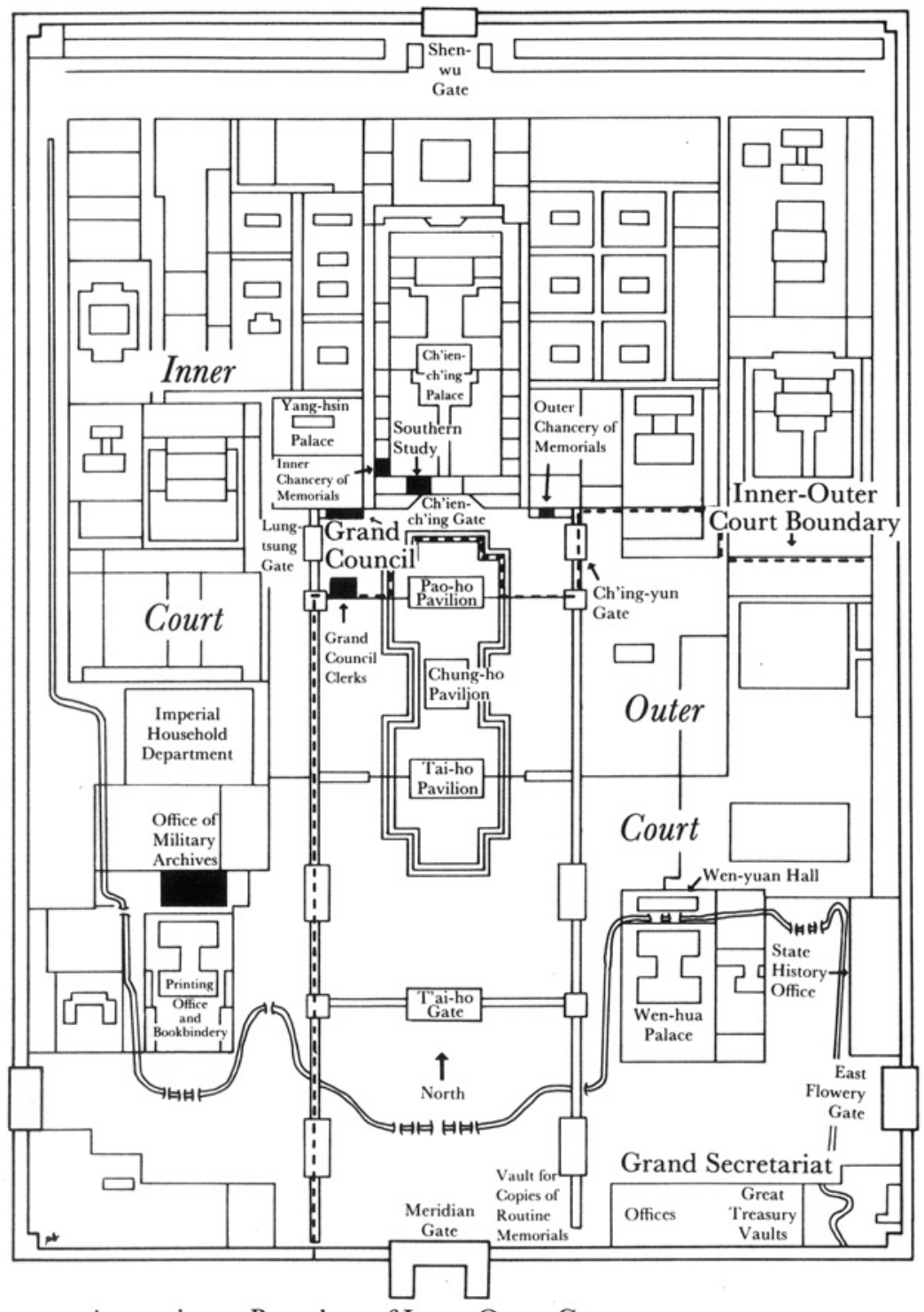

- - - - Approximate Boundary of Inner-Outer Court

Figure 1. Inner and outer court: the Forbidden City in the 17th and 18th centuries (from: Beatrice S. Bartlett, Monarchs and Ministers. The Grand Council in Mid-Ch'ing China, 1723-1820 (Berkeley 1991) p. 14). 
acquire sensitive intelligence about outer court and provincial officials and to maintain the throne's dominance over its civil service.

Similar to the Ming eunuchs, bondservants functioned as new informal channels for controlling court politics as long as strong emperors were able to pull these strings. Young or weak rulers easily fell victim to such networks of communication. Compared to the Ming eunuchs, Qing bondservants lacked military power as well as the ability to control decision-making processes at court, but their economic status often corresponded to the eunuch supervision of imperial manufactories and customs bureaus. In both cases, the power derived from direct imperial grants and by-passed the regular bureaucracy. The bondservants represented a new type of informal agents of autocratic rule. They often misused the authority granted to them and contributed to the economic, social and political crisis of their time. ${ }^{86}$ The balance-ofpower system at court, as described by Norbert Elias, depended on the constant intervention of the emperor himself. He could safeguard his position only by playing off members of the upper strata within court society against each other, if he was really strong enough to maintain himself as the remote arbiter. ${ }^{87}$

Sociological models like Norbert Elias's "court society" expose some characteristics of the late imperial court in China. Multiple roles of the respective monarchs are thrown into sharper relief. The personality of individual emperors mattered a great deal. But to some extent they were prisoners of the very system they had helped to create. A further question to be addressed in terms of the model might be the declining effectiveness of court mechanisms after the Qianlong period.

The creation of a Sino-Manchu empire as some kind of precursor to the multiethnic nation state of the twentieth century was never the Qing rulers' political goal. Comparable to the absolute monarchy of the French king Louis XIV, the Qing empire was no planned project realized by exceptional individual personalities. Even strong Qing emperors like Kangxi or Qianlong had to come to terms with other social groups in the network of court society. The figuration model of Elias can help to explain how monarchs developed a system of checks and balances at court and in society at large in order to sepa-

\footnotetext{
${ }^{86}$ Torbert, The Ch'ing Imperial Household Department, pp. 181-182.

${ }^{87}$ Norbert Elias, Die höfische Gesellschaft. Untersuchung zur Soziologie des Königtums und der höfischen Aristokratie (Frankfurt a.M. 1989) p. 254.
} 
rate the conquerors from the conquered while achieving a degree of institutional integration indispensable for the government of the most populous country in the world. The institutionalization and bureaucratization of the autocratic court was meant to give duration to imperial government, prevent arbitrariness of individual and collective action and make the future as predictable as possible. ${ }^{88}$ The new institutions created new channels of court policy and influenced different groups of court society. ${ }^{89}$ Imperial power was strengthened by new ways of communication. Yet the attempt to exercise imperial control over the elaborate networks of communication never lost its precariousness.

${ }^{88}$ For general thoughts about the role of institutions in historical sciences see Gert Melville, 'Institutionen als geschichtswissenschaftliches Thema. Eine Einleitung', in: Institutionen und Geschichte. Theoretische Aspekte und mittelalterliche Befunde, Gert Melville, ed. (Cologne; Weimar; Vienna 1992) pp. 1-24, here p. 7.

${ }^{89}$ For this logic see also Wolfgang Balzer, 'Entstehung und Wandel sozialer Institutionen', in: Institutionen und Geschichte. Theoretische Aspekte und mittelalterliche Befunde, Gert Melville, ed. (Cologne; Weimar; Vienna 1992) pp. 73-96, here p. 86. 


\title{
TURKS IN THE OTTOMAN IMPERIAL PALACE*
}

\author{
İ. Metin Kunt
}

Sans family, sans ethnicity?

To a non-specialist "Turks in the Ottoman Imperial Palace" may sound reasonable, even expected, certainly innocuous, but in Ottoman studies the expression comes with a question mark and an exclamation point. Both in terms of the underlying principles and in terms of actual practice there were supposed to be no Turks in the Ottoman palace, except in special circumstances. But from the late sixteenth century, as critics put it, Turks and Kurds and other riffraff penetrated the palace and so caused the deterioration of the venerable institution of the imperial household. ${ }^{1}$

Any royal palace might be cosmopolitan to a certain degree but in Europe, except perhaps in the multi-ethnic Habsburg capitals, Madrid and Vienna, the main national element in a given polity would constitute the largest ethnic component in the royal establishment. In Islamic polities the reverse was true. Caliphs and sultans preferred to distance themselves from the main ethnic groups in society by developing household troops composed of outsiders. Furthermore, these outsiders were imported as enslaved, deracinated warriors owing sole loyalty to their masters: the perfect troops for dynastic empires. Slavs, Turks, Franks, pagan or Christian but always non-Muslim for they were slaves, were then trained to develop their supposed "innate" warlike qualities inherited from life in the Eurasian steppe, and served caliphs as highest commanders and loyal troops. They lived apart from the people as an elite corps with distinct dress, languages and customs. ${ }^{2}$ In time some such mamluk slave-turned-commanders wielded

* I thank Collegium Budapest Institute for Advanced Study for a period of Fellowship in Spring 2008 which facilitated the writing of this article.

1 The most forceful statement on this is to be found in the work of Mustafa Âlî: see especially Cornell Fleischer, Bureaucrat and Intellectual in the Ottoman Empire: the Historian Mustafa Ali, 1541-1600 (Princeton 1986) pp. 156-157.

${ }^{2}$ For the early development of the mamluk phenomenon see, for example, Patricia Crone, Slaves on Horses: the Evolution of the Islamic Polit (Cambridge 1980). 
great political as well as military power and sometimes established their own dynastic states. Slave soldiers even established sultanates by acclamation rather than on dynastic lines, as in the Mamluk Sultanate of Egypt and Syria and the Delhi Sultanate, a similar one in northern India, coming into being at about the same time in the thirteenth century. ${ }^{3}$

In addition to this model of Islamic empires, there was also a feature of tribal life in the Eurasian steppe in the background of Ottoman royal household building. This is the institution of nöker, companions of the chieftain, a group made up of individuals cut off from their original tribes and adopted into a new tribe through joining the chieftain's retinue. ${ }^{4}$ Later narrative accounts of the early, heroic but blurred Ottoman times mention Osman Bey the eponymous founder of the dynasty, though at first a very modest frontier chieftain, having a few mamluk-style slaves, $k u l$ in Turkish, among his own men and some nökers as well. As his successors enlarged their retinues, "outsiders" or "strangers" (gurebâ) was the name of one of the sections of the household cavalry, implying the continuation of the nöker-like phenomenon while a majority of household members were of kul origin.

As it fully developed, the Ottoman system of administering the realm was based on the distribution of livings (dirlik) so that the recipients could maintain proportionate official households ( $k a p \imath$ ). All sources of revenue, urban and rural, taxes, dues, fines and fees, were given out as revenue grants. The recipient of a rural revenue grant was expected to live at the source of his revenues, usually a village. Most of such rural revenue would consist of land rent for the peasant families and share of their crop, but there were also fees and fines collected in the course of keeping the peace and punishing crimes and misdemeanours. Thus the revenue grant-holder was the administrator of his area as well as serving in campaigns as a fully armed and equipped cavalryman. A revenue grant-holder of higher level of income was required to maintain out of his revenues a fully armed retainer for each multiple of the minimum allocated. A provincial official might have a dozen or so men in his retinue, a district governor bey a hundred or so, and

${ }^{3}$ See Peter Jackson, The Delhi Sultanate: A Political and Military History (Cambridge 1999); David Ayalon, Islam and the Abode of War: Military Slaves and Islamic Adversaries (Aldershot 1994).

${ }^{4}$ Halil İnalcık, 'The Question of the Emergence of the Ottoman State', International Journal of Turkish Studies II (1980) pp. 71-79. 
a governor-general pasha several hundred. The vezirs of the imperial council had revenues sufficient for thousands in their households, and the sultan's own revenue sources paid for tens of thousands. ${ }^{5}$

In addition to its magnitude the imperial household differed from others in two qualitative ways, one having to do with firearms and the other with the method of recruitment. The imperial household was supposed to have a monopoly on the use of gunpowder and firearms, only partly to be explained on the basis of the traditional royal prerogative of controlling all mining. Copper and iron mines, used in casting cannon, were included in royal revenue sources, and only the magnitude of royal revenues might be sufficient for cannon foundries and large-scale gunpowder production. But in small arms, too, the royal household jealously maintained a monopoly. ${ }^{6}$

The second distinguishing quality, a peculiar method of recruitment, is harder to explain. In all other Islamic polities, whether forerunners or contemporaries of the Ottomans, the mamluk or kul militaryadministrative slaves of the ruler had to be imported from pagan or at least non-Muslim areas. Slavic and Turkic peoples of the Eurasian steppe were the most common source in addition to captives in wars against Byzantium or the Franks, on land and at sea. Non-Muslims living within the boundaries of a Muslim political entity had the status of protected zimmi non-believers. They paid an extra jizye tax per adult male, or a lump-sum haraj tribute for the community as a whole, and in return they had rights as subjects of the ruler. They might even be exempted from certain taxation if they provided public services, individually or as a community, such as supplying food delicacies to the palace or being charged with the safety and protection of public highways, passes, and bridges. The Mamluk Sultanate of Egypt and Syria, for example, went to great lengths to ensure a steady supply of mamluk warriors from among the Qipchak Turks north of the Black Sea and from the Circassians in the northern Caucasus because their realm did not have a border against infidels except at sea, in the Mediterranean, and naval warfare was never their strong suit. The peculiar

\footnotetext{
${ }^{5}$ See n. 22 below.

${ }^{6}$ The ruler's monopoly broke down in the late sixteenth century not because of competition from other households but because muskets became readily available in large numbers to commoners who then served as seasonal or occasional mercenaries in all households (see $n$. 35 below).
} 
practice of Ottoman $\mathrm{kul}$ recruitment was collecting boys from among the sultan's own zimmi non-Muslim subjects.

How did this practice, known as devshirme come about? Earlier writers suggested a link with conquest and removal of young local aristocrats for palace service but that is a very different phenomenon. ${ }^{7}$ The best explanation so far is that in fact devshirme started in a frontier zone where a region open to raiding was in the process of becoming conquered territory. Most often a conquest is accomplished at a certain moment in time but on the frontier conditions could differ: a village may be raided, it may then submit, it may revert to an earlier status. It seems that frontier lords under loose Ottoman authority may have started devshirme in areas that had already submitted to them, as if they were still raiding such lands. ${ }^{8}$ Need for manpower, especially at times when the flow of volunteers to the frontier was cut at the Dardanelles crossing by enemy ships, may have lead to devshirme from areas no longer resisting. Admittedly this is speculation which will have to serve as a working hypothesis for the time being.

\section{Training to Create a New Person}

Whatever its true origins, devshirme was a much more effective way of recruitment than simply grabbing human booty during a raid because it provided an element of choosing: this is probably why it became a royal prerogative. ${ }^{9}$ Later accounts, after it had become regularized and institutionalized, talk of the devshirme process of palace officials arriving at a village and reviewing all the boys between the ages of 10 and 15 or so, young enough to be remoulded and old enough to be marched away from their homelands. The palace officer in charge would look the boys in the eye to see sparks of intelligence and honesty, for the belief was that inner qualities would be reflected in one's visage, as well as for more obvious signs of robust constitution. One in 40 boys in a given area were to be taken, not more than one from the same family, certainly not an only son. A few thousand "chosen"

${ }^{7}$ Speros Vryonis, 'Isidore Glabas and the Turkish devshirme', Speculum 31, 3 (1956) pp. 433-443.

${ }^{8}$ Vassilis Demetriades, 'Some Thoughts on the Origin of the devshirme', in: The Ottoman Emirate (1300-1389), Elizabeth Zachariadou, ed. (Rethymnon 1993).

${ }^{9}$ V.L. Menage, 'Devshirme', EI2, vol. 2, p. 210. And Menage, 'Some Notes on the Devshirme', Bulletin of the School of Oriental and African Studies 29 (1966) pp. 64-78. 
or hand-picked boys were than marched towards the capital. Further groupings were made: some were sent to royal establishments in Edirne (Adrianople) and Gelibolu (Gallipoli); of those arriving in Istanbul some were assigned to a secondary training centre in Pera. The select few, numbering several score, finally arrived at the Topkapi imperial palace. Along the way they became Muslims and were given new Muslim names. They all shared the common patronymic Abdullah, literally servant of God.

The newcomers were assigned to two halls in the innermost courtyard of the palace known as the Big Chamber and the Little Chamber simply for their size. These two chambers were for basic instruction under the general supervision of the white eunuchs (as opposed to the black eunuchs of the Harem, the women's quarters). After a few years of book learning from invited tutors and physical training by the white eunuchs the palace pages moved on to chambers where further study and training was combined with practical service to the sultan. Names of these chambers, lining the third court, reflect the kind of service: those in the Pantry Hall helped in the bringing and distributing of food from the palace kitchens; the Campaign Hall pages were involved in wardrobe, linen, and laundry duty as well as packing for campaigns and hunting excursions; the more senior pages in the Treasury Chamber served in preserving and securing valuables, cloth, books, and jewels. The highest and most senior group was in the Privy Chamber in charge of the Inner Sanctum of Holy Relics (of the Prophet and earliest caliphs); the two most senior pages served as the sultan's sword-bearer and cloak-bearer. During their time in the Inner Service (enderûn) the pages were always under the supervision of the white eunuch officers who directed their education, training, and practical service.

Then came graduation, chikma, literally "leaving", the first of a series. From the third (inner) court some of the enderun pages moved out through the Gate of Felicity to the second and first courts for Outer Service (bîrûn). One should not envisage a "palace school" although it has been called that; not all pages moved from level to level and on to graduation. ${ }^{10}$ A page could be asked to leave when he was deemed to

${ }^{10}$ Barnette Miller, The Palace School of Muhammad the Conqueror (Cambridge, Mass. 1941). The most comprehensive studies of the palace and imperial household remain the works of İsmail Hakkı Uzunçarşıll, Kapıkulu Ocakları [Household Troops] (Ankara 1943) and Osmanlı Saray Teşkilâtı [Ottoman Palace Organisation] (Ankara 1945). 


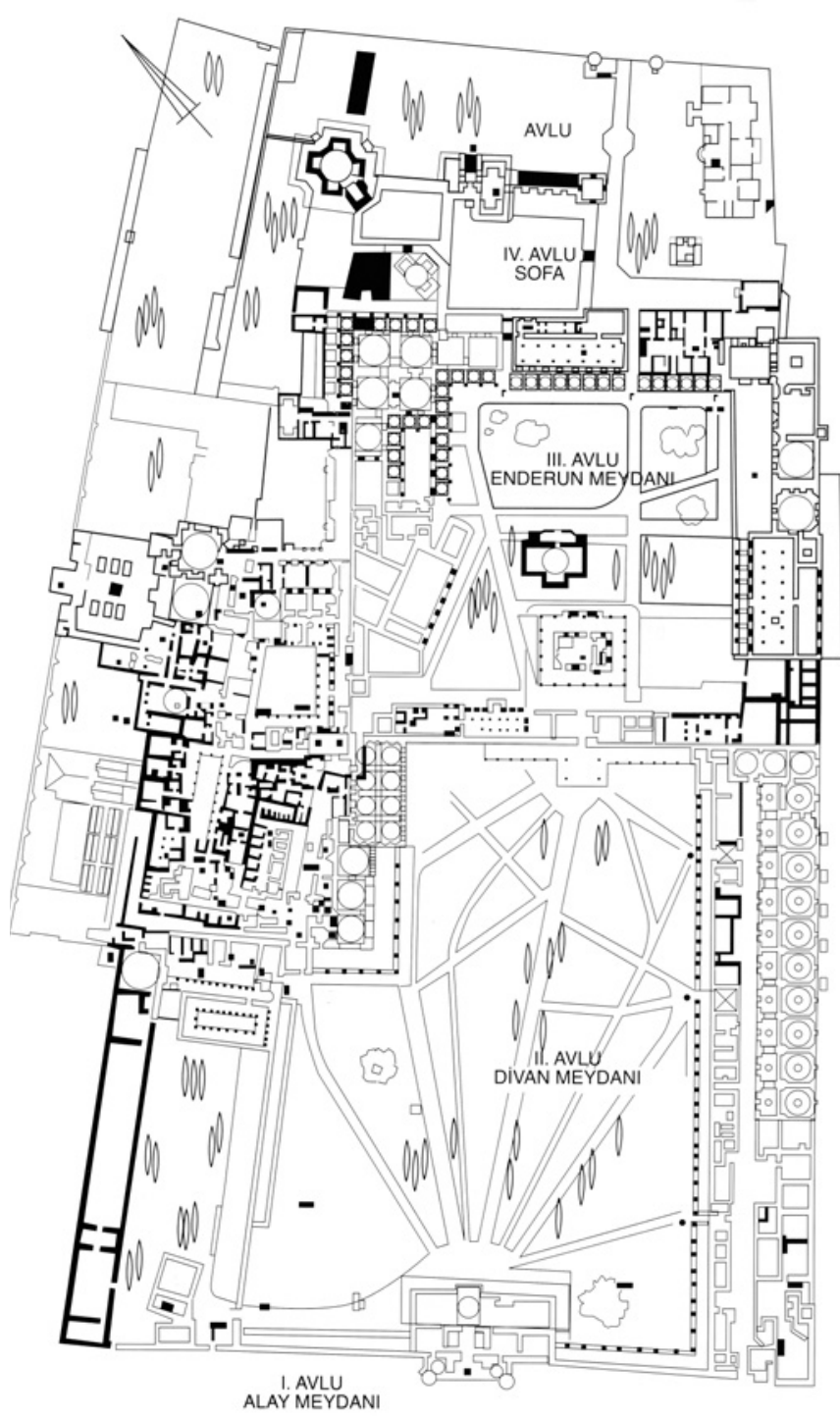

II: Second, outer court (bîrûn), including the Chamber of the Imperial Council with the Imperial Treasury right next to it on the upper left (NW corner) and kitchens along the right $(\mathrm{E})$.

III: Third, inner court (enderûn). Facing the gate between the outer and inner courts is the Audience Chamber, with halls for the pages along the sides of the court.

The women's harem, a 16th century addition, straddles the two courts on the West side. The Fourth Court (IV) is gardens with pavillions added in the 17th c.

Simplified from Deniz Esemenli, Osmanlı Sarayı ve Dolmabahçe, (İstanbul, Homer Kitabevi 2003); by kind permission of author and publisher.

Figure 1. This map shows the main parts of the Topkapı Palace, leaving out the first, public, court (I). 
have reached the end of his capacity for learning or for personal service to the sultan or when he himself preferred to. Some left, or "graduated" after the course in the Big and Little chambers, others after a few years of service in the Pantry, Campaign, or Treasury chambers. They took up salaried active offices in the Outer Service, their ranks depending on how long they had stayed in the enderûn. There they served as gatekeepers or groundsmen, supervising the kitchens or the stables or the tentsmen and bannersmen (including the mehter marching band), as message runners, or special guardsmen; most joined the six sipâhi elite household cavalry regiments and a few might even be assigned as officers to the various divisions of lower-ranking household troops, infantry, armourers, artillerymen, etc., which were all made up of kul recruits less privileged than the enderûn pages. Some pages of a bookish disposition might receive an appointment in the palace scribal service, chancery or treasury; those with an artistic bent developed their talents and crafts in palace studios and workshops as painters, calligraphers, gold- and silversmiths. At least in the sixteenth century there was no clear-cut distinction between the learned or artistic individuals and those with military qualities; those who wielded the pen or the painter's brush would be expected to be adept with the sword as well, as we know from numerous examples of household cavalrymen or gatekeepers co-opted to book production (one even from the artillery corps) and, conversely, scribes ultimately getting provincial administrative office.

Outer Service officers may have had high rank but essentially they were still in service to their master the sultan directly and were paid by him in salary and expenses. A second graduation or leaving was for independent office with an independent source of income, a "living", a revenue grant; this was when they really started their career ladder. This time palace people left through the Imperial Gate for the outside world. In the sixteenth century a palace officer might hope to gain a provincial post below a district governor but certainly superior to and sometimes supervising basic revenue grant-holders. Ordinary household troopers, too, hoped to receive a provincial revenue grant, but their "living" would be at a much lower level. A few of white eunuchs who had been supervisors and tutors in the enderûn might also leave at this point, directly gaining higher provincial office, commensurate with the length of their service. Not much is known about how these supervisor eunuchs were recruited. Judging by the fact that the Chief White Eunuch was the head of the Inner Service 
and thus the highest ranking palace official, furthermore that some at least attained the highest offices in the realm, even-almost routinelybecame grand vezirs, they may have been ordinary devshirme recruits who volunteered for castration to prolong their palace careers and to obtain provincial office at the highest possible rank. ${ }^{11}$ We now know that Gazanfer Agha, perhaps the most illustrious Chief White Eunuch who, however, never held outside office was a Venetian; he underwent castration to enter palace service where he rose to become one of the most important figures in the politics of his time. ${ }^{12}$

Palace service, then, prepared the kul recruits for provincial office where they joined others from a purely provincial background, some of them indeed of Turkish stock. Theirs was a military-administrative career; they were now ümerâ commanders. ${ }^{13}$ They were expected to work as administrators alongside and cooperating with kâd $\imath$ magistrates from a different educational background, the madrasa colleges, and who had an entirely different career line as ulemâ men of learning (of theology and law). By the rationale of their career the ümerâ officers were also soldiers; at campaign times they mobilized the revenue grant-holders of each district under its banner and joined the sultan's campaign, paying for their own expenses out of their "living". Those ümerâ who distinguished themselves in the provinces and on campaign became district governors; about twenty out of 200 or so sancakbeyi district governors were later promoted to the rank of pasha and served as province governors. A handful of the most distinguished province governors were invited to join the Imperial Council which met at its hall in the Second Court of Topkapı Palace. Although there were Turkish ümerâ and other revenue grant-holders in provincial administration some of whom rose to district governor, in the sixteenth century almost all the pashas and the vezirs of the Imperial Council were of $k u l$ origin and had been trained at the palace. Those

${ }^{11}$ White eunuchs (hadim) who eventually held high office are too numerous to mention but those who became grand vezirs in the sixteenth century are Hadım Ali Pasha, a Bosnian, grand vezir in 1501-1503 and also 1506-1511; Hadım Sinan Pasha, a Bosnian, gv in 1515 and also 1516-1517; Hadım Süleyman Pasha, origin unknown, gv in 1541-1544; Hadım Mesih Mehmet Pasha, origin unknown, gv in 1585-1586; Hadım Hasan Pasha, origin unknown, gv in 1597-1598.

${ }^{12}$ Maria Pia Pedani, 'Safiye's Household and Venetian Diplomacy', Turcica 32 (2000) pp. 9-32.

${ }^{13}$ I. Metin Kunt, The Sultan's Servants: The Transformation of Ottoman Provincial Government, 1550-1650 (New York 1983) chaps. 3 and 4. 
few who became vezirs thus returned to the familiar surroundings of Topkap 1 for council meetings in the Second Court after an absence of perhaps 15 or 20 years.

\section{From the Father's House to the Son's Household}

Palace service, both in the Inner and Outer Courts, had a special ethos. The concentration of such large numbers of men in the confines of Topkap1 required that pages, servitors and troopers behave with decorum, respect, and above all maintain an almost monastic silence..$^{14}$ Etiquette aside, the most important fact about the palace was that people there spoke many different languages. In this veritable Tower of Babel Turkish was the common language but people's original tongues, no less than their original names and family backgrounds were never forgotten. In his conversion from peasant boy to enderûn page a Petro son of Dimitri may have become Davud bin Abdullah but this happened at an age when his mother tongue was already firmly a part of his person. As at any public school nicknames abounded, some of which, Apostol and Vasil for example, alluded to the "previous" person. ${ }^{15}$ Nicknames were particularly useful in the palace because in their refashioning there seems to have been a limited store of names. There were Muslim names: Mehmed, Mustafa, Ali being the most common. Another source was the Bible or, more correctly the Muslim form of Old Testament names: Davud (David), Yahya (John), and of course Süleyman (Solomon). The Iranian Shahname was another source of inspiration with Iskender (Alexander) and the great heroes Rüstem and Behram. To distinguish the various Mehmeds at any one time some were "the tall", some were "the blond", some "the ox" (was he particularly strong or dense? one wonders).

These new Mehmeds and Davuds and Iskenders were now all Muslims, some no doubt very devout, but their Islam could be peculiar to them. In the seventeenth century there was word of a group of

\footnotetext{
${ }^{14}$ Alan Fisher and Carol Garrett Fisher, 'Topkap1 Sarayı in the mid-Seventeenth Century, Bobovi's Account', Archivum Ottomanicum 12 (1987) pp. 5-81.

${ }^{15}$ For example Mahmud/Apostol, pp. 220-221, and Halil/Vasil, p. 265, both Janissary commanders, in Selâniki Mustafa, Tarih [History], Mehmed İpşirli, ed. and transcription (İstanbul 1988).
} 
hub-mesîhi Christ-lovers in the Inner Palace. ${ }^{16}$ Most pages went on to serve in the six prestigious cavalry regiments; for the general lowerranking household troops dervishes of the Bektâshi order served as chaplains. This sûfi mystic devotional order takes its name from an Anatolian sheyh of a much earlier age but as an order it was the recent coalescence of various syncretic movements. ${ }^{17}$ Like the Shi'is the Bektâshi venerated Ali but some of their beliefs and symbolism call to mind a trinity (of God-Muhammad-Ali) with twelve being a special number and the dove a special creature. Their rituals included partaking of wine (in various quantities). This was an ideal religious outlook, then, for a new Muslim, a convert from Christianity. Bektâshism was of course strong in Anatolia, its birthplace, but it grew even stronger as it spread in the Balkans, especially Albania, and into Hungary, wherever there was large-scale conversion to Islam. As opposed to Bektâshism, if the enderûn page and by extension a sipâhi of the six cavalry regiments was of a siff bent he would most likely become a Mevlevi, a relatively urban and sophisticated order much involved in musical and literary arts, also noted for its tolerant view of religiosity.

Belonging to a particular order may have strengthened their new identity, but as in any confined institution of people there was cliquishness as well. ${ }^{18}$ Groups were naturally formed along linguistic or ethnic lines and included more senior and incoming pages as well as their connections in the Outer Service. One of the most fascinating documents I ever came across in the Topkapi Palace Archives is a short little note, undated (but of the sixteenth century) and unsigned, reporting the information supplied by another. ${ }^{19}$ It simply says that in a particular village in Bosnia there is a particular family with three sons and the youngest son is very bright. The inevitable conclusion, to my mind, is that somebody (a white eunuch supervisor?) asked enderûn pages about their own villages and for recommendations for devshirme

\footnotetext{
${ }^{16}$ Ahmet Yaşar Ocak, Osmanlı Toplumunda Zındıklar ve Mülhidler [Atheists and Miscreants in Ottoman Society] (İstanbul 1998) pp. 228-230.

17 Ahmet Karamustafa, God's Unruly Friends (Salt Lake City 1994); also 'Kalenders, Abdals, Hayderîs: The Formation of the Bektashiye in the Sixteenth Century', in: Süleyman the Second and His Time, Halil İnalcak and Cemal Kafadar, eds. (İstanbul 1993).

${ }^{18}$ Metin Kunt, 'Ethnic-Regional (cins) Solidarity in the Seventeenth-Century Ottoman Establishment', International Journal of Middle East Studies 5, 3 (1974) pp. 233-239.

19 Topkapi Palace Archives, E.9607.
} 
recruitment. Was this recommendation acted upon? Impossible to know, but the important thing is that the question was asked at all and a reply given. Alongside such informal groupings based on ethnicity or educational bent or religiosity it is astonishing that there were high palace officials who had their own kul in the palace. I have in mind a Cafer Agha, Chief White Eunuch, the Director of the Inner Service, who left behind at his death in the mid-sixteenth century, among other property, a group of owned slaves some of whom were in the palace. This we know because the sultan inherited Cafer Agha's property (as, obviously, he died without issue) and decreed that the rest of Cafer Agha's kul should be also incorporated into palace service. The curious conclusion is that not all in the palace were the sultan's own slaves; some owed direct loyalty to another master. ${ }^{20}$

Such connections formed while at the palace, formal or informal, may have played a role in the chikma graduation movement, helping determine who got what posting. Graduation occurred at irregular intervals; Outer Service officers and troopers went off to the provinces, Inner Service pages took up postings in the Outer Service, new recruits were brought in both to the enderun and to the various bodies of household troops. Some of these occasions were termed "lesser" graduations when relatively few people moved on but at "greater" chikma thousands of people may have been involved. Such was the case especially at the death of a sultan and the enthronement of one of his sons. This was true in the fifteenth and sixteenth centuries when princes were traditionally sent out of their father's palace as district governors; whoever survived the struggle for the throne returned to the capital in triumph. ${ }^{21}$ From the turn of the seventeenth century this custom was allowed to lie fallow but enthronement still entailed graduation for the coming of a new sultan, whether from the provinces or emerging from the shadows in the palace itself, meant the taking over of the palace, making his father's people his own. For this purpose the new sultan gave out the traditional "accession gratuity" to his palace servants, and promotions and salary increases to many independent

${ }^{20}$ Ottoman Archives, KK 4990. I analyzed this list in 'Kulların Kulları' [Slaves of Slaves], Bosporus University Journal-Humanities 3 (1975) pp. 27-42.

${ }^{21}$ This is not the place to go into a discussion of Ottoman succession; suffice it to say that there was no method of succession, no seniority, not even a pre-designated heir, except that succession was from father to one of his sons (and not to any other member of the family), the one who had the political and military nous to defeat the others if it came to that. 
office- and revenue grant-holders. In one sense the new sultan started things anew although in another he took pride in being the scion of an illustrious dynasty: he was a new link in the dynastic chain, a basic element in his legitimation as ruler.

An Ottoman prince grew up in his father's house and, before he was confined to the palace from around 1600, went out to a provincial posting, usually upon puberty and after being circumcised, when he took his first steps to adulthood. ${ }^{22} \mathrm{He}$ was now a district governor, a sancakbeyi, one of perhaps two or three hundred such ümerâ commanders, but the revenues assigned to him could be more than given a grand vezir. While a vezir might keep a household of one thousand men or more, a prince-governor's household was much more modest. At his "graduation" from the palace his father the sultan gave the prince his initial household out of the imperial palace; the occasion was not really a graduation for the palace people assigned to the prince, on the contrary they might feel that they were demoted from the secure existence of the palace to an unsure future with one of the princes. But in any case the people were imperial property, so to speak. If "their" prince eventually won the throne struggle they would come back to Topkapı in his retinue. Even if he lost they would not be punished unless they were in the prince's inner circle; they would be taken back into the imperial fold. The numbers involved were not even close: there were tens of thousands attached to Topkap1 whereas the prince's initial household numbered around five hundred. ${ }^{23}$ The political advisors assigned to the prince were high-ranking pashas; being with a prince for a number of years was but one step in their career ladder although there might develop covert alliances between certain pashas and particular princes.

Up to this point I have been talking in generalities, presenting a somewhat idealized picture, routines rather than rough edges; it is now time to become more specific and explain the problem of "Turks in the Imperial Palace!". I have in mind two instances of change of sultan:

${ }^{22}$ Metin Kunt, 'A Prince Goes Forth (Perchance to Return)', Identity and Identity Formation in the Ottoman World, Karl Barbir and Baki Tezcan, eds. (Madison Wis. 2007) pp. 63-71.

${ }^{23}$ For an estimate of around 36,000 in and attached to the imperial palace in the mid-sixteenth century: Halil İnalcik, The Ottoman Empire: The Classical Age, 13001600 (London 1973), (several hundred in the Inner Service and the rest in Outer Service and in various regiments of household troops), pp. 80-83; for Prince Mehmed's household of less than 500 in 1541: Topkapı Palace Archives, D.9706/3. 
the accession of Selim II on Sultan Süleyman's death in 1566 and the accession of Murad III in 1574 on Selim's death only eight years later. Selim's accession took place under very unusual circumstances because his aged father died on campaign in faraway Hungary, besieging the obscure but problematic stronghold Szigetvar, and this story is wellknown. The second aspect of Selim's unusual accession has to do with his inordinately large princely household and how "graduation" and "integration" were handled. Murad's accession eight years later was routine by comparison. Both events are well-documented, in extensive narratives for 1566 and in a unique document for 1574 which details the prince's household and how exactly it was to be integrated into Topkapi. Both stories are extremely important for trying to answer basic questions: how did the Ottomans conceive their political structure? What was their idea of the "state"? Was there an evolution of state institutions aside from the instruments of the dynastic state?

\section{Accession of Selim II}

Sultan Süleyman had five sons, two of whom died of natural causes. ${ }^{24}$ The sultan had his oldest son executed in 1553 when he became suspicious that Prince Mustafa might have designs on the sultanate. Five years later the younger of the two remaining princes, Bayezid, feared that his older brother Selim was more advantageously positioned in his provincial posting for a quick dash to Istanbul at the death of Süleyman, now well-advanced in years and suffering from gout and possibly other infirmities. The father tried to reassure Bayezid of his impartiality but the prince, his fears unallayed, started to recruit an army for a show-down with Prince Selim to pre-empt the issue of succession. Suleyman had no choice but to support Selim against Bayezid, by now considered a rebel. Prince Selim, too, recruited Anatolian peasants for an army; bolstered by imperial troops and able commanders seconded to his service he defeated the rebel prince. Bayezid sought refuge with the Safavi Shah Tahmasb but having recently concluded a peace the two rival empires were on relatively amicable terms and Shah Tahmasb eventually had the rebel prince and his sons killed (for which he gained the gratitude of and substantial gratuity from both

\footnotetext{
${ }^{24}$ Alan Fisher, 'Süleyman and his Sons', in: Soliman le Magnifique et son temps, Gilles Veinstein, ed. (Paris 1992) pp. 89-104.
} 
Sultan Süleyman and the surviving prince) ${ }^{25}$ Prince Selim the lone survivor now just had to sit comfortably and wait for life to continue on its course.

Süleyman's death may have been long-anticipated but it finally came eight years later when at age 72 and infirm he went on his last campaign in Hungary. ${ }^{26}$ His troops were about to conquer the frontier stronghold Szigetvar when he died. How Prince Selim succeeded to the throne and how he was enthroned twice, once in Istanbul where he hurried upon receiving the news of his father's death and once outside of Belgrade where he eventually took over the imperial household, is an interesting and illuminating story I studied elsewhere for the clues it provides to understanding the Ottoman political order. For my present purpose the more relevant aspect of Selim's accession is the uncertainties surrounding the general palace chikma graduation occasioned by the coming of the new sultan and the integration of the prince's household into the imperial palace. This process would have been routine at any other time. As a prince in 1520 Sultan Süleyman himself had a total household, Inner and Outer, of several hundred, a small number compared to the thousands in the palace organization. The problem in 1566 was that Selim had a conscript army of about eight thousand formed eight years previously to fight his rebellious brother: how were they to be integrated into the system? What palace people and who of the prince's retinue were to receive which appointments?

A game of musical chairs (sofa cushions in the Ottoman context), a scramble for offices started as Selim was speeding from his provincial seat in Kütahya to Istanbul. ${ }^{27}$ On the way, the day after he learned of his father's death, some of his courtiers and princely retinue pleaded for imperial office; it is an indication of the elderly prince's perception of Ottoman ways that he responded with irritation that he hadn't even sat on the throne, that it was too soon to grant their requests, and that in the glorious past of his ancestors no service went unrewarded. There was friction when the prince and his small retinue reached the palace.

${ }^{25}$ Rhoads Murphey, 'Süleyman's Eastern Policy', in: Süleyman the Second and his Time, Halil İnalc1k and Cemal Kafadar, eds. (İstanbul 1993) pp. 229-248.

${ }^{26}$ The main contemporary and eyewitness Ottoman narratives of the events surrounding Sultan Süleyman's death are to be found in Feridun Bey, Nüzhetü'l-esrâri'lahbâr der sefer-i Sigetvar [The inside story of the Szigetvar campaign], Topkapı Palace Library, MS H.1339, an unabashed apologia for Sokollu Mehmed Pasha; and Selâniki Mustafa, Tarih, vol. 1, who wrote his history later in his life.

${ }^{27}$ Selâniki, Tarih, p. 41. 
The prince's equerry prepared his horse in the palace grounds for him to ride up from the shore but palace people wanted to take over. The equerry was not a "palace product", they objected: he wouldn't know how and where to lead the horse. It wasn't simply a question of knowing the palace grounds; it was also a matter of palace decorum. The prince asked the Chief Groundsman to show his equerry the way so that the officials had to co-operate, if grudgingly. ${ }^{28}$

When the prince eventually heeded the grand vezir's advice to go to meet the returning imperial army for the process of succession to be completed there was much more serious trouble at the camp outside of Belgrade. The janissaries noted that some of the prince's Anatolian conscripts accompanied him. Accession to the throne was the time for promotions, salary increases, and graduation to independent revenue grant: how was the prince going to accommodate both the imperial household and his Anatolian men? Worried that they might be shortchanged, since the new sultan made no explicit reference to their satisfaction, they raised their voices and listed their demands: campaign bonus as well as accession gratuity; they were especially incensed after hearing that these conscripts had already been housed in their barracks while in Istanbul. "That uncouth lot who accompanied the prince should not mingle with us or else we will kill them like dogs" is how Selâniki reports their words. ${ }^{29}$ There were fisticuffs and daggers were drawn; some Anatolians were killed. Sultan Selim in the end acceded to the financial demands of the household troops in order to be able to keep his promises to reward the recruits who helped to defeat his brother in 1558. But the troubles were not over: Selim's recruits were ex-peasants; provincial revenue-grant holders in the army recognized some of them among the sultan's men, some indeed now grant-holders themselves. They demanded peasant dues from such men as being their registered peasants. The sultan ruled that the revenue grants which suffered because of losing peasants should be compensated from revenues not previously registered; otherwise the ex-peasants were confirmed in their new appointments. He felt that he had to justify his action in the face of opposition, sullen as well as loud, by saying, as reported by Selâniki, that he was simply following his

28 Selâniki, Tarih, pp. 42-43.

29 Selâniki, Tarih, p. 51. 
father's orders in 1558 to form an army from Anatolian "horse-riding, weapon-handling" peasants just as his rebellious brother had done. ${ }^{30}$

In 1566 there were 12,000 janissaries at the Szigetvar campaign, according to Selâniki. ${ }^{31}$ As many as 2,000 had been sent on a different campaign at the other end of the empire, included in a task force to put down a rebellion in the marshlands near Basra. There were also janissaries stationed in some major cities. But Rhoads Murphey has concluded that at the end of Selim's reign eight years later there were more than 21,000 janissaries. ${ }^{32}$ Most of the huge increase in janissary numbers came from the incorporation of peasant recruits from the princely army. According to Murphey's numbers, the total pay to janissaries increased from about 20 million akches in 1547 to about 35 million in 1567. Even taking into consideration a possible limited increase between 1547 and the end of Süleyman's reign, the burden to the sultan's treasury was increased by about half. But the problem was not only financial for there were also considerations of "proper" recruitment into the imperial palace. Selâniki notes that the palace personnel given to a prince when he first went out to provincial office normally returned to positions in the palace when their prince succeeded. In Selim's case, the historian adds, 350 men went out of the palace but 8,000 loutish, unschooled men came to Istanbul with him, many of them no better than thugs (I soften the historian's words, he says "common criminals and murderers"). ${ }^{33}$ The epithets used by each group about the other point to a vast gap in service ethos and group solidarity. But two senior commanders of household troops and several troopers were executed when first they remonstrated too vociferously with the grand vezir about the "Anatolians" coming into the palace guard, their protests leading to mutinous disorder.

In the palace itself, the Campaign Hall was emptied and pages from other Halls too were "graduated" for Kütahya pages to come to Topkapi. As for senior officials, some of Süleyman's leading servitors were given the option of sinecures and retirement to make room for men from the princely court. These men, according to older palace officers, were not the products of the palace itself and were therefore deficient in their understanding of the palace ways. "Outsiders" is the

${ }^{30}$ Selâniki, Tarih, pp. 56-57.

${ }^{31}$ Selâniki, Tarih, p. 51.

${ }^{32}$ Rhoads Murphey, Ottoman Warfare (London 1999) pp. 42-44.

${ }^{33}$ Selâniki, Tarih, p. 58. 
least they were called. ${ }^{34}$ In higher echelons, too, there was a conception of the "proper" way of doing things, of recruitment into household troops. There was also a generally acknowledged principle at work, that "subjects should remain subjects" and not switch to the ruling group, not least because it would lead to diminishing of subject dues. It was certainly not impossible for the son of a subject to gain his way into the military-administrative elite; social mobility was not totally stifled, but there were accepted ways of doing this. A Muslim Turk could go to the madrasa colleges and eventually become a $k a \hat{a} d \imath$ magistrate; native wits and patronage would help. Or, if his bent was military rather than bookish as was likely, he could attend imperial campaigns when it was announced that any young volunteer would be rewarded for valiant service. Normally his reward would be a revenue grant but never inclusion into the imperial household.

It would be in order to ask whether the decision in 1566 to include Anatolian peasant-mercenaries in the imperial household could have been based on military considerations. To support this view we may recall that the Habsburg ambassador Busbecq reported that as early as the 1550s the grand vezir Rüstem Pasha tried to train the household cavalry in the use of muskets..$^{35}$ Although the Ottoman military ethos was not nearly as conservative as that found in the main Mamluk and Safavi armies, firearms were still looked down upon. In the event the cavalry, a superior corps, rejected musket training (the whole gunpowder business was too dirty and unseemly), and the idea was dropped. If there was a perceived military need for a musket-bearing cavalry force and the household cavalry refused to adopt to changing needs, why did Selim justify himself by referring to his father's orders eight years previously? Could he not have formed the Anatolian mercenaries into a separate and special troop?

The interesting thing is that there was still an Anatolian military organization, first formed in the mid-fourteenth century, at a level below the revenue-grant holding provincial cavalry. They were not supported by taxes and fees collected from the peasants but held land and were tax-exempt; essentially they were privileged farmers, considering military service as a privilege in the Ottoman conception of

\footnotetext{
${ }^{34}$ Selâniki, Tarih, pp. 59-60.

35 C.T. Forster and F.H. Blackburne Daniell, trans., The Life and Letters of Ogier Ghiselin de Busbecq I (London 1881) pp. 242-243.
} 
polity and society. Some of these farmer-soldiers were infantry and some cavalry. Before the Ottoman ruler formed and expanded his own retinue of janissary infantry and the household cavalry the peasant infantry (yaya) and cavalry (müsellem) had an important military function. This organization existed only in western Anatolia, the initial heartland; they were never installed in the Balkans where akıncı frontiersmen and non-Muslim martolos tax-exempt peasants performed a similar function. In the mid-sixteenth century the Anatolian yaya and müsellem still existed on paper as military groups but by then such auxiliary troops were in terminal decline, their effectiveness long eclipsed by household troops, both imperial and grandee retinues. Could such men have been assigned to Selim to fight his brother in 1558? When Selim referred to his father's ferman he quotes "your brother raised mercenary troops (yevmlü, lit."on a daily wage"), you should do the same and raise in your area yevmlü troops of horse-riding, weaponhandling peasants". Some peasants, then, good on horseback and with weapons' practice, were already deemed more effective as mercenary soldiers than the tax-exempt peasant-soldiers of yesteryear. Indeed, in the decades to come the revenue-grant holding provincial cavalry too declined to the status of auxiliary troops, though in typically conservative Ottoman fashion they were not abolished until well into the nineteenth century.

If the idea of household troops was to have a standing army which could be regularly trained in weaponry, effective musket-firing in ranks, and group maneuvers, and if, in addition to the janissary infantry there was need for a musket-bearing cavalry, would Selim's Anatolian mercenaries have served that purpose? Though muskets are not specified among the weapons they "handled" they are referred to as sekbân when they first came to Istanbul from Kütahya and were housed in the empty janissary barracks: the significance of the term is that it was used later for Anatolian mercenaries employed extensively during the long Habsburg and Safavi wars at the end of the century. ${ }^{36}$ On the other hand, horse-riding they might have been, but Selim's mercenaries were incorporated into the janissary corps and not into the elite cavalry regiments: that would have been unthinkable. Once in

${ }^{36}$ Selâniki, Tarih, p. 29 refers to "musket-bearing sekbân and hunters in grandee households" at Szigetvar; unless this is an anachronism or a case of his old-age memory failing the author, the employment of sekbân mercenaries must have been earlier than hitherto presumed. 
the janissary corps, though the regular janissaries gave them the cold shoulder to say the least, they never constituted a special unit and the need for musket-bearing cavalry was met by employing mercenaries seasonally and as needed by campaigns. All in all, my conclusion is that Selim did not act with any long-term military need in mind but simply kept his promise to the mercenaries who helped him defeat his brother and secure his eventual succession.

\section{Accession of Murad III}

More "outsiders" were to come just eight years later when Selim died and his son Murad succeeded to the throne. This time there was no crisis of numbers for Murad's court in Manisa employed about 1,800 men, a large number for a princely retinue but minor in comparison with Selim's recruit army. In this case a document was prepared for the attention of the new sultan listing all members of the Manisa retinue for the sultan to decide how they were to be placed. This whole process is interesting for it shows what principles were commonly accepted as "ancient law and usage". ${ }^{37}$

Five senior officers of the princely household were taken into the palace with pay increases but at lesser imperial ranks compared to their office in Manisa; some 35 lower officers were given revenue grants. The document goes on to list different sections in the household and for each section differentiates groups according to seniority of service to the prince during his 18 years as governor. The senior service, so to speak, was the cavalry, divided into four regiments bearing the same names as in the imperial household (where the last two were divided into right-hand and left-hand regiments, making six altogether), in order of prestige the sipâhi, the silahdâr, the ulûfeci, and the gurebâ. Each of the four regiments was considered in six groups in order of longevity in the prince's service: some since his first appointment as governor in 1558, some who graduated from the palace and had been sent to the prince's court, those who joined after the prince was transferred to Manisa in 1564, those taken into regiment sometime later, and finally those who were promoted to the regiment after the prince's succession but before the Manisa household was transferred

\footnotetext{
${ }^{37}$ Ottoman Archives, MAD 1324.
} 
to Istanbul. Further details would be interesting for Ottomanists and I may provide them elsewhere but here I will make some general observations. The top two groups in each regiment were incorporated into one lower imperial regiment, the rest to the next lower regiment: of the prince's sipâhi the top two became imperial silahdâr, the next two became imperial right-hand ulûfeci and the last two became lefthand uluffeci. This pattern is repeated for all the regiments until the last regiment, the gureba who joined the same imperial regiment. To give an indication of numbers involved, the prince's four regiments totaled 389 men (of whom, however, by far the largest was the top sipahi regiment with 230 men); they were included into the imperial regiments that totaled just under 6,000 . Some of them were given the option of a provincial revenue grant. All in all the incorporation of the Manisa court into the imperial palace was not a troublesome business, especially compared to the ugly situation in 1566. Unlike Selim's, Murad's retinue conformed to the pattern of a "normal" princely court, that is to say without any infantry, thus it did not present a problem for the janissaries. The superior standing of the imperial palace was acknowledged and affirmed once more and the relatively few men who came into the various imperial corps did not cause disruption, or at least none worthy of note in the histories.

There was a problem, however, of a different nature: there were a significant number of last-minute promotions into the prince's more senior regiments, and some people were even taken into the household after the prince's succession. At the imperial council the argument was put forth that upon succession the prince's accounts became part of the central imperial treasury, and therefore his chief of finance was out of order when he took on more people and authorized various other payments. The princely treasurer Kara Üveys was reprimanded but escaped further punishment, perhaps at Murad's request; sometime later Murad appointed him the imperial Chief of Finance, perhaps as part of his programme of reasserting arbitrary sultanic power over bureaucratic principles. ${ }^{38}$ Here, I think, we can detect an important political principle being established and observe that there was a government in the budding, an administrative institution separate from the will of the sultan. As with most Ottoman developments it is far

${ }^{38}$ Selâniki, Tarih, p. 112. 
from being unambiguous. What the grand vezir argued, with the concurrence of the rest of the imperial council, was the supremacy of the imperial household itself; yet, by extension, it was for the central ministers to administer the affairs of the palace. Indeed, one can make a strong case that especially from the later decades of Süleyman's reign, there was an evolution towards a government with established procedures where the sultan himself went along with usage-to-becomeancient-custom. For example the vezirs of the council were ranked from the first, the grand vezir, through the second down to the seventh. When the grand vezir died or was dismissed they all moved up one seat so the second vezir became the grand vezir. Usually the Governor of Rumeli was promoted to the council as the new seventh vezir, and the second most senior governor, of Anatolia, became the Governor of Rumeli. In a system which worked almost automatically, where was the will of the sultan? If he was sufficiently interested he could decide who should be the new Governor of Anatolia, usually on the recommendation of the grand vezir. In terms of policy-making, too, the sultan nominally had the last word but it was the grand vezir's vision that determined options and recommendations.

I have been speaking in general terms: there was also a specific grand vezir who took full advantage of the procedures and vezirial power that Süleyman had allowed to emerge, the last grand vezir of Süleyman, Sokollu Mehmed Pasha who went on to serve through Selim's reign and during Murad's first five years as well, for fourteen years altogether until his assassination in 1579. After that Murad asserted the arbitrary power of the ruler, as opposed to "established usage and custom", when he changed and promoted his vezirs at will, played them against each other and never allowed one to become paramount as Sokollu Mehmed Pasha had been. What Murad nipped in the bud was certainly not a constitutional development, perhaps not even an institutional one: Sokollu was not one to share vezirial power with the council willingly, the size of his own household and his extensive nepotism and patronage was legendary. Cemal Kafadar rightly recalls Cardinal Richelieu in this context, and not a "prime minister". Yet Sokollu's way would have led to ministers with departments and a restriction of the role of the palace; in any case it would have been a different development, but it's no use thinking about what did not happen. Ottoman writers themselves thought at the time that the "debasement" of palace procedures was a much more important point. 


\section{Toward a New Palace}

So in 1566 at Selim's accession Turks came into the imperial palace in large enough numbers that the way of the janissary was forever changed. This coincided with growing problems, financial, military, and political, which gathered momentum to reach a crisis point by the end of the sixteenth century. Ottomanists have long given up starting an inexorable Ottoman decline from then, a patently ludicrous notion given that the empire survived to the Great War in the twentieth century. The crisis, however, was real. Many Ottomans at the time wrote about what had gone wrong. Prominent among various reasons they cited was the deterioration of the imperial household. Looking back to the period it is clear that there developed a fierce competition for military and administrative appointments in the Ottoman system by the middle of the century. Already around 1540 Sultan Suleyman had to issue an edict on how revenue grants were to be assigned because those holding grants did not want any "outsiders" coming into their midst, expressions echoed during the janissary reaction of 1566 . The provincial cavalry wanted to keep the revenue grants in the family, for their sons to succeed them. Süleyman's ferman in response bears close scrutiny: in the preamble the sultan asks, "how can anybody within my domains be considered an outsider?" Whether revenue grantholders or members of households or plain subjects, you are all my $k u l$ servitors, he goes on to say. This is a significant broadening of the sense of "servitor" from his household servants to include all officeholders and subjects. The rest of the ferman is devoted to who among descendants of grant holders could be given livings, under what conditions and circumstances, keeping the group open to newcomers. ${ }^{39} \mathrm{~A}$ similar profusion of candidates for ulemâ judicial-educational offices was also experienced, with madrasa college students without hope of appointment spending longer periods as professional students at their endowment-supported colleges. Employment in households, too, was becoming hard to come by. Murad's list of his Manisa household members is replete with marginal comments on many of his officers, "taken into the household on the recommendation of thus and so". Ottoman subjects could certainly make a living outside the ulemâ and ümerâ careers, but having a foothold in a household would guarantee

\footnotetext{
${ }^{39}$ Kunt, The Sultan's Servants, p. 38.
} 
change of status from ordinary subject to member of the ruling elite with all the tax exemptions and other privileges it brought.

This was a social order where somebody with an appointment certificate was deemed to have higher status than the richest merchant. Lütfi Pasha, the grand vezir dismissed in disgrace who turned to scholarship in retirement, wrote in his history with approval that when the burghers of Bursa came in their holiday best to greet the sultan visiting their city, Süleyman was cross and told them such fineries should be for officials only, not merchants. ${ }^{40}$ The pressure for official employment inevitably reached the imperial palace itself. As in other grandee households, Topkapı started to admit free, Muslim-born youth on recommendation. Judging by the careers of some such Turks reaching high office in the early decades of the seventeenth century this practice must have already started in the sixteenth century. With so many candidates for household service devshirme was no longer needed. There were intermittent instances of it during the seventeenth century but more as a result of calls for a return to the good old days before the time of troubles, exceptions that prove the observation that it had been, in effect, abandoned.

It does not follow, however, that the palace turned Turkish. Certainly there were Turks trained and schooled in the Inner Court and in growing numbers. There were also many Albanians, Bosnians, Circassians, Abkhaz, Georgians, and some European captives or volunteers, but we no longer find the young sons of Christian subjects. The enderûn was not meant to be composed of the peoples of the empire; its purpose was not to create a mingling of the empire's ethnicities to be representative of its peoples, but simply to train officials loyal to the sultan. This it continued to do although its conditions were changed in more ways than one. Palace "pages" tended to spend longer in palace service; they were not young men but getting on in years. Because they tended to spend many years in the same Hall, solidarity based on service tended to strengthen. Informal groupings based on common origin or common interest, too, gave the place a certain "clubbishness" (if I can make up a word). When eventually they went out on graduation, a few senior "pages" got high office, typically directly as province governors, and many others formed their first official household based on

${ }^{40}$ Lütfi Pasha, Tevârih-i Âl-i Osman [History of the House of Osman] (İstanbul 1922) p. 382. 
connections and relationships formed during the long time spent in the palace. As the devshirme had not made a connection between the palace and the subjects, except incidentally, so the presence of Turks in the palace did not signify a "Turkification" of the empire. There may have been more Turkish-born among the household troops (not least because many were the sons of janissaries) and in the Inner Court, but it was still the "Domains of the House of Osman" and not the "Turkish Empire" as Europeans insisted on calling it. 


\title{
THE MUGHAL AUDIENCE HALL: A SOLOMONIC REVIVAL OF PERSEPOLIS IN THE FORM OF A MOSQUE ${ }^{1}$
}

\author{
Ebba Koch
}

\section{Shah Jahan's Court}

After Shah Jahan (rul. 1628-58), the fifth emperor of the Mughal dynasty, was enthroned on 8th Jumada al-Thani of the Hijri year 1037, corresponding to 14 February $1628 \mathrm{CE}$, he issued an order that halls for his public audiences should be constructed in all the great fortress palaces of the capitals of the Mughal empire. The audience hall was a new building type in the Mughal palace, of central importance for the proceedings of the Mughal court and for the interaction of the emperor with his subjects.

Under the rule of Shah Jahan, the Mughal empire entered its classical phase of greatest prosperity and stability. ${ }^{2}$ The conquests of Babur (1526), enlarged and consolidated under Akbar (rul. 1556-1605) and Jahangir (rul. 1605-1627), had established the Empire of the Great Moghul (or Mughal) as one of the three leading powers of the Islamic world, the other two being the Ottoman Empire and Safavid Persia. The informal set up of Babur as primus inter pares among his Central Asian followers, had-in particular through the efforts of Akbardeveloped into the court of an absolute ruler who, as head of a centralized state, personally and diligently oversaw the administration of

1 This paper is based on an earlier study of the audience halls of Shah Jahan with detailed references, see Ebba Koch, 'Diwan-i 'Amm and Chihil Sutun: The Audience Halls of Shah Jahan', Muqarnas 11 (1994) pp. 143-165; available in the internet under $<$ http://www.archnet.org/library/documents/one-document.tcl?document_id=3696>. In the present reassessment I have put the halls into the context of Shah Jahan's court, condensed the argument and added new references as well as several new observations, especially in regard to the connection of audience hall and mosque.

${ }^{2}$ For this and the following see Ebba Koch, 'The Hierarchical Principles of ShahJahani Painting', in: Milo C. Beach and Ebba Koch, King of the World: The Padshahnama: An Imperial Mughal Manuscript from the Royal Library, Windsor Castle, Wheeler Thackston, trans. (London; Washington, D.C. 1997) pp. 130-143, with further references; Ebba Koch, Mughal Art and Imperial Ideology: Collected Essays (New Delhi 2001) pp. 130-162. 
his vast empire, supported by his amirs and mansabdars, the militarily structured ruling elite. Distinction in the hierarchy of the bureaucratic apparatus had to be acquired through personal achievement, as acknowledged by the emperor; even the succession to the throne was not regulated by primogeniture. This fused the ruling classwhose members belonged to diverse ethnic and religious communities reflecting the heterogeneous components of the empire-into a coherent administrative body which, by the time of Shah Jahan, depended entirely on the emperor. This was particularly true of the Muslim nobles. The indigenous Rajput chieftains, when incorporated into Mughal service, were able to retain some of their independence, such as the hold over their ancestral dominions. Since the imperial authority represented the main guaranty for the functioning of the hybrid political system, the emperor's appeal to a purely personal loyalty depended largely on his personal charisma which was supported and magnified by the myth created for his kingship. Here the Mughals drew with their own disarming lack of inhibition on all the notions of kingship they could lay their hands on and which they deemed suitable to be put into the service of their cause. These included Muslim caliphal, Qur'anic prophetic and Sufi; Achaemenian and Sasanian Persian, and Perso-Islamic; Turko-Mongolian; Hindu and Islamic Indian; Christian-Messianic and recent European concepts of universal monarchy. Within this eclectic array each ruler set his own accent.

\section{Court Ceremonial and its Buildings}

The hierarchic relationship between Shah Jahan and his subjects was confirmed and acted out symbolically in a rigid court ceremonial, focusing on the emperor, which was repeated daily. Hand in hand with the regulation of every detail of court life went an ever-increasing formalization of the court arts which were represented as a necessary instrument of rule. The ruler who exerted himself in the sphere of artistic representation was sure of the loyalty, obedience and recognition of his subjects, as well as of the esteem of his rival rulers. This is put into words by the historian Muhammad Salih Kanbo in one of the rare self-reflective passages which tell us how the purpose of pomp and show was perceived at the Mughal court. It is found in his history of Shah Jahan, the Shah-Jahannama or 'Amal-i Salih (completed 1659-60): 
Whenever the highest Wisdom of the Majesty exalted above all [God]may His proof be exalted everywhere-out of concern for His servants and His countries finds it apt to choose a dynastic family of sultans of the world, He bestows special distinction on the lords of that God-given empire among all other masters of empires with perfect grandeur and majesty and He gives necessarily whatever is essentially connected with [maintenance] of the rule. Such matters may belong [to the category] of beautiful and external things the existence of which is not so necessary [in the context] of overall rule, but they must be [present] to give full distinction and spectacular display-the more so since it becomes a matter of increase of pomp and power, magnificence and elegance...It is evident that the increase of such things creates esteem for the rulers in the eyes [of the people] and augments respect [for the ruler] and [their own] dignity in [their] hearts. In this form the execution of divine injunctions and prohibitions and the enforcement of divine decrees and laws which is the ultimate aim of rulership and kingship are carried out in a better way. ${ }^{3}$

Pomp and show, ceremonial, architecture and the arts were emphasized as indispensable instruments of rulership. This conformed to prevailing ideas in the Islamic world where architecture and the arts had long been considered as the immediate expression of the ruler, true to the Arabic saying 'Athar-una tadu-ll-alina'- 'Our monuments will speak of us.' The great Arab historian Ibn Khaldun (1332-82), in his famous work al-Muqaddima, the 'Introduction' to history, had drawn attention to the decisive role Muslim rulers played in the development of architecture and the crafts which served as their status symbol and to the fact that their patronage was echoed by the nobility and the urban classes of the cities, the centres of power, religion, learning and culture. ${ }^{4}$ In Europe such ideas did not manifest themselves widely until the age of absolutism from the 16th century onwards, when the leading role of the church as patron of the arts was challenged by worldly rulers.

${ }^{3}$ Muhammad Salih Kanbo, 'Amal-i Salih or Shah-Jahannama, Wahid Qurayshi, rev. and ed., based on the Calcutta edn of 1912-46 by Ghulam Yazdani, 2nd edn (Lahore 1967-72) vol. 3, p. 25; as translated in Ebba Koch, 'The Baluster Column: A European Motif in Mughal Architecture and Its Meaning', Journal of the Warburg and Courtauld Institutes 45 (1982) p. 259; Ebba Koch, Mughal Art and Imperial Ideology: Collected Essays (New Delhi 2001) pp. 38-60.

${ }^{4}$ Ibn Khaldun, The Muqaddimah, An Introduction to History, F. Rosenthal, trans., and abridged by N.J. Dawood (London 1967) pp. 216, 263-266, 314-317, 319-321, 327-332, et passim; cf. Doris Abouseif, Beauty in Arabic Culture (Princeton 1999) pp. 159-185. 
Shah Jahan's approach stands out in the consistent systematization of highly aestheticized form as an expression of his specific state ideology, of centralised authority and hierarchy bringing about balance and harmony. A counterpart, if not a follower, in the West would be Louis XIV of France (rul. 1643-1715) whose use of ceremony, art and architecture as an instrument of absolute monarchy was in turn emulated by other European courts. ${ }^{5}$

Shah Jahan and his advisers structured court proceedings with a rigid ceremonial which, if we are to believe his historians, he himself followed to the minute in his daily routine. From morning to evening Shah Jahan moved from one place of interaction with his court and subjects to another. The audiences were progressively limited in access, from the most public form in the viewing window or Jharoka-i Darshan on the outer wall of the palace to the great darbar in the Public and Private Audience Hall, the Daulat Khana-i Khass-u-'Amm (or Diwan-i 'Amm in short form), to the Hall of Private Audiences, where the main government business was conducted, the Daulat Khana-i Khass or Diwan-i Khass, to the Royal Tower, the Shah Burj, the chamber of secret councils, and from there to the most remote form of audience in the Harem or zanana, the female palace where the affairs of the women were regulated. The appearance in the Jharoka-i Darshan took place only in the morning at sunrise, when the emperor appeared to his subjects as 'the earthly sun opposite the sun in the sky', as a true sun ruler spreading bounty; the remaining cycle was repeated in the afternoon. ${ }^{6}$

Not only were the assemblies standardized but also their architectural frame. For each 'station' of the emperor's movement through the palace there was a specifically designed building, and its shape followed, within a margin of variation, the similar formal criteria (or showed a similar configuration of components) in all imperial palaces. The form of a palatial building can thus tell us about its function. The most standardized type in the programme of palace buildings was the

\footnotetext{
${ }^{5}$ For Louis XIV's interest in 'Oriental rulers', see Gülru Necipoğlu, 'Framing the Gaze in Ottoman, Safavid, and Mughal Palaces', Ars Orientalis 23, special issue: Premodern Islamic Palaces (1993) p. 317.

6 'Abd al-Hamid Lahawri, Padshahnama, M. Kabir-ud-Din Ahmad and M. 'Abd alRahim, eds. (Calcutta 1865-72) vol. 1, pt. 1, pp. 144-154; translated Nur Bakhsh, 'The Agra Fort and Its Buildings', Archaeological Survey of India Annual Report (1903-4) pp. 188-193.
} 
hall for public audience, a new invention of Shah Jahan, and the subject of our discussion.

\section{The Audience Halls}

New halls for public audience were constructed after Shah Jahan's accession in the great fortress palaces of the Mughal empire, at Agra, Lahore, and, according to some sources, also at Burhanpur in central India. These halls were first built in wood to replace a smaller tent hall that had been used for the purpose up to then. As we can see from the images illustrating the history of Shah Jahan's reign (Fig. 1), the wooden halls were hypostyle constructions with green pillars topped with red elements ${ }^{7}$ and the court poet Abu Talib Kalim compared the first hall at Agra to a garden full of cypresses

This new building which is under the same shadow as the Divine Throne ('arsh) [meaning that is on the same level in the highest stage of heaven]

Loftiness is a mere word with regard to the position of its plinth.

It is a garden of which every green pillar is a cypress

And high and low find rest under its shadow. ${ }^{8}$

The historians also give us the dimensions of the wooden hall (iwan-i chubin) of Agra which was enormous, namely 70 gaz padshahi long and $22 \mathrm{gaz}$ wide, corresponding to $56.89 \mathrm{~m} \times 17.88 \mathrm{~m}$ because the gaz employed in Shah Jahan's architecture had (ideally) a length of $81.28 \mathrm{~cm}$ or 32 inches.

By January 1637, the wooden halls of Agra and Lahore had in turn been replaced by even larger permanent versions, constructed "of red sandstone made white with marble plaster" (Fig. 2). Between 1639 and 1648 a corresponding stone hall was built in the emperor's new palace at Shahjahanabad (Delhi) (Fig. 3).

All of these halls including their wooden precursors are described by Shah Jahan's historians and poets as Iwan-i Dawlat Khana-i Khassu-'Amm, and Iwan-i Chihil Sutun. Iwan means in Mughal Persian a pillared construction of any dimension and plan; dawlat khana can be rendered in English as 'house of royal power and authority' and

\footnotetext{
7 Beach and Koch, The Padshahnama, cat. nos. 14, 32, 43, 44.

${ }^{8}$ Kalim's verses are cited by Lahawri, Padshahnama, vol. 1, pt. 1, pp. 221-223 where he gives a description of the Agra hall.
} 


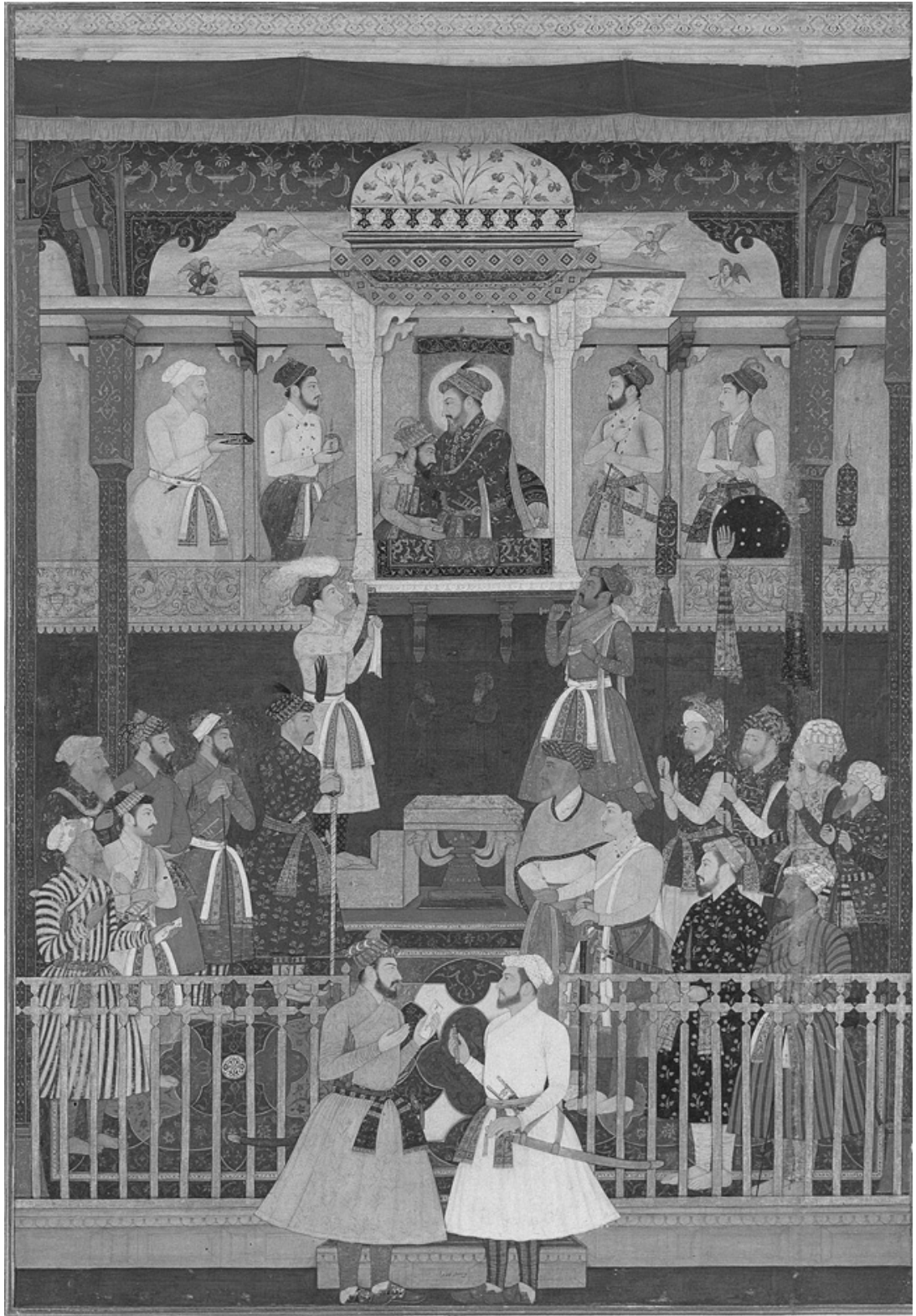

Figure 1. Shah Jahan receives his son Awrangzeb in the Hall of Public Audience or Diwan-i 'Amm of Lahore, painted by Murar, ca. 1645, Royal Library, Windsor, Copyright 2006, Her Majesty Queen Elizabeth II. 


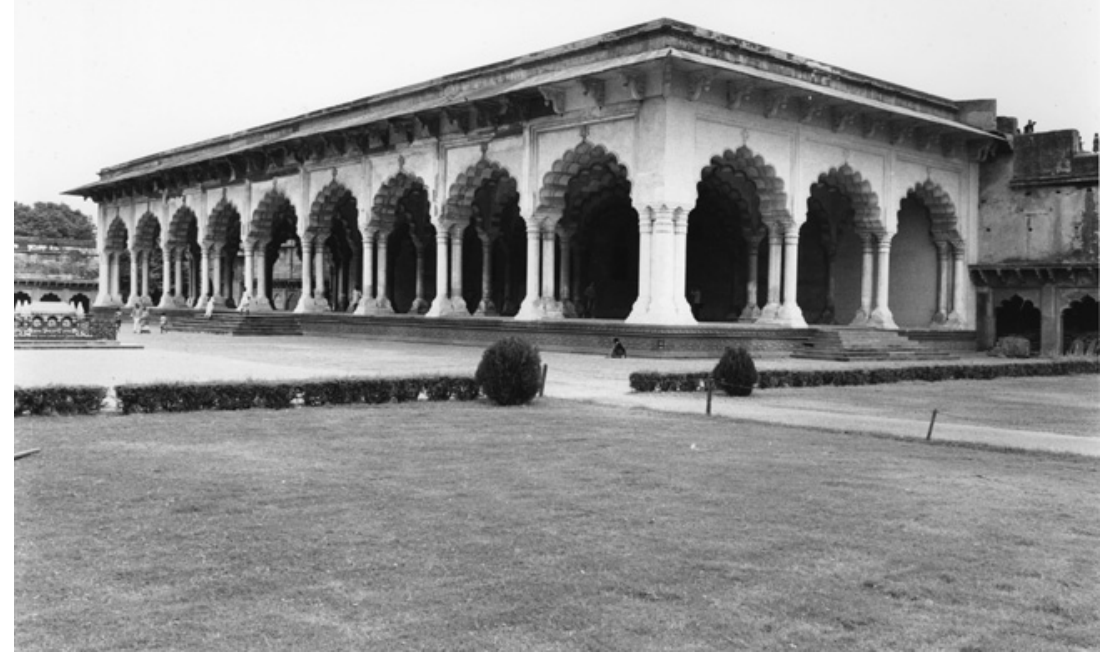

Figure 2. Diwan-i 'Amm, Agra, completed 1637 (Photo Ebba Koch).

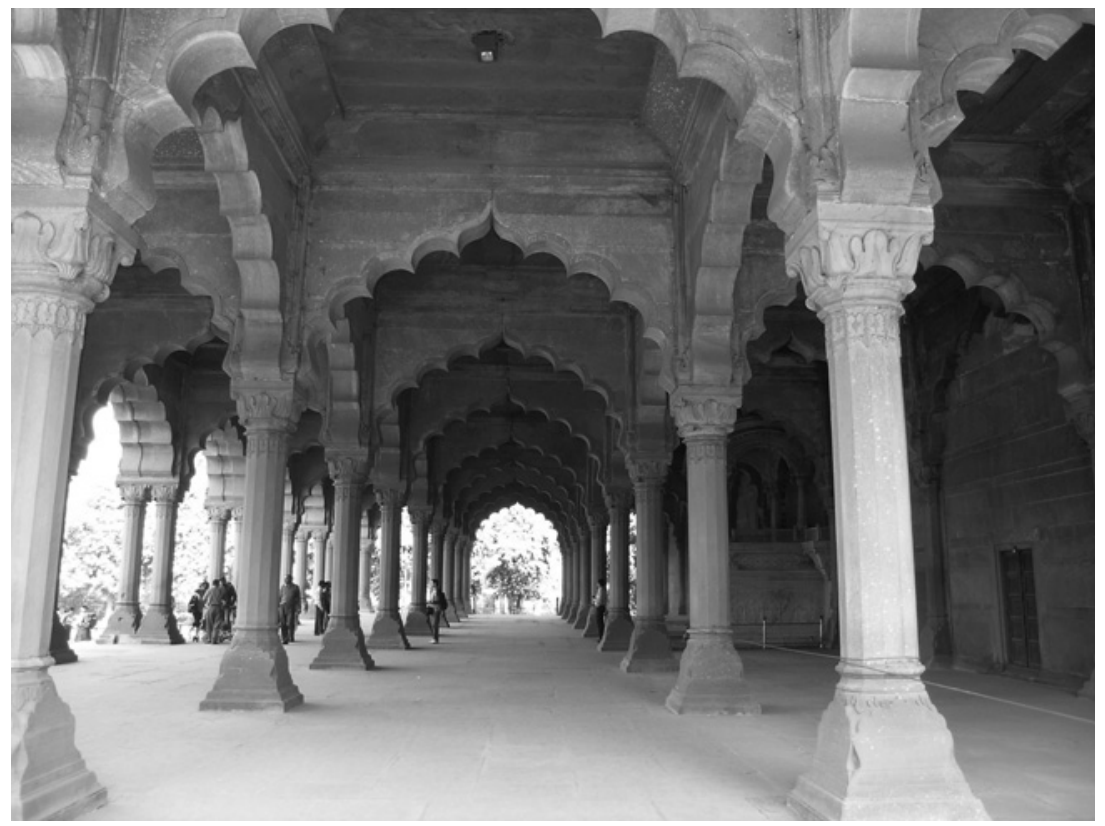

Figure 3. Diwan-i 'Amm, Delhi, completed 1648 (Photo Ebba Koch). 
is used for an imperial palace or palace building; khass, meaning the special, the close ones, referred to the group which represented the highest ranks of the empire; and 'amm were all the others. Iwan -i Dawlat Khana-i Khass-u- 'Amm can thus be translated as state hall for high and low or Hall of Public Audience. Iwan-i Chihil Sutun means Hall with Forty (Chihil) Pillars (Sutun). The Dawlat Khana-i Khassu- 'Amm, (Diwan-i 'Amm in short form), or Iwan-i Chihil Sutun represents a new type in the palatial building program of the Mughals because, as the sources tell us, under the predecessors of Shah Jahan most of those who took part in the audience had to stand unprotected from sun and rain in front of the emperor's viewing window or Jharoka in the open courtyard, the Sahn-i Khass-u-'Amm, where the audience was held (Fig. 4a). The emperor, we are told, ordered the construction of the halls out of concern for his nobles, to protect them from the vicissitudes of the weather. And we also learn that the halls made it easier to maintain the proper hierarchy and etiquette of an audience which, as we have seen, were aspects of special concern to Shah Jahan. The public audience or bar-i 'amm was also a state council and attendance was obligatory for every Mughal officeholder present at the residence, whether amir or mansabdar. The nobles and their retinues had to stand positioned according to their rank in front of the Jharoka-i Khass-u 'Amm (Fig. 1), the place of appearance of the emperor along the back wall of the hall, from where he dealt with the administration of the imperial household and the empire (which was treated like its extension) and other affairs of state.

The new audience halls were put up in front of the wall with the Jharoka and were only accessible to holders of a certain rank, namely those courtiers who had a mansab above two hundred. The halls were open on three sides and to ensure restricted access, they were enclosed on the outside by a silver railing, the three doors of which were closely guarded. An additional space, fenced off by a red railing which surrounded the halls at some distance, was reserved for those with a mansab below two hundred. The remaining area of the Sahn-i Khass-u-'Amm was used by retainers and others without any particular rank (Figs. $4 a$ and $b$ ).

\section{Function of the Audience Halls}

In addition to being a place of daily proceedings in the government of the Mughal empire the Diwan-i 'Amm provided a stage for the great court festivals, in particular Nawruz, the Persian New Year which was 


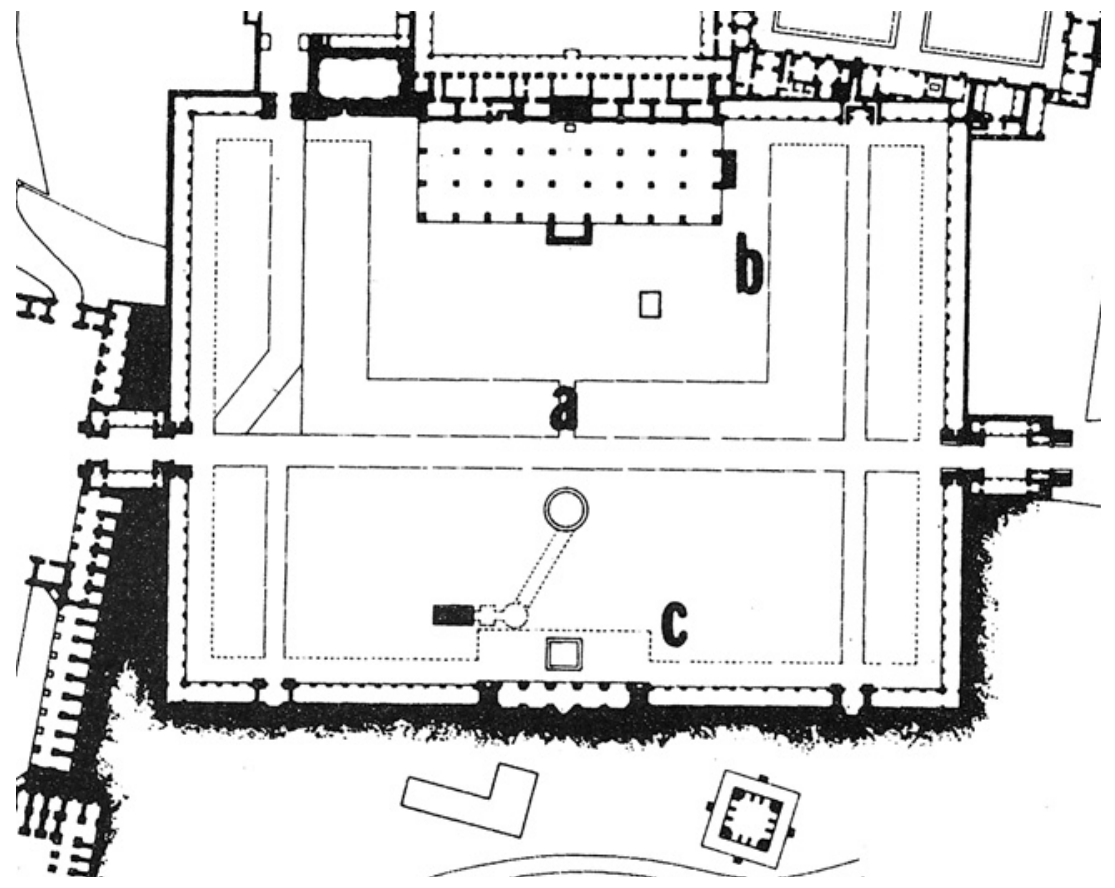

Figure 4. Site plan of Agra Fort, detail, (a) courtyard of khass-u-'amm; (b) Diwan-i 'Amm hall; (c) mosque (Drawing: R.A. Barraud and E. Koch).

celebrated with great pomp and show at the Mughal court, and julus, the anniversary of the emperor's accession to the throne. It was also the setting for such state ceremonies as the weighing of the emperor on his solar and lunar birthdays (jashn-i wazn-i shamsi, jashn-i wazn- $i$ qamari). When a royal prince's wedding was held, the Diwan-i 'Amm was at times called khalwat ("seclusion" or "retirement"), because on those occasions men had to evacuate the courtyard to allow the imperial women to use the Diwan-i 'Amm as an exhibition hall where they arranged the dowry and the wedding presents for display to the court during the emperor's public audience. The audience hall played also a part in the celebration of religious festivals such as the 'Id. The emperor also hosted scholars and pious persons with a banquet there on the Milad (the Prophet's birthday). During the whole month of Ramazan fast-breaking meals (iftar) would be given to deserving poor persons at imperial expense in the audience hall. The emperor also used it to receive foreign dignitaries and delegations. All in all, the Diwan-i 'Amm was the center of court events and Mughal rule where the power and pomp of the Grand Moghul was enacted. 


\section{Sources of the Audience Halls as Chihil Sutuns (Forty-Pillared Halls)}

The halls are described by Shah Jahan's historians, 'Abd al-Hamid Lahawri and Muhammad Salih Kanbo, ${ }^{9}$ and there are also reports of contemporary European eye witnesses. These literary sources tell us what the various functions of the halls were and something about their form, but not what would also interest the modern architectural historian, namely, why such a monumental hypostyle audience hall was introduced in the palace architecture of the Mughals. Aside from panegyric comparisons and poems written when a hall of Shah Jahan was completed, the sources have nothing to say about their architectural programme. This should not surprise us because direct statements about the meaning of architecture, indeed of works of arts altogether, are not a special genre of Mughal writing. Contemporary interpretations are often embedded in a more or less enciphered form in the courtly panegyric. The greatest problem here is to recognize which themes and concepts were merely literary conventions and which had an actual bearing on a work of art.

Shah Jahan's court historians, by designing the halls as Chihil Sutun, provide us with a clue about their concept. In Iran the term was used in the sense of halls with many, though not necessarily forty, columns. The Safavids who ruled over Iran during the period of the Mughal empire used it in this way.

The Mughals considered their immediate neighbours, the Safavids, their greatest rivals. They also wanted to measure themselves against the Persians on the level of the arts, so Iran became an important factor for the concept of Mughal rulership. It is well known that their great ancestor Timur had tried to establish himself as a TurcoMongolian warlord and conqueror in the Persian-Islamic tradition of rulership. His successors, the Timurids, oriented themselves even more strongly towards Persianate culture. Given this orientation of the Mughals towards Iran, one is tempted to relate the sudden appearance of Mughal audience halls designated with the Persian term chihil sutun to the hypostyle porticoes or talars of the reception pavilions of the Safavids, because they are formally and functionally related. One feels in particular inclined to make this connection because the first version

\footnotetext{
${ }^{9}$ Lahawri, Padshahnama, vol. 1, pt. 1 pp. 144-154; translated Bakhsh, 'The Agra Fort and Its Buildings', pp. 188-193; Kanbo, Shah Jahannama, vol. 1, pp. 201-210.
} 


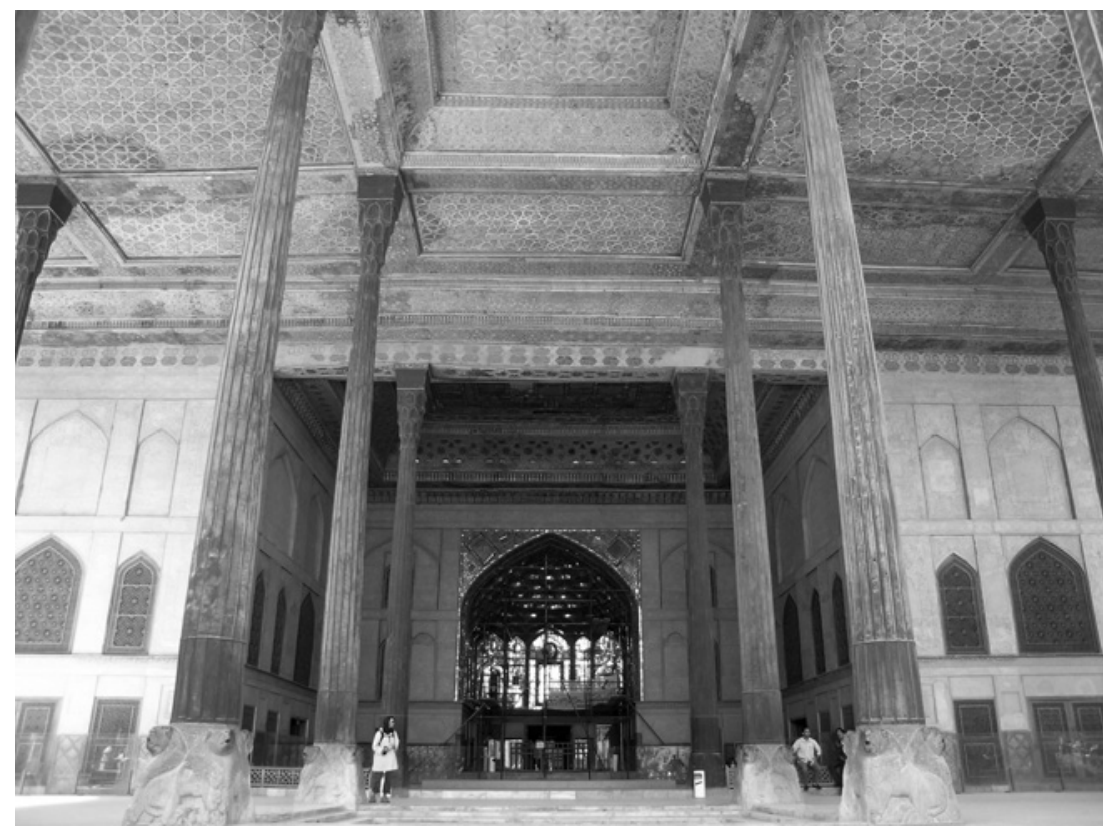

Figure 5. Chihil Sutun, Isfahan, 1647 (Photo Ebba Koch).

of Shah Jahan's Chihil Sutuns was-like the Safavid talars-a hypostyle wooden construction open on three sides set before a masonry wall with a seat for the shah in the centre.

The problem, however, is that neither the date nor the origin of the Safavid talars has as yet been established with certainty. The immediate namesake and functional equivalent of Shah Jahan's Chihil Sutuns, the reception pavilion in the palace of Isfahan dates, in its present form, from 1647 (Fig. 5). The shape of the earlier Safavid Chihil Sutun at Qazwin is uncertain. ${ }^{10}$ Buildings called Chihil Sutuns occur also in the Timurid context, the best known of which is the one Ulugh Beg built in the first half of the fifteenth century at Samarqand. Although it has not survived, we know from Babur that it had stone columns arranged in two stories.

${ }^{10}$ Sussan Babaie, Isfahan and Its Palaces: Statecraft, Shi'ism and the Architecture of Conviviality in Early Modern Iran (Edinburgh 2008) pp. 53-55, 157-182. 


\section{References to Persepolis as Chihil Sutun and site of the Iranian Kings} and Solomon

However, among the sites known as Chihil Sutun in the earlier seventeenth century there was one of particular historical significance which predates all the Chihil Sutuns discussed so far. In connection with audience halls it must have been pivotal for the Iran-inspired concept of rulership of the Mughals. This is Persepolis, the great ritual and representative centre of the Achaemenid empire, the place where the ceremonies of the world-ruling Persian kings were held in multicolumned audience halls (Fig. 6). Alexander the Great had destroyed Persepolis but it remained over the centuries a symbolically highly charged place for any ruler who sought to associate himself with the Persian concept of sacred kingship. This is even true of the Habsburg rulers of the Holy Roman Empire. Their great architect Josef Bernhard Fischer von Erlach is said to have planned the new royal palace at Schönbrunn in Vienna on a hill in the same way as it is reported of the royal castle at Persepolis or Tschehelminar, so that His Majesty [Charles VI, 1685-1740]-like Cyrus overlooking his empire-can see as far as the borders of Hungary.'.

In Iran, the references to Persepolis begin with the Sasanians who, incidentally, came from the region of Istakhr where Persepolis is situated. The tradition was continued by the Muslim rulers beginning with the Buyids (tenth century) who sought to establish their royalty in face of the 'Abbasid caliphs at Baghdad, the spiritual rulers of Islam. The unbroken associations of Persepolis with the Iranian-Muslim tradition of kingship are evident from Arabic and Persian inscriptions of Muslim princes who visited Persepolis throughout the centuries. The engraved inscriptions of these royal visitors are still to be found in the palace of Darius, the Tachara. They have similar contents and, at times, even copy from each other, clearly to emphasize the aspect of continuity related to the place. Their themes reflect on the transitory nature of human achievement, in particular of worldly power and kingship, thoughts which were considered as befitting for princes contemplating ancient sites. An example comes from Ibrahim Sultan, the son of Shah Rukh, a relative of the Mughals and a highly ambitious

${ }^{11}$ Georg Kunoth, Die historische Architektur Fischers von Erlach (Düsseldorf 1956) pp. 120-124, pl. 102. 
Timurid governor of Fars. In the year 826/1423 he left the following verses on the palace of Darius:

Do you know any one of the old kings of Iran

of the time of Faridun, Zahhak or Jam[shid]

Whose throne and empire did not perish and who was not

ruined by the hand of destiny?

Did not the throne of Solomon-peace be upon him-

from morning to evening fly upon the wind?

Did you not see that finally it was gone with the wind?

Happy the one who departed, leaving behind knowledge and justice!

Beware! that you bring up the tree of generosity-no doubt

you will then taste the fruits of fortune.

Written by Ibrahim Sultan bin Shah Rukh in the year

eight hundred twenty-six. ${ }^{12}$

The verses tell us that, in Islamic Iran, Persepolis was not associated with its historical founders, the Achaemenids, but with the mythical rulers of Iran as they were popularized by Firdawsi's great epic of kings, the Shah nama (written around $1000 \mathrm{CE}$ ), in particular with Jamshid. In Muslim Iran Persepolis was (and still is) not only known as Chihil Sutun or Chihil Minar but also as Takht-i Jamshid (Throne of Jamshid). The Arab tradition too claimed Persepolis under the name of nearby Istakhr, by regarding it as a place of Solomon, who, in the Koran and Muslim legends, appears as prophet king and ideal ruler of Islam. The Arab geographers of the Middle Ages from about the 10th century onwards like Istakhri, Muqaddasi or Mas'udi described Persepolis as mal'ab-i-Sulayman a playground of Solomon and in particular as masjid-i Sulayman, as mosque of Solomon. ${ }^{13}$ In popular Persian tradition Jamshid and Solomon were amalgamated into one and the same person. ${ }^{14}$ Davani, for instance, who writes in 1476 about Persepolis, says that it is known as Chihil Sutun and that it was founded by

${ }^{12}$ My translation from the French translation of A.S. Melikian-Chirvani, 'Le royaume de Salomon: les inscriptions persanes de sites achéménides', Le Monde iranien et l'Islam 1 (1971) pp. 24-25.

${ }_{13}$ Paul Schwarz, Iran im Mittelalter nach den arabischen Geographen, vol. 1 (Leipzig 1896) pp. 13-16.

${ }_{14}$ Georg Salzberger, Die Salomo-Sage in der semitischen Literatur. Ein Beitrag zur vergleichenden Sagenkunde (Berlin 1907) pp. 2-5, 8, 23; and Georg Salzberger, Salomos Tempelbau und Thron in der semitischen Sagenliteratur, Schriften der Lehranstalt für die Wissenschaft des Judentums 2, 1 (Berlin 1912) p. 57. Colin P. Mitchell (The Practice of Politics in Safavid Iran: Power, Religion and Rhetoric [London 2009], pp. 120-44) has recently also referred to this issue in his discussion of Solomon as an exemplar of rulership of the Safavids. 
Jamshid whom tradition identifies with Solomon. ${ }^{15}$ From the German observer Engelbert Kämpfer we learn that Persepolis as Chihil Sutun or Chihil Minar (Forty Towers) was as strongly connected to Solomon in the late seventeenth century as in the earlier periods. He reports that it was believed to be the seat of Solomon and the model of the Solomonic temple. ${ }^{16}$

\section{The Mughal Audience Halls as a Solomonic Reference to Persepolis}

Both traditions, that of the ancient Persian kings as well as that of Solomon, were fundamental to the concept of rulership of the Mughals. That the Great Mughals liked to appear as second Khusraws (synonym for Sasanian kings), as second Jamshids, and as second Solomons, is transmitted through their courtly panegyric as well as through the arts created for them. Like other Muslim princes, the Mughals were keen to compare themselves with Solomon, but they were unique in their visual realisation of Solomonic schemes in art and architecture. The theme of the Solomonic prophet king became predominant from the time of Jahangir (r. 1605-27) onward and was also used for his son and successor, Shah Jahan. ${ }^{17}$

Both themes, that of the Persian kings and that of Solomon, are featured also in the panegyric written upon the completion of the audience halls of Shah Jahan. Beside the more general allusions of Lahawri who praises the heaven-reaching loftiness of the wooden Agra hall and its stone replacement, and the repeatedly quoted ruba' $i$ (quatrain) of Abu Talib Kalim who, as we have learnt, compares the columnar construction of the wooden Agra hall to a garden full of shade-giving cypresses, it is Muhammad Salih Kanbo who informs us which particular buildings and sites the Mughals associated with the audience halls. Kanbo relates both the wooden hall of Agra (1637) and the stone hall of Delhi (1648), which he describes as bargah (iwan)-i chihil sutun (forty-pillared state hall), diwankada-i 'adl-u-dad (court house of equity and justice) and bargah-i Sulaymani (Solomonic hall)

\footnotetext{
15 A.S. Melikian-Chirvani, 'Le royaume de Salomon, les inscriptions persanes de sites achéménides', Le monde iranien et l'Islam I (1971) pp. 1-41, pp. 2-3, 26 ff.

${ }_{16}$ Engelbert Kämpfer, Amoenitatum exoticarum politico-physico-medicarum (Lemgo 1712) pp. 302, ff. 326.

${ }^{17}$ Koch, Mughal Art and Imperial Ideology, pp. 12-37, 104-129; Ebba Koch, 'The Mughal Emperor as Solomon, Majnun and Orpheus or the Album as a Think Tank for Allegory', Muqarnas 27 (2010) pp. 277-311.
} 
to several famous legendary and historical palaces of the past, in particular to the iwan-i Nushirwan, the sab-i Shaddad and, again, the bargah-i Sulayman. Such passages should not be dismissed as superfluous eulogical exercises, as past translators of historical Mughal texts have often done. Court panegyrics represent an indispensable source for establishing the meaning of a Mughal work of art.

When we look critically at Kanbo's eulogical comparisons mentioned above which, because of their repeated use, appear to have had a special relevance for Shah Jahan's halls, we immediately recognize that the reference to the iwan-i Nushirwan belongs to a definite literary tradition alluding to 'the global sovereignty claimed by the Sasanian King of Kings from his fabled palace at Ctesiphon'. ${ }^{18}$ In Arabic and Persian literature the Ctesiphon palace was known as Iwan-i (Khusraw) Nushirwan, and also called Taq-i Kisra (Arch of Khusraw) and under both names it was used proverbially to refer to any grand royal building. In the context of the audience halls of Shah Jahan the reference appears to have an additional terminological significance because it plays on the flexible meaning of iwan, a word Shah Jahan's authors did not use for a monumental vaulted hall open at the front, but in the Central Asian sense of a pillared construction, similar to the way the Iranians use the term chihil sutun.

Kanbo's claim that Shah Jahan's halls were a copy (nuskhat) of the $s a b$ - $i$ Shaddad (seven [layered construction] of Shaddad) refers to the legendary Iram at Aden built by King Shaddad bin 'Ad as a paradise on earth. The connection to Shah Jahan's halls could be that it was, as the Koranic sura 89:6, says "of Columns."

But what about bargah-i Sulayman? Did Kanbo refer generally to a Solomonic hall or did the reference have a more specific significance? First of all bargah in Mughal Persian has the precise architectural meaning of audience tent or audience hall; accordingly, Shah Jahan's halls are also called bargah-i chihil sutun. Second, by the time of Shah Jahan's accession in 1628, after which the first wooden versions of the audience halls were constructed, Solomonic imagery had already made a strong impact upon the arts of the Mughal court; Jahangir had used it extensively in the decoration of his palaces. Consequently, in Mughal eulogies of a building of that time, any reference to Solomonic imagery must be taken seriously, which means that it may well have

\footnotetext{
${ }_{18}$ John Renard, Islam and the Heroic Image: Themes in Literature and the Visual Arts (Columbia, SC 1993) p. 169.
} 
a bearing on the actual architecture. This applies in particular to the audience halls, because the gathering of Shah Jahan's courtiers in front of the emperor in the Jharoka-i Khass-u 'Amm would evoke among contemporaries strong Solomonic associations. Qazwini, for instance, calls it majlis-i diwan-i Sulayman-i zaman, "the court assembly of the Solomon of the Age" (Fig. 1). True, Kanbo does not tell us what exactly he had in mind when he calls Shah Jahan's audience halls bargah-i Sulaymani or compares them favourably to the bargah-i Sulayman. However, in connection with the designation of the halls as Chihil Sutun, the name under which Persepolis was known, we are on safe grounds in assuming that, in the whole chain of panegyrical comparisons, bargah -i Sulayman [i] was the one notion which advertised the symbolic and architectural program. The Shahjahani halls would therefore have been meant as a deliberate quotation of the most famous and most ancient Chihil Sutun of Iran, the audience halls of Persepolis, believed to have been founded by Solomon-Jamshid. This connection was intensified by the traditional association of Persepolis with Nawruz, and Davani reported that Jamshid-Solomon celebrated Nawruz there. ${ }^{19}$ In a comparable way Shah Jahan's Chihil Sutuns in the courtyard of khass-u-'amm acquired their greatest splendour during the yearly Nawruz celebrations of the Mughal court.

\section{The Mughal Halls as a Recreation of Chihil Sutun (Forty Pillared)-Persepolis}

How then could the Mughals have expressed the reference to Chihil Sutun-Persepolis architecturally over such great distance of time and space? Up to the seventeenth century the main thing that was known about the great audience halls of Persepolis was that they had many columns-namely chihil sutun - of which only a few were left standing (Fig. 6). The way of referring to Persepolis with synonyms of "manycolumned" can be traced as far back as the Sasanians, who designated it as "Sat Sutun" (of a hundred columns). Muslim writers such as Davani tell us that "in the time of the [old] Persian kings" (muluk-i 'Ajam) Persepolis was called "Hazar Sutun" (of a thousand columns). The latter brings to mind the famous Hazar Sutun of the Delhi sul-

\footnotetext{
${ }^{19}$ See V. Minorsky, 'A Civil and Military Review in Fars in 881/1476', Bulletin of the School of Oriental and African Studies, 10 (1940) pp. 141-178, at pp. 150-51.
} 


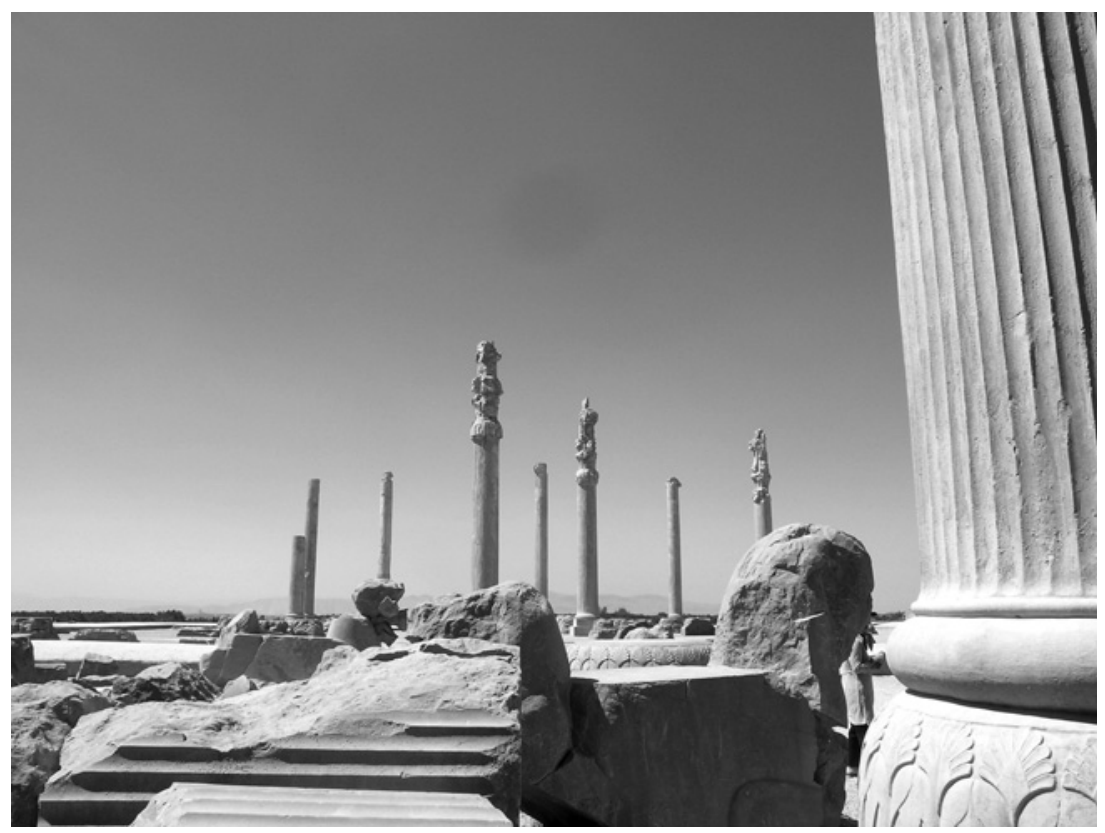

Figure 6. Persepolis, Apadana (c. 500-490 BCE) and Hall of Hundred Columns (c. 480-460 BCE) (Photo Ebba Koch).

tan Muhammad b. Tughluq, a vast public audience hall with wooden painted pillars built in 1343 in his palace at Jahanpanah-Delhi; it is likely that this structure represented an allusion to Persepolis and that it inspired Shah Jahan.

In any case, as we have pointed out above, in the seventeenth century Persepolis was known as Chihil Sutun in the sense of a proper name and this "numerical title" contained the only formal information about Persepolis which the Mughal conceptualists had at their disposal when they wanted to allude architecturally to the famous site. So chihil sutun, in the sense of the multi-columned halls of Persepolis, the Diwan-i 'Amms of Shah Jahan had to be, but what form would the numerical concept be given?

All three audience halls follow exactly the same scheme, but they are not all the same size. The biggest hall is that of Agra $(61.48 \mathrm{~m}$ long, $20.72 \mathrm{~m}$ wide and $11.55 \mathrm{~m}$ high); those of Lahore (54.05m long, $18.32 \mathrm{~m}$ wide, original height not known) and Delhi $(54.66 \mathrm{~m}$ long, $18.41 \mathrm{~m}$ wide, $12.66 \mathrm{~m}$ high) are smaller and close to each other in their dimensions (Figs. 7, 8). Each of the Diwan-i- 'Amms shows the same flat-roofed hypostyle construction erected on a grid pattern which 

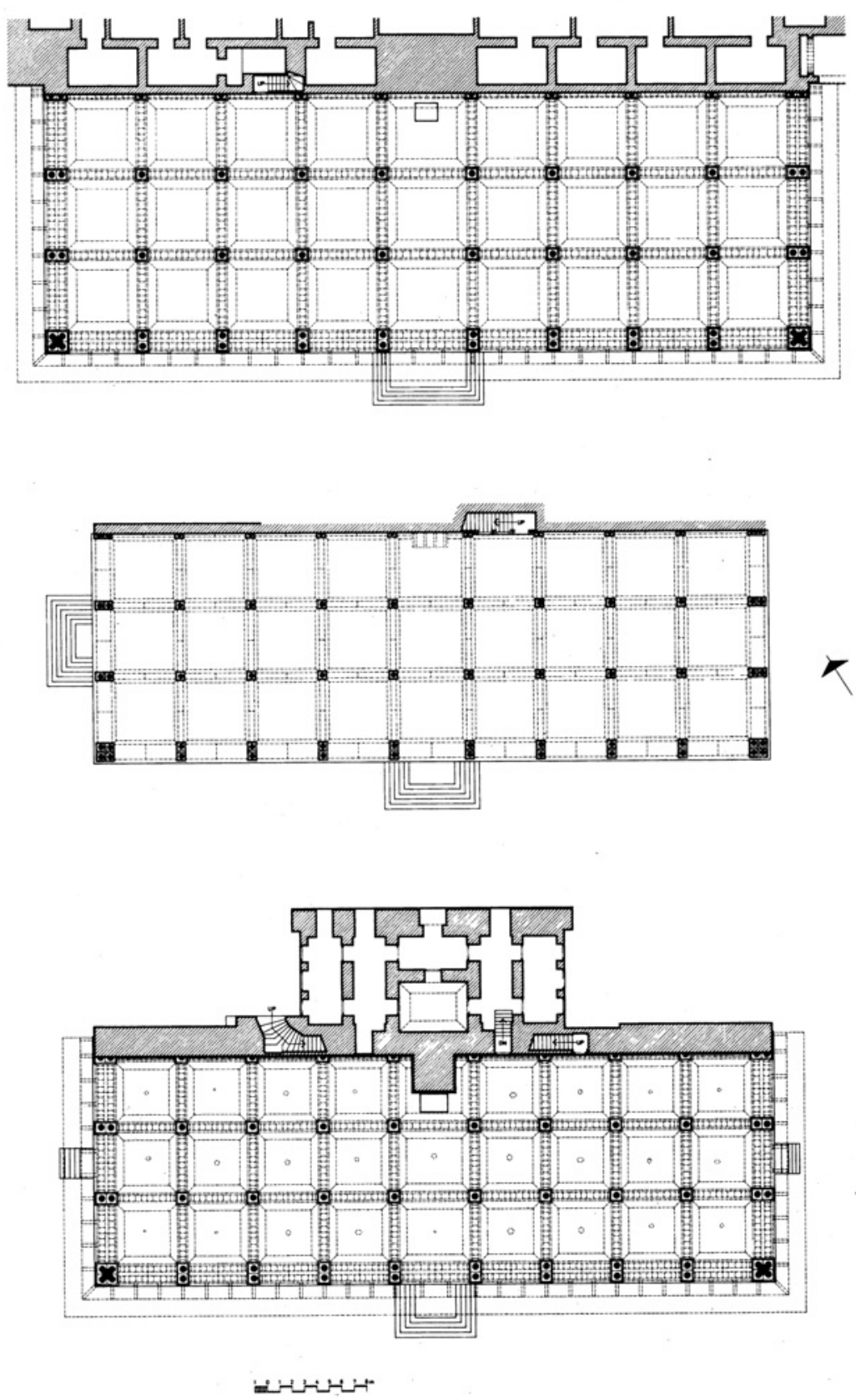

Figure 7. Ground plans of the Diwan-i 'Amms of Agra, Lahore, and Delhi (Drawing: R.A. Barraud and E. Koch). 

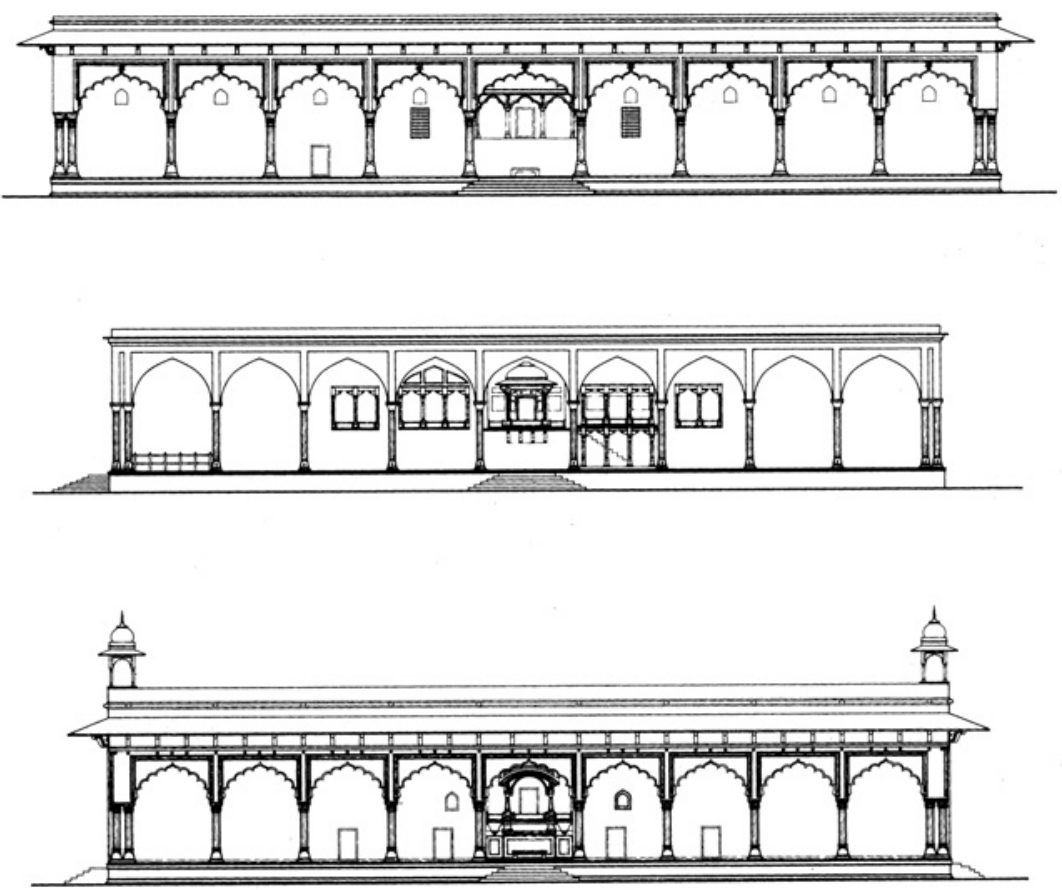

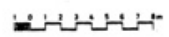

Figure 8. Elevations of the Diwan-i 'Amms of Agra, Lahore, and Delhi (Drawing: R.A. Barraud and E. Koch).

forms twenty-seven bays. The bays are demarcated by coved ceilings (chashma), set off by multi-lobed arches (taq-i marghuldar) and large twelve-sided 'Shahjahani' columns. The columns are paired on the outer sides which produces a quadruple formation in the corners. Each hall thus has forty-eight full columns and twelve half columns. If, however, each columnar unit is read as a single one, we get exactly forty supports, with ten on the longer side of the hall and four on the shorter sides. From this it becomes evident that the Mughals were careful to take the main formal information about Persepolis they had at their disposal, namely its 'numerical title' chihil sutun, as literally as possible. This shows that Shah Jahan's Chihil Sutuns were not merely intended as a Mughal version of the Safavid and Timurid Chihil Sutuns but as a direct reference to what, in the last analysis, could well be the common prototype of all, namely Chihil Sutun-Persepolis. Whereas the Timurid and Safavids referred to it more loosely and perhaps less 
consciously with a hypostyle, columnar hall, the Mughals had the ambition to come up with what they took to be the most authentic reproduction of the original. As often happens, the periphery here is more literal than the center, 'more catholic than the Pope.'

Moreover, in medieval architecture numbers were among the prominent elements that would determine the relationship between copy and original; a point stressed by Krautheimer in his pivotal study on the subject. ${ }^{20} \mathrm{He}$ showed that medieval thinkers felt perfectly justified in relating buildings to one another as long as some of the outstanding elements seemed to be comparable. In addition to numbers, often only the name of a building was considered sufficient to arouse associations connected with the prototype. Since in the case of Chihil Sutun-Persepolis the name was actually a number, it offered itself as the determining factor for the Mughal copy.

\section{Audience Hall and Mosque}

In any case, because of its ruined state, Persepolis could not serve as a model for the arrangement of these forty columns. For models of the layout of the Diwan-i 'Amms we do not have to look at Persia; its sources can be found closer to home, namely, within Mughal architecture itself. Shah Jahan's Diwan-i 'Amms have an overall scheme of a hall constructed over a grid pattern, with paired pillars around the periphery. Their oblong shape generates three aisles along the longer side and nine naves along the shorter side. This plan has its closest parallel in the mosque known as Patthar Masjid at Srinagar (Fig. 9), said to have been built by Jahangir's wife Nur Jahan. The traditional attribution of the mosque to this patroness of architecture is corroborated by the stylistic evidence which points to the 1620s. The prayer hall of the Patthar Masjid is built in a more massive idiom than the Diwan-i 'Amm halls, with cruciform piers instead of columns. Both buildings have a wider nave in the center, indicating the direction in which the hall should be read. In the case of the mosque it leads to the mihrab, the arched niche in the qibla wall towards which prayer is directed, in the case of the audience hall to the emperor's place of appearance, the jharoka.

\footnotetext{
${ }^{20}$ Richard Krautheimer, 'Introduction to an "Iconography" of Medieval Architecture', Journal of the Warburg and Courtauld Institutes 5 (1942) pp. 1-33.
} 


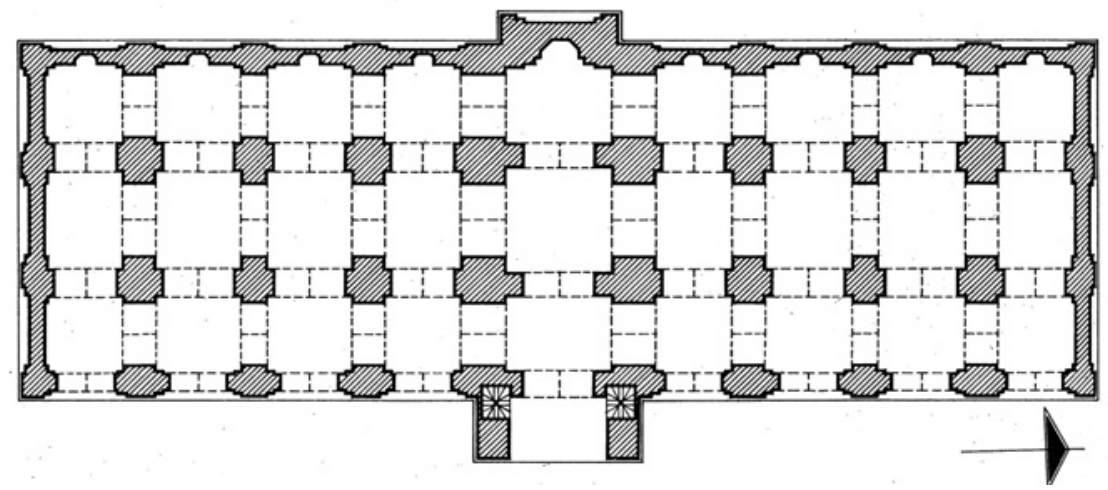

Figure 9. Ground plan of the Patthar Masjid, Srinagar, 1620s (Drawing: R.A. Barraud and E. Koch).

Such parallels are by no means accidental: Shah Jahan's eulogists extol the emperor as the qibla and mihrab of his subjects. Here is Abu Talib Kalim:

May his court always be revered

May it be like the Ka' ba a qibla for the seven climates! ${ }^{21}$

And, more specifically, as if to illustrate our argument, Qazwini describes the emperor holding court in the Diwan-i 'Amm as qibla-i hajat, the place to which people turn for the attainment of their wants. ${ }^{22}$

The connection between audience hall and mosque was in the palace of Agra-which is the only place where the greater architectural context of a Diwan-i 'Amm of Shah Jahan is preserved-reinforced by an additional architectural accent. When we look at the plan of the Agra fort, we notice that the hall (Fig. $4 \mathrm{~b}$ ) sets the main accent of the eastern wing of the courtyard of public audiences (Fig. 4a). The central part of the western wing of the audience courtyard-that is, the section situated exactly opposite the audience hall-was given the shape of a mosque-a fact which has hitherto gone unnoticed (Fig. 4c). The raised central part, which projects slightly from the plane of the courtyard wings represents the facade of the mosque which has five

${ }^{21}$ Abu Talib Kalim, Diwan, Partaw Bayza'I, ed. (Tehran 1336 sh/1957) p. 373.

${ }^{22}$ Muhammad Amin Qazwini, or Amina-i Qazwini, Padshahnama, BL, ms. Or. 173, fol. 138a. 
domed bays flanked on each side by stairs leading up to the roof; in the center is a mihrab. Since Shah Jahan had originally no congregational mosques built in his palaces (the Moti Masjid of the Agra Fort was constructed only towards the end of his reign), it appears that the audience courtyard was also used as a mosque courtyard. The narrow arcaded galleries surrounding the Sahn-i Khass-u- 'Amm corresponded in shape and designation to those of mosque courtyards of the period (cf. Figs. 4 and 10). It is significant that the Jharoka of the audience hall in the east and the mihrab of the prayer hall in the west were set on the same axis (Figs. $4 \mathrm{a}$ and c). With regard to form and content, the whole arrangement conformed to the concept of qarina ("counter image") which was the governing principle of planning in Shahjahani architecture and art. Here it had to express that the Jharoka marked the emperor's own qibla as opposed to that oriented to Mecca. The imperial qibla was the east because it related to the sun rulership of Shah Jahan; the Jharoka-i Khass-u-'Amm where the emperor presented himself before the eyes of his subjects was perceived as the 'rising place of the sun of the sky of the empire and caliphate (matla' -i khurshid-i asman-i dawlat wa khilafat). ${ }^{23}$

The parallels between audience hall and mosque are all the more noteworthy, since Shah Jahan originally had no congregational mosques built in his palaces; the Moti Masjid of the Agra Fort was constructed only in 1647-53 (Figs. 10, 11). It is of special interest in our context that the Moti Masjid represents the grandest expression of a type of Shahjahani mosques which can be traced back formally to the same source as the audience halls, namely, the Patthar Masjid at Srinagar (Fig. 9). Like that of the audience halls, its plan is based on a grid system of bays. But in contrast to the audience halls, the central nave of these mosques which leads to the mihrab is not wider than the aisles flanking it. In the Moti Masjid of the Agra Fort this idea is pushed even further in that the nave leading to the mihrab is minimized by a shift of axis. The main axis is here the one parallel to the qibla wall and not the one perpendicular to it. This is obvious from the treatment of the aisles. It is the central aisle parallel to the qibla wall which is wider and emphasized, in addition, by the insertion of three

${ }^{23}$ I am studying the sun rulership of Shah Jahan and its European connections. See Koch, 'The Hierarchical Principles of Shah-Jahani Painting', p. 160; cf. Necipoğlu, 'Framing the Gaze', p. 317. 


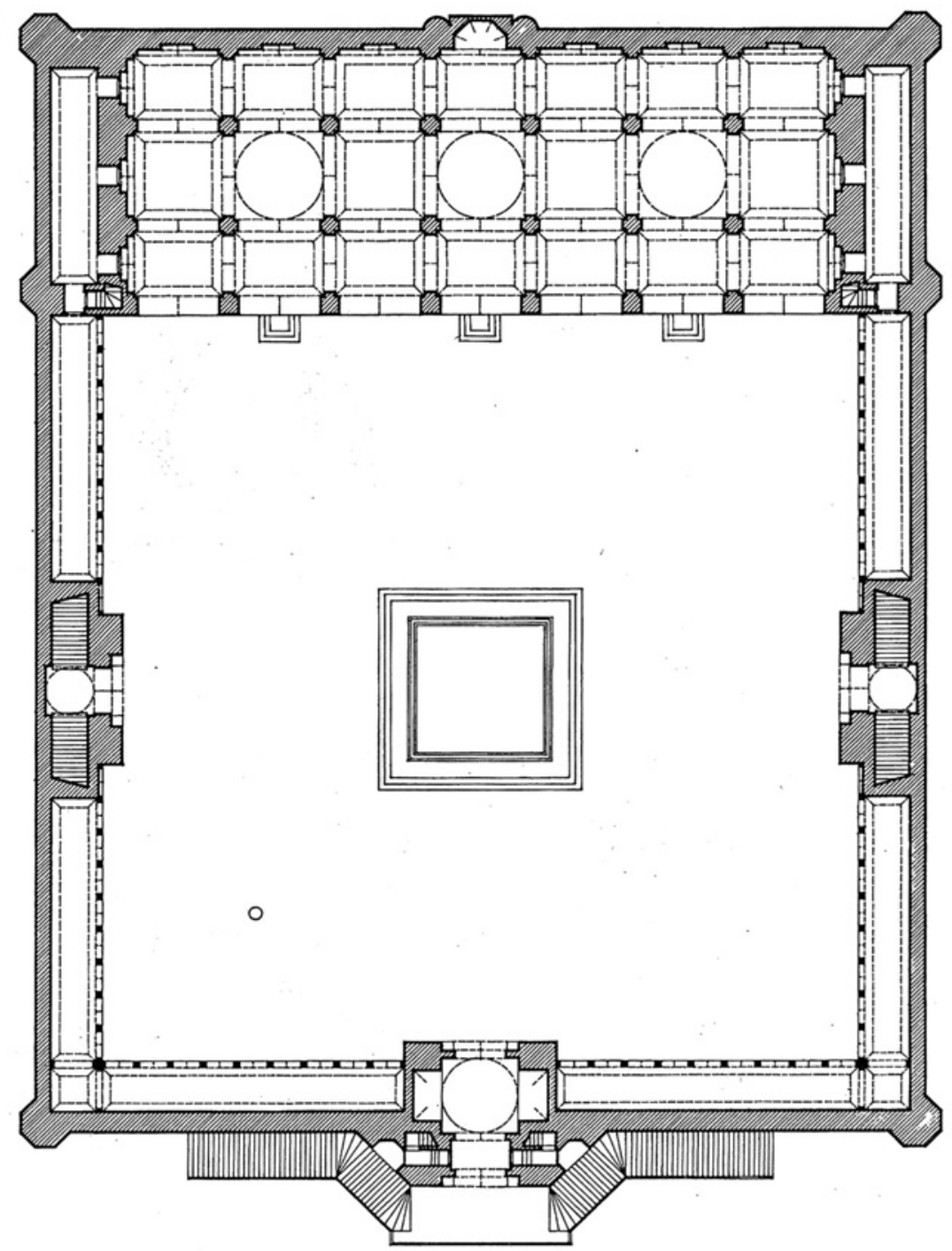

Figure 10. Main-floor plan of the Moti Masjid, Agra Fort, 1647-53 (Drawing: R.A. Barraud and E. Koch). 


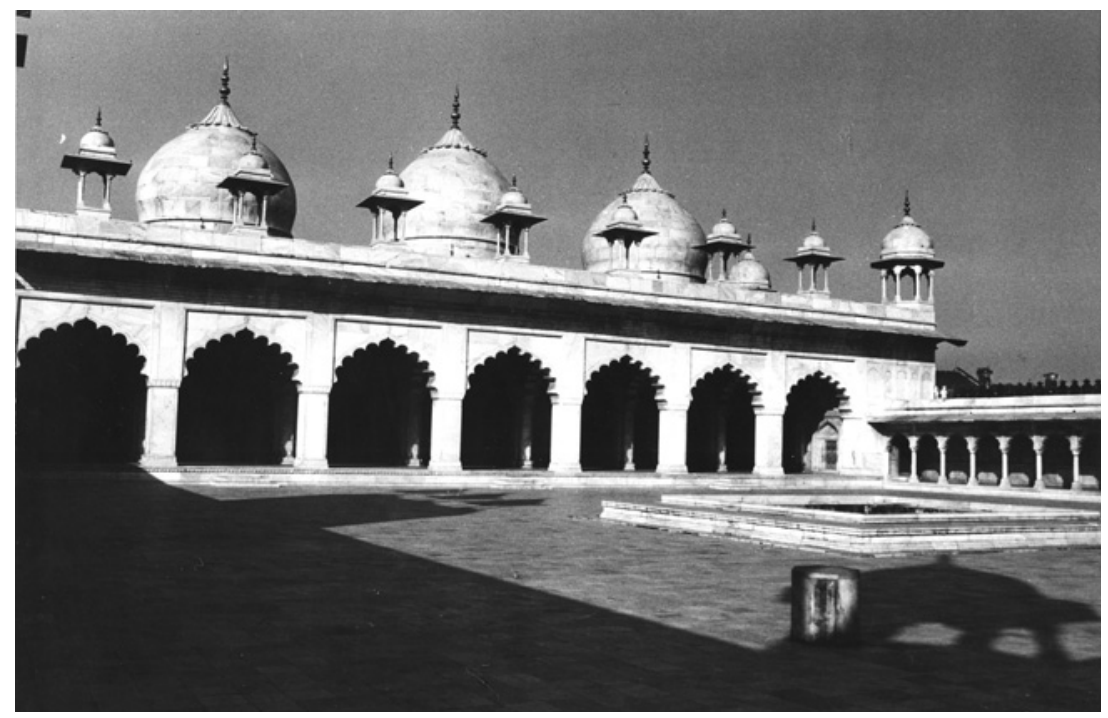

Figure 11. Facade of the prayer hall, Moti Masjid, Agra Fort (Photo Ebba Koch).

domes which alternate with the coved ceilings, used otherwise-as in the audience halls-as covering for the bays. On the outside, this orientation is highlighted by three outer domes set above the inner ones. The Shahjahani mosques with a special royal connotation had to cede their most highly charged symbolic feature, namely, the wider central mihrab nave, to the palatial audience halls.

These connections between mosque and audience hall take us back to the earliest period of Islamic architecture, much debated to the present day. Shah Jahan's audience halls support, in reverse and retrospect, over time and space, the hypothesis of Jean Sauvaget who in 1947 suggested that the mihrab and the axial nave of the earliest Umayyad mosques, such as the great mosque of Damascus (706) were borrowings from the palace: they 'emphasize[d] the area reserved to the prince, and imitated a palace throne room. ${ }^{24}$ In other words, the

${ }^{24}$ Jean Sauvaget, La mosquee omeyyade de Medine: Etude sur les origins architecturales de la mosquee et de la basilique (Paris 1947); English translation 'The Mosque and the Palace', in: Jonathan M. Bloom ed., Early Islamic Art and Architecture (Aldershot Hampshire 2002) pp. 109-147. 
early mosques were enhanced with a feature of worldly authority, which acquired over the centuries a purely religious meaning. ${ }^{25}$

One wonders whether and how the Mughals knew about these early connections between mosque and audience halls; what they certainly knew was that the pillared audience halls of Chihil Sutun-Persepolis evoked in the Islamic traditions associations with mosques. The early Arab geographers of the 10th century who were certainly read at the Mughal court had described it as masjid-i Sulayman. In this context the reason given by Shah Jahan's court historians for the construction of the Diwan-i 'Amms - to protect the emperor's courtiers from sun and rain-acquires a new meaning. The passage seems to have to do less with a genuine concern of Shah Jahan but rather with a literary trope, namely of the reason given by Arab sources for the construction of the first mosque of Islam, taken to be a covered hall of palm trunks supporting a roof of woven palm branches and mud in the prophet Muhammad's house at Medina, to protect his followers from the sun. ${ }^{26}$ And we remember also, that the pillars of the Agra hall were seen by Kalim poetically as cypresses, as trees. One of the fascinating aspects of the Mughals is their historicity and that they preferred to actualize for the construction of their identity as rulers themes from the past which had multiple meanings, which could cover more than one aspect of their self-propagated image. It seems thus quite possible that Shah Jahan (or whoever advised him) undertook his reconstruction of the royal halls of Persepolis with an eye on the prophet Muhammad, sheltering, like him, his followers with an hypostyle-pillared hall patterned on a mosque.

In any case, Shah Jahan's claim to unite, as a universal ruler, spiritual and political authority could not have been given clearer architectural expression. The Mughal emperor, as heir to the Persian kings and a second Solomon, held audience in a pillared hall where he appeared

${ }^{25}$ Cf. Robert Hillenbrand, Islamic architecture: form, function and meaning (Edinburgh 1994) p. 16, for an assessment of the mutual influence between mosque and palace in the early period of Islamic architecture that "each building type received an added charge from the other".

${ }^{26}$ See L. Caetani, Annali dell' Islam vol. 1 (Milan 1905) p. 377; see also Robert Hillenbrand, Islamic Architecture (Edinburgh 1994) p. 40. J. Johns, 'The "House of the Prophet" and the Concept of the Mosque', in: Bayt al-Maqdis, Jerusalem and Early Islam, Oxford Studies in Islamic Art, vol. IX, part 2 (Oxford 1999) pp. 59-112, questioned in thorough investigation the archaeological and historical probability of the tradition of long standing that the origin of the mosque was in the house of the prophet but does not dispute the reason for its construction as a protection from the sun. 
(like a Hindu idol) in a jharoka, positioned in the hall like a mihrab, to symbolize that he was the qibla of his subjects and al-zill Allah, or the Shadow of God on Earth. In his last audience hall at Delhi, Shah Jahan's claim was reinforced by a spectacular realisation of the Jharoka, which formally stands for the mihrab. It was given the shape of a huge Solomonic throne, with its characteristic components, namely supports in the form of artificial trees, with birds and lions on the niche behind it. They were expressed in Florentine and Mughal commesso di pietre dure, or inlay with semi-precious stones, topped by the image of the beast-charming Orpheus, who symbolizes the Solomonic justice of Shah Jahan. ${ }^{27}$

Shah Jahan's audience hall emerges as an ingenious and creative historical reconstruction which transforms a vague numerical concept into the purposeful logic of a building, planned perfectly as a manifesto of the emperor's rule. But then, who after all would have ever believed in the first place that Shah Jahan's audience halls were constructed merely as a shelter against sun and rain?

${ }^{27}$ Ebba Koch, Shah Jahan and Orpheus: The Pietre Dure Decoration and the Programme of the Throne in the Hall of Public Audiences at the Red Fort of Delhi (Graz 1988). 


\title{
ROYAL WEDDINGS AND THE GRAND VEZIRATE: INSTITUTIONAL AND SYMBOLIC CHANGE IN THE EARLY EIGHTEENTH CENTURY
}

\author{
Tülay Artan
}

A city is never neutral: the urban fabric is a device for tracking, measuring, controlling, and predicting behaviour over space and time," writes Donald Preziosi in his Introduction to a commendable compilation on The Ottoman City and Its Parts. "Ideology and urban structure are not external to each other," he continues: Cities and their parts do not just "exemplify, embody, and express, but at the same time enforce, perpetuate, and engender relations of power. ${ }^{1}$

A case in point is the intricate relationship that evolved over the first quarter of the 18th century between the Ottoman court and the urban space of the capital. Around this time, there emerged (or re-emerged) a specific variety of court festival which, at least in part, was played out on the streets and squares of İstanbul. This came after a long 17thcentury crisis had entailed a break with previous Ottoman rites of power in the shape that they had assumed in the 16th century. Hence the early 18 th-century practices represented both a return to the past and something new, with their innovative side being introduced, as would seem to be the case with all such moments of "the invention of tradition," under the guise of conformity with ancient law and custom (kanûn-ı kadìm). Thus it was not altogether new for royal princesses to be married off to high-ranking dignitaries, or for their weddings to be organised on a vast and sumptuous scale. ${ }^{2}$ But first, such ostentatious

${ }^{1}$ Donald Preziosi, 'The Mechanisms of Urban Meaning', in: The Ottoman City and Its Parts, I.A. Bierman, R.A. Abou-el-Haj and D. Preziosi, eds. (New York 1991) p. 5 .

${ }^{2} 16$ th- and 17 th-century marriage celebrations and processions are narrated briefly in period chronicles. One interesting account is that of Grand Vezir İbrahim Pasha's marriage to the grand-daughter of a by-then deceased prominent political figure. It was celebrated over several weeks, starting in May 1524 and the Hippodrome thus became a new ceremonial stage. Despite repeated assertations in modern scholarship that the bride was a sister of Süleyman I, two new challenges were necently raised to this assertion. Compare: Ebru Turan, The Sultan's Favourite: Ibrahim Pasha and the Making of the Ottoman Universal Sovereignty in the Reign of Sultan Süleyman (1516-1526), unpub. PhD Diss., Chicago University (Chicago 2007) pp. 137-139 and 
weddings had fallen into social neglect and disuse for a hundred years or so (except for a single occasion in 1675 , and then not in İstanbul but Edirne). Second, when and as they appeared to be revived, they came to be organised not just on a vaster scale than in earlier periods, but also in a qualitatively new way that spread and expanded beyond the confines of the Topkapi and other, lesser palaces in the historical peninsula. Linking these palaces together, urban centers and public thoroughfares evolved into the stage and decor of the pageantries. Paramount in this regard were processions bearing (a) betrothal tokens (alay-ı nişân), (b) trousseaus (alay-ı cihâzz), and (c) the brides themselves (alay-ı arûs), all of which now achieved a degree of visibility that was much more accessible to, and consumable by, the populace.

Our evidence for these processions and other celebrations comes mostly from various histories, annals or chronicles, as well as festival books called sûrnâmes in Ottoman Turkish. ${ }^{3}$ Early in the 18th century, at least some of these manuscripts came to mention the weddings of royal princesses more frequently and in relatively greater detail. This is significant in itself, and is the court narrative counterpart to the enhanced visibility mentioned above. Nevertheless, it is to a specific sûrname that we must turn for truly comprehensive coverage: one in the Nationalbibliothek in Vienna that sheds light on the triple wedding organised by the powerful grand vezir (Nevşehirli) Damad Ibrahim Pasha for three of Ahmed III's (r. 1703-1730) many daughters in

210-223, and Zeynep Yelçe, 'Evaluating Three Imperial Festivals: 1524, 1530, 1539', in: Celebration, Entertainment and Theater in the Ottoman World, Suraiya Faroqhi and Arzu Öztürkmen, eds. (forthcoming).

${ }^{3}$ For an exhaustive bibliography on the 18th-century sûrnâmes: Hatice Aynur, The Wedding Ceremony of Saliha Sultan: 1834, 2 vols (Duxburry 1995) pp. 2-5. For various documents, archival and narrative, on the marriage ceremonies during the reign of Ahmed III: M. Çağatay Uluçay, 'Beş Yaşında İken Nikâhlanan ve Beşikte Nişânlanna Sultanlar', Yeni Tarih Dergisi I (1957) pp. 103-107; idem, 'Fatma ve Safiye Sultanların Düğünlerine Ait Bir Araştırma', İstanbul Enstitüsü Mecmuası IV (1958) pp. 139-148; Mehmet Arslan, 'III. Ahmed'in Kızı Fatma Sultan'ın Düğünü Üzerine Bir Belge', in: Osmanl Makaleleri. Edebiyat, Tarih, Kültür (İstanbul 2000) pp. 527-552; idem, 'II. Mustafa'nın Kızları Ayșe Sultan ve Emine Sultan'ın Düğünleri Üzerine Bir Belge', in: Osmanl Makaleleri, pp. 553-566; idem, 'II. Mustafa'nın Kızı Safiye Sultan'ın Düğünü Üzerine Bir Belge', in Osmanl Makaleleri, pp. 567-574. For a transcription, translation and a facsimile of the 1720 festival: Mertol Tulum, 'Çeviri Yazılı Metin', in: Sûrnâme. III. Ahmed'in Düğün Kitabı (Bern 2000) pp. 221-308. For a textual analysis, critical edition and facsimile of a 19th-century marriage ceremony: Aynur, The Wedding Ceremony of Saliha Sultan. 
early $1724 .{ }^{4}$ This was when Hadice (1710-1738), 'Atîke (1712-1737), and Ümmügülsüm (1708-1732) were married: the first to a prominent provincial governor (Hafiz Ahmed Pasha), the son of a distinguished vezir, a royal-damad and a close companion of the current grand vezir; ${ }^{5}$ the second and third, more significantly, to a son (Genç Mehmed Pasha) and a nephew (Tevkîî il Ali Pasha) of the said Damad Ibrahim Pasha. ${ }^{6}$

The celebrations, lasting from 20 February to 16 March, comprised not only many indoor activities (situated in the Topkapı Palace as well as the three palaces allocated to the royal brides in question), but also a total of nine imperial processions, meaning three each of alay-ı nişân, alay-ı cihâz, and alay-ı arûs. By tracing the routes they took through the Imperial Gate (Bâb-ı Hümâyûn) to their ultimate destinations, I will be arguing that they were not only court festivals but at least partly in the nature of an invented tradition of urban festivities, too, even if they did not grow from below, from a point of origin located in popular culture. Moreover, I shall be showing that these processions became part and parcel of the grand vezir's designs to gain public recognition, acclaim and approval. This had to do with the way they were centered on the ancient Hippodrome (called Atmeydan in literal translation). As they were made to move in and out of this single most urban core of the Ottoman capital, the grand vezir's palace and household were

${ }^{4}$ Österreichische National Bibliothek (Vienna), Codex Vindobonensis Palatinus HO 95: G. Flügel, Die arabischen, persischen und türkischen Handscriften der Kaiserlichköniglichen Hofbibliothek zu Wien, vol. 2 (Vienna 1865) p. 289.

5 At the time, Hafiz Ahmed Pasha was the governor of Sayda. He was the son of Çerkes Küçük (Sinek) (Silâhdâr) Osman Pasha (d. 1727), then the governor of Damascus, who himself had married a princess in 1720. According to the French Ambassador Marquie de Bonnac, Osman Pasha was an intimate friend of the grand vezir: M. Charles Schefer, Mémoire historique sur l'Ambassade de France a Constantinople. Par le Marquie de Bonnac. Publié avec un précis de ses négociations a la porte ottomane (Paris 1894) p. xxix. There is some confusion in the secondary literature regarding (Küçük) Sinek Osman Pasha himself being married to a princess. Mehmed Süreyya noted that he was engaged to Emetullâh Sultan, a daughter of Mustafa II: Mehmed Süreyya, Sicill-i Osmani 4, Nuri Akbayar, ed. (İstanbul 1996) p. 1307. But Osman Pasha who married Emetullâh Sultan in 1720 was actually Sirke Osman Pasha (d. 1723), originally from Kanije: Süreyya, Sicill-i Osmanî 4, p. 1308. For the 1720 marriage: Mehmed Râşid/İsmâil 'Âsım Küçükçelebizâde, Tarih-i Râşid / Tarih-i İsmail 'Âsım Küçükçelebizâde V (İstanbul, 1282 [1865]) p. 225. See also: İsmail Hakkı Uzunçarşıllı, Osmanlı Devletinin Merkez ve Bahriye Teşkilatı (Ankara 1988 [1948]) p. 250ff; for the brides: M. Çağatay Uluçay, Padişahların Kadınları ve Kizları (Ankara 1980) p. 78.

${ }^{6}$ Mehmed Râşid, Tarih-i Râşid V, pp. 90-92, 97-101. 
also put on display, and loom large in connection with these processions. Hence I will also be revisiting some long-standing convictions regarding the separation of the grand vezir's office from the imperial household.

\section{Ottoman Royal Marriages in the 15th and Early 16th Centuries}

Before that, however, something needs to be said about the previous history of Ottoman royal marriages within the framework of dynastic structures and procedures in general. As with all other social institutions or practices, there was no such thing as a single type or model of royal marriage that remained static over time. On the contrary: the sultans' own marriage policies were constantly undergoing change and evolution in the context of all the different power configurations that kept emerging and receding within and around Ottoman society-and so were policies and practices regarding the female members of the House of Osman, including their prospective bridegrooms, and the rituals and ceremonies that crowned their marriages. In other words, it was nothing new for a role to be found for princesses in this tangled web of matrimonial alliances; rather, it was the specific definition of this role and function that would be the subject of fresh codifications from around 1700 onwards.

Much earlier, in a formative phase when the leaders of the small but rising emirate had not yet been led or constrained to take only slave consorts for themselves, the various princes (and their mothers coming from dynasties of more or less equal stature with the Ottomans) had to some extent shared power with the sultan. Similarly, Ottoman princesses for their part had usually been married to the sons of these dynasties, as well as to influential statesmen (or their offspring) who in one way or another had gathered around the House of Osman. Such practices had not simply ceased to exist with the conquest of Constantinople and Mehmed II's relative "despotisation of the sultanate," as evidenced by some of the matrimonial alliances arranged for and through the sons and daughters of Bayezid II (r. 1481-1512).

In time, however, the Ottomans did find themselves standing alone in a space they had largely cleared of all possible rivals, and the previous custom of marrying their princesses to princes of comparable dynasties was gradually abandoned. Instead, in the 16th century even greater importance came to be attached to sultans' daughters in terms 
of ensuring the support of the highest-ranking office holders like grand vezirs and grand admirals. Starting with Selim I (r. 1512-20), these frequent marriages of Ottoman princesses to a succession of appointees of vezirial rank functioned as a way of coopting "established stars" amongst the top office holders-even though the designated husbands in question were rather old, and were likely to be replaced by men of more or less the same generation. ${ }^{7}$ For if the chosen bridegroom was killed or else died of natural causes (though people did not frequently die of old age in those days), the princess in question would be married off to another top dignitary regardless of her or his age.

In any case, like royal births and circumcisions, these weddings were celebrated through parades and other spectacles designed for public consumption-as well as acrobatic performances, sporting competitions, theatrical shows, nightly entertainments and stately banquets that all took place in the privacy of the imperial palace. There is, however, a paradox, in that in stark contrast to all these massive celebrations and festivities, at least part of which were very much in the public eye, the same royal marriages, including especially the names of the royal women who were being married off, went unrecorded and unreported in period chronicles. Princesses' marriages were private, family affairs. In 1539, for example, a famous circumcision festival was organized for the sons of Süleyman I. Simultaneously, Süleyman I gave his only daughter Mihrümah in marriage to Rüstem Pasha. ${ }^{8}$ Strikingly, Celâlzâde, Solakzâde or Peçevi all wax eloquent on the

\footnotetext{
7 It is curious to note that once, on 8 December 1515 , the sultan, angered by his vezirs at an Imperial Council meeting, ordered all princesses to be married. He was so furious that in the next eight days, he left for hunting and did not convene the Imperial Council: Şehr-i zilkade el-şerife, sene 921: "İkinci gününde divan olub Hüdavendigar vüzeraya münkesir olub ne mikdar dul șehzâde var ise ere virmek emr olundl. Badehu Hüdavendigar şikara süvar olub sekiz gün divan itmedi." Feridun Ahmed Bey, Münşeatü's-selatin, vol. 1, (İstanbul 1858). See note 16 below.

${ }^{8}$ Zeynep Yelçe quotes Hammer (b.3, v.5) who gives the information based on Nicolo Paruta's reports (DIEZ no.31 in Staatsbibliothek Berlin Preußischer Kulturbesitz). Paruta mentions that the wedding of the sultan's daughter and the circumcision of his sons were at the same time, and elsewhere that the sultan's daughter was married to Rüstem. In fact, such is the quasi-official silence in which it comes to be shrouded, that contemporary Venetian sources report that Rüstem Pasha has been married without saying to whom-a failure to mention Mihrümah Sultan which can only be explained by ignorance-while the much later Sicill-i Osmani goes astray in ascribing the wedding to 1543 , which again reflects the same silence and later ignorance: Süreyya, Sicill-i Osmani 5, p. 1402. See: Yelçe, 'Evaluating Three Imperial Festivals: 1524, 1530, 1539', (forthcoming).
} 
circumcision displays with the royal wedding being accorded no mention whatsoever.

What was subsequently expected of both the royal bride and her politically successful husband was that they should set up pious endowments so as to visibly channel funds into works of public faith and charity that would merge with and complement the efforts of the sultan himself in this regard. ${ }^{9}$ Such endowments and works, in other words, became material emblems of the alliance, the bonding between the ruler and the rest of his elite. In return, however, the sultan promised neither loyalty nor kinship. At the end of the day, being a royal in-law was no guarantee that anyone would be able to keep his head. And dynastic continuity through the female side of the Ottoman line was out of the question.

To this there corresponded a certain configuration of the capital city, and of the way the ruling house and the rest of the elite were inscribed into that urban space. The functions of early modern court cities and/or capitals basically included: attracting settlement and providing a habitat; embodying ideological, social and political control in space; creating venues for charity and worship; and fostering economic development. All these served, in turn, to underscore the power, the piety, and hence the legitimacy of the ruler. ${ }^{10}$ In the Ottoman capitals or court cities of Bursa, Edirne and İstanbul, these functions were institutionalized in and around, first, the royal palace, and second, great imperial socio-religious complexes at the center of each of which stood a major mosque. Both types and sets of buildings incorporated a specific siting, embodied a certain level of grandeur, and were invested with non-random signs and symbols of a royal, dynastic nature.

Architecture constituted a visual language of power accessible to the people. Thus both the Topkapi Palace at the tip of the historical peninsula, ${ }^{11}$ and the great socio-religious complexes on the hill-

9 Tülay Artan, 'Periods and Problems of Ottoman (Women's) Patronage on Via Egnatia', in: The Via Egnatia under Ottoman Rule 1380-1699, Elizabeth Zachariadou, ed. (Rethymnon 1996) pp. 19-43.

${ }^{10}$ Howard Crane, 'The Ottoman Sultan's Mosques. Icons of Imperial Legitimacy', in: The Ottoman City and Its Parts, I.A. Bierman, R.A. Abou-el-Haj and D. Preziosi, eds. (New York 1991) pp. 173-243.

${ }^{11}$ Gülru Necipoğlu, Architecture, Ceremonial, and Power. The Topkapi Palace in the Fifteenth and Sixteenth Centuries (Cambridge, Mass.; London 1991). See also: Gülru Necipoğlu, The Age of Sinan: The Architectural Culture in the Ottoman Empire (Princeton 2005). 
tops overlooking the Golden Horn, came to imprint so many dynastic manifestations on the face of the city, and hence also on the social memory of its inhabitants. ${ }^{12}$ Simultaneously, it was the imperial processions from the royal palace to one or the other of these great imperial mosques (on the occasion of royal visits to ancestral tombs, of a new sultan's ritual girding with a sacred sword, of triumphal re-entries at the conclusion of successful military campaigns, or of Friday prayers), that linked these imperial symbols to one another and placed the Ottoman ruler at center-stage in a carefully contrived theater of power. ${ }^{13}$

\section{Late-16th Century Problems of Legitimation and Changes in Dynastic Politics}

Later in the 16th century, for reasons and in ways that we can here only briefly outline, an enormous crisis engulfed the Ottoman empire. Because of the negative effects of the "paradox of empire", as well as the consequences of operating against stiffening European resistance, Ottoman armies found themselves no longer able to carry off rapid and decisive victories. In terms of dynastic politics the upshot was that it became increasingly risky for sultans to persist in leading from the front in quest of the sort of military-charismatic legitimacy achieved by the likes of Mehmed II, Selim I or Süleyman I. Simply put, the immediate successors of Süleyman I (r. 1520-1566), meaning Selim II, Murad III, and Mehmed III, stopped going on campaigns, and started delegating field command to their grand vezirs. Simultaneously, both urban and rural unrest assumed gigantic proportions. As the royal center weakened, the capital's political elite underwent a comprehensive factionalisation, with each rival group courting the support of the janissaries and the populace, who thereby became so unruly as to

\footnotetext{
12 Gülru Necipoğlu, 'The Süleymaniye Complex in İstanbul: An Interpretation', Muqarnas 3 (1985) pp. 92-118. See also:

${ }_{13}$ Gülru Necipoğlu, 'Dynastic Imprints on the Cityscape: The Collective Message of Imperial Funerary Mosque Complexes in İstanbul', in: İslâm Dünyasında Mezarlıklar ve Defin Gelenekleri (Ankara 1996) pp. 23-36; Cemal Kafadar, 'Eyüp'te Kılıç Kuşanma Törenleri', in: Eyüp: Dün / Bugün, Tülay Artan, ed. (İstanbul 1994) pp. 50-61; Nicolas Vatin, 'Aux origines du pèlerinage à Eyüp des sultans Ottomans', Turcica XXVII (1995) pp. 91-99; Mehmet İpşirli, 'Osmanlılarda Cuma Selamlığı (Halk-Hükümdar Münasebetleri Açısından Önemi)', in: Prof Dr. Bekir Kütükoğlu'na Armağan (İstanbul 1991) pp. 459-471.
} 
constantly threaten the throne, and to render a stable government and policy continuity virtually impossible.

In the provinces, large numbers of former peasants equipped with firearms (who at some point had been recruited into the army, and then had either deserted or been demobilized) swelled the ranks of Celâli rebels. For decades they roamed the countryside under leaders who kept circulating between a number of roles-such as being outlaws, entering the service of this or that local power-holder, emerging as local power-holders themselves, sometimes being coopted into imperial service and even into royal family, and then perhaps continuing in field command or relapsing into banditry, or even being executed. All this translated into a long period of abnormality that extended from the late-16th into the mid-17th century. Only from the late 1650s onwards did some semblance of order begin to be restored, in quite draconian fashion, under Köprülü Mehmed Pasha's strongman rule at the grand vezirate. At the very center or apex of power, this long period of abnormality was reflected in a massive break in dynastic structures and practices, including (i) relations between the sultan, the grand vezir, and other courtiers; (ii) the location of the court itself; (iii) royal marriages; and (iv) all kinds of rites, rituals or ceremonies of power. ${ }^{14}$

First, as already indicated, sultanic legitimacy could no longer be risked on the outcome of uncertain campaigns. Direct military leadership devolved more and more on their grand vezirs. A corollary was that these non-campaigning, or at best infrequently campaigning, sultans could not keep building imperial mosques and surrounding them with socio-religious complexes-since the right to build these was supposed to be earned only through major, personally led victories, and even to be supported at the material, financial level by the spoils of war. ${ }^{15}$ Thus from a certain point onward, there emerged a disparity between the further growth of the Topkapi Palace and the accumulation of mosque complexes punctuating the skyline. The first continued, but the second came to an end. More specifically, the imperial palace kept growing in an organic agglutinative way, with each sultan contributing a loggia of his own to symbolize his sovereignty

14 Tülay Artan, 'Was Edirne a Capital and a Royal Court in the Second Half of the 17th Century?', paper presented at the Voyvoda Caddesi Konuşmaları Series, 16 April 2003.

${ }^{15}$ Crane, 'Ottoman Sultan's Mosques', p. 204. 
and to commemorate his name as part of the royal residence. But this was a relatively private affair going on behind the perimeter walls of the palace. In contrast, the mosque and annexes of the Sultan Ahmed complex, completed in 1617, was to be the last imperial project of its kind-the last great public monument in the tradition of the "Classical Age" to be offered for quite some time to the residents of Istanbul. As the sultan's extensive parades through the city grew more and more risky, this complex, which stretched from one end to the other of the Hippodrome's longer eastern side, came to occupy a central role in all state ceremonies. The ceremonial Friday processions, too, came to be limited to visits to the Sultanahmed mosque.

Simultaneously, there appeared signs that now, it was personal legitimation through messages of dynastic durability that sultans were beginning to crave above all. Apart from the overall atmosphere of crisis and uncertainty, they may have had other, more special reasons to do so. No fewer than six sultans who succeeded one another in the first half of the 17th century were either mentally disturbed, or else very young when they were enthroned. This both resulted from the general crisis (in the form of palace coups and depositions), and fed into it (in the form of a certain lack of authority). A shift from primogeniture to seniority was proceeding in tortuous, ambiguous fashion, shot through as it was with vestiges of earlier practices that kept re-surfacing. For example, Murad IV (r. 1623-1641), probably motivated by his own fears of being deposed amidst all this instability, had all his brothers except one murdered at various times, stopping only when nobody was left except the clearly demented İbrahim. Such conditions can only have further impressed the rest of the elite with the potential fragility of the royal line. In any case, it is interesting to note that Murad IV, like his immediate predecessors Ahmed I and Osman II, visited Bursa to pray at the tombs of the early Ottoman sultans. Ahmed I is also said to have stopped at Gelibolu to pay his respects to the remains of Süleyman Şah and other martyrs and gazis believed to have led the way across the Dardanelles in the early waves of Ottoman expansion into Rumelia. This was something of a new phenomenon; it seems to indicate that in troubled times, the sultans took special care to show themselves associating with their illustrious and long-deceased ancestors, thereby underlining the direct line of continuity, hence legitimacy, between them.

Only a few of the princesses born in the last quarter of the 16th century continued to be married off to top-ranking statesmen. These 
were the daughters of the future Selim II (r. 1566-1575) who were given away by their grandfather Süleyman I. Later, marriage alliances were rarely made during the reign of the brides' fathers; and if their arranged marriage happened to fall in the succeeding reigns of their uncles, brothers or nephews, many ended up taking as their husbands lesser officials or courtiers below the rank of pasha. ${ }^{16}$ Among Murad III's (r. 1575-1594) own daughters, said to have been more than thirty at the time of his death, only two were married off to topranking statesmen during the reign of their father. Many died during the small-pox epidemic of 1595, and the rest were married off by their nephew Ahmed I. ${ }^{17}$ Neither did Mehmed III (r. 1594-1603) take any steps towards marrying off his sisters or daughters. In fact, his own daughters are hardly ever mentioned by name in the chronicles or in any other kind of documentation. ${ }^{18}$

It seems that somewhere during or after the reign of Ahmed I (r. 1603-1617), the role ascribed to royal princesses began to change yet again. This, once more, was part of the impact of the general crisis on the dynasty, or of the interaction or overlap between a social and a dynastic crisis. At this time, there must have been an extremely high rate of attrition and turnover within the ruling elite, with most people teetering much more precariously than usual between enjoying sultanic (or grand vezirial) grace one day, and being handed over to the

16 The Veliyyüddin telhis, which Rhodes Murphey claims to be an antecedent of Koçi Bey's treatise, includes a note on suitable husbands that should be found for each of the Sultan's daughters. "What the author implies here," says Murphey, "is that while the sultanas remained at court they were both a burden on the treasury and liable to interfere in matters of state": Rhodes Murphey, "The Veliyyüddin telhis: Notes on the Sources and Interrelations between Koçi Bey and Contemporary Writers of Advice to Kings', Belleten XLIII, 171 (July 1979) p. 549. Murphey goes on to give a similar quote from Hirz al-Mulûk, written between 1575 and 1579, which in general condemns Sokollu's practices (fol. 12a), Murphey, 'The Veliyyüddin telhis', p. 559: "lâzim olan dahi budur ki eğer kerime-i mu'âzeme ve eğer hemşire-i mufahhereleridir, aslen ve kat'en vüzerâya ve beylerbeylerine tevzi' buyurulmayup dört yüz bin beş yüz akçe hasslar ile sancağa mutasarrif bir namdâr bey'e tevzi' buyurulup, onun dahi sancağı serhâdd'da olmayup iç-illerde olup ber vech-i te'bid mutesarrıf ola."

17 No other Ottoman sultan seems to have had as many children as Murad who is said to have over a hundred sons only. Naturally many died very young. In addition to the 31 little coffins located at the tomb of their grandfather Selim II, 25 more were to be found in a tomb made specially for his offsprings.

${ }^{18}$ In Mehmed III's reign, only one of his sisters, Ayşe, was married for the second time in April 1602; the marriage was consummated in February 1603: Uluçay, Padişahların Kadınları ve Kizları, p. 47. Alderson who does not give the names of his daughters records four husbands for Mehmed III's daughters: Anthony D. Alderson, The Structure of the Ottoman Dynasty (Oxford 1956) Table XXXIII. 
executioner the next. This was probably true of the more established members of the bureaucracy as well as of a host of newcomers. In the capital, factions kept rising and falling, regrouping and being crushed. Meanwhile, as previously explained, the Celâli uprisings sweeping the provinces, as well as the attempts to suppress them, were throwing up, in complicated ways, fresh groups of provincial magnates, commonly known as eşraf and $a^{c} y \hat{a} n$, who were constantly forcing their way or being coopted into the ranks of Ottoman officialdom. Like moths and flies flocking to the light only to be burned by it, they were engaging in a very dangerous game when they allowed themselves to be seduced by promises of wealth and rank into accepting an amnesty, coming to the capital, assuming some high post or command, and perhaps even marrying a royal princess. To many it may have seemed like a fulfillment of their wildest dreams, but frequently it amounted to nothing other than putting their heads in the lion's mouth.

Those jaws did close often enough, particularly if the would-be dignitaries in question were seen to be far removed from their power bases and therefore isolated and vulnerable. And every time they closed and opened, they could have released a freshly widowed royal princess to be re-married to yet another adventurous provincial arriving with the next wave from Anatolia in this meat-grinder of Istanbuliote politics, or else yet another middling courtier (an ăga or a kethudâ) hoping against hope to better his chances of survival by grasping, clasping at the skirts of the House of Osman. Hence this rash of royal women being married off to all-comers, with some of them going through as many as a dozen marriages. There could be no question here of a few select, carefully arranged alliances; instead, just short-run reflexes would have prevailed on all sides, allowing no more than a day-to-day groping for survival. There could be no question, either, of major wedding ceremonies, for nobody could afford to make any great investment in marriages fashioned one day and destroyed the next. One could say that the unpredictable fluidity and mediocrity of these marriages (as well as of the corresponding wedding ceremonies) had come to reflect the general chaos and mediocritisation of these unsettled times.

\section{Marriage Alliances and Ottoman Protocol from the Mid-17th Century Onwards}

By the mid-17th century, however, a somewhat different pattern was emerging as at least some princesses began to be given in marriage 
to their father's boon companions (musahib). ${ }^{19}$ This may have been a reflection of the sultans' search for ways to break out of their loneliness, and to find or create fresh networks of close, dependable circles around them. ${ }^{20}$ A new kind of court society appeared to be taking shape, one provisionally dominated not so much by autonomously established grandees making their regular way up the Ottoman bureaucracy, as by courtiers jostling around the sultan. This may also be why most princesses continued to get relatively minor courtiers as their husbands. Meanwhile, these early- or mid-17th-century sultans continued to shy away from public displays of imperial power. They included even Murad IV, who was relatively fortunate in having achieved a few military victories. All fell short of commissioning imperial mosque complexes or even Books of Kings (şahnâmes) in their own name-the two most outstanding symbols of personal rule. They also fell short of patronizing dynastic ceremonies, such as celebrations of royal births, circumcisions, or marriages.

At around this time, a drastic step was taken, probably by Köprülü Mehmed Pasha, in removing the very young Mehmed IV (r. 16481687) from the capital. Istanbul had become too unsafe under the double impact of internal sedition and the external menace posed by the Venetians blockading the Dardanelles (and even establishing themselves, albeit temporarily, on Limnos and Tenedos). ${ }^{21}$ Entrusted with extraordinary powers, the old grand vezir may also have wished to render the sultan inaccessible to any and all rival factions prior to cracking down on the latter. But in any case, by the second half of the 17 th century the court had settled in Edirne, which then functioned

19 This seems to have begun with Murad IV. He wanted to marry Kaya Sultan to his sword-bearer, Silâhdâr Mustafa Pasha, but upon the opposition of the Grand Vezir Kara Mustafa Pasha, Kaya was married to Melek Ahmed Pasha. It seems that it was the need to control and guide the mentally disordered İbrahim that led to the incorporation of those favourites who guarded him into the royal family. Thus all three surviving daughters were married to his boon-companions (musahib) when they were toddlers: Fatma's (b.1642) husbands were her father's best man (she was first married to Musahib Yusuf Pasha in 1645; and upon his death to Musahib Fazlı Pasha in 1646); Gevher(han) (b. 1642) was married to another favourite of İbrahim, Musahib Cafer Pasha in 1646); Beyhan (b. 1646) was married to then grand vezir Hazerpare Ahmed Pasha (1647) who, although, not a musahib at the time of the marriage, was certainly a favourite. See: Uluçay, Padişahların Kadınları ve Kızları, pp. 54-65.

${ }^{20}$ For similar needs (and more) see: J.H. Elliot and L.W.B. Brockliss, The World of the Favourite (New Haven; London 1999).

${ }^{21}$ Metin Kunt, The Köprülü Years: 1656-1661, unpub. PhD Diss., Princeton University (Princeton 1971) pp. 14-21. 
as the de facto seat of government for nearly half a century-without ever stripping Istanbul of its status and privileges as the official capital of the Ottoman empire.

During the long sojourn of the Ottoman court (and part of the state) in Edirne, the sultans seem to have taken a break not only from the military-charismatic mode of leadership of the 14th, 15th and 16th centuries, but also from assiduously cultivating the basic attributes or manifestations of the ideal of Islamic kingship, such as religiosity, justice, wisdom, permanence, devotion to learning, charity and benevolence. Instead, what we see is an emphasis on the continuity of the Ottoman dynasty. Thus Mehmed IV, following in the footsteps of Ahmed I and his direct successors (except for the mentally unfit Mustafa and İbrahim), chose Bursa as his destination on his very first trip out of Istanbul (and before he took up near-permanent residence in Edirne), during which he also made the same rounds of martyrs' and gazis' tombs at or near Gelibolu. ${ }^{22}$ This was not all, however. To this new mode of legitimation in the making, Mehmed IV added a few elements of his own, for example by using the opportunities provided by the military victories (achieved or expected) of his grand vezirs of the Köprülü family to commission both a novel genre of royal chronicle (vekâyi-nâme, commissioned in 1663 after the conquest of Uyvar), ${ }^{23}$ and a conforming dynastic genealogy (silsilenâme, commissioned on the eve of the Vienna campaign in 1683). ${ }^{24}$ The timing of the circumcision of his two sons, as well as the simultaneous marriage of his elder daughter to his boon companion (in 1675), captured for posterity in several sûrnâmes, ${ }^{25}$ roughly coincided with the military

\footnotetext{
${ }^{22}$ For tomb visits in the vicinity of Edirne: Fahri Çetin Derin, Abdurrahman Abdi Paşa Vekâyi'-nâme [Osmanlı Târihi (1648-1682) (İstanbul 2008) p. 139 (fol. 45a).

${ }^{23}$ For the development of the vekâyi'nâme genre: Rhodes Murphey, 'Ottoman Historical Writing in the Seventeenth Century: A Survey of the General Development of the Genre After the Reign of Sultan Ahmed I (1603-1617)', Archivium Ottomanicum XIII, Tibor Halasi-Kun Memorial Volume (1993-4) pp. 277-311. For the 1663 Austrian campaign, the conquest of Uyvar (13 September): Tarih-i Sultan Mehmed Han (Bin) İbrahim Han see: Topkapı Sarayı Müzesi Kütüphanesi R. 1308.

${ }^{24}$ Hans Georg Majer, 'Gold, Silber und Farbe. Musavvir Hüseyin, ein Meister der osmanischen Miniaturmalarei des späten 17. Jahrhunderts', in: Studies in Ottoman Social and Economic Life/Studien zu Wirtschaft und Gesellschaft im Osmanischen Reich, Proceedings of the VII. Internationaler Kongress für Osmanische Wirtschafts und Sozialgeschichte (1300-1920), Heidelberg, 25-29 July, 1995 (Heidelberg 1999) pp. $9-42$.

${ }_{25}$ Asl Göksel, The Surname of Abdi, unpub. MA Thesis, Bosphorus University (İstanbul 1983). For a treatment of the 1675 festival: Özdemir Nutku, IV. Mehmed'in Edirne Şenliği (Ankara 1987).
} 
triumph at Kamaniçe in 1672 . This also happened to be the campaign in which an Ottoman sultan took personal command of the army after a long interruption-and also the first and only campaign personally led by Mehmed IV. ${ }^{26}$ In 1676, a practical manual-called a law code (kânûnnâme) - setting out rules for promotions, and describing hierarchies and ranks for ceremonies ${ }^{27}$ was promulgated, followed in 1687 by a more extensive and elaborate code on all such administrative practices. $^{28}$

The authors of these works were experienced state officials. They took care to describe the state of affairs before Mehmed IV came to power, and thence to note the need to re-define state protocol. ${ }^{29} \mathrm{In}$ other words, Mehmed IV committed himself to a book of imperial festivities, a dynastic genealogy, and new codes of law-all of which were basic sources or emblems of legitimacy-only when he felt assured of the strength and durability of the House of Osman. ${ }^{30}$ In the meantime, the mundane doings of the sultan kept being chronicled, in yet another invention of tradition which was meant as an interim display of the sultanic presence. Altogether, while "a preoccupation with the health of the monarch and longevity of the dynasty was reflected in the tendency to provide detailed accounts of births, deaths, and marriages of persons related to the royal house" in Ottoman historical

${ }^{26}$ For an account of the campaign parade: Antoine Galland, İstanbul'a Ait Günlük Hatıralar (1672-1673), Charles Schefer, ed., Nahid Sırrı Örik, trans. (Ankara 1987 [1949]) vol. 1, pp. 114-130.

${ }_{27}$ Tevkîîi (Nişâncı) Abdurrahman Paşa, 'Osmanlı Kanunnameleri', Millî Tetebbu'lar Mecmû'ası 1, 3 (İstanbul 1331 [1916]) pp. 497-544.

${ }^{28}$ Hezarfen Hüseyin Efendi, Telhîsü'l-Beyân fî Kavânîn-i Âl-i Osman, Sevim İlgürel, ed. (Ankara 1998). It is mistakenly dated to 1675. Actually, the latest date recorded in the Telhisü'l-Beyân is 1686. Hezarfen correctly records the dismissal of Şeyhü'l-islâm Çatalcalı Ali Efendi on 27 September 1686 and names his successor Ankaravî Mehmed Emin Efendi as the final note on the section on the şeyhü'l-islâms. Mehmed Emin Efendi died on 2 November 1687 when he was still in office.

${ }_{29}$ The office of protocol started to function as a separate unit at around this time. Abdurrahman Pasha himself mentioned in several places the necessity and obligation for the state protocol that was forgotton in Mehmed IV's reign. Hezarfen, on the other hand, stressed his gentle criticisms here and there regarding the current sultan and his reign even more by devoting a large space to the circumcision of the two princes and the marriage of the two princesses towards the end of his manuscript. While the task was given to Abdurrahman Pasha by the grand vezir Mustafa Pasha, Hezarfen seems to have written his manuscript on his own initiative. It is possible that he received a commission, possibly from a foreigner-and most probably from Antoine Galland.

${ }^{30}$ Pal Fodor, 'Sultan, Imperial Council, Grand Vizier: Changes in the Ottoman Ruling Elite and the Formation of the Grand Vizieral Telhis', Acta Orientalia Academiae Scientiarum Hungaricae Tomus XLVII, 1-2 (1994) p. 70. 
writing, ${ }^{31}$ visits to ancestral tombs, participation in imperial campaigns, celebrations of dynastic rites of passages were also intended to convey broader messages about the enduring power and endurance of the House of Osman.

Mehmed IV was succeeded by two rather weary brothers both of whom reigned only briefly, but his elder son Mustafa II, who after a long wait finally took over in 1695 , was also keen to invest in public manifestations of dynastic permanence. Mustafa II seems to have been bent on formally re-instating Edirne as the capital and the abode of the imperial court. At the same time, he appears to have tried to reformulate the accession ceremonies of the sultanate. This is evidenced by the first Ottoman Book of Ceremonies that has come down to us, the Defter-i Teşrîfât of Mehmed bin Ahmed (Nî̀metî). ${ }^{32}$ Penned during the early years of Mustafa II's reign, it carefully distinguishes between the old and the new in this regard, including rites and ceremonies as they had been performed in İstanbul and were now to be performed in Edirne. Significantly, the master of protocol (teşrîfât tî or teşrîfâttçıbaşı) who authored this manual (and whose father Nî́metî Ahmed had served Mehmed IV in the same capacity for nearly three decades) attributes the search for both new designs and their conformity with kânûn-ı kadîm to the fertile mind of the sultan. Furthermore, the wedding ceremonies of royal princesses were now among the court rituals

\footnotetext{
${ }^{31}$ Murphey, 'Ottoman Historical Writing', p. 285. Contrary to Murphey's suggestion that all these features were found in Ottoman historical writing of all periods, the increase in detail and care to record the rites of passage of the royal women is striking especially towards the end of the 17th and throughout the 18th century.

${ }^{32}$ (Teşrîfâtîzâde) Mehmed bin Ahmed Efendi, Defter-i Teşrîfat, Süleymaniye Library Es'ad Efendi no. 2150 (80 folios); İstanbul University Library TY. 9810 (128 folios). Uzunçarșll ı made ample use of Nimetî (Ahmed) Efendi's "Kânûnnâme" (which apparently was in his private collection) in his seminal survey of Ottoman statecraft: Uzunçarşıll, Merkez ve Bahriye Teşkilâtı. For Ottoman ceremonies and protocol also see: Tevkîî ibdurrahman Paşa, 'Kanunnâme-i Âl-i Osman'; Ali Seydi Bey, Teşrîfat ve Teşkilatımız (İstanbul n.d.); Es’ad Efendi, Osmanlılarda Töre ve Törenler (Teşrîfât-ı Kadîme) (İstanbul 1979); İsmail Hakkı Uzunçarşıllı, 'Saltanat Şiarından Olan Bâzı Merasim ve Usul,' in: Osmanlı Devletinin Saray Teşkilatı (Ankara 1984 [1945]) pp. 184-224; Filiz Çalışkan/Karaca, Osmanlı Devleti'nde Teşrîfât Kalemi ve Teşrîfâtçıllk, unpub. MA Thesis, IUÜ Sosyal Bilimler Enstitüsü (İstanbul 1989); eadem, 'Defter-i teşrîfât', TDV İslâm Ansiklopedisi IX (1994) p. 94; eadem, Tanzimat Dönemi ve Sonrasında Osmanl Teşrîfat Müessesesi, unpub. PhD Diss., İÜ Sosyal Bilimler Enstitüsü (İstanbul 1997); Hakan T. Karateke, Das osmanische Hofzeremoniell im 19. Jahrhundert (Marburg 1998) translated Padişahım Çok Yaşa! Osmanlı Devletinin Son Yüzyllinda Merasimler (İstanbul 2004); idem, An Ottoman Protocol Register. Containing Ceremonies from 1736 to 1808: BEO Sadaret Defterleri 350 in Prime Ministry Ottoman State Archives, İstanbul (İstanbul; London 2007).
} 
described in detail by the master of protocol. This inclusion is remarkable also because Mustafa II is known to have acted quickly in assigning palaces, retinues and revenue sources to his numerous daughters born soon after his accession to the throne. ${ }^{33}$ At the same time, the sultan carefully arranged marriages for his infant daughters.

In the end, however, Mustafa II was not allowed to keep ruling in and from Edirne, and did not live to see his daughters' marriages. ${ }^{34} \mathrm{He}$ was forced to abdicate in 1703. His brother Ahmed III was enthroned and taken back to İstanbul only after he promised that he would reside there permanently and not try to leave for the provinces. Ensconced once more in the urban matrix of Istanbul, Ahmed III and his immediate successors set about reconstructing dynastic legitimation in the capital. This was the moment when the sultan turned yet again to the female members of the imperial family, and began to arrange marriages between his daughters (or daughters of Mustafa II) and promising members of his new court. Another pattern thus appeared, which was both old and new. After a hiatus of a century or so, once more there were repeated marriage celebrations that enlivened the capital. On the one hand, the sultan delegated power to princesses as partners in enhancing the dynasty's public profile. On the other hand, they for their part imparted a novel identity to a set of symbolic rituals in which they had been major actors only in the distant past. All this was in full conformity with the re-inscription of the court and the dynasty into the capital, and the re-legitimation of the post- 1703 sultanate in the wake of resettling in Istanbul.

\section{Reflections of a Festive Court in Early-18th Century İstanbul}

The 1724 processions were not a unique occasion. Instead, they constituted only one link, albeit a very important one, in a series of imperial

\footnotetext{
${ }^{33}$ Among the reasons for the disturbances that culminated in the 1703 upheaval, contemporary chroniclers like Fındıklılı Mehmed Ağa and Defterdâr Sarı Mehmed Pasha refer to the two palaces of equal size and splendour, modeled on the Old Palace in Istanbul, which were under construction for Ayşe and Safiye. Taken as an indication of the court's moving to Edirne, the rumour that the personnel of the Old Palace were going to be moved to these two palaces had caused considerable unrest in İstanbul. Mustafa II was dethroned in 1703 and the collective marriage ceremony that he was anticipating was cancelled.

${ }^{34}$ Rifa'at Ali Abou el-Haj, The 1703 Rebellion and the Structure of Ottoman Politics (İstanbul 1984).
} 
projects that were designed in the reign of Ahmed III to engender fresh images of dynastic power and permanence. As part of a subordinate enterprise of massively upgrading royal weddings and reinstating them as ceremonies at least partially accessible to the general public, there were several major royal weddings that were organised in the first quarter of the 18th century. Four princesses were married off by the sultan between 1708 and 1710. One was Ahmed III's firstborn, Fatma Sultan, and three were his then-deceased brother and predecessor Mustafa II's (r. 1695-1703) daughters who had already been betrothed during their father's reign. After an interval of ten years, nine more princesses were married off in triple ceremonies in 1720 , 1724, and 1728, including daughters of both Ahmed III and Mustafa II. There were numerous other royal marriages in this period which were neither lumped together nor celebrated with pomp and display. On the contrary, these were rather private, silent and humble observances. It appears that in all such cases it was the second, third or fourth marriages of the princesses in question. ${ }^{35}$

So the 1724 weddings did not stand alone. At the same time, it would be naive to claim that this entire course of events had already been charted back in 1703-08, or that there was a single blueprint adopted right from the outset which kept being repeated. Rather, we see Ahmed III and his counselors (including of course the key figure of Nevşehirli Damad İbrahim Pasha) nurturing a basic notion of what they wanted to do (probably in terms not far from those that I have used, i.e. offering grandiose ceremonies and spectacles to the public, and needing to upgrade royal weddings, too, to that end), and then groping their way towards their objective partly in a trial-and-error kind of way, and partly by studying the dynasty's past (but not entirely forgotten) rites of power. In other words, while embarking on projects aiming to bring back the grandeur of the capital, the sultan and his aides not only launched designs to empower the city with a new urban scheme and architecture, but also took a keen interest in the implantation of stately urban rituals, new processional routes, new festival

\footnotetext{
${ }^{35}$ Among those who were married in the same period for the second and third, even fourth times were Mustafa II's daughters: Emine marrying to Receb Pasha in 1712, İbrahim Pasha in 1724 and Abdullah Pasha in 1728; Ayșe marrying to Tezkereci İbrahim Pasha in 1720 and Koca Mustafa Pasha in 1725; and Safiye marrying to Mirzazâde Mehmed Pasha in 1726.
} 
grounds, and new ceremonial procedures. They were also becoming absorbed in recording such events.

The numerous sûrnâmes of this period had yet another function. In sharp contrast to the late-17th-century attempts to re-formulate the state protocol and ceremonies (in Edirne), witnessed by the treatises of Hezarfen Hüseyin Efendi, Abdurrahman Pasha, and Mehmed bin Ahmed (Nî́metî), the reign of Ahmed appears at first sight to have lacked a new book of protocol or ceremonies. ${ }^{36}$ However, the surviving sûrnâmes of the $1708,1709,1710$ and 1724 royal weddings did serve that purpose. The last named, replete with detailed codes of ceremonial attire and trappings, reflects not only a collective effort but also the personal initiative of Damad İbrahim Pasha. That they were trying out new strategies and also adapting to new circumstances is evident from the differences between the 1724 processions and those of 1708 , 1709 and 1710.

The Vienna sûrnâme requires an explanation vis-à-vis its dating. At the very beginning of the account, the main actors, including Ahmed III (d. 1736), Ümmügülsüm (d. 1732), Ali Pasha (d. 1732), Hadice (d. 1738), Ahmed Pasha (d. 1735), 'Atîke (d. 1737) are all referred to as deceased. Only Mehmed Pasha (d. 1768) was alive when the 1724 weddings were recorded. It seems that the Vienna sûrnâme, written in fine riqa script, was re-copied sometime in Mahmud I's reign, perhaps in preparation for the official chronicles of Mehmed Râşid/Küçük Çelebizâde and Subhî. Not only the quality of the manuscript, but also the fact that the text has no repeat reference to the main characters as deceased, suggests that the Vienna copy was a later rendering intended as a book of protocol.

\section{The (Re)invention of a Tradition}

In April 1708, the late Mustafa II's elder daughter Emine (born in 1696) was given in marriage to the then-grand vezir Çorlulu Ali Pasha. Emine had been betrothed to Ali when he was her father's

${ }^{36}$ A new Code of Law that is incorrectly attributed to the reign of Ahmed III is devoted solely to the issues of administration of land tenures. It is more likely to have been put together in the reign of Osman II, and copied both in 1706-7, and in 1798: Oğuz Ergene, III. Ahmet Dönemi Osmanlı Kanunnamesi (İnceleme, Meting, Dizin), unpub. MA Thesis, Mersin Üniversitesi (Mersin 1997). 
sword-bearer. ${ }^{37} \mathrm{~A}$ month after this sumptuous wedding, in May 1708, another daughter of Mustafa II, Ayşe Sultan (also born in 1696), was married to Fazll Mustafa's son Köprülüzâde Numan Pasha, then the governor of Belgrade, to whom she had remained betrothed since she was seven. In the first case, both Emine's trousseau and her marriage procession-i.e. two of the three key pageants-headed for the grand vezir's palace which was just across the road from the Kiosk of Processions (Alay Köşkü), a pavilion incorporated into the outside wall of the Topkapı Palace during the reign of Murad III (1574-1595) where sultans came to watch and enjoy parades. Both processions, led by top dignitaries, left from the Imperial Gate, passing by the Cebehâne (the Church of St Irene), the Bath of Ayasofya, and through the street called Soğukçeşme to reach the grand vezir's palace. It was quite a short and direct route for such sumptuous parades. ${ }^{38} \mathrm{~A}$ month later, after sending on her trousseau, Ayşe and her equally magnificent procession left for the Zeyrek palace that had been allocated to her. But instead of accompanying Ayşe Sultan all the way to Zeyrek, a neighbourhood to the northwest of the Valens Aqueduct, it seems that in this case, too, the dignitaries went only as far as the grand vezir's palace. From this point onwards, the more functional core of the procession, comprising the princess and her trousseau, was taken to the Zeyrek palace in a relatively quiet and unostentatious way. ${ }^{39}$

Ahmed III seems to have been quite taken with the splendour of the collective wedding of his two nieces. Next year, in May 1709, the sultan engaged his two year-old Ümmügülsüm to the vezir Abdurrahman Pasha, a loyal follower of the Köprülü family, ${ }^{40}$ and also married his

37 When Emine was five she was engaged to the governor of Damascus (Emîr-i Hac) Hasan Pasha: Defterdâr Sarı Mehmed Paşa, Zübde-i Vekâyiât. Tahlil ve Metin (10661116-1656-1704), Abdülkadir Özcan, ed. (Ankara 1995) p. 724. This engagement was anulled in 1701 and the same year she was engaged to (then Silâhdâr) Çorlulu Ali: Mehmed Râşid, Tarih-i Râşid II, p. 529.

${ }_{38}$ For the sûrnâme and a document recording the gifts see: TSM Library H. 1573/2 (late 18th century?) and TSM Archives, E. 962, respectively: Mehmet Arslan, 'II. Mustafa'nın Kızları Ayşe Sultan ve Emine Sultan'ın Düğünleri Üzerine Bir Belge', Revak Dergisi (Sivas 1996) pp. 60-70. See also: Mehmed Râşid, Tarih-i Râşid III, pp. 243-245; Silâhdâr Findıklılı Mehmed Ağa, Nusretnâme II/II, İsmet Parmaksızoğlu ed. (İstanbul 1962) pp. 243-244; Uşşâkizâde es-Seyyid İbrâhîm Hasîb Efendi, Uşşâkî̀âde Tarihi, Raşit Gündoğdu, ed. (İstanbul 2005) pp. 940-943; M. Çağatay Uluçay, Harem II (Ankara 1985) p. 100, Uluçay, Padişahların Kadınları ve Kızları, p. 76.

39 Mehmed Râşid, Tarih-i Râşid III, pp. 243-245.

40 Abdurrahman Pasha was the steward of Köprülüzâde Numan Pasha. He probably fell out of favour when Numan Pasha was dismissed from the grand vezirate in 1710 . 
four-year-old daughter Fatma to his own sword-bearer, the upwardly mobile Silâhdâr Ali Pasha. Once more the ceremony was exciting and engaging for İstanbuliotes. They first watched the transfer of Fatma's trousseau. Then, while the infant Ümmügülsüm stayed with her family, the child bride Fatma was formally taken to the waterfront palace of her grandmother at Bahariye (Valide Yalisl), further down from Eyüb, at the far end of the Golden Horn. The procession, again led by top dignitaries, left the Imperial Gate, passed through Soğukçeşme, and under the Alay Köşü̈, arrived outside the gate of the grand vezir's palace, turned and went uphill to Dîvânyolu (the Byzantine Mese). It then proceeded along this ceremonial route to reach Saraçhâne by way of Vezneciler, passed by the medrese of (Fatih) Sultan Mehmed and the Büyük Karaman Çarşusu, marched through Edirnekapı, went all the way through Otakçllar, and reached the Valide Yalısı. In a minor mishap, a group of attendants from the naval arsenal carrying nahils, that is to say, symbols of fertility and good fortune in the form of sugar gardens, could not make it through narrow streets as part of the procession. They stopped in the vicinity of the Şengül Hamamı (next to the grand vezir's palace), and brought the nahils after the evening prayers, probably by another route. ${ }^{41}$

Exactly a year later, in May 1710, it was the turn of Safiye Sultan, the third daughter of Mustafa II (also born in 1696), to be married. Betrothed at the same time as her sisters Emine and Ayşe, she had been waiting for her turn since 1703, and her fiancé was the son of Merzifonlu Kara Mustafa Pasha, known as Maktûlzâde Ali Pasha, and the governor of Adana at the time. This procession traveled only a short distance from the Imperial Gate (via Cebehâne and Soğukçeşme) to the princess's palace at Demirkap1, known as "Râmi Pasha's palace", where the marriage was consummated-despite the fact that the bridegroom still had several palaces of his own which he had inherited from his disgraced father. ${ }^{42}$ Soon afterwards, in June 1710 , the bridegroom

Abdullah Pasha then served as the chief treasurer (defterdâr) in the retinue of yet another Köprülü descendant, Abdullah Pasha, who was the second son of Köprülü Mehmed Pasha.

${ }^{41}$ TSM Archives D. 10590 (23 S 1121). Uşşâkizâde, Uş̧̧âkîzâde Tarihi, pp. 962, 972-4. See also: M. Çağatay Uluçay, 'Fatma ve Safiye Sultanların Dügünlerine Ait Bir Araştırma'; Mehmet Arslan, 'III. Ahmed'in Kızı Fatma Sultan'ın Düğünü Üzerine Önemli Bir Belge', Yedi İklim Dergisi 34 (1993) pp. 66-74.

${ }^{42}$ TSM Archives D. 10591 (2 RA 1122). See: Mehmet Arslan, 'II. Mustafa'nın Kızı Safiye Sultan'ın Düğünü Üzerine Önemli Bir Belge', Kızılırmak Dergisi 8 (1992) pp. 15-22. 
was sent away to Diyarbekir as provincial governor, and almost never made it back to İstanbul. The grand vezir himself was dismissed on 16 June, and Köprülüzâde Numan Pasha followed him into office.

Here we come up against an interesting problem with regard to building power bases, close circles, and extended households. At first glance it seems that at least in 1708, 1709 and 1710, the husbands chosen for Sultan Mustafa II's daughters were more established personages at the time of marriage when compared with the husbands Ahmed III was picking for some of his own daughters. At betrothal time, however, Çorlulu Ali, too, had been no more than Mustafa II's sword-bearer (and had therefore been known as Silâhdâr Ali Ağa), but both Köprülüzâde Numan and Maktûlzâde Ali had already risen to become governors thanks to their Köprülü connections. As we shall see, in the course of the 18th century it would become increasingly common for a sultan to select his sword-bearer as (one of) his future son(s)-in-law, whereas it was much more exceptional for royal princesses to be engaged to established pashas (such as grand vezirs or grand admirals). Indeed it was Çorlulu himself who was instrumental in elevating the post of sword-bearer. ${ }^{43}$ Beyond their rank, what was common to Numan and Ali was that they both belonged to the Köprülü family. In arranging for them to eventually marry two of his daughters, Mustafa II may well have been looking to bond with this powerful clan (which his father Mehmed IV seems to have neglected). ${ }^{44}$ Mustafa II appears to have made his choice against many Köprülü opponents among his statesmen.

At the same time it becomes important to note that Ahmed III abided by his brother's wishes, though this was not automatic: as reigning sultan he could well have replaced existing arrangements with others. On the other hand, he may have preferred not antagonizing his late brother's household and inner circle, at least when his own was still in the making (in 1708-10). Nevertheless, he seems to have taken certain measures to keep the former in their place, and perhaps to indicate to them that this was no longer their day. Thus while (his now grand vezir) Çorlulu Ali’s marriage was sumptuous, Köprülüzâde

\footnotetext{
${ }^{43}$ M. Aktepe, "Çorlulu Ali Paşa," TDV İslâm Ansiklopedisi VIII (İstanbul 1993) pp. $370-71$.

${ }^{44}$ Indeed Mehmed IV gave his infant daughter Emetullah (Ümmî), known as Küçük Sultan, to Merzifonlu Kara Mustafa Pasha in 1675: Derin, Abdurrahman Abdi Paşa Vekâyi '-nâme, pp. 443-444 (fols.134a-135b).
} 
Numan's was very modest; and Maktûlzâde Ali was not even permitted to take his royal bride to a palace he had inherited from his father. On closer examination, it also becomes clear that while it was usual for royal bridegrooms to move back and forth between the provinces and the capital, Numan and Maktûlzâde Ali (as well as the rest of the surviving members of the Köprülü family) were always kept away from the capital. Furthermore, these royal in-laws who were descendants of the later Köprülü grand vezirs, and who had once been loyal to Mustafa II, were not going to survive for long. Eventually Ahmed would be bringing in his own men both as royal grooms and topranking bureaucrats. Later, indeed, Ahmed III did move, carefully and strongly, to set up his own household and power clientele by marrying his nieces (for a second and even a third time) as well as his own daughters to his own supporters in positions of power and influence. So the story of Mustafa II's daughters' marriages embodies not only a shift from one royal household to another, but also a parallel subplot of the rise and then fall of a secondary but still very powerful military-bureaucratic dynasty. It reveals how the half-century sway of the Köprülüs was brought to an end as Ahmed III consolidated his own networks of power.

\section{Royal Marriages as Part of Damad İbrahim Pasha's Ruling Strategies}

Only after he found himself a strong and staunch ally in the person of İbrahim Pasha, did Ahmed III move in more open and determined fashion to re-inscribe his House and himself into the capital. Nevşehirli became "Damad", the Royal Bridegroom, by marrying Fatma Sultan on 19 February 1717, and took over as grand vezir on 9 May 1718, that is to say just over a year later. From then on, a succession of royal betrothals and weddings began in real earnest, so much so that within Ottoman history as a whole, it is the latter part of Ahmed's reign which truly stands out in this regard. Furthermore, this went hand in hand with a massive investment in architectural patronage in the capital. The weddings and palaces reserved for princesses in the historical peninsula became the last word in pomp and circumstance. The value of all gifts given and received, the way they were presented, the festivities running through each wedding-in short, all that was expected from such a union-came to be regarded as extremely important, indeed essential for both parties. 
Last but not least, while we have to rely on only a few sources for our understanding of pre- or early-18th-century royal weddings, for the festivities of 1720,1724 and 1728 there is much more ample documentation, which also casts light on the underlying motivations and thought processes. For now, behind these last three collective marriages, one can discern the strong planning, designing, staging hand of none other than Damad İbrahim Pasha whose own marriage to Fatma, the widow of Silâhdâr/Şehid Ali Pasha, had not been celebrated extensively because it was the princess's second marriage.

\section{Collective Marriage I (1720)}

The marriage ceremonies that preceded the circumcision of Ahmed III's four sons, united two daughters of Sultan Mustafa II with two senior statesmen. (1) Ayşe, whom we have already met, and who had been married to Köprülüzâde Numan Pasha (in 1708), was now given in her second marriage to Silâhdâr İbrahim Pasha, previously a sword-bearer of Ahmed II, while (2) Emetullah was given in her first marriage to Osman Pasha. Known by at least four different nicknames-Silâhdâr, Çerkes, Küçük, Sinek - this Osman Pasha had also risen from serving as a sword-bearer to Mustafa II, and had been previously married to Rukiye, a daughter of Fatma Sultan, who in turn was a younger sister of the royal brothers Mustafa II and Ahmed III. Both bridegrooms are known to have brought valuable gifts to members of the royal family, and these gifts were immediately transferred to the Imperial Treasury.

However, once again their marriages were given only passing mention in period chronicles, European mémoires, and two sûrnâmes which otherwise record the circumcision festivities in minute detail. ${ }^{45}$ Such was the relative silence surrounding the princesses' marriages, that it gave rise to some confusion regarding their identities. Thus even Sûrnâme-i Vehbi, the official account of the whole event, probably goes astray in identifying the royal wife of ex-Silâhdâr İbrahim not as Ayşe but as Emine Sultan. But tellingly, it also notes that the whole arrangement was kept secret, and that there were "various rumours" at the

\footnotetext{
${ }^{45}$ Mehmed Râşid, Tarih-i Râşid V, pp. 214-272; Schefer, Mémoire historique, pp. $38,40,70,142$.
} 
time ${ }^{46}$ Although it was Ayşe's (and it would also have been Emine's) second marriage, Emetullah was a virgin bride. It might have been Osman Pasha's earlier royal marriage (to Rukiye) that led to the relative discounting of Emetullah's marriage alongside her elder sister's.

\section{Collective Marriage II (1724)}

Four years later, in 1724, the marriage ceremony that was carefully designed to impress the capital was also orchestrated by Damad İbrahim Pasha, who happened to be marrying his own son (from an earlier marriage) as well as his nephew to two of Ahmed III's daughters. ${ }^{47}$ Also under his patronage, an outstanding statesman with an illustrious pedigree was getting married to yet another daughter of the sultan. The sûrnâme that was written for this collective wedding ceremony in 1724 after the death of Ahmed III was, as already indicated, a rare record which seems to have doubled as a register of protocol.

\section{Collective Marriage III (1728)}

Before embarking on the exploration of the 1724 festivities, it is necessary to note that in 1728 , there took place the third and last collective marriage of Ahmed III's reign. All the princesses in question were daughters of the reigning sultan who were getting married for the first time: Ayşe (1719-1775) to Silâhdâr (Istanbullu) (Kunduracizâde) Mehmed Pasha; Saliha (1715-1778) to Sarı Mustafa Pasha, then commander of Revan (and son of Deli Hüseyin Pasha); and Zeynep (?-1774) to yet another nephew of the grand vezir, (Küçük) Sinek Mustafa Pasha, the second head of the royal stables (mîrâhûr-l sagìr) at the time.$^{48}$ In the aftermath of the 1730 rebellion which cost the grand vezir's life and terminated the reign of Ahmed III, not only did

${ }^{46}$ Tulum, 'Çeviri Yazılı Metin', p. 218 (32a); Mübeccel Kızıltan, The "Sûrnâme” of Mehmed Hazin As a Sample of Old Turkish Prose, unpub. MA Thesis, Bosphorus University (İstanbul 1987). The confusion is reflected in the secondary sources. Mehmed Süreyya says that Osman Pasha was married to Emetullah in 1694: Mehmed Süreyya, Sicill-i Osmanî 4, p. 1307.

${ }_{47}$ Tülay Artan, 'Yönetici Elitin Saltanatın Meșruiyet Arayışına Katılımı', Toplum ve Bilim 83 (Osmanlı: Muktedirler ve Mâdunlar) (Winter 1999/2000) pp. 292-322.

${ }_{48}$ The three princesses were settled at Valide Sultan Kethüdası Mehmed Pasha's palace at Süleymaniye; at the Defterdâr İskelesi Palace at Eyüb; and at the Kıbleli Palace at Ayasofya respectively. 
collective marriages come to an end, but occasions for festive urban celebrations also became much more rare in general. ${ }^{49}$

\section{The 1724 Wedding Processions: The Court and the City}

I shall now turn to the Vienna sûrnâme, which, I am convinced, indicates that it was in 1724 that the route and routines utilized in 1708-1709-1710 (and possibly 1720) were reformulated so as to further highlight and glorify Damad İbrahim Pasha, his family, and his household.

What is immediately striking about the anonymous sûrnâme in the Vienna Nationalbibliothek is its extremely detailed account of the various 1724 processions. ${ }^{50}$ As such it differs from accounts of the 1708 , 1709 and 1710 celebrations, which were actually written in the 1740s. In fact, it could be that these other accounts, too, were ordered to be penned a posteriori in a way that was intended either to help with Nevşehirli's re-designing effort and/or to mark the differences between the three earlier festivals and the grand vezir's stipulations for 1724 .

While Küçük Çelebizâde İsmâil Âsım Efendi's addendum to Tarihi Râşid, covering October 1722-July 1729, also provides an account of the events of $1724,{ }^{51}$ it is the sûrnâme in question that is the most extensive. Included are marching orders for all the top dignitaries, secondary officials, guards and servants that participated in each procession, as well as the descriptions of the head-gear and costume that each statesman, functionary and attendant wore on these occasions.

${ }^{49}$ The only account of the 1728 marriage has been located in Küçük Çelebizâde: On 25 May 1728 ( $15 \mathrm{~L} 1140$ ), the bridal gifts were sent by the procession designed in 1724, in the company of Tevkîi î Ali Pasha, the best men and the proxy of the bride, and the grand vezir's steward Mehmed Pasha. Two days later, trousseau of Saliha Sultân was transferred to her palace at the Defterdâr İskelesi at Eyüb. The next day, following the wedding ceremony, the princess left from the Bâğçekapı and was taken to her palace via the road outside the city walls with the established procession which took two hours: On 18 November (15 R 1140), wedding ceremonies of Ayşe and Zeynep took place at the Topkapı Palace, in the way they were accounted in earlier ceremonies. Five days later, Ayşe Sultân's trousseau was sent to her palace. Then, on 8 December (6 CA 1140) Zeynep's trousseau was sent and the next day the wedding procession took place. The only other collective marriage that was celebrated later in the 18th century was in 1740 .

${ }^{50}$ Karateke noted that Vienna National Library obtained three protocol registers through Hammer-Purgstall: Karateke, Ottoman Protocol Register, p. 38, n. 122.

${ }^{51}$ Mehmed Râşid, Tarih-i Râşid V, pp. 90-101. 
There is even a systematic account of their horse trappings. It is this level of detailed description that imparts something of the nature of a book of ceremonies to this sûrnâme. Thus while it is very similar to the aforementioned 1695 Defter-i Teşrîfât of Mehmed bin Ahmed (Ni'metî) in paying special attention to head-gears and costumes, it is strikingly different from earlier sûrnâmes which are not at all concerned about dress codes and horse trappings. What is also different in the 1724 sûrnâme is the recording of the exact route that the processions took in each specific case, perhaps another indication that the event was both new and important. ${ }^{52}$ The ancient Hippodrome, long distinguished as the monumental core of the city where imperial and dynastic rites were observed, was now (once again) being ceremonially connected to the grand vezir's palace.

The 1724 sûrnâme displays virtually a modern flavor in its level of exactitude-something that would appear to have been demanded. Of a total of nine imperial parades, namely three each of alay-ı nişân, alay-ı cihâz, and alay-ı arûs, the following were minutely recorded:

Alay-ı Nişân (of Ümmügülsüm and 'Atîke [and Hadice]): ${ }^{53}$ On 20 February 1724 (25 CA 1136), the betrothal gifts presented by the two bridegrooms (Ali and Mehmed) were transported from the palace of the grand vezir to the Imperial Palace. ${ }^{54}$ While the first file of gifts is

${ }^{52}$ The accounts of the marriages of Emine and Ayşe, Fatma, and Safiye preserved in TSM Archives, H. 1573/2, D. 10590 and D. 10591, are the closest examples in this genre. However, they list only the titles of the statesmen, functionaries and attendants but do not include the ceremonial attires and their horses' trappings which are crucial in the delineation of hierarchy and rank. Küçük Çelebizâde Âsım Efendi on the other hand, did record the ceremonial attire and the trapping of those dignitaries who were going to be part of these processions for the first time.

${ }_{53}$ Codex Vindobonensis Palatinus $\mathrm{OH}$ 95: for the preparations:, 65a-65b; procession: $66 \mathrm{a}-67 \mathrm{~b}$; marriage ceremonies: $67 \mathrm{~b}-70 \mathrm{~b}$.

${ }^{54}$ A day earlier, the grand vezir Damad İbrahim Pasha's palace and the Imperial Council Hall (Divanhâne/Kubbealtı) were decorated in the manner very similar to the embellishments during the religious festivals, with luxurious cushions, pillows and Persian rugs. The sultan's seat was facing the entrance of the Dîvânhâne. Offices of the government were also furnished (by the mehterhâne). Again, just a day before the ceremony, the betrothal gifts (of Ali Pasha and Mehmed Pasha, the grand vezir's nephew and son) were put on display at the grand vezir's palace. On the day of the engagement the grand admiral was assigned as the best man of Ali Pasha and the Kethudâ Beg became the proxy and best man of Ahmed Pasha and Mehmed Pasha. There were two witnesses for each couple. These were, for all the three princesses, the treasurer and the boon-companion of the sultan. The two witnesses representing Ali Pasha were his steward and a senior officer of his household council (dîvân efendisi); and, for Ahmed Pasha, too, the witnesses were his steward and a representative of his household (ademîsi), possibly also his dîvân efendisi. Mehmed Pasha, the grand 
given in detail, the second, which immediately followed, is only noted as conforming to the same order. Furthermore, although all three marriage contracts were concluded the same day, there is no mention of Hafız Ahmed Pasha's betrothal gifts. Apparently Hafız Ahmed had not yet arrived from Sayda, so that his marriage to Hadice was formalised in the presence of his proxy. His betrothal gifts were either not paraded that day, or else the procession was not mentioned in the sûrnâme because-as was also the case with Mehmed-it entailed nothing but a repetition of the procession for Ali's gifts. In any case, Hafiz Ahmed Pasha arrived four days later. That they could not wait even for a few days for his arrival suggests that the final schedule was taken very seriously. [Appendix I]

Alay-ı Cihâz of Ümmügülsüm: ${ }^{55}$ On 28 February 1724 (3 C 1136), the trousseau of the princess was taken from the Topkapi Palace to her palace at Kadırga Limanı in no fewer than eleven carriages (kapaklı araba). [Appendix II)

Alay-ı Arûs of Ümmügülsüm::5 Then, on 2 March 1724 (6 C 1136), which was a Thursday, the princess was taken from the Topkapi Palace and transported to the Kadırga Palace. [Appendix III]

Alay-ı Arûs of Hadice: $:^{57}$ On 6 March 1724 (10 C 1136), it was the turn of the trousseau of Hadice Sultan to be transported from the Topkapı Palace via Ahırkapı Yolu to the Kibleli Palace that had been assigned to her. Then on the 9th (13 C 1136), which also happened to be a Thursday, the princess herself was taken to her palace.

Alay-ı Arûs of 'Atîke:58 Ten days later, that is to say on 13 March, 'Atîke's trousseau, and on 16 March 1724 (17 and 20 C 1136), 'Atîke Sultan herself were transported from the Topkapı Palace to her palace at Cağaloğlu.

The Vienna sûrnâme thus lists a nişân (for both pashas), a cihâz, and three arûs processions. The missing accounts are the nişân procession

vezir's son, however, was represented by the Re' is Efendi and the Çavuşbaşı, the two high-ranking state officials, members of the Imperial Council.

${ }_{55}$ Codex Vindobonensis Palatinus $\mathrm{OH}$ 95: for the procession: 71a-73a; gifts: 73b-74a.

${ }^{56}$ Codex Vindobonensis Palatinus $\mathrm{OH}$ 95: for the preparations: 74a; procession: 74b-77b; gifts of the bridegroom: 78a.

${ }^{57}$ Codex Vindobonensis Palatinus $\mathrm{OH}$ 95: for the procession: 82b-83b; celebrations: $83 \mathrm{~b}-84 \mathrm{a}$.

${ }^{58}$ Codex Vindobonensis Palatinus $\mathrm{OH}$ 95: for the procession: $84 \mathrm{~b}-85 \mathrm{a}$; gifts: $85 a-86 a$. 
for Hadice and the cihâz processions of both Hadice and 'Atîke. Strikingly, Küçük Çelebizâde chose to include exactly the same events in his chronicle. Indeed the order of parade for the grandees (alay-ı ricâl) is also not repeated for each procession, but briefly referred to as "with the procession organized formerly for Ümmügülsüm Sultan (mukaddema Ümmügülsüm Sultan hazretleri için tertib olunan alay ile)”.

In other words, what we have is one complete set, recording the three separate processions for the marriage of Ali Pasha and Ümmügülsüm, reflecting on the identities of the participants, ranks and hierarchy, ceremonial costumes and head-gears, horse trappings, gifts and palace rituals. ${ }^{59}$ The rest is there in a shorthand format. Furthermore, it seems that the transfer of all three brides is included only to describe the different routes leading to the palaces of the princesses in different quarters of the historical peninsula. To be more specific, the accounts of Hadice's and 'Atîke's wedding parades appear to draw attention to the center of gravity, the Hippodrome. For regardless of where the assigned palaces might lie, all such processions had to go through the Imperial Gate, pass below the Alay Köşkü for acclamation (alkış), stop before the gate of the grand vezir's palace, move on to Dîvânyolu, ${ }^{60}$ and then enter the Hippodrome/Atmeydani. They even had to go around the Hippodrome a second time before they went their different ways.

${ }^{59}$ For the identification of ranks and hierarchy in the first quarter of 18th century I relied primarily on Hezarfen Hüseyin Efendi and Abdurrahman Abdi Pasha's manuals which were both written in the last quarter of the 17th century when the court was residing in Edirne. Despite their obvious limitations, both Uzunçarşıll and Gibb and Bowen, are also still helpful. While the first introduces a variety of sources on the structure of the Ottoman court and administration, the most significant for our purposes being the Nimetî Ahmed Efendi Teşrîfatnamesi (which was in Uzunçarşıllı's private collection), the latter makes a full use of a late-18th-century source, that of Mouragea D’Ohsson's Tableau Générale de l'Empire Ottoman, and several mid-19thcentury sources such as the chronicles of Ahmed Cevded Pasha and Tayyârzâde Atâ and Mustafa Nurî Pasha's Netâ'icü'l-vukû̀ât.

${ }^{60}$ Dîvânyolu, the major thoroughfare in the historical peninsula that joined the Topkapi Palace to the Beyazid square via Sultanahmed square, was the Byzantian Mese, the imperial route which joined the Augusteion to the Filadelfion. It does not really correspond to Dîvânyolu today and this is attested to even by some early-19thcentury maps if not by numerous narrative sources. For comparison see: Maurice Cerasi, The Istanbul Divanyolu. A Case Study in Ottoman Urbanity and Architecture (Würzburg 2004). 


\section{Ottoman Processions in a Broader Context: Atmeydan at the Center, the Grand Vezir as the Core}

There are several differences between the processions of 1708, 1709, 1710 and 1720, and what happened in 1724. (Discrepancies with the 1675 Edirne processions are even more remarkable, but this is beyond the limits of this study.) First, the nişân processions in the 1708, 1709, and 1710 weddings were not spectacular pageants-betrothal gifts were taken to the imperial palace in a rather private and subdued way. ${ }^{61}$ The starting point of the processions was always the Sublime Porte-the grand vezirial palace. As for the royal weddings of 1720 , they were hushed-up in a more comprehensive way. In contrast, in 1724, the parade of betrothral gifts leaving the grand vezir's palace was certainly designed to help enhance the public understanding that the royal bridegrooms were Damad İbrahim Pasha's relatives and accomplices. The gifts themselves were richer and more varied. Also, the symbolic items that were ritually displayed in earlier engagement ceremonies differed considerably from those that were publicly paraded in 1724 .

Second, the valide sultan played an obviously crucial role in the three earlier ceremonies. ${ }^{62}$ She was Emetullah Gülnûş (wife of Mehmed IV), and quite possibly she had been instrumental in arranging the marriages of Mustafa II's daughters to the descendants of the Köprülüs.

${ }^{61}$ The gifts of Çorlulu Ali Pasha (and that of Numan Pasha) were modest. The gifts that were prepared and kept at the palace of the grand vezir were transferred to the Imperial Palace by guards carrying trays on their heads. The gifts of Silâhdâr Ali Pasha, more sumptuous than those of Ali and Numan, were kept at the Sofa Köşü. The grand admiral who was assigned as the best man of the bridegroom, the bridegroom himself, the steward of the grand vezir, and the steward of the bridegroom arrived at the Sofa Köşü rather silently by way of the Imperial Gardens. Then they accompanied the gifts, nahils, sugar gardens and various other ritualistic items that were transported from the Sofa Köşü, via the Imperial Gardens, through the Demirkapı, passed by the grand vezir's palace, and reentered the Imperial Palace from the Imperial Gate. The gifts of Maktûlzâde Ali Pasha, on the other hand, which seems even more unassuming than those of Ali and Numan, were also brought from the grand vezir's palace into the Imperial Palace humbly. The best man of the bridegroom (who was also the proxy), the steward of the grand vezir, and the steward of the bridegroom arrived together with the marriage attendants carrying trays.

${ }^{62}$ It is interesting to note that the halberdiers of the Old Palace were demoted in 1724. Their important role in the processions of 1708,1719 and 1710 could have been related to the presence of valide sultan at the time of these marriages. Even though she did not live there (her second son was then on the throne), she seems to have had the authority over the personnel at the Old Palace which was reserved for the mothers and women of the preceding rulers. Gülnûş Emetullah died in 1715. 
After she died in 1715, Damad İbrahim Pasha may have stepped in immediately to find husbands of his preference for any remaining royal princesses. Thus while Emetullah Gülnûş may have been keen to maintain the bonds between Mehmed IV and Mustafa II, on the one hand, and the Köprülüs on the other, the new grand vezir appears to have acted not only to block out the Köprülü descendants, but also to push a number of his own blood relatives onto the stage. He would get his chance in 1724 .

Third, in all earlier weddings, only routine (and minor) modifications took place in the parade order of the grandees and the number of attendants in their retinues. In contrast, the weight of the grand vezir's household made a quantum jump in 1724. This is consistent with all the other changes. The highlighting of the nişân processions taking off from the grand vezir's palace; the rise to prominence of the grand vezir's kith and kin, including two sons-in law as proxies or best men; the central role his household came to play in the entire pageantry-all these give the impression of converging to magnify the rising power of the Sublime Porte and of Damad İbrahim Pasha. This can perhaps be better seen by looking separately at several sub-components:

\section{a. The Grand Vezir's Palace}

Changes of this scope and magnitude cannot be attributed merely to the blood-ties between the grand vezir and two of the bridegrooms of 1724. Rather, what was placed center-stage and highlighted was the house and household, or the palace, of Damad İbrahim Pasha. It is true that regardless of its location the grand vezir's palace was traditionally the starting point of nişân processions. Still, İbrahim Pasha seems to have taken special advantage of this tradition in order to enhance his personal visibility, public presence, and institutional authority.

By 1724 the grand vezir and his royal wife had several palaces at different locations. Following their marriage in 1717, the one across from the Kiosk of Processions on the landwalls of the Topkapi Palace, which had long housed many grand vezirs, grew into a monumental complex as Damad İbrahim Paşa and Fatma Sultan continued to annex nearby palaces, and busied themselves with restoring and rebuilding them. ${ }^{63}$

${ }^{63}$ I have traced the history of the grand veziral palaces in the vicinity of the Topkap1 Palace from 1654 to 1730 , often referred to as no more precisely than "across from" or "below" the Kiosk of Processions: Tülay Artan, "The making of the Sublime 
The particular location of this compound, conveniently neighbouring the Topkapı Palace and the Hippodrome, as well as its layout and parts, all reflect Damad İbrahim's ambition of establishing his own conspicuous house and household. Its level of architectural grandeur and luxury is a question that needs to be addressed separately. In 1724 the grand vezir, like Sultan Ahmed III had done after the court resettled in İstanbul, made a determined move in strikingly overt fashion to inscribe his palace and himself into the capital as he orchestrated the various processions moving in and out of his residence.

But was this show simply a contingency arising from the swing of political fortune? Or did he really have in mind a permanent officeresidence to symbolize his power and commemorate his name? In other words, is it really possible to date the making of the Sublime Porte to Damad İbrahim Pasha's tenure?

\section{b. The Imperial Council}

A key historiographical weakness at this point is the prevailing and hardly explicable neglect of the Edirne episode, which began in the late 1650s and lasted for nearly five decades, and which then required the re-inscription of the court back into Istanbuliote space immediately after $1703 .{ }^{64}$ At least partly as a result of the comprehensive failure to deal with such a momentous interlude, the existing secondary (and encyclopedic) literature remains stuck in the assertion that it was (Nevşehirli) Damad İbrahim Pasha who played the decisive role in the finalization of the grand vezir's control of the Imperial Council (Divân-ı Hümâyûn); and in the transfer of its offices to the Sublime Porte. $^{65}$

Porte near the Alay Köşkü and a tour of a grand veziral palace at Süleymaniye', in: In Memoriam Stefanos Yerasimos 1942-2005, Çağatay Anadol, Edhem Eldem and Aksel Tibet, eds. (İstanbul 2011).

${ }^{64}$ Artan, 'Was Edirne a Capital'.

${ }^{65}$ With reference to Mehmed Süreyya's Sicill-i Osmanî (v. iv, 755), it was Deny who claimed that "the 'Porte', which at the same time was the personal dwelling of the Grand vezir and at the outset tended to be rather mobile, gradually lost the character of a semi-private residence and became finally established, under what was henceforth to be its official name, from 1718, when the Grand vezir Nevşehirli Damad İbrahim Pasha returned with his father-in-law, Sultan Ahmed III, from Adrianople to İstanbul, after the peace of Passarowitz”: Jean Deny, 'Bâb-1 Âlî', EI2, vol. 1, p. 836. See also: Metin Kunt, 'Sadrazam', EI2, vol. 8, pp. 751-752. For the description of the ethics and manners of the Grand vezir in early 18th century: Walter Livingstone Wright, Nesâyihü’l-vüzerâ ve'l-ümerâ (Princeton 1935); Abdülkadir Özcan, 'Şehid Ali Paşa’ya 
We know the grand vezirs to have supervised a hierarchically ordered staff of officials divided between the two main offices of the central administration: the Imperial Chancery and the Imperial Finance Bureau. The transformation in the status of the Imperial Chancery in particular is argued to have been achieved by Nevşehirli-as expressed in the bestowal of veziral status on three key officials who were thereby transformed into the three main agents of the grand vezir. These were his steward, the chief sergeant-at-arms, and the chief of the chancery clerks, who were respectively assigned to managing interior affairs, justice, and foreign relations, while only the chief treasurer, also known as the chief keeper of the registers (defterdâr-1 evvel or başdefterdâr), in his capacity as the custodian of imperial records, remained under sultanic jurisdiction. ${ }^{66}$

However, even as early as the 1650 s, there is evidence that the Imperial Chancery and its departments collectively referred to as the bureaus of the Imperial Council (divan-ı hümayûn kalemleri), had moved out of the Topkapi Palace and become part of the grand vezir's household. ${ }^{67} \mathrm{~A}$ related point is that the second main department, responsible for financial affairs, ${ }^{68}$ was separated from the grand vezir's authority at about the same time-in the 1650s, and not in the early 18th century. By 1724 İbrahim's ambition to expand and display his house and household was still centered on those offices that visibly came under the grand vezir's jurisdiction. Hence Damad İbrahim Paşa was emphatic about putting all this on show throughout the capital via the marching order, the ceremonial costumes and headgear, and the trappings of the horses of the members of his household.

İzafe Edilen 'Talimât-nâme’ye Dair', Tarih Enstitüsü Dergisi 12, Prof. Tayyib Gökbilgin Hatıra Sayısı (1981-1982) pp. 191-202. The latter was probably commissioned by Çorlulu Ali Pasha.

${ }^{66}$ Uzunçarşıll, Merkez ve Bahriye Teşkilâtı; Bernard Lewis, 'Dîvân-1 Hümâyûn', EI2, v. 2, pp. 337-339; Carter Vaughn Findley, Bureaucratic Reform in the Ottoman Empire. The Sublime Porte 1789-1922 (Princeton 1980); and also "Dîvân-1 Hümâyûn" in Bayerle, Pashas, Begs, and Effendis, pp. 38-39.

${ }^{67}$ See note 63 above.

68 The Office of the chief treasurer was called the Porte of the Register (Bâb-1 Defter). See: Joel Shinder, 'Career Line Formation in the Ottoman Bureaucracy, 1648-1750: A New Perspective', JESHO XVI, Parts I-III (1973) pp. 217-237. 


\section{c. The Household}

He was also said to have led the way in inserting "his men" (i.e. members of his household) into the administration. Indeed, Damad İbrahim Pasha's focus on his household as a unit of possibly proto-dynastic organization in its own right was exceptionally ambitious.

When the decision on the marriage of three princesses was taken on 6 January 1724 (9 R 1136), all three bridegrooms were promoted. ${ }^{69}$ The grand vezir's son (Genç) Mehmed Beg, being only thirteen, had no official position at the time of his royal marriage. ${ }^{70} \mathrm{He}$ was made a pasha (of three horse-tails). Ali Beg, the grand vezir's nephew, had been a second master of the royal stables. He was first made the steward of the imperial gatekeepers (kethudâ-i bevvâbân-ı şehriyârî), and then received a further distinction as he became a vezir and a member of the Imperial Council. Hence, at the time of his marriage, he was called Tevkîî il Ali Pasha. Damad İbrahim Pasha's other nephew, (Küçük) Sinek Mustafa Pasha, a younger son of his brother Halil, (d. 1764), was also promoted with the title of beylerbeyilik prior to his wedding in 1728 . He, too, had been a second master of the royal stables at the time. ${ }^{71}$

All three blood relations survived the 1730 uprising while the grand vezir and his two in-laws were brutally murdered. Both Kethüda Mehmed and Kaymak Mustafa, respectively appointed on 27 March 1719 and 7 September 1721, had been hand-picked by İbrahim Pasha. The French authorities in İstanbul, relying on reports by the ambassador Marquis de Bonnac, noted that the grand vezir delegated great authority to his sons-in-law, and also included in his retinue the Chief of the Clerks (re'isü'l-küttâb), Üçanbarlı Mehmed Efendi (2 August 1718-18 October 1730); the Head of the Ulemâ (şeyhü'lislâm), Yenişehirli Abdullah (7 May 1718-30 September 1730); the Head of the Treasury (defterdâr), Hacı Türk İbrahim Ağa (9 May 1719-died in office in 1729); as well as Grigore Ghika, the Dragoman. ${ }^{72}$ In addition, it should also be noted that the Chief Physician (hekimbaşı), Hayâtîzâde Mustafa Feyzi Efendi (1724-1735); the Chief

\footnotetext{
${ }^{69}$ Mehmed Râșid, Tarih-i Râşid V, pp. 90, 96.

${ }^{70}$ Mehmed Râşid, Tarih-i Râșid V, pp. 90-92, 97-101.

${ }^{71}$ Artan, 'Yönetici Elitin Saltanatın Meşruiyet Arayışına Katılımı', pp. 292-322.

72 Schefer adds to this list also a certain Hac1 Mustafa: Schefer, Mémoire historique, pp. $\mathrm{xxx}-\mathrm{xxx}$.
} 
Black Eunuch (dârü's-sa'âde ăgası), Hacı Beşir Ağa (1717-1746); the Master of the Horse (imrahor), Haydar Ağa (1717-1726); and the Janissary Commander (yeniçeri ağası), Şahin Mehmed Ağa (1722-1731), all had unprecedentedly long tenures at this time. Taken together, this is quite an unusual and intriguing picture.

It is possible to deepen our understanding of this oligarchy with its intricate political relations, marriage alliances, and ties of patronage and clientelage. Lesser members of Damad İbrahim Pasha's household, for example, can be carefully identified from registers of allocations and household expenses. Upon closer examination, they, too, are found to be connected to all these high-ranking dignitaries. Exploring these, however, is beyond the limits of this study.

\section{d. Protocol}

The 17th century had constituted a long break with "Classical Age" customs and practices. The first half of the 17th century had been a time of instability, and over its second half Mehmed IV and his immediate successors had been forced to quit İstanbul for Edirne. What was lost in the process was reinvented in the Defter-i Teşrîfât of Mehmed bin Ahmed (Ni'metî), recorded by order of Mustafa II, and most probably elaborating on his father Ahmed Efendi's own work presented as law code (kanûnnâme). The section on ceremonies involving grand vezirs in the Teşrîfatî Mehmed's protocol register, along with borrowings from Lutfî Pasha's (d. 1563) Âsafnâme elaborating on the conduct of the grand vezirs has given rise to a claim that a grand vezir must have patronized this manuscript. ${ }^{73}$ This is not quite sustainable, for in the text there are explicit references not only to Mehmed IV but also, and much more emphatically, to Mustafa II: the former is blamed for his laxity with regard to rites and rituals, while the latter is clearly and repeatedly cited, praised, for being determined to remedy the situation.

${ }^{73}$ Karateke, An Ottoman Protocol Register, pp. 36-38. Karateke, dating Teşrifâtî Mehmed's register to early or mid-18th century, notes its difference from later registers of protocol: "in the later registers, entries for similar ceremonies repeat each other almost identically, unless unusual conduct had occurred," and concludes that "the later registers are but bureaucratic products of governmental offices". Karaca and Karateke located more than 50 registers of protocol. Karateke notes that in the 19th century, registers containing only one type of ceremony were put together. Thus, one such register contained only mevlid ceremonies; another which included weddings and circumcision ceremonies: BOA, Sadaret Defterleri 366 (1251-1308/1836-1891). 
Nevertheless, this is an understandable misinterpretation, for as with many other, comparable texts, Teşrifâtî Mehmed's work is also full of references to the crucial role of the grand vezir. Although we do not know the origins of the tradition, it is true that it had "always" fallen on the grand vezirs to orchestrate the weddings of royal princesses. ${ }^{74}$ It is interesting, for example, that information on wedding protocols can also be found in registers emanating from the office of the grand vezirate. ${ }^{75}$ So it is no surprise that the presence of the grand vezir should be so noticeable in 1675 , should have been restated in 1695 , and should then have been felt even more strongly in 1708-for then, it was a matter of the grand vezir Çorlulu Ali Pasha himself marrying a princess. In 1709 and 1710, too, the processions more or less followed the same order.

Although we do not have a detailed account of the 1720 marriages, we know that Damad İbrahim Pasha was the mastermind behind the whole design. ${ }^{76}$ It is against this whole background of grand vezirial involvement that we have to assess İbrahim's specific role and contribution. He was not inventing an entirely new protocol, but he was subtly playing with what already existed, innovating here and there to enhance his own and his family's role. His interest in the "re-invention of tradition" over 1718-1730 extended not only to processions directly involving the grand vezir, but even royal princes' circumcision rites. It is safe to assume that he not only studied earlier sûrnâmes, and also built on them to elaborate his own design. Four years later, the bridegrooms were the grand vezir's own son and nephew, but it was not just this fact that stamped itself on the 1724 festivities. Rather, it was the evolution of a number of administrative offices of the Imperial Council and their progressive transfer into the grand vezir's household that was heavily reflected in these processions. Even more explicitly, what was involved was the (re)emergence of the grand vezir as the favourite

\footnotetext{
${ }^{74}$ Another compilation of protocol registers, dated to 1743 , was ordered from 'Abdullah Nâ'ilî Pasha by Mahmud I: 'Abdullah Nâ'ilî, Kavânîn-i Teşrîfat: Türk Tarih Kurumu Y. 49. The reason for this commission was, once again, the pressing need to organize the loose documents in the archives-likes of the 1724 sûrnâme. For excerpts: 'Abdullah Nâ'ilî, 'Dîvân-1 hümâyûna â'id teşrîfât', Türk Tarih Encümeni Mecmuasi 16 (1926) pp. 249-260.

${ }^{75}$ Başbakanlık Ottoman Archives, Bâbıâlî Evrak Odası (BEO) Sadâret Defterleri.

${ }^{76}$ For the transcription of Sûrnâme-i Vehbî by Mertol Tulum, see: Sûrnâme. An Illustrated Account of Sultan Ahmed III's Festival of 1720, Ahmet Ertuğ ed. (Bern 2000).
} 
and alter ego of the sultan. Thus while the nişân procession was dominated by the grand vezir's and the cihâz by the sultan's household, the arûs procession was in the nature of a display of the imperial apparatus incorporating the ministers of state (vüzerâ- $y ı$ izâm), religious scholars (ulemâ-yı kirâm) and the high-ranking state and court functionaries (erkân-ı devlet). Still, the grand vezir seems to have made a majestic display of his family and household on this occasion.

Küçük Çelebizâde, narrating the 1728 royal marriages, points out the role that the 1724 protocol was meant to play. He notes that Salihâ Sultan's bridal gifts were sent with a procession as designed in 1724. ${ }^{77}$ Then when the bride was taken to her palace at Eyüb, Küçük Çelebizâde remarks yet again that this was done in conformity with the "established procession" ${ }^{78}$ Likewise, in November 1728, he notes that Ayşe's and Zeynep's weddings at the Topkapı Palace was in the manner of "earlier accounts". ${ }^{79}$ Then, Ayşe's trousseau is also said to have been paraded in the manner of the "earlier accounts" ${ }^{80}$ It was only in the case of the transfer of Zeynep's troussau and her marriage procession to the Kıbleli Sarayı in December 1728, that Küçük Çelebizâde felt compelled to speak of a new development. ${ }^{81}$

\section{e. The Hippodrome}

Another exceptionally striking aspect of 1724 is the accentuation of the urban center, namely the Hippodrome, which had been completely left out of the ceremonial route in all previously recorded cases of royal marriages from the 16th century onwards. This denial must have

\footnotetext{
77 "bin yüz otuz altı târîhinde vâki" olan sûr-ı sultânî beyânında tahrîr olunduğu minvâl üzre alay-ı nezzâre-pîrâ ile."

78 "kevâkib-i dürriyye-i sipihr-ismet iffetlü sultânlarhazarâtının sarâyve makāmlarına

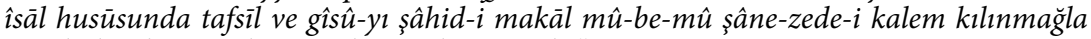
tatvîl olunduğu vech üzre alay-ı şehr-ârây ile."

79 "mukaddemâ vâki" olan akidlerde tafsìl-i keyfiyyet-i ahvâl olunduğu üslûb ve minvâl üzre."

80 "mukaddemâ tahrîr olunan alâylarda tafsīl olunduğu tertîb üzre alay ile."

81 "Zikr olunan alayda imâm-ı evvel ve sânî-i sultânî ve Hekîmbașı ve Cerrâhbaşı ve Haremeyn-i muhteremeyn müfettişi efendilerin örf ve üst kürkleri ile süvâr olmaları fermân ve Enderûn-ı Sarây-ı Hümâyûn ağaları ve hidmet-i Âsafîde olan Enderûn ağalarından gediklü ze'âmete mutasarrıf olanlar sâir zümreleri ricâli gibi mücevveze ve ferâce semmûr kürkler ve evkāf-ı selâtîn mütevellîleri ağalar perị̂̂̂nî ve ferâce kürkler ile râkib olup imâm-ı Âsafì efendinin Muharrir-i Fakìr ile horasanî destâr ve ferâce kürkler ve saçaklı ile hem-nâm olması istihsân buyurulmağla, mukaddem olan alay-ı vâlâdan zînet ve kesreti efzûn ve dü-bâlâ oldu."
} 
been all the more strongly felt since it was routine for the marriages of princesses to coincide with princely circumcisions. But while the latter took place in the Hippodrome, the former were excluded from it even in the early 18 th century, at a time when royal marriages were becoming part and parcel of public parades.

On the other hand, the relation of the Hippodrome to the grand vezirial palace had been established back in 1521-22 when Süleyman I's favourite İbrahim Pasha rebuilt, and settled in, a palace flanking its western side. In doing so, in his time he too appears to have aimed at enhancing his personal visibility and authority in the capital. ${ }^{82}$ In 1708 , while Emine's marriage processions took the shortest route to the palace of the grand vezir, we see that during the two following weddings there were attempts at coming close to the Hippodrome. However, they did not enter the large open space, the arena of Ottoman celebrations and public spectacle. In 1709, the procession of the trousseaus had to cross the city from one end to the other, and the procession taking the bride seems to have passed right by the Hippodrome: leaving the Imperial Gate, it went past the Cebehâne (St Irene), and from one end of the Hippodrome (At Meydanı başından), it went into the Dîvânyolu, from where it proceeded to Eyüb. During the 1710 marriage of Safiye Sultan, the procession of the princess passed through the same route, leaving the Imperial Gate, passing by the Cebehâne, and coming close to the Hippodrome (At Meydanina kârib mahalden), but did not enter the vast square, instead taking the Imperial Route (nehc-i şahî) of Soğukçeşme, by way of Alay Köşkü reaching the Râmî Pasha Palace at Demirkapi.

In Spring 1724, in contrast, İbrahim Pasha appears to have been keen to restore the Hippodrome back to its former centrality, though we shall never know whether he was consciously emulating his 16thcentury namesake in the process. For it is clear that whatever happened to be their final destination (the palace allocated to the newlywed couple), in 1724 all such processions had to (a) go through the Imperial Gate, (b) pass below the Alay Köşkü (for acclamation), (c) stop before the gate of the grand vezir's palace, (d) move on to Dîvânyolu, and

${ }^{82}$ İbrahim Pasha's own marriage there in the Spring of 1524 displayed unprecedented imperial grandeur-even though he was not marrying a princess, but the granddaughter of a grandee. For the political and ideological setting of İbrahim Pasha's palace (a rebuilding of the palace of janissary novices): Turan, Sultan's Favourite, pp. 145-179. 
then (e) enter the Hippodrome. It was only then, only from the center of this vast urban plaza, that the procession headed out again towards its eventual destination, whether it happened to be on the shores of the Golden Horn, or on the Marmara Sea, or in older and more traditional neighbourhoods.

Route of the

Alay-1 cihâz of Ümmügülsüm

Bâb-1 Hümayûn'dan çıkılıp

Cebehâne önünden

Ayasofya Hamamı önünden

Dîvânyolu'na gidecek dörtyol ağzına

bakkallar köşesinden dik aşağı

Soğukçeşme önünden

Alay Köşkü altından

Şengül Hamamı yokuşundan

Vezir-i azam[Sarayı'n]ın ard kapisindan

Sebil köşesinden sapılip

Dîvânyolu'na çıkıldıkta

Firuz Ağa Camii önünden

At Meydani'na

miyâne-i meydandan

Şeyhü'l-islâm Efendi'nin

bahçe duvarıyla

ard kapısı sokağından

Nahılbend Çarşısı'ndan

Çardaklı Hamamı önünden

Kadırga Limanı'na varulup

Alay-1 cihâz of Hadice

Bâb-1 Hümayûn'dan çıkılıp

Cebehâne önünden

Ayasofya Hamamı önünden mürûr

bakkallar köşesinden dönülüp

Soğukçeșme önünden
Alay-1 arûs of Ümmügülsüm

Bâb-1 Hümayûn'dan çıkılıp

Cebehâne önünden

Ayasofya Hamamı önünden

$=$

$=$

$=$

$=$

$=$

$=$

$=$

$=$

Talimhâne sokağından

At Meydanı'na

miyâne-i meydandan

Şeyhü'l-islâm Efendi'nin bahçe duvar1

sokağından

Nahılbend Çarşısı'ndan

Çardaklı Hamamı önünden

Kadırga Limanı'na varulup

Alay-1 arûs of Hadice

Bâb-1 Hümayûn

Cebehâne yolu ile

Ayasofya Hamamı önünden mürûr

Soğukçeşme'ye 
Alay Köşkü altından

Şengül Hamamı yokuşundan

Vezir-i 'azâm [Sarayı] ard kapisindan

Sebil sokağından

Çatalçeşme'den

Dîvânyolu'na

Dîvânyolu ile geri

Ayasofya Hamamı önünden

Cebehâne önünden

Saray Meydanı'na

Kaya Sultan Sarayı önünden

Kibleli Saray
Alay Köşkü altına varıldıkta

(alkış)

Şengül Hamamı yokuşu ile doğru

$=$

$=$

$=$

Dîvânyolu'na çıkıldıkta

Firuz Ağa Camii önünden

At Meydanı'na duhul

miyâne-i meydandan

Tavukçular Kârhânesi sokă̆ından

Arabacılar Kârhânesi önünden

Ahurkapı önünden mürûr,

Unluk Anbarı önünde meydanda

[Kıbleli Saray demekle meşhur]

saray-1 mezbura varıp

Alay-1 arûs of 'Atîke

Bâb-1 Hümayûn'dan çıkılıp

Cebehâne ve

Ayasofya Hamamı önünden mürûr

Soğukçeşme yolu ile

Alay Köşkü altına varıldıkta

(alkış),

Şengül Hamamı yokuşundan

Çatalçeşme önünden

Dîvânyolu'na

Firuz Ağa Camii önünden

At Meydanı'na çıkılıp

miyane-i meydandan

Kule Bostanı duvarı ile

Valide Hamamı önünden

Vezir Hanı'ndan

Cebecibaşı Sırrı Ağa hânesi önünden

Servi Mahallesi kurbundan

Cağaloğlu Sarayı yoluna

'Atîke Sultan Sarayı 
One can see on the map (Fig. 1$)^{83}$ what the overall historical and dynastic situation demanded of Ibrahim Pasha. On the one hand, Ottoman imperial processions were occasions to show off the might of the Ottoman state, to renew it, and to display it to the people of the capital. On the other hand, as with all pre-modern and even most early modern societies, continuity (or at least a semblance of it) had to be protected and emphasized, since the established order resisted innovation. Any outright change or explicit "innovation" was considered tantamount to degeneration..$^{84}$ All this was largely concerned with the legibility and hence legitimacy of power relations.

\section{The Wedding Processions of 1724: Continuity and Change}

One of the least noted paintings of Jean-Baptiste Vanmour, a native of Valenciennes who lived and worked in İstanbul over 1699-1737, shows a procession of the grand vezir through the Hippodrome with the Sultan Ahmed Mosque on the left and the 16th-century palace of (Süleyman I's favourite) İbrahim Pasha on the right. (Fig. 2) It is a rare view of the urban center by an European artist. The grand vezir Damad İbrahim Pasha and his retinue of forty to fifty attendants are depicted as moving diagonally at one end of the vast empty space, approaching a free-standing fountain. They seem to be on their way either to the Topkap1 Palace or the palace of the grand vezir across from Alay Kösskü. A document relating to this painting, dated 1817, ${ }^{85}$ identifies the rider at the front of the procession as his steward and son-in-law (Mehmed Pasha), who is followed by a group of perhaps sixteen people, noted as his running footmen. They are wearing red kaftans with long hems tucked into the front of their belts, wide trousers to below the knee, yellow boots, and short kâtibî turbans, with white muslin wrapped bulbously around a short cap. Mehmed Pasha

${ }^{83}$ I am grateful to Ersen Kavaklı from Sabancı University Information Center and to my colleague Murat Güvenç and his team (Şehir Araştrımaları Merkezi, İstanbul Sehir University) for creating this map based on: Ekrem Hakkı Ayverdi, 19. Asırda İstanbul Haritası (İstanbul 1978).

${ }^{84}$ For a discussion of the problem of personal and dynastic legitimacy of the ruler in the Ottoman context particularly relevant to our case here see: Crane, 'The Ottoman Sultan's Mosques', pp. 193-201.

${ }^{85}$ For the document found in Rijksmuseum Archives: Eveline Sint Nicolaas, 'Old Archives, New Insights', in: An Eye Witness of the Tulip Era. Jean-Baptiste Vanmour, Eveline Sint Nicolaas et al., eds. (İstanbul 2003) pp. 103-135. 


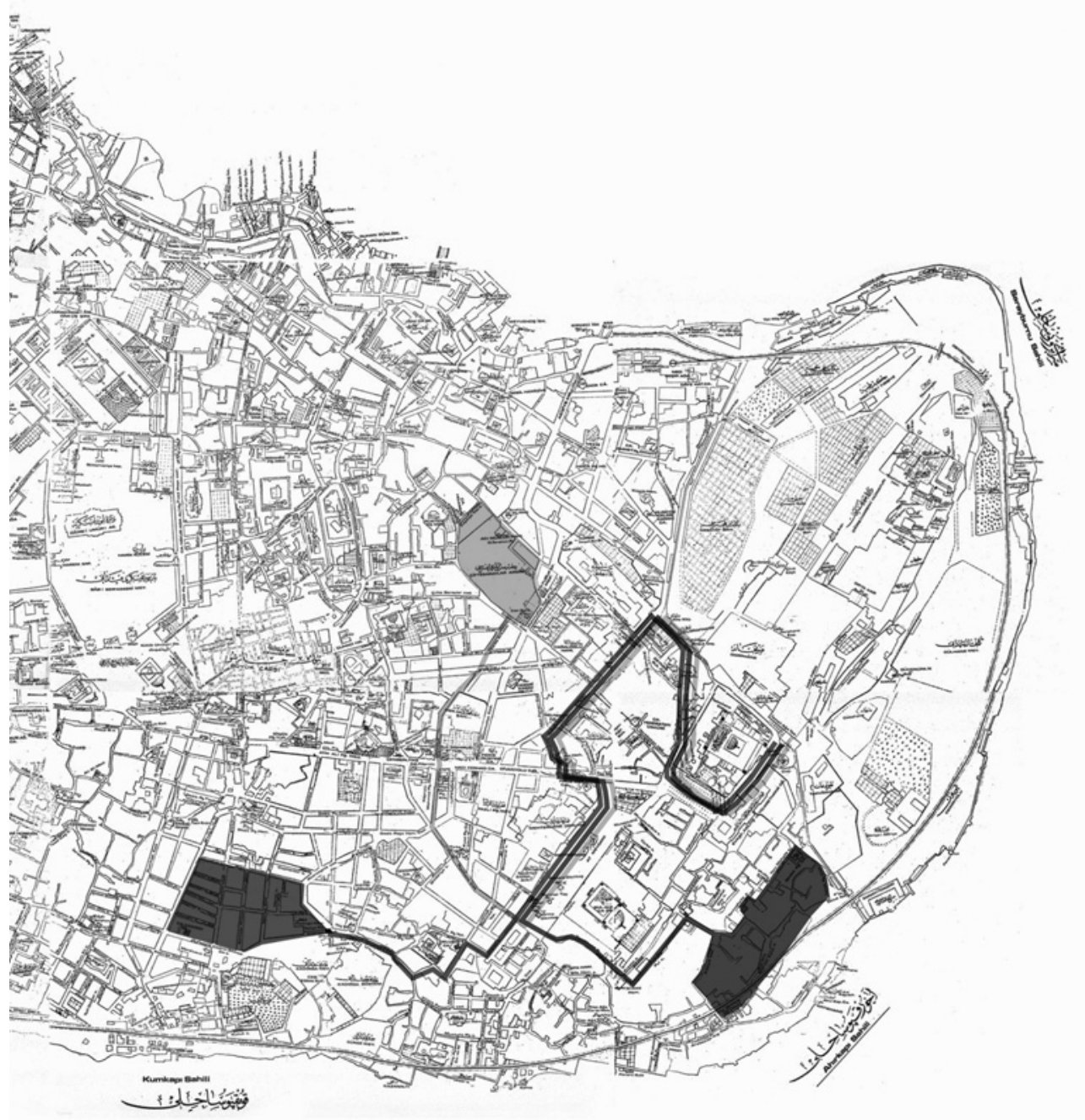

Figure 1. Map showing the routes of the 1724 processions. Reproduced from: Ekrem Hakkı Ayverdi, 19. Asırda İstanbul Haritası (İstanbul 1978). 


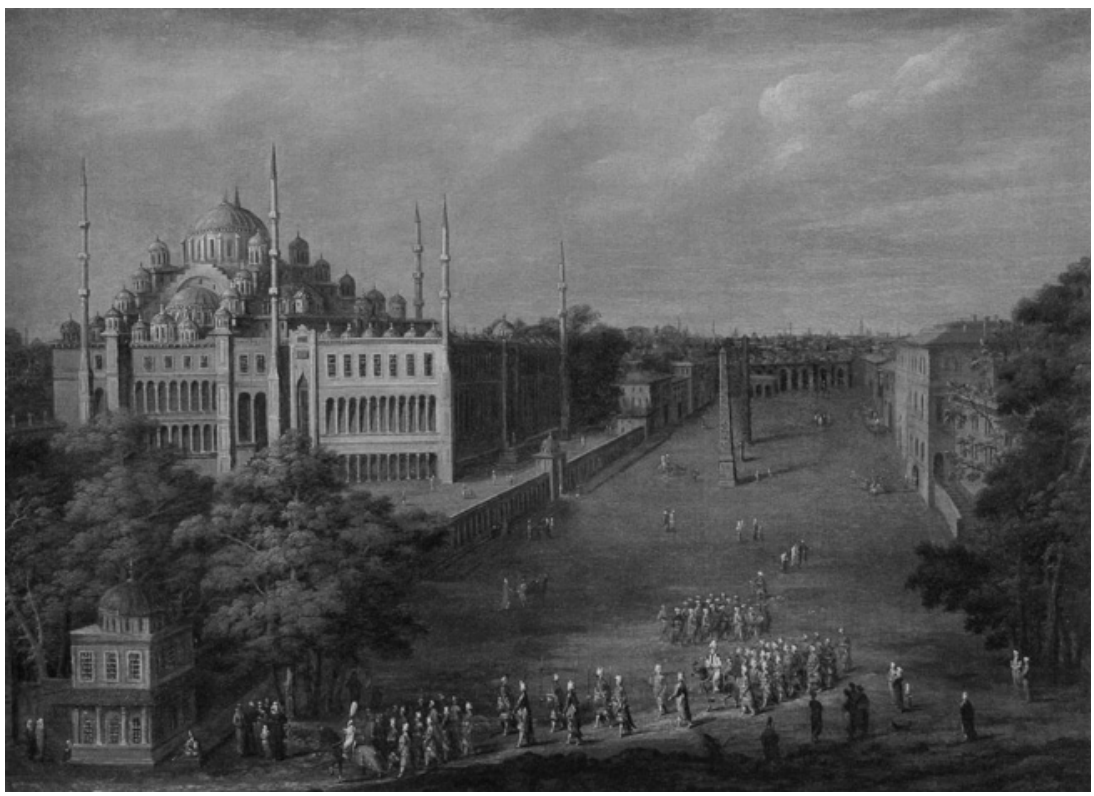

Figure 2. Damad Ibrahim Pasha's processions through the Hippodrome/ Atmeydanı by Jean-Baptiste Vanmour. SK-A-1998. Amsterdam, Rijksmuseum

wears a mücevveze, a tall ceremonial turban of many plaited folds, and a white ceremonial kaftan. Then comes another group of six, the şatırs or guards who are marked by the shiny pikes that they carry in a rather awkward manner. Wearing green kaftans also with long hems, turned up in front and tucked into their broad shimmering belts, these guards display gilded swords on slings as well as matchlock muskets. In addition, they too wear kâtibî turbans, wide trousers to below the knee, and yellow boots. This group is followed by another two wearing red kaftans of the same cut, each carrying a red bundle, perhaps a prayer rug and a cushion (to be used when the vezir had to kneel), and finally the grand vezir himself riding his horse. He is wearing a kallâvî, a tall ceremonial turban that only vezirs wore, and a white ceremonial kaftan with fur lining. He is followed by a rather unassuming rearguard of nearly two dozen attendants.

The narrator, perhaps a descendant of Cornelis Calkoen, the Dutch ambassador to İstanbul in 1727-1744 and a major collector of Vanmour paintings, explains that the prayer rug and the cushion would have needed to be used if the grand vezir was still out and moving about at prayer time. It is more likely, however, that Damad İbrahim 
Pasha is shown here on his way back from prayers at his recently completed socio-religious complex at Şehzâdebaşı. He is surrounded by his running footmen and followed by janissary guards: "They are always thousands, sometimes up to eight thousand men, that accompany him as such in the streets. Yet this crowd walks with extraordinary speediness, and one can hear the noise they create by running, from far away," says the author of the 1817 document, relating perhaps what he had heard from his ancestors. ${ }^{86}$

When it comes to providing a visual image of that "crowd", once more it is to Vanmour that we must turn again for a depiction of the majesty of the grand vezir's retinue-this time on another (unidentified) occasion. This, now, is not in an urban setting, though it might nonetheless be related to the wedding processions of 1720,1724 or $1728 .^{87}$ (Fig. 3) For his representations of such stately parades, including at least three which involve the sultan himself, Vanmour seems to have made use of a pictorial convention-one in which a procession begins in the foreground and then winds its way further and further back into and up the canvas. (Fig. 4) This allowed him to fit the whole procession into a single frame. At about the same time, the celebrated court artist Levnî was also capturing these imperial parades. His depictions of the various 1720 processions, however, are linear, and have therefore to be spread over several pages. In the past, Ottoman artists had not paid much attention to urban pageants. Now, however, the new rites and ceremonies launched by Ahmed III upon his return from Edirne to İstanbul, together with a new marriage policy involving royal women, seem to have caught their interest. ${ }^{88}$

\footnotetext{
${ }^{86}$ Actually, the most interesting feature in the painting is the walking style of the attendants: they seem to have been paired, and half-turned to one another, they appear to be carefully orchestrating their steps. This marching mode is not noted elsewhere. There is a reference, however, to a certain pâsdâr makam in the company of which the procession of the troussau of Safiye Sultan marched to her palace on 1 May 1710: TSM Archives D. 10591.

87 Olga Nefedova, A Journey into the World of the Ottomans. The Art of Jean-Baptiste Vanmour (1671-1737) (Milan 2009) p. 134. For other processions including those of the sultan depicted by Vanmour, see pp. 134-137. For another rare depiction of the grand vezir and the grand admiral parading through the city: Nikolaus Kleeman, Tagbuch der Reisen (Prague 1783) p. 388 from Gravürlerle Türkiye III. İstanbul (Ankara 1996) p. 139.

${ }_{88}$ Esin At1l, Levni and the Surname. The Story of an Eighteenth-Century Ottoman Festival (İstanbul 1999) pp. 112-143 (157b-174a) and 234-241 (12b-16a).
} 


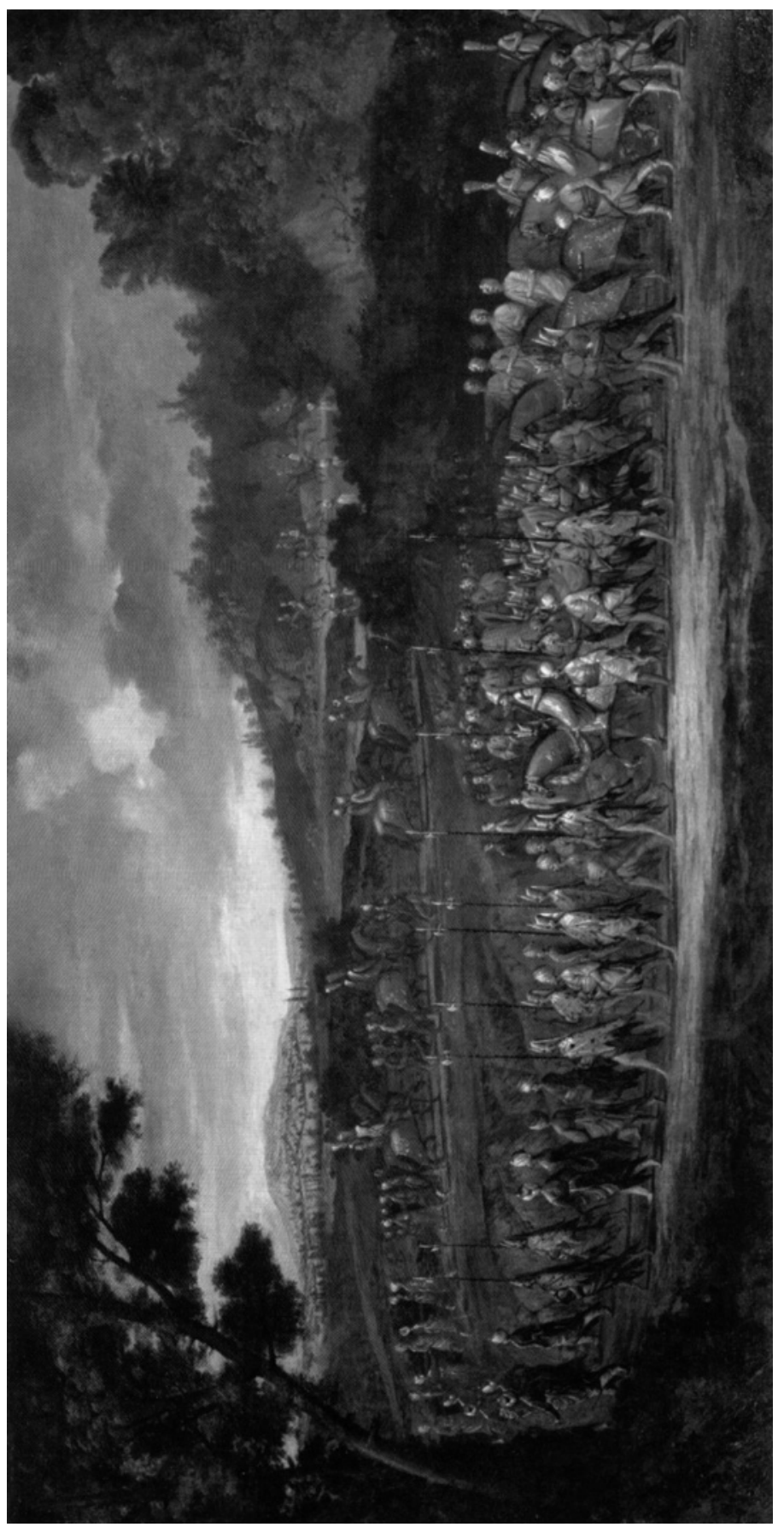

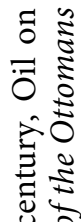

可

$\Phi 3$

해ㅇㅛㅛ

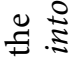

पे इे

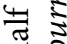

두 0

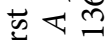

证 80

它运

焉

艺年

ते

\% क

.

굴

๑ึ है

สี

ฮี ․ㅡㄹ

ลิ

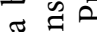

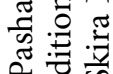

2

घ뭉

䨔娄

党

몽ํㅇ

घั

อี

प्त

올

D

ठ્ छ

르유

\& $\frac{1}{x}$

i 6

๑ ฐ

范 


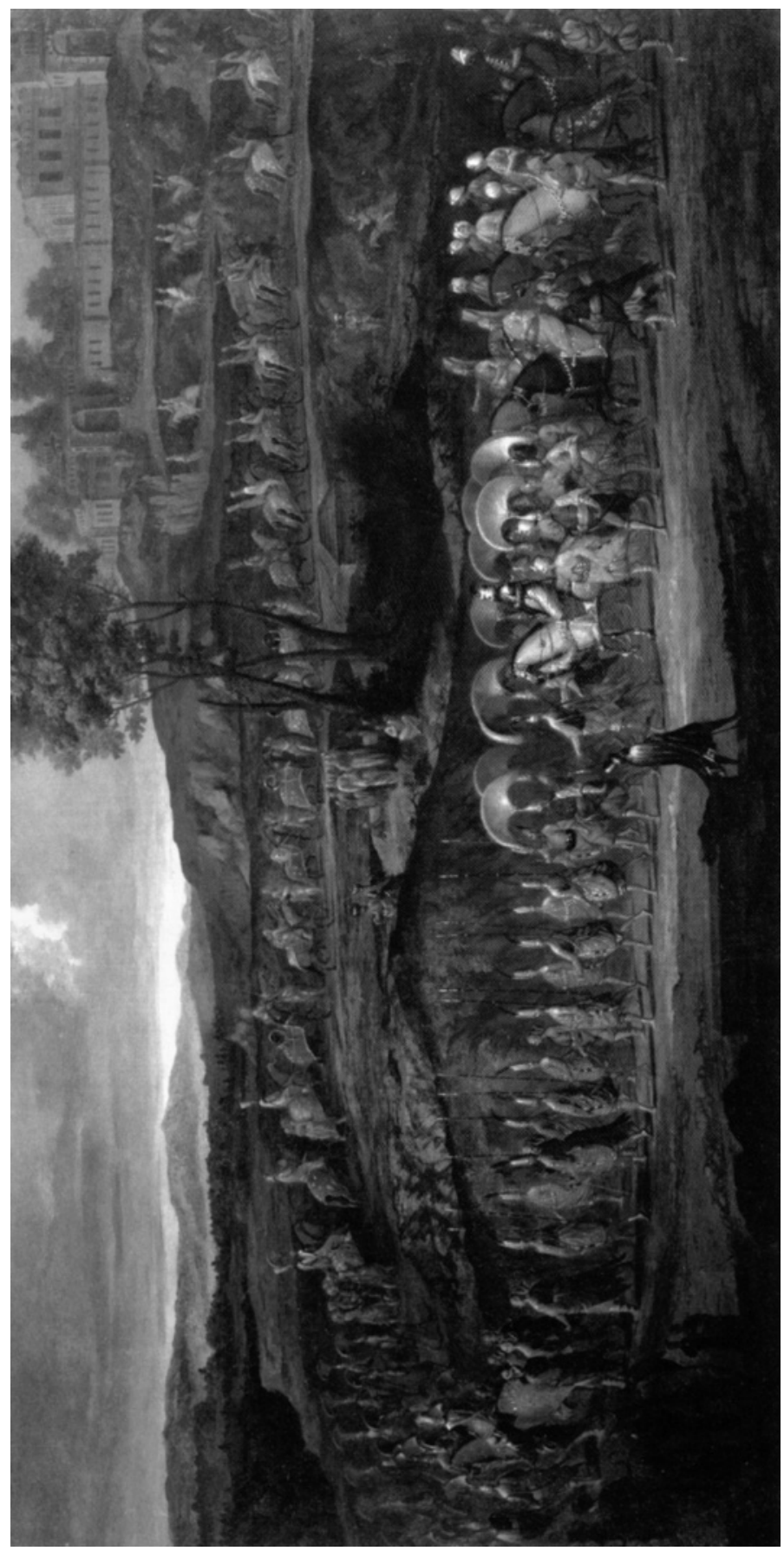

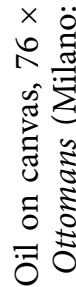

$\hat{x} \frac{1}{\pi}$

娄交

ये

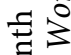

\& $\approx$

눙

$\cdot \frac{\infty}{2} \stackrel{0}{ \pm}$

‡े

पै है

承

๘匠

की

社

$\therefore$.

苟

궁

तี

\%

苛輐

훙ㅁㅇ

ตै क

สี

$\stackrel{\Xi}{\Xi}$

ลें

三

ヨ.이

멍

证

运全

4

ㄷำ

ㄷํ으

娄

$\stackrel{\infty}{=}$

ช

है

뉼

है

D

म

\&

항요 
We have seen that from 1718 onwards, Damad İbrahim Pasha became a part of this project in many ways. With what seem to have been his proto-modern aesthetics and his organizational talents, his feel for both neatness and magnificence, he seems to have studied the ceremonies and festivities of the 16th-17th centuries in order to arrive at an acceptable format for something that was not a simple revival but part of a new social reality, a different historical epoch. ${ }^{89}$ İbrahim Pasha's solution was to establish or consolidate a route that had two components: a common element that was a solemn state occasion, and a second part that depended on the procession's destination. In between, the Hippodrome became the hinge and hence (once more) the center of urban festivals. The first part involved a procession allowing for a general display of rank and status (including especially the grand vezir's household). As a result, these royal weddings became both private-family and public-dynastic affairs. And in the end, it was this established route and its repetition that imprinted all these complex messages on the collective memory of İstanbuliotes. The Hippodrome, the single most important arena of public space where the sultans came for selective encounters with the populace, was reinvented in the festive atmosphere of the early 18th century.

This ceremonialization coincided with Ahmed III's and his grand vezir's grand design to re-assimilate the power being accumulated by the administrative elite. Together they took the major step of allowing,

${ }^{89}$ Thus, no matter how the programmatic functions of double or triple marriages of the royal daughters and nieces went far beyond a kind of one-dimensional dynastic aggrandizement, the established order of the processions were not challenged. No deviation was allowed. It has been repeatedly recorded in the Books of Protocol that they turned to the "kânûn-ı kadìm" whenever a marriage or circumcision was planned. As we have noted above Damad İbrahim Pasha, too, ordered the earlier Books of Festivals in 1720 and studied them carefully. Moreover, Râşid records that his predecessor Şehid (Silâhdâr) Ali Pasha also studied the books of protocols and that he had intended to revive the tradition of büyük kol, which was the grand vezir's visiting of the yeniçeri ağasi on the third days of the religious festivals. The chronicles records that Ali Pasha had to give in because of the financial dire straits, but his successor ordered to observe this procession in 1721. Thus Merzifonlu Kara Mustafa Pasha's waterfront palace at Eyüb was assigned for this ceremony which continued thereafter: Mehmed Râşid, Tarih-i Râşid V, p. 308. As Mehmed IV's master of ceremonies Ahmed bin Mehmed Ni'metî Efendi claims that it was Merzifonlu who had initiated the ceremony in 1677 (possibly in Edirne), it is safe to say that it was during the successive terms of Köprülü Mehmed and his son Ahmed that the stately rituals were neglected and the new grand vezir was in search of a revitalization. Moreover, Uzunçarşll remarks that the office of the master of ceremonies was also shifted to the Sublime Porte during the reign of Ahmed III: Uzunçarşıll, Merkez ve Bahriye Teşkilâtı, pp. 58-59, 144. 
indeed inciting royal women to engage in public manifestations of dynastic sovereignty on their own. They thereby interpolated them between the throne and the aspirations of (the rest of) the political elite. A crucial factor in this attempt to subdue the elite was the delegation of the sultanic prerogative of constructing palaces in the capital for princesses. These waterfront-palaces on the Golden Horn and the Bosphorus architecturally and symbolically put their husbands in their place by dwarfing their adjacent and much more modest residences. They also displayed and represented the dynasty as a whole. Such quasi-royal and sub-royal edifices were in turn followed and emulated by the summer houses of a whole host of lesser dignitaries, retired jurists, judges and Islamic scholars plus guild administrators, nonMuslim merchants, goldsmiths, moneylenders, and physicians who were closely connected with the court. Thus first the Golden Horn proved to be a extensive urban plaza for stately gatherings, entertainments, and processions (as was the case in 1720), and then the Bosphorus, gently winding its way from one pond-like bay to another, evolved into a new ceremonial avenue lined with large and small kiosks.

While princesses continued to be married to grandees and then settled in their waterfront palaces throughout the 18th century, it is striking that no urban-scale marriage ceremony was organized in the post-1730 period. It is therefore not surprising that after the 1743 compilation of 'Abdullah Nầilî Pasha's Kavânîn-i teşrîfât (The Laws of Protocol), no other pre-Tanzimat registers, including even the defter of 1736-1808, cover betrothal, trousseau or brides' processions. The atmosphere surrounding the 1720,1724 and 1728 royal weddings was lost. Ironically, in the 19th century it would be only princesses' funerals which kept being recorded in Ottoman chronicles and protocol registers. ${ }^{90}$

\footnotetext{
${ }^{90}$ Karateke, Ottoman Protocol Register.
} 


\section{Appendix I: Alay-1 Nişân of Ümmügülsüm, 'Atîke and Hadice?91}

The first of the processions on 20 February 1724 (25 CA 1136), on the occasion of the transfer of the betrothal gifts of Ali and Mehmed (and Ahmed?) from the grand vezir's palace to the Topkapi Palace, was led by the Grand Admiral Kaymak Mustafa Pasha. The grand admiral (a Köprülü descendent and a son-in-law of the grand vezir) was the best man of the grand vezir's nephew Ali Pasha (who was marrying Ümmügülsüm). ${ }^{92}$ Although the grand admirals had enjoyed this honour on previous occasions, it seems that in this case it was not only Kaymak Mustafa Pasha's office, but also his private relation to the grand vezir which was being highlighted by placing him at the head of the procession. ${ }^{93}$ He rode a horse with opulent trappings of the kind used by members of Imperial Council on the days of their official meetings.

Then came the head saddler (sarrâçbaşı) ${ }^{94}$ marching together with the water-bottle carriers (matharaci) and the musketeers (tüfengci), who may have constituted the close body-guard in the grand admiral's immediate retinue. ${ }^{95}$ Behind them was the commander (steward)

91 Codex Vindobonensis Palatinus OH 95, 65a-70b.

92 Artan, 'Yönetici Elitin Saltanatın Meşruiyet Arayışına Katılımı', pp. 292-322.

93 In the marriages of Emine and Fatma, then grand admiral İbrahim Pasha was the best man of Çorlulu Ali Pasha. For Safiye's husband Maktûlzâde Ali Pasha, it was Süleyman Pasha, a member of the Imperial Council, who was chosen as his proxy and best man.

94 I was not able to locate the head saddler in Damad İbrahim Pasha's household accounts. For the ceremonial roles of this office-holder (in relation to the yeniçeri ă̆ası and sekbanbaşı) see: Hezarfen Hüseyin Efendi, Telhîsü'l-Beyân, pp. 145, 149. Uzunçarşılı refers to the head saddler only in one instance, during the routine inspection of the grand vezirs on the third day of the religious festivals (büyük kol) and notes that he marched in front of the grand vezir together with the orta çavuşu: Uzunçarşılı, Merkez ve Bahriye Teşkilâtı, p. 144. His functions are not described in Gibb and Bowen either who nevertheless include the head saddler with the Masters of the Horse: H.A.R. Gibb and H. Bowen, Islamic Society and the West. A Study of the Impact of Western Civilization on Moslem Culture in the Near East I (Islamic Society in the Eighteenth Century Part I) (London; New York; Toronto 1950) p. 355.

95 The text identifies these three as attendants in the retinue of the grand admiral (rikâblarında olan). Uzunçarşılı refers to the matharacıbaşı and tüfengcibaşı within the ceremonial retinue that accompanied the grand vezir on the days of the Divan (and when he visited the şeyhü'l-islâm): Uzunçarşılı, Merkez ve Bahriye Teşkilâtı, p. 146. Gibb and Bowen, quoting D'Ohsson and Osman Nûrî, note that the two officers of the muhzir ăgas orta, called tüfengcibaşı and matharacıbaşı marched on either side of the grand vezir when he went on his rounds: Gibb and Bowen, Islamic Society and the West, p. 325, n. 5. 
of the gatekeepers (kapıcılar kethudâsi), who acted as the master of ceremonies. ${ }^{96}$ Marching next to him was another attendant of ceremonies (selâm ağası) whose regular duty was to escort the master of a household. ${ }^{97}$ Altogether this group of five, all mounted, were actually the aghas of the imperial stirrup (rikâb-ı hümâyûn ${ }^{98}$ who served in immediacy to the sultan and attended him during processions as chief guards and officers of ceremonies. ${ }^{99}$ At the same time, together with many other functionaries who were gradually shifted from the Court to the Porte and began to serve in the capacity of middlemen between the sultan and the grand vezir while still stationed at the sultan's palace,

${ }^{96}$ The stewards of the doorkeepers (responsible for the guardianship of the Imperial Gate and the Gate of Salutation) were also a member of the sultan's "agas of the stirrup" and served at the Imperial Council in some ceremonial capacity. The kânûnnâmes of Abdurrahman Pasha and Hezarfen Hüseyin Efendi both of which describe the ceremonies before the reign of Mehmed IV refer to him as receiving the dignitaries entering the second courtyard, and gives further particulars of his duties at the Imperial Council meetings: Tevkîî̀ Abdurrahman Paşa, 'Kanunnâme-i Âl-i Osman', p. 506 ff and Hezarfen Hüseyin Efendi, Telhîsü'l-Beyân, pp. 74-79, 259-262, 264. See also: Uzunçarşıll, Osmanl Devletinin Saray Teşkilâtı, pp. 392-396. By the 18th century, they were copied as the majordomo in the grandee palaces modeled on the imperial palace while they ceased to be ranked aghas of the stirrup owing to the fact that their duties came to be connected more closely with the grand vezir than with the sultan: Gibb and Bowen, Islamic Society and the West, p. 83, and n. 7. It was the special duty of the kapicilar kethudâsı to carry memoranda (telhis) from the grand vezir to the sultan on these occasions. With the transfer of the Imperial Council to the grand vezir's residence, the ceremonial duties of the kapıcılar kethudâsı must have been observed at the Sublime Porte, but whether his various functions at the imperial palace were discontinued or not requires further elaboration.

${ }^{97}$ Uzunçarşıl is the only secondary source that refers to documents that identify selam ağası in the retinue of the grand vezir: Uzunçarşıll, Merkez ve Bahriye Teşkilâtı, pp. 132, 201. Moreover, selam ăgast is listed in Damad İbrahim Pasha's household accounts as a member of his retinue: Başbakanlık Arşivi Cevdet Dahiliye 6611 ( $\mathrm{R} 1134$ ).

${ }_{98}$ Hezarfen Hüseyin Efendi (who refers them also to özengi ağas) notes their number as 60 , and lists their majors as the agha of the Janissaries, the mir'alem, the kapıcubaşıs, the [two] mîrâhûrs, the çakırcıbaşı, the çaşnigirbaşı and the bölük ağas, all of those who personally assisted the sultan in mounting his horse: Hezarfen Hüseyin Efendi, Telhîsül-Beyân, pp. 92, 85. To these listed above the kapıcılar kethudâsı and the çavuşbaşı are added in other sources. See also: Gibb and Bowen, Islamic Society and the West, pp. 82-83, n. 2.

${ }_{99}$ For general information on these functionaries (originally) serving at the Topkap1 Palace see: Uzunçarşıll, Osmanlı Devletinin Saray Teşkilâtı: sarraçbaşı: 492-494, matharacı[başı]: 397, tüfengci[başı]: 326, kapıcılar kethudâsı: 392-396, selâm ağası (duacı çavuş): 419. As the host happens to be the grand vezir here, there is also the possibility that the functionaries listed here represents the grand vezir's householdhis household was a replica of the imperial palace. 
we find the five also listed in the grand vezir's household accounts. ${ }^{100}$ Here, however, they were organized around the grand admiral.

Next marched the Kethudâ Beg, the steward of the grand vezir and his chief secretary in/for internal affairs, who clearly marks the household of Damad İbrahim Pasha. The position of Kethudâ Beg (who was emerging as a minister of the interior) has been noted as "the product of an unusual evolution" in the household of the grand vezir in the early 18th century. ${ }^{101}$ Actually, the office in question seems to have been part of the grand vezirate since the mid-17th century. In this particular case, Kethudâ Mehmed Efendi was another son-inlaw of the grand vezir, and was also the proxy and best man of both the grand vezir's son Mehmed Pasha (who was marrying 'Atîke) and Ahmed Pasha (who was marrying Hadice). ${ }^{102}$ His horse was embellished with sumptuous trappings that were used on Imperial Council meeting days.

Then came the guide, the marshal leading the procession ( $k u l a g u z$ çavuş), conventionally a member of the sultan's household troops whose duty was to keep the route open and thus direct the march. ${ }^{103}$ There would be an officer serving in the same capacity in vezirial households,

${ }^{100}$ For a complete list of the functionaries in the enderûn and bîrûn quarters of Damad İbrahim Pasha in early 1722: Başbakanlık Arşivi Cevdet Dahiliye 6611 (R 1134). Among those listed here only the tüfengcis are missing in Damad İbrahim Pasha's household records. It is important to note that in 1676, they were not listed in the household of the grand vezir either. Compare with Kara Mustafa Pasha's household: Galland, İstanbul'a Ait Günlük Hatıralar II, pp. 132-136.

${ }^{101}$ Uzunçarş1l, Merkez ve Bahriye Teşkilâtı, pp. 256-59. "He had begun as a domestic functionary, managing the grand vizier's household and lacking any official character. At the Sublime Porte, he became an official of high status, serving the grand vizier as a kind of deputy, though he was not to be confused with the kaymakam or lieutenant appointed during the grand vizier's absences from the capital in wartime. The responsibilities of the steward are usually described as having to do with internal and military affairs. Beyond this sources on the eighteenth century disagree as to the details of his role or the roster of officers who came under him": Findley, Bureaucratic Reform, p. 73.

${ }_{102}$ Codex Vindobonensis Palatinus OH 95, 69b.

${ }^{103}$ It was not the kılaguz çavuş, but an alay başçavuşu who was listed in the retinue of Damad İbrahim Pasha in 1722, for keeping the route of the processions unobstructed. Hezarfen refers them as part of the marshals (çavuşan): Hezarfen Hüseyin Efendi, Telhîsü'l-Beyân, p. 146. Gibb and Bowen identify twelve alay çavuşes in the grand vezirial households who directed the march on occasions of public procession: Gibb and Bowen, Islamic Society and the West, p. 362, n. 6. In 1709, it was the regiments of the muhzır ağa, a member of the janissaries at the Imperial Court, who kept the route unobstructed and thus lead the procession, together with the 'asesbaşı and sübaşı. See also: Uzunçarşıll, Merkez ve Bahriye Teşkilâtı, p. 283. 
and this one seems to have been attached to the grand vezir's household. Behind him was the steward of Ümmügülsüm Sultan who led the betrothal gifts of Ali Pasha. The gifts of the bridegroom included twenty small nahıls, decorative structures made out of (silver) wires symbolizing fertility and good fortune, carried by colonels, that is to say orta-commanders (çorbacı) of household troops (the janissary corps) lined in pairs, ${ }^{104}$ followed by thirty exquisitely decorated trays carried by guards (nigâhban), said to be worthy of kind consideration (vâcibü'r-ri'âye), all dressed in white and in new boots. Theirs is a curious identity. While the 1708 and 1710 sûrnâmes are silent about them, in 1709 this group was explicitly noted as belonging to the grand vezir's household (sadrazam hazretlerinin vâcibü'r-ríâye ağaları). Each tray held three boxes of candies with delicately coloured coverings ( $p$ uşide). Then came two trays of sugar gardens (şeker bağçeleri) and a small nahıl of (solid?) silver. To the left of this nahıl a silver tray, crowned by a jewelry box, was paraded. Then there were four more silver trays, each carried by the chief gatekeepers (kapıcıbaşı ağas) of the grand vezir's palace, ${ }^{105}$ displaying the gifts of the bridegroom Ali Pasha. Each kapıcıbaşı ağa was escorted by two guards (nigâhban) who were again praised as worthy of kind consideration, again dressed in white. These could have been the lesser blood relatives of Damad İbrahim Pasha, or else youngsters or regular attendants.

Among the gifts on these trays were a jeweled belt, a diamond tiara, a set of rings and bracelets, a pair of large earrings with diamonds and emeralds, a jeweled mirror, pairs of various shoes to be worn indoors, outdoors, and in wet and slippery areas (papuç, mest, nalın), a diamond aigrette (sorguç), and a diamond belt (çaprast). Each of the four

${ }^{104}$ It is not clear whether in later times these soup men, soup purveyors, cooks and scullions were still functioning in the capacity that their titles imply, or acted also or, exclusively, as subordinate commanders. For more see: İsmail Hakkı Uzunçarşıll, Osmanlı Devleti Merkez Teşkilâtından Kapıkulu Ocakları I (Acemi Ocağı ve Yeniçeri Ocağı) (Ankara 1988 [1943]); Gibb and Bowen, Islamic Society and the West, pp. 61, 319-20.

${ }^{105}$ For kapıcıs and kapıcıbaşıs see: Uzunçarşı1lı, Osmanlı Devletinin Saray Teşkilât, pp. 396-407, and idem, Merkez ve Bahriye Teşkilâtı. The number of kapıcıs reached 2000 by mid-17th century. At about this time, there were nine kapicıbaşıs under the supervision of a başkapıcıbaşı. In the course of the 18th century the numbers of the kapıcıbassis were in constinuous increase-reaching 60 at the beginning and 150 at the end of the century. But the kapıcıs and kapıcıbassis listed here in the 1724 wedding were identified as those serving in the capacity of guards and attendants of ceremonies that have been attached to the grand vezir's household which was modeled on that of the sultan. For more: Gibb and Bowen, Islamic Society and the West, p. 347. 
trays was made of 500 dirhems of silver (a dirhem equals 3,207 gram). ${ }^{106}$ Then the steward of Ali Pasha marched. The document continues with a brief reference to the gifts of Mehmed Pasha paraded in the same order. There is neither an extensive account of this succeeding procession, nor any mention of the third bridegroom, namely Ahmed Pasha and his gifts for Hadice.

The procession, comprising the high-ranking members of the two best men's retinues (hazerât), and a crowd of elite guards chosen from the private entourage of the grand vezir, entered the palace from the Imperial Gate, and a series of rituals took place in the palace. ${ }^{107}$ It is in this section of the sûrnâme that Ahmed Pasha's absence is made clear: as attested by the steward and another dependent of Ahmed Pasha, as well as the Re'is Efendi and the Çavuşbaşı, Kethüda Mehmed was made the proxy and best man of both Ahmed and Mehmed pashas. The sultan's gifts to the three bridegrooms were received, and the marriage contracts were signed. ${ }^{108}$

After the ceremony at the Imperial Palace came to a conclusion, the grand vezir left his palace together with the top-ranking state dignitaries. Led by the marshal serving as the guide (kulaguz çavuş), the envoy including the scribes and the treasurers of the marshals of the court (çavuşân), mounted their horses and rode to the Topkapı Palace. Then the director of the imperial chancery ( $\left.r e^{\prime} i s\right)$, the chief sergeant-atarms (çavuşbaşı), the janissary agha and the chief treasurer (defterdâr) marched. At the end of the procession was the grand vezir and the şeyhü'l-islâm. The magnitude and the composition of these dignitaries' retinues was not indicated in the sûrnâme.

${ }^{106}$ Küçük Çelebizâde Âsım Efendi's account differs slightly. He says that each vâcibü'r-ri'âye carried a tray with a silver box of sweets, candies and other sugar assortments. The contents of the four trays were not specified, but he remarks that these were followed by two gold trays each carrying 2,000 tuğralı altun (also known as cedid zolota or cedid Eşrefî) as mihr-i mu'accel, that is the part of the dowry, mandatory in Islam, which is given by the groom to the bride at marriage.

107 Codex Vindobonensis Palatinus $\mathrm{OH}$ 95, 67b-70b: Both the engagement and marriage ceremonies of the three couples were on the same day.

${ }_{108}$ With 10,000 altın mihr-i müeccel, the other part of the dowry agreed to be given to the wife if she is widowed or divorced: Codex Vindobonensis Palatinus $\mathrm{OH} 95$, 68a, 69b. Küçük Çelebizâde confirms the amount of mihr-i müeccel as 10,000 tuğralı altun. 


\section{Appendix II: Alay-1 cihâz of Ümmügülsüm}

On 28 February 1724 ( $3 \mathrm{C} 1136$ ), the trousseau of the princess was transferred from the Topkap 1 Palace to her palace at Kadırga Limanı. Now, it seems that court functionaries took over the grand vezir's household (which, a week earlier, had led the way to the Imperial Palace). First marched the marshal leading the procession (kulaguz çavuş), and then the captains of the mounted guards and troops who served as a police force ('asesbaşı ${ }^{109}{ }^{\left.\text {sübaş }{ }^{110}\right)}$ ). All were wearing their special costumes for Imperial Council meetings (kisve-i dîvâniye), and were followed by their respective corps wearing their regular felt headgear (keçe). Then came the marshals of the imperial palace, those guards or messengers of the sultan who regularly served as his escorts in official ceremonies (çavuşân-ı dergâh $-\iota$ 'âlî), ${ }^{111}$ to be followed by more such attendants, marshals of his standing cavalry corps (çavuşân- $\iota$ sipâh and silâhdâr). ${ }^{112}$ The ceremonial escorts and the court cavalry were cited by their headgear.

109 The 'asesbaşı was traditionally the bölükbaşı of the 28th bölük of the Janissary Corps. He was the second of the officers (after muhzir ağa) under whose supervision sentences were carried out; he was the chief of the night patrols of İstanbul and also the superintendent of public prisons in İstanbul. It was his duty to keep the streets clear of impending crowds on festive occasions and stately processions (including the routine inspections of the grand vezir-kola çıkma): Uzunçarşılı, Merkez ve Bahriye Teşkilâtı, p. 142; Gibb and Bowen, Islamic Society and the West, pp. 325-26; Bayerle, Pashas, Begs, and Effendis, p. 11. For their roles in the 1675 festival see: Hezarfen Hüseyin Efendi, Telhî̀ül-Beyân, pp. 153, 238, 241-42.

110 The subaşı was the commander of a subdivision of sipâhîs exercising the functions of the police as distinct from their military duties. He was the third of the officers (after the muhzır ăga and the 'asesbaşı) under whose supervision sentences were carried out. He marched in the processions together with the 'asesbaşı to keep the streets clear: Uzunçarşıll, Merkez ve Bahriye Teşkilâtı, p. 142; Gibb and Bowen, Islamic Society and the West, p. 324. For their roles in the 1675 festival see: Hezarfen Hüseyin Efendi, Telhîsül-Beyân, pp. 238, 241-42.

${ }_{111}$ The çavuşes of the Imperial Council served as escorts in official ceremonies as well as personal guards for ambassadors, and as messengers, as diplomatic envoys, and when needed, as executioners of high officials condemned to death. Their numbers reached 1000 by mid-17th century: Bayerle, Pashas, Begs, and Effendis, p. 29. See also: Uzunçarşıll, Merkez ve Bahriye Teşkilâtı; Gibb and Bowen, Islamic Society and the West, pp. 87, 327-28.

112 Another group of çavuşes served in the 5th bölük of the Janissary Corps and carried the orders of the commanders to the troop officers and performed various services as marshals: Bayerle, Pashas, Begs, and Effendis, pp. 29-30. For sipâhîs and silâhdârs see also: İsmail Hakkı Uzunçarşıl, Osmanlı Devleti Teşkilâtından Kapukulu Ocakları II (Cebeci, Topcu, Top Arabacıları, Humbaracı, Lağımcı Ocakları ve Kapukulu Süvarileri) (Ankara 1988 [1944]), pp. 146-50; Gibb and Bowen, Islamic Society and the West, pp. 69-71, 327-28. 
The composition of the next group is interesting. These were the exclusive members of the court elite, [the sons of the] select cavalrymen (gediklü zü'emâ-i müteferrikagân), ${ }^{113}$ the so-called trustees (ümenâ), ${ }^{114}$ and the scribes (bureau chiefs) of the imperial chancery (hâcegân), ${ }^{115}$ who were traditionally under the jurisdiction of the sultan. They were all on horseback. At this point, Küçük Çelebizâde Âsım Efendi also lists the treasurer of the sergeants (çavuşlar emîni) and his secretary as among the chiefs of the grand vezir's household (sâhib-i devlet ağalart). A lot of these were part of a quasi-nobility that subsisted on fiefs, while others were part of clerical services that were in transition from the Imperial Council to the grand vezir's palace. By that time, council meetings were taking place in the grand vezirial palace, and the

113 The honorific rank of müteferrika is a designation reserved for distinguished servants of the sultan. Angiolelo, an Italian page attached to Mehmed II's court, reports that the members of this motley group receiving monthly wages included the sons of nobles and defeated monarchs, physicians, astrologers, architects, engineers, painters, goldsmiths, jewellers, and other artisans: Gülru Necipoğlu, The Age of Sinan. Architectural Culture in the Ottoman Empire (London 2005) p. 153. Literally meaning "separated," müteferrika is thought to have been applied to men of guard employed on special duties: "they serve no one but the Imperial Council and the Sultan, and the road to advancement for them leads to the vezirate". Foreigners referred to them as the sultan's noble bodyguard. Their duties ranged from serving as mounted escorts to the sultan to carrying messages between the grandees. They accompanied him on military campaigns, but performed no military service. Only the member's of the sultan's Privy Chamber, the sons of eminent servitors, and exceptionally, the relatives of tributary rulers, were admitted to the corps: Gibb and Bowen, Islamic Society and the West, pp. 87-88, 328.

114 Plural of emîn, which means men entrusted with some property as intendants, stewards, keepers, custodians and trusties. Hezarfen notes the intendants of the city (şehremîni), the Arsenal (tersane emîni), Kitchen (matbah emîni), the barley (arpa emîni) and the biscuits (peksimet emîni): Hezarfen Hüseyin Efendi, Telhîsüll-Beyân, pp. 97-98. To these listed above the intendants of the mint (darbhâne emini), the cannon foundry (tophâne nâzırı) and the secretary of the royal expenditures (masraf-ı şehriyâri) should be added. See also: Uzunçarşıll, Merkez ve Bahriye Teşkilâtı, pp. 68-69; Gibb and Bowen, Islamic Society and the West, pp. 84-86. For the emins referred in the household accounts of Damad İbrahim Pasha, namely emîn-i kâtib-i çavuşan, emîn-i kâtib-i gedükliyan, emîn-i hesab, emîn-i şa'ir and emîn-i saman: Başbakanlık Arşivi Cevdet Dahiliye 6611 (R 1134).

${ }_{115}$ Referred in the 1709 procession as aklâm haceleri, that is to say clerks of the government offices, these were the senior scribes of the imperial chancery: Uzunçarşll, Merkez ve Bahriye Teşkilâtl, pp. 68-71. "In the 16th century 25 scribes had the title bestowed on them annually by the sultan upon the recommendation of the sultan...In 1732 the divan had 50 secretaries, 20 apprentices and 30 candidates": after Bayerle, Pashas, Begs, and Effendis, p. 72. For the politization of the Chancery as a result of the unfavourable diplomatic climate and the transfer of the ambitious hâcegân to the Chancery as the critical career step: Itzkowitz, 'Eighteenth Century Ottoman Realities', passim; Shindler, 'Career Line Formation', p. 221. 
Imperial Council Hall of the Topkapı Palace had already turned into a stage setting for certain ceremonial occasions such as the distributions of wages to the troops, receptions of foreign envoys, or celebrations of religious festivities. Nevertheless, the functioning of these officers at the Imperial Council in the grand vezir's palace in 1724 requires further investigation, even though at the time those listed above were included in Damad İbrahim Pasha's household accounts.

In due course came the sultan kethüdalarl, the stewards of the princesses, who were all high-ranking dignitaries. Later in the document Ümmügülsüm Sultan's steward is clearly identified as marching together with the steward of the bridegroom. Hence, an all-inclusive reference to the princesses' stewards is rather misleading. These must be the stewards of Hadice and 'Atîke, and perhaps of all other princesses of the time. They were all on horseback and their horses were armored. These stewards are not mentioned by Küçük Çelebizâde. In the sûrnâme, they were followed by the mounted chiefs of the household troops (the janissary corps), namely captains of the cart-artillery (top 'arabacılarbaşı), the artillery (topçubaşı), the armory (cebecibaşı), the imperial hunters-head keeper of the hounds (zagarcıbassi) and keeper of the sultan's mastiffs (samsuncu) - and others who together formed the council (dîvân) of the janissary corps (ocak), all in their ceremonial divvân attires. ${ }^{116}$ Küçük Çelebizâde identifies the latter as saksoncu (which translates as the keeper of the hounds from Saxony), and also adds the head of the turnacis to this group. This last person took care of the dogs trained to hunt game birds such as cranes. The hunting establishment, originally a palace organization, was a regiment of the janissary corps. ${ }^{117}$ Then came the deputy to the janissary commander (kul kethudâsi) ${ }^{118}$ the secretary of the janissary corps (yeniçeri

116 Uzunçarşıll, Kapukulu Ocakları II. See also: Gibb and Bowen, Islamic Society and the West, pp. 315-316.

117 The seksoncıbassı, literally the head dog-keeper, was in command of the zagarcıs (greyhound-keepers), samsoncus (mastiff-keepers), and turnac1s (keepers of the cranehunting dogs): Uzunçarşıll, Kapukulu Ocakları I, pp. 199-204; Gibb and Bowen, Islamic Society and the West, p. 315.

${ }^{118} \mathrm{Kul}$ kethudâsı was the deputy of the Janissary commander and was third in rank in the Janissary corps after the segbanbaşı. However, kul kethudâsı (a title probably abbreviated from kapıkulu kethudâsı) who was in command of the bölük representing the force first used as a body-guard for the sultan at his head-guards (therefore the kapıkulus par excellence), enjoyed a much greater esteem than the segbanbaşı, second place in the Janissary hierarchy: Uzunçarş1l, Kapıkulu Ocakları I; Gibb and Bowen, Islamic Society and the West, pp. 314-315. 
efendisi), ${ }^{119}$ the senior deputy to the janissary agha (segbânbaşı), the stewards of the commanders of the cavalry regiments (sipâh and silâhdâr kethüdalari), the mounted messenger (atlu mukabeleci) and his scribes, the commanders of the cavalry regiments themselves (sipâh ağa and silâhdâr ağa), and chiefs of the imperial hunt (şikâr-ı hümâyûn ağas). ${ }^{120}$ Küçük Çelebizâde identifies these as the head keepers of the goshawks and the peregrine falcons (çakırcıbaşı and şahincibaşı). At first glance these military officers, chiefs, commanders and captains all appear as representing the sultan. However, there were also those who acted as intermediaries between their regiments (ocak) and regimental subgroups on the one hand, and the Sublime Porte on the other. Therefore their presence and position in the procession could be "read" in a different way. ${ }^{121}$

Next in line were the high-ranking functionaries of the Imperial Court such as the chiefs of the gatekeepers (kapıcıbaşı ağas). Even though it is not explicitly stated (as opposed to the previous procession, where it was noted that those in question were attached to the grand vezir's household), it is likely that the gatekeepers listed here did represent the sultan and the court. Following them came high-ranking bureaucrats of the Imperial Bureau of Finances: the keeper of the [land/ cadastral] registers (defter emini), and the chief treasurer (başdefterdâr or defterdâr-1 evvel), who had remained under the authority of the sultan although they were the first to move out of the palace, and the latter's two aides (defterdâr-1 şıkk-ı sânî and şıkk-ı sâlis). ${ }^{122}$

In due course the commander in chief of the janissaries (yeniçeri ağa) appeared. Apart from being a military commander, the head of the janissaries was also something of a police officer and was therefore responsible for the maintenance of law and order and the protection

119 The secretary, who was not a janissary himself, kept the rolls with the assistance of a large group of clerks: Uzunçarşıll, Kapukulu Ocakları I, pp. 386-90; Gibb and Bowen, Islamic Society and the West, p. 316, n. 6.

${ }_{120}$ Also referred as ser-şikârî: Uzunçarşılı, Kapukulu Ocakları I, pp. 229-30; Gibb and Bowen, Islamic Society and the West, p. 321.

${ }^{121}$ In this group of intermediaries Uzunçarşılı lists: muhzır ağa, bostancılar odabaşısı, kethudâs of sipâh and silâhdâr bölüks, kapı çavuşes of the cebecis, topçus, toparabacıs, 'asesbaşı, sübaşı, müteferrikabaşı: Uzunçarşll, Merkez ve Bahriye Teşkilâtı, p. 172.

${ }_{122}$ The separation of defterdâr kapısı is a debated issue. It is dated either to the end of the 16th century or to the creation of the grand vezir's separate office in mid-17th century. For the debate see: Fodor, 'Sultan, Imperial Council, Grand vizier', p. 73, n. 15. For the "organizational components of the Sublime Porte" see: Findley, Bureaucratic Reform, pp. 70-79. 
of property in most of İstanbul proper (excluding Eyüb, Üsküdar, and Galata). In the heart of the capital, only the sultan's palace and an adjacent quarter were outside his jurisdiction. ${ }^{123}$ This last neighbourhood as well as the outlying belt around the capital were under the control of other military officers (such as the topçubaşı and the cebecibaşı). ${ }^{124}$

Then came the grand admiral in his capacity as the best man of Ali Pasha, followed by his sword-bearer (silâhdâr) and the keeper of his seal (mühürdâr), his spare horse, and his master of protocol (teşrîfâtî̀). ${ }^{125}$ The stewards of the bridegroom and the bride came after the grand admiral and his retinue.

Next in line were more functionaries of the Imperial Court: the master of the stables (mîrâhur-ı evvel ăga), riding a horse in ceremonial trappings, was followed by thirty aghas (eunuchs) of the Imperial Harem, who bore cages displaying precious items of gold and silver. Then came the second master of the horse (mîrâhûr-ı sân $a \breve{g} a$ ), riding together with the head of the military band of the tentpitchers (hayme-i hassa mehterbaşı). The seven files of mules (70 in all) carrying the trousseau were escorted by the corps of tent-pitchers (mehteran neferatı), and two senior tent-pitchers (mehter odabaşı) were assigned to each file. Finally, eleven carriages carrying the female attendants (kapakl arabalar), and the standard-bearer of the mehter (mehterhâne-i mîr-i âlem ağa). Küçük Çelebizâde adds that at the end of the procession was the chief of the sultan's military band (çalicl mehterbaşısı ăga $)$ and his band (mehterhâne-i padişâhî).

${ }^{123}$ Gibb and Bowen, Islamic Society and the West, p. 66.

124 İstanbul, divided into the four judgeships of İstanbul and bilad-ı selase (Eyüb, Galata and Üsküdar), was policed by soldiery under the command of no less than five officers, the limits of whose respective jurisdictions did not coincide with those of these judgeships. Those part of the capital under the jurisdiction of the agha of the janissaries, the topçubaşı and the cebecibaşı were confined to İstanbul itself, and part of the judgeship of Galata. Referring to Osman Nurî, Gibb and Bowen records that while Pera and Beyoğlu were under the jurisdiction of the topcubaşı, the quarters of Ayasofya, Ahurkapı and and Hocapaşa were controlled by the cebecibaşı: Gibb and Bowen, Islamic Society and the West, pp. 66-69, 323.

${ }^{125}$ Küçük Çelebizâde Âsım Efendi does not list the members of the grand admiral's retinue. 


\section{Appendix III: Alay-ı arûs of Ümmügülsüm}

Finally, two days later, on 2 March 1724 (6 C 1136), which was a Thursday, Ümmügülsüm was taken from the Topkapı Palace and transported to the Kadirga Palace. This final procession included the sultan, the grand vezir and their households, as well as members of the ulema, and various formalities were observed along the way, such as an elaborate acclamation in front of Alay Köşkü. Küçük Çelebizâde notes that the procession of dignitaries followed "the previously established order" (ricâl-i devlet bi'l-cümle tertîb-i sabık üzre). ${ }^{126}$ In addition to the household troops (janissary corps), he also mentions the chiefs of the imperial guards (solakbaşı ağas) as passing on horseback.

The 1724 sûrnâme provides us with all the details. Again at the head of the procession were the chiefs of the imperial guards and their retinues: kulaguz çavuş was followed by the 'asesbaşı, sübaşı, çavuşân-ı dergâh-ı 'âlî, and çavuşân-ı sipâh and silâhdâr. While we find that the chief of the sergeants had exchanged his felt cap for a turban of many plaited folds and was also wearing an official fur coat, the rest of the lead group was once again described only by their headgear.

Then came the aghas of the grand vezir. Their presence at this point confirms that the group which followed, namely the quasi-nobility of the Imperial Council's gedikli zü'ema-i müteferrikagân, once again riding armored horses with sumptuous trappings, were really those who had already been transferred to the grand vezir's palace. The aghas in question were probably the grand vezir's chief gatekeepers.

The procession continued with the princesses' stewards (sultan kethudâları), ümenâ and hâcegân. In due course the chiefs of the artillery and armory followed. These were: the steward of the cart-artillery (toparabacı kethudâsı) and his sergeant (çavuş); [then probably their captain (top 'arabacılarbaşı)]; the steward of the artillery (topçular kethudâsı) and his çavuş; the captain of the artillery (topçubaşı); the steward of the armorers (cebeciler kethudâsi) and his çavuş; and the captain of the armorers (cebecibași). As mentioned above, these were the intendants, chiefs and captains who represented their corps

126 The janissary commander was followed by the chiefs of the finance bureau and the top members of the religious establishment: the defterdâr and the inspector of the Haremeyn treasury, and the judge of İstanbul, representative at İstanbul of the Sherif of Mecca (nakîü̈l-eşrâf efendi, who was also the chief of the descendants of the Prophet) and the two military judges of Anatolia and Rumelia (sadreyn efendis). 
(ocak) at the Sublime Porte. They were followed by more military staff ranging from the officers of the janissary regiments (yeniçeri zâbitân) to the affiliates known as the camel-drivers (deveciler). Then in due order came the chief sergeants (başçavuş) of the hound-keepers (samsuncu, zagarcı), and the kul kethudâsı, the standing cavalry of the court (sipâh and silâhdâr), the mounted messenger (atlı mukabeleci) and his scribes, the chiefs of the standing cavalry (sipâh and silâhdâr ă̆as), and the heads of the imperial hunt (şikâr-ı hümâyûn ağas).

Then came the gatekeepers and their chiefs: kapıcıbaşı ăgas and kethudâ-i bevvabin. ${ }^{127}$ As mentioned above, these two were traditionally members of the sultan's household, but those represented here may have actually been the members of the grand vezir's palace-the steward was explicitly mentioned in the nişân procession. This is further confirmed by the fact that the functionaries of the state under the grand vezir's command, namely his chief secretary and his two aides, the first and second secretaries to the grand vezir (mekt $\hat{u} b \hat{\imath}-i$ sadr$\hat{a} l i$; tezkere-i evvel and tezkere-i sânî), were introduced immediately afterwards. ${ }^{128}$ Then came the keeper of the [land] registers and his two aides (defter emîni; şıkk-ı sânî and şıkk-ı sâlis), and the chief treasurer (defterdâr efendi) who remained under the authority of the sultan even after the transfer of the chancery offices of the Imperial Council to the grand vezir's palace. ${ }^{129}$

After the commander of the janissaries (yeniçeri ağasi), who seems to have been marching in line with the chief treasurer (başdefterdâr or defterdâr-1 evvel), members of the 'ulemâ made their first public appearance in these processions: the inspector of the treasury of Mecca and Medina (haremeyn müfettişi), the chief of the descendants of the Prophet (the nakîbü'l-eşrâf, the Mecca sheriff's representative in İstanbul), the chief judge of İstanbul as well as the supreme judges for Anatolia and Rumelia who, of course, were permanent members of the Imperial Council (and were collectively called sadreyn efendiler).

Then came Ali Pasha, the bridegroom on horseback, though he was mistakenly referred to as Ahmed Pasha. (Küçük Çelebizâde repeats

${ }_{127}$ Uzunçarşılı, Osmanlı Devletinin Saray Teşkilâtı, pp. 392-407; and idem, Merkez ve Bahriye Teşkilâtı, pp. 132, 138, 201.

${ }_{128}$ Uzunçarşıll, Merkez ve Bahriye Teşkilâtı, pp. 55, 260-261.

129 In 1709 , it is noted that from the muhzır ağa to the yeniçeri ağası, the hierarchy that was observed in the procession of the trousseaus was repeated in the procession of arûs. The household of the grand vezir, including the çavuşbaşı, re'isü'l-küttâb, and tezkerecis, followed the yeniçeri ağası and preceded the members of the ulema. 
the same confusion.) He was followed by a row of dignitaries who, except for the steward of the grand vezir and, of course, the grand admiral, were those members of the Imperial Council who had been already incorporated into the grand vezir's household. ${ }^{130}$ Following the steward of the grand vezir, and then the grand admiral, and after him the second bridegroom Mehmed Pasha, there came the chief of the imperial chancery clerks $\left(r e^{\prime} i s\right),{ }^{131}$ and the chief sergeant of the Imperial Council (çavuşbaşı). ${ }^{132}$

Then rode the grand vezir himself escorted by the muhzır ağa, who was posted as aide-de-camp to the office of the grand vezir, ${ }^{133}$ and by the senior officer of the imperial gardeners (bostancilar odabaşısi), who in that capacity was also the commanding officer of the imperial guards. ${ }^{134}$ To the left of the grand vezir was the şeyhü'l-islâm wearing

${ }^{130}$ For the incorporation of the Imperial Council in the Bâb-1 Âlî by mid-17th century as a result of centralization and increase in paper work see also: Recep Ahıskalı, Osmanlı Devlet Teşkilatında Reisülküttâblık (İstanbul 2001); Ahmet Mumcu, Hukuksal ve Siyasal Karar Organı Olarak Divan-ı Hümâyûn (Ankara 1986).

${ }^{131}$ Halil İnalc1k, 'Reisülküttâb', İA IX, pp. 671-683. For a through study of the office: Ahıskalı, Reisülküttâblık. For the role of the re'is efendi in state ceremonies, especially in the dynastic marriages see: pp. 230-322, in particular pp. 309-311.

132 The commander of the çavuşes of the divan who was present in the divan meetings and was in charge of the protocol: Uzunçarş1l, Osmanl Devletinin Saray Teşkilâtt; and idem, Merkez ve Bahriye Teşkilâtt; Gibb and Bowen, Islamic Society and the West, pp. 349-50; Bayerle, Pashas, Begs, and Effendis, p. 30. See also: Murat Uluskan, Dîvân-ı Hümâyûn Cavuşbaşılı̆̆ı (XVI-XVII. Yüzyıllar), unpub. MA Thesis, MÜSBE Türkiyat Araştırmaları Enstitüsü (İstanbul 1998). Referring to two types of çavuşes, those of pay-drawers and those that subsisted on fiefs, Gibb and Bowen remark: "What is certain is that as time went on both were supplanted as couriers by other functionaries-kapıcıbaşıs, hasekis and müteferrikas, and that apart from their continued participation in the sultan's public processions, they came to be attached to the service of the grand vezir (who eventually discharged all the sultan's other public duties) rather than that of the palace. Hence the loss of the "stirrup" rank by the çavuşbaşı and his classification by D'Ohsson as a minister of state rather than a court official. That he continued to act jointly with the kapıcılar kethudâsı as master of ceremonies at divans did not mean that he was thereby properly a member of the Outside Service, since the divans were now presided over not by the sultan, but by the grand vezir."

${ }_{133}$ The muhzır ağa who was one of the bölükbaşıs of the janissary corps acted as the liason between the office of the grand vezir and the Janissary corps. In other words, as he was the representative of the janissaries in the grand vezir's household, janissaries from his bölük guarded the grand vezir's quarters: Uzunçarş1l, Merkez ve Bahriye Teşkilâtı, pp. 138-39, 142, 144; Gibb and Bowen, Islamic Society and the West, p. 325; Bayerle, Pashas, Begs, and Effendis, p. 112.

${ }_{134}$ Uzunçarşıll, Kapıkulu Ocakları I. Wearing a simple külah, a seraser kuşak and red çuka dolama, the bostancis were recruited from the acemis, and formed a training pool of the janissary corps while performing manual labour in the palace gardens. The bostancıbaşı, the commander of the bostancı corps, was one of the officers who was close to the sultan, holding his stirrup: Bayerle, Pashas, Begs, and Effendis, p. 23. 
a fur-lined white broadcloth cloak ( ferâce) as well as a special turban (örf) worn only by the leading judiciary and the sultan. Then the grand vezir's sword-bearer (silâhdâr-ı sadr-ı âlî), wearing a sable fur and with a jeweled sword over his shoulder, walked side by side with the keeper of the grand vezir's seal (mühürdâr-ı sadr-ı âlî). ${ }^{135}$ Next were the grand vezir's two spare horses, followed by the retinue of the muhzır ağa.

There marched the master of ceremonies of the Imperial Council (teşrîfât-ı dîvân-ı hümâyûn). He was followed by the stewards of the bridegroom (damad paşa kethüdast) and of the bride (sultan kethudâsi), who walked at the head of a couple of hundreds of sailors from the arsenal (tersâne bahadırları), who filed past in pairs carrying their campaign pikes, followed by their captains (kaptan). ${ }^{136}$ After a group of carpenters and two large nahıls, in this case tall decorative trees paraded as symbols of fertility, came the chief architect (mi'mâr $a \breve{g} a$ ), the chief of the Imperial Kitchens who was assigned to supervise the nahıls (nahıl emîni olan matbah-ı âmire emîni Halil Ağa), and the steward of the arsenal (tersâne kethudâsı). We are given to understand that all three had been employed in the making of the nahils.

Next were the spare horses of the princes, and the first and second masters of the horse (mirahur-ı evvel and mirahur-ı sâni ağas). The four princes (Süleyman, Mehmed, Mustafa and Bayezid), all followed riding their highly decorated horses, each accompanied by a pair of imperial guards (rikâb solak).

Then came another prominent member of the Imperial Court, the chief black eunuch of the Topkapı Palace (dârü's-sa'âde ağası), Hacı Beşir Ağa, surrounded by numerous attendants, and by a show of pomp and circumstance. His retinue was followed by six small nahils and then a silver nahil. Then came the silver carriage of the princess drawn by six horses, followed by other imperial carriages. At the end of the procession was the standard-bearer of the household troops (mîr-i âlem a $\breve{g} a$ ), and the head of the military band (çalıcı mehterbaşı ağa), leading the entire military (mehter) band. When the grand vezir appeared, as he came abreast of Ahmed III, the çavuşes acclaimed the sultan.

${ }^{135}$ Küçük Çelebizâde Âsım Efendi identifies this mühürdâr as Mustafa Ağa (who had replaced çukadâr ağa).

${ }^{136}$ Küçük Çelebizâde Âsım Efendi remarks that there were 400 soldiers from the Arsenal (tersane huddamları). Their costumes were in bright colours. They carried two, huge nahils. 


\title{
VERSAILLES, VIENNA AND BEYOND: \\ CHANGING VIEWS OF HOUSEHOLD AND GOVERNMENT \\ IN EARLY MODERN EUROPE
}

\author{
Jeroen Duindam
}

\section{Introduction}

The palace of Versailles encapsulates the image of the European court in the early modern age. The imposing architecture of the palace buildings and gardens, amplifying the monarch in the symbolic heart of his realm, tells a story repeated and embellished since the times of the Sun King. Royal power, restored after the Fronde rebellion (1648-1653), prevailed over unruly nobles for good. Court and palace had served as the king's instruments in the process. Bringing together the nobles of the realm in Versailles, Louis XIV (1638-1715) managed to 'domesticate' these erstwhile indomitable characters. Financial problems had propelled them towards the palace, where they enjoyed the king's benefits. Once at court, the grandees gradually lost their connections in the regions. Conspicuous consumption made them ever more dependent on royal graces. The ongoing battle for prestige among the nobles in the centre allowed the king to rule by fomenting strife among his former rivals. Occupying and balancing the nobles through the niceties of ceremony and politesse, the king in the meantime renovated and modernized the state apparatus in tandem with his bourgeois administrators. The court catered for the nobles and nominally upheld their position, yet at the same time it imprisoned them in a web of vanities and eroded their regional power bases.

This persuasive image, implicitly present in French literature since the later eighteenth century, was most systematically and powerfully worded by Norbert Elias. ${ }^{1}$ His sociological study relied strongly on

\footnotetext{
${ }^{1}$ Norbert Elias, Die höfische Gesellschaft. Untersuchungen zur Soziologie des Königtums und der höfischen Aristokratie. Mit einer Einleitung: Soziologie und Geschichtswissenschaft (Darmstadt; Neuwied 1969); idem, Über den Prozeß der Zivilisation. Soziogenetische und Psychogenetische Untersuchungen. I: Wandlungen des Verhaltens in den Weltlichen Oberschichten des Abendlandes. II: Wandlungen der Gesellschaft. Entwurf zu einer Theorie der Zivilisation (Bern 1969).
} 
the memoirs of the duke of Saint-Simon, son of one of Louis XIII's favourites whose hopes of favour and high office at Louis XIV's court had been disappointed bitterly. Elias took over his main witness' carefully constructed view of the Sun King as nemesis of the French nobility. Their version of Versailles became shorthand for a coherent definition and explanation of court life all over Europe, stressing the centrality of the king in his palace, and depicting the court as a predominantly noble environment secluded from the apparatus of the state. We see a punctilious salon writ large, rather than a centre of power and decision-making; we encounter nobles as participants in an ongoing battle for préséance rather than as councilors, governors and soldiers. The isolation of the nobles in the vacuum of court life offered an explanation for the expansion of courts in early modern Europe, and their increasingly rigid ceremonial: this was a luxurious prison, a gilded cage. The political rationale of the court, then, had been to separate pouvoir from grandeur, ministers from nobles, state from household. ${ }^{2}$ The expanding and ceremonializing households had offered a convenient solution for the main obstacle hindering state building: entrenched noble regional elites.

The view of the court as a gilded cage matched a phase in European historiography showing a strong predilection for institutions and offices seen as leading towards the modern state: bureaucracies, councils, ministers, parliaments. The domestic context of dynastic rulership was seen as trivial and unworthy of study. Research concentrated on the political institutions that were to become the heart of the state in the nineteenth and twentieth centuries-when indeed the domestic establishments serving royalty were receding into political insignificance. With his work, Elias restored the historical relevance of the dynastic household, and provided an incisive analysis of several aspects of court life. His powerful analytical framework, however, was based solidly on the anachronistic notion of a separation of the spheres of household service and state service. Thus, a relatively modern situation, the result of a long and uneven development, was projected backwards onto early modern history.

In recent decades many of the axioms related to the notion of 'absolute' rulership and the creation of a 'modern' bureaucracy in

\footnotetext{
2 See an early and intelligent variant of this thesis in Henri Brocher, A la cour de Louis XIV. Le rang et l'étiquette sous l'ancien régime (Paris 1934).
} 
the seventeenth century have been reviewed critically. State institutions were clearly gaining force, and increasingly penetrated society in terms of extraction of resources as well as coercive power. Paperwork, standard procedures and hierarchies gradually became more important from the later sixteenth into the later eighteenth centuries. Early modern rulership, however, remained limited in practice even where in theory it was presented as 'absolute'. Not only did the person at the heart of the machinery of state remain vulnerable; the centralized state itself consisted of competing layers, institutions and personalities, all necessarily working together with a variety of regional corporations. A confident ruler determinedly using the state apparatus could act with great authority and power; run of the mill government, however, was characterized by endless compromise rather than by authoritarian practices. The decline and loss of power of noble elites has likewise been questioned. Nobles lost their military autonomy and their independence as regional rulers, but many among them achieved key positions in the structures of the early modern state, both at the local and central levels. Magnates may have been drawn to the court-but by moving towards the centre they didn't necessarily lose power. Did the king-or the state, that somewhat abstract and deceivingly unitary notion-'domesticate' them, or did they take control of the state apparatus? Neither answer will do; the question itself is mal posée.

Clearly, however, a new balance between centre and periphery, between ruler and elites, was formed in early modern states. The court, comprising household as well as government, was the central theatre of that reorientation. Tracing the outlines of this process, as well as the layout of the institutional environment in which it took place, has served as the main agenda of a new generation of court historians. Their archival research has provided a wealth of new details, substantially revising the clichés connected to the image of Versailles. ${ }^{3}$ The revisionist views undermined the strength and cohesion of the older model, but did not lead to a clear alternative mode of analysis. Some general structures have nevertheless become clear. I will outline these

\footnotetext{
${ }^{3}$ References to literature have been kept to a minimum here; for relevant titles see my Myths of Power. Norbert Elias and the Early Modern European Court (Amsterdam 1995) and Vienna and Versailles. The Courts of Europe's Dynastic Rivals (Cambridge 2003). The current text follows some of the issues pursued in Vienna and Versailles, where more substantial description as well as references to primary sources are offered.
} 
in the first part of my paper, which forms a general reappraisal of the early modern European court. In the second part of my paper, I will come back to the question of 'domestication' and the balance between household and government. While this paper discusses themes relevant for all European courts, examples are taken from the French and Austrian Habsburg courts, where my own knowledge is concentrated.

\section{The Court: A Mobile, Changeable, and Multipolar Environment}

The eighteenth-century German erudite Johann Heinrich Zedler opened his learned description of the court with a succinct formula: 'Hof wird genennet, wo sich der Fürst aufhält'. Zedler's open formula underlines the variability of the court: rulers could be seen in many different contexts, surrounded by different persons. The 1694 Dictionnaire de l'Académie described the court as: 'la maison, les officiers, les principaux seigneurs, \& la justice ordinaire d'un roy, d'un prince''maison' itself covering dynasty as well as household and house. As a rule, contemporaries describing the court cite at least three dimensions: the palace, the ruler with his great nobles, and the ruler with his council. Subsequently, they often list a range of connected terms, related to courts of law, and to courtly manners-the latter invariably in the form of an ideal of politesse or refined manners as well as a critique censuring vanity, hypocrisy, flattery, intrigues, and moral laxity. Ideally, the dimensions of palace, nobles and government could fit together neatly: nobles forming the entourage of the ruler could serve him in the palace, and were expected to provide advice and support in governing the realm. In practice, we see two main functions at court, performed by overlapping staffs: a household catering for the ruler's personal needs, a staff overseeing the government of his realm. For both spheres of service, we find a differentiated group formed by a non-noble majority of lesser servants, and a smaller segment of nobles present at court that could expand rapidly on special occasions.

The balance between these two major component parts was further complicated by many other factors. First of all, courts retained great mobility throughout the early modern age. All courts developed a main winter residence in the course of the sixteenth and seventeenth centuries, usually in a major city that increasingly functioned as a capital. The Vienna Hofburg, a complex of buildings with medieval 
beginnings, continually adapted and expanded from the 1530's into its bloated early twentieth-century manifestations, may serve as an example. With the exception of Rudolf II, who moved his court to Prague, the Austrian Habsburgs remained loyal to Vienna, turning it into the courtly centre of their composite monarchy. The interaction of courts and capitals entailed the reconstruction and redecoration of many European cities, particularly those not holding prime positions before dynasties chose to grace them with their presences, such as Madrid or Turin. Bustling capitals such as London or Paris could never be dominated by the court to the same extent. Notwithstanding the prevalence of winter residences, we cannot depict early modern rulers as sedentary: in many respects they continued medieval forms of itinerant kingship. Movement necessitated by political and ceremonial meetings long remained important in 'composite' domains, where new rulers were expected to visit the various parts of their realm to be received there in person. In France, coronation and sacre took place in Rheims until the end of monarchy. Sixteenth-century kings, moreover, still initiated their rule with a 'tour de France royal', whereas deep into the eighteenth century, entries into major cities would be staged. Increasingly, however, the French court expected agents of the institutions and regions to come to the palace, and it no longer intended to go out and visit them systematically. For the Austrian Habsburgs, with their multiple titles pertaining to the Habsburg hereditary duchies, the crowns of Bohemia and Hungary, and the elective dignity as emperor of the Holy Roman Empire, travel remained an obvious necessity.

While the political necessity of movement slowly declined in relatively centralized states, other compelling reasons remained in force. Warfare and disease could require incidental travel. Louis XIV frequently traveled to the armies, for campaigns, maneuvers or mustering; Leopold I (1640-1705) fled from the Plague and unheroically sought to evade the Ottoman armies in the years around 1680. More importantly, all courts changed character and location following the seasons, with a high season for ceremony dominated by the Christmas and Easter cycles in winter and early spring and a low tide in summer when warfare demanded the presence of many courtiers doubling as officers in the army. The dominant royal pastime of the hunt dictated seasonal movement. Rulers would travel in early spring to visit a sequence of hunting lodges, returning only in late autumn for a protracted stay in the major winter residence. Indeed, only a core group 
consisting of servants as well as trusted secretaries would follow the ruler throughout the year. A reduced establishment catered for him in the hunting lodges; the bulk of administrative services stayed behind in the capital. Government services became sedentary before rulers and their immediate following did; financial and legal institutions that had gone 'out of court', literally leaving the palace precincts, would no longer follow royal peregrinations but pursue their routines in the ruler's absence.

After a protracted stay in the Hofburg, the Habsburgs would follow a trajectory including various palaces changing somewhat over time, including Neugebäude, Laxenburg, Favorita, and Ebersdorf. French kings followed a similar pattern, shifting from Parisian residencesLouvre, Tuileries, and Palais Royal-to Chambord and other favoured Loire châteaux, or alternatively to castles in the Île de France, such as Saint-Germain-en-Laye, Fontainebleau, or Compiègne-the latter conveniently situated halfway between Paris and Rheims. In his early years, Louis XIV often lodged in Saint-Germain, selecting it as his main residence in 1666. The move to Versailles in May 1682 did not turn his court into a static environment, but it did limit movement. The huge and expanding territories connected to Versailles, including the palaces of Trianon and Marly, offered enough opportunities for outdoor recreation throughout the year. After the last decades of Louis XIV's reign, longer sojourns other than the six-week autumn voyage de Fontainebleau did not recur on an annual basis. In the eighteenth century the voyage to Fontainebleau remained habitual, in addition to sojourns in Compiègne, and shorter stays in various smaller hunting lodges. ${ }^{4}$ In Vienna from the 1690's onwards, plans were developed to construct a Habsburg variant of Versailles: Schönbrunn. Only under Maria Theresa did these plans come to fruition, and even then Schönbrunn had to share its position with the more venerable Hofburg. Possibly a major outdoor 'palais d'état' was more relevant for rulers whose rich and splendid capitals tended to overshadow palace and court. ${ }^{5}$

As an institution the court had an everyday, permanent form, but on the basis of this usually relatively modest manifestation, it could develop into a staging ground for a variety of grand occasions. In the

\footnotetext{
${ }^{4}$ See Duindam, Vienna and Versailles, pp. 143-149.

${ }^{5}$ See Gérard Sabatier, 'Le palais d'État en Europe, de la Renaissance au Grand Siècle', in: Palais et Pouvoir de Constantinople à Versailles, Marie-France Auzépy and Joël Cornette, ed. (Saint-Denis 2003) pp. 81-107.
} 
sources, we find various terms distinguishing the modest permanent 'inner' court and the incidentally recurring but usually more exuberant 'outer' court: aula and curia; curia and curia solemnis; alternatively curia minor and curia maior or domus providentiae and domus magnificentiae. ${ }^{6}$ These various terms are related to presence as well as to rank: on top of a largely non-noble permanent daily service establishment for the ruler and his family, we find various higher-ranking echelons connected to the court, but not invariably present. As a rule, the basic tasks in the ruler's personal service, pertaining to the chamber, the table, and the stables, were performed by a hierarchy of servants, of which only the lesser-ranking groups were permanently present. The presence of higher honorary servants of noble stock was organized through more or less systematized forms of job rotation. Honorary servants were entitled to attend court in their official capacity, but were not as a rule present. They could attend court when their turn came, or when special occasions demanded their presence. Ordinances at the fifteenth-century Burgundian court, a pioneer in methodical job rotation, stipulated that only those actually serving their turn could live at court; others were not allowed to eat and lodge at the court's expense. $^{7}$

Each court had several categories of honorary officers; in France the gentilshommes servants (divided into panetiers, échansons and écuyers tranchants) and maîtres d'hôtel serving at the king's tables, or the equerries in the stables were major examples. In Vienna table servants responsible for carving meat, presenting bread and pouring wine and water were likewise present, but from the seventeenth century onwards chamberlains and councilors formed numerically far more important categories of honorary office. A nomination as chamberlain marked a person's entry into the ranking at court; nomination as a councilor (geheime Rat) promoted him into the next echelon of

\footnotetext{
${ }^{6}$ Bernd Ulrich Hegemöller, 'Die "solempnis curia" als Element der Herrschaftsausübung in der Spätphase Karls IV. (1360 bis 1376)' in: Deutscher Königshof, Hoftag und Reichstag im Späteren Mittelalter, Peter Moraw, ed. Vorträge und Forschungen XLVIII (Stuttgart 2002) pp. 451-476, see defining criteria of the solempnis curia on p. 459; the English convention, with the Steward's 'below stairs' staff as Domus providentiae and the Chamberlain's 'above stairs' staff as domus magnificentiae differs from the other distinctions, though it seems related to the same difference.

${ }^{7}$ For Burgundian examples see Holger Kruse, 'Die Hofordnungen Herzogs Philipps des Guten von Burgund' in: Höfe und Hofordnungen 1200-1600. 5. Symposium der Residenzen-Kommission der Akademie der Wissenschaften in Göttingen, Holger Kruse, Werner Paravicini, ed. (Sigmaringen 1999) pp. 141-165 at pp. 149-153.
} 
honorary membership of the court. Only a handful of such councilors actually advised the ruler in his councils: this was an honorary distinction rather than an actual duty. Presence at court, both for male and female youngsters, could start earlier. Youths with suitably noble pedigree could be educated at court: young boys as pages in the stables, and slightly older female teenagers in the following of a queen or empress. Their temporary service represented an initiation into elite life, a relatively brief phase leading to other careers often connected to the world of the court. ${ }^{8}$ At the highest level of honorary office, we find orders of chivalry. Every court in the course of the later Middle Ages and early modern age developed its own order of chivalry-or more usually a series of orders, pertaining to various domains of service. The structure was topped by one elite order which included the members of the dynasty-the Golden Fleece for the Habsburgs, the Saint-Esprit for the French court. The limited number of knights in these elite orders secured exclusivity; their annual series of activities formed a marked element in the court's calendar.

For greater occasions, more numerous as well as more prestigious servants were recruited. Service at the ruler's table, for instance, could be performed at many levels, from great ceremonial banquets, via public as well as more private dining in the state apartment, to a brisk meal in the safe seclusion of the cabinet, or 'sur sa serviette' on the road. Each form demanded a different array of servants. At the French court, the table staff featured a hierarchy of three offices labelled grand, premier, and ordinaire - a pattern reflected with some variation in the hierarchy of the staffs for chamber and stables. The highest office at court was that of high steward or grand maitre de l'hôtel (alternatively grand maitre de France); his noble substitute the premier maitre de l'hôtel was followed by a lesser-ranking proxy, the maître d'hôtel ordinaire. The maittre d'hôtel ordinaire, finally, was assisted by 36 honorary

\footnotetext{
${ }^{8}$ See on the female Hofstaat, female rulers and ladies-in-waiting an expanding literature, e.g. Jan Hirschbiegel; Werner Paravicini, Das Frauenzimmer. Die Frau bei Hofe in Spätmittelalter und früher Neuzeit 6. Symposium der Residenzen-Kommission der Akademie der Wissenschaften in Göttingen (Stuttgart 2000); Fanny Cosandey, La reine de France. Symbole et pouvoir xve-xviiie siècle (Paris 2000); Clarissa Campbell Orr, ed., Queenship in Europe. The Role of the Consort (Cambridge 2004); Katrin Keller, Hofdamen. Amtsträgerinnen im Wiener Hofstaat des 17. Jahrhunderts (Vienna; Cologne; Weimar 2005).
} 
gentilshommes servants and 48 maitres d'hottel. ${ }^{9}$ The procession of the king's viande from kitchen to table was a serious matter, with many participants, in a rich array of insignia and rituals ranging from the essai to the offering of the serviette. During banquets following coronations, marriages or other similarly important dynastic occasions, major princes of the realm would personally serve as panetier, échanson, and écuyer tranchant.

In Vienna, the Truchseß, Fürschneider, and Schenk, charges held by several persons, performed the duties parallel to those of the panetier, écuyer tranchant, and échanson. Chamberlains habitually served as cupbearer or carver when the emperor dined in his apartment; Hofdamen or court ladies served the empress during supper in her apartment. The full range of officers was present only on stately occasions when the sovereign's meal was witnessed by numerous spectators. Such meals were ideally attended by all noble courtiers and the entire corps diplomatique, while all suitably dressed visitors were allowed in to watch. The emperor and empress and their guests were served on bended knee, by an array of court officers. Eduard Vehse, a nineteenth-century erudite, calculated that any dish went through twenty-four pairs of hands before it actually reached the emperor. ${ }^{10}$ The emperor's table was marked by the pan-European insignia of sovereignty: it stood on a dais and his chair was crowned by a canopy of state. He would remain covered throughout the meal, taking off his hat only during prayers, or when the empress drank to his health. The most spectacular manifestation of public dining undoubtedly was the banquet following the imperial election and coronation ceremonies, an occasion attracting huge crowds into the city of Frankfurt. The audience first witnessed a curiously ritualized table service performed on horseback by the electors serving as 'archcourtiers of the empire' or Reichserzämter on the Römer square in Frankfurt. The imperial

\footnotetext{
9 These numbers remained stable after Louis XIV's reductions of the 1660's; in the 1640's and particularly the 1650's numbers had been far higher, see at http://www .zeitenblicke.de/2005/3/Duindam a brief internet overview with numbers and financial data, 'Vienna and Versailles. Materials For Further Comparison and Some Conclusions', zeitenblicke 4 (2005) Nr. 3 [13.12.2005].

${ }^{10}$ Eduard Vehse, Geschichte der deutschen Höfe seit der Reformation (Hamburg 1851-1860). Zweite Abtheilung: Oestreich. Geschichte des Österreichischen Hofs und Adels und der Österreichischen Diplomatie. particularly volume I-VIII (Hamburg 1851-1852) vol. VI, pp. 289-290; other sources in Duindam, Vienna and Versailles, pp. 176-177.
} 
marshal rode through a mound of oats, filling a silver container; the Truchse $\beta$ or seneschal carved meat from a roasted ox; the chamberlain followed with water and towel, the cupbearer with a cup filled with water and wine taken from a spouting fountain. After the proceedings, the populace was allowed to tear down and take home the attributes of the show-including the kitchen with the roasted ox, and wooden structures with rich textiles used for the procession from church to banqueting hall.

The honorary extensions of the permanent household were not limited to the noble upper echelons: priests, scholars, secretaries, musicians, artists, artisans, purveyors, labourers, and soldiers could likewise serve on an incidental basis, but still acquire the privileges that came with nominal membership in the court. In addition to the honour implicit in the connection to the court, members of the ruler's Hofgesinde, his 'court family', enjoyed freedom from regular legal and fiscal regimes. Clearly, both the mobility of the court and the differentiation between inner and outer courts make it difficult to establish the numbers of courtiers and servants. Do we count only the relatively small numbers present at court and listed in its payrolls, or do we include all persons in one way or another entitled to present themselves as belonging to the court? We find lists based on payment as well as lists representing nominal membership, with seriously diverging numbers. The wild estimates of numbers in contemporary sources as well as in the literature on the court reflect yet another problem. The court attracted visitors in many guises: high-ranking princes and nobles with their followings, petitioners, fortune-seekers, tourists. ${ }^{11}$ Should we measure a court at a high point of its recurring cycle of events, including all these groups, it would represent an overestimation of daily numbers.

Taking as a starting point the overviews generated by the court itself, including the main honorary officers, but excluding incidental visitors, an estimate of numbers can be given for the Austrian Habsburg and French courts from the sixteenth into the eighteenth century. Figure 1 represents the sum of the main court staffs (chapel, table, chamber, stable, hunt, guards) serving the French king and the Austrian Habsburg emperor from the 1550's into the later eighteenth

\footnotetext{
${ }^{11}$ Michaela Völkel, Schloßbesichtigungen in der frühen Neuzeit. Ein Beitrag zur Frage nach der Öffentlichkeit höfischer Repräsentation (Munich; Berlin 2007).
} 


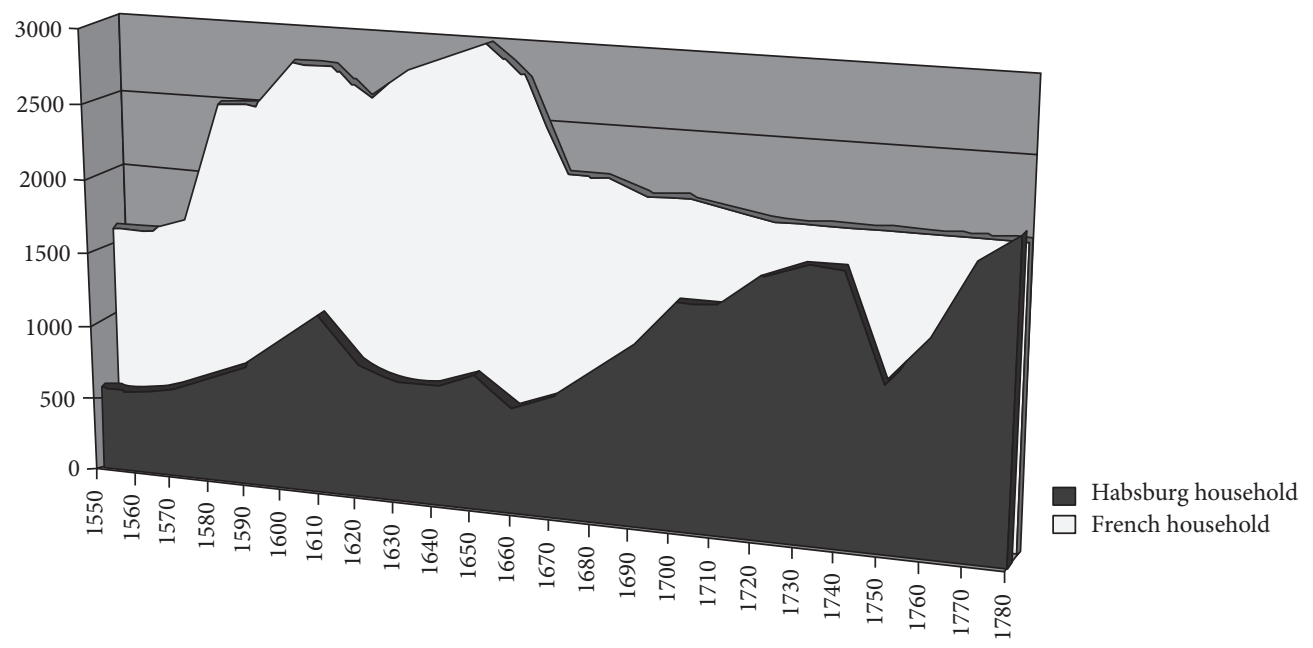

Figure 1. Numbers of the rulers' core staffs at the Austrian Habsburg and French courts

century; numbers are tentative for the first century, more reliable for the latter phase.

Both courts show a jagged curve, with numbers diverging sharply in the sixteenth and early seventeenth century, slowly converging in the course of the eighteenth century. After a steady rise in the early sixteenth century the French court exploded in the phase of religious wars; a brief attempt to reduce numbers under Cardinal Richelieu couldn't prevent another round of spectacular inflation in the 1640's and 1650's, during the regency of Anne of Austria and the Fronde. Louis XIV in the course of the 1660's effectively reduced and stabilized numbers around 2,000-a level that would roughly be maintained until the sharp reforms and reductions of the 1780's. The Austrian Habsburg court experienced a brief phase of inflation towards the end of the Prague-based reign of Rudolf II (1552-1612)-typically, again in years of crisis rather than in years of stability. On the whole, it increased gradually from 600 to 800 , expanding more rapidly only in the reign of Leopold I, who allowed the numbers of chamberlains and later councilors to explode. Expansion continued under Charles VI (1685-1740) and his daughter Maria Theresa (1717-1780), though the combination of succession crisis and warfare led to an abrupt drop in the 1740 's. In the later eighteenth century numbers came close to 2,000 . 
Several points need to be made on the basis of these numbers. First of all, we should take for granted that while regular staffs tended to grow steadily but slowly, honorary office could expand and decline sharply, following the curve of political developments. Crisis led to expansion, with rulers as well as major courtiers attracting friends and followers to the court, rewarding them mostly with honorary offices and titles. Typically, the French king Henry III (1551-1589) in the 1570's repeatedly argued that he himself had to confirm all appointments to court office, demonstrating that his Guise rivals, holding several high court offices, had willfully neglected this rule. A similar situation, with courtiers inviting in their own protégés, helps to explain the expansion of the court under Rudolf II. Reducing the court after numbers had inflated proved particularly difficult for the French kings. They had started selling offices, and hence needed to provide financial compensation for those they wanted to send away-a hard challenge for structurally impecunious rulers. This predicament furthered the tendency towards hereditary of court offices at all levels, based on repeated payments into the king's coffers. French court lists in the first half of the seventeenth century somewhat wearily repeat the intended abolition of supernumerary offices, using the formula 'vacation avenant': upon the death or departure of the incumbent. The great reductions in the 1660 's had become almost inevitable by the final peak of inflation in the 1650's, yet they clearly demonstrate that Louis XIV held the reins of power securely in his hands. The Sun King proved his strength not by indiscriminately including people in his court, but by sending most of the hangers-on away.

The Austrian Habsburgs never openly and systematically sold court offices in any rank or staff. Their court adhered to a traditional feudal pattern, in which all court officers and servants would nominally lose their place upon the death of the emperor. The successor would confirm most of them in their positions, but could within certain limits refrain from doing so. All honorary officers likewise had to be reconfirmed. As a rule a new emperor installed his own intimates and servants in the highest echelons of court service, confirmed the daily staffs at court, and nominated new honorary officers on the occasion of special dynastic festivities. Allowing inflation of numbers, thus, was less troublesome for the Habsburgs than it would have been for French kings, who took their place in an already existing court, in which they could make only limited changes because of the impact of heredity and venality. 
One last important point must be made about the aggregates of court staffs given here. ${ }^{12}$ Generally, we picture the court as a more or less unitary or unifocal structure organized around a single sovereign. This matches the increasing emphasis on undivided sovereignty and primogeniture evident in the early modern European context. We have to keep in mind, however, that in practice the ruler's relatives as well as his spouse had their own households; the same held true for the major nobles of the realm whether or not they stayed at court. Ferdinand I (1503-1564) still chose to divide his heritage among his sons, starting two junior Habsburg branches in the Tyrol and Styria, to be reunited to the main line only in the course of the seventeenth century. In late sixteenth century, the French king's younger brothers expanded their households as did the king, and even adopted offices mimicking the dignity of the state, such as the introducteur des ambassadeurs. ${ }^{13}$ On the whole, in the seventeenth century, rulers were better able to secure their pre-eminence among their relatives, and certainly less inclined to divide their heritage; yet they still accepted the necessity to place their relatives in a suitably dignified environment.

'The' court, then, consisted of a series of households, located in various palaces. Louis XIV's brother Philippe d'Orléans and Philippe's spouse, the Palatine princess Elisabeth Charlotte resided in the palace of Saint-Cloud. In 1699, Philippe's household numbered 830 persons; his wife's following numbered another 242 persons. They formed the most substantial of a series of similar establishments. While women were only marginally present in the ruler's predominantly male household, they served on a regular basis in the households of the female members of the dynasty. The queen's household in France formed a parallel of the king's with most staffs present on a smaller scale, plus a substantial female following consisting of several categories of court ladies and female servants. In all, she was usually served by more than

\footnotetext{
${ }^{12}$ For the sake of brevity and clarity I leave out the presence of substantial military units around court, part of them as constituent elements in the maison militaire of the French king. This institution never developed to the same extent under the Austrian Habsburgs, although they did add more elite guard units to their court in the second half of the eighteenth century. See Guy Rowlands, 'Louis XIV, aristocratic power and the elite units of the French army', French History 13 (1999) pp. 303-331; Michael Hochedlinger, 'Mars ennobled. The ascent of the Military and the Creation of a Military Nobility in Mid-Eighteenth-Century Austria', German History 17 (1999) pp. 141-176.

${ }_{13}$ Duindam, Vienna and Versailles, p. 52 on Anjou and his 'sovereign' household officers.
} 
500 persons. The ruling empress in Vienna headed a much smaller establishment, consisting of ladies-in-waiting, female servants, and a small male household, totaling between 60 and 80 persons. The dowagerempress, however, was served by a 250 -person establishment, expanding further in the later seventeenth century. Travelers visiting Vienna in the later seventeenth century were impressed by the Italianate splendour and cultural patronage of the dowager-empress Eleonora II Gonzaga's court. In addition to the dowager-empress, the only other sizeable separate establishment in Vienna was that of the King of the Romans, chosen during his father's lifetime as emperor-elect, waiting for his turn to ascend to imperial dignity. In this position, he gradually built up his own household, forming a basis for his later court and government. Joseph I's (1678-1711) household expanded to more than 400 during the 15 years he had to wait before succeeding after his election in 1690. The French Dauphin or heir-apparent, however, would no longer have his separate household after Louis XIII. Louis XIV reached maturity long after his father's death; his son Monseigneur had his menins or boon companions, in addition to a special staff for hunting, but on the whole was served by his father's staffs. Surprisingly, the Dauphine, usually a foreign princess, did have a major household of her own-only the Dauphin, the person closest to his father's sovereign position, was denied a personal household.

On the whole there were fewer secondary households in Vienna, and they were smaller: the grand total of all secondary households around court was far higher in Versailles. This may have been a consequence of dynastic demography more than of conscious dynastic policies. Maria Theresa effectively changed the traditional situation by merging the various dynastic households. This attempt, however, led to the temporary doubling or even tripling of senior household offices, because sending away trusted servants was not deemed acceptable. In the course of the eighteenth century, secondary households proliferated at the French court because of the expanding royal family, turning Versailles into a rather crowded place with a seriously reduced potential for accommodating courtiers. ${ }^{14}$ During the reforms of the

\footnotetext{
${ }^{14}$ See three studies by William Ritchey Newton based on his extended knowledge of eighteenth-century apartments and their occupants, L'Espace du roi. La cour de France au château de Versailles 1682-1789 (Paris 2000); La petite cour. Services et serviteurs à la cour de Versailles au XVIII siècle (Paris 2006); Derrière La Façade-Vivre Au Château de Versailles Au xviii ${ }^{e}$ Siècle (Paris 2008).
} 
1780 's the proliferation of secondary households was taken in hand, in a drawn-out and precarious process. Typically, Louis XVI curtailed his own staffs, but could not convince his queen to do likewise, and had difficulties in persuading his two headstrong brothers to follow his example. The king or emperor was the formal leader of the realm as well as of his house; the other households under his umbrella, however, played an important role as alternative centres of patronage, and sometimes as the core of rival factions. Tensions between fathers and sons, between ruler and brothers (or their offspring), and more generally among those sharing in the sovereign status of a ruling house, had a notable and lasting impact on other forms of political contention at court. ${ }^{15}$

How can we restore some coherence to the splintered image of a court determined by mobility, changeability, and multipolarity? Clearly, almost all European courts shared a similar structure of staffs, with table, chamber and stables as the three central staffs, immediately followed by the often more diverse establishments for guards and hunting. A religious establishment was present at all courts, but it was fitted into the institutional structure in many different ways. The steward, chamberlain and master of the horse were almost universally the three pre-eminent nobles serving at court in Europe. The marshal, symbolizing the connection with the army and with justice, was markedly present at German courts, where he frequently followed the steward or Hofmeister as second-in-rank, and sometimes even preceded him. Service in the chamber tended to promote lesser figures to higher rank-from antiquity to modern times, notorious favourites would emerge in the immediate privacy of the ruler's chamber. Chamber staffs were also most likely to change, with new intermediary layers or offices arising according to the new ruler's personal preferences. The introduction of the 'Scottish' bedchamber under James VI at the English court, the rise to prominence of the sumiller de corps at the sixteenth-century Spanish court, or the proliferation of offices in the French chamber and wardrobe can serve as examples. The numerous high offices in the French chamber and wardrobe, with their troubled hierarchical relationships, may have developed simply as an

${ }^{15}$ Emmanuel Le Roy Ladurie, 'Auprès du roi, la Cour', Annales ESC 38, 1 (1983) pp. 21-41; 'Système de la cour (Versailles vers 1709)', L'Arc 65 (Aix-en-Provence 1973) pp. 21-35 stressing rivalry in the dynasty-a point taken up in the general introduction of this volume. 
ad hoc response to urgent demands for office in the ruler's proximity. Court ordinances indicate that the major staffs long retained a strong sense of autonomy, with the principals priding themselves on their personal relationship to the ruler, symbolized by the oath 'entre les mains de sa majesté. They would accept orders only from the king in person, or from his direct representatives. Hierarchies among these highest officers, particularly at the French court, were never clear or generally accepted.

Within each of the staffs at court, three echelons can be identified. At the top, we find a very small and exclusive upper layer of court dignitaries leading their staffs, including high steward, chamberlain, master of the horse, marshal, guard captains, the grand veneur and his colleagues in the hunt, the almoner or other functional equivalents in the chapel. They had substitutes of lesser standing, but did not usually share their responsibilities with equals on the basis of job rotation Only the four prestigious French premiers gentilshommes serving a full year in alternation in the chamber, and the two lesser-ranking but still important maîtres de la garderobe serving under a single grand maitre de la garderobe on a semester-basis appear to form an exception to this rule. This handful of highest courtiers, almost inevitably of high noble stock, formed the apex of status and prestige in France as well as in the Habsburg lands. No sharp line can be drawn between the first echelon and lesser noble officers, who didn't share their office on the basis of job rotation, but clearly all officers pledging their oath with the king or emperor in person need to be included in the upper echelon.

The noble honorary officers performing occasional temporary service in one of the court staffs, by definition sharing their position with numbers of others, can be seen as a second echelon universally present at the early modern European court. The nature and organization of their connection to the court could vary immensely, but we can distinguish them easily both from the small upper layer of the major court officers, and from the numerous non-noble service establishment catering for basic daily services. Sharply diverging practices vis-à-vis the nomination of honorary officers characterized the courts of Vienna and Versailles: in Vienna numbers started to explode when in France they were reduced. Leopold's generosity, however, was not very expensive and in retrospect decidedly useful. Only the small numbers of actually serving chamberlains were paid. At the same time, all nobles keen on entering the court's ranking and the court's higher nominations had to proceed through the two-tiered ranking 
system formed by chamberlains and councilors, precedence in each rank organized on the basis of seniority. This system underlined the indisputable impact of the imperial nomination into these ranks, at a time when the prestige of the title of chamberlain had sustained serious depreciation because of increasing numbers. The ranking also gave a measure of clarity and tranquility to the court's internal contentions about precedence; conflict remained typical, but it never reached the Hobbesian proportions of the French court, where servants and courtiers seemed permanently busy scheming to improve the status of their offices, preferably at the cost of others.

The third echelon, the most varied and usually by far the most numerous part of the court, consisted of non-noble personnel in the multiple services catering for dynasty and palace. Educated scholars, trained specialists and artisans stood at the upper limit of this groupnotable among them musical virtuosi, or painters of name and fame. They could in practice count among the ruler's intimates, and in that sense were not so distant from the first echelon. Louis XIV explicitly allowed Jean Baptiste Lully privileges usually reserved for highstatus courtiers; Leopold engaged in intimate correspondence with his learned librarian Lambeck. Usually servants in all staffs, however, remained at a greater distance from the ruler as well as from his high noble servants. They counted among the commensaux $d u$ roy, or members of the emperor's Hofgesinde, and hence were entitled to food and accommodation. This core of the household establishment hardly fits Castiglione's image of the courtier: yet these 'below stairs' servants were numerically dominant as well as characteristic for the atmosphere of life at court. A measure of conviviality must have existed between the various layers at court; early arrangements for dining, with their hierarchical positioning of tables and proportioning of food, also lay down the shifts of people eating at court, with the leftovers of the highplaced being in turn consumed by lesser servants. Possibly the worlds of noble as opposed to menial service became more sharply separated in the course of the early modern age. Louis XIV's reduction of the court in the 1660's not only concerned the honorary officers: the king also purged the ranks of the lower commensaux du roy. He sent away many servants, only to hire them again on the basis of commissioned labour without the status and rights connected to court office-a procedure not unlike modern 'outsourcing'. The status and privileges of honorary officers as well as lesser non-noble servants maintained at court by the king were consolidated and improved. In fact even the 
lesser ranks of servants could aspire to achieve noble status through their court service.

The third echelon of the household also had many connections in the outside world, and acted as intermediary between the 'economies' of court and city. ${ }^{16}$ Purveyors and artisans found their name and reputation enhanced thanks to their service to the dynasty-as the indication 'K.u.K.', imperial and royal, still indicates in Viennese streets. The financial protocols of the court suggest a dense traffic in finances, labour, and products connecting city and court. A recent study lists thousands of artisans and workmen related to the court. ${ }^{17}$ The nonnoble dimension, numerically dominant at court, and strongly present in the city, was long forgotten by court historians, who usually focused on the elites pictured in Castiglione's salon-like depiction of the court. It deserves to be restored to its fundamental role in the household as well in the urban environment of the court.

\section{Domestication}

Each of the three echelons of the household relates to different themes of research: decision-making and patronage for the upper layer, integration of regional elites for the second layer of honorary extensions, and finally the artisanal and urban connections of the court for the third layer of non-noble service. None of the three fits easily into the traditional image of the courts, as a prison for nobles rendered powerless.

Domestication can be described the 'taming' of the nobles, turning them from an independent warrior-elite into a reduced palace elite of domestics. As a corollary, in the ruler's immediate dependence these

${ }^{16}$ John P. Spielman, 'Status as commodity. The Habsburg Economy of Privilege', in: State and Society in Early Modern Austria, Charles Ingrao, ed. (West-Lafayette 1994) pp. 110-118 and his wide-ranging study of quartering in Vienna: The City \& the Crown. Vienna and the Imperial Court 1600-1740 (West Lafayette, Indiana 1993).

${ }_{17}$ Herbert Haupt, Das Hof- und hofbefreite Handwerk im barocken Wien, 1620 bis 1770. Ein Handbuch (Innsbruck; Vienna; Bozen 2007) Forschungen und Beiträge zur Wiener Stadtgeschichte 46; see also Susanne Claudine Pils and Jan Paul Niederkorn, eds., Ein zweigeteilter Ort? Hof und Stadt in der frühen Neuzeit, Forschungen und Beiträge zur Wiener Stadtgeschichte. Publikationsreihe des Vereins für Geschichte der Stadt Wien, Band 44 (Vienna 2005); Werner Paravicini and Jörg Wettlaufer, eds., Der Hof und die Stadt. Konfrontation, Koexistenz und Integration im Verhältnis von Hof und Stadt in Spätmittelalter und Früher Neuzeit, Residenzenforschung Band 20 (Ostfildern 2006). 
tamed elites adopted more refined and subdued forms of behaviour. Elias, in fact, presented his detailed study of the court as the main example for his grand psychohistory, Über den Prozeß der Zivilisation. In this important two-volume study, he outlined the late medieval and early modern Verhöflichung der Krieger (awkwardly translated as 'courtization'), based on the changeover from external coercion (Fremdzwänge) to internal ideals and controls (Selbstzwänge) and the concomitant rise of Affektbeherrschung-a more optimistic variant of Freud's notion of Triebverzicht. Domestication represents a vital component in the chain of developments finally leading to the Verhöflichung of the warrior-elite. In its turn, domestication can be divided into several elements, such as financial dependence, residence at court, political isolation, and dependence on court-created hierarchies or court culture. Some of these elements are undeniably present in the context of the early modern courts, whereas others are more problematic, or even plainly mistaken. It is necessary to briefly reassess the coherence of the domestication thesis on the basis of the more differentiated picture of the court presented here.

First of all it is clear that rulers were hardly interested in drawing 'the' nobility into court. They were keen mostly to attract into their orbit the highest elite echelons, potential rivals outside the ruling dynasty as well as members of the dynasty. Ritual domestic service of such high nobles, while demonstrating their subservience and loyalty to the ruler, should not in itself be seen as a demeaning activity: it confirmed the high rank of the honorary attendants as much as it showed the pre-eminence of the ruler. Other groups would more likely find access to the court difficult, and certainly could not as a rule become regular attendants eating at the king's tables. To be successful in accommodating the grandees, rulers had to prevent the dignity of the court from being undermined by an excessive inflation of honours, hence their permanent though often futile attempts to reduce numbers. Only an exclusive environment, conspicuously underpinning the high rank of its members, could induce grandees to attend or hold high office at court. Domestication, therefore, cannot simply be connected to growing numbers. As stated before, expansion of courts indicated political turmoil rather than stability, open competition at court rather than the dominance of a resolute ruler. As soon as courts expanded beyond a critical point, the ruler's coffers were emptied whereas at the same time the dignity of the court declined. 
A closer look at physical presence at court-a returning element in the gilded-cage thesis-underlines the same point: it necessarily remained limited to small groups. Versailles, with its exceptionally large and diverse facilities, housed an approximate 3,000 logeants, court staff with usually exceedingly modest apartments in one of the buildings in the complex. ${ }^{18}$ Nobles holding high court office could expect to be accommodated decently in the more prestigious buildings, but might still prefer their own country seats, or more likely their Parisian and Versailles-based houses. In the 1690's, after the brilliant opening decades of Versailles, Paris regained its cultural prominence; in the morose and financially hard-pressed first decade of the eighteenth century Versailles lost much of its remaining appeal. It would never entirely regain its position after the intermezzo of the regency and Louis XV's (1710-1774) minority. In the course of the eighteenth century, the expanding dynasty itself required most of the more sumptuous apartments in Versailles. As many courtiers held court office in combination with other high offices in regional government, army command, and diplomacy, their presence was always temporary. ${ }^{19}$ Following a pattern common in the sixteenth and seventeenth centuries, the Viennese court into the eighteenth century was based on a system of billeting courtiers and servants of all ranks in the city. Accommodation in the palace was limited to the dynasty and a very small number of intimate servants. Nor were the diverse groups on the court's payroll, or specifically the upper noble layers and honorary servants necessarily engaged in daily interaction. The dynasties' activities determined the presence of courtiers, servants, and spectators in different settings; there was no ongoing series of salon-like social occasions at court before the later eighteenth century. Presence at court and 'court life', therefore, need to be understood as a chain of events in a calendar repeated annually with minor variations, rather than as a permanent set-up. Only very gradually did 'court life' evolve from the incidental

${ }_{18}$ Newton, L'Espace du Roi provides a welter of information on the logements in the palace, yet no assessment of the overall capacity of the palace and surrounding buildings; see estimates of the logeants in Jean François Solnon, 'Cour', in: Dictionnaire de l'Ancien Régime, Lucien Bély, ed. (Paris 1996) p. 356: 3,000 logeants in Versailles.

${ }^{19}$ See Leonhard Horowski, 'Pouvez-vous trop donner pour une chose si essentielle? Eine prosopographische Studie der Obersten Chargen am Hof von Versailles', Mitteilungen der Residenzenkommission 11, 1 (2001) pp. 32-53 and his major forthcoming study on courtiers and their careers 1660-1789, to be published in the Pariser Historische Studien-series of the German Historical Institute in Paris. 
high points of the ruler 'holding court' with his grandees, to an annual, weekly and finally almost daily pattern of social activities. The French court, traditionally cultivating a convivial and accessible style of court life, pioneered this development, taken over by other courts in the eighteenth century.

Did nobles flock to the court because they were poor? Indebtedness was a common phenomenon in a group based on hereditary status and landed wealth, though temporary pennilessness could go together with long-term solvency. Supplementary sources of ready cash were quite welcome: service in the armies, at court, in government, and in the church had long since provided these for nobles, prevented from engaging in commerce by the strictures connected to their hereditary status. The court, however, was an insecure source of income. Wages were low, and frequently went unpaid. Extras could be enormous, but such windfall profits reached only the very fortunate. Financial backgrounds of court service vary widely: rulers could attract high nobles to court service by paying them lavish pensions in addition to their wages. On the other hand, we regularly find lesser-ranking aspirants paying substantial amounts to the ruler with a view to obtaining office. This could be done discreetly, without any obvious connection between the payments offered to the crown and the accession to high office, or in more open and organized forms of venality. The advantages of obtaining a court office could convince rich nobles aspiring to greater honour to pay handsomely; conversely their more prestigious fellownobles might hesitate to accept office if it would not be accompanied by lavish rights and advantages.

On the whole, the small upper layer of nobles serving at court was far more likely to seriously benefit financially from service than the more numerous layer of honorary officers. At the French court, the upper layer of court officers had turned the rights and benefits connected to their semi-venal and semi-hereditary offices into financially lucrative ventures, even without counting the king's incidental graces, or payments made by diplomats and petitioners to secure their support. Among these families, some strengthened their independent sources of mostly landed income in the process, whereas others increasingly depended on the various incomes generated by their court establishment. In Vienna no hereditary rights to the highest court offices developed: novices even from the upper crust of noble families had to start at the lower honorary rank of chamberlain. A solid financial basis was a prerequisite for entering court service as a nobleman. Investments 
were necessary to effectively perform service with sufficient dignity, whereas rewards could only be expected at higher levels, and were not to be taken for granted. Financial support, hence, cannot be seen as the main incentive for high nobles to enter court service in Vienna. In the French case the dependence of high nobles on their court-created incomes was greater, but here the rapid development of venality and hereditary rights seriously limited the king's potential to actively use his grace as an instrument to include or exclude whom he saw fit. We have many examples of overspending grandees being supported by the king's or emperor's largesse; on the other hand, rulers likewise often found financial support among their noble servants. ${ }^{20}$ The financial nexus linking rulers and their highest echelon of courtiers cannot simply be presented in terms of the courtiers' increasing dependence.

Risks and benefits were different for the intermediate echelon of honorary noble servants. They formed a pool from which the talented and driven could be chosen for more rewarding positions and honours, but this lottery necessarily disappointed most. Attending court, in their case, could indeed mean investing family finances in dress and other marks of high status without receiving any serious material compensation. Clearly, the benefits of court service for this second echelon can in no way be compared to those of the upper layer. It was quite possible for these temporary courtiers, moreover, to overspendand in their case, rulers were less likely to step in and pay the bill. In terms of 'taming rivals', however, this group was not as relevant as the first echelon. The staff in the lowest echelon received meagre wages, though the court usually provided some extra support in the form of small pensions for incapacitated or elderly servants, and widows. Servants were often able to use their position at court to generate extra income by asking gratuities from visitors and tourists before granting them access or leading them through the court-a practice frowned upon but tolerated by rulers who didn't have the means to pay decent salaries. Servants, artisans and soldiers in the lower ranks at court also profited from their exemption from fiscal and legal regimes, sometimes by practicing trades illegally without paying the regular urban dues. The protocols generated by the perpetual petitions sent to the emperor by servants at the Viennese court give a lively image of their

${ }^{20}$ Daniel Dessert, Argent, pouvoir et société au grand siècle (Paris 1984) shows that high nobles were involved in financing the state through intermediaries. 
hardships, opportunities and quarrels. Only the very special servantspainters, musicians, incidentally scholars-could hope to reach comfortable levels of wealth through their court functions; virtuosi in the musical establishment were among the best-paid persons at the Habsburg court.

The separation of grandeur from pouvoir, of prestige from political power, or household from government and courtiers from ministers, occupies a key position in the domestication thesis. It finds support in the unquestioned growth, differentiation and professionalization of administrative services around the ruler. The domains of council and household were institutionally separated to a large extent. Separate services pertaining mostly to finances, law and warfare were set up; chancelleries and proto-ministries developed. They usually operated in the palace or its immediate vicinity, sometimes in separate buildings such as the ailes des ministres in Versailles or the Reichskanzleitrakt in Vienna, but tended to move to more distant locations in the course of the eighteenth century-repeating a trajectory followed earlier by institutions such the Parisian parlement or sovereign court of law, 'going out of court' in the later middle ages. The central bureaucracies remained relatively small in early modern Europe. The six French central 'ministries' counted fewer than 700 servants until the Revolution, when numbers rapidly expanded-even Louis XIV's brother's household numbered more servants than the aggregate of these agencies of the state. In the Austrian Habsburg domains, numbers were even lower, though a gradual and ongoing rise characterized the eighteenth century, accelerating under Maria Theresa and Joseph II (1741-1790). During the brief personal reign of this intriguing monarch (17801790), the bureaucracy went beyond the household in numbers.

Even when ministries or specialized councils developed into sedentary separate bodies, housed in their own buildings and increasingly distant from the domestic context of rulership, final decisions were usually taken in the ruler's cabinet or council room, frequently in the proximity of, though not necessarily in consultation with, noble court officers. Louis XIV barred high nobles and cardinals, the two notorious categories of favourites in the preceding phase of political crisis, from his inner privy council. His purge was neither complete nor lasting: high noblemen soon entered the council, and in the eighteenth century also repeatedly served as sécrétaire d'état or minister. His initiative remained the exception rather than the rule, which envisaged a wise mix of specialized administrators and high nobles in the exclusive 
highest council. In Vienna, the high steward routinely chaired the emperor's privy council into the eighteenth century, though in the later eighteenth century executive administrative officers became more dominant, and a tendency towards political marginalization of the household did appear.

The leading officeholders among the new state servants had first pledged their oath with their traditional superior the chancellor, but in the course of the later sixteenth or seventeenth century they would typically be promoted to the personal oath with the ruler. In this respect, these ennobled state servants gradually achieved an uneasy parity with the greater courtiers. The balance between the two categories of servants could vary widely. French grandees were not as a rule tempted to meddle with details of law and finance; they were keen on the highest executive offices of the state, but unwilling to learn the trade by devoted study and a gradual procession through the bureaucratic ranks. Their Habsburg compeers proved far more willing in both respects, study and advancement through administrative career. Hence, in Vienna no strong and lasting formation akin to the noblesse de robe emerged: a varied group of noble families dominated household as well as government, and accepted the intrusion of a handful of isolated social climbers without signs of great distress. In France, the most successful dynasties of state servants, the 'robe de conseil', gradually mixed with noble courtier dynasties-scions of the two ministerial dynasties of Colbert and Le Tellier would hold court offices just below the upper ranks from the later seventeenth century onwards. Apparently, for these conspicuously successful bureaucrats, court office still represented the acme of social success.

The increasing institutional separation of household and government, in France strengthened by a relatively clear divide in social background of families active in these domains, provides some support for the domestication thesis. It is based, however, on a limited and anachronistic reading of institutional and political structures. In the context of a debate about Tudor England, a useful corrective was put forward by David Starkey, who underlined in his works that access and proximity to the ruler almost necessarily entailed power. ${ }^{21}$ Positions

${ }^{21}$ See e.g. David Starkey, 'Representation through Intimacy. A Study in the Symbolism of Monarchy and Court Office in Early-Modern England', in: Symbols and Sentiments. Cross-Cultural Studies in Symbolism, Ioan Lewis, ed. (London 1977) 
in the emerging bureaucracies, moreover, depended on professional capabilities as well as on personal prestige and easy access; they could dwindle to insignificance if the incumbent proved inept in any of these respects. High noble courtiers functionally enjoyed personal access to the ruler, and frequently became his intimate advisers without holding formal office in the bureaucracy. Access didn't necessarily lead to power in the formal processes of decision-making; neither did it always bring the friendship of the ruler. This small group, however, through its functions determined access to the ruler in domestic settings, and was well placed to influence patronage. Moreover, high courtiers enjoyed extensive rights of nomination themselves, which in fact allowed them to use to court as a basis for supporting their dynastic networks of clientage. ${ }^{22}$

In practice, courtiers were keen to exert a direct influence on decision-making mostly when important regional or dynastic interests were at stake, or in times of instability and civil strife. Succession crises, regencies and minorities offer a structural example of such phases, the religious turmoil of the later sixteenth and early seventeenth centuries a more incidental though particularly disruptive and long-lasting example. On the whole, the interest of courtiers' families and regional alignments-with clients eagerly waiting for their patron's successes at court-were dominant, and this meant that establishing some control over the distribution of honours was their first priority. The level of 'micropolitics' was more important than the level of great decisions of state. ${ }^{23}$ Rulers, on the other hand, invariably listed a direct personal control over the distribution of honours among the highest priorities of rulership. ${ }^{24}$ Petitioners swarmed the halls and courtyards of European

pp. 187-224, and a volume edited by him: The English Court from the Wars of the Roses to the Civil War (London; New York 1987).

${ }^{22}$ See e.g. on Condé Katia Béguin, Les princes de Condé. Rebelles, courtisans et mécènes dans la France du grand siècle (Paris 1999); on Condé's court patronage Christophe Blanquie, 'Dans la main du Grand maitre. Les offices de la maison du roi, 1643-1720', Histoire \& Mesure XIII, 3-4 (1998) pp. 243-288.

${ }_{23}$ 'Mikropolitik' refers to the work of Wolfgang Reinhard and his pupils, characterized by careful research of family connections and nominations, and a stress on this level of interest-related strategies rather than on grosse Politik-hence a tendency related to the examples of Lewis Namier and Ronald Syme.

${ }^{24}$ See e.g. on Philip II and Louis XIV, H.G. Koenigsberger, 'The Statecraft of Philip II', in: Politicians and Virtuosi. Essays in Early Modern History (London 1986) p. 81; Duindam, Vienna and Versailles, pp. 228-229; Charles Dreyss, ed., Mémoires de Louis XIV pour l'instruction du Dauphin, 2 vols. (Paris 1860) vol. 2, pp. 341-342. 
courts, waiting for a chance to be heard, for a person willing to intercede in their favour. Clearly, access was a cherished commodity here, and control of access a vital sinew of power in the hands of courtiers. Taking account of the nature of early modern rulership and political culture, therefore, it makes no sense to picture courtiers as 'outsiders'. Power and influence at court, the duke of Luynes suggested in 1754, demanded contacts in the council as well as among the 'courtisans qui approchent du roi'. ${ }^{25}$ Court factions recognized this principle, and sought support among both groups. Clashes among courtiers and state servants were endemic particularly at the French court, but as a rule alignments were based on rivalry among persons with similar backgrounds, rather than on the supposed compartmentalization of household and government.

In each of the themes discussed-numbers of courtiers, presence at court and 'court life', financial dependence, political isolationthe domestication thesis overstated one tendency at the cost of other equally important developments, and it also failed to differentiate between the different echelons of staff at court. One final and important aspect remains to be discussed: the impact of the court on noble hierarchies, aptly termed by one historian the 'economy of honour'. ${ }^{26}$ Rulers could selectively elevate their servants to noble rank; they could include intimates into orders of chivalry, and support and reward more distant clients in a variety of ways. Without accepting the onesided image of penniless full-time courtiers brought together in the palace under the wary eye of the ruler, we can only acknowledge the remarkable impact of honours and nominations emanating from the court. These distinctions had the immense advantage that they in no way demanded permanent presence at court and payment from the ruler's coffers. People could obtain titles or honorary offices during a short stay at court, or even during the ruler's visits to their territories. While they obtained a nominal membership of the court, and the right to be present as a participant rather than as a spectator, they could stay at home and perform incidental part-time service. At the same time,

${ }_{25}$ Charles Philippe d'Albert, duc de Luynes, Mémoires du duc de Luynes sur la cour de Louis XV, L. Dussieux, Eud. Soulié, ed., 17 vols. (Paris 1860-1865) vol. 13, pp. 430431, 436-437, July 1754, quote on p. 437 about Pierre-Marc de Voyer de Paulmy, comte d'Argenson, secretary for war, and Jean Baptiste Machault d'Arnouville, controleur-général and garde des sceaux.

${ }_{26}$ Andreas Pečar, Die Ökonomie der Ehre. Der höfische Adel am Kaiserhof Karls VI. (1711-1740), Symbolische Kommunikation in der Vormoderne 5 (Darmstadt 2003). 
their court title became an important element in local ranking. The Baron de Pöllnitz, an indefatigable eighteenth-century travel writer, noted that a Bohemian court chamberlain's wife enjoyed precedence over the spouses of nobles whose husbands didn't enjoy this rank. ${ }^{27}$ Such court-related noblemen, of course, were also more likely to benefit from the ruler's patronage. Local noble society and noble government were increasingly oriented towards the centre, even where the presence of central institutions remained insubstantial. A conspicuous court, in other words, would allow relatively lean and cheap structures of government, because it made possible a reliance on the administrative capacities of loyal, court-oriented, local elites.

Honorary office arguably was more important for the Habsburgs than for the relatively unified Bourbon state, because it allowed them to strengthen the connections between the centre in Vienna and the other parts of the realm. Typically, expansion of territory went together with the introduction of honorary offices for the elites of the newly incorporated area. Maria Theresa adopted Italian and Hungarian guards and honorary officers at her court. Even Frederick II of BrandenburgPrussia, no devotee of the courtly apparatus, followed the same logic when he introduced new positions for Silesians at his court after his conquests in the wars of the Austrian succession. Arguably, the very success of Louis XIV's purge of honorary office had less positive longterm consequences. The French court in the eighteenth century had only a limited potential for accommodating relative outsiders. Offices had long since been monopolized by court families. Noble sons who had had their pedigree approved by the king's genealogist could seek to enter the stables and the chamber as pages, but numbers were limited. In addition, only the presentation to the king-with the concomitant right to join the king's procession of coaches for the hunt-was available for elites who wanted to attend court. There no longer was a close parallel for the inflated ranks of councilors and chamberlains at the Viennese court, who could legitimately see themselves as participants in the court's activities rather than as mere spectators. Everybody could visit the French court as a spectator and an outsider, but access to its formal offices and functions remained very limited.

${ }^{27}$ Mémoires de Charles-Louis Baron de Pöllnitz, 2 vols. (Amsterdam 1734) vol. 1, p. 279. 
Who would choose to remain outsider, consciously evading the court system of honour? Families priding themselves on their ancient lineage looked with dismay at the promotion of less venerable families, but in the long run usually opted for inclusion into the court's ranking. In the century of instability following the 1550's, many families changed place, and the rulers of Europe could include their trusted servants into the upper layers of a newly formed nobility, that would soon close its borders. In addition to instituting a new exclusive order of chivalry, French royalty recreated the traditional corps of ducs et pairs, in practice placing its rights of nomination and promotion above the genealogy of families. Habsburg rulers rewarded their most trusted servants with the high ranks of counts and princes-although they needed to conform to certain restrictions imposed by the collectivity of the empire, the Reichsstände. The role of the court as the centre of patronage and the adjudicator of elite ranking went together with a more general influence of the court on noble education, noble manners and style, and of course fashion. The noble extensions of the court, from pages and court ladies, knights in the orders, to honorary officers in various capacities, spread the influence of the court over larger territories. In the Habsburg case, it has been argued that the 'stamp' of the court helped to create a 'gesamthabsburgische Adel', replacing the regionally oriented noble cultures of a previous period. These noble men and women cherished their ties to the dynasty and the court, and possessed territories in the various components of Habsburg monarchy.

\section{Conclusions}

The tension between rulers and overmighty subjects recurs in history, as do the oscillations in power between the centre and regional forces. Military force would often determine the outcome of such balances, but consolidation also required less confrontational means. Courts could play a conspicuous role in stabilizing connections. The metaphor of domestication, with its connotations of herding together the elites to control them in a central palace, does not resemble common practices in early modern Europe. Not even the Sun King's admittedly successful restructuring of the court in Versailles fits the image. The household, with its remarkably flexible and variable structures, offered multiple occasions for rulers and their elites to interact. Rulers would 
'hold court' in very different settings, with a variety of groups attending. In this way, they could accommodate different territories and different elites under their courtly umbrella. If courts were able to offer an alluring meeting point for their elites, attracting them with festive occasions and with the promise of offices and honours, they could substantially alleviate the burden of governing distant provinces.

Not all groups, however, were easily charmed into loyalty and subservience. The persons closest to the ruler-notably those included in the right of dynastic succession-were also his most dangerous potential rivals. These relatives, as well as the upper layer of nobles with great regional power, needed to be held in check. We find them in the most elevated and profitable positions at the French court, clearly not isolated from power, but still in positions underlining their deference towards the ruler. The Habsburg dynasty with its world empire could accommodate its scions as viceroys and governors in many places, and dynastic demography alleviated the problem of the presence of rivals for the Viennese rulers-in fact their main concern was the production of male heirs, late under Leopold and dramatically unsuccessful under Charles VI. The more relevant Habsburg emperor's noble rivals, the other prominent dynasties of the Holy Roman Empire, ruled outside of his hereditary lands.

Charles IV had stipulated in the Golden Bull (1356) not only the rights and privileges of the electors, but also their duty to perform ritualized domestic service-on horseback-during the Frankfurt coronation banquet. Their presence could never entirely be taken for granted, but from the seventeenth century onwards the worldly electors absented themselves more often, and after the 1740 succession crisis they no longer attended in person. Ritual service could no longer be squared with their status as kings or near-sovereigns. The imperial court in this sense of the emperor being served by his electors was defunct. We see the opposite of domestication here: the rivals of the central ruler take their distance from the court, underlining their own status as rulers. The French situation shows the opposite development. The greater French nobles, drawn towards the court in a protracted process complicated by the phase of religious strife, took up their lucrative and powerful leading offices at court and turned them into major assets for their dynasties. In the case of the Holy Roman Empire, the curia maior gradually lost its allure because it could no longer attract its superior echelon of court servants. The Viennese court took over 
part of this role, but its pull was far more important in the Habsburg hereditary lands than in the Empire. In the French case, curia maior and curia minor overlapped increasingly in the immediate group of persons around the ruler. In this sense, the term domestication is justified, but it should no longer be associated with powerlessness of great nobles at court. They formed a bastion in the heart of the French state, that wouldn't budge until the 1780's.

The Habsburgs, losing their grip on the electors, were more successful than the French kings in turning their nobles into something approaching a service elite, in household as well as government. The highest Habsburg courtiers stood at a greater hierarchical distance from the ruler-the French Condé high steward, a prince du sang with a position in the line of succession, cannot be compared to the Habsburg high stewards, even if some among them, notably the Liechtenstein, finally achieved sovereign status. Moreover, no hierarchical layer stood between the highest courtiers and the royal family in France, whereas the electors and the other princes of the empire nominally still ranked between the emperor and his Viennese courtiers. This absent rival layer helped to strengthen the connections between the emperor and his Viennese courtiers. In addition to the impact of venality and heredity at the French court, these differences made Habsburg courtiers far more deferential and less contentious than their higher-ranking French colleagues.

The balance between the ruler and the upper echelon of potential rivals was a vital interest for both parties: tensions as well as rewards were far more significant here than for the second echelon of honorary noble service. Yet the honour of belonging to the court was important for this group. If nobles accepted the need of at least occasional presence at court for all persons above a certain rank, this may be the strongest argument in favour of a refurbished domestication thesis. The 'court society', then, was not so much the socially diverse group daily present and serving at court, but the wider world of noble part-time courtiers integrated into the court's 'economy of honour' through a variety of titles and offices, but not usually present at court. Integration, admittedly a term with somewhat bland and less concrete associations than domestication, approaches better the multi-layered and multi-directional character of the reorientation of nobles and rulers, and leaves room for the variations outlined here. In the Habsburg context integration of nobles was partly the unintended consequence of the proliferation of honorary titles under Leopold I. Louis XIV's 
reductions, on the other hand, in the long run may have contributed to the relative isolation of the elites assembled at court.

The integrative potential of the court was not limited to the nobility. The wider world of artisans, purveyors, labourers and specialists of many kinds likewise could be attracted into the orbit of the court, partly owing to the court's huge demand for goods and services of great variety, partly because of its ability to compensate service with exemptions and distinctions in addition to payments. Civic authorities were not pleased when court personnel used the court's legal status aparte and fiscal exemption for activities undermining the legitimate urban trades and crafts, and struggled to maintain their corporate rights against the court's repeated incursions. Yet although connections between court servants and their urban or rural environments were rarely trouble-free, they were essential for both sides. A lively amalgamation of lesser household staff with the upper layers of noble courtiers, moreover, remained typical for sixteenth- and seventeenthcentury courts, though the hierarchical separation between these levels became stronger in time. Therefore, picturing the court as an 'above stairs' world only, isolated from servants as well as from the outside world makes no sense. The Castiglionian salon with conversation among near-equal esprits fins of high rank was only one of the many manifestations of court life. 


\section{INDEX}

'Arib b. Sa'd al-Qurtubi, 204

Aachen, 147, 149, 155, 157-159, 161-168 as administrative centre, $152-153$

Abbasid, 19, 199-216, 324

Abdullah (servant of God), 293

absolutism, 5-7, 87-88, 110, 265-266, 268-269, 273, 315, 402-403

Abu al-'Abbas, 13, 199, 204-216

Abu al-Hasan, 201

Abul Fazl, 103

access

to Roman offices, 94-97, 101, 107

to the caliph, 208

to the harem, 51-52

to the inner court, 87,276

to the inner courtyard, 38

to the king, $1,41,316$

to the pope, 241,244

to the Roman emperor, 123-124

to the women's quarters, 58-59

accession (see also dynasticism;

succession)

of Antiochos III, 72-74

of Murad III, 307-309

of Selim II, 301-307

Achaios, 73-76, 83

Adami, Andrea, 255

Adrian VI, 243 table 1

Adrianople, 131, 293

Affektbeherrschung, 419

Agra fort, 321 fig. 4, 333-334, 335

fig. 10, 336 fig. 11

Agrippa, 116

Ahmed III, 15, 18, 340, 354-362, 369, 384, 399

procession of, 383 fig. 4

Aï Khanoum, 71

Akbar, 103, 121n58, 313

akinci, 306

al-'Arudi, 205

Alexander the Great, $46,63,69,75,82$, $88,91-92,103-104,122,324$

court of, 74n33, 75

Persian influence on, 104

Alexander VI, 243 table 1, 247

Alexander VII, 243 table 1, 256-257

Alexander VIII, 243 table 1, 255
Alexandros I Balas, 74n33, 87

Alexandros the Akarnanian, 79

Alexiakos triklinos, 228

al-hasham (court attendants), 201

al-hashiya/hawashi (see also courtiers), 200-201

Ali b. 'Isa, 200-201, 211, 213-214

al-julasa' (see also courtiers), 201

Al-Khasibi, 209

Allacci, Leone, 256

Al-Sabi', Hilal, 201, 203

Al-Suli, 204-210, 215-216

ambassadors, 38, 70, 76-77, 88, 134, $143,230,232-233,249,253,261,305$, 371,380

An Lushan rebellion, 178, 184

Anatolia, 73, 82, 298, 306, 309

conscripts from, 301-307

Andronikos II Palaiologos, 228-229

Andronikos III Palaiologos, 234

Anselm of Canterbury, 155

Antigonid dynasty, 63, 79

Antioch on the Orontes, 71

Antiochos I Soter, 71

Antiochos II Theos, 68

Antiochos III the Great, 63, 67-68, $72-74,83-86,88$

courtiers of, $74-81$

Antiochos IV Epiphanes, 63, 87

Antipatros, 76-77

Apameia, 71

architecture

Assyrian, 29-39

Byzantine, 132-133, 140-141

Mughal, 315-338

Ottoman, 344, 355, 360, 369, 385

Roman, 113, 132

Armenia, 63, 82-83

Arsakes, 83

Arsenios, 226n 48

Artabazanes, 74

Asch, Ronald, 241

Assemani, Giuseppe Simonio, 256

assemblies, 41, 134, 151-152, 155-157, 159, 166-167, 327-328

Assurnasirpal II, 27, 30n5, 32, 35 fig. 3, $41,45,47,61$

Atmeydanı. See hippodrome 
Attalid dynasty, 63

audience hall, 103, 313-338

Augustus, 105-106, 109-113, 115-119 palace of, 29

Avignon, 242, 254, 263

Babylonia, 71, 74-76

Baghdad, 202, 208, 211, 214, 324

Baktria, 71, 83

Baldwin II, 226n 47

Balkans, 63, 101, 298, 306

Balkh, 71

Ban Gu, Hanshu (History of the Former Han), 178, 181

banner system, 266, 275-277, 280

banquets

at the Apostolic Palace, 260-261

at the Assyrian court, 34-35, 36 fig. 4, 37 fig. 5, 40, 43-46, 60-61

at the Byzantine court, 136-137, 142

at the French court, 408-409

at the Habsburg court, 409-410

at the Qing court, 279

book on (Kletorologion), 220

Ramadan/Ramazan, 321

tableware, 43, 218

Baqi tongzhi (Comprehensive history of the Eight Banners), 277

Basil I, 138

basilikoi paides (see also staff, pages), 75

Bayezid, 301, 399

Beishi, 190

Bektashi, 298

Benedict XIII, 243 table 1, 258, 260-263

Benedict XIV, 243 table 1, 256

bey, 290

beylerbeyi, 371

Blachernae, 131, 135

as imperial residence, 139,141 , 226-235

church, 231

Bohemia, 405

Book of Ceremonies (see also ceremony; rituals), 133-134, 138-139, 141-142, 218-220, 225-227, 231-235

Books of Kings (şahnâmes), 350

Boschetti, Francesco Maria, 251

Bosnia, 298

Bosphoros, 131, 231

Bottari, Giovanni, 256

Bourbon, 427

Braschi, Giulia, 258

Braschi Onesti, Romualdo, 258, 263
Britannicus, 97, 99-100

brokerage, 96

Brühl, Carlrichard, 146n6, 150

Brunt, Peter, 94

Brutus, 109

Buddhism, 178, 197

Bureau of Literary compositions (zhuzo cao), 182-183

Bursa, 311, 344, 347, 351

Busbecq, 21n23, 305

Byzantium, 92, 131-132, 143, 164

Cafer Agha, 299

Caligula, 96-97, 104, 121

Caliph al-Muqtadir, 13, 199-214

Caliph al-Mu'tamid, 202, 210

Caliph al-Qahir, 208, 214-215

Caliph al-Radi, 204, 215

Calkoen, Cornelis, 380

Callistus III, 243 table 1, 248

capitals, 16, 19, 404-406

Assyrian, 27, 29, 45, 60-61

Byzantine, 131-144

European, 404-405

Mughal, 313

Ottoman, 339, 341, 344, 347, 349, 351, $353-355,360$

Roman, 131-132

Capitulare de villis, 150-152

Castiglione, Baldassare, 2, 417-418

censorate, 268, 274, 283

ceremony (See also Book of Ceremonies; rituals), 6-7, 19, 91

at the Abbasid court, 212-214

at the Assyrian court, 39-48, 60

at the Byzantine court, 131-144, 217-219, 221-235

at the Chinese court, 279

at the Papal curia, 255, 261

at the Roman court, 111, 127-128

chamberlain Nasr (see also staff, chamberlain), 202, 205-208, 213-214

Chang'an, 172, 173 fig. 1, 179, 193

Chapel of the Mother of God the

Victory Bringer, 228

Charlemagne, 145-161, 164-169, 264

Charles IV, 429

Charles VI, 324, 411, 429

charters, 145, 153-169

chasdeon, 222n 29

Chengzu, 270-272, 284

Chen Shou (Record of the Three Kingdoms), 179 
Chief White Eunuch (see also eunuchs), 295-296, 299

Chihil sutun, 317, 320, 322, 323 fig. 5, 324-332, 337

chiliarch (see also officials, palace supervisor), 40-41

Christmas Eve, 232, 260

Chrysotriklinos, 227n 49

Circassians, 291, 311

circumcision festival, 343-344, 350-352, $361,373,375$

civil documentation bureau, 273

Claudius, 95-97, 102, 110-115, 122

Clavijo, 143, 229-230

Clement VII, 243 table 1, 252

Clement VIII, 243 table 1

Clement IX, 243 table 1

Clement X, 243 table 1, 254n42

Clement XI, 243 table 1, 255

Clement XII, 243 table 1

Clement XIII, 243 table 1, 258

Clement XIV, 243 table 1

Cleopatra, 110

clothing, 219-223, 255, 277, 363-364, 378-380

batons, 221-223

headgear, 221-223, 363, 378

communication

formalised, 41

language, 297-298

secret palace memorials (zhupi zouzhe), 281-282, 284

written, 146, 167

comparative method, 1-5, 9-11

concubines, 11, 16, 50, 203-204, 266

Confucianism, 178, 193, 267, 273-274, 282

conquest dynasty, 275

conspicuous consumption, $21,23,115$, 401

Constantine, 91, 132-133, 140

Constantine VII Porphyrogennetos, 14, $133,218,220-221,225$

Constantinople, 87, 92, 131-137, 141, $144,217-235,342$

coronation. See rituals

Coscia, Niccolò, 258

Council of 1351, 221n24, 228n65

Council of Ferrara-Florence, 229

court

Abbasid, 199-216

Assyrian, 29-61

Byzantine, 131-144, 217-218, 221-235
European, 404-431

inner and outer, 18-20, 30-31, 34-39, 47-48, 87, 266-287, 289-297, 298, $302,312,407,410$

Ming and Qing, 266-287

Mughal, 313-338

Ottoman, 289-312, 339-399

Papal, 239-264

Persian, 37n20, 39-40, 45-46

relation with cities, 69-71, 131-144

Roman, 91-102, 105-128

Seleukid, $67-89$

Tang, 171-198

court diaries (qiju zhu), 182, 184-187

courtiers (see also al-hashiya/hawashi; al-julasa'; gurebâ; philoi)

Abbasid, 199-202, 208-211

cross-cultural studies, 2-3

European, 405, 409-417, 420-426, $430-431$

foreign dignitaries 33 fig. 2, 321

outsiders, $21-22,78-79,82-84,88$, 101-102, 289-290, 304-305, 307, $310,426-428$

Seleukid, 74-81, 86-87

visitors, $22,41,45,52,229-230,410$

crown prince (see also princes), 13

Assyrian, 33 fig. 2, 40, 43, 46-47, 56

Seleukid, 76-77, 80

Tang China, 171, 187, 189

cupbearer. See officials

Curia maior, 407, 429-430

Curia minor, 407, 430

curtains, 142, 232

Cybo, Camillo, 258-261

Dagron, Gilbert, 143

Damad Ibrahim Pasha, 340-341, 355-356, 360-393

Daoguang, 280

Dardanelles, 292, 347, 350

Darius III, 63

Dauphin (see also heir apparent), 414

Dauphine, 414

Davani, 325, 328

De cerimoniis. See Book of Ceremonies

Defter-i Teşrîfât (Ottoman Book of Ceremonies), 353, 364, 372

Delhi sultanate, 290, 328

Demetrios, 83

despotism, 104-105, 109-110, 132, 265, 268

devshirme. See recruitment 
Dio, 93, 97, 120

Diocletian, 104, 131

Diodoros, 87

Diodotos, 84

Diogenes, 76

Diwan-i 'Amm, 316, 318 fig. 1, 319 fig. 1-2, 320-321, 329, 330 fig. 7, 331 fig. 8, 332-333, 327

Diwan-i Khass, 316

domestication. See Elias, Norbert

Domitian, 104, 117

Donglin Academy, 273-274

Dorgon, 278

dowager-empress. See women

Düren, 153-156, 161-162

Dur-Sharrukin, 29

dynastic genealogy (silsilenâme), 351

dynasticism (see also accession; succession), 16-18 integration and disruption, 23, 141

Early Türk, 171-179, 190-198

Easter, 135-136, 142, 148, 154, 156-157, $159,219,224,233,261,405$

Edirne, 15, 293, 340, 344, 367, 369, 372, 381

Ottoman court in, 350-356

education, 21

madrasa colleges, 296, 305, 310

Ministry of Rites, 270

of Abbasid princes, 205-207

of eunuchs, 272

of Seleukid pages, 75

tutor, 199, 205-207, 210, 216, 293, 295

Ekbatana, 71

Elam, 71, 76

election, of Roman consuls, 111-112

Elias, Norbert,

competition for power, 99-101, 112-113

court ceremonial, 43-44

courtization, 286-287

domestication, 16, 106-107, 109, 117, 124-128, 401-404, 418-428

modernization, 126-127

role of, in court studies, $6-8$

The Court Society/Die höfische

Gesellschaft, 6, 66

Über den Prozeß der Zivilisation, 419

Elig Qaghan (Xieli Qaghan), 179, 192-193, 195-196

empress. See women

Epictetus, 97, 101
Epigenes, 73, 76

Epiphany, 232, 233-234

Erchanrad, 155

Erythrai, 68, 70, 72n27

ethnicity

at the Byzantine court, 224, 233

at the Ming and Qing courts, 274-276, 279, 283, 286

at the Mughal court, 314

at the Ottoman court, 289, 291, 297-299

at the Papal curia, 246-249, 257-258

of Roman senators, 115

of Seleukid courtiers, 81-84, 87

etiquette. See ceremony; rituals

Eugene III, 264

Eugene IV, 243 table 1, 247

eunuchs (see also Chief White Eunuch; staff; officials), 2, $21 \mathrm{n} 26$

at the Abbasid court, 200-201

at the Assyrian court, 32-33 fig. 2, 36

fig. 4, 37 fig. 5, 42, 47, 57-59

at the Ming and Qing courts, 266, 270-273, 280, 284, 286

at the Ottoman court, 293, 295-296

castration of, 58-59

Eurasian steppe, 289-291

Family (see also household; officials; staff)

Assyrian, 29

Roman imperial, 95, 114

Fang Xuanling, 180, 183, 189

Ferdinand I, 413

Ferdinand IV, 94

Ferguson, Adam, 126

ferman, 306, 310

Fifth Syrian War, 77n 48

firearms, 291, 305-307, 346, 380, 386

Foggini, Pietro, 256

Fontainebleau, 406

Forbidden City, 269, 271, 278, 285 fig. 1

Forum of Nerva, 150

Fourth Crusade, 217, 227

Fourth Syrian War, 77-78

Frankfurt, 147, 153, 163, 409, 429

Frederick II of Brandenburg Prussia, 427

freedmen, 95-97, 114, 122-123

freedwomen (see also women), 96-97

Freud, Sigmund, 126, 419

Friends of the King. See philoi

Fronde rebellion, 401, 411

Frontinus, 116

Fulrad, 155, 158 
Galata, 224, 395

Galerius, 104

Galletti, Pietro Luigi, 246, 262

Gandhara, 67n12, 83

Garampi, Giuseppe, 256

Gattico, Giovan Battista, 243

Gauert, Adolf, 145-147

Gazanfer Agha, 296

Gelibolu, 293, 347, 351

Gelzer, Matthias, 94

Genesius, 163-165

Genoese, 224, 233

Germanicus, 117-120

Gibbon, Edward, 91-92

Gong, 279-280

Gonzaga, Eleonora II, 414

governors

Assyrian, 44, 47

Chinese, 271, 276, 281, 290-291

Habsburg, 429

Ottoman, 296, 299-300, 309, 311, 359

Roman, 112-144

Seleukid, 67, 71-78, 83-86

governor-general, 291

graduation (chikma), 293-295, 299-307, 311

Grand Council (Office of Military

Plans), 283-285 fig. 1

grand secretary. See officials

Grand Councillors, 268, 270, 283

grand vezir. See officials

Graves, Robert, 95

Green Standards, 276

Gregory XIII, 243 table 1, 259

Gregory XIV, 243 table 1

Gregory XV, 243 table 1, 257

Guillemain, Bernard, 242, 254

gurebâ (see also courtiers), 290, 307-308

Habicht, Christian, 81-82

Habsburg dynasty 22, 107n12, 289, 305-306, 324, 404-416, 423-424, 427-430

Hagia Sophia, 135, 138-139, 141, 226

Han Chinese, 274, 276-284

Han dynasty, 172, 177, 266

Hanlin Academy, 269, 282-283

Hannibal Barkas, 22, 79

haraj, 290

harem (see also women)

Abbasid, 200-201, 203-204

Assyrian, 48-56

size of, $53-54$
Mughal, 316

Ottoman, 395-397

Harun, 202, 205, 207, 210-211, 214

Harun b. Gharib, 214

Hasmonean dynasty, 87

heir apparent (see also crown prince;

Dauphin), 59, 183, 193, 277, 282, 414

Hellenism, 64-66, 85, 88-89

Henry III, 412

herald. See officials

Hermeias, 72-74, 76-77

hierarchy, 20-21, 403

at the Abbasid court, 203, 212-214

at the Assyrian court, 39-48

at the Byzantine court, 137-138, 219, 221-226

at the European courts, 403, 407-408, 415-423, 426, 430-431

at the Mughal court, 314, 316, 320

at the Ottoman court, 352, 366, 377

at the Papal curia, 245, 249-250

at the Roman court, 111, 115

at the Seleukid court, $68,84-87$

spatial, 44-48, 61-61, 203, 212-214, 225-226

hippodrome, 132-139, 141-142, 225, 230, 234-235, 341, 347, 364, 366, 369, $374-378,380,384$

Historiographical Office, 176, 182-184, 190

history writing, 171-198

by commission, 171, 179-181, 198

politization of, $171,176,178,186-198$

Hitherius, 156, 160-162, 164

Hodegetria, icon of the, 230

Hof ohne Staat, 108-109

Holstenio, Luca, 256

Holy Roman Empire, 324, 405, 429

House of Osman, 290, 311n40, 312, 342, 349, 352-353

House of the Porphyrogennetos, 229

household (see also family; staff), 1-11, 240-241

Abbasid, 200-202

Assyrian, 29-61

of officials, 43

of the crown prince, $46-47$

of the queen, 46-47, 53, 56

royal corps, 59

size, $45-47,53-54$

Chinese, 266-267, 280-281

European, 402-404, 410, 413-418, 423-431

echelons, 416-418 
of the queen, 413-414

secondary, 413-415

Ottoman, 289-301, 359-360, 363,

371-372, 388, 397

princely, 300-312

troops, 289, 295, 298-299, 301-312,

$388-389,393,393,399$

veziral, 341-342, 368-370, 373-374,

$384,388-389,391-398$

Papal, 239-264

Roman imperial, 95-97, 105-107, 112, $114,116-117,112$

Seleukid, 66, 87

household servants. See staff

Hu Weiyong, 268

Huang Zongxi, 271

Hub-mesihi, 298

Hungary, 298, 301-302, 324, 405

Iasos, 80

Ibn al-Furat, 201, 208, 211

Ibn Khaldun, 315

Ibrahim Sultan, 324-325

icon of St George, 228

Imperial bride-to-be, 219, 232

Imperial council, Ottoman, 291, 294

fig. 1, 296, 308-309, 369-370

Imperial Chancellery, 176

Imperial Secretariat, 176

infantry, 78, 295, 306, 308

Ingelheim, 147, 149, 150, 153, 159, 163-164

Inner Asia, 22, 196, 265-266, 274, 279

Inner Cabinet (neike), 271-273, 283

inner service (enderûn), 15, 293, 294

fig. 1, 295-299, 311, 388n100

Innocent VIII, 243 table 1

Innocent IX, 243 table 1

Innocent X, 243 table 1

Innocent XI, 243 table 1, 260

Innocent XII, 243 table 1, 257-259

Innocent XIII, 243 table 1

insignia of office, 220-221

Islam, 121, 125, 197, 297-298, 324-325, 337

Istanbul, 50, 293, 301-308, 339-340,

$344,347,349-354,359,362,369$,

371-372, 378-381, 384, 395, 397

itinerant kingship (see also kings), 13,

$71,145-169,405$

as an economic system, 146-147

James VI, 415

Jamshid, 325-326, 328 janissaries, 303-304, 306-308, 310, 312, $345,372,381,389,390,393-398$

Jharoka, 320, 332, 334, 337-338

Jharoka-i Darshan, 316

Jharoka-i Khass-u 'Amm, 320, 328, 334

Jianwen, 272

Jiu Tangshu (Old History of the Tang),

181, 184, 190-196

jizye ( $\operatorname{tax}), 291$

job rotation, 16, 407, 416

John VI Kantakouzenos, 218, 228

John VIII Palaiologos, 229

Joseph II, 423

Julius II, 243 table 1, 260

Julius III, 243 table 1, 250

Julius Caesar, 108-110

Justinian II, 137

kaballikeuma, 234

kadı, 296, 305

Kafadar, Cemal, 309

Kalim, Abu Talib, 317, 326, 333, 337

Kanbo, Muhammad Salih, 314, 322, 326-328

Kangxi, 281-282, 286

kap1, 290

Kappadokia, 83

kathisma, 133-134, 234

khassa, khawass, 201-202

kings (see also itinerant kingship)

Assyrian, 31, 33 fig. 2, 34, 35 fig. 3, 37 fig. $5,38-41$

in Roman context, 109-110

Mughal, 314-317, 318 fig. 1, 320, $322-323,326-327$

Seleukid, 64-64, 67-68, 72-74, 83-88

Kiosk of Processions (Alay Köşkü), 357-358, 366, 375, 378, 396

Kletorologion, 136n23, 139n33, 220

Kommagene, 83

kraktai (see also staff), 224

kul, 290-296, 299, 310

Kütahya, 302, 304, 306

Lahawri, Abd al-Hamid, 322, 326

Laodike, $79-80$

Latins, 224, 226

law code (kânûnnâme), 352, 372

Le Roy Ladurie, Emmanuel, 93

legitimation, 20-21

in art and architecture, $32-35$ fig. 2-3, 315-323, 326-338

in historiography, 171, 179-182, 186-198 
through tradition, 339-341, 345-354, 378

Leo X, 243 table 1, 249-253, 260, 262

Leo XI, 243 table 1

Leopold I, 10n15, 405, 411, 430

Leviathan, 126

Li family, 177

Li Jing, 179

Li Shimin, 171, 186, 189, 192-194

Li Yuan, 172, 185-187, 189, 194

Lifanyuan (Court of Colonial Affairs), 274, 279

Linghu Defen, 179-180

literati elite, 177-178, 266, 272, 274, 284

Livy, 75, 84

Louis XIII, 414

Louis XIV, 5-6, 93, 113, 251, 286, 316, 401-406, 411-414, 417, 423, 427, 430

Louis XV, 420

Louis XVI, 415

Lütfi Pasha, 327

Luynes, duc de, 426

Lydia, 71, 77

Magnaura, 134-135, 138, 141

majalis/majlis, 209-210, 215

mamluk, 289-291

Mamluk sultanate, 291

Manchu, 22, 265-267, 274-286

Mangana, 231

Mango, Cyril, 139

Manisa, 307-310

mansabdars, 116, 314

Manuel I Komnenos, 140

Manuel II Palaiologos, 229

Marc Antony, 110, 119n52

Marcellus II, 243 table 1

Marcus Aurelius, 97, 101

Maria Theresa, 406, 411, 414, 423, 427

marriage alliances, $64,83,86-87,113$, $115,278-279,340-344,347-354$, $360-363,372$

Martin V, 243 table 1, 246-247

Massotti, Zenobio, 256

medrese, 358

mehter, 295, 395, 399

Merv, 71

Mevlevi, 298

Michael VIII Palaiologos, 217, 226, 228

Millar, Fergus, 94, 97n17

Emperor in the Roman World, 93, 96

Ming dynasty, 265-287

Ming Taizu, 265, 267-272
Mingchao shilu (Veritable Records of the Ming Dynasty), 269

ministries, 268, 270, 272, 274, 278, 280-283, 423-424

mirrors for princes, 126

Miskawayh, 200-201, 207, 215

Mithradates II, 79

Molon, 72-76, 83

Momigliano, Arnaldo, 95

Mommsen, Theodor, 92-93, 98

Mongols, 14, 22, 177, 196, 265-267, 271, 275-278

Monseigneur, 98-99, 414

Morales, Ambrogio, 255

Moroni, Gaetano, 247n23, 260

mosque, 202, 212, 321 fig. 4, 325, 332-337, 344-347, 350, 378

Moti Masjid, 334, 335 fig. 10, 336 fig. 11

Mu'nis al-Khadim, 211

Mu'nis al-Khazin, 209

Muflih, 202

Murad III, 301, 307-310, 345, 348, 357

Murphey, Rhoads, 304, 353n31

müsellem, 306

Mustafa II, 353-361, 367-368, 372

nadim, 201, 209

Nanking, 271

Nero, 97, 100-101, 120n55, 122

Nerva, 116-117

New Constantine, 217

Nicholas III, 246, 249

Nicholas V, 243 table 1

Nikephoros Gregoras, 228

Nikephoros II Phokas, 139, 235

Nikephoros Kallistos Xanthopoulos, 228

Nineveh, 29, 30n6, 34, 54n 48

nobility

Abbasid, 200

Assyrian, 41-42

European, 401-431

Ming and Qing, 266-267, 277-280

Roman, 112-115, 120-124, 239, $257-258$

nöker, 290

non-Muslim, 289, 291-292, 306, 385

Northern Qi, 172, 177, 185

nudama, 201, 209

Octavian. See Augustus

officials (see also eunuchs, staff; titles), 20-22

consul, 94, 111-112 
cupbearer, 37n20, 42-43, 47, 56, 409-410

chamberlain, 59, 85, 202, 205-208, 213-214, 243-244, 246-252, 257, 262, 277, 407-411, 415-417, 421, 427

chief cook, 43

chief eunuch, 42-43, 47, 59

chief judge, 42-43, 397

commander of the royal corps, 59

demarchoi, 134, 142

grand secretary, 268-272, 281-284

grand vezir, 15, 40-43, 296, 300, 303-305, 309, 311, 340-351, 357-399

herald, 40, 42, 244, 248-249, 252

Major-Domo, Papal (Magister Hospitii), 244-244, 257-259, 263

marshals, 143, 390-391, 410, 415-416

masters of ceremony, 219, 249n17, 353-354, 384n89, 387, 395, 398n132, 399

master of the horse, 372, 386n94, 395, 399, 415-416

palace supervisor (see also chiliarch), $40-41,43,47$

prime minister, 265, 268, 309

seneschal, 143, 410

shield-bearers, 244, 246-252

steward, 249, 370-371, 378, 386-390, 393-399, 408, 415-416, 424, 430

treasurer, $42,56,248,254,259,263$, 308, 370, 390, 392, 394, 397

tropheus (Master of the Pages), 75, 85

Olga of Kiev, 227n52, 230n73

Olgiati, 259

Olivieri, Fabio, 258

Olmi, Giuseppe, 253n40

Opium War, second, 280

Orléans family, 413

Osman Bey, 290

outer service (birûn), 15, 293, 294 fig. 1, 295, 298-300, 388n100

Paderborn, 149, 153, 157

pages. See staff

palace, $18-20$

ablution rooms, 31,35

dining room, 227, 250

inner courtyard, 37-39, 45, 176

outer courtyard, 30-38, 176

reception rooms, $31-34,37$ fig. 5, 38, $45,227-228,231$ royal living quarters (see also harem), 38-39, 49-53, 172, 225-230

throne room, 31-35, 34-35 fig. 3, 38, $60,203,336$

women's quarters, 48-57, 59, 203, 293 palaces

Al-Firdaws, 202

Al-Mukharrim, 208, 210

Al-Taj, 202-203

Apostolic Palace (Sacrum Palatium), 244, 246, 250-253, 260, 264

Boukoleon, Palace of the, 139-140

Chengde summer palace, 22, 279

Daming Palace, 174 fig. 2, 175-176, 183

Dar al-Khilafa, 202-203, 208

grand vezir, of the, 368-369

Great Palace, 131-144, 226-228, 232-235

ekklesia, 227-228

kellion, 227-229

prokypsis, 228, 232, 234

triklinos, 227-228

Hasani Palace, 202, 213

Hofburg, 404-406

Jiucheng Palace, 175

North-West Palace, 27-39, 28 fig. 1, $41,45,49-53$

Palatium, Roman Imperial, 93-94, 97

Renshou Palace, 175

Schönbrunn Palace, 324, 406

Taiji dian (Taiji Hall, Great Joy Palace), 172, 173 fig. 1, 175

Topkapı palace, 294 fig. 1, 296-297, 300-301, 304, 311, 340-341, 344, $346,357,368-370,378,386$

Palestrina, P. Luigi, 255

Panormos, Battle of, 79

Parthian Empire, 63-64, 83-84

patronage, 9, 415, 418, 425-428

in Imperial Rome, 94-96, 112, 116, 127

of cities, 68-69

Ottoman, 309, 315

under Charlemagne, 156

Paul II, 243 table 1

Paul III, 243 table 1, 250, 252-253

Paul IV, 243 table 1, 250, 253

Paul V, 243 table 1, 259-260

Peking, 271, 276, 280

Peña, Francisco, 251

Pera, 229, 293

Pergamon, 63 
Peribleptos, 231

peripatos, 227

Persepolis, 15, 37n20, 103, 323-328, 329

fig. 1, 330-332, 337

petitions, 123, 142, 148, 156-157, 233-234, 421-422

Petra, 231

Philippos, 75-77

philoi (Friends of the King), 69-88

Philotheos, 220, 225

Piso, 117-120

Pius II, 243 table 1, 247-248

Pius III, 243 table 1, 247-249

Pius IV, 243 table 1, 250

Pius V, 243 table 1

Pius VI, 258, 262-263

Pius IX, 243 table 1

plague, 217, 405

podesta, 224

Pöllnitz, Baron de, 427

Polybios, 72-79, 84-85

Polyxenidas, 79

Pontos, 63, 83, 131

power-sharing, 171, 176-181, 198

Prague, 405, 411

prebendal, 116

princely household. See household princes (see also crown prince)

Abbasid, 200-215

Ming and Qing, 277-280, 282-283

Ottoman, 298-312, 342, 373, 399

princess (see also women), 339-343,

347-375, 385, 391, 393, 393, 399, 413-414

Principate, 93, 106

privileges, $251-259$

privy council, 423-424

processions

Abbasid, 213-214

Byzantine, 135-136, 225, 230-231

Ottoman, 340-342, 344-347, 354-358, 363-399

alay-1 arûs, 340-341, 364-365, 396-399

alay-1 cihâz, 340-341, 364-365, 391-395

alay-1 nişân, 340-341, 364, 386-390

prooimion, 218

prostration. See rituals

protocol. See ceremony

Pseudo-Kodinos, 141-143, 218-220, 223-235

Ptolemaic dynasty, 64-67, 85-86
Qianlong, 278, 281, 286

Qin Shihuangdi, 265

Qing, 72, 265-268, 274-286

Q1pchak Turks, 291

queen (see also women)

Abbasid, 204, 206-207

Assyrian, 39, 46-47, 51, 53-56

Seleukid, 79-80

Quierzy, 153-158, 161-164

Rado, 154-164

rank. See hierarchy

Raphia, Battle of, 76, 78, 84n72

recruitment

devshirme, 15, 21, 291-299, 311-312

of Abbasid courtiers, 209

of Anatolian conscripts, 304-307

of Seleukid courtiers, 67-71, 75-81

Regensburg, 147, 149, 159, 163-164

Reichserzämter, 409

Renazzi, Filippo Maria, 263

revenue grant (dirlik), 290, 295-296, $300,303,305-308,310$

Rheims, 406 coronation, 405

rituals (see also Book of Ceremonies;

ceremony; processions)

Agni Dei, 261

acclamations, 133, 135-138, 142, 234

audiences, 113, 172-173, 229-233, 316-320

coronation, 44, 136, 218-219, 226, 233-234, 405, 409, 429

parakyptikon, 137, 142

prokypsis, 142, 228, 232, 234

prostration, 103-104

Roman cremation, 127-128

Roman triumph, 111

silention, 134

weddings, $87,134,136,140,232,321$, 339-399

Robert of Clari, 227

Roberto di Santa Maria, 256

Roman imperial court. See court

Roman republic, 93-94, 105-109

republican heritage, 93-95, 108-110, $112-113,116,121-122,125$

Roman roads, 148

royal bridegroom, 360, 367

royal chronicle, 351

royal council

Assyrian, 42

Seleukid (sunedrion), 72, 79 
Rudolf II, 405, 411-412

Rüstem Pasha, 305, 343

Safavi, 5, 15, 301, 305-306, 313, 322-323, 331

Saint-Simon, duc de, 95, 99, 402

Saller, Richard, 96

Salvetti, Domenico, 256

sancakbeyi, 296, 300

Sargon II, 30n4, 35, 36 fig. 4, 48

Sauvaget, Jean, 336

Savelli, Giovan Battista, 251

Savignani, Aurelio, 251

Sea of Marmara, 231, 376

Selaniki, 303-304

Sélestat, 153-156, 163

Seleukeia on the Tigris, 71-72

Seleukos I Nikator, 63, 82-83

Seleukos III Soter, 72-77, 84

Seleukos IV Philopator, 77

Selim II, 15, 18, 301-310, 345, 348

senate, $93,98,112-116$

Septimius Severus, 127

servants. See staff

Shah Jahan, 313-317, 318 fig. 1, 320, 322-323, 326-338

Shah Tahmasb, 301

Shahnâme, 397

Shi'i, 298

Shibi, 194

Shunzhi, 278

Sima Guang, 185, 189

Sima Qian, 178, 181

Records of the Historian, 178, 181

Simeon, 87

sipahi (cavalry), 290, 295, 298, 305-308, 310

Sixtus IV, 243 table 1

Sixtus V, 243 table 1, 254, 259

skaranikon, 221-224

skiadion, 221

Sokollu Mehmed Pasha, 309, 302n26, $348 \mathrm{n} 16$

Solomon, 297, 323, 325-328, 337-338

Sophagasenos, 83

Spannocchi, Ambrogio, 248

Spannocchi, Giulio, 248

St Demetrios, 228, 231

St Denis, 153-163

St Lazaros, 231

St Peter's basilica, 150, 158

staff (see also eunuchs; kraktai; officials; women) at the Assyrian court, 34-38 fig. 4-5, 39-61

at the Byzantine court, 142

at the European courts, 404, 411

fig. 1, 412-417, 422, 426

at the Papal curia, 239-264

bearded men, 11, 33 fig. 2, 36 fig. 4, 47,58

bondservants, 14, 280-282, 286, 280-281, 286

clerks, 200, 249, 256, 281, 283, $370-371,398$

guards, $20,47,78,85,114,134,140$, $142,272,276-277,295,304,363$, 380-381, 386-399

living quarters, 38-39

musicians, 35, 47, 54, 61, 142, 201, $233,410,423$

notaries, 156-169

pages, 75, 80, 85, 293-295, 297-299, $304,311,408,427-428$

palace women, $38,51-56,203,270$, 272, 409

servants, $1-2,22,35,38,40,43,47$, 58-59

slave girls, 203

wine allotments to, 45

Starkey, David, 424

state, 402-403

Ecclesiastical, 239

Roman, 93, 105-128

status, 2, 6-7, 20-21, 40-41, 61, 67, 69-71, 74. 76, 84, 276-286, 291-292, $315,384,416-418,421-422$

succession (see also accession;

dynasticism), 16-17

European, 411, 425-430

Mughal, 314

Ottoman, 343, 360

Qing, 277-278

Seleukid, 77

Tang, 192

Suetonius, 96-97, 101

Sufi, 298, 314

Sui dynasty, 172, 177, 180

Suishu, 190

Süleyman, 301-302, 304, 309-311, 343, 345

sultan, 299-300

sunedrion. See royal council

supreme commander, 271

Sûrnâme (Ottoman Book of Festivals), 340, 351, 356-357, 361-365, 373, 389-390, 393, 396 
Susa, 71, 76

Syme, Ronald, 95, 101

Szigetvar, 301-302, 304

Ta Hypsela, 228, 230

Tacitus, 93, 96, 99, 101, 106

Tafur, Pero, 143, 229-230

taxis, 138,218

Theodotos the Aitolian, 78

Theophilos, 233

Tiberius, 101-104, 117-120

Timur, 103, 322

titles (see also officials)

at the Papal curia, 244-259

domini, 246-249, 253

familiares, 244, 246-253, 258-259

officiales, 242, 248-249, 253

Augustus, 110

commander-in-chief, 42, 110, 143

distribution of, 85-87, 96, 107

Heavenly Qaghan (Tian Kohan), 179, 192, 196-197

honorary, 22, 85-86, 261-262, 407-408, 410, 412, 416-422, 426-430

selling of, 250-251, 412

Son of Heaven (Tianzi), 179, 197, 265

tradition, invention of, $111,339,352$, 356-360, 373

travelling (see also itinerant kingship) between palaces, $52-53$

campaigns, 131, 147, 156, 158-159

distances, 149

governmental, 152-169, 405

seasonal, 131, 147-148, 405-406

speed, $148-150$

Treatise on the court titles, 141, 218-227, 232-235

triclinium, 136, 139

Triebverzicht, 419

trumpet, 2, 224, 234

Tuli Qaghan, 179, 192-193

Tumu incident, 271

tyranny. See despotism

ulemâ, 296, 310, 371, 374, 396-397

ümerâ, 296, 300, 310

umm musa, 202

umm walad, 203-204

Urban VII, 243 table 1

Urban VIII, 243 table 1, 257, 263

Üveys Pasha, Kara, 308
Vanmour, Jean-Baptiste, iv, 378, 380

fig. 2, 381, 382 fig. 3, 383 fig. 4

Varangian guard, 142, 231

Vardariots, 224n 35

Vatican

Chapel, 255, 260

Library, 256

Vehse, Eduard, 409

vekâyi'-nâme (royal chronicle), 351

Veralltäglichung, 6

Verhöflichung, 12, 419

Veritable Records (shilu), 183-190, 193, 198, 269

verre eglomisé, $223 \mathrm{n} 30$

Versailles, 6, 43, 61, 100, 113, 127, 208, 401-406, 414-416, 420, 428

vestiarion, 235n 104

Veyne, Paul, 93

vezir (see also officials, grand vezir), 291, 297, 309

Vienna, 127, 289, 324, 351, 404-409, 414, 416, 421-424, 427

Vitale, Francesco Antonio, 263

Wanli, 273

Wei Shu, 184

Wei Zheng, 180, 187-188

Wei Zhongxian, 273-274

Wen Daya, Zhenguan Zhengyao (Diary of the Founding of the Great Tang Dynasty), 185-187, 194-195

Wigbald, 154-156, 158-162

Winterling, Aloys, 92, 102, 108-109, $113 n 30,122 n 59$

women (see also freedwomen; harem; princess; queen; staff)

empress, 178, 186, 229-230, 408-409, 414

dowager-empress, 14,414

palace women, 38, 51-56, 203, 270, 272

role in production, $21 \mathrm{n} 25,39 \mathrm{n} 22$, 55-56

Wu Jing, Zhenguan Zhengyao

(Important Principles of Government from the Zhenguan Period), 183-190

Xerxes, 83, 104

Xianfeng, 280

Xuanwu Gate incident, 187, 189, 192-193

Xuanzong, 178

Yangzi, 273 
Yannai, 87

yaya (infantry), 306

Yongzheng, 278, 281-283

Yuan dynasty, 265-267

Zalum, 204

Zariadris, 83

Zaydan, 202, 206
Zedler, Johann Heinrich, 404

Zeuxippos, 138

Zeuxis, 76-77

Zhangsun Wuji, 180, 184, 193

Zhen Guan reign, 171, 184, 188

Zhengde, 271

Zhoushu, 190

Zimmi (non-believers), 291-292 